\title{
WEST VALLEY DEMONSTRATION PROJECT ANNUAL SITE ENVIRONMENTAL REPORT CALENDAR YEAR 2012
}

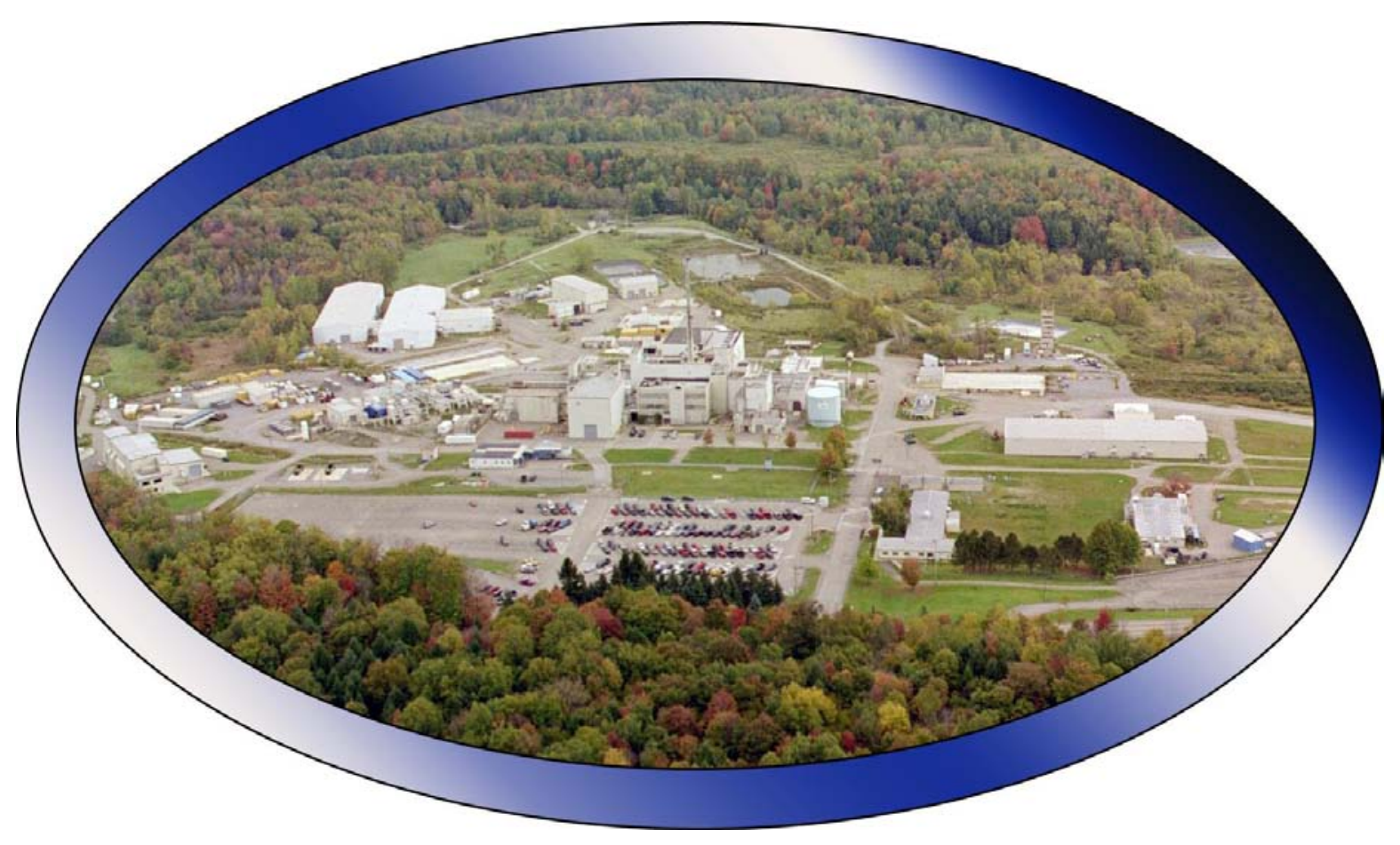

CH2M HILL • B\&W WEST VALLEY, LLC

Prepared by: $\mathrm{CH} 2 \mathrm{M} \mathrm{HILL} \bullet \mathrm{B} \& W$ West Valley, LLC

Prepared for: U.S. Department of Energy DOE-WVDP 



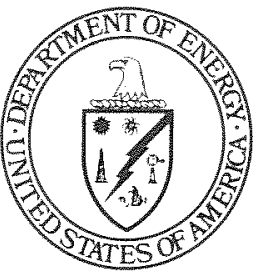

\author{
Department of Energy \\ West Valley Demonstration Project \\ 10282 Rock Springs Road \\ West Valley, NY 14171-9799
}

To the Reader:

This report, prepared by the United States (U.S.) Department of Energy (DOE) West Valley Demonstration Project (WVDP), summarizes the environmental protection program at the WVDP for calendar year 2012.

Monitoring and surveillance of the WVDP facilities are conducted to verify that public health and safety and the environment are protected. The quality assurance requirements applied to the environmental monitoring program by the DOE ensure the validity and accuracy of the monitoring data.

At the WVDP, radiological air emissions are controlled and permitted by the U.S. Environmental Protection Agency (EPA) under National Emission Standards for Hazardous Air Pollutants, Subpart H, regulations. Nonradiological liquid effluent discharges are controlled and permitted through the New York State Pollutant Discharge Elimination System. Generation, storage, and treatment of hazardous and mixed wastes are conducted in accordance with Resource Conservation and Recovery Act interim status regulations and New York State Environmental Conservation Law.

Air, surface water, groundwater, storm water, soil, sediment, and biological samples are collected and analyzed for radiological and nonradiological constituents. The resulting data are evaluated to assess effects of activities at the WVDP on the nearby public and the environment.

The calculated dose to the hypothetical maximally exposed off-site individual from airborne radiological emissions in 2012 was estimated to be $0.027 \%$ of the 10 -millirem (mrem) EPA limit. The dose from combined airborne and waterborne radiological releases in 2012 to the same individual was estimated to be $0.019 \%$ of the 100-mrem DOE limit, verifying that dose received by off-site residents continues to be minimal.

The WVDP was operated in a safe manner during 2012. In 2012, the employees achieved a cumulative total of 5.5 million safe work hours without a lost-time work accident or illness, while accomplishing complex decontamination and waste management activities.

CH2M HILL • B\&W West Valley, LLC (CHBWV) continued to perform Phase I Decommissioning and Facility Disposition activities for DOE during 2012. The term of the Phase I Decommissioning and Facility Disposition contract is from August 2011 to June 30, 2017.

If you have any questions or comments about the information in this report, please contact WVDP Communications at (716) 942-4601 or complete and return the enclosed survey.

Sincerely,

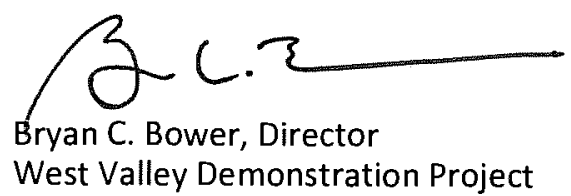





\title{
West Valley Demonstration Project
}

\section{Annual Site Environmental Report}

\author{
for
}

Calendar Year 2012

Prepared for the U.S. Department of Energy

West Valley Demonstration Project Office

Under: Contract DE-EM0001529

September 2013

CH2M HILL •B\&W West Valley, LLC

10282 Rock Springs Road

West Valley, New York 14171-9799 


\section{Disclaimer}

This report was prepared by $C H 2 M H I L L \bullet B \& W$ West Valley, LLC (CHBWV) undercontract number DE-EMO001529 with the United States (U.S.) of America, represented by the Department of Energy. Neither the U.S. Government nor CHBWV nor any of their contractors, subcontractors, or employees makes any warranty, expressed or implied, or assumes any legal liability or responsibility for any apparatus, product, or process disclosed, or represents that its use would not infringe on privately owned rights. References herein to any specificcommercial product, process or service by trade name, trademark, manufacturer, or otherwise does not necessarily constitute or imply its endorsement, recommendation, or favoring by the U.S. Government or CHBWV. This report contains a summary of major or significant activities occurring at the West Valley Demonstration Project (WVDP) only and is not a full disclosure of all details associated with WVDP-related activities. The views and opinions of authors expressed in this report may not specifically state or reflect those of the U.S. Government or any agency thereof. 


\section{Can We Make This Report More Useful to You?}

We want to make the WVDP Annual Site Environmental Report useful to its readers. Please take a few minutes to let us know if the report meets your needs. Then print, fold and tape this page to place it in the mail.

Mail to:

$$
\begin{aligned}
& \text { WEST VALLEY DEMONSTRATION PROJECT } \\
& \text { 10282 ROCK SPRINGS ROAD } \\
& \text { WEST VALLEY, NY } 14171
\end{aligned}
$$

1. How do you use the WVDP Annual Site Environmental Report?

To learn general information about the WVDP

To learn about doses received for the current year

To learn about site compliance information

To gather effluent or environmental surveillance data

Other:

2. Does the WVDP Annual Site Environmental Report contain enough:
a. Useful illustrations and graphs? $\square$ Yes
b. Project background information? $\square$ Yes
$\square$ No
c. Scientific background information? $\square$ Yes
$\square$ No
Comments:

3. Is this report: (please check one)

At appropriate technical level?

Too technical? For example:

Not technical enough? $\quad$ For example:

4. If you could change this report to make it more readable and useful to you, what would you change?

5. What is your affiliation?
$\square$ U.S. DOE
Elected official
NYSERDA
Media
Other government office/agency
$\square$ Group:
Public interest group
Individual:

6. To help us identify our audience, please indicate your educational background.
Graduate degree:
Undergraduate degree:
$\square$ Scientific
Nonscientific
Experience with science outside college setting
Little or no scientific background

If you have questions or comments about the information in this report, please contact WVDP Communications at (716-942-4601). 



\section{Preface}

Environmental monitoring at the West Valley Demonstration Project (WVDP) was conducted by $\mathrm{CH} 2 \mathrm{M}$ HILL $\bullet B \& W$ West Valley, LLC (CHBWV), under contract to the United States Department of Energy. The data collected provide a historical record of radionuclide and radiation levels, and chemical data from natural and man-made sources in the survey area. The data also document the chemical and radiological quality of the groundwater on and around the WVDP and of the air and water released by the WVDP. Meteorological data are also presented.

It is the policy of CHBWV to conduct the WVDP in a safe, compliant, and cost-effective manner that protects human health and the environment. We achieve this by integrating environmental requirements and pollution prevention into our work planning and execution, and taking actions to minimize the environmental impacts of our operations. We establish and communicate environmental responsibilities, provide environmental training to our workforce, and implement controls to mitigate environmental hazards. These activities are conducted in accordance with our Environmental Management System.

This report represents a single, comprehensive source of on-site and off-site environmental data collected during 2012. The environmental monitoring program and results are discussed in the body of this report. Additional monitoring information is presented in the appendices. Appendix A contains maps of on-site and off-site sampling locations and a summary of the site environmental monitoring schedule. Appendices $B$ through H contain summaries of data obtained during 2012 and are intended for those readers interested in more detail than is provided in the main body of the report. Appendix I contains a copy of the WVDP Act. All of the appendices are included in electronic forms of the document. Appendices $B$ through I can be found in electronic format on the compact disk located inside the back cover of the printed versions of the ASER.

A reader opinion survey has been inserted in this report. Requests for digital copies of the 2012 Annual Site Environmental Report (ASER) and questions regarding the report should be referred to WVDP Communications, 10282 Rock Springs Road, West Valley, New York 14171 (telephone: 716-942-4601). Additional Project information, including links to the current and previous WVDP ASERs, is available on the internet at http:// www.wv.doe.gov. 
This page intentionally left blank 


\section{TABLE OF CONTENTS}

PREFACE.

EXECUTIVE SUMMARY

EXE-1

Purpose of This Report

EXE-1

Major Site Programs.

EXE-1

Record of Decision

EXE-1

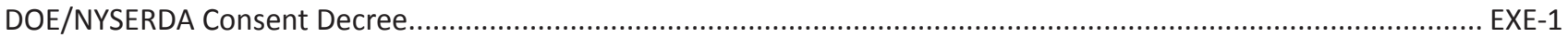

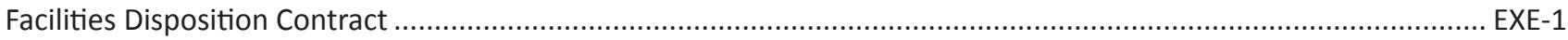

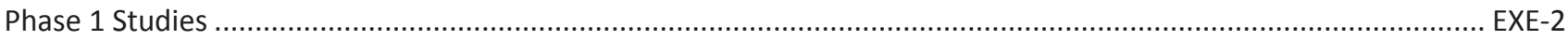

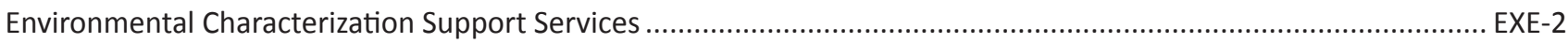

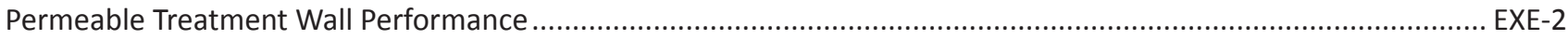

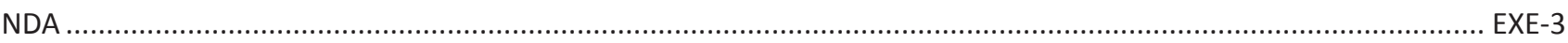

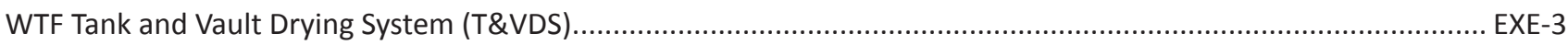

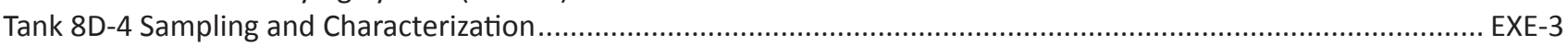

Waste-Incidental-to-Reprocessing (WIR) Evaluations for HLW Processing Vessels ..................................................... EXE-3

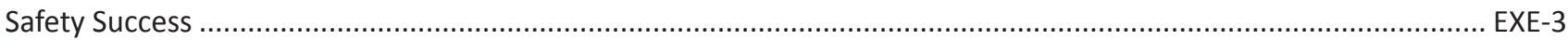

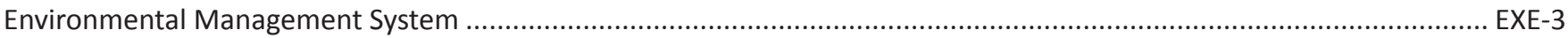

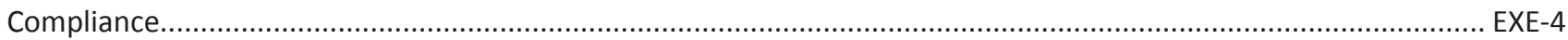

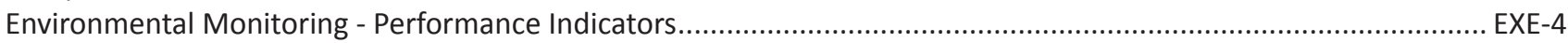

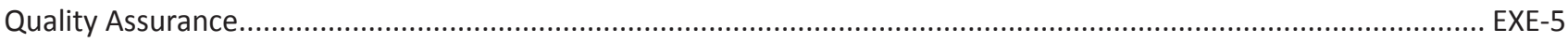

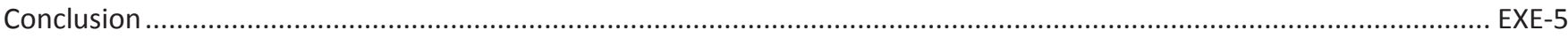

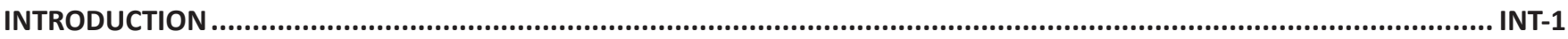

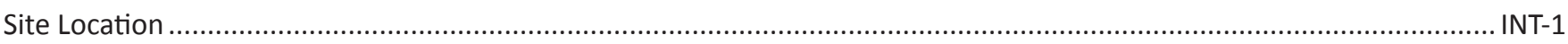

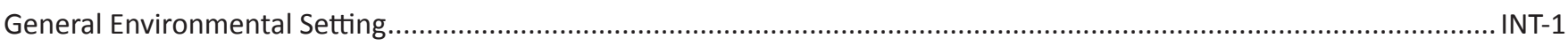

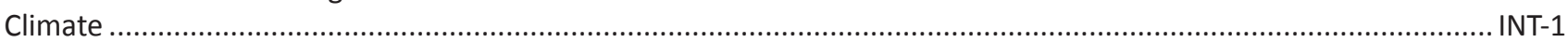

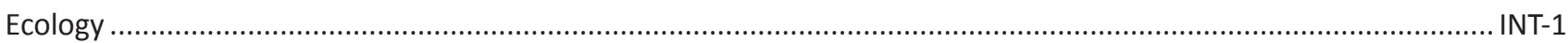

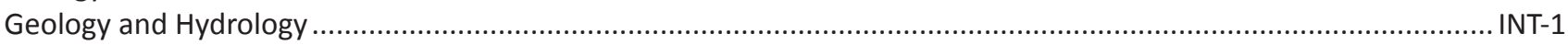

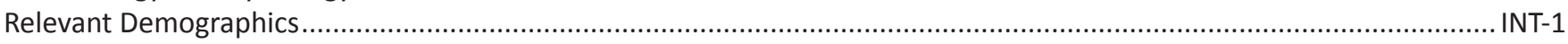

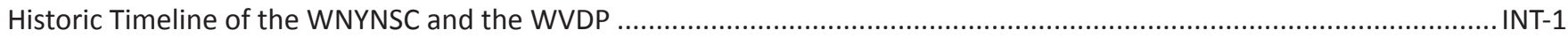

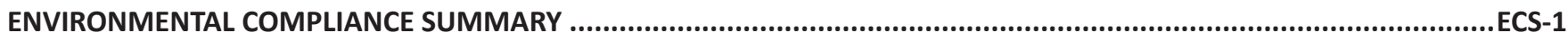

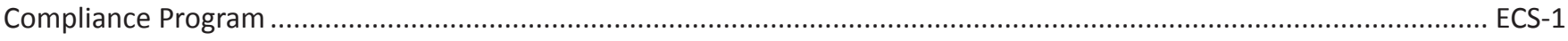

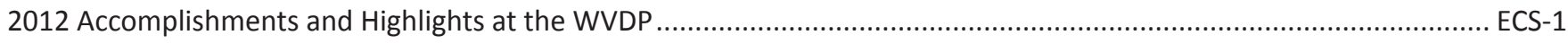

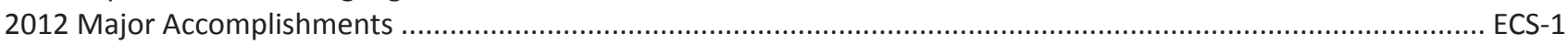

State Pollutant Discharge Elimination System (SPDES) Permit Noncompliance Events ............................................ ECS-2

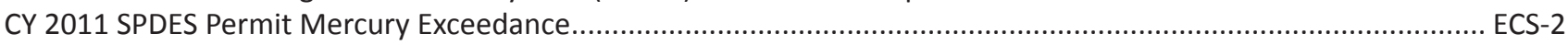

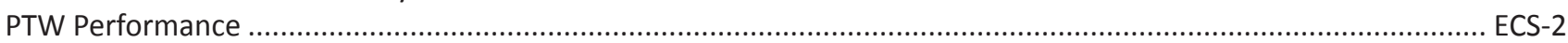

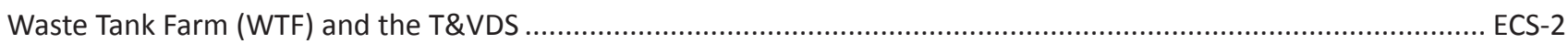

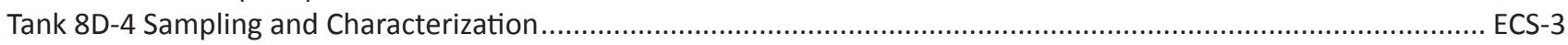

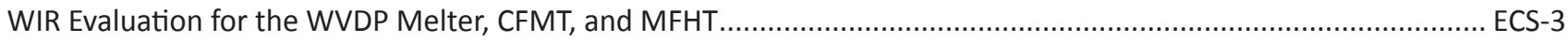

NEPA

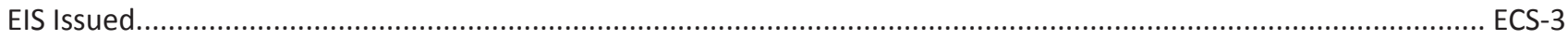

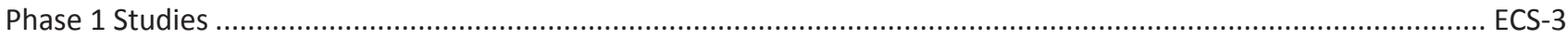




\section{ENVIRONMENTAL COMPLIANCE SUMMARY (concluded)}

\section{NEPA (concluded)}

Phase 1 Decommissioning Plan (DP) for the WVDP

Phase 1 Characterization Sampling and Analysis Plan (CSAP) and the Phase 1 Final Status Survey Plan (FSSP) for the WVDP

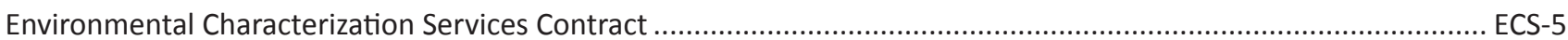

RCRA.

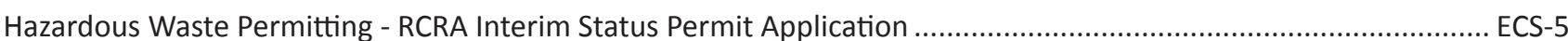

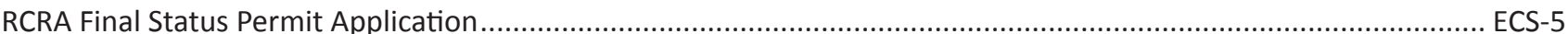

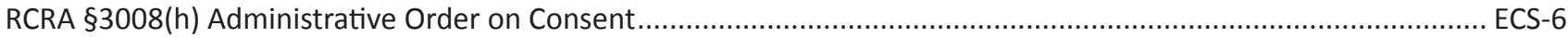

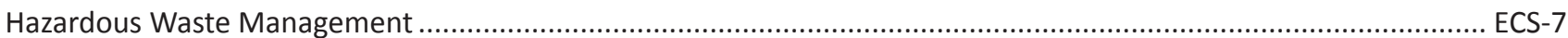

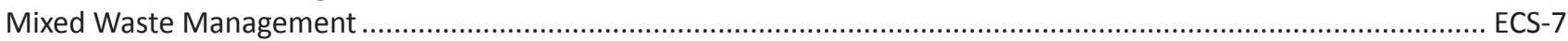

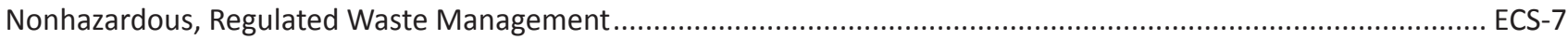

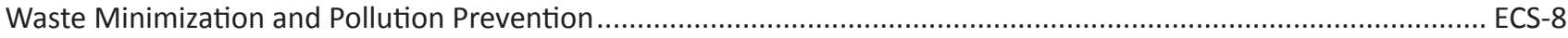

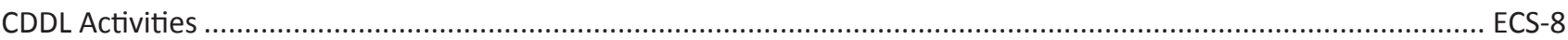

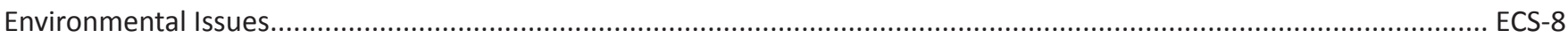

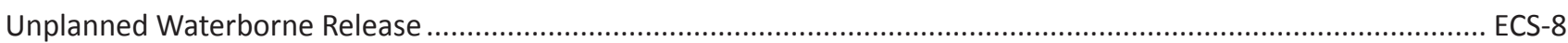

EPA Interim Approval to Use Environmental Measurements for National Emission Standards for Hazardous

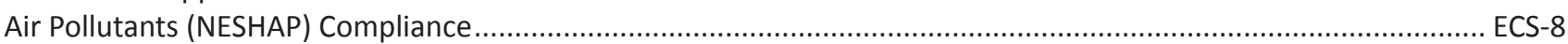

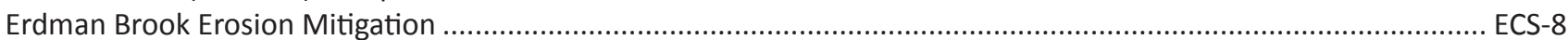

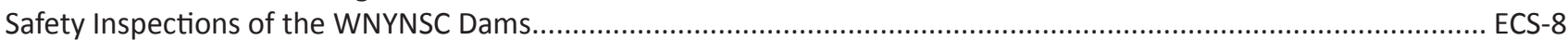

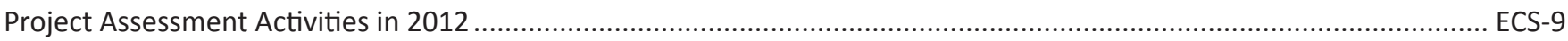

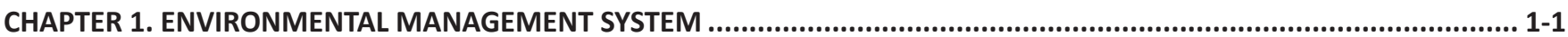

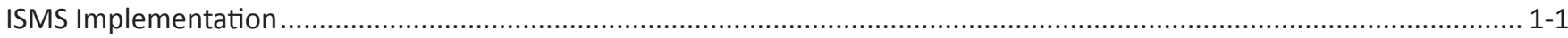

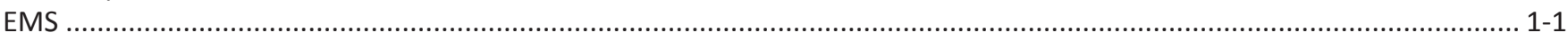

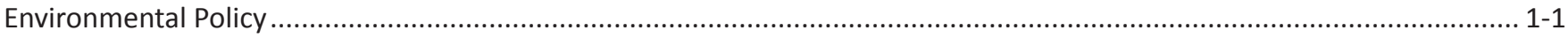

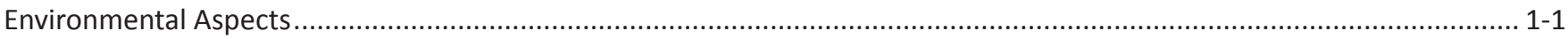

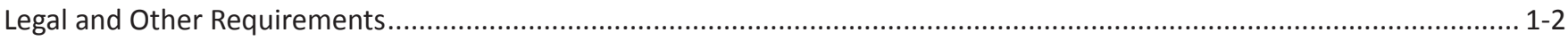

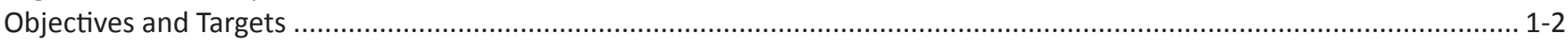

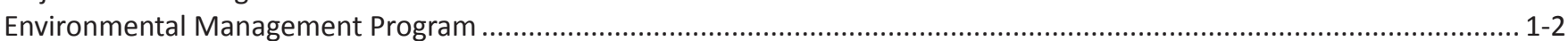

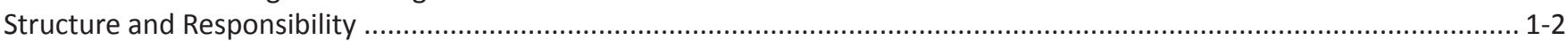

CHBWV West Valley Decommissioning Team Environmental Policy ............................................................... 1-3

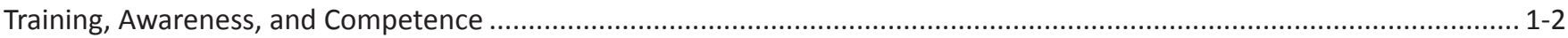

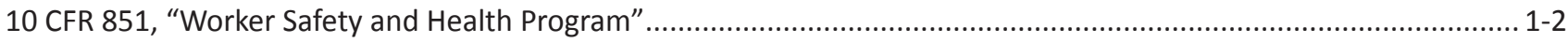

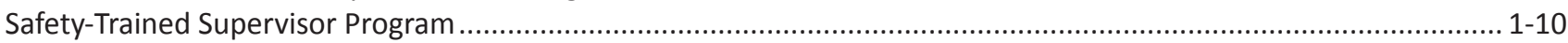

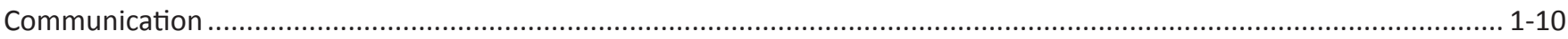

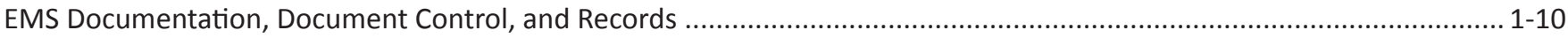

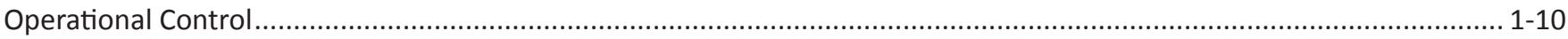

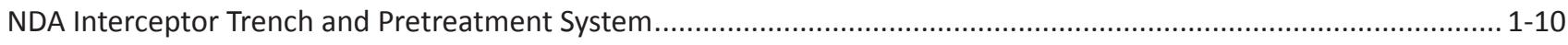

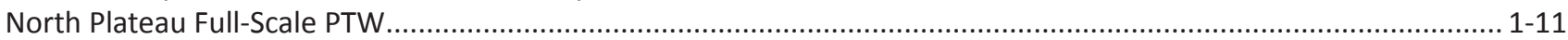

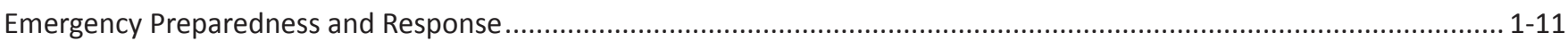

Environmental Monitoring and Measurement..................................................................................................... 11

Environmental Management of Wastewater .............................................................................................. 12

Environmental Management of Airborne Emissions...................................................................................... 1-12

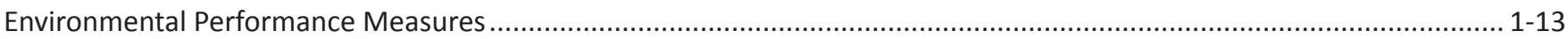

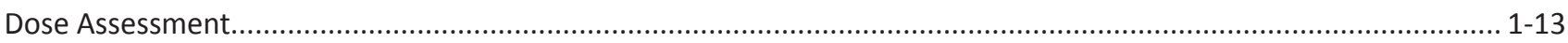

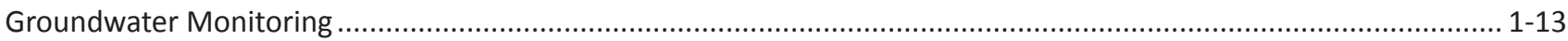

Environmental Management of Radiation Exposure.................................................................................. 13

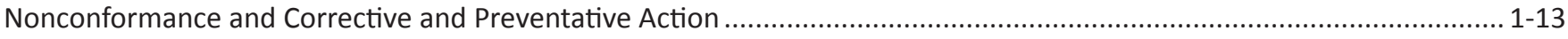




\section{CHAPTER 1. ENVIRONMENTAL MANAGEMENT SYSTEM (concluded)}

QA Program

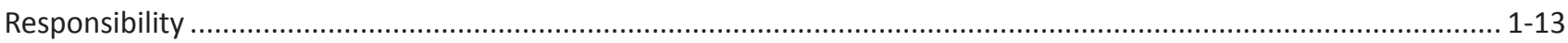

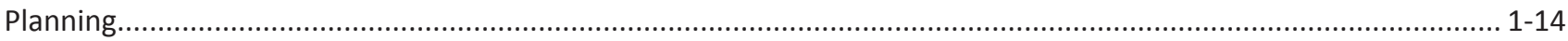

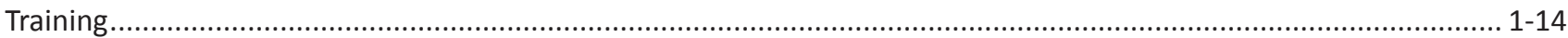

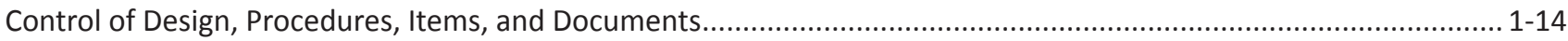

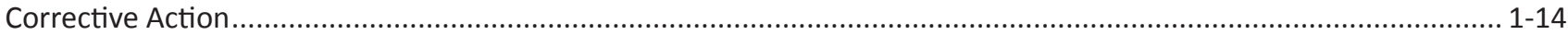

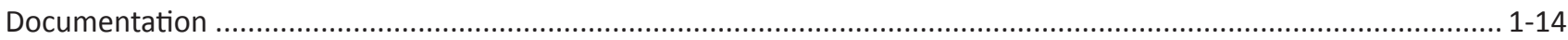

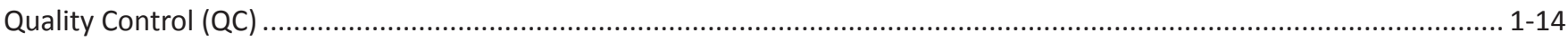

Field QC

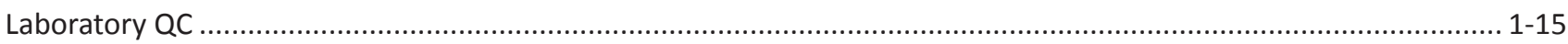

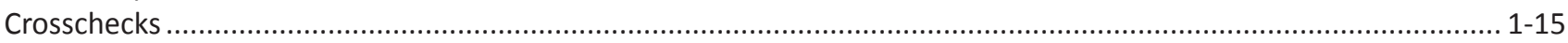

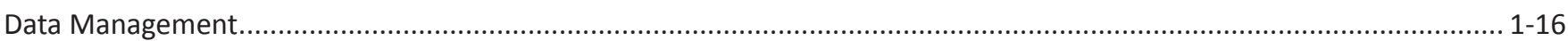

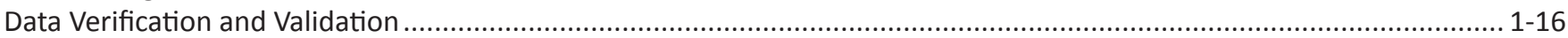

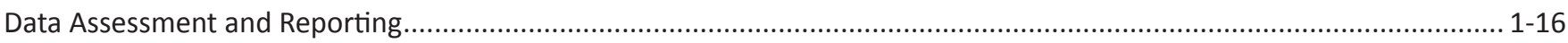

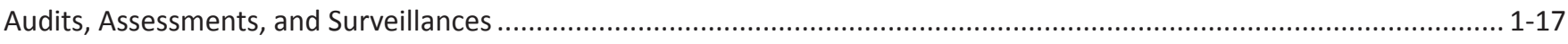

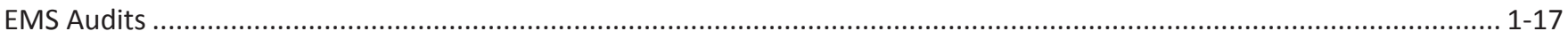

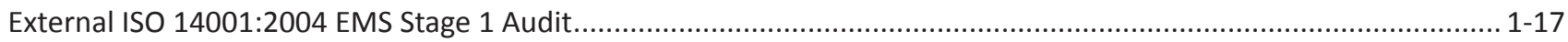

External ISO 14001:2004 EMS Registration Audit ........................................................................................... 1-17

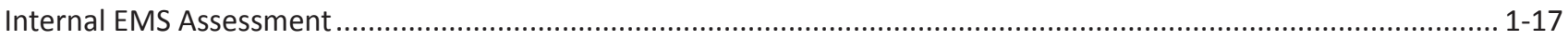

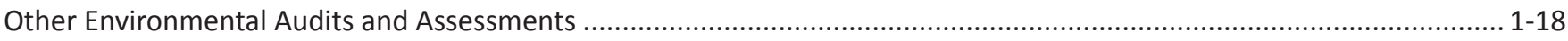

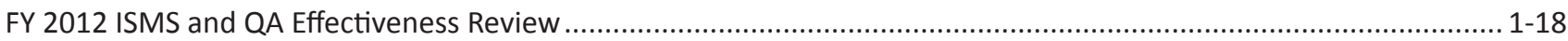

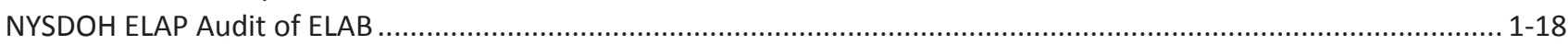

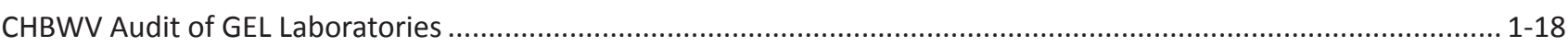

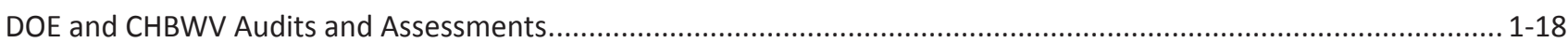

DOE-WVDP Oversight Assessment of RCRA Hazardous Waste Shipments................................................................. 1-18

DOE-WVDP Oversight Assessment of Process for Reporting Spills/References of Petroleum Products ........................ 1-18

DOE-WVDP Oversight Audit of CHBWV Environmental Protection Programs, Surface Water, Drinking Water

Quality, and Groundwater Monitoring Programs ............................................................................................. 1-18

DOE-WVDP Oversight Assessment of the SPDES Program ............................................................................. 1-18

CHBWV Regulatory Strategy Assessment of RCRA Hazardous/Mixed Waste Container Storage Management.............. 1-19

CHBWV Regulatory Strategy Assessment of New SPDES Permit Compliance ............................................................ 1-19

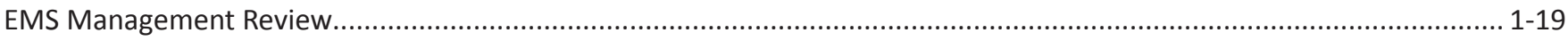

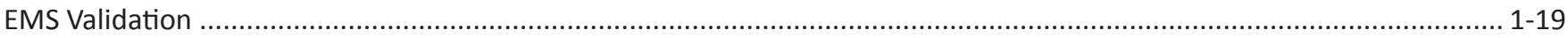

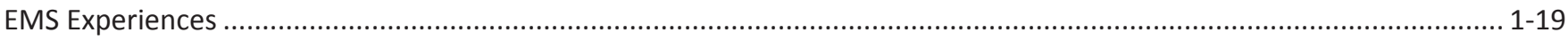

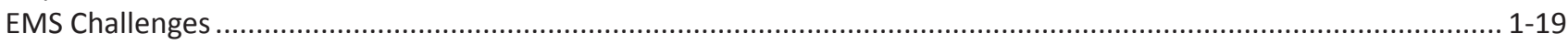

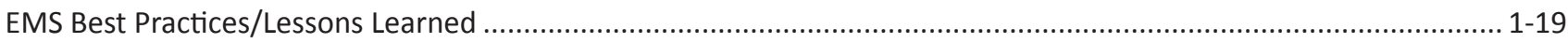

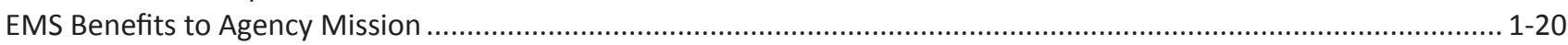

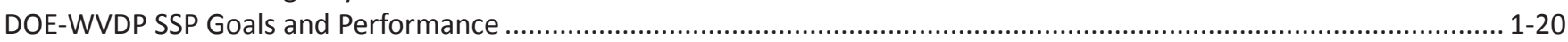

Summary

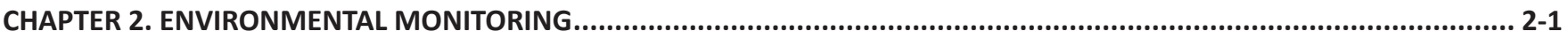

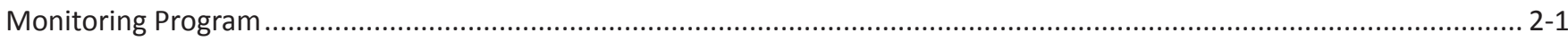

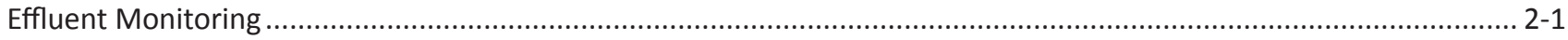

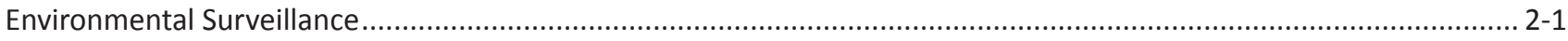

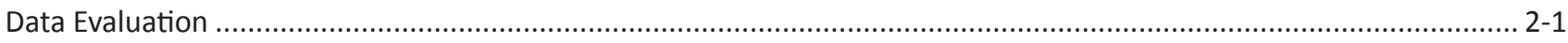

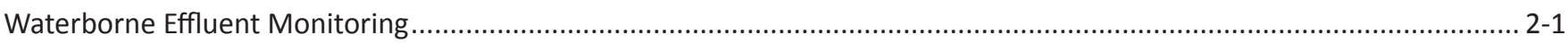

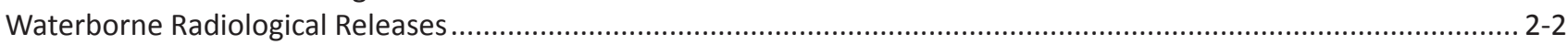

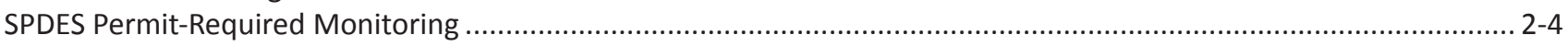

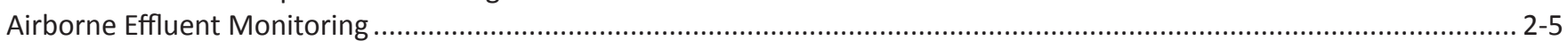




\section{CHAPTER 2. ENVIRONMENTAL MONITORING (concluded)}

Airborne Effluent Monitoring (concluded)

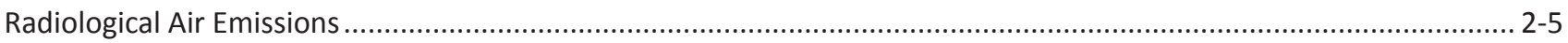

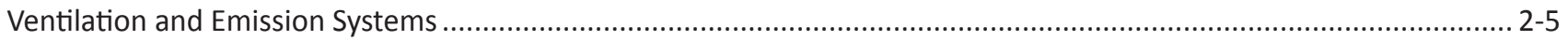

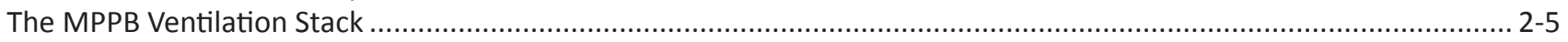

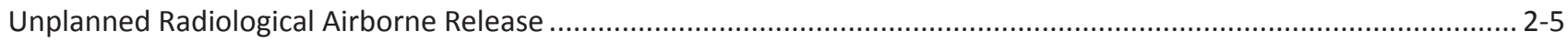

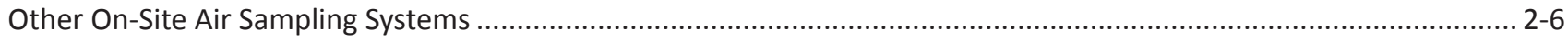

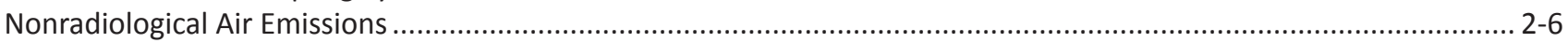

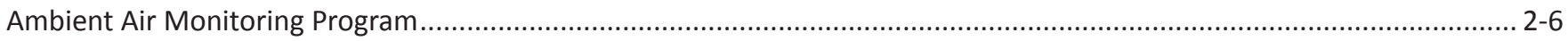

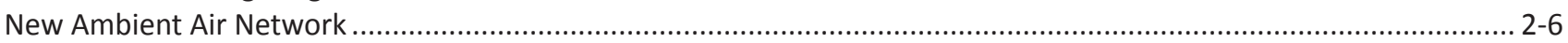

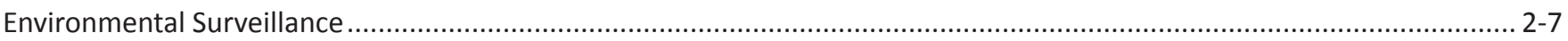

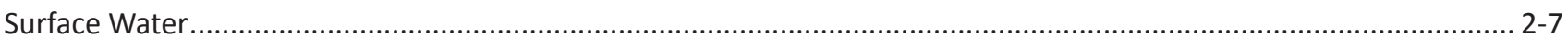

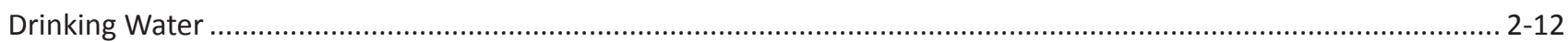

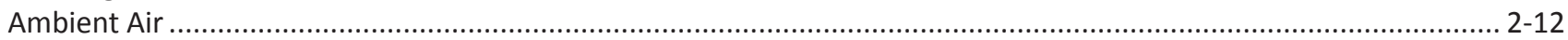

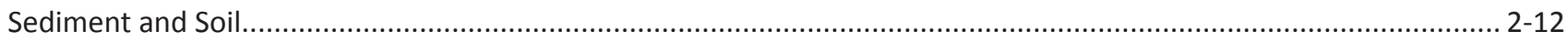

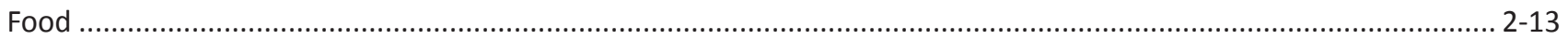

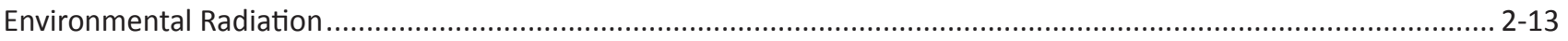

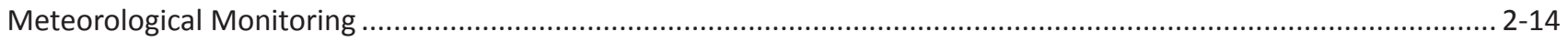

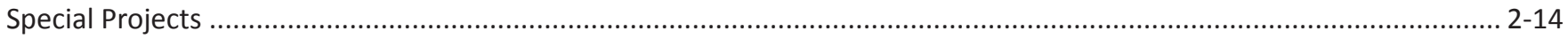

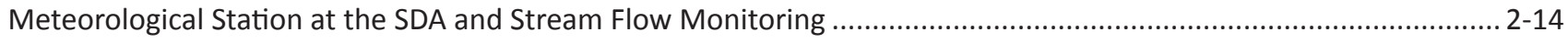

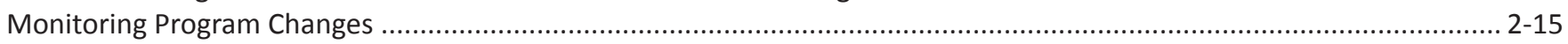

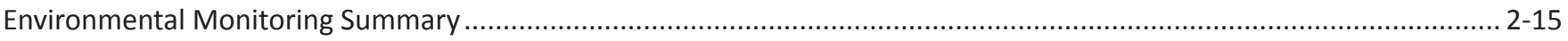

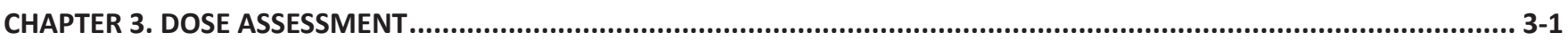

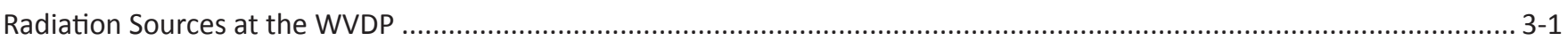

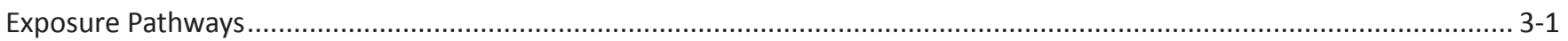

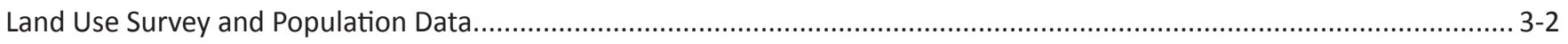

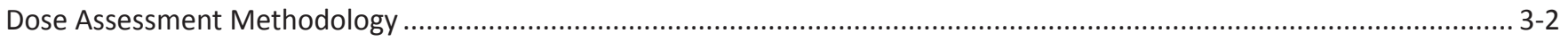

Determination of Radionuclide Concentrations in the Environment from Liquid and Airborne Releases ......................3-2

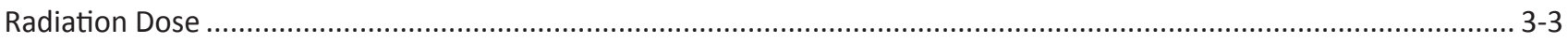

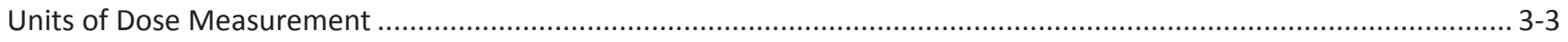

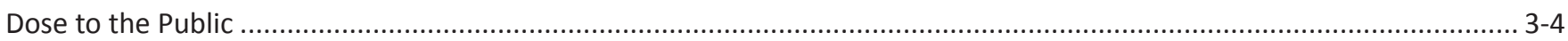

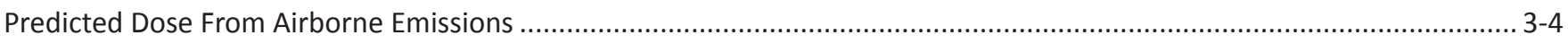

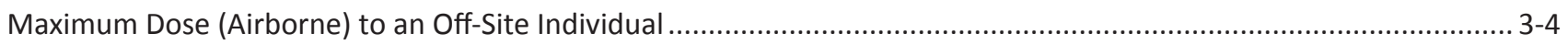

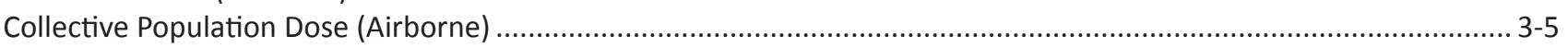

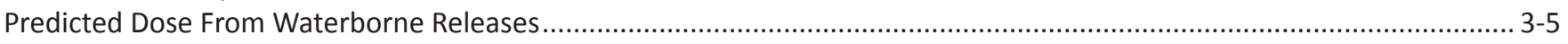

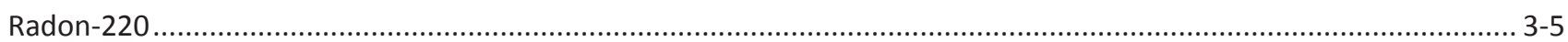

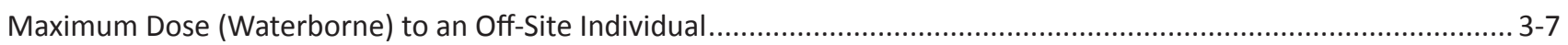

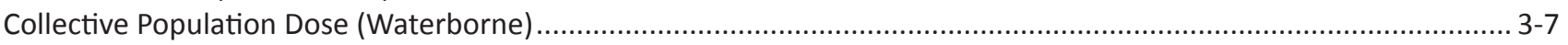

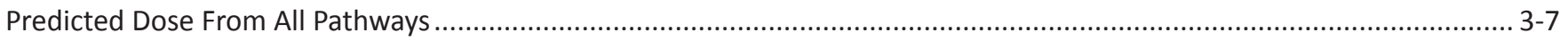

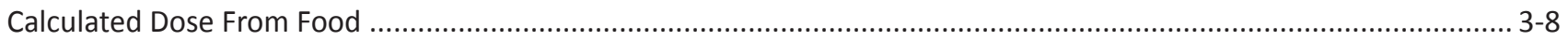

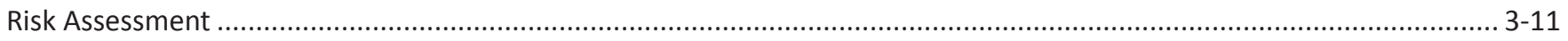

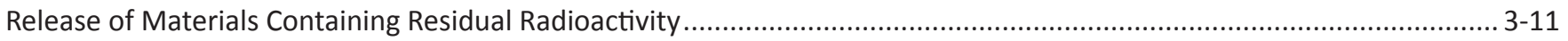

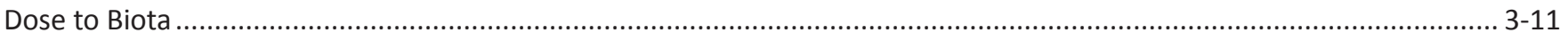

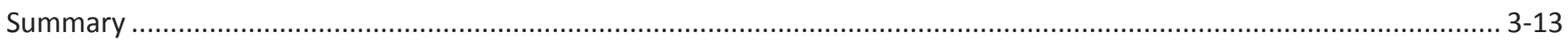

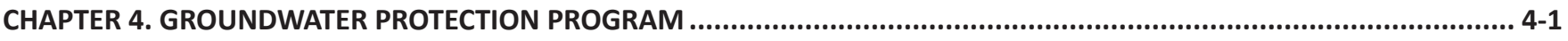

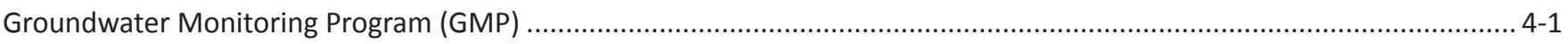

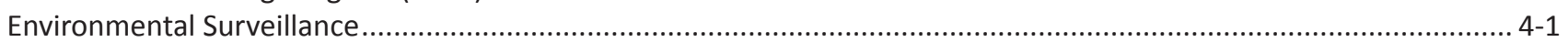




\section{CHAPTER 4. GROUNDWATER PROTECTION PROGRAM (concluded)}

Groundwater Monitoring Program (GMP) (concluded)

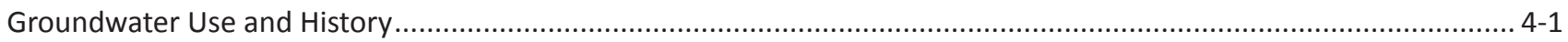

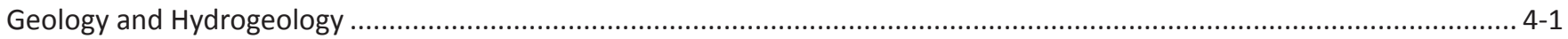

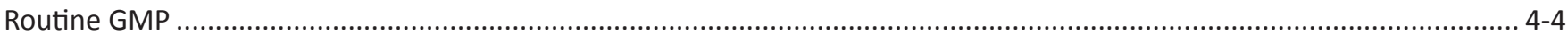

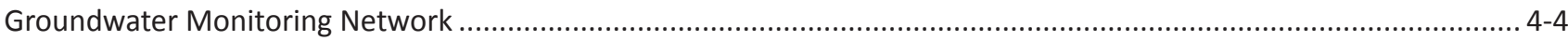

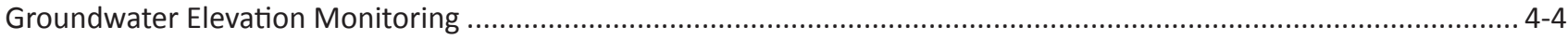

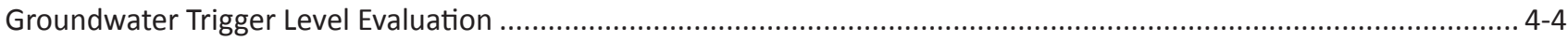

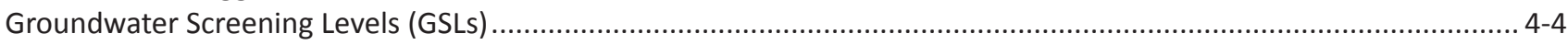

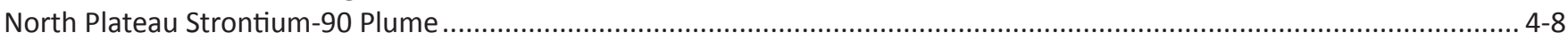

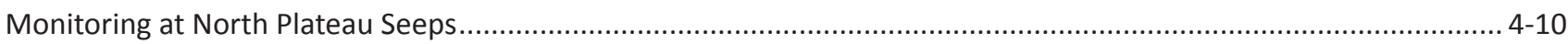

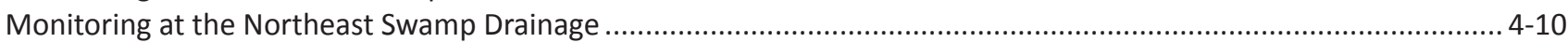

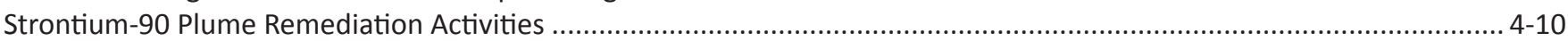

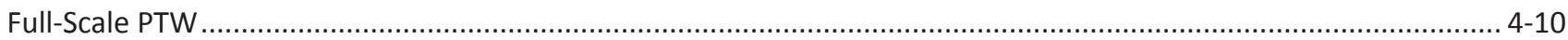

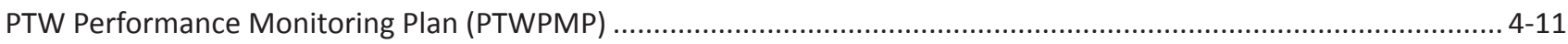

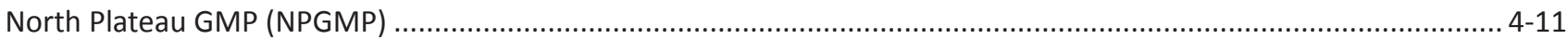

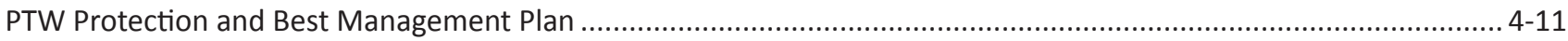

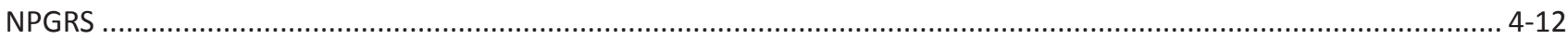

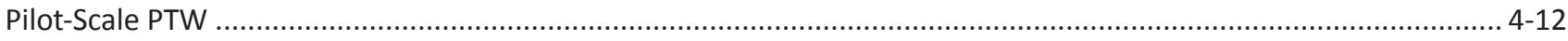

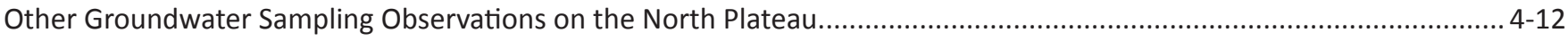

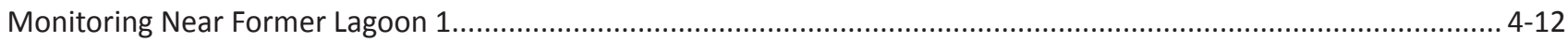

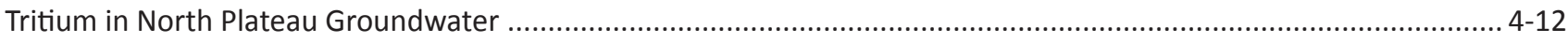

Radioisotopic Sampling Results on the North Plateau ..............................................................................

Results for Volatile and Semivolatile Organic Compounds (VOCs and SVOCs) ...................................................4.12

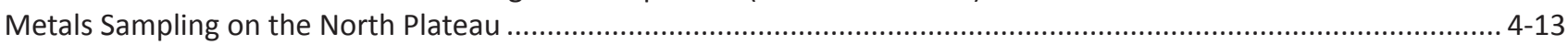

Groundwater Sampling Observations on the South Plateau: Weathered Lavery Till (WLT) and the NDA.......................... 4-13

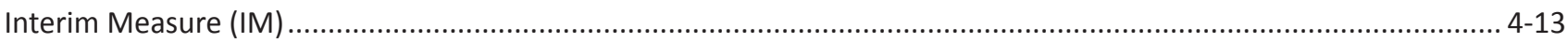

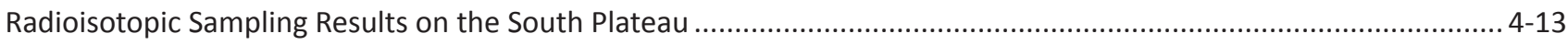

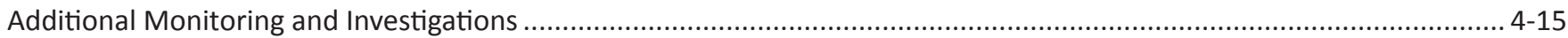

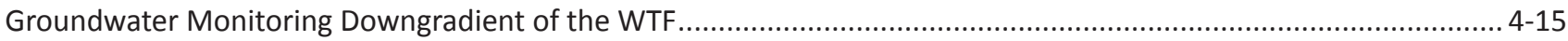

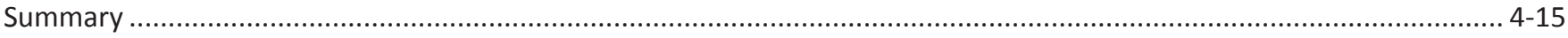

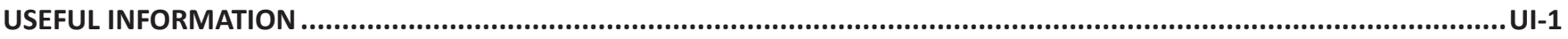

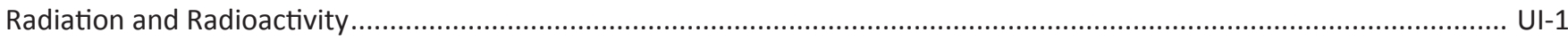

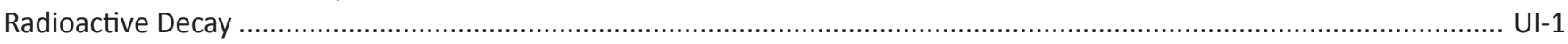

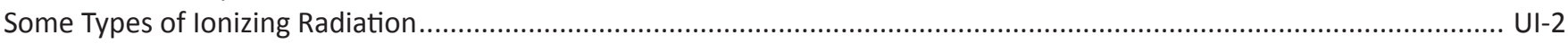

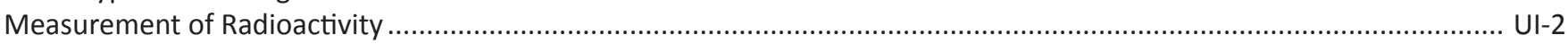

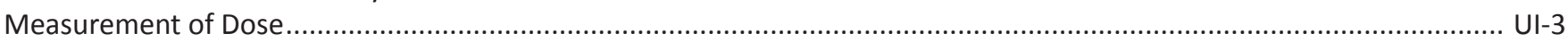

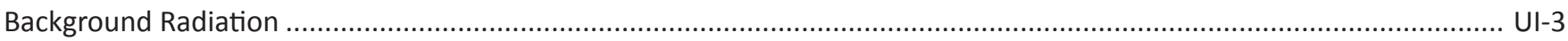

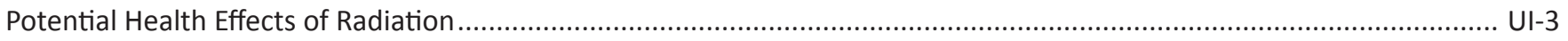

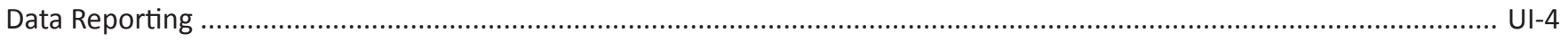

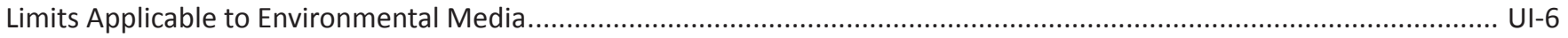

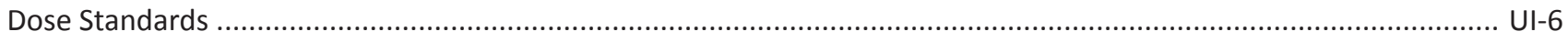

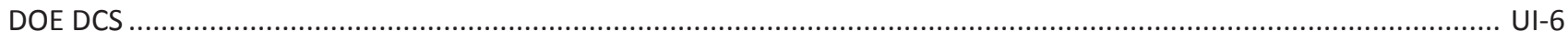

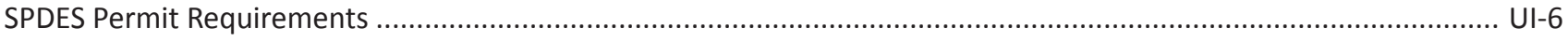

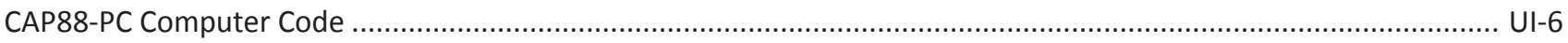

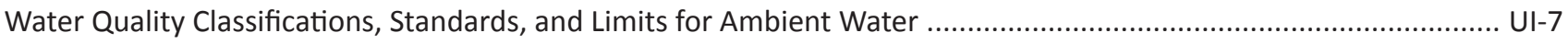

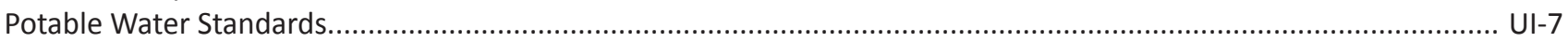

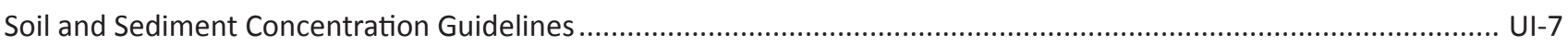

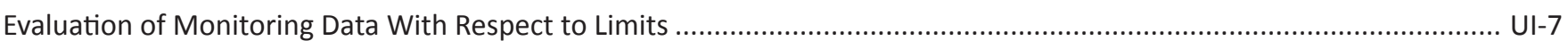


GLOSSARY GLO-1

ACRONYMS AND ABBREVIATIONS A\&A-1

REFERENCES AND BIBLIOGRAPHY R\&B-1

DISTRIBUTION DST-1

ACKNOWLEDGMENTS ACK-1

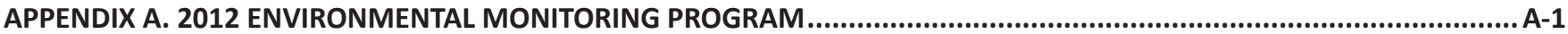

Environmental Monitoring Program Drivers and Sampling Rationale ........................................................................ A

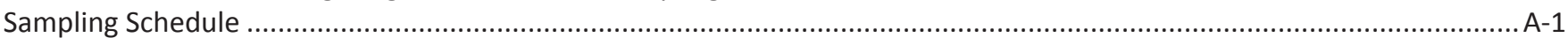

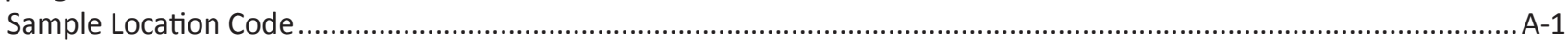

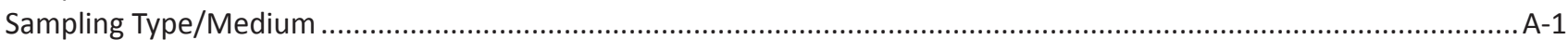

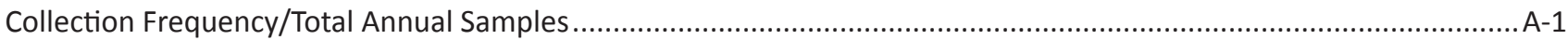

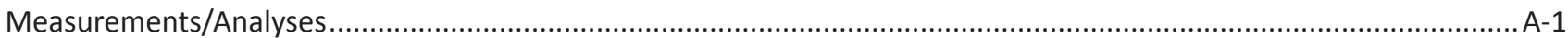

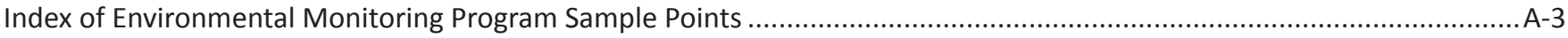

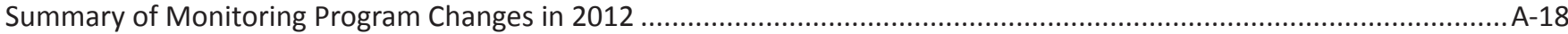

APPENDIX B-1. SUMMARY OF WATER LIMITS, GUIDELINES,AND STANDARDS ..................................................... B-1

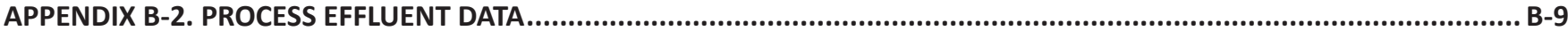

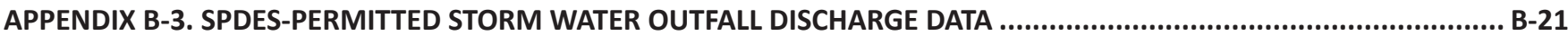

APPENDIX B-4. SITE SURFACE DRAINAGE, SUBSURFACE DRAINAGE, AND CONTAINED WATER DATA........................... B-37

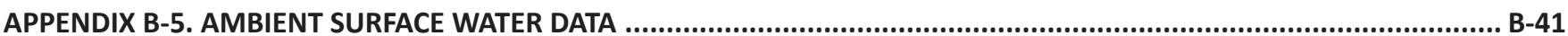

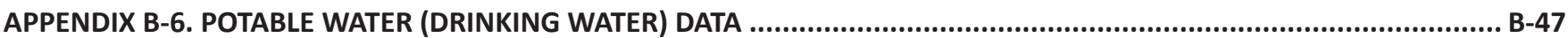

APPENDIX C. SUMMARY OF AIR MONITORING DATA .......................................................................................... C-1

APPENDIX D-1. SUMMARY OF GROUNDWATER SCREENING LEVELS AND PRACTICAL QUANTITATION LIMITS .................. D-1

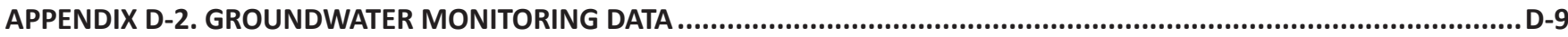

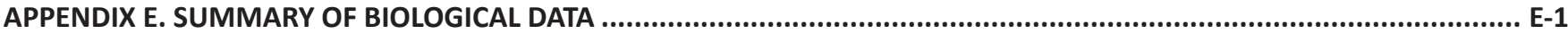

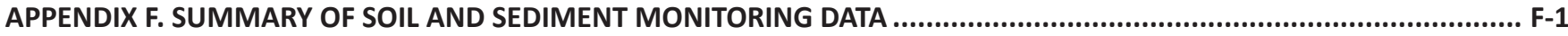

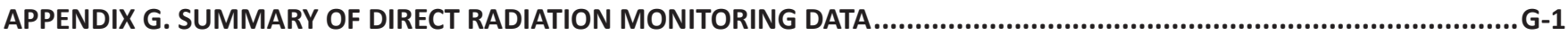

APPENDIX H. SUMMARY OF QUALITY ASSURANCE CROSSCHECK ANALYSES............................................................ H-1

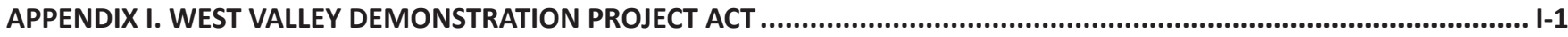




\section{List of Figures}

INT-1 Location of the Western New York Nuclear Service Center

1-1 Annual Effective Dose Equivalent to the Maximally Exposed Off-Site Individual.....

2-1 Average Gross Beta and Strontium-90 Concentrations in Surface Water on the South Plateau at WNNDADR and WNERB53 Before and After the NDA Interim Measure (IM) was Installed....

2-2 Average Concentration of Tritium in Surface Water at WNNDADR: 2003-2012 10-Year Trends of Environmental Radiation Levels at Perimeter and Background Thermoluminescent Dosimeters (TLDs)

Wind Frequency and Speed From the Meteorological Tower (10-m and 60-m Elevations) January 1-

December 31, 2012.

3-1 Comparison of Doses From Natural and Man-Made Sources to the Dose From 2012 WVDP Effluents .................... 3-1

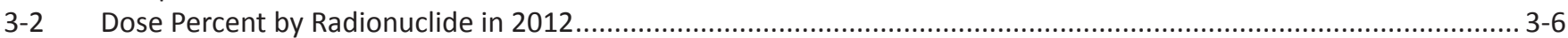

3-3 Effective Dose Equivalent from Liquid and Airborne Effluents to a Maximally Exposed Individual Residing Near the WVDP.

Collective Effective Dose Equivalent From Liquid and Air Effluents to the Population Residing Within 50 Miles

$(80 \mathrm{~km})$ of the WVDP

4-1 Geologic Cross Sections of the North and South Plateaus at the WVDP

4-12 Concentrations of Tributyl Phosphate at Monitoring Wells Near Former Lagoon 1 in the S\&G Unit

4-13 Annual Average Gross Beta Concentrations at Monitoring Wells Downgradient of the NDA and at the NDA Trench

4-14 Volume of Water Pumped From the NDA Interceptor Trench.....

\section{APPENDIX A. 2012 ENVIRONMENTAL MONITORING PROGRAM}

A-1 West Valley Demonstration Project Base Map

A-2 On-Site Surface Water, Drinking Water, and Soil/Sediment Sampling Locations .................................................. A-20

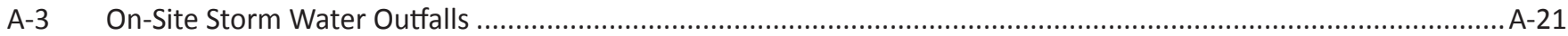

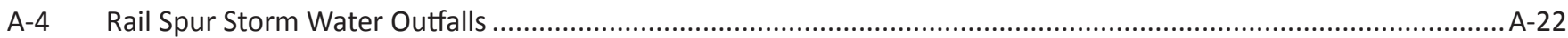

A-5 Off-Site Surface Water and Soil/Sediment Sampling Locations ...................................................................23

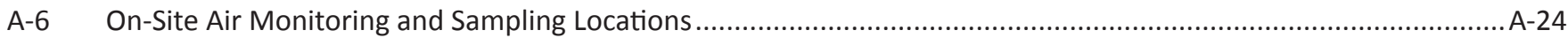

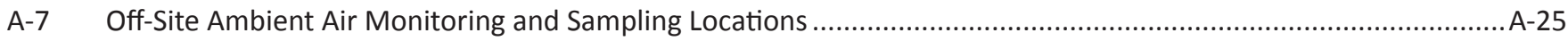

A-8 North Plateau Groundwater Monitoring Network (includes Wells Used for Water-Level Measurements) ............... A-26

A-9 South Plateau Groundwater Monitoring Network (includes Wells Used for Water-Level Measurements) ..............A-27

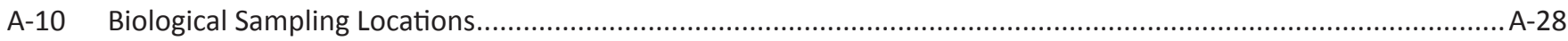

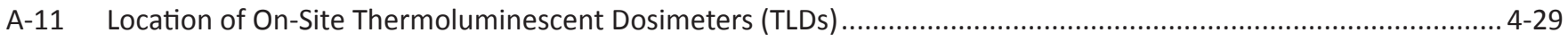




\section{List of Figures (concluded)}

APPENDIX A. 2012 ENVIRONMENTAL MONITORING PROGRAM (concluded)

A-12 Location of Off-Site Thermoluminescent Dosimeters (TLDs) Within 5 Kilometers of the WVDP ...............................30

A-13 Environmental Sampling Locations More Than 5 Kilometers From the WVDP ....................................................31

A-14 Population by Sector Within 80 Kilometers of the WVDP (2002 Estimate) ........................................................32

\section{List of Tables}

INT-1 Historic Timeline of the WNYNSC and the WVDP

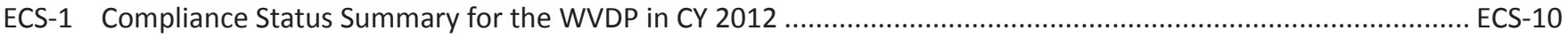

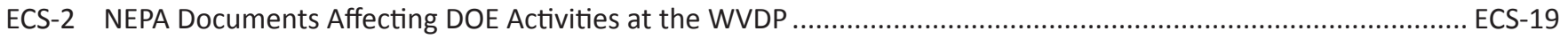

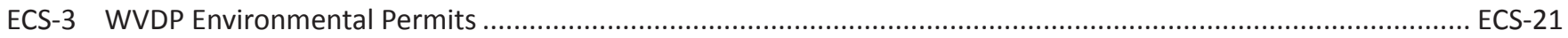

ECS-4 WVDP RCRA SSWMUs and Constituent SWMUs Identified in the RFI under the RCRA 3008(h) Order

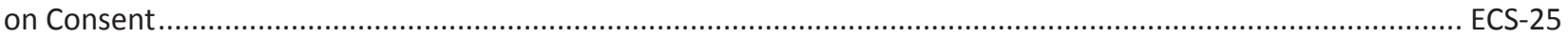

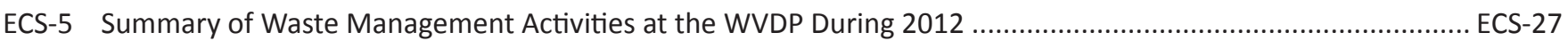

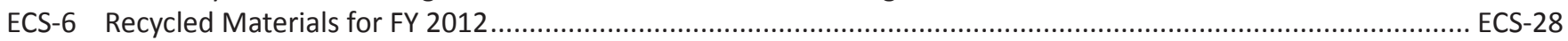

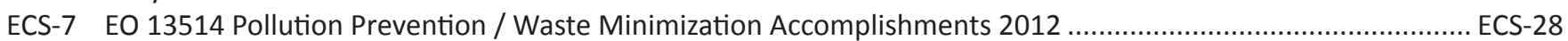

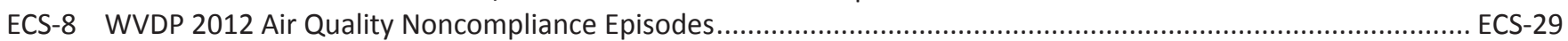

ECS-9 Status of EPCRA (SARA Title III) Reporting at the WVDP For CY 2012 ...........................................................CS-29

ECS-10 Reportable Chemicals Above EPCRA 312 (SARA Title III) Threshold Planning Quantities Stored at the

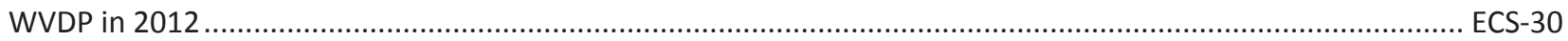

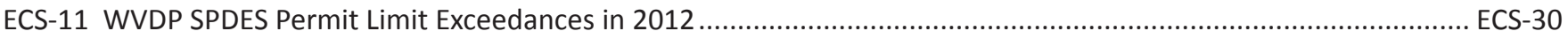

ECS-12 WVDP Migratory Bird Nest Depredation Activities in Fiscal Year 2012 ...........................................................30

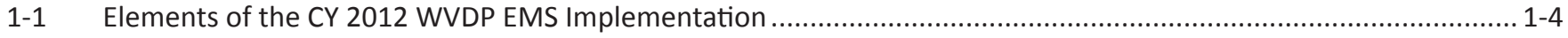

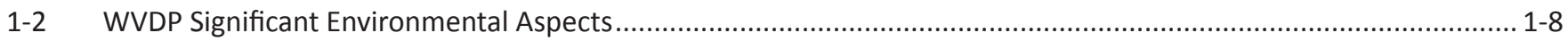

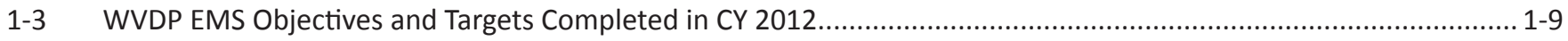

1-4 2012 Radioactivity Releases Versus 10-Year Averages ..............................................................................12

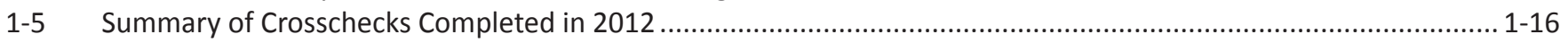

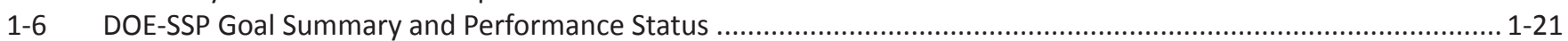

2-1 Total Radioactivity Discharged at Lagoon 3 (WNSP001) in 2012 and Comparison of Discharge Concentrations

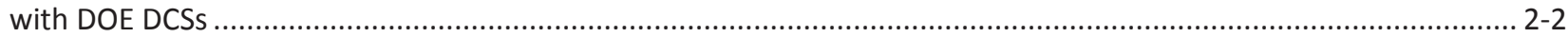

2-2 Total Radioactivity Released at Northeast SWAMP (WNSWAMP) in 2012 and Comparison of Discharge

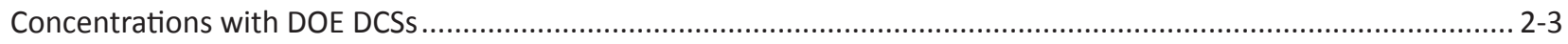

2-3 Total Radioactivity Released at Main Plant Stack (ANSTACK) in 2012 and Comparison of Discharge

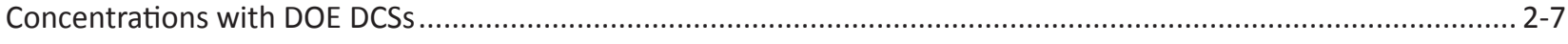

2-4 2012 Comparison of Environmental Monitoring Results with Applicable Limits and Backgrounds ......................... 2-8

2-5 WVDP 2012 Monthly Precipitation Totals Compared with 10-Year Monthly Averages........................................ 2-14

3-1 Potential Exposure Pathways from the WVDP to the Local Off-Site Population ..................................................... 3-2

3-2 Summary of Annual Effective Dose Equivalents (EDEs) to an Individual and Population From WVDP Releases

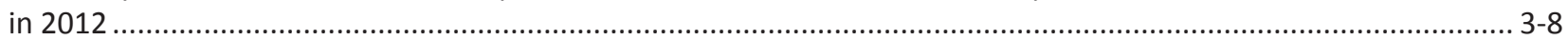

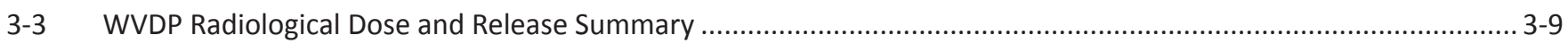

3-4 2012 Evaluation of Dose to Aquatic and Terrestrial Biota............................................................................ $3-12$

4-1 Highlights of Groundwater Monitoring History at the WVDP and the WNYNSC ............................................... 4-2

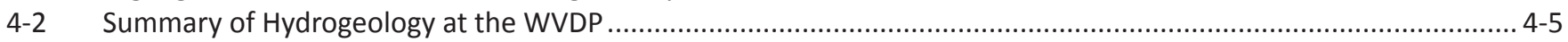




\section{List of Tables (continued)}

4-3 WVDP Groundwater Monitoring Network Sorted by Geologic Unit................................................................ 4-6

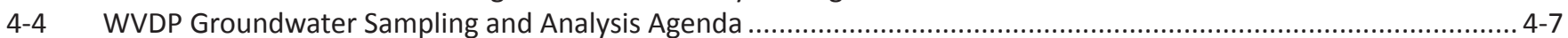

4-5 2012 Groundwater Monitoring Overview by Geographic Area ......................................................................... 4-7

4-6 WVDP 2012 Groundwater Monitoring Overview by Monitoring Purpose............................................................ 4-7

4-7 2012 Maximum Concentrations of Radionuclides in Groundwater at the WVDP Compared With WVDP

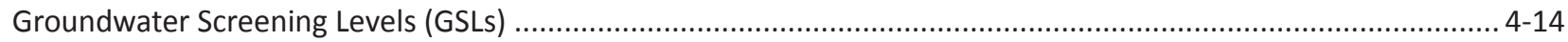

4-8 2012 Summary of Maximum Concentrations or Organic Constituents in Select WVDP Groundwater Wells ............ 4-14

4-9 2012 Groundwater Monitoring Results Exceeding GSLs and Background Levels ............................................4-16

\section{USEFUL INFORMATION}

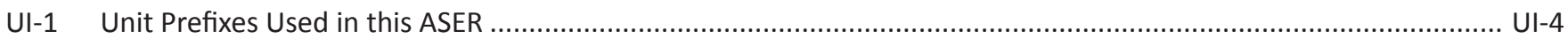

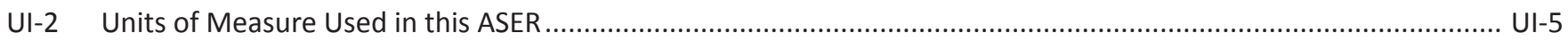

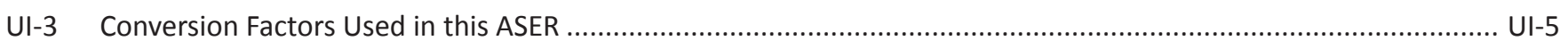

UI-4 U.S. Department of Energy Derived Concentration Standards (DCSs) for Inhaled Air or Ingested Water ( $\mu$ Ci/mL)... UI-8

\section{APPENDIX A. 2012 ENVIRONMENTAL MONITORING PROGRAM}

A-1 WVDP Environmental Program Drivers and Sampling Rationale ..................................................................

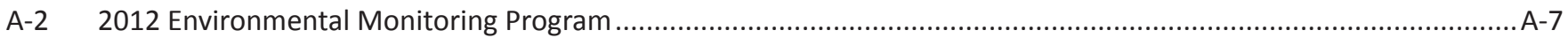

APPENDIX B-1. SUMMARY OF WATER LIMITS, GUIDELINES, AND STANDARDS...................................................... B-1

B-1A West Valley Demonstration Project State Pollutant Discharge Elimination System (SPDES) Sampling Program.......... B-1

B-1B New York State Water Quality Standards and Guidelines ........................................................................... B-4

B-1C New York State Department of Health/U.S. EPA Potable Water MCLs, MCLGs, and Raw Water Standards................ B-6

B-1D Department of Energy (DOE) Derived Concentration Standards (DCSs) in Ingested Water ................................... B-7

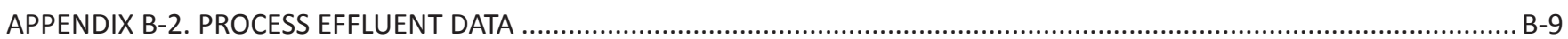

B-2A Comparison of 2012 Lagoon 3 (WNSP001) Liquid Effluent Radioactivity Concentrations With U.S. DOE-

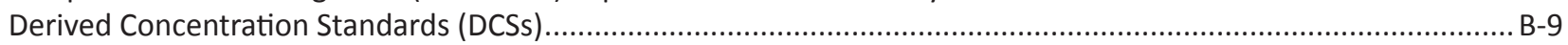

B-2B 2012 SPDES Results for Outfall 001 (WNSP001): Water Quality .................................................................10

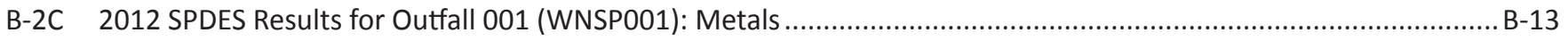

B-2D 2012 SPDES Results for Outfall 007 (WNSP007): Water Quality and Iron .........................................................14

B-2E 2012 SPDES Results for Sums of Outfalls 001, 007, and 116: Water Quality ....................................................16

B-2F 2012 Annual and Semiannual SPDES Results for Outfall 001: Metals, Water Quality and Organic Compounds ........ B-17

B-2G 2012 SPDES Action Level Requirement Monitoring Results for Outfalls 001 and 007 Metals and Water Quality ...... B-18

B-2H 2012 SPDES Results for Outfall 01B (WNSP01B): Water Quality .....................................................................18

B-2I 2012 PARAQUAT DICHLORIDE Data for Storm Water Discharge Monitoring ...........................................................19

B-2J 2012 Radioactivity Results for Sewage Treatment Outfall (WNSP007) ...............................................................19

APPENDIX B-3. SPDES-PERMITTED STORM WATER OUTFALL DISCHARGE DATA ......................................................... B-21

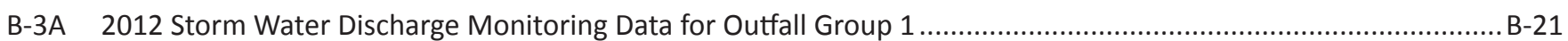

B-3B 2012 Storm Water Discharge Monitoring Data for Outfall Group 2 .................................................................23

B-3C 2012 Storm Water Discharge Monitoring Data for Outfall Group 3 ..................................................................25

B-3D 2012 Storm Water Discharge Monitoring Data for Outfall Group 4 ................................................................27

B-3E 2012 Storm Water Discharge Monitoring Data for Outfall Group 5 .............................................................29

B-3F 2012 Storm Water Discharge Monitoring Data for Outfall Group 6...............................................................31 


\section{List of Tables (continued)}

APPENDIX B-3. SPDES-PERMITTED STORM WATER OUTFALL DISCHARGE DATA (concluded)

B-3G 2012 Storm Water Discharge Monitoring Data for Outfall Group 7 ................................................................33

B-3H 2012 Storm Water Discharge Monitoring Data for Outfall Group 8 ...............................................................35

APPENDIX B-4. SITE SURFACE DRAINAGE, SUBSURFACE DRAINAGE, AND CONTAINED WATER DATA................................ B-37

B-4A 2012 Radioactivity and pH in Surface Water at Facility Year Drainage (WNSP005) ..............................................37

B-4B Comparison of 2012 Radioactivity Concentrations in Surface Water at the North Swamp (WNSW74A)

With U.S. DOE-Derived Concentration Standards (DCSs) ........................................................................... B-38

B-4C Comparison of 2012 Radioactivity Concentrations in Surface Water at the Northeast Swamp (WNSWAMP)

with U.S. DOE-Derived Concentrations Standards (DCSs) ...........................................................................

B-4D 2012 Radioactivity in Surface Water Drainage Between the NDA and SDA (WNNDADR) .................................... B-39

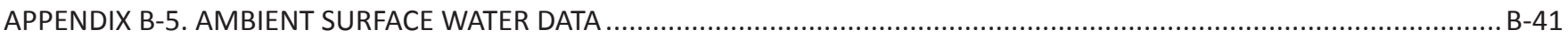

B-5A 2012 Radioactivity and pH in Surface Water Downstream of the WVDP in Cattaraugus Creek at Felton

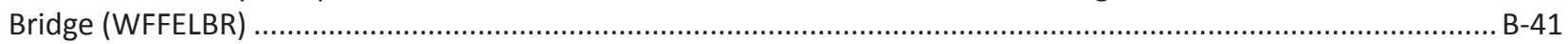

B-5B 2012 Water Quality of Surface Water Downstream of the WVDP in Buttermilk Creek at Thomas Corners

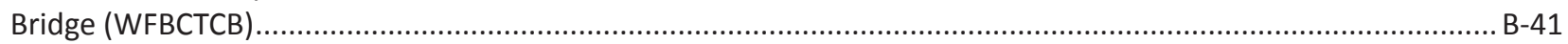

B-5C 2012 Radioactivity of Surface Water Downstream of the WVDP at Franks Creek (WNSP006) ................................ B-44

B-5D 2012 Radioactivity and $\mathrm{pH}$ in Surface Water at Erdman Brook (WNERB53) ......................................................44

B-5E 2012 Radioactivity and pH in Surface Water at Franks Creek (WNFRC67) .......................................................45

B-5F Historical Radioactivity and pH in Surface Water at Bigelow Bridge Cattaraugus Creek Background (WFBIGBR)...... B-45

B-5G 2012 Radioactivity and pH in Surface Water at Fox Valley Road Buttermilk Creek Background (WFBCBKG)............. B-46

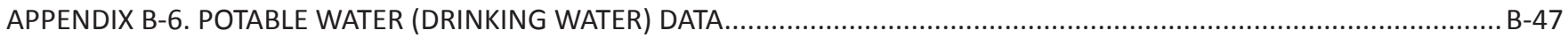

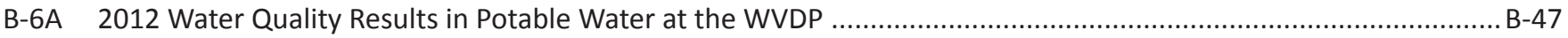

B-6B 2012 Water Quality Results in Utility Room Potable Water (Entry Point 002) .....................................................47

B-6C 2012 Water Quality Results in Utility Room Raw (Untreated) Water ..................................................................48

B-6D 2012 Biological and Chlorine Results From Various Site Tap Water Locations (Analyzed by Cattaraugus

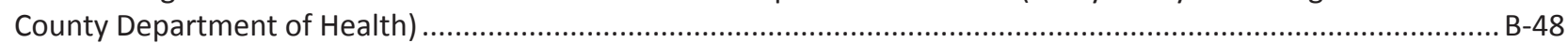

B-6E 2012 Nitrate Results From the Utility Room Raw Tap Water (Analyzed by Cattaraugus County Department

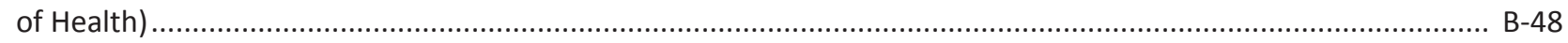

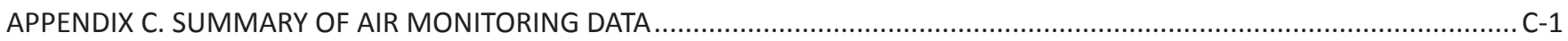

C-1 Total Radioactivity Released at Main Plant Stack (ANSTACK) in 2012 and Comparison of Discharge Concentrations with U.S. DOE-Derived Concentration Standards (DCSs) .......................................................

C-2 2012 Effluent Airborne Radioactivity at Vitrification System HVAC (ANVITSK) ......................................................

C-3 2012 Effluent Airborne Radioactivity at 01-14 Building (ANCSSTK) ..................................................................

C-4 2012 Airborne Radioactivity at Contract Size-Reduction Facility (ANCSRFK) ........................................................ C-3

C-5 2012 Effluent Airborne Radioactivity at Supernatant Treatment System (ANSTSTK) ............................................... C-3

C-6 2012 Effluent Airborne Radioactivity at Container Sorting and Packaging Facility (ANCSPFK) ................................. C-4

C-7 2012 Effluent Airborne Radioactivity at Outdoor Ventilation Enclosures/Portable Ventilation Units (OVEs/PVUs).... C-4

C-8 2012 Effluent Airborne Radioactivity at Remote-Handled Waste Facility (ANRHWFK) ............................................. C-5

C-9 2012 Ambient Airborne Radioactivity and Background Great Valley Location (AFGRVAL) .................................... C-5 


\section{List of Tables (concluded)}

APPENDIX C. SUMMARY OF AIR MONITORING DATA (concluded)

C-10 2012 Gross Alpha and Beta Radioactivity at Nearsite Ambient Air Sampling Locations and at Background

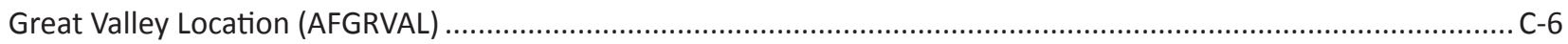

C-11 2012 Ambient Airborne Radioisotope Activity and Background Great Valley Location (AFGRVAL) ......................... C-7

APPENDIX D-1. SUMMARY OF GROUNDWATER SCREENING LEVELS AND PRACTICAL QUANTITATION LIMITS ......................D-1

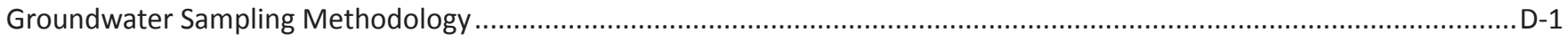

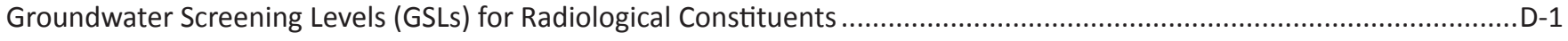

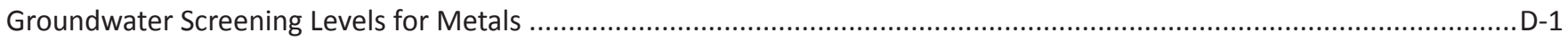

D-1A Groundwater Screening Levels (GSLs) for Radiological Constituents..............................................................

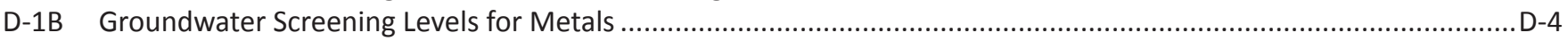

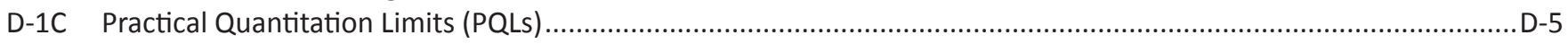

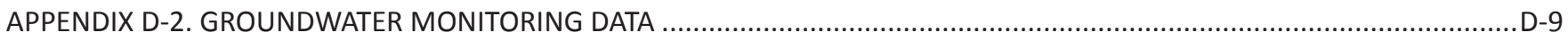

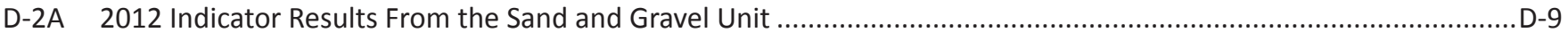

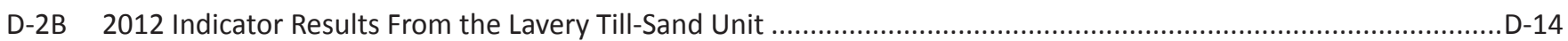

D-2C 2012 Indicator Results From the Weathered Lavery Till Unit..........................................................................15

D-2D 2012 Indicator Results From the Unweathered Lavery Till ......................................................................16

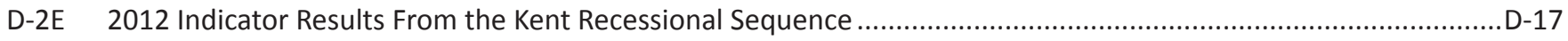

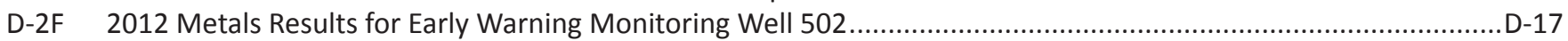

D-2G 2012 Results for Metals in Groundwater Compared With WVDP Groundwater Screening Levels .........................D-18

D-2H 2012 Radioactivity in Groundwater From Selected Monitoring Locations .......................................................

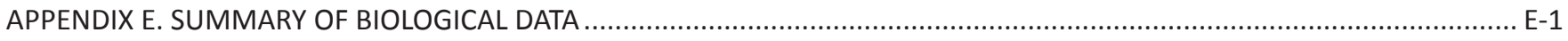

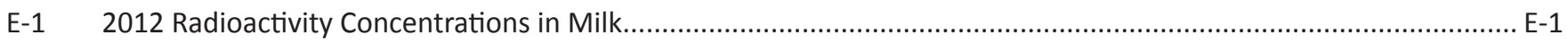

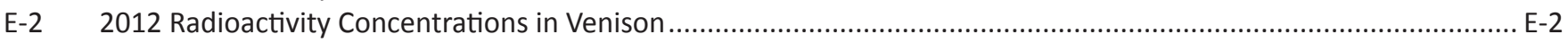

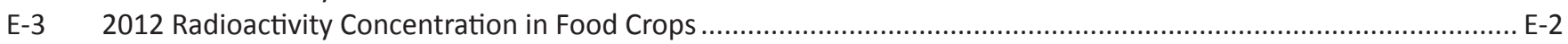

E-4 2012 Radioactivity Concentrations in Edible Portions of Fish From Cattaraugus Creek......................................... E-3

APPENDIX F. SUMMARY OF SOIL AND SEDIMENT MONITORING DATA .............................................................. F-1

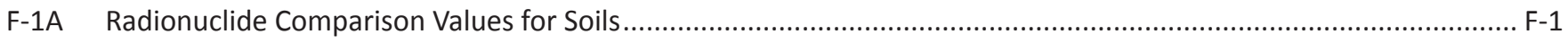

F-2A 2012 Contaminants in On-Site Soils Downstream of the WVDP at Franks Creek (WNSP006) ................................. F-2

F-2B 2012 Contaminants in On-Site Soils From North Swamp (SNSW74A) .......................................................... F-3

F-2C 2012 Contaminants in On-Site Soils From Northeast Swamp (SNSWAMP) .................................................... F-4

F-2D 2012 Results in Surface Soils Collected at Air Stations Around the WVDP .......................................................... F-5

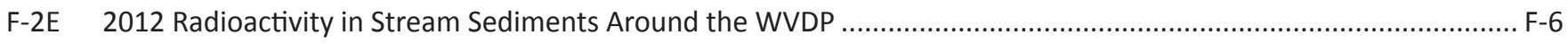

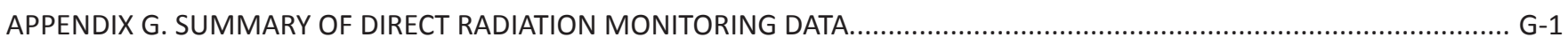

G-1 Summary of 2012 Semiannual Averages of Off-Site TLD Measurements........................................................... G-1

G-2 Summary of 2012 Semiannual Averages of On-Site TLD Measurements ............................................................. G-2 


\section{List of Tables (concluded)}

APPENDIX H. SUMMARY OF QUALITY ASSURANCE CROSSCHECK ANALYSES

H-1 Crosscheck Sample Comparisons From the DOE Mixed Analyte Performance Evaluation Program (MAPEP); Study 26, February 2012

H-2 Crosscheck Sample Comparisons From the DOE Mixed Analyte Performance Evaluation Program (MAPEP); Study 27; August 2012.

H-3 Comparisons of Results from Crosscheck Samples Analyzed for Water Quality Parameters as Part of the EPA's 2012 Discharge Monitoring Report - Quality Assurance (DMR-QA) Study 32; (2012) for the National Pollutant Discharge Elimination System (NPDES)

APPENDIX I. WEST VALLEY DEMONSTRATION PROJECT ACT 


\section{EXECUTIVE SUMMARY}

\section{Purpose of This Report}

The Annual Site Environmental Report (ASER) for the West Valley Demonstration Project (WVDP or Project) is published to provide information about environmental conditions at the WVDP to members of the public, to the United States (U.S.) Department of Energy (DOE) Headquarters, and to other interested stakeholders. In accordance with DOE Order 231.1B, "Environment, Safety, and Health Reporting," this document summarizes calendar year (CY) 2012 environmental monitoring data, describes the performance of the WVDP's environmental management system (EMS), confirms compliance with environmental standards and regulations, and highlights important environmental monitoring programs. WVDP activities are conducted in cooperation with the New York State Energy Research and Development Authority (NYSERDA).

\section{Major Site Programs}

The WVDP is located on the site of a former commercial nuclear fuel reprocessing plant, which shut down in 1976. In 1980, Public Law 96-368 (the WVDP Act) was passed, which authorized DOE to demonstrate a method for solidifying approximately 660,000 gallons (gal) (2.5 million liters [L]) of liquid high-level radioactive waste (HLW) that remained at the site. HLW vitrification (VIT) began in 1996 and was completed in September 2002. Activities for decontaminating and dismantling the facilities and for managing and disposing of wastes were then initiated and continued through CY 2012.

Record of Decision. In April 2010, DOE released a Record of Decision (ROD) for the Final Environmental Impact Statement (FEIS) for the WVDP and the Western New York Nuclear Service Center (WNYNSC) ("Final Environmental Impact Statement for Decommissioning and/or Long-Term Stewardship at the West Valley Demonstration Project and Western New York Service Center," DOE/ EIS-0226, issued on January 29, 2010), allowing for the continued decommissioning and cleanup efforts at the site using a two-part phased decisionmaking process. NYSERDA published its corresponding decision under the State Environmental Quality Review Act in a statement of findings in May 2010. In the FEIS, DOE and NYSERDA evaluated four alternatives: Sitewide Removal, Sitewide
Close-In-Place, Phased Decision Making (the Preferred Alternative), and No Action.

Under the Phased Decisionmaking alternative, the work will be conducted in two phases. Actions identified under Phase 1 Site Decommissioning are being carried out under a facilities disposition contract awarded in 2011 and discussed below. During Phase 1, originally estimated to take about 10 years, a number of highly contaminated facilities would be removed at an originally estimated cost of approximately 1 billion dollars. Phase 1 also includes characterization work and focused studies that could facilitate future decisionmaking for the remaining facilities or areas on the property. DOE intends to complete any remaining WVDP decisionmaking with its Phase 2 decision (to be made within 10 years of the ROD) and expects to select either removal or in-place closure, or a combination of those two for the portions of the site for which it has decommissioning responsibility. The complete EIS and the ROD can be viewed online at the DOEWVDP website at www.wv.doe.gov.

On February 25, 2010, the U.S. Nuclear Regulatory Commission (NRC) transmitted to DOE-WVDP the "Technical Evaluation Report for the Phase 1 Decommissioning Plan (DP)," concluding that the Phase 1 DP was consistent with the preferred alternative in the EIS. NRC also determined that there is reasonable assurance that the proposed actions will meet the decommissioning criteria.

DOE/NYSERDA Consent Decree. DOE and NYSERDA reached an agreement on the cost sharing for cleanup of the WVDP and the WNYNSC by signing a Consent Decree on August 17, 2010 in the U.S. District Court, Western District of New York. While the Consent Decree defines the cost-sharing agreement, it does not affect in any way what the cleanup will be or the end state of the WVDP and the WNYNSC.

Facilities Disposition Contract. On June 30, 2011, DOE awarded the Phase 1 Decommissioning and Facility Disposition Contract to $\mathrm{CH} 2 \mathrm{M} \mathrm{HILL} \bullet$ Babcock \& Wilcox, LLC (CHBWV). CHBWV is made up of $\mathrm{CH} 2 \mathrm{M}$ HILL Constructors Inc., Babcock \& Wilcox Technical Services Group, Inc., and Environmental Chemical Corporation. CHBWV's small business protege is American Demolition and Nuclear Decommissioning, Inc. The term of the contract 
is approximately seven years. The scope of the contract is divided into four primary milestones described below.

The contract status at the end of CY 2012 for the Facilities Disposition Contract scope of work includes:

Milestone 1 - Completion of HLW canister relocation at the WVDP: Design of the system is complete and under review. The first activities will be construction of the storage pad and construction of numerous vertical storage casks.

Milestone 2 - Processing, shipment and disposal of all legacy waste off site: low-level waste (LLW) shipment is $34 \%$ complete, mixed LLW shipment is $25 \%$ complete, and industrial and hazardous waste shipment is $100 \%$ complete.

Milestone 3 - Demolition and removal of the main plant process building (MPPB) and the VIT facility: Preparations continue for demolition, including removal of asbestos, piping, ceiling grids, lighting and isolation of utility lines.

Milestone 4 - Completion of all work described in the Performance Work Statement (including Resource Conservation and Recovery Act [RCRA] clean closure of the remote handled waste facility (RHWF) and disposition of the balance of site facilities: Demolition of several nonradiological facilities was completed in 2012, including the maintenance storage area, product storage area, old warehouse and counting lab slabs, vehicle repair shop, VIT test facility waste area slab, VIT construction fabrication shop slab, and waste tank farm (WTF) test tower. Demolition of the 01-14 building began in 2012 and was completed in 2013.

The CHBWV contract scope also includes continuing safe operation of the site which involves:

- managing and maintaining site infrastructure;

- maintaining the lagoon system;

- conducting environmental monitoring; and

- maintaining the underground HLW storage tanks, the NRC-licensed disposal area (NDA), and the north plateau permeable treatment wall (PTW).

Phase 1 Studies. In September 2011, DOE and NYSERDA jointly awarded the Phase 1 Studies contract to Enviro Compliance Solutions, Inc., an independent, agency-neutral contractor that is jointly funded by the agencies to administer contracts for all Phase 1 Study activities, including contracting with the facilitator, subject matter experts (SMEs), the independent scientific panel (ISP), and contractors performing the study activities. DOE and
NYSERDA intend to conduct these scientific studies to facilitate interagency consensus to complete decommissioning of the remaining facilities.

The Phase 1 Study process employs the ISP and teams of SMEs to evaluate the currently identified Potential Areas of Study (PAS). During 2012, the following teams of SMEs started to evaluate their respective PAS to develop Phase 1 Study recommendations:

- engineered barriers working group,

- exhumation working group; and

- erosion working group (EWG).

A climate change workshop was held in August 2012 where climate scientists shared their ideas on climate change topics as they relate to decommissioning and/or long-term stewardship.

In January 2013, the ISP provided comments to DOE and NYSERDA on the document titled "Recommendations for Phase 1 Erosion Studies," prepared by the EWG, dated July 20, 2012.

Environmental Characterization Support Services. A separate contract was awarded by DOE to Safety and Ecology Corporation (SEC) to implement work associated with the Phase 1 environmental characterization support services, including work associated with the Phase 1 Characterization Sampling and Analysis Plan and the Final Status Survey Plan, which support Phase 1 decommissioning for the WVDP.

Services to be provided by SEC may include, but are not limited to:

- soil, sediment, and groundwater characterization;

- environmental monitoring; and

- preparation of applicable regulatory documentation supporting WVDP decommissioning activities.

Permeable Treatment Wall Performance. The fullscale PTW, installed in November 2010, has now been monitored for two years. Performance monitoring to date indicates:

- Groundwater flow patterns in the PTW area are similar to those observed prior to PTW construction, indicating that the PTW installation did not significantly alter groundwater flow conditions on the north plateau; 
- Strontium-90 activity in groundwater wells inside the PTW typically is substantially lower than strontium-90 activity levels upgradient of the PTW;

- Geochemical differences were observed in groundwater that has migrated into and through the zeolite, indicating that cation exchange (i.e., treatment) is occurring; and

- Strontium-90 activity in groundwater downgradient of the PTW is decreasing.

- Based on the January 2013 annual sampling results, there are no longer strontium-90 concentrations greater than $1.0 \mathrm{E}-05 \mu \mathrm{Ci} / \mathrm{mL}(10,000$ picoCuries per liter [pCi/L]) in the downgradient western or central lobes and no detected strontium-90 activities above 1.0E-06 $\mu \mathrm{Ci} / \mathrm{mL}(1,000 \mathrm{pCi} / \mathrm{L})$ in the downgradient eastern lobe.

These observations indicate the ongoing processes within the PTW are currently achieving the remedial action objectives and the functional requirements of the PTW defined in the PTW Performance Monitoring Plan.

NDA. Water level data indicates the cap and slurry wall installed in 2008 are causing the weathered Lavery till to become dry in some areas as designed. Reduced water volume extracted from the interceptor trench since the cap and slurry wall were installed also indicates groundwater flow through the NDA is effectively being reduced.

WTF Tank and Vault Drying System (T\&VDS). With an ultimate goal of preventing the underground steel tanks from corroding under ambient tank and vault conditions, the WVDP installed a T\&VDS in the WTF in 2010. The T\&VDS was designed to reduce the liquid volumes in the tanks, thereby reducing the harmful effects of corrosion on the underground waste tanks situated within concrete vaults originally installed in the 1960s. During the first 26 months of operation (as of the end of February 2013), the system has operated effectively, achieving the following results:

- maintained dry conditions in tanks 8D-1 and 8D-2;

- reduced liquid levels below level indicators in the 8D-1 and 8D-2 vaults and pans;

- reduced liquid levels in tanks 8D-3 and 8D-4 by about 1,400 gal $(5,300 \mathrm{~L})$ per tank, resulting in a residual of approximately 270 gal $(1,022 \mathrm{~L})$ in tank $8 \mathrm{D}-3$ and 4,700 gal $(17,791 \mathrm{~L})$ in tank $8 \mathrm{D}-4$;

- evaporated all liquid from tank 8D-3 and 8D-4 vault; and
- achieved lower relative humidity in the tanks and vaults further reducing the corrosion rate.

System operations continue to be monitored to reduce air infiltration, and individual air flows are adjusted to maintain dry conditions in tanks $8 \mathrm{D}-1$ and $8 \mathrm{D}-2$, and to reduce the humidity in the remaining tanks and vaults.

Tank 8D-4 Sampling and Characterization. Sampling of the liquid, sludge, and internal walls to characterize the tank 8D-4 contents and internals for radiological and hazardous constituents was performed in CY 2012. The 8D-4 characterization report was issued to DOE on August 30, 2012. DOE and stakeholders now have current data to develop disposition plans for tank 8D-4 and its contents.

Waste-Incidental-to-Reprocessing (WIR) Evaluations for HLW Processing Vessels. In February 2012, DOE issued the Final WIR determining that the melter used during the HLW VIT process is LLW incidental to reprocessing. In February 2013, DOE issued the Final WIR Evaluation for the Concentrator Feed Makeup Tank and the Melter Feed Hold Tank, determining that these vessels are also LLW incidental to reprocessing. These vessels therefore may be managed under DOE's authority in accordance with the LLW requirements.

This categorization as LLW enables the DOE to determine a disposal location for the vessels, and allows preparation for disposal to begin. Prior to shipment off site, it will be necessary to obtain Department of Transportation approval and route definition and coordinate a schedule for transportation. The vessels can then be shipped to the selected facility for disposal. The WIR evaluation report indicates either the Nevada National Security Site (formerly the Nevada Test Site) or the Waste Control Specialists facility in Texas are the most suitable off-site LLW facilities under consideration for this waste disposal.

Safety Success. The radiological and hazardous work environment at the WVDP warrants strict adherence to safety procedures. During 2012, the WVDP workforce achieved a cumulative total of 5.5 million safe work hours without a lost time work injury.

\section{Environmental Management System}

The WVDP EMS satisfies the requirements of DOE Order 436.1, "Departmental Sustainability," and is a key part of the WVDP Integrated Safety Management System. In 2012, WVDP employees continued to demonstrate their commitment to an all-inclusive approach to safety, 
coordinating the EMS with other safety management and work planning processes through the integrated environmental, health, and safety management program. CHBWV received a certificate of registration for the International Organization for Standardization 14001:2004 certification of it's EMS on July 31, 2012. (Refer to Chapter 1, "Environmental Management System.")

Compliance. WVDP management continued to provide strong support for environmental compliance in 2012. Requirements and guidance from applicable state and federal statutes, executive orders, DOE orders, and standards are integrated into the Project's compliance program.

- There were no New York State Pollutant Discharge Elimination System (SPDES) permit limit exceedances in CY 2012. However, there were two noncompliance events that occurred associated with submittal of discharge monitoring reports.

- In 2011, a sample result for mercury exceeded the SPDES permit limit causing discharge to outfall 007 to be suspended, as described in the 2011 ASER. Following investigation and steps taken to address the source of the mercury, the discharge from outfall 007 was restarted on February 14, 2012.

- Inspections by New York State Department of Environmental Conservation (NYSDEC) and the Cattaraugus County Department of Health verified Project compliance with the applicable environmental and health regulations in 2012.

- WVDP waste management areas were inspected in CY 2012 by NYSDEC and the U.S. Environmental Protection Agency (EPA) to ensure compliance with the RCRA Interim Status Facility regulations. No findings were noted.

- Requirements of the Emergency Planning and Community Right-to-Know Act were met in 2012 by collecting information about hazardous materials used at the Project and making this information available to the appropriate emergency response organizations.

- No exceedances to the EPA's National Emission Standards for Hazardous Air Pollutants (NESHAP) dose standard occurred in 2012.

Environmental Monitoring - Performance Indicators. As part of the WVDP EMS, environmental monitoring contin- ued on and near the site to detect and evaluate changes in the environment resulting from Project (or pre-Project) activities and to assess the effect of any such changes on the environment or human population. Within the environmental monitoring program, airborne and waterborne effluents were sampled and environmental surveillance of the site and nearby areas was conducted.

- Waterborne Radiological Releases

Waterborne radiological releases from the site were from two primary sources, lagoon 3 and a drainage channel on the WVDP's north plateau that is contaminated with strontium-90 from pre-WVDP operations. During 2012, treated process water was released in five batches from lagoon 3, totaling approximately 8.3 million gallons (31.6 million L), and approximately 13.5 million gallons (51.2 million $L$ ) flowed from the site through the north plateau drainage channel.

There were no unplanned releases of waterborne radioactivity in 2012 .

- Airborne Radiological Releases

In 2012, the WVDP maintained seven NESHAP permits for point source release of radiological airborne emissions. The RHWF stack was permitted in 2012. The primary controlled air emission point at the WVDP is the MPPB ventilation stack. Uncontrolled releases from diffuse sources such as evaporation from the lagoons currently contribute more to the site airborne radioactivity releases than controlled sources.

There were no unplanned radiological airborne releases at the WVDP during 2012.

- Estimated Dose

In 2012, the estimated dose to a Maximally Exposed Off-Site Individual (MEOSI) from airborne emissions at the WVDP was 0.0027 mrem $(0.000027$ millisievert [mSv]), about $0.027 \%$ of the 10 -mrem NESHAP standard. Estimated dose from waterborne sources in 2012 was about 0.016 mrem (0.00016 mSv), with 0.007 mrem (0.00007 mSv) attributable to liquid effluent releases and 0.009 mrem (0.00009 mSv) attributable to the north plateau drainage.

Total estimated dose to the MEOSI from both airborne and waterborne sources in 2012 was 0.019 mrem (0.00019 mSv), about $0.019 \%$ of the annual $100-\mathrm{mrem}$ 
DOE standard. In comparison, the average dose to a member of the public from natural background sources is 310 mrem per year.

Estimated dose to the population from both air and water within a 50-mile (80-kilometer) radius of the WVDP from DOE activities in 2012 was 0.07 person-rem (0.0007 person-Sv). This same population would have received approximately 522,000 person-rem from natural background radiation in 2012 .

- Dose to Biota

A dose to biota evaluation for CY 2012 concluded that aquatic and terrestrial biota populations (both plants and animals) were not exposed to doses in excess of the existing DOE dose standard for native aquatic animal organisms (1 rad/day) nor the recommended thresholds for terrestrial animals (0.1 rad/day) and plants (1 rad/day).

- Nonradiological Releases

Nonradiological releases from Project wastewater and storm water monitoring points were measured and documented under the site's SPDES permit. As noted previously in this chapter, there were no SPDES permit limit exceedances and two noncompliance events that occurred in 2012.

Quality Assurance (QA). In 2012, the QA program continued for activities supporting the environmental and groundwater monitoring programs at the WVDP. As part of this ongoing effort, on-site and subcontract laboratories that analyze WVDP environmental samples participated in independent radiological and nonradiological constituent performance evaluation studies. In these studies, environmental test samples with concentrations only known by the testing agency, were analyzed by the laboratories. Of 250 performance evaluation analyses conducted by or for the WVDP, $99.0 \%$ fell within acceptance limits.

Numerous inspections, audits, assessments, and surveillances of components of the environmental monitoring program were conducted in 2012. Although actions were recommended to improve the program, nothing was found that would compromise the quality of data in this report or the environmental monitoring program in general. Refer to "EMS Audits and Other Audits and Assessments" in Chapter 1.

\section{Conclusion}

In addition to demonstrating compliance with environmental regulations and directives, evaluation of data collected in 2012 continued to indicate that WVDP activities pose no threat to public health or safety, or to the environment. 
This page intentionally left blank 


\section{Site Location}

The West Valley Demonstration Project (WVDP or Project) is located in western New York State (NYS), about 30 miles (mi) (50 kilometers [km]) south of Buffalo, New York (Fig. INT-1). The WVDP facilities currently occupy a security-fenced area of about 152 acres (61 hectares [ha]) within the 3,338-acre (1,351 ha) Western New York Nuclear Service Center (WNYNSC or Center) located primarily in the town of Ashford in northern Cattaraugus County. In 2009, the United States (U.S.) Department of Energy (DOE) released approximately 15.5 acres (6.3 ha) of the WVDP (on the north side of the New York State-licensed disposal area [SDA]) back to the New York State Energy Research and Development Authority (NYSERDA) as an SDA buffer area for conducting ongoing erosion monitoring, control, and maintenance activities associated with the SDA.

\section{General Environmental Setting}

Climate. Although extremes of $98.6^{\circ} \mathrm{F}\left(37^{\circ} \mathrm{C}\right)$ and $-43.6^{\circ} \mathrm{F}$ $\left(-42^{\circ} \mathrm{C}\right)$ have been recorded in western New York, the climate is moderate, with an average annual temperature of $48.5^{\circ} \mathrm{F}\left(9.2^{\circ} \mathrm{C}\right)(1981-2010$, National Oceanic and Atmospheric Administration, May 2013). Precipitation is markedly influenced by Lake Erie to the west and, to a lesser extent, by Lake Ontario to the north. Regional winds are generally from the west and south at about 9 miles per hour (4 meters/second).

Ecology. The WNYNSC lies within the northern deciduous forest biome, and the diversity of its vegetation is typical of the region. Equally divided between forest and open land, the site provides a habitat especially attractive to white-tailed deer and various indigenous migratory birds, reptiles, and small mammals. No species on the federal endangered species list are known to reside on the WNYNSC.

Geology and Hydrology. The Project lies on NYS's Allegheny Plateau at an average elevation of about 1,300 feet ( $\mathrm{ft}$ ) (400 meters [m]) above mean sea level. The underlying geology includes a sequence of glacial sediments above shale bedrock. The Project is drained by three small streams (Franks Creek, Quarry Creek, and Erdman Brook) and is divided by a stream valley (Erdman Brook) into two general areas: the north plateau and the south plateau.
Franks Creek, which receives drainage from Erdman Brook and Quarry Creek, flows into Buttermilk Creek, which enters Cattaraugus Creek and flows westward away from the WNYNSC. (See Figures A-1 and A-5.) Cattaraugus Creek ultimately drains into Lake Erie, to the northwest.

\section{Relevant Demographics}

Although several roads and a railway approach or pass through the WNYNSC, the public is prohibited from accessing the WNYNSC. A limited public deer hunting program managed by NYSERDA is conducted on a yearto-year basis in designated areas on the WNYNSC. No unescorted public access is allowed on the WVDP premises.

Land near the WNYNSC is used primarily for agriculture and arboriculture. Downgradient of the WNYNSC, Cattaraugus Creek is used locally for swimming, canoeing, and fishing. Although some water is taken from the creek to irrigate nearby golf course greens and tree farms, no public drinking water is drawn from the creek before it flows into Lake Erie. Water from Lake Erie is used as a public drinking water supply.

The communities of West Valley, Riceville, Ashford Hollow, and the village of Springville are located within approximately $5 \mathrm{mi}(8 \mathrm{~km})$ of the Project. The nearby population, approximately 9,200 residents within $6.2 \mathrm{mi}(10 \mathrm{~km})$ of the Project, relies largely on an agricultural economy. No major industries are located within this area.

\section{Historic Timeline of the WNYNSC and the WVDP}

The following summary, presented in Table INT-1, depicts a historic timeline for the WNYNSC and the WVDP beginning with the establishment of the WNYNSC as a commercial nuclear fuel reprocessing facility, to the creation of the WVDP, to the current Project mission. The summary includes significant legal directives, major activities, and accomplishments. 
FIGURE INT-1

Location of the Western New York Nuclear Service Center

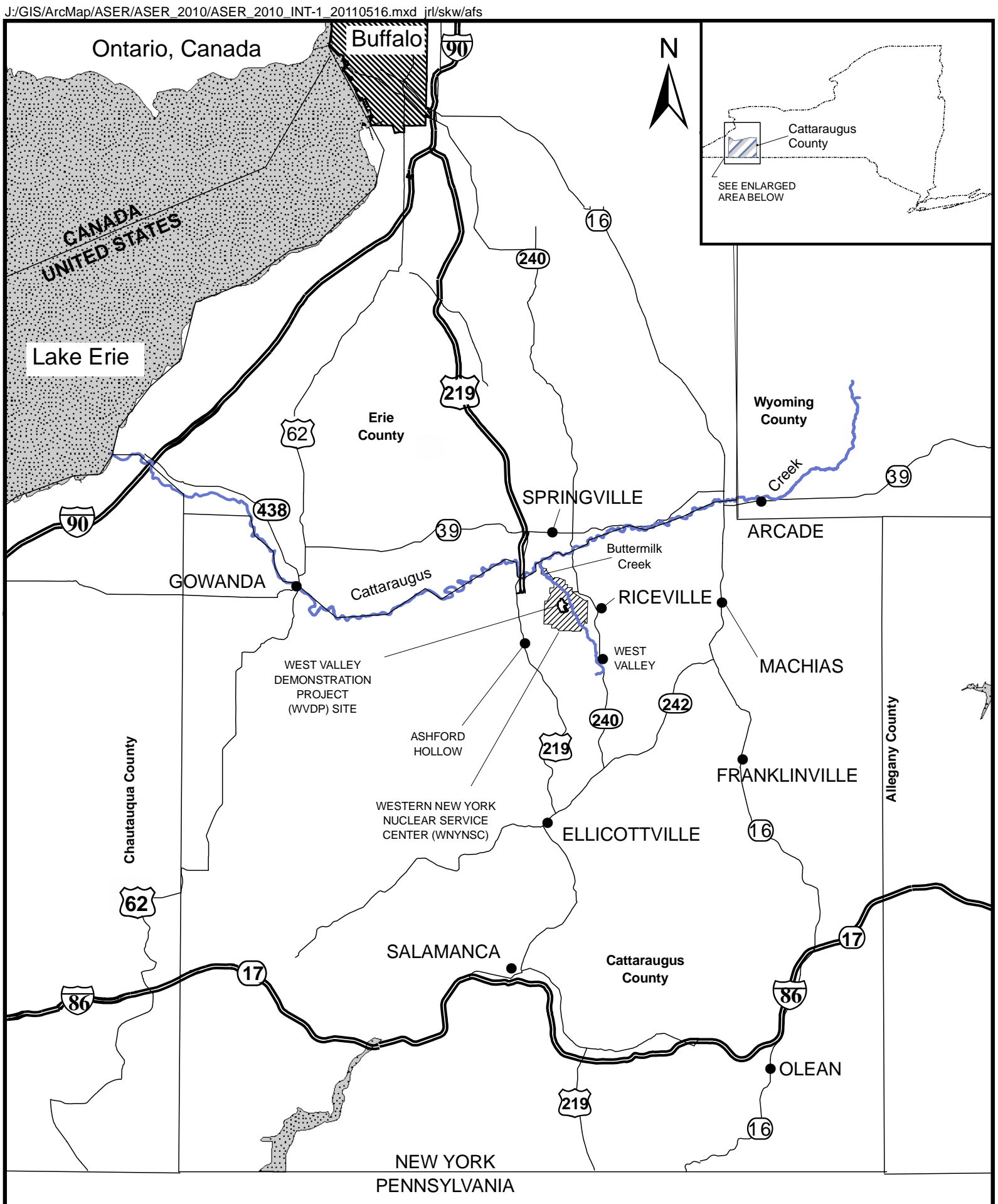


TABLE INT-1

Historic Timeline of the WNYNSC and the WVDP

\begin{tabular}{|c|c|}
\hline Year & Activity \\
\hline 1954 & ne Federal Atomic Energy Act (AEA) promoted commercialization of reprocessing spent nuclear fuel. \\
\hline 1959 & NYS established the Office of Atomic Development (OAD) to coordinate the atomic industry. \\
\hline 1961 & $\begin{array}{l}\text { The NYS OAD acquired 3,345 acres (1,354 ha) of land in Cattaraugus County, Town of Ashford (near West Valley), in } \\
\text { western New York and established the WNYNSC. }\end{array}$ \\
\hline 1962 & $\begin{array}{l}\text { Davison Chemical Company established Nuclear Fuel Services, Inc. (NFS) as a nuclear fuel reprocessing company, and } \\
\text { reached an agreement with NYS to lease the WNYNSC (also referred to as "the Center"). }\end{array}$ \\
\hline 1966 & $\begin{array}{l}\text { NFS constructed and operated the commercial nuclear fuel reprocessing facility at the WNYNSC from } 1966 \text { to } 1972 \text {. NFS } \\
\text { processed } 640 \text { metric tons (mt) of spent reactor fuel at the facility, generating 660,000 gallons (gal) ( } 2.5 \text { million liters [L]) } \\
\text { of highly radioactive liquid waste. A 5-acre landfill, the U.S. Nuclear Regulatory Commission (NRC)-licensed disposal area } \\
\text { (NDA) was operated for disposal of waste generated from the reprocessing operations from } 1966 \text { until 1986. Also, a 15- } \\
\text { acre commercial disposal area, the SDA regulated by NYS agencies, under delegation of authority from the NRC, } \\
\text { accepted low-level radioactive waste (LLW) from operations at the WNYNSC and from off-site facilities from } 1963 \text { until } \\
1975 .\end{array}$ \\
\hline 1972 & $\begin{array}{l}\text { In 1972, while the plant was closed for modifications, more rigorous regulatory requirements were imposed upon fuel } \\
\text { reprocessing facilities. NFS determined the costs to meet regulatory requirements of spent nuclear fuel reprocessing } \\
\text { were not economically feasible. NFS then notified the NYSERDA, the successor to NYS OAD, in } 1976 \text { that they would } \\
\text { discontinue reprocessing and would not renew the lease that would expire at the end of } 1980 .\end{array}$ \\
\hline 1975 & $\begin{array}{l}\text { Water infiltrated into the SDA trenches and waste burial operations ceased. Between } 1975 \text { and } 1981, \text { NFS pumped, } \\
\text { treated, and released liquids to the adjacent stream. Redesigning the covers reduced, but did not eliminate, water } \\
\text { accumulation in the trenches. }\end{array}$ \\
\hline 1980 & $\begin{array}{l}\text { The U.S. Congress passed Public Law 96-368, the West Valley Demonstration Project Act (WVDP Act), requiring the DOE } \\
\text { to be responsible for solidifying the liquid high-level radioactive waste (HLW) stored in underground tanks, disposing of } \\
\text { the waste that would be generated by solidification, and decontaminating and decommissioning the facilities used } \\
\text { during the process. Per the WVDP Act, the DOE entered into a Cooperative Agreement with NYSERDA that established } \\
\text { the framework for cooperative implementation of the WVDP Act. Under the agreement, DOE has exclusive use and } \\
\text { possession of a portion of the Center (i.e., WNYNSC) known as the Project Premises (approximately } 167 \text { acres). A } \\
\text { supplement to the Cooperative Agreement (1981 amendment) between the two agencies set forth special provisions for } \\
\text { the preparation of a joint Environmental Impact Statement (EIS). }\end{array}$ \\
\hline 1981 & $\begin{array}{l}\text { DOE and NRC entered into a Memorandum of Understanding (MOU) that established specific agency responsibilities and } \\
\text { arrangements for informal review and consultation by NRC. Because NYSERDA holds the license and title to the } \\
\text { WNYNSC, NRC put the technical specifications of the license (CSF-1) in abeyance to allow DOE to carry out the } \\
\text { responsibilities of the WVDP Act. }\end{array}$ \\
\hline 1982 & $\begin{array}{l}\text { West Valley Nuclear Services (WVNS), a Westinghouse subsidiary, was chosen by DOE to be the management and } \\
\text { operating contractor. WVNS commenced operations at the WVDP on February } 28,1982 \text {. }\end{array}$ \\
\hline 1983 & $\begin{array}{l}\text { Before discontinuing fuel reprocessing operations, NFS had accepted } 750 \text { spent fuel assemblies which remained in } \\
\text { storage in the on-site fuel receiving and storage (FRS) area. Between } 1983 \text { and 1986, } 625 \text { of those assemblies were } \\
\text { returned to the utilities that owned them. In 1983, NYSERDA assumed management responsibility for the SDA and } \\
\text { focused efforts to minimize infiltration of water into the trenches. In the 1990s, installation of a geomembrane cover } \\
\text { over the entire SDA and an underground barrier wall were successful in eliminating increases in trench water levels. The } \\
\text { DOE selected the vitrification (VIT) process as the preferred method for solidifying the HLW into glass. }\end{array}$ \\
\hline 1984 & $\begin{array}{l}\text { Nonradioactive testing of a full-scale VIT system was conducted from 1984-1989. NFS entered into an agreement with } \\
\text { DOE in which DOE assumed ownership of the remaining } 125 \text { fuel assemblies in the FRS pool and the responsibility for } \\
\text { their removal. }\end{array}$ \\
\hline
\end{tabular}


TABLE INT-1 (continued)

Historic Timeline of the WNYNSC and the WVDP

\begin{tabular}{|c|c|}
\hline Year & Activity \\
\hline 1986 & $\begin{array}{l}\text { A large volume of radioactive, non-HLW would result from WVDP activities. On-site disposal of most of this waste was } \\
\text { evaluated in an Environmental Assessment (EA [DOE/EA-0295, April 1986]), and a finding of no significant impact was } \\
\text { issued. The Coalition on West Valley Nuclear Waste (The Coalition) and the Radioactive Waste Campaign filed suit } \\
\text { contending an EIS should have been prepared. The NYS Department of Environmental Conservation (NYSDEC) was } \\
\text { authorized by the U.S. Environmental Protection Agency (EPA) to administer the Resource Conservation and Recovery } \\
\text { Act (RCRA) hazardous waste program. }\end{array}$ \\
\hline 1987 & $\begin{array}{l}\text { A decision to potentially dispose of LLW at the Project led to a legal disagreement between DOE, The Coalition, and the } \\
\text { Radioactive Waste Campaign. The lawsuit was resolved by a Stipulation of Compromise which states that LLW disposal } \\
\text { at the site and the potential effects of erosion at the site must be included in a comprehensive EIS. }\end{array}$ \\
\hline 1988 & $\begin{array}{l}\text { In December 1988, the DOE and NYSERDA issued a Notice of Intent (NOI) in the Federal Register (FR) to prepare an EIS in } \\
\text { accordance with Section 102(2)(C) of the National Environmental Policy Act (NEPA) and Section 8-0109 of the New York } \\
\text { State Environmental Quality Review (SEQR) Act. To prepare for VIT, the integrated radwaste treatment system was } \\
\text { constructed to process liquid supernatant from the underground HLW tanks by removing most of the radioactivity in the } \\
\text { supernatant, concentrating the liquid, and blending it with cement. The HLW sludge layer was then washed to remove } \\
\text { soluble salts. The water containing the salts was also stabilized into cement. About 20,000 drums of cement-stabilized } \\
\text { LLW were stored in the aboveground drum cell. The process was completed in 1995. }\end{array}$ \\
\hline 1990 & $\begin{array}{l}\text { Organic solvent was observed in a groundwater monitoring well immediately downgradient of the NDA in } 1983 . \\
\text { Following characterization of the area, an interceptor trench bordering the northeast and northwest boundaries of the } \\
\text { NDA and a liquid pretreatment system (LPS) were built in 1990-1991. The trench was designed to collect liquid that } \\
\text { might migrate from the NDA and the LPS was designed to recover free organic product (if present) from the recovered } \\
\text { liquid. To date, no organic product has been detected in the interceptor trench water; therefore, the water has been } \\
\text { pumped and treated through the LLW treatment system. In 1990, NYS was granted the authority to regulate the } \\
\text { hazardous waste constituents of radioactive mixed waste. Subsequently, a Title } 6 \text { New York State Official Compilation of } \\
\text { Codes, Rules, and Regulations (NYCRR) RCRA Part 373-3 (Part A) Permit Application for the WVDP was filed with NYSDEC } \\
\text { for storage and treatment of hazardous and mixed wastes. }\end{array}$ \\
\hline 1992 & $\begin{array}{l}\text { In 1992, DOE and NYSERDA entered into a RCRA } \S 3008(\mathrm{~h}) \text { Administrative Order on Consent (Consent Order) with } \\
\text { NYSDEC and the EPA. The Consent Order pertained to management of hazardous waste and/or hazardous constituents } \\
\text { from solid waste management units (SWMUs) at the WVDP. It also required DOE and NYSERDA to perform a RCRA } \\
\text { Facility Investigation (RFI) at the WNYNSC to determine if there had been or if there was potential for a release of RCRA } \\
\text { hazardous constituents. Final RFI reports were submitted in 1997, completing the Consent Order investigative activities. }\end{array}$ \\
\hline 1993 & $\begin{array}{l}\text { In 1993, gross beta activity in excess of } 1.0 \mathrm{E}-06 \text { microcuries per milliliter }(\mu \mathrm{Ci} / \mathrm{mL}) \text { (the applicable DOE Derived } \\
\text { Concentration Guide [DCG] for strontium-90) was detected in surface water on the north plateau, in the vicinity of } \\
\text { sampling location WNSWAMP. The gross beta radioactivity was determined to be strontium-90. }\end{array}$ \\
\hline 1994 & $\begin{array}{l}\text { Extensive subsurface investigations delineated the extent of the strontium-90 plume and determined that the plume } \\
\text { originated beneath the southwest corner of the main plant process building (MPPB) during NFS operations and migrated } \\
\text { toward the northeast quadrant of the north plateau. A second lobe of contamination was attributed to the area of } \\
\text { former lagoon 1, which was backfilled in } 1984 \text {. }\end{array}$ \\
\hline 1995 & $\begin{array}{l}\text { In 1995, a groundwater recovery system consisting of three wells was installed on the north plateau to extract and treat } \\
\text { the strontium-90-contaminated groundwater. In 1999, a pilot-scale permeable treatment wall (PTW) was constructed to } \\
\text { test this passive in-situ remediation technology. The VIT building shielding was installed in 1991, the slurry-fed ceramic } \\
\text { melter was assembled in 1993, and the remaining major components were installed and tested by the end of 1994. In } \\
\text { 1995, the VIT facility was completed, fully tested, and "cold operations" began. }\end{array}$ \\
\hline
\end{tabular}




\section{TABLE INT-1 (continued) \\ Historic Timeline of the WNYNSC and the WVDP}

\begin{tabular}{|c|c|}
\hline Year & Activity \\
\hline 1996 & $\begin{array}{l}\text { The DOE and NYSERDA issued a draft EIS (DEIS) for completion of the WVDP and closure or long-term management of } \\
\text { the WNYNSC. Following evaluation of the public comments on the DEIS, the Citizen Task Force was convened to enhance } \\
\text { stakeholder understanding and input regarding the WVDP/WNYNSC closure process. VIT operations began in } 1996 \text { and } \\
\text { continued into 2002, producing } 275 \text { ten-foot-tall stainless-steel canisters of hardened radioactive glass containing up to } \\
12 \text { million curies of radioactive material (primarily cesium/strontium, without radioactivity from daughter products } \\
\text { included). The glass melter was shut down in September 2002. NYSDEC and DOE entered into an Order on Consent } \\
\text { negotiated under the Federal Facilities Compliance Act (FFCA) for handling, storage, and treatment of mixed wastes at } \\
\text { the WVDP. The Seneca Nation of Indians Cooperative Agreement was signed in } 1996 \text { to foster government-to- } \\
\text { government relationships between the Seneca Nation and the U.S. government, as represented by DOE. }\end{array}$ \\
\hline 1999 & $\begin{array}{l}\text { VIT expended materials processing was initiated to begin processing unserviceable equipment from the VIT facility. This } \\
\text { success helped in developing a remote-handled waste facility (RHWF) to process large-scale, highly contaminated } \\
\text { equipment excessed during decontamination and decommissioning activities. }\end{array}$ \\
\hline 2000 & Restructuring of the work force and construction of the RHWF began. \\
\hline 2001 & $\begin{array}{l}\text { The } 125 \text { spent fuel assemblies that remained in storage at the WVDP since } 1975 \text { were prepared for transport to the } \\
\text { Idaho National Engineering and Environmental Laboratory (INEEL). Initial decontamination efforts began in two } \\
\text { significantly contaminated areas in the MPPB, the process mechanical cell and the general purpose cell, to place the } \\
\text { cells in a safer configuration for future facility decommissioning. DOE published formal notice in } 66 \text { FR } 16447 \text { to split the } \\
\text { EIS process into (1) the WVDP Waste Management EIS, and (2) the Decommissioning and/or Long-Term Stewardship EIS } \\
\text { at the WVDP and the WNYNSC. }\end{array}$ \\
\hline 2002 & $\begin{array}{l}\text { NRC issued "Decommissioning Criteria for the West Valley Demonstration Project (M-32) at the West Valley Site; Final } \\
\text { Policy Statement" (67 FR 5003). }\end{array}$ \\
\hline 2003 & The remaining 125 spent fuel assemblies were shipped to INEEL, allowing for decontamination of the FRS to begin. \\
\hline 2004 & $\begin{array}{l}\text { The RHWF became operational. Major decontamination efforts continued and site footprint reduction began as } 20 \\
\text { office trailers were removed. In December, the } 6 \text { NYCRR Part 373-2 Permit Application (i.e., Part B) was submitted to } \\
\text { NYSDEC. }\end{array}$ \\
\hline 2005 & $\begin{array}{l}\text { In June, the DOE published its final decision on the "WVDP Waste Management Environmental Impact Statement (68 FR } \\
26587) . " \text { The DOE implemented the preferred alternative for the management of LLW and mixed LLW. The decision on } \\
\text { transuranic (TRU) waste was deferred, and the HLW canisters will remain in on-site storage until they can be shipped to } \\
\text { a repository. In November, the WVDP was downgraded to a Category } 3 \text { nuclear facility, marking the first time in the } \\
\text { site's history that it has been designated the least of the three DOE nuclear facility designations. The categorization is } \\
\text { based on amounts, types, and configuration of the nuclear materials stored and their potential risks. }\end{array}$ \\
\hline 2006 & $\begin{array}{l}\text { An EA (DOE/EA-1552) evaluating the proposed decontamination, demolition, and removal of } 36 \text { facilities was issued. By } \\
\text { the end of 2006, } 11 \text { of the } 36 \text { structures were removed. The DOE-WVDP office initiated a collaborative, consensus- } \\
\text { based team process, referred to as the "Core Team," that involved NYSERDA, EPA, the New York State Department of } \\
\text { Health (NYSDOH), NRC, and NYSDEC. This team brought individuals with decisionmaking authority together to resolve } \\
\text { challenging issues surrounding the WVDP EIS process and to make recommendations to move the Project toward an } \\
\text { "Interim End-State" prior to issuance of the "Final EIS for the Decommissioning and/or Long-Term Stewardship at the } \\
\text { WVDP and the WNYNSC." Shipment of the cement-filled LLW drums was initiated. }\end{array}$ \\
\hline 2007 & $\begin{array}{l}\text { Demolition and removal of four more structures identified under DOE/EA-1552 was completed. On June } 29,2007, \mathrm{DOE} \\
\text { awarded West Valley Environmental Services, LLC (WVES) a four-year contract (Contract DE-AC30-07CC30000) to } \\
\text { conduct the next phase of cleanup operations at the WVDP. The remaining drums of cemented LLW in the drum cell } \\
\text { were packaged and shipped to the Nevada Test Site for disposal. In the fall of 2007, an interim measure to minimize } \\
\text { water infiltration into the NDA was initiated with site surveys and soil borings. }\end{array}$ \\
\hline
\end{tabular}


TABLE INT-1 (concluded)

Historic Timeline of the WNYNSC and the WVDP

\begin{tabular}{|c|c|}
\hline Year & Activity \\
\hline 2008 & $\begin{array}{l}\text { During 2008, a trench was excavated along two sides of the NDA, on the south plateau. The trench was backfilled } \\
\text { with bentonite and soil to form a slurry wall, a low-permeability subsurface barrier to infiltration. A geomembrane } \\
\text { cover was placed over the entire landfill. On the north plateau, additional subsurface soil and groundwater } \\
\text { samples were collected in the summer and fall of } 2008 \text { to further characterize chemical and radiological } \\
\text { constituents within the contaminated groundwater plume beneath and downgradient of the MPPB. The revised } \\
\text { DEIS for Decommissioning and/or Long-Term Stewardship at the WVDP and WNYNSC was issued in December for } \\
\text { public review, which continued through September } 8,2009 \text {. Concurrently, the Proposed Phase } 1 \\
\text { Decommissioning Plan (DP) for the WVDP was prepared and submitted to NRC. }\end{array}$ \\
\hline 2009 & $\begin{array}{l}\text { Extensive characterization was completed on the north plateau in } 2009 \text { to delineate the leading edge of the } \\
\text { subsurface strontium-90 groundwater plume and to find a suitable material to capture and retain the } \\
\text { contamination. DOE released approximately } 15.5 \text { acres ( } 6.3 \text { ha) of the WVDP on the north side of the SDA back to } \\
\text { NYSERDA. }\end{array}$ \\
\hline 2010 & $\begin{array}{l}\text { In January, DOE and NYSERDA issued the final EIS (FEIS) for the WVDP and the WNYNSC (DOE/EIS-0226). The } \\
\text { phased decisionmaking alternative was selected as the preferred alternative. The phase } 2 \text { decision was deferred } \\
\text { for no more than } 10 \text { years. In February, NRC issued a Technical Evaluation Report (TER) for the DP, concluding } \\
\text { that the DP was consistent with the preferred alternative in the EIS. A SEQR notice of completion for the EIS and } \\
\text { its acceptance by NYSERDA was issued on January 27. On April 14th, DOE issued the Record of Decision (ROD) for } \\
\text { the EIS, and on May 12, NYSERDA issued a SEQR Findings Statement, selecting the phased decision-making } \\
\text { alternative. On August 17th, DOE and NYSERDA reached an agreement and signed a Consent Decree that formally } \\
\text { defined the cost sharing for cleanup of the WVDP and the WNYNSC. In September, a revised RCRA Part 373-2 } \\
\text { Permit Application was submitted to NYSDEC. An } 860-\text { foot-long full-scale PTW near the leading edge of the } \\
\text { strontium-90 plume was installed and completed. The Tank and Vault Drying System (T\&VDS) was installed to } \\
\text { reduce the harmful effects of corrosion on the underground waste tanks. MPPB cell decontamination and } \\
\text { deactivation activities continued. }\end{array}$ \\
\hline 2011 & $\begin{array}{l}\text { DOE awarded the Phase } 1 \text { Decommissioning and Facility Disposition contract to CH2M HILL } \bullet \text { B\&W West Valley, LLC } \\
\text { (CHBWV) on June } 29,2011 \text {. The "continuity of contract" period extended to August } 29,2011 \text { during which time work } \\
\text { activities were transitioned, environmental monitoring continued, and licenses and permits were transferred to } \\
\text { CHBWV. A separate contract was awarded to Safety and Ecology Corporation to implement work associated with } \\
\text { the Phase } 1 \text { characterization support services, which are requirements of the Phase } 1 \text { DP. In September 2011, DOE } \\
\text { and NYSERDA jointly awarded a Phase } 1 \text { Studies contract to Enviro Compliance Solutions, Inc. to identify and } \\
\text { implement the Phase } 1 \text { Studies. The objective of the studies is to use technical experts to conduct scientific studies } \\
\text { that will facilitate interagency consensus for decisionmaking in the Phase } 2 \text { decommissioning process. }\end{array}$ \\
\hline 2012 & $\begin{array}{l}\text { CHBWV continued work on the Phase } 1 \text { Decommissioning Facilities Disposition Contract, including design of the HLW } \\
\text { canister relocation and storage system, continued legacy waste shipment, preparation for demolition of the MPPB } \\
\text { and VIT facility, and nonradiological demolition of Balance of Site Facilities (BOSF). Demolition of the 01-14 building } \\
\text { began in } 2012 \text { and was completed in 2013. DOE issued a final Waste Incidental to Reprocessing (WIR) Evaluation for } \\
\text { the HLW melter in February 2012. DOE also issued a second WIR for the Concentrator Feed Makeup Tank (CFMT) } \\
\text { and Melter Feed Hold Tank (MFHT) in February 2013, determining that these vessels are LLW incidental to } \\
\text { reprocessing and therefore may be managed under DOE's authority in accordance with the requirements of LLW. } \\
\text { Phase } 1 \text { Studies teams of subject matter experts (SMEs) continued development of recommendations for the } \\
\text { identified areas of study. Environmental characterization services performed in } 2012 \text { included characterization of } \\
\text { two reference areas, the HLW canister interim storage area and characterization of two building footprints following } \\
\text { demolition. }\end{array}$ \\
\hline
\end{tabular}




\section{ENVIRONMENTAL COMPLIANCE SUMMARY}

\section{Compliance Program}

DOE is currently focusing on accomplishing the Phase 1 decommissioning activities specified in the ROD for the EIS for Decommissioning and/or Long-Term Stewardship of the WVDP and the WNYNSC.

Activities at the WVDP are regulated by various federal and state, public, worker, and environmental protection laws. These laws are administered primarily by the EPA, the U.S. Fish and Wildlife Service, the U.S. Army Corps of Engineers, NYSDEC, and NYSDOH through programs and regulatory requirements for permitting, reporting, inspecting, self-monitoring, and auditing.

Table ECS-1 describes the WVDP's compliance status with applicable environmental statutes, DOE directives, executive orders (EOs), and state laws and regulations applicable to the Project activities.

Table ECS-2 presents a summary of the significant NEPA document history. An update of NEPA activities is provided later in this chapter.

EPA, NYSDEC, and DOE have established standards for effluents that are intended to protect human health, safety, and the environment. DOE applies to EPA for permits to release limited amounts of radiological constituents to the air and applies to NYSDEC for permits to release limited amounts of nonradiological constituents to the air and water, in concentrations determined to be safe for humans and the environment. In general, the permits describe release points, specify management and reporting requirements, list discharge limits on those pollutants likely to be present, and define the sampling and analysis regimen. Releases of radiological constituents in water are subject to the requirements in DOE Orders 458.1 (Radiation Protection of the Public and the Environment, Change 2) and DOE-STD-1196-2011 (Derived Concentration Standards [DCSs]). A summary of the WVDP environmental permits is found in Table ECS-3. (See the compliance tables at the end of this chapter.)

\section{Accomplishments and Highlights at the WVDP}

In August 2011, CHBWV began performing the Phase I Decommissioning and Facility Disposition activities for DOE. The term of the Phase I Decommissioning and Facility Disposition contract is from August 2011 to June 30, 2017 and includes the following scope:

- packaging and relocating canisters of HLW to a new interim dry storage;

- processing and shipping legacy waste;

- dismantling and removing the VIT facility and the MPPB;

- removing ancillary facilities; and

- continuing safe operations of the site, including:

- managing and maintaining site infrastructure;

- conducting environmental monitoring;

- maintaining the underground HLW storage tanks, the NDA, and the north plateau PTW; and

- maintaining the lagoon system.

2012 Major Accomplishments. Major accomplishments towards achieving Phase I Decommissioning and Facility Disposition included:

- developing the design for the HLW canister storage system;

- removing waste materials from the MPPB as necessary for canister movement;

- shipping legacy waste off site for disposal;

- preparing the MPPB and VIT facility for demolition;

- piping removal and asbestos abatement; and

- isolating utilities and off-gas piping;

- initiating demolition of the 01-14 building;

- completing demolition of several minor facilities;

- establishing an off-site ambient air monitoring network in support of facility demolition; and

- receiving final NYSDEC approval of RCRA closure of the Hazardous Waste Storage Lockers (HWSLs). 
State Pollutant Discharge Elimination System (SPDES) Permit Noncompliance Events. During calendar year (CY) 2012, there were no SPDES permit limit exceedances. However, there were two noncompliance events that occurred associated with submittal of discharge monitoring reports.

- On March 20, 2012, NYSDEC issued a Notice of Violation to the WVDP for failure to submit a complete SPDES Discharge Monitoring Report (DMR) for the period of January 1 through January 31, 2012. A conference call was held on March 30 to discuss this matter, and it was confirmed that a complete version of the DMR in question was received by the NYSDEC Region 9 office in Buffalo, NY. The WVDP submitted three re-signed pages of the DMR to the NYSDEC Division of Water in Albany, NY, and on April 12, 2012, NYSDEC issued correspondence rescinding the Notice of Violation.

- On March 13, 2012, NYSDEC issued correspondence to the WVDP documenting the plan to modify the reporting periods for annual and semiannual SPDES outfall sampling to fall on calendar reporting periods. NYSDEC provided new DMR forms and requested that 2011 annual and semiannual results be resubmitted on the new forms. On March 29, 2012, the 2011 results, which were all within effluent discharge limits, were resubmitted on the new DMR forms. Since the resubmitted forms contained the new SPDES permit limits (effective July 1, 2011), a March 2011 sample result for hexachlorobenzene appeared to be non-compliant, although, it was within permit limits in effect at the time of sampling. Although this was explained on the transmittal letter to NYSDEC with a note added to the bottom of the DMR form, NYSDEC recorded this submittal as the second noncompliance event for 2012.

CY 2011 SPDES Permit Mercury Exceedance. As described in the 2011 annual site environmental report (ASER), discharge from outfall 007 at the wastewater treatment facility (WWTF) was suspended in 2011 due to a result for mercury exceeding the SPDES permit limit. Following investigation and steps taken to address this issue, on February 9, 2012, NYSDEC was notified of the pending restart of the WWTF, and with confirmatory laboratory results, the discharge from outfall 007 was restarted on February 14, 2012. On June 27, 2012, the WVDP submitted a Mercury Minimization Program Report per the SPDES permit. The report identified actions implemented to reduce mercury discharges at effluent discharge points, and concluded that, based on obtained results, actions taken by the WVDP have had a significant impact on reducing overall discharges of mercury from WVDP effluents.

PTW Performance. Since completion of the full-scale PTW, performance monitoring has indicated the following:

- Groundwater flow patterns in the PTW area are similar to those observed prior to PTW construction, indicating that the PTW installation did not significantly alter general groundwater flow conditions on the north plateau;

- Strontium-90 activity in groundwater wells inside the PTW typically is substantially lower than strontium-90 activity levels upgradient of the PTW;

- Geochemical differences were observed in groundwater that has migrated into and through the PTW zeolite, indicating that cation exchange (i.e., treatment) is occurring; and

- Strontium-90 activity in groundwater downgradient of the PTW is decreasing.

- Based on the January 2013 annual sampling results, there are no longer strontium-90 concentrations greater than $1.0 \mathrm{E}-5 \mu \mathrm{Ci} / \mathrm{mL}(10,000$ picoCuries per liter $[\mathrm{pCi} / \mathrm{L}])$ in the downgradient western or central lobes and no detected strontium-90 activities above 1.0E-6 $\mu \mathrm{Ci} / \mathrm{mL}(1,000 \mathrm{pCi} / \mathrm{L})$ in the downgradient eastern lobe.

These observations indicate the ongoing processes within the PTW are currently achieving the remedial action objectives and functional requirements of the PTW defined in the PTW Performance Monitoring Plan.

Waste Tank Farm (WTF) and the T\&VDS. With an ultimate goal of preventing the underground steel tanks from corroding under ambient tank and vault conditions, the WVDP installed a T\&VDS in the WTF in 2010. The T\&VDS was designed to reduce the liquid volumes in the tanks, and thereby the harmful effects of corrosion on the underground waste tanks situated within concrete vaults originally installed in the 1960s. During the first 26 months of operation (as of the end of February 2013), the system has operated effectively, achieving the following results:

- maintained dry conditions in tanks 8D-1 and 8D-2;

- reduced liquid levels below level indicators in tanks 8D-1 and 8D-2 vaults and pans; 
- reduced liquid levels in tanks 8D-3 and 8D-4 by about 1,400 gal $(5,300 \mathrm{~L})$ per tank resulting in a residual 270 gal $(1,022 \mathrm{~L})$ in tank $8 D-3$ and 4,700 gal $(17,791 \mathrm{~L})$ in tank 8D-4;

- evaporated all liquid from 8D-3/8D-4 vault; and

- achieved lower relative humidity in the tanks and vaults, further reducing the corrosion rate.

System operations continue to be monitored to reduce air infiltration, and individual air flows are adjusted to maintain low humidity in the tanks and vaults.

Tank 8D-4 Sampling and Characterizations. Sampling of the liquid, sludge and internal walls to characterize the tank 8D-4 contents and internals for radiological and hazardous constituents was performed in CY 2012. The 8D-4 characterization report was issued to DOE on August 30, 2012. DOE and stakeholders now have current data to develop disposition plans for tank 8D-4 and its contents.

WIR Evaluation for the WVDP Melter, CFMT, and MFHT. The melter, CFMT, and MFHT, which were used during the HLW VIT process, were flushed during shutdown and characterized for radioactivity. The DOE-WVDP performed evaluations to determine if the components met the WIR criteria of DOE Manual 435.1-1, "Radioactive Waste Management Manual." Based on the final WIR evaluations for the melter (February 2012) and CFMT and MFHT (February 2013), and based on consultation with the NRC, DOE made final determinations that the melter, CFMT, and MFHT may be disposed of as LLW at an appropriate LLW disposal facility, pursuant to DOE's authority under the AEA of 1954, as amended, and in accordance with the provisions of Chapter IV of DOE Manual 435.1-1, "Radioactive Waste Management Manual."

\section{NEPA}

NEPA requires DOE to consider the overall environmental effects of its proposed actions. Draft documents are prepared that describe potential environmental effects associated with proposed Project activities. The level of evaluation and documentation depends upon whether the action constitutes a major federal action significantly affecting the quality of the human environment within the meaning of NEPA. The categories of documentation include categorical exclusion (CX), environmental assessment (EA), and EIS.

CXs document actions that, by their nature, will not have a significant effect on the environment. EAs are used to evaluate the extent to which a proposed action, not categorically excluded, will affect the environment.

Based on the analyses presented in an EA and considering regulatory agency, stakeholder, and public comments, DOE may determine that the proposed action is not a major federal action significantly affecting the quality of the human environment within the meaning of NEPA. Therefore, DOE may issue a notice indicating the finding of no significant impact (FONSI) and therefore would not be required to prepare an EIS.

If a proposed action has potential for significant environmental effects, an EIS would be prepared that describes proposed alternatives to an action and explains the effects of each. Based on the analyses presented, and considering regulatory agency and public input, DOE will determine the preferred alternative and issue a ROD regarding the action.

Since the Project began, a number of proposed site activities have warranted environmental impact evaluations. A summary of the significant NEPA document history is presented in Table ECS-2.

EIS Issued. On April 14, 2010, DOE issued the ROD for the EIS, "Decommissioning and/or Long-Term Stewardship at the WVDP and the WNYNSC" (DOE/EIS-0226), selecting the phased decisionmaking alternative. In Phase 1, DOE will decommission the MPPB, the VIT facility, RHWF, the wastewater treatment lagoons, and a number of other facilities. No decommissioning actions will be taken on the underground HLW tanks or the NDA, and the HLW canisters will be safely stored on site. NYSERDA will manage the SDA. Phase 1 was estimated to take up to 10 years, during which time DOE will manage the site's remaining facilities in a safe manner. The Phase 2 decision will be made within 10 years of the EIS ROD. During this time, DOE and NYSERDA intend to conduct additional scientific studies (i.e., Phase 1 Studies) in order to facilitate interagency consensus to complete decommissioning of the remaining facilities.

Phase 1 Studies. In September 2011, DOE and NYSERDA jointly awarded the Phase 1 Studies contract to Enviro Compliance Solutions, Inc., an independent, agency-neutral contractor that is jointly funded by the agencies to administer contracts for all Phase 1 Study activities, including contracting with the facilitator, SMEs, the Independent Scientific Panel, and contractors performing the study activities. During 2012, the following 
teams of SMEs evaluated their respective Potential Areas of Study to develop Phase 1 Study recommendations:

- engineered barriers working group;

- exhumation working group; and

- erosion working group.

A climate change workshop was also held in August 2012, and, with contributions from climate scientists, a Climate Guidance Document for Phase 1 Studies was prepared. The public was updated on the status of Phase 1 Studies during public meetings in May, August, and November 2012.

Phase 1 Decommissioning Plan (DP) for the WVDP. On December 5, 2008, the DOE issued the "Phase 1 Decommissioning Plan for the West Valley Demonstration Project, West Valley, NY" (73 Federal Register 74162) and transmitted it for NRC review. The DP addressed Phase 1 of the proposed two-phased approach for WVDP decommissioning, consistent with the preferred alternative selected in the ROD and the Findings Statement for the WVDP and the WNYNSC. On December 18, 2009, DOE submitted revision 2 of the Phase I DP after incorporating responses to NRC's comments.
On February 25, 2010, NRC transmitted to DOE-WVDP a Technical Engineering Report for the Phase 1 DP, concluding that the Phase 1 DP was consistent with the preferred alternative in the EIS. NRC also determined that there is reasonable assurance that the proposed actions will meet the decommissioning criteria.

Phase 1 Characterization Sampling and Analysis Plan (CSAP) and the Phase 1 Final Status Survey Plan (FSSP) for the WVDP. The Phase $1 \mathrm{DP}$ required the preparation of two supplemental documents, the CSAP and the FSSP. These two documents provide the specific details of sampling activities to support Phase 1 decommissioning of the WVDP. The CSAP describes the radiological environmental data collection activities (surface and subsurface soils, sediments, and groundwater) that will specifically support the implementation of the Phase 1 decommissioning actions within the WVDP premises as described in the Phase 1 DP.

The FSSP provides the technical basis and sampling protocols to demonstrate that specific portions of the WVDP premises meet the Phase 1 radiological cleanup goals for surface and subsurface soils identified in the Phase 1 DP.

\section{Summary of WVDP Contracts}

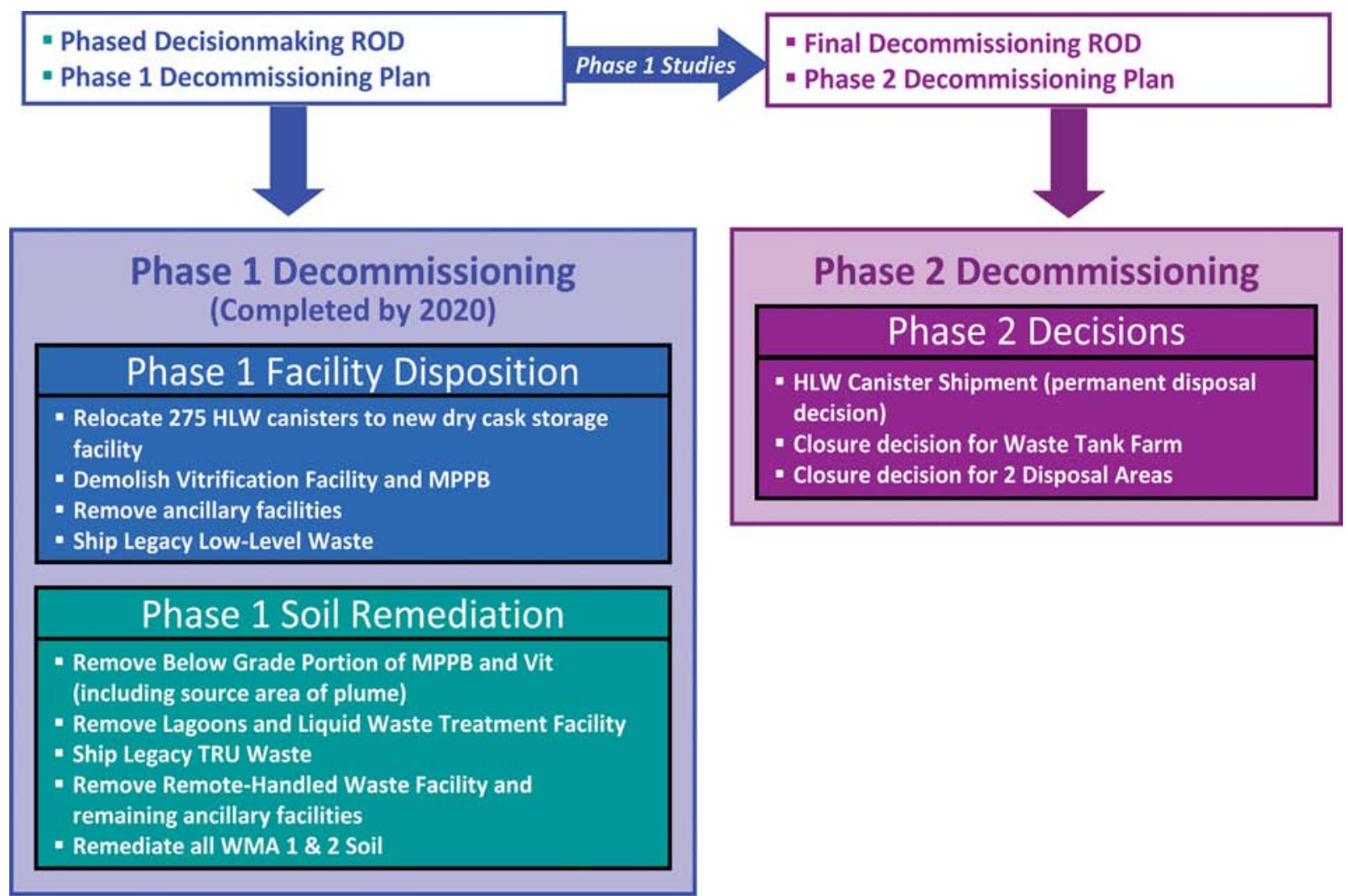


The FSSP is consistent with the Multi-Agency Radiation Survey and Site Investigation Manual.

Environmental Characterization Services Contract. In December 2010, DOE awarded the Environmental Characterization Services contract to Safety and Ecology Corporation (SEC) to provide environmental characterization services to support Phase 1 decommissioning activities at the WVDP. SEC is responsible for implementing the data collection activities described in the CSAP and the FSSP. Environmental characterization services performed by SEC at the WVDP during 2012 included:

- characterization of two reference areas used to develop background data sets;

- characterization of the HLW canister interim storage area; and

- footprint characterization following removal of the product storage area and the maintenance storage area.

\section{RCRA}

RCRA and its implementing regulations govern the life cycle of hazardous waste from "cradle-to-grave" and mandate that generators take responsibility for ensuring the proper treatment, storage, and ultimate disposal of their wastes. A hazardous waste permit is required for facilities that store large quantities of hazardous waste for more than 90 days or treat or dispose of hazardous waste at the facility.

EPA is responsible for issuing guidelines and regulations for the proper management of solid and hazardous waste (including mixed [radioactive and hazardous] waste). In New York, EPA has delegated the authority to issue permits and enforce these regulations to NYSDEC. In addition, the U.S. Department of Transportation is responsible for issuing guidelines and regulations for labeling, packaging, and spill reporting for hazardous and mixed wastes while in transit.

Hazardous Waste Permitting - RCRA Interim Status Permit Application. In 1984, DOE notified EPA of hazardous waste activities at the WVDP and identified DOE as a hazardous waste generator. In 1990, to comply with 6 NYCRR Part 373-3, a RCRA Part A (i.e., Interim Status or Part A) Permit Application for the WVDP was filed with NYSDEC for storage and treatment of hazardous waste. The WVDP has operated under interim status ever since. RCRA facility operations are limited to those described in the RCRA Part A Permit Application and must comply with the interim status regulations; therefore, the RCRA Part A permit application must be revised prior to changes to the Project's RCRA waste management operations. The latest revisions to the RCRA Part A Permit Application were submitted to NYSDEC on February 3, 2010 and were conditionally approved by NYSDEC on June 9, 2011.

In accordance with the Part A requirements, DOE prepared closure plans for the hazardous waste management units at the WVDP. The closure plans were transmitted to NYSDEC in anticipation of closure activities, and are revised as appropriate to address NYSDEC comments or changes in activities. To complete closure of a RCRA unit, NYSDEC must approve the closure plan and must be notified of the closure schedule. Waste is removed, and impacted areas and facilities are decontaminated and/or removed. When specified in the closure plan, confirmatory sampling and analysis are performed, and data are evaluated and presented to NYSDEC in a closure certification report to document completion of closure activities.

The HWSLs underwent clean-closure activities and sampling in December 2011, to confirm clean closure per the RCRA hazardous waste management unit closure plan. The RCRA closure certification report was submitted to NYSDEC on March 14, 2012, and a revised and re-certified report was submitted on August 9, 2012 to address NYSDEC comments. In November 2012, NYSDEC approved the revised report and considered the unit closed in accordance with all applicable regulations.

The RCRA closure plan for the Cement Solidification System was submitted in May 2013 to NYSDEC for review and approval. Closure plans for the remaining units were submitted with the RCRA 6 NYCRR Part 373-2 Permit application, as described below.

RCRA Final Status Permit Application. In 2003, NYSDEC officially requested the submittal of a 6 NYCRR Part 373-2 Permit Application (i.e., Part B) for the WVDP. The completed permit application was transmitted to NYSDEC in December 2004.

On April 16, 2009, NYSDEC officially requested the submittal of a revised Part B Permit Application for the WVDP. The revised permit application was submitted to NYSDEC on September 30, 2010. Due to the scope and breadth of the permit application, DOE and NYSERDA agreed to NYSDEC's request for an indefinite suspension of NYSDEC's completeness review in January 2011. 
On March 22, 2012, NYSDEC notified NYSERDA and DOE that they would suspend further action relative to a Part B Permit. As part of this approach, processing of the September 2010 Part B Permit Application, including revisions, will be deferred to authority provided by the RCRA Consent Order for corrective actions or operation under existing (Part A) Interim Status. The site will continue to operate according to the 6 NYCRR Part 373-3, Part A (Interim Status) Permit Application. Upon completion of interim status closure activities, it is anticipated that the 6 NYCRR Part 373-2, Part B (Final Status) Permit Application will be revised to include corrective actions, and the closure and post closure requirements for any remaining facilities/units.

RCRA §3008(h) Administrative Order on Consent. Section $\S 3008(\mathrm{~h})$ of RCRA authorizes EPA to issue an order requiring corrective action to protect human health and the environment if there has been or there is potential for a release of hazardous waste or hazardous constituents to the environment from a SWMU. DOE and NYSERDA entered into the Consent Order with NYSDEC and EPA in March 1992. Consent Order activities performed to date are summarized below.

- RCRA Facility Investigation (RFI)

The Consent Order required NYSERDA and DOE's WVDP office to conduct RFIs (unit-specific environmental investigations) at SWMUs to determine if a release occurred or if there was a potential for release of RCRA-regulated hazardous constituents from a SWMU. As many SWMUs are contiguous or close together, most were grouped into larger units, called super SWMUs (SSWMUs); terminology unique to the WVDP. SSWMU descriptions and the individual constituent SWMUs are presented in Table ECS-4. Figures A-8 and A-9 in Appendix A show the WVDP SSWMU locations. Final RFI reports were submitted in 1997, completing the Consent Order investigative activities. No corrective actions were required at that time.

Groundwater monitoring, as recommended in the RFI reports and approved by EPA and NYSDEC, continued during 2012 per the Consent Order requirements. The groundwater program and monitoring results at the WVDP are discussed in Chapter 4 "Groundwater Protection Program."
- Current Conditions Report

Per a NYSDEC request, a report entitled "WVDP Solid Waste Management Unit Assessment and Current Conditions Report" was submitted in November 2004, which summarized the historic activities at each SWMU through the RFI activities and provided environmental monitoring data and information on SWMU activities performed since the RFI reports were submitted.

This document was revised and submitted on September 29, 2010, incorporating operational status changes of each SWMU and providing updated environmental monitoring data.

- Corrective Measures Study (CMS)

In 2004, NYSDEC requested CMSs to be performed on six specific SWMUs at the WVDP. The six SWMUs were:

- $\quad$ NDA Burial Area (SWMU \#2);

- NDA Interceptor Trench (SWMU \#23);

- Demineralizer Sludge Ponds (SWMU \#5);

- $\quad$ Lagoon 1 (SWMU \#3);

- Construction Demolition and Debris Landfill (CDDL) (SWMU \#1); and

- The Low-Level Waste Treatment Facility (LLWTF) (SWMUs \#17, \#17a, and \#17b).

The CMS Work Plan was conditionally approved by NYSDEC in October 2006. Draft CMS reports were revised in 2010 to be consistent with the EIS and ROD and provide corrective measures evaluations. The revised documents were submitted to NYSDEC and EPA on September 29, 2010.

- Interim Measure (IM)

The NDA (SSWMU \#9) is regulated under the Consent Order. As an IM in 1990, a trench system was constructed through the weathered Lavery till along the northeast and northwest sides of the NDA to intercept and collect groundwater potentially contaminated with a mixture of $n$-dodecane and tributyl phosphate (TBP). Monitoring results in 2012 detected no TBP in groundwater from the NDA interceptor trench.

Per the approved CMS Work Plan, in 2008 DOE implemented an IM to ensure a minimum 4-ft-thick earthen cap, minimize the potential release of impacted groundwater from the NDA, and minimize water infiltration into the NDA until the final disposition of the 
NDA is determined and can be implemented. An approximate 850-ft-long low permeability slurry wall was constructed along the south and western sides of the NDA to limit lateral groundwater migration. Part two of the project involved resurfacing the entire five-acre ( 2 ha) landfill with additional soils, re-grading, compacting, and applying an impermeable geomembrane cover. The volume of water pumped from the NDA interceptor trench has decreased significantly, to 64,035 gal (242,399 L) in CY 2012, compared with pre-IM volumes. Refer to Chapter 4, "Groundwater Protection Program."

In July 2012, the entire NDA cap was inspected, including storm water basins, walkways, ballast tubes, field seams, pipe penetrations, and the anchor trench. The need for several minor repairs, such as sealing minor holes, was observed; however, the overall cap condition was good, with no general deterioration of the geomembrane noted. The minor repairs identified have been performed.

\section{- Quarterly Reporting to EPA and NYSDEC}

Per the Consent Order, DOE transmits a quarterly progress report to EPA and NYSDEC, summarizing all Consent Order activities at the WVDP for the previous quarter. The report includes progress and accomplishments, contacts with local community interest groups and regulatory agencies pertaining to Consent Order activities at the WVDP, changes to personnel, projected future work activities, and an inventory of mixed waste generated from decontamination activities during the reporting period. The other report submitted quarterly to EPA and NYSDEC under the Consent Order is the groundwater exception report, including NDA water level data for the interceptor trench and the $2008 \mathrm{IM}$.

Hazardous Waste Management. Under RCRA, hazardous wastes at the WVDP are managed in accordance with 6 NYCRR Parts 370-374 and 376. Hazardous and mixed waste activities are reported to NYSDEC in the WVDP's Annual Hazardous Waste Report, which specifies the quantities of waste generated, treated, and/or disposed of, and identifies the treatment, storage, and disposal facilities used. The Annual Hazardous Waste Report for 2012 was submitted to NYSDEC in February 2013.
Additional reports are submitted each year to document hazardous waste reduction efforts. Pursuant to Article 27, Section 0908 of New York State Environmental Conservation Law, an annual update of the WVDP's Hazardous Waste Reduction Plan must be submitted to NYSDEC biennially and a status report must be submitted in the interim years. The plan is updated to reflect changes in the types and amounts of hazardous wastes generated at the WVDP. The most recent biennial update to the Hazardous Waste Reduction Plan was submitted to NYSDEC on July 1,2011 . The next plan update will be submitted in 2013. During the interim years, an Annual Status Report, essentially an abbreviated version of the biennial update, is submitted. The CY 2011 Annual Status Report for the Hazardous Waste Reduction Plan was submitted to NYSDEC on June 27, 2012.

Mixed Waste Management. Mixed wastes that cannot be treated or disposed of within one year are managed according to the "Site Treatment Plan (STP)," prepared by the DOE under requirements of the FFCA (an amendment to RCRA), in accordance with a Consent Order agreement. The annually updated plan describes the development of treatment capabilities and technologies for treating mixed waste. The fiscal year (FY) 2012 update brought the mixed waste inventory and treatment information current to the end of FY 2012. The FY 2012 plan identified four proposed milestones for waste streams managed under the WVDP STP, all of which were completed by September 30, 2012. During 2012, 16,619 pounds (7.54 mt) of hazardous and mixed waste were shipped off site for disposal. (See Table ECS-5.)

Nonhazardous, Regulated Waste Management. Nonradioactive, nonhazardous material was shipped off site to solid waste management facilities in 2012. Certain components of this waste (lead-acid batteries and spent lamps [i.e., universal wastes]) were reclaimed or recycled at off-site, authorized reclamation and recycling facilities. (See Tables ECS-5 and ECS-6.) Digested sludge from the site sanitary WWTF was shipped to the Buffalo Sewer Authority for disposal. Sanitary treated wastewater was routinely sampled and discharged to Erdman Brook in compliance with the WVDP's SPDES permit. (See Table ECS-5.) During periods when the WWTF was 
not operating, sanitary wastewater was shipped to the Buffalo Sewer Authority for treatment and disposal.

Waste Minimization and Pollution Prevention. The annual pollution prevention report was submitted to DOE summarizing recycling and waste generation information. See Table ECS-6, "Recycled Materials for FY 2012;" Table ECS-7, "EO 13514 Pollution Prevention/Waste Minimization Accomplishments in 2012;" and Chapter 1, "Environmental Management System (EMS)." Reports are submitted to DOE to document hazardous waste reduction efforts, as discussed previously in the "Hazardous Waste Management" section.

CDDL Activities. The CDDL was closed in 1986 under a NYSDEC-approved closure plan for a nonradioactive solid waste disposal facility. A general inspection of the CDDL, to note the overall conditions of the grounds, was performed in the spring and fall of 2012, with no concerns noted. Over time, the north plateau strontium-90 plume has migrated from the MPPB into the CDDL area and beyond. In 2010, a full-scale PTW was installed, south of the CDDL. Construction of the PTW did not impact the CDDL. See "Strontium-90 Plume Remediation Activities" in Chapter 4.

\section{Environmental Issues}

Unplanned Waterborne Release. There were no unplanned nonradiological waterborne releases during 2012. Refer to "SPDES Permit Noncompliance Events" earlier in this chapter. There were also no unplanned waterborne releases of radiological constituents from the WVDP in 2012.

EPA Interim Approval to Use Environmental Measurements for National Emission Standards for Hazardous Air Pollutants (NESHAP) Compliance. Radiological NESHAP compliance at the WVDP is currently demonstrated by (1) measuring (and/or estimating) radiological emissions in air released from the site during the $\mathrm{CY}$ of interest and (2) using EPA-approved computer models to estimate dose to the maximally exposed off-site individual (MEOSI). This method is referred to as the "measure and model" approach, and is most suitable for point sources of air emissions such as stacks or ducts. Resulting dose estimates for the WVDP have always been far below the 10-millirem (mrem)/year compliance standard. (See Chapter 3 for a discussion of dose assessment methodology.)

NESHAP regulations in Title 40 Code of Federal Regulations (CFR) Part 61, Subpart $\mathrm{H}$ allow (with prior EPA approval) for use of an alternate method of demonstrating compliance by measuring environmental concentrations of airborne radionuclides at critical receptor locations. As WVDP facilities continue to be closed, the alternative approach of environmental air sampling will become the more appropriate method.

DOE submitted an updated request to EPA in February 2009 for approval to use environmental air measurements to demonstrate NESHAP compliance at the WVDP. The plan includes a one-year period of using both the "measure and model" and the "environmental measurement" approach to confirm compliance. EPA granted interim conditional approval in July 2009, and extensions have been granted through July 2014 .

The ambient air monitoring network was installed with the system undergoing operational baselining and equipment testing in 2012. (Data from the fourth quarter is included in Appendix C.) The network consists of 16 ambient air low-volume sampling stations (one for each of the 16 wind directions), strategically located and operated in areas that provide coverage for airborne radiological environmental measurements to support NESHAP compliance during demolition activities.

In addition, one high-volume sampler is co-located in the sector most often identified as the critical receptor. This sampler serves as an independent source of data for comparison with the compliance network data at that location. Ambient air continues to be monitored at the background location, although data from this sampler is not used to demonstrate NESHAP compliance under normal operating conditions.

Erdman Brook Erosion Mitigation. During the first half of 2011, design work for erosion mitigation measures was completed, and work activities in these areas designated as federally protected wetlands was permitted under the Nationwide Permit 27 - Stream and Wetland Restoration Activities. A portion of this work was completed in the 2011 field season, and the remainder was completed in 2012. The work was performed by NYSERDA, but jointly funded by DOE and NYSERDA.

Safety Inspections of the WNYNSC Dams. The two dams located on the WNYNSC property are maintained because they provide water for drinking and operational purposes for the WVDP. Also, the WVDP Rail Spur and an access roadway are located parallel to and run along the crest of both dams. A severe rain event in August 2009 caused flood damage to areas of the reservoirs and spillways. 
Standard operating procedure for maintenance, inspection, and operation of the lake dams and emergency spillway has been enhanced. Assessment and inspection of the dams occurred during 2012, with no significant findings identified.

\section{Project Assessment Activities in 2012}

Throughout CY 2012, assessments were conducted through the Integrated Assessment Program (IAP) at the WVDP. This program effectively complies with applicable DOE directives, regulations, standards, and integrated safety management system (ISMS) requirements. The IAP applies to all disciplines including, but not limited to, safety and health, operations, maintenance, environmental protection, quality, decontamination and decommissioning (D\&D), HLW activities, emergency management, business processes, and management. Inspections, reviews, and oversight activities are routinely conducted to evaluate performance, reduce risk, and identify improvement opportunities.

DOE-WVDP and other agencies with responsibilities for the WVDP also independently reviewed various aspects of the environmental and waste management programs. At the conclusion of the reporting period, there were no outstanding issues that were not satisfactorily addressed. Overall results reflected continuing, well-managed environmental programs at the WVDP. Refer to Chapter 1, "Environmental Management System." 
TABLE ECS-1

Compliance Status Summary for the WVDP in CY 2012

\begin{tabular}{|c|c|c|}
\hline Citation & $\begin{array}{l}\text { Environmental Statute, } \\
\text { DOE Directive, EO, Agreement }\end{array}$ & $\begin{array}{l}\text { WVDP Compliance } \\
\text { Status }\end{array}$ \\
\hline $\begin{array}{l}42 \text { United States } \\
\text { Code (USC) } \\
\S 2011 \text { et seq. }\end{array}$ & $\begin{array}{l}\text { The AEA of } 1954 \text { was enacted to assure the proper } \\
\text { management of source, special nuclear, and by- } \\
\text { product materials. The AEA and the statutes that } \\
\text { amended it delegate the control of nuclear energy } \\
\text { primarily to DOE, NRC, and EPA. }\end{array}$ & $\begin{array}{l}\text { See discussions of the WVDP Act, DOE Orders } \\
435.1 \text {, and } 458.1\end{array}$ \\
\hline $\begin{array}{l}\text { Public Law } \\
96-368\end{array}$ & $\begin{array}{l}\text { The WVDP Act of } 1980 \text { authorized DOE to carry out a } \\
\text { HLW demonstration project at the WNYNSC (the } \\
\text { Center) in West Valley, New York. }\end{array}$ & $\begin{array}{l}\text { DOE is focusing on goals that will lead to } \\
\text { completion of responsibilities listed in the WVDP } \\
\text { Act. }\end{array}$ \\
\hline $\begin{array}{l}\text { Cooperative } \\
\text { Agreement } \\
\text { between DOE } \\
\text { and NYSERDA }\end{array}$ & $\begin{array}{l}\text { The Cooperative Agreement between DOE and } \\
\text { NYSERDA established a cooperative framework for } \\
\text { implementing the WVDP Act, effective October 1980, } \\
\text { as amended in September 1981. In 1990, the first } \\
\text { supplemental agreement was signed by DOE and } \\
\text { NYSERDA which set forth specific provisions for } \\
\text { preparing a joint EIS. A second supplemental } \\
\text { agreement to the Cooperative Agreement was drafted } \\
\text { in January } 2010 \text { and issued by DOE and NYSERDA in } \\
\text { March } 2011 .\end{array}$ & $\begin{array}{l}\text { Except as delineated in specific sections of the } \\
\text { agreement, DOE was given sole responsibility to } \\
\text { carry out the requirements of the WVDP Act. } \\
\text { DOE and NYSERDA issued a joint final EIS in } \\
\text { January 2010, and subsequent ROD and a Findings } \\
\text { Statement thereby fulfilling the purpose and } \\
\text { intent of the original Supplemental Agreement. In } \\
\text { March 2011, DOE and NYSERDA issued a Second } \\
\text { Supplemental Agreement setting forth the } \\
\text { procedures and responsibilities associated with } \\
\text { conducting the Phase } 1 \text { Studies, initiated during } \\
2012 \text {. }\end{array}$ \\
\hline $\begin{array}{l}\text { WVDP MOU } \\
\text { between DOE } \\
\text { and NRC }\end{array}$ & $\begin{array}{l}\text { The } 1981 \text { MOU, mandated by the WVDP Act, } \\
\text { established procedures for review and consultation by } \\
\text { NRC with respect to activities conducted at the } \\
\text { WNYNSC by DOE. The agreement encompassed } \\
\text { development, design, construction, operation, and } \\
\text { D\&D activities associated with the Project as described } \\
\text { in the WVDP Act. Under the WVDP Act, and to satisfy } \\
\text { commitments made to NRC, DOE was required to } \\
\text { prepare a DP for the Project and submit it to NRC for } \\
\text { review. }\end{array}$ & $\begin{array}{l}\text { In 2002, NRC issued "Decommissioning Criteria for } \\
\text { the WVDP (M-32) at the West Valley Site; Final } \\
\text { Policy Statement" (67 FR 5003). The "Phase } 1 \text { DP } \\
\text { for the West Valley Demonstration Project" was } \\
\text { prepared by DOE and submitted to NRC in } \\
\text { December 2008, and March and December, } 2009 . \\
\text { In February 2010, NRC issued a TER on DOE's } \\
\text { Phase } 1 \text { DP. NRC conducted monitoring visits at } \\
\text { the WVDP on June } 12-13, \text { November } 14-15, \text { and } \\
\text { December 4, } 2012 \text { to review ongoing } \\
\text { decommissioning activities. }\end{array}$ \\
\hline $\begin{array}{l}\text { DOE Order } \\
231.1 \mathrm{~B}\end{array}$ & $\begin{array}{l}\text { DOE Order 231.1B, Environment, Safety, and Health } \\
\text { Reporting (updated and approved on June 27, } 2011 \\
\text { with Change } 1 \text { issued on November } 28,2012 \text { ), was } \\
\text { issued to ensure that DOE and National Nuclear } \\
\text { Security Administration receives timely and accurate } \\
\text { information about events that could adversely affect } \\
\text { the health, safety, and security of the public or } \\
\text { workers, the environment, the operations of DOE } \\
\text { facilities, or the credibility of the Department. } \\
\text { (continued on next page) }\end{array}$ & $\begin{array}{l}\text { This WVDP ASER is prepared and submitted } \\
\text { annually to DOE Headquarters (HQ), regulatory } \\
\text { agencies, and interested stakeholders in } \\
\text { compliance with DOE Order 231.1B. }\end{array}$ \\
\hline
\end{tabular}


TABLE ECS-1 (continued)

Compliance Status Summary for the WVDP in CY 2012

\begin{tabular}{|c|c|c|}
\hline Citation & $\begin{array}{l}\text { Environmental Statute, } \\
\text { DOE Directive, EO, Agreement }\end{array}$ & $\begin{array}{l}\text { WVDP Compliance } \\
\text { Status }\end{array}$ \\
\hline $\begin{array}{l}\text { DOE Order } \\
231.1 \mathrm{~B} \\
\text { (continued) }\end{array}$ & $\begin{array}{l}\text { This is accomplished through timely collection, } \\
\text { reporting, analysis, and dissemination of data } \\
\text { pertaining to environment, safety, and health issues as } \\
\text { required by law or regulations, or in support of U.S. } \\
\text { political commitments to the International Atomic } \\
\text { Energy Agency. }\end{array}$ & $\begin{array}{l}\text { This WVDP ASER is prepared and submitted } \\
\text { annually to DOE HQ, regulatory agencies, and } \\
\text { interested stakeholders in compliance with DOE } \\
\text { Order 231.1B. }\end{array}$ \\
\hline $\begin{array}{l}\text { DOE Order } \\
458.1\end{array}$ & $\begin{array}{l}\text { DOE Order 458.1, Radiation Protection of the Public } \\
\text { and the Environment (including change June 2, 2011), } \\
\text { replaced DOE Order } 5400.5 \text { and established } \\
\text { requirements to protect the public and environment } \\
\text { against undue risk from radiation associated with } \\
\text { radiological activities conducted under control of DOE } \\
\text { pursuant to the AEA, by ensuring that (1) operations } \\
\text { are conducted to limit radiation exposure to members } \\
\text { of the public pursuant to limits established in the } \\
\text { Order, (2) radiological clearance of DOE real and } \\
\text { personal property is controlled, (3) potential radiation } \\
\text { exposures to members of the public are as low as } \\
\text { reasonably achievable (ALARA), (4) routine and } \\
\text { nonroutine releases are monitored and dose to the } \\
\text { public is assessed, and (5) the environment is protected } \\
\text { from the effects of radiation and radioactive material. }\end{array}$ & $\begin{array}{l}\text { This ASER summarizes radiological estimates of } \\
\text { dose to the public and the environment, and } \\
\text { compares these values with release and dose } \\
\text { standards established by this Order. In } 2012 \text {, } \\
\text { estimated doses from airborne and waterborne } \\
\text { releases to the MEOSI were } 0.019 \% \text { of the } 100- \\
\text { millirem (mrem) standard, and about } 0.006 \% \text { of } \\
\text { natural background radiation. Refer to Chapter } 3 \text {, } \\
\text { "Dose Assessment," for further discussion. }\end{array}$ \\
\hline $\begin{array}{l}\text { DOE Order } \\
435.1-1\end{array}$ & $\begin{array}{l}\text { DOE Order 435.1-1, Radioactive Waste Management, } \\
\text { issued in 1999, ensures that all DOE radioactive waste } \\
\text { is managed in a manner that is protective of worker } \\
\text { and public health and safety and the environment, and } \\
\text { complies with applicable state, federal, and local laws } \\
\text { and regulations. Under the Order, sites that manage } \\
\text { radioactive waste are required to develop, document, } \\
\text { implement, and maintain a site-wide radioactive waste } \\
\text { management program which includes actions to } \\
\text { minimize radioactive waste generation. }\end{array}$ & $\begin{array}{l}\text { The WVDP maintains program documentation } \\
\text { separately for each waste type. Management of } \\
\text { HLW was conducted in accordance with the } \\
\text { "WVDP Waste Acceptance Manual;" TRU waste } \\
\text { was managed in accordance with the "TRU Waste } \\
\text { Management Program Plan;" LLW was managed } \\
\text { as summarized in the "LLW Management Program } \\
\text { Plan;" and the radioactive component of mixed } \\
\text { LLW was managed as summarized in the "Site } \\
\text { Treatment Plan (STP) FY } 2012 \text { Update." In } \\
\text { February 2012, DOE issued the "Waste Incidental } \\
\text { to Reprocessing Evaluation for the West Valley } \\
\text { Demonstration Project Vitrification Melter," } \\
\text { pursuant to DOE Order 435.1-1. In June 2012, } \\
\text { DOE issued the "Draft Waste Incidental to } \\
\text { Reprocessing Evaluation for the Concentrator } \\
\text { Feed Makeup Tank and Melter Feed Hold Tank" } \\
\text { for NRC and public review. The final document } \\
\text { was issued in February 2013. Refer earlier in this } \\
\text { chapter for further discussion. }\end{array}$ \\
\hline
\end{tabular}


TABLE ECS-1 (continued)

Compliance Status Summary for the WVDP in CY 2012

\begin{tabular}{|c|c|c|}
\hline Citation & $\begin{array}{l}\text { Environmental Statute, } \\
\text { DOE Directive, EO, Agreement }\end{array}$ & $\begin{array}{l}\text { WVDP Compliance } \\
\text { Status }\end{array}$ \\
\hline $\begin{array}{l}\text { DOE Order } \\
436.1, \text { and EOs } \\
13423 \text { and } \\
13514\end{array}$ & $\begin{array}{l}\text { DOE Order 436.1, Departmental Sustainability, May 2, } \\
2011 \text { replaced DOE Orders } 450.1 \mathrm{~A} \text {, and 430.2B. The } \\
\text { Order also incorporates the initiatives of EOs } 13423 \\
\text { and } 13514, \text { which provide requirements and } \\
\text { responsibilities for managing sustainability within DOE } \\
\text { to (1) ensure the DOE carries out its missions in a } \\
\text { sustainable manner that addresses national energy } \\
\text { security and global environmental challenges, and } \\
\text { advances sustainable, efficient and reliable energy for } \\
\text { the future, (2) institute cultural change to factor } \\
\text { sustainability and greenhouse gas (GHG) reductions } \\
\text { into all DOE decisions, (3) ensure DOE achieves the } \\
\text { sustainability goals established in its Strategic } \\
\text { Sustainability Performance Plan (SSPP) pursuant to } \\
\text { applicable laws, regulations, and EOs. }\end{array}$ & $\begin{array}{l}\text { The WVDP supports the objectives of DOE Order } \\
436.1 \text {, and has an established culture of } \\
\text { environmental stewardship through it's } \\
\text { environmental management system (EMS). } \\
\text { Pollution prevention, waste minimization, and } \\
\text { energy efficiency have been incorporated into the } \\
\text { culture through standard practices, procedures, } \\
\text { training, and encouraging new ideas. On } \\
\text { November } 29,2012 \text {, DOE-WVDP submitted the } \\
\text { "WVDP FY 2013 Site Sustainability Plan" to DOE- } \\
\text { HQ, which outlined performance status and } \\
\text { planned goals to support DOE's sustainability } \\
\text { mission. Refer to Chapter } 1, \text { "Environmental } \\
\text { Management System." CHBWV, the WVDP Phase } \\
1 \text { decommissioning and facilities disposition } \\
\text { contractor, received a Certificate of Registration } \\
\text { for the International Organization for } \\
\text { Standardization (ISO) } 14001: 2004 \text { certification of } \\
\text { its EMS on July } 31,2012 \text {. In May 2013, an } \\
\text { independent EMS ISO } 14001 \text { maintenance audit } \\
\text { was completed resulting in the recommendation } \\
\text { to retain certification. }\end{array}$ \\
\hline $\begin{array}{l}\text { Title } 10 \text { Code of } \\
\text { Federal } \\
\text { Regulations }(10 \\
\text { CFR) Part } 830 \\
\text { Subpart A }\end{array}$ & $\begin{array}{l}\text { 10 CFR Part 830, Nuclear Safety Management, Subpart } \\
\text { A, Quality Assurance Requirements, and DOE Order } \\
\text { 414.1D Quality Assurance, provide the quality } \\
\text { assurance (QA) program policies and requirements } \\
\text { applicable to WVDP activities. }\end{array}$ & $\begin{array}{l}\text { A QA program that provides a consistent system } \\
\text { for collecting, assessing, and documenting data } \\
\text { pertaining to radionuclides in the environment is } \\
\text { implemented at the WVDP. }\end{array}$ \\
\hline $\begin{array}{l}42 \text { USC §4321 et } \\
\text { seq. }\end{array}$ & $\begin{array}{l}\text { The NEPA of } 1969 \text { and as amended in 1970, established } \\
\text { a national policy to ensure that protection of the } \\
\text { environment is included in federal planning and } \\
\text { decision-making. The President's Council on } \\
\text { Environmental Quality established a screening system } \\
\text { of analyses and documentation that requires each } \\
\text { proposed action to be categorized according to the } \\
\text { extent of its potential environmental impact. }\end{array}$ & $\begin{array}{l}\text { NEPA documents are prepared at the WVDP to } \\
\text { describe potential environmental effects } \\
\text { associated with proposed activities. The level of } \\
\text { documentation depends upon whether the action } \\
\text { constitutes a major federal action significantly } \\
\text { affecting the quality of the human environment } \\
\text { within the meaning of NEPA. Draft documents are } \\
\text { prepared and issued for public comment for } \\
\text { major federal actions requiring an EIS. Based on } \\
\text { the analyses presented, considering regulatory } \\
\text { agency and public input, DOE determines the } \\
\text { preferred alternative and issues a ROD. Refer to } \\
\text { previous sections of this chapter for discussion of } \\
\text { NEPA activities. }\end{array}$ \\
\hline
\end{tabular}


TABLE ECS-1 (continued)

Compliance Status Summary for the WVDP in CY 2012

\begin{tabular}{|c|c|c|}
\hline Citation & $\begin{array}{c}\text { Environmental Statute, } \\
\text { DOE Directive, EO, Agreement }\end{array}$ & $\begin{array}{l}\text { WVDP Compliance } \\
\text { Status }\end{array}$ \\
\hline $\begin{array}{l}6 \text { NYCRR Part } \\
617 \text { NYS } \\
\text { Environmental } \\
\text { Conservation } \\
\text { Law (ECL) }\end{array}$ & $\begin{array}{l}\text { The NY SEQR Act of January 1, 1996, enacted in } \\
\text { September } 1976 \text { and as amended on June 26, 2000, } \\
\text { requires adequate environmental review and } \\
\text { assessment of whether a proposed action has the } \\
\text { potential to have a significant environmental impact, } \\
\text { prior to a decision regarding the action. Where a } \\
\text { project involves both NYS and federal approvals, it is } \\
\text { preferred to coordinate the SEQR and NEPA processes. }\end{array}$ & $\begin{array}{l}\text { The SEQR process is an action-forcing statute that } \\
\text { requires state agencies to incorporate } \\
\text { environmental considerations directly into their } \\
\text { decisionmaking, and where necessary, to modify } \\
\text { that action to mitigate adverse environmental } \\
\text { effects. Coordinated efforts were made at the } \\
\text { WVDP to effectively utilize information from the } \\
\text { federal EIS process to make the required SEQR } \\
\text { Findings Statement for the WVDP and WNYNSC, } \\
\text { which was issued in May } 2010 \text {. }\end{array}$ \\
\hline $\begin{array}{l}42 \text { USC } \S 6901 \text { et } \\
\text { seq., and NYS } \\
E C L\end{array}$ & $\begin{array}{l}\text { The RCRA of } 1976 \text { and the NYS Solid Waste Disposal } \\
\text { Act (NYS ECL Article } 27 \text { [Title 9]) govern the generation, } \\
\text { storage, handling, and disposal of hazardous wastes } \\
\text { and closure of systems that handle these wastes. RCRA } \\
\text { was enacted to ensure that hazardous wastes are } \\
\text { managed in a way that protects human health, safety, } \\
\text { and the environment. }\end{array}$ & $\begin{array}{l}\text { Generation, storage, handling, treatment, and } \\
\text { disposal of hazardous waste, and closure of } \\
\text { systems that handle hazardous waste at the } \\
\text { WVDP, are conducted in accordance with the } \\
\text { RCRA interim status regulations. NYSDEC } \\
\text { performed a RCRA hazardous waste compliance } \\
\text { inspection of the WVDP facilities on March 21, } \\
2012 \text { and reported no violations. DOE performed } \\
\text { a surveillance of the RCRA hazardous and mixed } \\
\text { waste inventories and shipments at the WVDP } \\
\text { between December } 2011 \text { and February } 2012 \text {, with } \\
\text { no findings or concerns identified. EPA performed } \\
\text { a RCRA compliance inspection in August 2012, } \\
\text { and found no violations. Further discussion of } \\
\text { RCRA activities is presented earlier in this chapter. }\end{array}$ \\
\hline $\begin{array}{l}\text { Amendment to } \\
42 \text { USC } \S 6961\end{array}$ & $\begin{array}{l}\text { The FFCA of } 1992 \text { (an amendment to RCRA) requires } \\
\text { DOE facilities to prepare an STP for treating mixed } \\
\text { waste inventories to meet land disposal restrictions } \\
\text { and to annually update the plan to account for changes } \\
\text { in mixed waste inventories, capacities, and treatment } \\
\text { technologies. DOE entered into a Consent Order with } \\
\text { NYSDEC for the WVDP in } 1996 .\end{array}$ & $\begin{array}{l}\text { The FFCA requires completing milestones } \\
\text { identified in the STP plan volume. The WVDP STP } \\
\text { for FY } 2012 \text { update was submitted to NYSDEC on } \\
\text { February 5, 2013. Refer to "Mixed Waste } \\
\text { Management," earlier in this chapter. }\end{array}$ \\
\hline $\begin{array}{l}\text { Docket No. II } \\
\text { RCRA 3008(h) } \\
92-0202\end{array}$ & $\begin{array}{l}\text { DOE and NYSERDA entered into the RCRA §3008(h) } \\
\text { Administrative Order on Consent with EPA (lead } \\
\text { agency) and NYSDEC in March 1992. The state and } \\
\text { federal RCRA regulations authorize the agencies to } \\
\text { issue orders requiring RCRA corrective actions } \\
\text { associated with the potential releases of hazardous } \\
\text { waste and/or hazardous constituents from SWMUs at } \\
\text { the WNYNSC. }\end{array}$ & $\begin{array}{l}\text { Written procedures and site activities are } \\
\text { compliant with the Consent Order. In accordance } \\
\text { with the Consent Order, DOE submits quarterly } \\
\text { reports to EPA and NYSDEC that summarize all } \\
\text { RCRA §3008(h) activities and progress conducted } \\
\text { at the WVDP for the representative quarter. A } \\
\text { discussion of CY } 2012 \text { activities is presented } \\
\text { earlier in this chapter. }\end{array}$ \\
\hline
\end{tabular}


TABLE ECS-1 (continued)

Compliance Status Summary for the WVDP in CY 2012

\begin{tabular}{|c|c|c|}
\hline Citation & $\begin{array}{l}\text { Environmental Statute, } \\
\text { DOE Directive, EO, Agreement }\end{array}$ & $\begin{array}{l}\text { WVDP Compliance } \\
\text { Status }\end{array}$ \\
\hline $\begin{array}{l}\text { RCRA } 3016 \\
\text { Statute }\end{array}$ & $\begin{array}{l}\text { The RCRA } 3016 \text { Statute applies to all federal hazardous } \\
\text { waste facilities currently owned or operated by the } \\
\text { government. It requires that facility hazardous waste } \\
\text { information be submitted to EPA and authorized states } \\
\text { every two years. }\end{array}$ & $\begin{array}{l}\text { WVDP facility hazardous waste activities are } \\
\text { reported biennially to EPA and NYSDEC. The RCRA } \\
3016 \text { Biennial Report for } 2011 \text { was submitted on } \\
\text { January 30, } 2012 \text {. }\end{array}$ \\
\hline $\begin{array}{l}42 \text { USC } § 7401 \text { et } \\
\text { seq.; } 40 \text { CFR 61, } \\
\text { Subpart H; and } \\
6 \text { NYCRR } \\
\text { Chapter 3, Air } \\
\text { Resources }\end{array}$ & $\begin{array}{l}\text { The Clean Air Act of } 1970 \text { and the NYS ECL regulate the } \\
\text { release of air pollutants through permits and air quality } \\
\text { limits. Emissions of radionuclides are regulated by EPA } \\
\text { via the NESHAP regulations. On April 5, 1995, DOE and } \\
\text { EPA entered into an MOU concerning the Clean Air Act } \\
\text { Emission Standards for Radionuclides } 40 \text { CFR Part } 61 \\
\text { Including Subparts H, I, Q, and T. Nonradiological } \\
\text { emissions are permitted under } 6 \text { NYCRR Part 201-4 } \\
\text { (Minor Facility Registrations). }\end{array}$ & 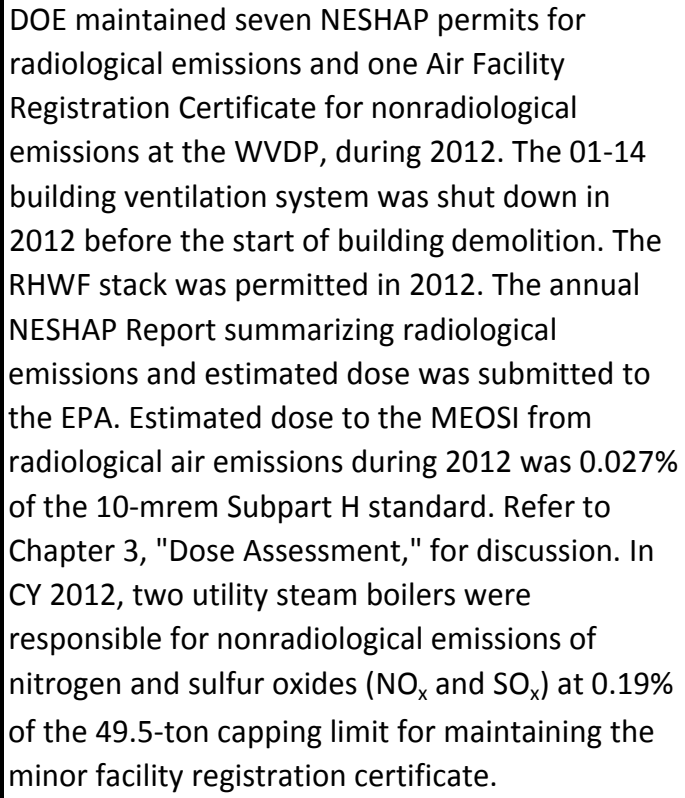 \\
\hline $\begin{array}{l}33 \text { USC } \$ 1251 \text { et } \\
\text { seq. and NYS } \\
\text { ECL }\end{array}$ & $\begin{array}{l}\text { The Federal Water Pollution Control Act of } 1977 \\
\text { (Clean Water Act [CWA]) and NYS ECL (Article } 17 \text { [Title } \\
\text { 8]) seek to improve surface water quality by } \\
\text { establishing standards and a system of permits. } \\
\text { Wastewater and storm water discharges are regulated } \\
\text { by NYSDEC through the SPDES permit. Discharges of fill } \\
\text { material are regulated through permits issued by the } \\
\text { U.S. Army Corps of Engineers (USACE) and water } \\
\text { quality certifications issued by NYSDEC. }\end{array}$ & $\begin{array}{l}\text { Monthly SPDES DMRs are submitted to NYSDEC. A } \\
\text { modified SPDES permit became effective on July } \\
\text { 1, 2011. Industrial wastewater was monitored for } \\
\text { chemical constituents during lagoon discharges } \\
\text { (outfall 001), and treated sanitary and industrial } \\
\text { wastewaters were monitored at outfall } 007 . \\
\text { SPDES-permitted storm water monitoring was } \\
\text { completed during } 2012 \text { by sampling the eight } \\
\text { drainage basins during storm events. During 2012, } \\
\text { all results were within the effluent discharge } \\
\text { limits specified in the SPDES permit. Refer to } \\
\text { "SPDES Permit Noncompliance Events" earlier in } \\
\text { this chapter, and to "SPDES Permit Required } \\
\text { Monitoring" in Chapter } 2 \text { for further discussion. }\end{array}$ \\
\hline
\end{tabular}


Table ECS-1 (continued)

Compliance Status Summary for the WVDP in CY 2012

\begin{tabular}{|c|c|c|}
\hline Citation & $\begin{array}{l}\text { Environmental Statute, } \\
\text { DOE Directive, EO, Agreement }\end{array}$ & $\begin{array}{l}\text { WVDP Compliance } \\
\text { Status }\end{array}$ \\
\hline $\begin{array}{l}\text { NYS ECL Article } \\
17, \text { Titles } 7 \text { and } \\
8 \text {, and ECL } \\
\text { Article } 70\end{array}$ & $\begin{array}{l}\text { NYS ECL Article } 17 \text { (Titles } 7 \text { and } 8 \text { ), and ECL Article } 70 \\
\text { regulate storm water discharges related to } \\
\text { construction activity. }\end{array}$ & $\begin{array}{l}\text { During } 2012 \text { there were no storm water } \\
\text { discharges related to construction activities. }\end{array}$ \\
\hline $\begin{array}{l}\text { NYS Navigation } \\
\text { Law and NYS } \\
\text { ECL }\end{array}$ & $\begin{array}{l}\text { NYS ECL Article } 17 \text { (Titles } 10 \text { and 17), } 6 \text { NYCRR 612-614 } \\
\text { and Parts 595-599, and } 6 \text { NYCRR Subpart 360-14 } \\
\text { regulate design, operation, inspection, maintenance, } \\
\text { and closure of aboveground and underground } \\
\text { petroleum bulk storage (PBS) and chemical bulk } \\
\text { storage (CBS) tanks. These laws also regulate spill } \\
\text { reporting and cleanup. Under terms of a } 1996 \\
\text { agreement, amended in 2005, DOE is not required to } \\
\text { report a spill of petroleum product onto an impervious } \\
\text { surface if the spill is less than five gal and is cleaned up } \\
\text { within two hours of discovery. }\end{array}$ & $\begin{array}{l}\text { The last CBS tank at the WVDP was closed under } \\
\text { these regulations in 2006. There remain nine } \\
\text { registered PBS tanks (eight aboveground storage } \\
\text { tanks [ASTs] and one underground storage tank } \\
\text { [UST]) that are periodically inspected and } \\
\text { maintained. Spills are reported and cleaned up in } \\
\text { accordance with WVDP policies and procedures. } \\
\text { There were no reportable spills during } 2012 . \\
\text { There were four small spills (less than five gal } \\
\text { [18.9 L] each) during CY } 2012, \text { which did not } \\
\text { require immediate notification to NYSDEC, but } \\
\text { were reported in quarterly reports. }\end{array}$ \\
\hline EO 11990 & $\begin{array}{l}\text { EO 11990, Protection of Wetlands, directed federal } \\
\text { agencies to avoid, where possible, impacts (e.g., } \\
\text { destruction, modification, or new construction) that } \\
\text { would adversely effect wetlands wherever there is a } \\
\text { practical alternative. Activities in wetlands are } \\
\text { regulated by the USACE and NYSDEC permits. The } \\
\text { wetlands on the WVDP are subject to regulation under } \\
\text { Section } 404 \text { of the CWA and NYS ECL Articles } 24 \text { and } 36 .\end{array}$ & $\begin{array}{l}\text { Wetlands are periodically identified and } \\
\text { delineated on the WVDP. In 2006, the USACE } \\
\text { confirmed that } 34.09 \text { acres ( } 13.8 \text { ha) of wetlands, } \\
\text { subject to federal jurisdiction, exist within and } \\
\text { adjacent to the WVDP. A wetland complex of } 17.4 \\
\text { acres ( } 7.0 \text { ha) is subject to NYSDEC jurisdiction. In } \\
\text { April 2011, updated wetland delineation was } \\
\text { completed for areas impacted by the Erdman } \\
\text { Brook erosion mitigation project. Refer to } \\
\text { "Erdman Brook Erosion Mitigation, " earlier in this } \\
\text { chapter. }\end{array}$ \\
\hline $\begin{array}{l}42 \text { USC §9601 et } \\
\text { seq. }\end{array}$ & $\begin{array}{l}\text { The Comprehensive Environmental Response, } \\
\text { Compensation, and Liability Act of } 1980 \text { (CERCLA, } \\
\text { including the Superfund Amendments and } \\
\text { Reauthorization Act of } 1986 \text { [SARA]) provided the } \\
\text { regulatory framework for remediation of releases of } \\
\text { hazardous substances and remediation of inactive } \\
\text { hazardous waste disposal sites. }\end{array}$ & $\begin{array}{l}\text { Based on the results of a Preliminary Assessment } \\
\text { Report prepared for DOE, it was determined that } \\
\text { the WVDP did not qualify for listing on the } \\
\text { national priorities list. Therefore, no further } \\
\text { investigation pursuant to CERCLA was warranted. } \\
\text { However, if a hazardous substance spill exceeds a } \\
\text { reportable quantity, CERCLA reporting } \\
\text { requirements may be triggered. }\end{array}$ \\
\hline
\end{tabular}


TABLE ECS-1 (continued)

Compliance Status Summary for the WVDP in CY 2012

\begin{tabular}{|c|c|c|}
\hline Citation & $\begin{array}{c}\text { Environmental Statute, } \\
\text { DOE Directive, EO, Agreement }\end{array}$ & $\begin{array}{l}\text { WVDP Compliance } \\
\text { Status }\end{array}$ \\
\hline $\begin{array}{l}42 \text { USC } \S 11001 \\
\text { et seq. }\end{array}$ & $\begin{array}{l}\text { The Emergency Planning and Community Right-to- } \\
\text { Know Act (EPCRA) of } 1986 \text { (also known as SARA Title } \\
\text { III) was designed to create a working partnership } \\
\text { between industry, business, state, and local } \\
\text { government, and emergency response representatives } \\
\text { to help local communities protect public health, safety, } \\
\text { and the environment from chemical hazards. }\end{array}$ & $\begin{array}{l}\text { Chemical inventories for the WVDP are reported } \\
\text { quarterly under EPCRA, as appropriate. A 13,000- } \\
\text { gal ( } 49.210 \text { L) liquid nitrogen tank was installed in } \\
2009 \text { to support the nitrocision effort. This tank } \\
\text { was removed in January 2013. Refer to Tables } \\
\text { ECS-9 and ECS-10. }\end{array}$ \\
\hline $\begin{array}{l}42 \text { USC } \S 300 f \text { et } \\
\text { seq. }\end{array}$ & $\begin{array}{l}\text { The Safe Drinking Water Act of } 1974 \text { requires that each } \\
\text { federal agency operating or maintaining a public water } \\
\text { system must comply with all federal, state, and local } \\
\text { requirements regarding safe drinking water. } \\
\text { Compliance in NYS is verified by oversight of the } \\
\text { NYSDOH, through NYS Public Health Law, and the } \\
\text { Cattaraugus County Health Department (CCHD). }\end{array}$ & $\begin{array}{l}\text { The WVDP operates a nontransient, } \\
\text { noncommunity public drinking water system } \\
\text { serving a population of less than 500. All CY } 2012 \\
\text { results from analyses of drinking water were } \\
\text { reported within limits to the CCHD. The CCHD } \\
\text { routinely performs inspections of the water } \\
\text { treatment and distribution system. }\end{array}$ \\
\hline \begin{tabular}{|l|}
10 CFR Part 851 \\
\end{tabular} & $\begin{array}{l}10 \text { CFR } 851 \text { "Worker Safety and Health Program" of } \\
2006 \text { requires DOE contractors to provide workers with } \\
\text { a safe and healthful workplace. To accomplish this } \\
\text { objective, the rule established program requirements } \\
\text { specific to management responsibilities, worker rights, } \\
\text { hazard identification and prevention, safety health } \\
\text { standards, required training, recordkeeping, and } \\
\text { reporting. }\end{array}$ & $\begin{array}{l}\text { Procedures and programs are revised to maintain } \\
\text { requirements that comply with } 10 \text { CFR } 851 \text {. Any } \\
\text { proposed modification that may invalidate a } \\
\text { portion of the worker health and safety program } \\
\text { at the WVDP must be approved by DOE-WVDP. } \\
\text { The plan was reviewed in April 2012, and it was } \\
\text { determined that no changes to the current plan } \\
\text { were necessary. }\end{array}$ \\
\hline 10 CFR Part 835 & $\begin{array}{l}10 \text { CFR Part 835, Occupational Radiation Protection, } \\
\text { amended May 2011, established radiation protection } \\
\text { standards, limits, and program requirements for } \\
\text { protecting individuals from ionizing radiation resulting } \\
\text { from the conduct of DOE activities. }\end{array}$ & $\begin{array}{l}\text { In February 2012, the document "CH2MHill·B\&W } \\
\text { West Valley, LLC Documented Radiation } \\
\text { Protection Program and Implementation for } 10 \\
\text { CFR Part 835, as amended May } 2011 \text { " was issued } \\
\text { providing an update to the prior revision. }\end{array}$ \\
\hline $\begin{array}{l}15 \text { USC } \S 2601 \text { et } \\
\text { seq., and } 12 \\
\text { NYCRR Part } 56\end{array}$ & $\begin{array}{l}\text { The Toxic Substances Control Act of } 1976 \text { regulates the } \\
\text { manufacture, processing, and distribution of chemicals, } \\
\text { including asbestos-containing material (ACM) and } \\
\text { polychlorinated biphenyls (PCBs). Effective September } \\
2006, \text { the NYS Department of Labor (NYSDOL) } \\
\text { significantly revised the asbestos regulations, cited in } \\
12 \text { NYCRR Part 56. As a result, operating procedures } \\
\text { were revised, special training for asbestos workers was } \\
\text { conducted, and the WVDP applied for and was granted } \\
\text { site-specific variances. }\end{array}$ & $\begin{array}{l}\text { ACM activities were managed in accordance with } \\
\text { the site "Asbestos Management Plan" and } \\
\text { activities were completed by personnel certified } \\
\text { by NYSDOL. Refer to Table ECS-5 for a summary } \\
\text { of asbestos waste management activities. PCBs } \\
\text { are managed in accordance with the WVDP } \\
\text { document "PCB and PCB-Contaminated Material } \\
\text { Management Plan." The WVDP operators } \\
\text { maintain an annual document log that details PCB } \\
\text { use and changes in storage or disposal status. }\end{array}$ \\
\hline
\end{tabular}


TABLE ECS-1 (continued)

Compliance Status Summary for the WVDP in CY 2012

\begin{tabular}{|c|c|c|}
\hline Citation & $\begin{array}{l}\text { Environmental Statute, } \\
\text { DOE Directive, EO, Agreement }\end{array}$ & $\begin{array}{l}\text { WVDP Compliance } \\
\text { Status }\end{array}$ \\
\hline $\begin{array}{l}7 \text { USC } \S 136 \text { et } \\
\text { seq. }\end{array}$ & $\begin{array}{l}\text { The Federal Insecticide, Fungicide, and Rodenticide } \\
\text { Act of } 1996 \text { and NYS ECL provide for EPA and NYSDEC } \\
\text { control of pesticide distribution, sale, and use. }\end{array}$ & $\begin{array}{l}\text { Chemical pesticides are applied at the WVDP only } \\
\text { after alternative methods are evaluated by } \\
\text { trained and NYSDEC-certified professionals and } \\
\text { determined to be unfeasible. Herbicides were not } \\
\text { used at the WVDP during } 2012 \text { so storm water } \\
\text { samples were not analyzed for paraquat } \\
\text { dichloride. During 2012, an average of } 1.0 \text { pounds } \\
\text { (lbs) per day of Steamate NA701 was used as a } \\
\text { corrosion inhibitor. }\end{array}$ \\
\hline $\begin{array}{l}\text { NYS ECL, Article } \\
\text { 15, Title 5, et } \\
\text { seq. }\end{array}$ & $\begin{array}{l}\text { NYS ECL, Article 15, Title 5, Protection of Water } \\
\text { regulates the safety of dams and other surface water } \\
\text { impounding structures, including construction, } \\
\text { inspection, operation, maintenance, and modification } \\
\text { of these structures. Revised dam safety regulations } \\
\text { became effective on August 19, 2009. The dams } \\
\text { maintained by the WVDP, on the WNYNSC property, } \\
\text { are classified as Class A - low-hazard dams. }\end{array}$ & $\begin{array}{l}\text { Two surface water impounding dam structures } \\
\text { are located on the WNYNSC: NYS Atomic } \\
\text { Development Dam \#1 (DEC Dam ID \#019-3149) } \\
\text { and NYS Atomic Development Dam \#2 (DEC Dam } \\
\text { ID \#019-3150). Inspections and maintenance were } \\
\text { routinely performed and documented in CY } 2012 .\end{array}$ \\
\hline $\begin{array}{l}\text { NYS ECL Article } \\
15, \text { Title 33, Part } \\
675\end{array}$ & $\begin{array}{l}\text { NYS ECL, Article } 15, \text { Title } 33 \text { Water Withdrawal } \\
\text { Reporting requires that any person who withdraws or } \\
\text { is operating any system or method of withdrawal that } \\
\text { has a capacity to withdraw more than } 100,000 \text { gal } \\
(378,541 \text { L) of groundwater or surface water per day } \\
\text { shall file an annual report with NYSDEC. The legislation } \\
\text { was enacted to gain more complete information for } \\
\text { managing the state's water resources. }\end{array}$ & $\begin{array}{l}\text { A nontransient, noncommunity public water } \\
\text { supply system for drinking water and operational } \\
\text { purposes is maintained and operated at the } \\
\text { WVDP. In compliance with the legislation, the } \\
\text { "2012 WVDP Great Lakes Water Withdrawal } \\
\text { Report" was submitted to NYSDEC in January } \\
\text { 2013. The WVDP withdrew an average of 58,708 } \\
\text { gal/day (222,234 L/day). }\end{array}$ \\
\hline $\begin{array}{l}\text { NYS Public } \\
\text { Health Law }\end{array}$ & $\begin{array}{l}\text { Public Health Law, Article } 5 \text { (Laboratories), Section } 502 \\
\text { (Environmental Laboratories, Examinations, and } \\
\text { Certificates of Approval) }\end{array}$ & $\begin{array}{l}\text { As of June 30,2012, the WVDP Environmental } \\
\text { Laboratory (ELAB) (URS Corporation Laboratory) } \\
\text { NYSDOH certification under the Environmental } \\
\text { Laboratory Approval Program (ELAP) ended. All } \\
\text { regulatory reported analysis is performed by ELAP } \\
\text { certified labs. }\end{array}$ \\
\hline $\begin{array}{l}49 \text { CFR Part 172, } \\
\text { and } 6 \text { NYCRR } \\
\text { Part } 364.9\end{array}$ & $\begin{array}{l}6 \text { NYCRR Part } 364.9 \text { regulates handling and storage of } \\
\text { potentially infectious regulated medical waste. } 49 \text { CFR } \\
\text { Part 172, Subpart H regulates transportation safety and } \\
\text { disposal of regulated medical waste at a licensed } \\
\text { facility. }\end{array}$ & $\begin{array}{l}\text { The on-site health services office is registered } \\
\text { with NYS as a "Small Quantity Generator" of } \\
\text { regulated medical waste. Medical services } \\
\text { generate potentially infectious medical wastes } \\
\text { that are securely stored in approved biohazard } \\
\text { containers and are handled and controlled by } \\
\text { authorized personnel. }\end{array}$ \\
\hline
\end{tabular}


TABLE ECS-1 (concluded)

Compliance Status Summary for the WVDP in CY 2012

\begin{tabular}{|c|c|c|}
\hline Citation & $\begin{array}{c}\text { Environmental Statute, } \\
\text { DOE Directive, EO, Agreement }\end{array}$ & $\begin{array}{l}\text { WVDP Compliance } \\
\text { Status }\end{array}$ \\
\hline $\begin{array}{l}16 \text { USC } \S 703 \text { et } \\
\text { seq., and } 6 \\
\text { NYCRR Part } 175\end{array}$ & $\begin{array}{l}\text { The Migratory Bird Treaty Act of } 1918 \text { implemented } \\
\text { various treaties and conventions between the U.S. and } \\
\text { foreign countries for the protection of migratory birds. } \\
\text { Under the Act, taking, killing, or possessing migratory } \\
\text { birds is unlawful. (See also } 6 \text { NYCRR Part 175, Special } \\
\text { Licenses and Permits - Definitions and Uniform } \\
\text { Procedures.) }\end{array}$ & $\begin{array}{l}\text { DOE maintains a U.S. Fish and Wildlife Bird } \\
\text { Depredation Permit for the WVDP. Effective April } \\
\text { 1, 2012, NYS implemented changes to NYS ECL 11- } \\
\text { 0521, no longer requiring a NYSDEC depredation } \\
\text { license. (See Tables ECS-3 and ECS-12.) }\end{array}$ \\
\hline $\begin{array}{l}16 \text { USC } \S 1531 \text { et } \\
\text { seq., and } 6 \\
\text { NYCRR Part } 182\end{array}$ & $\begin{array}{l}\text { The Endangered Species Act of } 1973 \text { provided for the } \\
\text { conservation of endangered and threatened species of } \\
\text { fish, wildlife, and plants. (See also } 6 \text { NYCRR Part 182, } \\
\text { Endangered and Threatened Species of Fish and } \\
\text { Wildlife; Species of Special Concern.) }\end{array}$ & $\begin{array}{l}\text { Several ecological surveys of the WNYNSC } \\
\text { premises have been conducted. Except for } \\
\text { "occasional transient individuals," no plant or } \\
\text { animal species protected under the Endangered } \\
\text { Species Act are known to reside at the Center. }\end{array}$ \\
\hline 16 USC $\S 470$ & $\begin{array}{l}\text { The National Historic Preservation Act of } 1966 \\
\text { established a program for the preservation of historic } \\
\text { properties throughout the nation. }\end{array}$ & $\begin{array}{l}\text { Surveys of the WNYNSC have been conducted for } \\
\text { historic and archaeological sites. Surveys revealed } \\
\text { American Indian and historic homestead artifacts, } \\
\text { consistent with the area. }\end{array}$ \\
\hline EO 11988 & $\begin{array}{l}\text { EO 11988, Floodplain Management, was issued to } \\
\text { avoid adverse impacts associated with the occupancy } \\
\text { and modification of floodplains and to avoid direct or } \\
\text { indirect support of floodplain development wherever } \\
\text { there is a practicable alternative. }\end{array}$ & $\begin{array}{l}\text { No activities were performed during } 2012 \text { at the } \\
\text { WVDP that would develop or be adversely } \\
\text { impacted by the } 100 \text {-year floodplain within the } \\
\text { premises. }\end{array}$ \\
\hline $\begin{array}{l}\text { Stipulation } \\
\text { Pursuant to NYS } \\
\text { ECL Section } 17- \\
0303 \text {, and } \\
\text { Section } 176 \text { of } \\
\text { the Navigation } \\
\text { Law }\end{array}$ & $\begin{array}{l}\text { In accordance with Stipulation No. R9-4756-99-03, } \\
\text { dated March 1999, DOE agreed to install a soil } \\
\text { bioventing system to remediate petroleum } \\
\text { contaminated soils in the warehouse UST site (NYSDEC } \\
\text { Spill number 9708617). The remediation plan was to } \\
\text { construct a bioventing system, operate it for two years, } \\
\text { assess performance, and report to NYSDEC. }\end{array}$ & $\begin{array}{l}\text { The system stimulated in-situ biodegradation of } \\
\text { petroleum hydrocarbons in the soil by providing } \\
\text { abundant oxygen to existing microorganisms. } \\
\text { After reviewing soil and water sampling data and } \\
\text { evaluations, NYSDEC determined that no further } \\
\text { remediation was required. A determination } \\
\text { regarding the potential need for future actions } \\
\text { will be made consistent with Phase } 2 \\
\text { decisionmaking under the NEPA process. }\end{array}$ \\
\hline 6 NYCRR 360 & $\begin{array}{l}\text { NYS ECL Solid Waste Management Facility Regulations } \\
\text { define requirements for closure of nonradioactive solid } \\
\text { waste disposal facilities in a manner that protects the } \\
\text { environment. }\end{array}$ & $\begin{array}{l}\text { Per a } 1986 \text { NYSDEC approved engineering closure } \\
\text { plan, the CDDL was closed. As required by the } \\
\text { plan, post-closure inspections of the CDDL cover } \\
\text { were performed on May } 31 \text { and November } 7, \\
2012 \text { and all areas were found to be in good } \\
\text { condition. }\end{array}$ \\
\hline
\end{tabular}


TABLE ECS-2

NEPA Documents Affecting DOE Activities at the WVDP

\begin{tabular}{|c|c|c|}
\hline Year & Action & Outcome \\
\hline 1982 & $\begin{array}{l}\text { The FEIS, "Final Environmetnal Impact Statement: Long- } \\
\text { Term Management of Liquid High-Level Radioactive } \\
\text { Wastes Stored at the WNYNSC, West Valley (DOE/EIS- } \\
0081 \text { )" and associated ROD were issued outlining the } \\
\text { actions DOE proposed for solidification of the liquid } \\
\text { HLW contained in the underground tanks. }\end{array}$ & $\begin{array}{l}\text { The initial period of WVDP Act work activities, } \\
\text { completed in September 2002, removed the HLW } \\
\text { from the tanks and immobilized it into borosilicate } \\
\text { glass through VIT. The glass canisters remain on site in } \\
\text { storage. }\end{array}$ \\
\hline 1988 & $\begin{array}{l}\text { DOE and NYSERDA published a NOI to prepare the EIS } \\
\text { for "Completion of the WVDP and Closure or Long-Term } \\
\text { Management of the Facilities at the WNYNSC (the } \\
\text { Center)." }\end{array}$ & The DEIS was issued in 1996. \\
\hline 1996 & $\begin{array}{l}\text { DOE and NYSERDA issued the "Draft EIS for the } \\
\text { Completion of the WVDP and Closure or } \\
\text { Long-Term Management of the Facilities at the } \\
\text { WNYNSC" (DOE/EIS-0226-D). }\end{array}$ & $\begin{array}{l}\text { The DEIS was issued without a preferred alternative } \\
\text { for a six-month review and comment period. After } \\
\text { issuing the DEIS, and despite long negotiations, DOE } \\
\text { and NYSERDA were unable to reach an agreement on } \\
\text { the future course of action for closure at the Center } \\
\text { (see Government Accounting Office, 2001). }\end{array}$ \\
\hline 1997 & $\begin{array}{l}\text { Following issuance of the } 1996 \text { DEIS, NYSERDA and DOE } \\
\text { formed a stakeholder advisory group (the West Valley } \\
\text { Citizen Task Force) to provide additional input to the } \\
\text { public comment process required by the NEPA. }\end{array}$ & $\begin{array}{l}\text { The Citizen Task Force's mission is to provide } \\
\text { stakeholder input to decisionmaking for development } \\
\text { of a closure option for the WVDP and the WNYNSC. }\end{array}$ \\
\hline 1997 & $\begin{array}{l}\text { DOE-HQ issued the "Final Waste Management } \\
\text { Programmatic EIS," (WM PEIS [DOE/EIS-0200F]) to } \\
\text { evaluate nationwide management and siting } \\
\text { alternatives for treatment, storage, and disposal of five } \\
\text { types of radioactive and hazardous waste. }\end{array}$ & $\begin{array}{l}\text { The WM PEIS (DOE/EIS-0200F) was issued with the } \\
\text { intent to issue a separate ROD for each type of waste } \\
\text { generated, stored, or buried over the next } 20 \text { years at } \\
54 \text { sites in the DOE complex. }\end{array}$ \\
\hline 1999 & $\begin{array}{l}\text { DOE issued a ROD for nationwide management of HLW, } \\
\text { Vol. 64, FR, p. } 46661 \text { (64 FR 46661) }\end{array}$ & $\begin{array}{l}\text { The ROD specified that WVDP-vitrified HLW will } \\
\text { remain in storage on site until it is accepted at a } \\
\text { geologic repository. }\end{array}$ \\
\hline 2000 & $\begin{array}{l}\text { DOE issued a ROD for nationwide management of LLW } \\
\text { and mixed LLW (65 FR 10061). }\end{array}$ & $\begin{array}{l}\text { The Hanford site in Washington State and the Nevada } \\
\text { Test Site were designated as national DOE disposal } \\
\text { sites for LLW and mixed LLW. }\end{array}$ \\
\hline 2001 & $\begin{array}{l}\text { DOE published an NOI (66 FR 16447) formally } \\
\text { announcing its rescoping plan for preparing the waste } \\
\text { management EIS for the WVDP. } \\
\text { DOE published an Advance NOI (66 FR 56090), } \\
\text { announcing in advance, its intention to prepare an EIS } \\
\text { for Decommissioning and/or Long-Term Stewardship at } \\
\text { the WVDP and the WNYNSC. }\end{array}$ & $\begin{array}{l}\text { The rescoping plan split the scope of the } 1996 \text { WVDP } \\
\text { DEIS into two phases: (1) near-term waste } \\
\text { management decisionmaking and (2) final } \\
\text { decommissioning and/or long-term stewardship } \\
\text { decisionmaking. The advanced NOI informed } \\
\text { interested parties of a pending EIS and provided } \\
\text { opportunity for public comments early in the process. }\end{array}$ \\
\hline 2003 & $\begin{array}{l}\text { DOE issued a notice of availability of the "WVDP Draft } \\
\text { Waste Management EIS" (68 FR 26587). }\end{array}$ & $\begin{array}{l}\text { The DEIS presented alternatives for near-term } \\
\text { management of WVDP LLW, mixed LLW, TRU waste, } \\
\text { and HLW. }\end{array}$ \\
\hline
\end{tabular}


TABLE ECS-2 (concluded)

NEPA Documents Affecting DOE Activities at the WVDP

\begin{tabular}{|c|c|c|}
\hline Year & Action & Outcome \\
\hline 2003 & $\begin{array}{l}\text { DOE, in cooperation with NYSERDA, issued an NOI (68 } \\
\text { FR 12044) to issue an EIS for "Decommissioning } \\
\text { and/or Long-Term Stewardship at the WVDP and the } \\
\text { WNYNSC." }\end{array}$ & $\begin{array}{l}\text { Based on comments during the scoping process and } \\
\text { the complexity of issues relating to long-term agency } \\
\text { responsibility, this EIS was delayed (DOE-EIS-0226-R). }\end{array}$ \\
\hline 2005 & $\begin{array}{l}\text { DOE issued a ROD, based on alternative A, for the } \\
\text { "WVDP Waste Management EIS (WVDP WM EIS- } \\
\text { 0337)" (70 FR 35073). }\end{array}$ & $\begin{array}{l}\text { The HLW canisters will remain in storage on site until } \\
\text { transfer to a geologic repository, the decision on TRU } \\
\text { waste would be deferred until certification is obtained } \\
\text { from the Waste Isolation Pilot Plant in Carlsbad, New } \\
\text { Mexico, and LLW and mixed LLW would be shipped off } \\
\text { site for disposal at commercial or DOE sites. }\end{array}$ \\
\hline 2005 & $\begin{array}{l}\text { On August 26, 2005, The Coalition filed a complaint in } \\
\text { the U.S. District Court, Western District of New York, } \\
\text { against DOE regarding the NEPA process at the WVDP. } \\
\text { The Coalition contended that DOE's rescoping plan to } \\
\text { split the } 1996 \text { WVDP DEIS violated NEPA and the } \\
\text { Stipulation of Compromise. The Coalition also sought } \\
\text { a declaration that DOE is not empowered to reclassify } \\
\text { waste at the WVDP using the "waste incidental to } \\
\text { reprocessing" determination. }\end{array}$ & $\begin{array}{l}\text { On September, 28, 2007, the U.S. District Court, } \\
\text { Western District of New York ruled to dismiss the } \\
\text { complaint in its entirety. Refer to Case 1:05-cv-00614- } \\
\text { JTC, Document 41, filed September 28, } 2007 \text { for the } \\
\text { ruling. }\end{array}$ \\
\hline 2006 & $\begin{array}{l}\text { An EA (DOE/EA-1552) evaluated the proposed } \\
\text { decontamination, demolition, and removal of select } \\
\text { site facilities. A FONSI was issued. }\end{array}$ & $\begin{array}{l}\text { The EA, with the FONSI, cleared the way for removal } \\
\text { of } 36 \text { facilities that were (or in the next four years } \\
\text { would be) no longer required to support WVDP } \\
\text { activities. }\end{array}$ \\
\hline 2007 & $\begin{array}{l}\text { DOE issued an NOI to prepare an EIS for the disposal } \\
\text { of Greater-Than-Class-C (GTCC) LLW (72 FR 40135). In } \\
\text { March 2011, DOE issued the DEIS for the disposal of } \\
\text { GTCC LLW and GTCC-like waste. }\end{array}$ & $\begin{array}{l}\text { Nine scoping meetings were held throughout 2007; } \\
\text { the draft was never issued. On February } 25,2011 \text {, a } \\
\text { notice of availability for the GTCC DEIS was issued } \\
\text { with the } 120 \text {-day public comment period ending on } \\
\text { June } 27,2011 .\end{array}$ \\
\hline 2008 & $\begin{array}{l}\text { DOE issued a notice of availability for the revised } \\
\text { "Draft Environmental Impact Statement for } \\
\text { Decommissioning and/or Long-Term Stewardship at } \\
\text { the WVDP and WNYNSC (DOE/EIS-0226-D [Revised])" } \\
\text { (73 FR 74160). }\end{array}$ & $\begin{array}{l}\text { The DEIS evaluated the range of reasonable } \\
\text { alternatives for decommissioning and/or long-term } \\
\text { stewardship of the facilities at the Center. This DEIS is } \\
\text { a revision of the } 1996 \text { Cleanup and Closure DEIS. This } \\
\text { DEIS was distributed December } 5,2008 \text {, for a six- } \\
\text { month public review period, which was extended } \\
\text { through September } 8,2009 \text {. }\end{array}$ \\
\hline 2010 & $\begin{array}{l}\text { In January 2010, DOE issued the "Final EIS (FEIS) for } \\
\text { Decommissioning and/or Long-Term Stewardship at } \\
\text { the WVDP and WNYNSC (DOE/EIS-0226 [Revised])". } \\
\text { On April 14, 2010, DOE issued the ROD for the FEIS, } \\
\text { selecting the phased decisionmaking alternative as the } \\
\text { preferred alternative. On May 12, 2010, NYSERDA } \\
\text { issued a SEQR Findings Statement selecting the } \\
\text { phased decisionmaking alternative as the preferred } \\
\text { alternative. }\end{array}$ & $\begin{array}{l}\text { In Phase } 1 \text { of the phased decisionmaking preferred } \\
\text { alternative, DOE will decommission the MPPB, the VIT } \\
\text { facility, RHWF, the wastewater treatment lagoons, } \\
\text { and a number of other facilities. The Phase } 2 \text { decision } \\
\text { will be made within } 10 \text { years of the EIS ROD. }\end{array}$ \\
\hline
\end{tabular}


TABLE ECS-3

WVDP Environmental Permits

\begin{tabular}{|c|c|c|c|c|}
\hline $\begin{array}{c}\text { Permit Name and } \\
\text { Number }\end{array}$ & $\begin{array}{c}\text { Agency / } \\
\text { Permit Type }\end{array}$ & Description & Updates & Status \\
\hline $\begin{array}{l}\text { WVDP RCRA Part A } \\
\text { Permit Application } \\
\text { (EPA ID } \\
\text { \#NYD980779540) }\end{array}$ & $\begin{array}{l}\text { NYSDEC } \\
\text { Hazardous } \\
\text { Waste }\end{array}$ & $\begin{array}{l}\text { Provides interim status } \\
\text { under RCRA for } \\
\text { treatment and storage } \\
\text { of hazardous waste. }\end{array}$ & $\begin{array}{l}\text { DOE is currently operating } \\
\text { under the February } 2010 \\
\text { RCRA Part A Permit } \\
\text { Application. Revisions } \\
\text { were submitted to NYSDEC } \\
\text { in February 2010, and } \\
\text { conditionally approved on } \\
\text { June } 9,2011 .\end{array}$ & $\begin{array}{l}\text { On August } 29,2011 \text {, } \\
\text { the permit was } \\
\text { transferred to CHBWV. }\end{array}$ \\
\hline $\begin{array}{l}6 \text { NYCRR Part 373-2 } \\
\text { (i.e., Part B) Permit } \\
\text { Application (Rev. 1) }\end{array}$ & $\begin{array}{l}\text { NYSDEC } \\
\text { Hazardous } \\
\text { Waste }\end{array}$ & $\begin{array}{l}\text { Provides final status } \\
\text { under RCRA for } \\
\text { treatment and storage } \\
\text { of hazardous waste. }\end{array}$ & $\begin{array}{l}\text { Submitted a revised } \\
\text { application to NYSDEC on } \\
\text { September 30, 2010. In } \\
\text { January 2011, NYSDEC } \\
\text { review was suspended } \\
\text { indefinitely. }\end{array}$ & $\begin{array}{l}\text { On March } 22,2012, \\
\text { NYSDEC suspended } \\
\text { action relative to the } \\
\text { Part B until completion } \\
\text { of Phase } 1 \text { work. } \\
\text { Thereafter, remaining } \\
\text { hazardous waste } \\
\text { management units will } \\
\text { be subject to RCRA } \\
\text { permitting. }\end{array}$ \\
\hline $\begin{array}{l}\text { Air Facility } \\
\text { Registration } \\
\text { Certificate } \\
(9-0422-00005 / 00099)\end{array}$ & $\begin{array}{l}\text { NYSDEC / Air } \\
\text { Emissions }\end{array}$ & $\begin{array}{l}\text { Certificate caps } \mathrm{NO}_{x} \text { and } \\
\mathrm{SO}_{x} \text { emissions from two } \\
\text { boilers. }\end{array}$ & None & No expiration date. \\
\hline $\begin{array}{l}\text { MPPB Ventilation } \\
\text { (WVDP-687-01) }\end{array}$ & EPA / NESHAP & $\begin{array}{l}\text { MPPB ventilation } \\
\text { radionuclide emissions } \\
\text { (originally the Liquid } \\
\text { Waste Treatment } \\
\text { System [LWTS]) }\end{array}$ & $\begin{array}{l}\text { Conditional approval was } \\
\text { received on July 9, } 2009 \text { to } \\
\text { discontinue monitoring } \\
\text { after establishing an } \\
\text { ambient monitoring } \\
\text { network and meeting EPA } \\
\text { criteria, with a 24-month } \\
\text { extension granted by the } \\
\text { EPA on July } 14,2011 .\end{array}$ & $\begin{array}{l}\text { Original approval on } \\
\text { December 22, } 1987 . \\
\text { Modified on May 25, } \\
1989 \text { for laboratories. } \\
\text { Modified February 18, } \\
1997 \text { to include the } \\
\text { slurry-fed ceramic } \\
\text { melter. No expiration } \\
\text { date. }\end{array}$ \\
\hline $\begin{array}{l}\text { VIT Facility Heating, } \\
\text { Ventilation, and Air- } \\
\text { Conditioning (HVAC) } \\
\text { System (no permit } \\
\text { number) }\end{array}$ & EPA / NESHAP & $\begin{array}{l}\text { VIT Facility HVAC } \\
\text { system for radionuclide } \\
\text { emissions }\end{array}$ & $\begin{array}{l}\text { Facility being used for } \\
\text { remote processing of } \\
\text { waste. }\end{array}$ & $\begin{array}{l}\text { Approved on February } \\
18,1997 . \text { No } \\
\text { expiration date. }\end{array}$ \\
\hline $\begin{array}{l}\text { 01-14 Building } \\
\text { Ventilation System } \\
\text { (WVDP-187-01) }\end{array}$ & EPA / NESHAP & $\begin{array}{l}\text { Ventilation of } \\
\text { radionuclide emissions } \\
\text { in the } 01-14 \text { building. }\end{array}$ & $\begin{array}{l}\text { The ventilation system and } \\
\text { sampling and monitoring } \\
\text { was discontinued in } \\
\text { October } 2012 \text { prior to the } \\
\text { start of building demolition } \\
\text { in December } 2012 \text {. }\end{array}$ & $\begin{array}{l}\text { Original approval on } \\
\text { October 5, } 1987 . \\
\text { Modified on May 25, } \\
1989 \text { for LWTS. No } \\
\text { expiration date. }\end{array}$ \\
\hline
\end{tabular}

Note: Permit and license expiration dates are current as of September 2013. 
TABLE ECS-3 (continued)

WVDP Environmental Permits

\begin{tabular}{|c|c|c|c|c|}
\hline $\begin{array}{c}\text { Permit Name and } \\
\text { Number }\end{array}$ & $\begin{array}{c}\text { Agency / } \\
\text { Permit Type }\end{array}$ & Description & Updates & Status \\
\hline $\begin{array}{l}\text { Contact Size- } \\
\text { Reduction Facility } \\
\text { (CSRF) } \\
\text { (WVDP-287-01) }\end{array}$ & EPA / NESHAP & $\begin{array}{l}\text { Contact size-reduction } \\
\text { and decontamination } \\
\text { facility radionuclide } \\
\text { emissions }\end{array}$ & $\begin{array}{l}\text { Ventilation not in service; } \\
\text { ventilated with portable } \\
\text { ventilation units (PVUs). }\end{array}$ & $\begin{array}{l}\text { Approved on October } \\
5,1987 . \text { No expiration } \\
\text { date. }\end{array}$ \\
\hline $\begin{array}{l}\text { Supernatant } \\
\text { Treatment System } \\
\text { (STS) /PVU } \\
\text { (WVDP-387-01) }\end{array}$ & EPA / NESHAP & $\begin{array}{l}\text { STS ventilation for } \\
\text { radionuclide emissions }\end{array}$ & $\begin{array}{l}\text { System receives air } \\
\text { ventilated from T\&VDS. }\end{array}$ & \begin{tabular}{|l|} 
Original approval on \\
October 5, 1987. \\
Modified on May 4, \\
1998 for full-time \\
ventilation of WTF. No \\
expiration date.
\end{tabular} \\
\hline $\begin{array}{l}\text { RHWF (WVDP-RHWF } \\
\text { Mod-001) }\end{array}$ & EPA / NESHAP & $\begin{array}{l}\text { RHWF ventilation for } \\
\text { radionuclide emissions }\end{array}$ & $\begin{array}{l}\text { Permit issued to allow use } \\
\text { of plasma arc cutting } \\
\text { techniques in the RHWF. }\end{array}$ & $\begin{array}{l}\text { Approved on April 18, } \\
\text { 2012. No expiration } \\
\text { date. }\end{array}$ \\
\hline $\begin{array}{l}\text { Outdoor Ventilated } \\
\text { Enclosures/ PVUs } \\
\text { (WVDP-587-01) }\end{array}$ & EPA / NESHAP & $\begin{array}{l}\text { Fifteen PVUs for } \\
\text { removal of } \\
\text { radionuclides. }\end{array}$ & $\begin{array}{l}\text { Since 2007, EPA approval } \\
\text { to expand usage of PVUs } \\
\text { from } 10 \text { to } 15 . \text { DOE tracks } \\
\text { usage on the basis of } \\
\text { annual cumulative } \\
\text { estimated dose. }\end{array}$ & $\begin{array}{l}\text { Original approved on } \\
\text { December } 22,1987 . \\
\text { Modified on December } \\
10,2007 \text { for } 15 \text { units. } \\
\text { No expiration date. }\end{array}$ \\
\hline SPDES (NY0000973) & $\begin{array}{l}\text { NYSDEC / } \\
\text { Effluent water }\end{array}$ & $\begin{array}{l}\text { Monitors discharges to } \\
\text { surface waters from } \\
\text { various on-site sources. }\end{array}$ & $\begin{array}{l}\text { An amended SPDES permit } \\
\text { was issued by NYSDEC, } \\
\text { effective July } 1,2011 \text {. }\end{array}$ & $\begin{array}{l}\text { The permit expires on } \\
\text { June } 30,2016 \text {. }\end{array}$ \\
\hline $\begin{array}{l}\text { NYSDOH ELAP } \\
\text { Certification to URS } \\
\text { Corporation, Lab ID } \\
\# 10474 \\
\text { EPA Lab Code } \\
\text { NY01259 }\end{array}$ & $\begin{array}{l}\text { NYSDOH / ELAP } \\
\text { certification }\end{array}$ & $\begin{array}{l}\text { Certification of the ELAB } \\
\text { for the analysis of } \\
\text { potable and nonpotable } \\
\text { water samples for } \\
\text { specific radiological and } \\
\text { nonradiological } \\
\text { constituents. }\end{array}$ & $\begin{array}{l}\text { Certification is held by URS } \\
\text { Corporation Laboratory. } \\
\text { Effective February } 2009, \\
\text { the certificate was revised } \\
\text { to remove total suspended } \\
\text { solids. The certification } \\
\text { was renewed on April 1, } \\
2012 \text {. }\end{array}$ & $\begin{array}{l}\text { Certification was } \\
\text { terminated on June } 30, \\
2012 \text {. }\end{array}$ \\
\hline $\begin{array}{l}\text { Frank's Vacuum Truck } \\
\text { Service } \\
\text { (Permit \#12-05-TR285) }\end{array}$ & $\begin{array}{l}\text { Sanitary sewage } \\
\text { sludge hauler } \\
\text { permit }\end{array}$ & $\begin{array}{l}\text { Permit issued to hauler } \\
\text { of waste from the } \\
\text { WWTF. }\end{array}$ & $\begin{array}{l}\text { Permit effective July 1, } \\
2012 .\end{array}$ & $\begin{array}{l}\text { Permit expires July 31, } \\
\text { 2013. The new } \\
\text { sanitary waste hauler } \\
\text { is Zuech's } \\
\text { Environmental } \\
\text { Services, Inc. }\end{array}$ \\
\hline CBS (\#9-000158) & $\begin{array}{l}\text { NYSDEC / } \\
\text { regulated CBS } \\
\text { tanks }\end{array}$ & $\begin{array}{l}\text { Registration of bulk } \\
\text { storage tanks used for } \\
\text { listed hazardous } \\
\text { chemicals. }\end{array}$ & $\begin{array}{l}\text { Currently no tanks at the } \\
\text { WVDP are regulated under } \\
6 \text { NYCRR Parts 595-599. }\end{array}$ & $\begin{array}{l}\text { If regulated CBS tanks } \\
\text { will be needed, a } \\
\text { permit application will } \\
\text { be submitted under } \\
\text { the existing CBS } \\
\text { registration. }\end{array}$ \\
\hline
\end{tabular}

Note: Permit and license expiration dates are current as of September 2013. 
TABLE ECS-3 (continued)

WVDP Environmental Permits

\begin{tabular}{|c|c|c|c|c|}
\hline $\begin{array}{c}\text { Permit Name and } \\
\text { Number }\end{array}$ & $\begin{array}{c}\text { Agency / } \\
\text { Permit Type }\end{array}$ & Description & Updates & Status \\
\hline $\begin{array}{l}\text { Public Water System } \\
\text { ID \#NY0417557 }\end{array}$ & $\mathrm{CCHD}$ & $\begin{array}{l}\text { The WVDP is a } \\
\text { nontransient } \\
\text { noncommunity public } \\
\text { drinking water system. }\end{array}$ & None & No expiration date. \\
\hline PBS (\#9-008885) & $\begin{array}{l}\text { NYSDEC / PBS } \\
\text { tank registration }\end{array}$ & $\begin{array}{l}\text { Registration of bulk } \\
\text { storage tanks used for } \\
\text { petroleum. }\end{array}$ & $\begin{array}{l}\text { Diesel fuel tank FO-D-11 } \\
\text { was permanently closed } \\
\text { and removed from the } \\
\text { registration on } \\
\text { September } 11,2008 .\end{array}$ & $\begin{array}{l}\text { License expires } \\
\text { September 2, } 2016 .\end{array}$ \\
\hline $\begin{array}{l}\text { Asbestos-Handling } \\
\text { License } \\
\text { CHBWV \#61646 }\end{array}$ & $\begin{array}{l}\text { NYSDOL / } \\
\text { asbestos- } \\
\text { handling and } \\
\text { sampling } \\
\text { activities }\end{array}$ & $\begin{array}{l}\text { Asbestos contractors } \\
\text { license with specific } \\
\text { variances for handling } \\
\text { and monitoring. }\end{array}$ & $\begin{array}{l}\text { CHBWV was granted } \\
\text { asbestos-handling license } \\
\text { in October } 2011 .\end{array}$ & $\begin{array}{l}\text { The license was } \\
\text { renewed on } \\
\text { September 5, } 2012 \\
\text { and expires on } \\
\text { September 30, 2013; } \\
\text { each variance has a } \\
\text { unique expiration } \\
\text { date. }\end{array}$ \\
\hline $\begin{array}{l}\text { NYS Atomic } \\
\text { Development Dam \#1 } \\
\text { (ID \#019-3149) } \\
\text { NYS Atomic } \\
\text { Development Dam \#2 } \\
\text { (ID \#019-3150) }\end{array}$ & $\begin{array}{l}\text { NYSDEC Division } \\
\text { of Water, } \\
\text { Bureau of Flood } \\
\text { Protection and } \\
\text { Dam Safety }\end{array}$ & $\begin{array}{l}\text { Two Class A Low-Hazard } \\
\text { dams on the WNYNSC } \\
\text { property, that supply } \\
\text { water for drinking and } \\
\text { operational purposes, } \\
\text { are maintained at the } \\
\text { WVDP. }\end{array}$ & $\begin{array}{l}\text { NYSDEC inspected the } \\
\text { dams in } 2009 \text { following a } \\
\text { major storm rain-event. } \\
\text { Repair or construction } \\
\text { activities related to the } \\
\text { dams will require permits } \\
\text { from NYSDEC. Inspections } \\
\text { and maintenance were } \\
\text { routinely performed and } \\
\text { documented in CY } 2012 \text {. }\end{array}$ & No expiration date. \\
\hline $\begin{array}{l}\text { Great Lakes Water } \\
\text { Withdrawal } \\
\text { Registration } \\
\text { Certificate } \\
\text { (NYGL08701) }\end{array}$ & NYSDEC & $\begin{array}{l}\text { The legislation was } \\
\text { enacted to gain more } \\
\text { complete information } \\
\text { for managing the NYS's } \\
\text { water resources. }\end{array}$ & $\begin{array}{l}\text { Certificate issued August } \\
24,2011 .\end{array}$ & $\begin{array}{l}\text { Certificate expires on } \\
\text { August 24, } 2013 . \\
\text { Due to changes in the } \\
\text { legislation, the WVDP } \\
\text { no longer requires a } \\
\text { registration certificate. }\end{array}$ \\
\hline $\begin{array}{l}\text { Underground Injection } \\
\text { Control Program } \\
\text { Regulation (UICID: } \\
\text { 11NY00906001) }\end{array}$ & $\begin{array}{l}\text { EPA } \\
\text { Groundwater } \\
\text { Compliance } \\
\text { Section }\end{array}$ & $\begin{array}{l}\text { EPA regulates injection } \\
\text { of tracer solutions into } \\
\text { groundwater wells. }\end{array}$ & $\begin{array}{l}\text { Several wells in the north } \\
\text { plateau PTW were used to } \\
\text { inject sodium bromide } \\
\text { tracer solution to estimate } \\
\text { groundwater flow } \\
\text { velocities. }\end{array}$ & $\begin{array}{l}\text { On November } 18, \\
2010, \text { EPA authorized } \\
\text { operation of injection } \\
\text { wells. }\end{array}$ \\
\hline
\end{tabular}

Note: Permit and license expiration dates are current as of September 2013. 
TABLE ECS-3 (concluded)

WVDP Environmental Permits

\begin{tabular}{|c|c|c|c|c|}
\hline $\begin{array}{c}\text { Permit Name and } \\
\text { Number }\end{array}$ & $\begin{array}{c}\text { Agency / } \\
\text { Permit Type }\end{array}$ & Description & Updates & Status \\
\hline $\begin{array}{l}\text { Bird Depredation } \\
\text { License (32) }\end{array}$ & $\begin{array}{l}\text { NYSDEC / } \\
\text { Division of Fish } \\
\text { and Wildlife }\end{array}$ & $\begin{array}{l}\text { State license for the } \\
\text { removal of nests of } \\
\text { migratory birds. }\end{array}$ & $\begin{array}{l}\text { NYS no longer requires this } \\
\text { license. }\end{array}$ & $\begin{array}{l}\text { Effective April 1, 2012, } \\
\text { NYS implemented } \\
\text { changes to NYS ECL 11- } \\
\text { 0521, no longer } \\
\text { requiring a } \\
\text { depredation license. } \\
\text { Federal permitting is } \\
\text { required. }\end{array}$ \\
\hline $\begin{array}{l}\text { Bird Depredation } \\
\text { Permit } \\
(\text { MB747595-0) }\end{array}$ & $\begin{array}{l}\text { U.S. Fish and } \\
\text { Wildlife Service }\end{array}$ & $\begin{array}{l}\text { Federal permit for the } \\
\text { limited taking of } \\
\text { migratory birds and } \\
\text { active bird nests. }\end{array}$ & $\begin{array}{l}\text { Permit was renewed on } \\
\text { October } 1,2012 .\end{array}$ & $\begin{array}{l}\text { Permit expires } \\
\text { September 30, } 2013 .\end{array}$ \\
\hline $\begin{array}{l}\text { Nationwide Permit } \\
\text { Number } 27 \\
\text { (NWP-27) } \\
\text { Stream and Wetland } \\
\text { Restoration Activities }\end{array}$ & $\begin{array}{l}\text { Joint } \\
\text { Application; } \\
\text { NYSDEC and } \\
\text { USACE }\end{array}$ & $\begin{array}{l}\text { Stream and wetland } \\
\text { restoration activities at } \\
\text { Erdman Brook. }\end{array}$ & $\begin{array}{l}\text { Permit effective on } \\
\text { September 14, } 2011\end{array}$ & $\begin{array}{l}\text { Permit expires in } \\
\text { November } 2013 .\end{array}$ \\
\hline $\begin{array}{l}\text { Nationwide Permit } \\
\text { Number } 33 \\
\text { Installation of a } \\
\text { temporary dam }\end{array}$ & $\begin{array}{l}\text { Joint } \\
\text { Application; } \\
\text { NYSDEC and } \\
\text { USACE }\end{array}$ & \begin{tabular}{|l|} 
Installation of a \\
temporary dam and a \\
temporary water \\
diversion structure in an \\
unnamed tributary to \\
Buttermilk Creek.
\end{tabular} & $\begin{array}{l}\text { Permit effective on } \\
\text { June } 29,2012 .\end{array}$ & $\begin{array}{l}\text { Permit is valid until } \\
\text { June } 29,2014 \text {. }\end{array}$ \\
\hline
\end{tabular}

Note: Permit and license expiration dates are current as of September 2013. 
TABLE ECS-4

WVDP RCRA SSWMUs and Constituent SWMUs

Identified in the RFI under the RCRA 3008(h) Order on Consent

\begin{tabular}{|c|c|c|}
\hline SSWMU & SWMU \# & Constituent SWMUs \\
\hline SSWMU \#1 - LLWTF & $\begin{array}{l}3,4,17,17 a \\
\text { and } 17 b\end{array}$ & $\begin{array}{l}\text { Former lagoon 1; } \\
\text { LLWTF; } \\
\text { lagoons 2, 3, 4, and 5; } \\
\text { neutralization pit; and } \\
\text { interceptors }\end{array}$ \\
\hline $\begin{array}{l}\text { SSWMU \#2 - Miscellaneous } \\
\text { Small Units }\end{array}$ & $5,6,7$, and 10 & $\begin{array}{l}\text { Demineralizer sludge ponds and solvent dike; } \\
\text { effluent mixing basin; and } \\
\text { waste paper incinerator }\end{array}$ \\
\hline SSWMU \#3 - LWTS & $\begin{array}{l}18,18 \text { a Sealed } \\
\text { Rooms, and } \\
22\end{array}$ & $\begin{array}{l}\text { LWTS; } \\
\text { cement solidification system; and } \\
\text { all sealed rooms in the MPPB (per the RFI Workplan and } \\
\text { Current Conditions Report) }\end{array}$ \\
\hline $\begin{array}{l}\text { SSWMU \#4 - HLW Storage } \\
\text { and Processing Area }\end{array}$ & $\begin{array}{l}12 / 12 a, 13 \\
19, \text { and } 20\end{array}$ & $\begin{array}{l}\text { WTF; } \\
\text { VIT test facility waste storage tanks; } \\
\text { STS; and } \\
\text { VIT facility }\end{array}$ \\
\hline $\begin{array}{l}\text { SSWMU \#5 - Maintenance } \\
\text { Shop Leach Field }\end{array}$ & 8 & Maintenance shop leach field \\
\hline $\begin{array}{l}\text { SSWMU \#6 - Low-Level } \\
\text { Waste Storage Area }\end{array}$ & $\begin{array}{l}9 / 9 a, 15 \\
16 / 16 a, \text { and } \\
38\end{array}$ & $\begin{array}{l}\text { Lag storage additions (LSAs) \#1 and \#2 hardstands; } \\
\text { old and new hardstand storage areas; } \\
\text { Lag storage building; } \\
\text { Lag storage extension; } \\
\text { LSAs \#3 and \#4; and } \\
\text { the drum supercompactor }\end{array}$ \\
\hline $\begin{array}{l}\text { SSWMU \#7 - Chemical } \\
\text { Process Cell-Waste Storage } \\
\text { Area }\end{array}$ & 14 & Chemical Process Cell-Waste Storage Area \\
\hline SSWMU \#8 - CDDL & 1 & CDDL \\
\hline SSWMU \#9 - NDA & $\begin{array}{l}2,11 / 11 a, 23 \\
31, \text { and } 39\end{array}$ & $\begin{array}{l}\text { NDA and NDA trench soil containment area; } \\
\text { kerosene tanks; } \\
\text { NDA container storage area; and } \\
\text { interceptor trench project and staging area for NDA }\end{array}$ \\
\hline $\begin{array}{l}\text { SSWMU \#10 - Integrated } \\
\text { Radwaste Treatment System }\end{array}$ & 21 & Integrated radwaste treatment system drum cell \\
\hline SSWMU \#11 - SDA & NA & $\begin{array}{l}\text { The SDA is a closed radioactive waste landfill that is contiguous with } \\
\text { the Project premises and is owned and managed by NYSERDA. } \\
\text { For more information, see their website at www.nyserda.ny.gov. }\end{array}$ \\
\hline SSWMU \#12 - HWSLS & 24 & HWSLs 1 to 4 \\
\hline
\end{tabular}

Note: The WVDP RCRA SWMUs and SSWMUs are discussed under the section titled "RCRA $3008(\mathrm{~h})$ Administrative Order on Consent". 
TABLE ECS-4 (concluded)

WVDP RCRA SSWMUs and Constituent SWMUs

Identified in the RFI under the RCRA 3008(h) Order on Consent

\begin{tabular}{|c|c|c|}
\hline \multicolumn{3}{|c|}{ WVDP RCRA SWMUs Not Associated with an SSWMU } \\
\hline \multirow{21}{*}{ Individual SWMUs } & 25 & $\begin{array}{l}\text { Inactive scrap metal landfill adjacent to bulk storage warehouse } \\
\text { (NYSERDA SWMU) }\end{array}$ \\
\hline & 26 & Subcontractor maintenance area \\
\hline & 27 & Fire brigade training area \\
\hline & 28 & VIT hardstand \\
\hline & 29 & Industrial waste storage area \\
\hline & 30 & Cold hardstand area near the CDDL \\
\hline & 32 & Old sewage treatment facility \\
\hline & 33 & Existing sewage treatment facility \\
\hline & 34 & Temporary storage locations for well purge water \\
\hline & 35 & Construction and demolition area \\
\hline & 36 & Old school house septic system \\
\hline & 37 & CSRF \\
\hline & 40 & Satellite accumulation areas and 90-day storage areas \\
\hline & 41 & Designated roadways \\
\hline & 42 & Product storage area \\
\hline & 43 & Warehouse extension staging area \\
\hline & 44 & $\begin{array}{l}\text { Fuel receiving and storage area; high-integrity container and } \\
\text { SUREPAK }{ }^{\mathrm{TM}} \text { staging area }\end{array}$ \\
\hline & 45 & Breach in laundry wastewater line \\
\hline & 46 & VIT vault and empty container hardstand \\
\hline & 47 & RHWF \\
\hline & --- & Sealed rooms in the MPPB \\
\hline
\end{tabular}

Note: The WVDP RCRA SWMUs and SSWMUs are discussed under the section titled "RCRA $\$ 3008(\mathrm{~h})$ Administrative Order on Consent". 
TABLE ECS-5

Summary of Waste Management Activities at the WVDP During 2012

\begin{tabular}{|c|c|c|c|}
\hline $\begin{array}{l}\text { Waste Description/ } \\
\text { Facility }\end{array}$ & $\begin{array}{l}\text { Type of Project } \\
\text { Generating Waste }\end{array}$ & $\begin{array}{l}\text { Quantity } \\
\text { in } 2012\end{array}$ & Discussion \\
\hline LLW & $\begin{array}{l}\text { Includes all sources of } \\
\text { generation }\end{array}$ & $\begin{array}{l}34,497 \text { cubic feet }\left(\mathrm{ft}^{3}\right) \\
\left(977 \text { cubic meters }\left[\mathrm{m}^{3}\right]\right)\end{array}$ & Waste packaged and shipped \\
\hline TRU waste & TRU waste processing & $\begin{array}{c}150 \mathrm{ft}^{3} \\
\left(4.25 \mathrm{~m}^{3}\right)\end{array}$ & $\begin{array}{l}\text { Legacy TRU waste processed in } \\
\text { preparation for shipment. }\end{array}$ \\
\hline $\begin{array}{l}\text { Hazardous and } \\
\text { Mixed LLW }\end{array}$ & $\begin{array}{l}\text { Waste management according } \\
\text { to the STP }\end{array}$ & $\begin{array}{l}16,619 \mathrm{lbs} \\
(7.54 \mathrm{mt})\end{array}$ & $\begin{array}{l}\text { Waste packaged and shipped during } \\
\text { CY } 2012\end{array}$ \\
\hline $\begin{array}{l}\text { Radiological } \\
\text { wastewater from } \\
\text { the LLWTF (LLW2 } \\
\text { [WNSP001]) }\end{array}$ & $\begin{array}{l}\text { NYSDEC regulates point-source } \\
\text { liquid effluent discharges of } \\
\text { treated process wastewater } \\
\text { through the SPDES permit for } \\
\text { the WVDP. }\end{array}$ & $\begin{array}{c}\text { Approximately } \\
8,300,000 \text { gal } \\
(31,600,000 \mathrm{~L})\end{array}$ & $\begin{array}{l}\text { During CY 2012, five batches of } \\
\text { wastewater were processed through } \\
\text { the LLW2. This included groundwater } \\
\text { recovered from the north plateau } \\
\text { groundwater recovery system } \\
\text { (NPGRS) and groundwater pumped } \\
\text { from the NDA interceptor trench. }\end{array}$ \\
\hline $\begin{array}{l}\text { Treated sewage and } \\
\text { industrial } \\
\text { wastewaters } \\
\text { (WNSP007) }\end{array}$ & $\begin{array}{l}\text { Wastewater processing, } \\
\text { discharge }\end{array}$ & $\begin{array}{c}\text { Approximately } \\
1,203,350 \text { gal } \\
(4,555,175 \mathrm{~L})\end{array}$ & $\begin{array}{l}\text { The WWTF treated sanitary and } \\
\text { industrial wastewater that was } \\
\text { discharged through outfall WNSP007 } \\
\text { in CY } 2012 \text {. }\end{array}$ \\
\hline NPGRS & $\begin{array}{l}\text { Pump and treat strontium-90 } \\
\text { contaminated groundwater }\end{array}$ & $\begin{array}{c}\text { Approximately } \\
2,900,000 \text { gal } \\
(11,000,000 \mathrm{~L})\end{array}$ & $\begin{array}{l}\text { The NPGRS operated to recover } \\
\text { groundwater from an area near the } \\
\text { leading edge of the strontium-90 } \\
\text { plume on the north plateau. Water } \\
\text { was treated by ion exchange in the } \\
\text { LLW2 to remove strontium-90, then } \\
\text { transferred to the lagoons. }\end{array}$ \\
\hline $\begin{array}{l}\text { NDA interceptor } \\
\text { trench }\end{array}$ & $\begin{array}{l}\text { Interceptor trench (WNNDATR) } \\
\text { and groundwater pre-treatment }\end{array}$ & $\begin{array}{c}\text { Approximately } \\
64,035 \text { gal } \\
(242,400 \mathrm{~L})\end{array}$ & $\begin{array}{l}\text { Groundwater was pumped and } \\
\text { transferred to the LLW2. } \\
\text { No n-dodecane or TBP were } \\
\text { encountered in CY 2012. No pre- } \\
\text { treatment was necessary. }\end{array}$ \\
\hline $\begin{array}{l}\text { Digested sanitary } \\
\text { sludge }\end{array}$ & Waste shipping and disposal & $\begin{array}{c}\text { Approximately } \\
2,250,000 \text { gal } \\
(8,520,000 \mathrm{~L})\end{array}$ & $\begin{array}{l}\text { Digested sludge and wastewater } \\
\text { from the WWTF were shipped to the } \\
\text { Buffalo Sewer Authority for disposal } \\
\text { during CY } 2012 \text {. }\end{array}$ \\
\hline Asbestos & $\begin{array}{l}\text { Asbestos management and } \\
\text { abatement }\end{array}$ & $\begin{array}{l}\text { 1,232 linear feet pipe } \\
\text { insulation; } 1,140 \text { square feet } \\
\left(\mathrm{ft}^{2}\right)\left(106 \text { square meters }\left[\mathrm{m}^{2}\right]\right) \\
\text { asbestos-containing fire doors, } \\
\text { tar coatings, and caulks. }\end{array}$ & $\begin{array}{l}\text { Insulation was removed from } \\
\text { piping, and fire doors, tar coatings, } \\
\text { and caulks were removed in the } \\
\text { MPPB during CY } 2012 \text {. }\end{array}$ \\
\hline Universal waste & Spent bulbs/spent batteries & $\begin{array}{l}\text { Bulbs - } 805 \mathrm{lb} \text { ( } 0.4 \text { ton) } \\
\text { Batteries - 3,901 lbs (1.9 ton) }\end{array}$ & $\begin{array}{l}\text { Waste disposed of as universal } \\
\text { waste. }\end{array}$ \\
\hline
\end{tabular}

Note: Certain waste totals are tallied by FY while others are tallied by CY. 
TABLE ECS-6

Recycled Materials for FY 2012

\begin{tabular}{|l|c|}
\hline \multicolumn{1}{|c|}{ Recycled Materials } & 2012 Quantity \\
\hline Mixed paper and corrugated cardboard & $45,600 \mathrm{lbs}(20.7 \mathrm{mt})$ \\
\hline Iron / steel & $26,780 \mathrm{lbs}(12.1 \mathrm{mt})$ \\
\hline Styrofoam & $30 \mathrm{lbs}(0.014 \mathrm{mt})$ \\
\hline Toner cartridges & $1,638 \mathrm{lbs}(0.74 \mathrm{mt})$ \\
\hline Wood & $3,600 \mathrm{lbs}(1.63 \mathrm{mt})$ \\
\hline Fluorescent bulbs & $805 \mathrm{lbs}(0.36 \mathrm{mt})$ \\
\hline Electronics reuse and recycling & $15,893 \mathrm{lbs}(7.21 \mathrm{mt})$ \\
\hline Batteries & $4,707 \mathrm{lbs}(2.14 \mathrm{mt})$ \\
\hline Drums & $960 \mathrm{lbs}(0.44 \mathrm{mt})$ \\
\hline
\end{tabular}

TABLE ECS-7

EO 13514 Pollution Prevention / Waste Minimization Accomplishments 2012

\section{DOE Sustainability Award of "Honorable Mention" for Operation of a PTW for Mitigation for Strontium-90 in Groundwater}

The WVDP selected a passive PTW technology to mitigate the spread of strontium-90 contaminated groundwater at the WVDP. Installed in the fall of 2010, the PTW is intended to replace the existing NPGRS. The PTW is an $860-\mathrm{ft}-$ long trench approximately three-feet wide and up to 30-ft-deep. It is a full-scale application of this technology, using a naturallyoccurring zeolite-containing mineral (clinoptilolite) for in-situ selective adsorption of strontium-90. The PTW was installed using a single-pass trenching system, which excavated the native soil through the surficial aquifer down to the clay confining layer and concurrently back-filled the trench with the treatment media. Upon completing the PTW construction, monitoring wells were installed to augment the existing 22 up- and down-gradient wells to evaluate its performance as a radiological groundwater contaminant mitigative measure. The performance monitoring objectives are to: 1) monitor the physical integrity of the PTW and its components, 2) assess the strontium-90 affected groundwater in the PTW vicinity, and 3) monitor and assess the strontium-90 removal from the groundwater moving through the PTW. During the first two years of monitoring, the PTW construction and ongoing monitoring has demonstrated that all of the design functional requirements have been acheived.

In August 2012, DOE received a DOE Sustainability Award of "Honorable Mention" for operation of the PTW and mitigating strontium-90 in groundwater, based on benefits of the mitigation unit including: 1) "Sustainability" construction is designed to meet a 20-year hydraulic and treatment performance life, 2) "Waste Minimization" avoidance of the current use of the pump-and-treat system which generates high volumes of wastewater requiring treatment, 3) "Energy Efficiency" - this is a passive operation that requires no utilities, 4) "Resources" - the treatment media is a naturally-occurring mineral with significant cation exchange capacity, 5) "Health, Safety, and Environment" the treatment media is non-toxic, easily installed and is below ground preventing inadvertent human exposure to the absorbed strontium-90, and 6) "Cost Effective" - the PTW requires no operation and maintenance with the exception of limited landscaping, erosion control, and periodic inspection of above-ground ancillary systems. 
TABLE ECS-7 (concluded)

EO 13514 Pollution Prevention / Waste Minimization Accomplishments 2012

\section{Installation of the WTF T\&VDS}

Through collaboration between the site's EMS and other site management systems, a T\&VDS was designed and successfully installed to evaporate residual liquids inside four underground tanks in the WTF, to evaporate groundwater that infiltrates into the associated underground vaults and containment pans, and to maintain a low relative humidity inside the tanks and vaults to essentially halt tank corrosion. The EMS helped to ensure environmental aspects were considered during the design process and facilitated the process of ensuring that all regulatory requirements were addressed, energy efficient components were utilized, and waste minimization was optimized. By evaporating liquid external to the tanks, the need for liquid pumping and treatment was eliminated, the rate of external tank corrosion was greatly reduced, and the potential for a tank leak will be eliminated after the tank interiors are dried out. The WTF consists of two 760,000-gal (2,876,913 L) carbon steel tanks, each contained in an underground steel-reinforced concrete vault, and two 15,000 gal $(56,781 \mathrm{~L})$ stainless steel tanks both contained within a common underground steel-reinforced concrete vault. Residual liquids in these tanks at the start of this drying project were approximately 25,700 gal $(97,285 \mathrm{~L})$.

The system is currently operating as expected and tank and vault liquid levels are decreasing. As of December 31, 2012, 20,700 gal ( $78,358 \mathrm{~L}$ ) of residual radiologically contaminated liquids from the four tanks have been evaporated in addition to thousands of gallons of liquids evaporated from the three underground vaults.

TABLE ECS-8

WVDP 2012 Air Quality Noncompliance Episodes

\begin{tabular}{|l|c|c|c|c|}
\hline \multicolumn{1}{|c|}{ Permit Type } & Facility & Parameter & $\begin{array}{c}\text { Date(s) } \\
\text { Exceeded }\end{array}$ & $\begin{array}{c}\text { Description/ } \\
\text { Solutions }\end{array}$ \\
\hline EPA, NESHAP & All & All & None & None \\
\hline NYSDEC Air Permit & All & All & None & None \\
\hline
\end{tabular}

TABLE ECS-9

Status of EPCRA (SARA Title III) Reporting at the WVDP For CY 2012

\begin{tabular}{|l|l|c|}
\hline \multicolumn{1}{|c|}{ EPCRA Section } & \multicolumn{1}{|c|}{ Description of Reporting } & Submission Required \\
\hline EPCRA 302-303 & Planning Notification & No \\
\hline EPCRA 304 & Extremely Hazardous Substance Release Notification & No \\
\hline EPCRA 311 & Material Safety Data Sheet & No \\
\hline EPCRA 312 & Hazardous Chemical Inventory & Yes \\
\hline EPCRA 313 & Toxic Chemical Release Inventory Reporting & No \\
\hline
\end{tabular}


TABLE ECS-10

Reportable Chemicals Above EPCRA 312 (SARA Title III) Threshold Planning Quantities Stored at the WVDP in 2012

\begin{tabular}{|l|l|l|}
\hline \multicolumn{3}{|c|}{ Chemicals Stored at the WVDP Above the Threshold Planning Quantities } \\
\hline Diesel fuel/No. 2 Fuel Oil & lon-exchange media & Sulfuric acid \\
\hline Unleaded Gasoline & Lead-acid batteries & Oils - various grades \\
\hline
\end{tabular}

TABLE ECS-11

WVDP SPDES ${ }^{\mathrm{a}}$ Permit Limit Exceedances in 2012

\begin{tabular}{|l|c|c|c|c|c|c|}
\hline Permit Type & Outfall(s) & Parameter & $\begin{array}{c}\text { No. of Permit } \\
\text { Exceptions }\end{array}$ & $\begin{array}{c}\text { No. of Samples } \\
\text { Taken }\end{array}$ & $\begin{array}{c}\text { No. of } \\
\text { Compliant } \\
\text { Samples }\end{array}$ & $\begin{array}{c}\text { Percent } \\
\text { Compliant } \\
\text { Samples }\end{array}$ \\
\hline SPDES & All & All & 0 & 1,580 & 1,580 & $100.0 \%$ \\
\hline
\end{tabular}

${ }^{a}$ Radionuclides are not regulated under the site's SPDES permit. However, special requirements in the permit specify that the concentration of radionuclides in the discharge is subject to requirements of DOE Order 5400.5, (see letter CHBWV to NYSDEC, January 8, 2013).

Note: The WVDP notified NYSDEC that DOE Order 5400.5 was replaced by DOE Order 458.1. The WVDP is currently executing the requirements of DOE Order 458.1, including its allied DCSs.

TABLE ECS-12

WVDP Migratory Bird Nest Depredation Activities in Fiscal Year 2012

\begin{tabular}{|l|l|c|c|}
\hline \multicolumn{1}{|c|}{ Permit/License Type } & Parameter & Permit Limit & 2012 Total \\
\hline $\begin{array}{l}\text { U.S. Fish and Wildlife - } \\
\text { Bird Depredation Permit }\end{array}$ & Removal of Active Barn Swallow Nests & 20 & 0 \\
\hline $\begin{array}{l}\text { U.S. Fish and Wildlife - } \\
\text { Bird Depredation Permit }\end{array}$ & Removal of Active American Robin Nests & 15 & 0 \\
\hline $\begin{array}{l}\text { U.S. Fish and Wildlife - } \\
\text { Bird Depredation Permit }\end{array}$ & Removal of Active Eastern Phoebe Nests & 5 & 0 \\
\hline $\begin{array}{l}\text { U.S. Fish and Wildlife - } \\
\text { Bird Depredation Permit }\end{array}$ & Removal of Active Common Grackle Nests & 15 & 0 \\
\hline $\begin{array}{l}\text { U.S. Fish and Wildlife - } \\
\text { Bird Depredation Permit }\end{array}$ & Removal of Inactive Migratory Bird Nests & Not limited \\
\hline $\begin{array}{l}\text { U.S. Fish and Wildlife - } \\
\text { Registration }\end{array}$ & Oiling of Canada Goose Eggs & NA & 1 \\
\hline
\end{tabular}

NA - Not applicable 


\section{ENVIRONMENTAL MANAGEMENT SYSTEM}

\section{ISMS Implementation}

A plan to integrate environmental, safety, health, and quality (ESH\&Q) management programs at the WVDP was developed and verified in 1998. Environmental SMEs routinely participate in a site-wide process to review work plans, identify ESH\&Q concerns, and specify practices that ensure work is performed safely. For purposes of this policy, the term "safety" includes environmental, radiological, industrial/chemical, and nuclear safety and health and encompasses the public, workers, and the environment.

\section{EMS}

During the ISMS development, the EMS was identified as an integral part of the ISMS. The WVDP EMS, as established, implements sound stewardship practices that are protective of the air, water, land, and other natural and cultural resources potentially impacted by DOE operations and by which DOE cost effectively meets or exceeds compliance with applicable environmental, public health, and resource protection requirements. The EMS objectives implement sustainable practices for enhancing environmental, energy, and transportation management performance.

The first objective emphasizes compliance with the sustainability requirements of the following EOs and legislation:

- EO 13423, "Strengthening Federal Environmental, Energy, and Transportation Management;"

- EO 13514, "Federal Leadership in Environmental, Energy, and Economic Performance;"

- National Energy Conservation Policy Act;

- Energy Policy Acts of 1992 and 2005;

- Energy Independence and Security Act of 2007;

- Inventory and reporting requirements of the EPCRA, Sections 301 through 313; and
- Pollution prevention reporting requirements of the Pollution Prevention Act of 1990.

To support the federal government's sustainability goals, contractors must develop site sustainability plans (SSPs) to identify their respective contributions toward meeting the goals. Contractors must integrate their SSPs with operational plans as applicable.

The second objective addresses the EMS, in that contractors must develop and implement a system that is certified by, or conforms with, International Organization for Standardization (ISO) 14001:2004. Site sustainability goals must be integrated into the EMS.

The environmental monitoring program is an important component of the EMS, ensuring accomplishment of its mission. The elements of the WVDP EMS are summarized in Table 1-1.

\section{Environmental Policy}

The official site environmental policy is provided on the following page. Activities at the WVDP during 2012 were conducted in full compliance with applicable environmental statutes, DOE directives, EOs, and state laws and regulations. Refer to Table ECS-1, "Compliance Status Summary for the WVDP in CY 2012," for details.

\section{Environmental Aspects}

Per the ISO:14001 standard, an environmental aspect is an element of an organization's activities, products, or services that can interact with the environment. Activities that have regulatory implications or those that could have significant environmental impacts are identified as significant aspects. The potential significant environmental aspects of site activities identified within the elements of the WVDP EMS are summarized on Table 1-2 together with the method by which aspects are graded.

Site activities related to hazardous and radiological waste management, pollution prevention, air and water emissions, energy and materials use, and recycling are presented in the Environmental Compliance Summary (ECS). 
The WVDP is currently in the D\&D phase of operations; therefore, current work scope encompasses waste management and disposition, decontamination, deactivation, facility disposition, and infrastructure reduction. For each facility or structure that is considered for demolition, the base environmental aspects are identified and addressed during work planning with the assistance of hazard control specialists. Before a building may be demolished, a "Demolition Readiness Checklist" that captures the relevant environmental aspects must be completed.

\section{Legal and Other Requirements}

Requirements contained in DOE orders and directives are incorporated into WVDP contracts with subcontractors as specific terms and conditions. Environmental regulatory reviews are conducted to identify, evaluate, and document changes to applicable environmental regulations. Items that have an effect upon compliance activities at the WVDP are communicated to other appropriate Project personnel.

\section{Objectives and Targets}

The EMS objectives and targets shown in Table 1-3 are intended to prevent pollution, reduce environmental hazards, protect the public and environment, reduce waste disposal costs, and improve operational capability. The goals and objectives were evaluated using a graded approach which took into consideration that buildings and infrastructure will be demolished in the coming years.

The WVDP's "Waste Minimization and Pollution Prevention Awareness Plan" establishes the strategic framework for integrating waste minimization and pollution prevention into waste generating and reducing activities, procuring recycled products, reusing existing products, and using methods that conserve energy. The comprehensive program drives continual effort to prevent or minimize pollution, with the overall objective of reducing health and safety risks, and protecting the environment. Refer to the ECS Table ECS-6, "Recycled Materials for FY 2012," and Table ECS-7, "Executive Order 13514 Pollution Prevention/Waste Minimization Accomplishments in 2012."

CHBWV has revised the program and received a Certificate of Registration for the ISO 14000:2004 certification of its EMS on July 31, 2012, in accordance with the requirements of DOE Order 436.1. New objectives and targets were established by CHBWV during CY 2012 to align with and assist in achieving the goals in the SSP.

\section{Environmental Management Program}

An environmental management program is a key element to successfully implementing an EMS. The program is implemented by the "WVDP EMS policy," which describes how the objectives and targets are achieved and clearly defines responsibilities and time frames. It also provides for modifications to ensure that environmental management will apply to new developments and new or modified activities. This is accomplished through routine review and update of policies and procedures, as well as through project schedules, milestone tracking, and commitment tracking.

\section{Structure and Responsibility}

All project personnel are responsible for adherence to the site's EMS policies. In addition, specific management representatives have defined responsibility and authority for ensuring that EMS requirements are implemented in accordance with the policy, and for reporting to staff management.

During 2012, audits were performed by internal and external agencies to identify areas for improvement and assess compliance to the EMS principles. For further discussion of audits, refer to "EMS Audits and Other Audits and Assessments" later in this chapter.

\section{Training, Awareness, and Competence}

Human performance/behavior-based safety (HP/BBS) training is conducted across the site. Project personnel are trained to HP/BBS concepts and practices, and HP/ BBS observer technique training is provided for safety department and safety observers. Self-assessment activities are also stressed as a mechanism for evaluating, improving, and maintaining worker safety. The WVDP operated throughout 2012 in a safe manner that was protective of its workers, the public, and the environment.

The radiological and hazardous work environment at the WVDP warrants strict adherence to safety procedures. During 2012, the WVDP work force achieved a cumulative total of 5.5 million safe work hours without a lost time work injury before experiencing a lost time event in November 2012.

10 CFR 851, "Worker Safety and Health Program." 10 CFR 851 became effective in February 2007, with full implementation at the WVDP by May 2007. The legislation superseded DOE Order 440.1A, "Worker Protection Management for DOE Federal and Contractor Employees," 


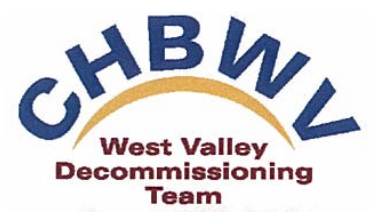

\section{Environmental Policy}

It is the policy of CH2M HILL B\&W West Valley, LLC (CHBWV) to conduct the West Valley Demonstration Project (WVDP) in a safe, compliant and cost-effective manner that protects human health and the environment. We achieve this by integrating environmental requirements and pollution prevention into our work planning and execution, and taking actions to minimize the environmental impacts of our operations. We establish and communicate environmental responsibilities, provide environmental training to our workforce, and implement controls to mitigate environmental hazards. These activities are conducted in accordance with our Environmental Management System (WV -980). Through employee involvement and management commitment to environmental excellence, we will:

- Identify and comply with all applicable environmental laws and regulations.

- Use practicable means to minimize or eliminate the generation of new wastes without a path for disposition.

- Protect the unique natural, biological and cultural resources associated with WVDP activities.

- Conserve natural resources by reusing and recycling materials, purchasing recycled materials, and using recyclable materials.

- Establish documented environmental objectives and targets and update them as necessary to reflect CHBWV's changing needs, missions, and goals.

- Consider the input of our stakeholders when weighing alternative environmental courses of action.

- Monitor our impact on the environment and measure our performance; and communicate the results to our employees, subcontractors, and stakeholders.

- Continuously improve our environmental management system through selfassessment and corrective action.

- Communicate this policy to all employees and subcontractors and make it available to the public and our stakeholders.

This policy applies to all persons working on behalf of CHBWV at the WVDP. Every employee and subcontractor is expected to follow this policy and to report environmental concerns to management. Managers shall promote environmental stewardship, take prompt action to address concerns and issues and have zero tolerance for noncompliance.

Daniel W. Coyne

CHBWV Acting Rresident and General Manager 
TABLE 1-1

Elements of the CY 2012 WVDP EMS Implementation

\begin{tabular}{|c|c|}
\hline \multicolumn{2}{|l|}{ Planning } \\
\hline $\begin{array}{l}\text { Environmental } \\
\text { Aspects }\end{array}$ & $\begin{array}{l}\text { CHBWV shall identify those environmental aspects of site activities, including energy and } \\
\text { transportation functions, which have, or can have significant impact on the environment, } \\
\text { including, but not limited to air emissions, water releases, waste management, contamination of } \\
\text { land, use of raw materials and natural resources, and other local environmental and community } \\
\text { issues. Since the WVDP is currently in the deactivation, and D\&D phase, the significant aspects } \\
\text { are related to these activities as shown in Table 1-2, "WVDP Base Environmental Aspects". These } \\
\text { aspects are addressed in the work instruction packages with the assistance of the hazard control } \\
\text { specialists. In addition, building demolitions require the completion of a demolition readiness } \\
\text { checklist which captures many of these environmental aspects. These aspects will be reviewed } \\
\text { and updated if needed when new or modified work scope is added to the contract. } \\
\text { Aspects related to these significant impacts must be considered in setting environmental } \\
\text { objectives at the site, project, activity, and task level. Consideration should be given to promoting } \\
\text { long-term stewardship of the WVDP's natural and cultural resources throughout its operational, } \\
\text { closure, and post closure life cycle. } \\
\text { Efforts should be taken to reduce or eliminate waste generation, the release of pollutants to the } \\
\text { environment, and the use of Class I ozone-depleting substances through source reduction } \\
\text { including segregation and substitution, re-use, recycling, and sustainable development, and by } \\
\text { procuring environmentally preferable products and services, pursuant to DOE Sustainable } \\
\text { Environmental Stewardship Goals. }\end{array}$ \\
\hline $\begin{array}{l}\text { Legal and Other } \\
\text { Requirements }\end{array}$ & $\begin{array}{l}\text { CHBWV shall identify and disseminate to employees, and the public upon request, those legal } \\
\text { and other requirements to which the company subscribes and which are applicable to the } \\
\text { environmental aspects of site activities. }\end{array}$ \\
\hline $\begin{array}{l}\text { Objectives and } \\
\text { Targets }\end{array}$ & $\begin{array}{l}\text { CHBWV shall establish documented environmental objectives and targets for relevant functions } \\
\text { and at multiple levels (i.e., site, project, activity, and task). The policy shall take into account and } \\
\text { be kept consistent with the following: environmental, legal, business, financial, and other } \\
\text { requirements; significant environmental aspects; SSP; technological options; and the views of } \\
\text { interested parties. Objectives and targets correlate with ISMS Core Function 1, Define the Scope } \\
\text { of Work, which requires that expectations be set, tasks identified and prioritized, and resources } \\
\text { allocated. Objectives and targets are set primarily through annual ISMS Performance Objectives, } \\
\text { Measures, and Commitments, SSP, management objectives, individual employee performance } \\
\text { objectives, and to mitigate potential environmental impacts associated with significant aspects at } \\
\text { the WVDP. In addition, specific environmental targets are established through regulatory permits } \\
\text { for discharges to air and water and through waste minimization and pollution prevention } \\
\text { planning. } \\
\text { DOE Order } 436.1 \text { requires that the WVDP commit to implementing an annual SSP that identifies } \\
\text { its respective contribution toward meeting DOE's sustainability goals. These goals are also } \\
\text { intended to: } \\
\text { 1. Prevent pollution; } \\
\text { 2. Reduce environmental hazards; } \\
\text { 3. Protect public health and the environment; } \\
\text { 4. Avoid pollution control and waste disposal costs; and } \\
\text { 5. Improve operational capability and overall mission sustainability. }\end{array}$ \\
\hline
\end{tabular}




\section{TABLE 1-1 (continued) \\ Elements of the CY 2012 WVDP EMS Implementation}

\begin{tabular}{|c|c|}
\hline \multicolumn{2}{|c|}{ Planning (continued) } \\
\hline $\begin{array}{l}\text { Objectives and } \\
\text { Targets } \\
\text { (continued) }\end{array}$ & $\begin{array}{l}\text { Objectives and measurable targets are developed to meet the above goals. Sustainable practices } \\
\text { listed in DOE Order } 436.1 \text { and the SSP, as well as other methods are utilized to meet these } \\
\text { targets. This list is treated as a "living document" and is updated regularly to track the status of } \\
\text { existing targets and to add additional objectives and targets. } \\
\text { The establishment of a green initiatives team was completed in early } 2012 \text { to brainstorm ideas to } \\
\text { help meet EMS goals. In addition, this team encourages energy use reduction practices that } \\
\text { employees can adopt at their homes. Consideration should be given to ensure the early } \\
\text { identification of, and appropriate response to, potential adverse environmental impacts } \\
\text { associated with DOE operations, including as appropriate, pre-operational characterization and } \\
\text { assessment; and effluent and surveillance monitoring. }\end{array}$ \\
\hline \multicolumn{2}{|c|}{ Implementation and Operation } \\
\hline $\begin{array}{l}\text { Structure and } \\
\text { Responsibility }\end{array}$ & $\begin{array}{l}\text { Each procedure referenced in the EMS must define roles, responsibilities, and authorities to } \\
\text { facilitate effective environmental management. All site procedures define roles and } \\
\text { responsibilities and CHBWV management provides resources essential to implement and control } \\
\text { the EMS. Resources include human resources and specialized skills, technology, and financial. } \\
\text { The environmental manager is the specific CHBWV management representative who, irrespective } \\
\text { of other responsibilities, has the defined role, responsibility, and authority for ensuring that EMS } \\
\text { requirements are established, implemented, and maintained in accordance with this policy, and } \\
\text { for reporting the EMS performance to the CHBWV General Manager. This reporting and } \\
\text { associated review provides the basis for EMS improvement. }\end{array}$ \\
\hline $\begin{array}{l}\text { Training, } \\
\text { Awareness, and } \\
\text { Competence }\end{array}$ & $\begin{array}{l}\text { CHBWV must ensure that employees are aware of the importance of conformance with the } \\
\text { environmental policy and with implementing EMS procedures; the significant environmental } \\
\text { impacts, actual or potential, of their work activities; the environmental benefits of improved } \\
\text { personal performance; their roles and responsibilities in achieving conformance with the } \\
\text { environmental policy and EMS procedures (including emergency preparedness and response } \\
\text { requirements); and, the potential consequences of departure from specified operating } \\
\text { procedures. }\end{array}$ \\
\hline Communication & $\begin{array}{l}\text { CHBWV shall provide for internal communication between the various levels and functions of the } \\
\text { company and for receiving, documenting, and responding to relevant communication from } \\
\text { external interested parties. Communication includes both formal review of EMS related } \\
\text { documents and informal meetings on a day to day basis to exchange critical environmental and } \\
\text { operational information. Internal communications include articles in "The West Valley } \\
\text { Chronicals" and "Take } 5 \text { for Safety," posters, training briefings, and presentations at all-employee } \\
\text { meetings. Key external parties include EPA, NRC, NYSDEC, NYSDOH, NYSDOL, and local } \\
\text { emergency responders. External communication, including information regarding significant } \\
\text { environmental aspects when approved by DOE, includes quarterly public meetings, the reading } \\
\text { room, regulatory round tables, monthly citizen task force meetings (for stakeholder } \\
\text { communications), and the ASER which is available on the internet at http://www.wv.doe.gov. }\end{array}$ \\
\hline $\begin{array}{l}\text { EMS } \\
\text { Documentation }\end{array}$ & $\begin{array}{l}\text { CHBWV shall establish and maintain information, in paper or electronic form, to describe EMS } \\
\text { core elements, their interaction, and to reference related implementing documentation. }\end{array}$ \\
\hline
\end{tabular}


TABLE 1-1 (continued)

Elements of the CY 2012 WVDP EMS Implementation

\begin{tabular}{|c|c|}
\hline \multicolumn{2}{|c|}{ Implementation and Operation (continued) } \\
\hline Document Control & $\begin{array}{l}\text { CHBWV shall maintain controls for EMS related documentation. These controls require that } \\
\text { documents be available at locations where operations essential to the effective functioning of the } \\
\text { EMS are performed; provide for periodic review and revision; require that obsolete documents } \\
\text { be promptly removed from all points of issue and points of use (or otherwise assured against } \\
\text { unintended use); and, require that any obsolete documents retained for legal and/or record } \\
\text { preservation purposes be suitably identified. } \\
\text { EMS related records must be legible, dated (with dates of revision), readily identifiable (uniquely } \\
\text { numbered or otherwise distinguishable), orderly maintained, and retained for a specified period. } \\
\text { EMS records are classified, inventoried, indexed, retained, and disposed in accordance with the } \\
\text { CHBWV Master File Plan. Documents and records are maintained electronically via easy-docs and } \\
\text { environmental data management system. }\end{array}$ \\
\hline$\overline{\text { Oper }}$ & $\begin{array}{l}\text { CHBWV shall identify those operations and activities that are associated with the identified } \\
\text { significant environmental aspects in line with this policy, as well as resultant objectives and } \\
\text { targets. Procedures for these operations and activities must provide specific conditions and } \\
\text { criteria that must be satisfied to ensure compliance with this policy, including objectives and } \\
\text { targets. }\end{array}$ \\
\hline \begin{tabular}{|l|} 
Emergency \\
Preparedness and \\
Response
\end{tabular} & $\begin{array}{l}\text { CHBWV shall address response to accidents and emergency situations, and the prevention and } \\
\text { mitigation of the environmental impacts that may be associated with them. CHBWV shall review } \\
\text { and revise, where necessary, its emergency preparedness and response procedures, routinely } \\
\text { and after the occurrence of accidents or emergency situations (where appropriate). CHBWV must } \\
\text { also periodically conduct drills and exercises to assess the effectiveness of the emergency } \\
\text { management program. }\end{array}$ \\
\hline \multicolumn{2}{|c|}{ Checking and Corrective Action } \\
\hline $\begin{array}{l}\text { Monitoring and } \\
\text { Measurement }\end{array}$ & $\begin{array}{l}\text { CHBWV shall provide for monitoring and measurement of the EMS on a regular basis, as well as } \\
\text { key characteristics of site operations and activities that can have a significant impact on the } \\
\text { environment. Monitoring equipment shall be calibrated and maintained and records of these } \\
\text { activities retained. CHBWV shall also provide for periodic evaluation of compliance with relevant } \\
\text { environmental legislation and regulations. }\end{array}$ \\
\hline $\begin{array}{l}\text { Evaluation of } \\
\text { Compliance }\end{array}$ & $\begin{array}{l}\text { CHBWV shall establish, implement, and maintain a procedure for periodically evaluating } \\
\text { compliance with applicable legal and other requirements. }\end{array}$ \\
\hline $\begin{array}{l}\text { Nonconformance } \\
\text { and Corrective and } \\
\text { Preventive Action }\end{array}$ & $\begin{array}{l}\text { CHBWV shall define responsibilities and authorities for handling and investigating } \\
\text { nonconformances, taking action to mitigate any associated impacts, and for initiating and } \\
\text { completing corrective and preventive actions. Corrective or preventive actions shall be taken to } \\
\text { eliminate the causes of actual and potential nonconformances tailored to the magnitude of } \\
\text { problems commensurate with the environmental impacts encountered. Where appropriate, } \\
\text { changes shall be made to procedures to formally address corrective and preventive actions. } \\
\text { Audit findings and root causes of nonconformance are tracked and addressed. }\end{array}$ \\
\hline Records & $\begin{array}{l}\text { CHBWV shall provide for the identification, maintenance, and disposition of environmental } \\
\text { records. These records include training records and the results of audits and other reviews. } \\
\text { Environmental records shall be legible, identifiable and traceable to the activity, or service } \\
\text { involved. These records shall be stored and maintained in such a way that they are readily } \\
\text { retrievable and protected against damage, deterioration, or loss. Retention times shall be clearly } \\
\text { established and recorded. Records pertaining to the EMS such as forms, data sheets, logs, } \\
\text { reports, or any other form of documentation are considered records and when created are to be } \\
\text { prepared, maintained, and transferred to the records department. }\end{array}$ \\
\hline
\end{tabular}


TABLE 1-1 (concluded)

Elements of the CY 2012 WVDP EMS Implementation

\begin{tabular}{|c|c|}
\hline \multicolumn{2}{|r|}{ ctive Action (continued) } \\
\hline $\begin{array}{l}\text { EMS Audit } \\
\text { (Assessments) }\end{array}$ & $\begin{array}{l}\text { CHBWV shall conduct periodic EMS assessments to determine whether or not the EMS conforms } \\
\text { to the policy requirements; that the EMS has been properly implemented and maintained; and, } \\
\text { to provide information on assessment results to CHBWV management. Assessments shall be } \\
\text { based on the environmental importance of site activities and consider the results of previous } \\
\text { reviews. Assessment procedures must cover scope, frequency, methodologies, and the } \\
\text { responsibilities and requirements for conducting assessments and reporting results. These } \\
\text { assessments will be performed following one of two methods: } \\
\text { - on specific tasks or activities and will include applicable ISO } 14001: 2004 \text { elements, or } \\
\text { - on individual core elements and will be assessed across multiple activities or projects. } \\
\text { Frequency of assessments will be at a minimum of one per calendar year. These assessments will } \\
\text { include participation by personnel outside the control or scope of the EMS to ensure objectivity } \\
\text { and the impartiality of the assessment process and will be included on the integrated assessment } \\
\text { schedule. }\end{array}$ \\
\hline \multicolumn{2}{|l|}{ Management $R e$} \\
\hline \multicolumn{2}{|c|}{$\begin{array}{l}\text { The CHBWV general manager shall review site environmental performance to ensure the continuing suitability, } \\
\text { adequacy, and effectiveness of the EMS. The review must address opportunities for improvement, the need for } \\
\text { changes to the EMS, including environmental policy, objectives, and targets, and the following specific set of inputs } \\
\text { - Results of internal compliance audits and evaluations with legal requirements and with other requirements } \\
\text { to which the organization subscribes; } \\
\text { - Communication(s) from external interested parties, including complaints; } \\
\text { - Environmental performance of the organization; } \\
\text { - Extent to which objectives and targets have been met; } \\
\text { - Status of corrective and preventive actions; } \\
\text { - Follow-up actions from previous management reviews; } \\
\text { - Changing circumstances, including developments in legal and other requirements related to its environmental } \\
\text { aspects; and }\end{array}$} \\
\hline \multicolumn{2}{|l|}{ EMS Validation } \\
\hline \multicolumn{2}{|c|}{$\begin{array}{l}\text { 1. Have been the subject of a formal audit by a qualified party outside the control or scope of the EMS; } \\
\text { 2. Have the regulatory strategy manager and the DOE-WVDP director recognize and address the findings of the } \\
\text { above audit. }\end{array}$} \\
\hline \multicolumn{2}{|c|}{$\begin{array}{l}\text { 3. Have the regulatory strategy manager and the DOE-WVDP director declare conformance of the EMS to the } \\
\text { requirements of DOE Order } 436.1 \text { or the EMS is certified to ISO 14001:2004 in accordance with the } \\
\text { accredited registrar provisions of the international standard. }\end{array}$} \\
\hline
\end{tabular}


TABLE 1-2

WVDP Significant Environmental Aspects

\begin{tabular}{|c|r|r|}
\hline \multicolumn{2}{|c|}{ Environmental Aspects that could have Potential Significant Environmental Impacts } \\
(graded with overall significance $=14$ or $>14$ as defined below)
\end{tabular}

Note: Environmental aspects correlate with ISMS Core Function 2, Analyze the Hazards, which requires that the hazards associated with work be identified, analyzed, and categorized. The process for ranking environmental aspects for significance is described in more detail in WV-980, "CHBWV Environmental Managment System".

Grading scales: Aspects with an overall significance of 14 or greater were identified as a significant aspect. Overall significance is computed by the product of the "Likelihood" (scaled from 1-5 as defined below) and the "Environmental Aspects" (also scaled from 1-5), added to the sum of the "Regulatory Impact" (scaled 0-5) and "Community Concerns" (scaled 0-4). Scores for each enviromental aspect are defined as follows:

Likelihood Scoring Scale (1-5):

$$
\begin{array}{ll}
1=\text { Unlikely } & 4=\text { Frequent } \\
2=\text { Seldom } & 5=\text { Continuous } \\
3=\text { Infrequent } &
\end{array}
$$

Environmental Impact Scale (1-5):

$$
\begin{aligned}
& 1=\text { Insignificant } \\
& 2=\text { Mild } \\
& 3=\text { Moderate }
\end{aligned}
$$$$
4=\text { Frequent }
$$

5 = Severe/Catstrophic

Regulatory Impact Scale (0-5):

$0=$ No applicable requirments

3 = DOE Operations Office policy

$1=$ Best Management Practice

4 = DOE-HQ policy

$2=$ Regulated in the future

5 = Regulated (mandated by a federal, state,

or local government agency or contract requirement)

\section{Scoring Community Concerns Scale (0-4):}

$0=$ Community not likely to become concerned

1 = Community is unconcerned but could easily become concerned

2 = Some community concerns

$3=$ Serious community concerns including stakeholders, watchdog or advocacy groups

4 = Public anger/lawsuits including statkeholders concerns 
TABLE 1-3

WVDP EMS Objectives and Targets

Completed in CY 2012

\begin{tabular}{|c|c|c|c|c|}
\hline Objective & Target & Responsibility & Target Date & Status \\
\hline $\begin{array}{l}\text { Electronic } \\
\text { Stewardship }\end{array}$ & $\begin{array}{l}95 \% \text { of the } \\
\text { purchase of PCs, } \\
\text { laptops, monitors } \\
\text { will be Electronic } \\
\text { Product } \\
\text { Environmental } \\
\text { Assessment Tool } \\
\text { (EPEAT) certified. }\end{array}$ & Environmental & Ongoing & $\begin{array}{l}\text { Goal Exceeded. } \\
\text { 100\% of purchases of eligible } \\
\text { equipment met EPEAT Gold } \\
\text { standards. }\end{array}$ \\
\hline Reduce fleet size. & $\begin{array}{l}\text { Fleet reduction: } \\
2 \text { vehicles in } \\
\text { FY2012. }\end{array}$ & Maintenance & $9 / 30 / 2012$ & $\begin{array}{l}\text { Goal Exceeded. } \\
\text { Fleet has been reduced by } 6 \\
\text { vehicles. }\end{array}$ \\
\hline $\begin{array}{c}\text { Direct construction } \\
\text { and demolition } \\
\text { waste to recycle. }\end{array}$ & $\begin{array}{l}\text { Waste reduction } \\
\text { from demolition of } \\
\text { test tower. } \\
100 \% \text { of clean steel } \\
\text { recycled. }\end{array}$ & Facility Disposition & $11 / 30 / 2012$ & $\begin{array}{l}\text { Goal not met. } \\
\text { Unable to recycle the test tower } \\
\text { scrap metal due to new NYS } \\
\text { requirements. Future scrap } \\
\text { metal recycling is pending an } \\
\text { out-of-state recycling contract } \\
\text { award and issuance of DOE-HQ } \\
\text { determination of the Product } \\
\text { Environmental Assessment } \\
\text { issued in the FR on 12/12/12 } \\
\text { (77 FR 73996). }\end{array}$ \\
\hline $\begin{array}{l}\text { Place } 01-14 \text { in a } \\
\text { cold and dark } \\
\text { condition. }\end{array}$ & Reduce energy use. & Facility Disposition & $11 / 30 / 2012$ & $\begin{array}{l}\text { Goal met. } \\
\text { Project complete. }\end{array}$ \\
\hline $\begin{array}{l}\text { Evaluate reducing } \\
\text { energy use from } \\
\text { moving water to } \\
\text { raw-water storage } \\
\text { tank. }\end{array}$ & $\begin{array}{c}\text { Reduce pump use } \\
\text { by } 50 \% \text {. }\end{array}$ & $\begin{array}{c}\text { Nuclear Operations } \\
\text { and Storage }\end{array}$ & $6 / 30 / 2012$ & $\begin{array}{l}\text { Goal Exceeded. } \\
\text { Initial results indicate a energy } \\
\text { savings of approximately } 60 \text { - } \\
70 \% .\end{array}$ \\
\hline $\begin{array}{l}\text { Evaluate and trend } \\
\text { release from the } \\
\text { sewage treatment } \\
\text { plant for the } \\
\text { presence of } \\
\text { mercury. }\end{array}$ & $\begin{array}{c}\text { Achieve less than } \\
50 \text { parts per trillion } \\
\text { criteria. }\end{array}$ & $\begin{array}{c}\text { Nuclear Operations } \\
\text { and Storage }\end{array}$ & $12 / 30 / 2012$ & $\begin{array}{l}\text { Goal met. } \\
\text { Actual lab results have shown } \\
\text { consistent results of } \\
\text { approximately } 20 \mathrm{ppt} \text {. }\end{array}$ \\
\hline
\end{tabular}


which directed compliance with specific Occupational Safety and Health Administration (OSHA) requirements.

Similar to the OSHA requirements, the rule established the framework for an effective worker health and safety program to provide DOE contractor workers with a safe and healthy workplace in which hazards are abated, controlled, or otherwise mitigated in a manner that provides reasonable assurance that workers are adequately protected from identified hazards.

The "WVDP Worker Safety and Health Plan" describes how the WVDP complied with 10 CFR 851. The plan was reviewed in February 2012 and no modifications were necessary.

Any person working at the WVDP who has a personal photo badge allowing unescorted access to administrative areas of the site receives general employee training (GET) that covers health and safety, emergency response, and environmental compliance issues. All visitors to the WVDP receive a site-specific briefing on safety and emergency procedures.

Safety-Trained Supervisor Program. A WVDP certification program is maintained whereby employees complete extensive training to become safety-certified. Standards are established by the Council on Certification of Health, Environmental, and Safety Technologists, and the certification is offered by the Board of Certified Safety Professionals. Certified personnel help ensure that the work force stay current with safety knowledge and practices that are applicable to managers, supervisors, and lead personnel. This is especially important in the WVDP's hazardous work environment at the WVDP, where every worker is expected to be responsible for safety. The WVDP certified personnel are recertified every five years by completing or conducting 30 hours of safety, health, or environmental training.

\section{Communication}

Communications with regulators, stakeholders, employees, and other interested parties are maintained on an ongoing basis. The WVDP keeps regulators informed through routine reports, teleconferences, and meetings. In addition, in 2012, regulatory roundtable meetings were held with representatives from NRC, EPA, NYSDEC, and NYSDOH in July and November. The roundtables provide forums for project personnel and the regulators to engage with one another on current activities and upcoming regulatory issues.
Public meetings are held on a monthly basis. In 2012, there were seven West Valley Citizen Task Force meetings and four quarterly public meetings. In addition to project status reports ad topical discussions, progress on the Phase 1 Study process was provided at the public meetings. In addition, a climate change workshop was help on August 2, 2012. Refer to "Phase 1 Studies" in the ECS.

\section{EMS Documentation, Document Control, and Records}

All EMS documentation is maintained, updated, and controlled per the WVDP records retention requirements, or in accordance with specific regulatory requirements for records maintenance (e.g., NESHAP). On November 13, 2012, the "WVDP FY 2012 EO 13514 RCRA/EO Annual Report on Sustainable Acquisition and Pollution Prevention Progress" was submitted via the online DOE, Office of Health, Safety and Security, Pollution Prevention Tracking and Reporting System website. In addition, on November 29, 2012, the "WVDP FY 2013 Site Sustainability Plan" was submitted to DOE headquarters.

\section{Operational Control}

NDA Interceptor Trench and Pretreatment System. Radioactively contaminated $\mathrm{n}$-dodecane, in combination with tributyl phosphate (TBP), was discovered in groundwater at the NDA's northern boundary in 1983, shortly after DOE assumed control of the WVDP. Investigations during 1983 and 1984 determined the source and location of the $n$-dodecane-contaminated water to be from eight 1,000-gal $(3,785 \mathrm{~L})$ tanks buried in the NDA. In 1985, these tanks were exhumed and the contaminated absorbent and tanks were treated and packaged for disposal. To mitigate subsurface migration of potential remaining organic mixture, an interceptor trench and the liquid pretreatment system (LPS) were installed in 1990. In 2008, a slurry wall was installed upgradient of the NDA and a geomembrane cover was installed over the NDA footprint.

Operations personnel maintain the water levels in the NDA trench and environmental monitoring personnel monitor for releases from the NDA. As in previous years, n-dodecane/TBP was not detected in the trench water; therefore, no water was treated by the LPS in 2012. Approximately 64,035 gal $(242,400$ L) of radiologically contaminated water were pumped and transferred from the interceptor trench to the LLW2 during CY 2012. Refer to Chapter 4, "Groundwater Protection Program," under "Groundwater Sampling Observations on the South Plateau: Weathered Lavery Till (WLT) and the NDA" for a 
discussion of surface and groundwater monitoring results in the vicinity of the NDA.

North Plateau Full-Scale PTW. A plume of strontium-90 contaminated groundwater migrating to the north-northeast, has been monitored for nearly two decades. The contamination source was determined to originate from piping leaks that entered the ground below the southwest corner of the MPPB, prior to Project operations. In October and November 2010, an 860-foot-long zeolite-filled PTW was installed along the existing roadway south of the CDDL. The PTW allows groundwater to pass through, while adsorbing the radioactive strontium-90. The zeolite used as the PTW media is a natural mineral with a porous structure that adsorbs positively charged ions, such as strontium. Sixty-six groundwater monitoring wells were installed to monitor the wall's performance. The work for this project was completed using American Recovery and Reinvestment Act funding. Refer to Chapter 4, "Groundwater Protection Program," under "Strontium-90 Plume Remediation Activities" for further discussion.

\section{Emergency Preparedness and Response}

In the event of health, safety, or environment emergencies, the Incident Commander activates the Emergency Operations Center (EOC) and the Technical Support Center in accordance with site Emergency Response Organization (ERO) procedures.

Throughout 2012, Emergency Management, ERO, and Operations personnel participated in 13 different drills and/or exercises. To continually improve emergency preparedness and response, corrective actions identified in drills and exercises are placed into open items tracking system (OITS) and followed to completion. Several drills are also incorporated in assigned training requirement validation checklists and were repeated throughout the year with appropriate personnel.

The WVDP has provisions in place for interface and coordination with federal, state, and local agencies and organizations responsible for implementation of off-site emergency response actions to protect the health and safety of the public and environment. Formal relationships with federal or state agencies are established through federal interagency agreements, internal DOE agreement or directives, state regulations, or state and local emergency plans. Other formal relationships with local agencies are documented via MOUs or Letters of Agreement (LOAs). All MOUs and LOAs between off site agencies and the WVDP were updated, revised and approved in 2012.
The ERO refresher training was updated and completed by 70 individuals. The emergency management sections of GET and the CHBWV annual mandatory briefing were also updated to reflect program changes. New CHBWV and NYSERDA members were provided training in ERO expectations and their assigned EOC positions.

\section{Environmental Monitoring and Measurement}

Since the WNYNSC is not an active nuclear fuel reprocessing facility, the environmental monitoring program at the WVDP focuses on measuring radiological and chemical constituents associated with the aged residual by-products of former NFS operations, the Project's former HLW treatment operations, and the current operations for management of HLW, TRU waste, and LLW.

Exposure to radioactivity from site activities could occur through air, water, and food pathways. Therefore, these potential pathways are monitored at the WVDP. Air and surface water pathways are the primary means by which radioactive material could move off site.

The WVDP's on- and off-site monitoring program includes measuring the concentration of alpha and beta radioactivity, conventionally referred to as "gross alpha" and "gross beta," in air and water effluents. Measuring the total alpha and beta radioactivity from key locations produces a comprehensive picture of on- and off-site radioactivity levels from all sources. Frequent updating and tracking of the gross radioactivity in effluents is required to maintain acceptable operations.

More-detailed measurements are also made for specific radionuclides. Radionuclides monitored at the Project are those that might produce relatively higher doses or that are most abundant in air and water effluents. Because man-made sources of radiation at the Project have been decaying for more than 40 years, the monitoring program does not routinely include short-lived radionuclides, that is, isotopes with a half-life of less than two years, which would currently be present at less than $1 / 100,000$ of their original radioactivity levels.

The WVDP monitoring program includes sanitary wastewater discharges and storm water for nonradiological water quality and chemical constituents. See Appendix A for the schedule of sample locations and analytical requirements, and Chapter 2 for a discussion of radiological and nonradiological monitoring program information. 
Environmental Management of Wastewater. Water containing radioactive material from site process operations is collected in the site's interceptors, then transferred to the LLW2 and treated. The LLW2 includes the LLW treatment building and associated holding lagoons.

Lagoon 3 water is contained, sampled, and analyzed before its release through a SPDES-permitted outfall. In 2012, about 8.3 million gal ( 31.6 million L) of water were discharged through outfall 001, the lagoon 3 weir. Table 1-4 summarizes the estimated radioactivity releases in the 2012 discharge waters, as compared to the previous 10-year average. (Also, see Table 2-1 in Chapter 2.) Note that the total releases of tritium, alpha and beta activity in 2012 through outfall 001 were all below the 10-year average. (See "Predicted Dose From Waterborne Releases" in Chapter 3.)

Effective operation of the site WWTF is indicated by compliance with the applicable discharge limits regulated by the SPDES permit. Approximately 60 chemical and water quality constituents are monitored regularly.

The analytical results are reported to the NYSDEC via monthly DMRs, required under the SPDES program. There were no SPDES effluent limit exceedances and two noncompliance events during 2012. (See "SPDES Permit Noncompliance Events" in the ECS.) Historical limit exceptions are discussed in previous ASERs. Although the goal of the LLW2 and operations is to maintain effluent water quality consistently within the permit requirements, if SPDES permit limit exceptions occur, the exceptions are evaluated to determine their cause and to identify corrective measures.

The NPGRS operated throughout 2012, recovering groundwater from an area within the western lobe of the strontium-90 plume on the north plateau. During 2012, approximately 2.9 million gal (10.9 million L) were recovered and treated by ion exchange to remove strontium-90. The water was transferred to the lagoon system and ultimately discharged through the lagoon 3 weir. For a more-detailed discussion of the plume and the NPGRS, see "Strontium-90 Plume Remediation Activities in 2012" in Chapter 4.

Environmental Management of Airborne Emissions. During operations, ventilated air from various WVDP facilities is sampled for radioactivity in gases and particulate matter. Ventilated air is monitored and an alarm is activated if particulate matter radioactivity increases above preset levels. Samples are analyzed in the laboratory for the specific radionuclides associated with the radioactive materials being handled in the facilities.

Ventilation air through facilities undergoing radioactive material cleanup passes through high-efficiency filters before being released to the atmosphere. The filters are generally more effective for particulate matter than for gaseous radioactivity. Therefore, facility air treatment tends to remove a lesser percentage of gaseous radioactivity (e.g., tritium and iodine-129) than radioactivity associated with particulate matter (e.g., strontium-90 and cesium-137). However, gaseous radionuclide emissions remain far below the most restrictive regulatory limits for public safety such that additional treatment technologies beyond those already provided are typically not necessary.

Table 1-4 shows the gaseous and particulate matter radioactivity emissions from the MPPB (location ANSTACK) in 2012 compared to averages from the previous 10-year period. All of the emissions from ANSTACK were well below the 10-year average.

TABLE 1-4

2012 Radioactivity Releases Versus 10-Year Averages ${ }^{a}$

\begin{tabular}{|l|c|c|c|}
\hline Radionuclide & $\begin{array}{c}\text { 10-Year } \\
\text { Average } \\
\text { Curies }\end{array}$ & 2012 Curies & $\begin{array}{c}\text { \% of } \\
\text { 10-Year } \\
\text { Average }\end{array}$ \\
\hline \multicolumn{4}{|c|}{ Aqueous Discharge LLW2 } \\
\hline Tritium & 0.077 & 0.019 & $25 \%$ \\
\hline $\begin{array}{l}\text { Gross Alpha } \\
\text { and Beta }\end{array}$ & 0.018 & 0.014 & $78 \%$ \\
\hline \multicolumn{4}{|c|}{ Airborne Discharge ANSTACK } \\
\hline \multicolumn{4}{|c|}{ Gaseous } \\
\hline Tritium & 0.010 & 0.0025 & $25 \%$ \\
\hline lodine-129 & 0.000070 & 0.000021 & $30 \%$ \\
\hline \multicolumn{4}{|c|}{ Particulate } \\
\hline $\begin{array}{l}\text { Gross Alpha } \\
\text { and Beta }\end{array}$ & 0.000089 & 0.0000093 & $10 \%$ \\
\hline
\end{tabular}

${ }^{a}$ All numbers were rounded to two significant digits after calculations were complete. 


\section{Environmental Performance Measures}

Performance measures can be used to evaluate effectiveness, quality, timeliness, safety, or other areas that reflect achievements related to organization or process goals, and can be used as tools to identify the need to institute changes.

Dose Assessment. As an overall assessment of Project activities and effectiveness of the ALARA policy, the low potential radiological dose to the MEOSI is an indicator of well-managed radiological operations.

The relative dose equivalents for radiological air emissions, liquid effluent discharges, and other liquid releases (including drainage from the WNSWAMP ditch) from 2003 through 2012 are graphed on Figure 1-1. Note that, when summed, the total dose is well below DOE's standard of $100 \mathrm{mrem} /$ year. The consistently low effluent concentrations indicate that radiological activities at the site are well-controlled. (See also Table 3-2 in Chapter 3, "Dose Assessment.")

Groundwater Monitoring. The WVDP's groundwater program is implemented according to DOE Order 458.1 and RCRA $\S 3008(\mathrm{~h})$ Consent Order requirements, as approved by NYSDEC and EPA. Monitoring continued during 2012. Refer to Chapter 4, "Groundwater Protection Program," for details.

Environmental Management of Radiation Exposure. Ambient environmental radiation is measured with thermoluminescent dosimeters (TLDs) at on- and off-site locations. (See Figures A-11 through A-13.) Consistent with historical data, 2012 results from three of the eight TLDs located near on-site waste storage facilities on the north plateau were generally higher than background. Results from perimeter TLDs, which are more representative of exposure to the public, were statistically indistinguishable from background concentrations. (See "Environmental Radiation" in Chapter 2.)

\section{Nonconformance and Corrective and Preventative Action}

Throughout CY 2012, comprehensive evaluations, reviews, audits, and assessments were performed evaluating the implementation of EMS elements at the WVDP. During CY 2012, there were no regulatory inspection findings. Results from various assessments indicate that an effective EMS has been implemented at the WVDP.
When a deficiency or issue is noted during an audit or assessment, corrective actions are initiated in a timely manner. In addition, there is a robust and well-managed operating experience program (lessons learned) at the WVDP. In CY 2012, one (1) external DOE lessons learned and 23 internal CHBWV lessons learned were written and formally issued. Additionally in CY 2012, over 175 other Lessons Learned from other facilities, DOE occurrence reports, local incidents and events received by other means were shared with workers via daily safety assessment center reports. Refer later in this chapter to "EMS Audits and Other Audits and Assessments" for further discussion.

\section{QA Program}

The WVDP's QA program provides for and documents consistency, precision, and accuracy in collecting and analyzing environmental samples and in interpreting and reporting environmental monitoring data. Subcontractor laboratories providing analytical services for the environmental monitoring program are contractually required to maintain a QA program consistent with WVDP requirements.

10 CFR Part 830, Subpart A, "Quality Assurance Requirements," Section 830.122, "Quality Assurance Criteria," and DOE Order 414.1D, "Quality Assurance" (DOE, April 2011), document the QA program policies and requirements applicable to WVDP activities. The WVDP QA program implements the requirement to provide "assurance that analytical work for environmental and effluent monitoring supports data quality objectives, using a documented approach for collecting, assessing, and reporting environmental data." The integrated QA program also incorporates the requirements from the consensus standard "Quality Assurance Program Requirements for Nuclear Facilities" (American Society of Mechanical Engineers [ASME] Nuclear Quality Assurance Level 1 [NQA-1], 1989). Controlled documents specific to the WVDP are used to implement the integrated QA program.

General areas addressed by the QA program are presented below.

Responsibility. Responsibilities for overseeing, managing, and conducting an activity must be clearly defined. Personnel who verify that an activity has been completed correctly must be independent of those who performed it. WVDP program, project, and task managers are responsible for ensuring that QA requirements applicable to activities under their cognizance are implemented. 
FIGURE 1-1

Annual Effective Dose Equivalent to the Maximally Exposed Off-Site Individual

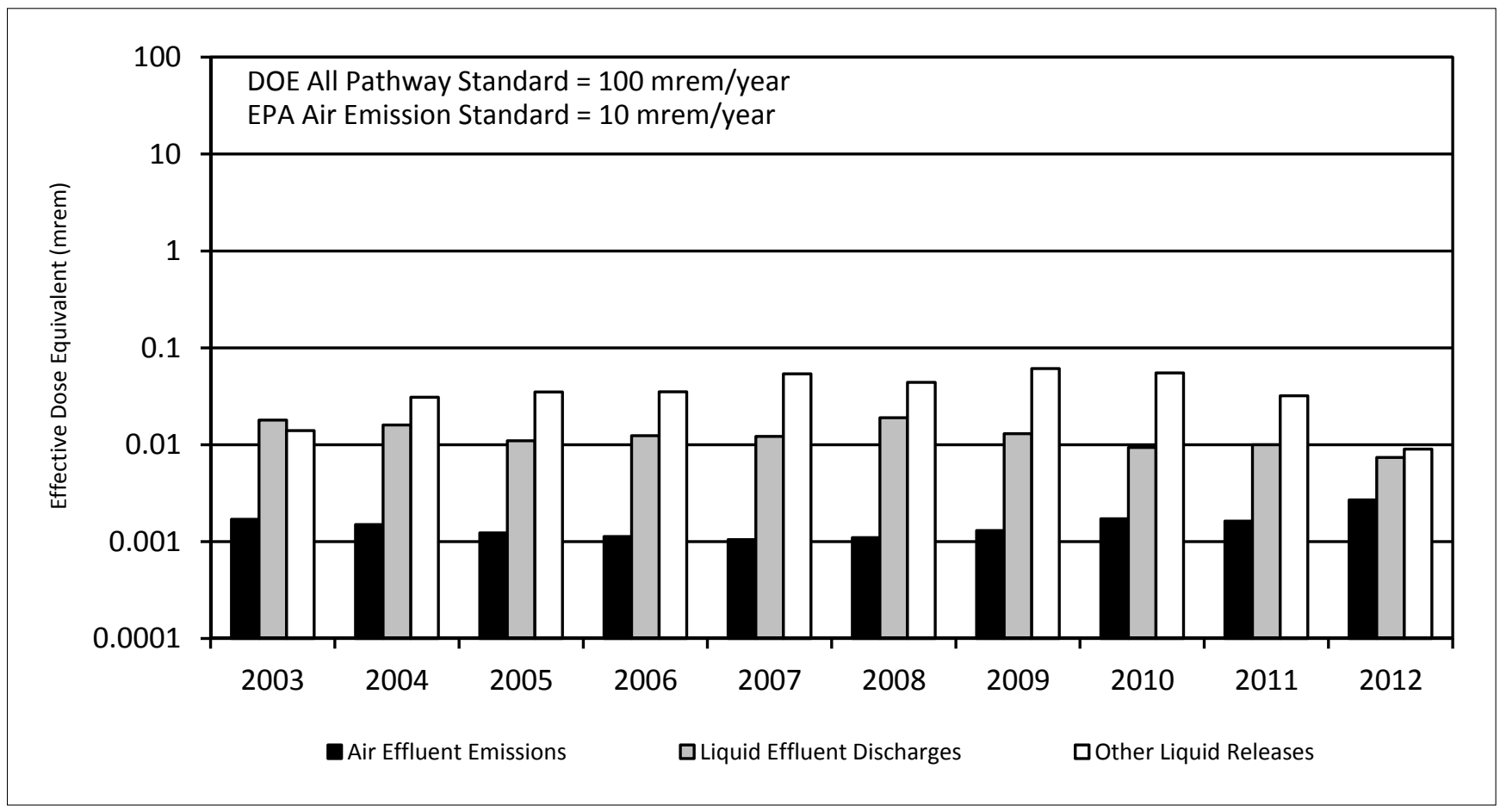

Planning. Work activities must be pre-planned, the plan followed, and activities documented. Purchases of quality-affecting equipment or items must be planned, precisely specified, and verified for correctness upon receipt.

Training. Anyone performing an activity supporting the WVDP environmental monitoring program must be trained in the appropriate procedures and qualified accordingly before carrying out the activity.

Control of Design, Procedures, Items, and Documents. Any activity, equipment, or construction must be clearly described or defined and tested. Design changes must be tested and documented. Procedures must clearly state how activities will be conducted. Procedures are reviewed periodically, updated when necessary, and controlled so that only approved and current procedures are used.

Equipment or particular items affecting environmental data quality must be identified, inspected, calibrated, and tested before use. Calibration status must be clearly indicated. Items that do not conform to requirements must be identified as nonconforming and segregated to prevent inadvertent use.

Corrective Action. Conditions adverse to quality must be promptly identified, a corrective action planned, responsibility assigned, and the problem remedied.

Documentation. All activity records must be kept to verify work done and by whom. Records must be clearly traceable to an item or activity. Records such as field data sheets, chain-of-custody (C-O-C) forms, requests for analysis, sample shipping documents, sample logs, data packages, training records, and weather measurements, in addition to other records in both paper and electronic form, are maintained as documentation for the environmental monitoring program.

\section{Quality Control (QC)}

The QC practices, an integral part of the WVDP QA program, are used to ensure that samples are collected and analyzed in a consistent and repeatable manner. 
QC methods are applied both in the field and in the laboratory.

Field QC. Procedures are defined for collecting each sample type, such as surface water, groundwater, soil, and air. Trained ELAB field personnel collect the samples. Field sampling locations are clearly marked to ensure that routine samples are continually collected in the same location. Collection equipment that remains in the field is routinely inspected, calibrated, and maintained, and automated sampling stations are kept locked to prevent tampering. Samples are collected into certified, precleaned containers of an appropriate material and capacity. Containers are labeled with sample information, such as date and time of collection, sample collection personnel, and special field conditions. Collection information is documented and kept as part of the sample record.

C-O-C documentation is maintained to trace sample possession from time of collection through analysis. Samples are stored in a locked, secure location before analysis or shipping. Samples sent off site for analysis are accompanied by an additional C-O-C form. Subcontract laboratories are required by contract to maintain internal $\mathrm{C}-\mathrm{O}-\mathrm{C}$ records and to store the samples under secure conditions. Special field QC samples are collected and analyzed to assess the sampling process. Duplicate field samples are used to assess sample homogeneity and sampling precision. Field and trip blanks (laboratory-deionized water in sample containers) are used to detect contamination potentially introduced during sampling or shipping. Environmental background samples (samples of air, water, vegetation, venison, fish, and milk taken from locations remote from the WVDP) are collected and analyzed to provide baseline information for comparison with on-site or near-site samples so that site influences can be evaluated.

Laboratory QC. In 2012, samples were collected by ELAB personnel. On-site analyses were performed at the ELAB or the WWTF laboratory. Off-site analyses were performed by General Engineering Laboratory, LLC (GEL) (Charleston, South Carolina), TestAmerica Laboratories, Inc. (Buffalo, New York), and Environmental Dosimetry Company (Sterling, Massachusetts). As samples were collected, shipped, and analyzed, C-O-C documentation was maintained to track sample possession from collection through analysis and data reporting. All laboratories are required to maintain relevant certifications, to participate in applicable crosscheck programs, and to maintain a level of QC as defined in their contracts.
To analyze regulatory reported environmental samples originating from NYS, analytical laboratories are required to maintain the relevant NYSDOH ELAP certification.

Laboratory QC practices specific to each analytical method are described in approved references or procedures. QC practices include proper training of analysts, maintaining and calibrating measuring equipment and instrumentation, and routinely processing laboratory QC samples such as standards and spikes (to assess method accuracy), duplicates and replicates (to assess precision), and blanks (to assess the possibility of contamination). Standard reference materials (materials with known quantities or constituent of interest concentrations traceable to the National Institute of Standards and Technology) are used to calibrate counting and test instruments and to monitor their performance.

The ELAB ended its participation in the NYSDOH ELAP certification program on June 30, 2012. Samples that had been analyzed by the ELAB are now being performed by ELAP certified off-site laboratories.

Crosschecks. Crosscheck samples (performance evaluation samples) contain a constituent of interest concentration known to the agency conducting the crosscheck, but unknown to the participating laboratory. Crosscheck programs provide an additional means of testing accuracy of environmental measurements. Subcontract laboratories are required to have at least $80 \%$ of reported results falling within control limits. Crosscheck results that fall outside of control limits are addressed by formal corrective actions to determine any conditions that could adversely affect sample data and to ensure that actual sample results are reliable.

The WVDP participates in formal crosscheck programs for both radiological and nonradiological analyses.

- Radiological Crosschecks

Organizations performing radiological analyses as part of effluent or environmental monitoring are encouraged by DOE to participate in formal crosscheck programs to test the quality of environmental measurements being reported to DOE by its contractors. Crosscheck samples for radiological constituents are analyzed on site by the ELAB and off site by GEL. In 2012, the WVDP participated in the DOE Radiological Environmental Sciences Laboratory Mixed Analyte Performance Evaluation Program (MAPEP), which provides performance evaluation samples for both radiological 
and nonradiological constituents. Results for Series 26 are listed in Appendix $\mathrm{H}$. Due to an administrative change at MAPEP the ELAB did not receive Series 27 samples.

\section{- Nonradiological Crosschecks}

As a SPDES permittee, the WVDP is required to participate in the EPA DMR QA performance evaluation studies (2012 DMR QA Study \#32) for the National Pollutant Discharge Elimination System. Samples from this program are analyzed both on site and by subcontract laboratories. In addition, subcontract laboratories performing nonradiological sample analyses that contain radiological contamination participate in the DOE MAPEP program.

In 2012, nonradiological crosschecks were analyzed by the WVDP WWTF Laboratory, ELAB, GEL, and TestAmerica. Results are summarized in Appendix $\mathrm{H}$.

Results for 2012 from all laboratories that analyzed samples from the WVDP monitoring program are summarized in Table 1-5. As presented, $99.0 \%$ of the crosschecks performed in 2012 were acceptable.

The whole effluent acute toxicity test on the freshwater Ceriodaphnia Dubia (water flea), performed by New England Bioassay for the DMR-QA Study 32 was not acceptable. The laboratory did a thorough evaluation of their process and found no obvious cause for the failure. The acute toxicity test was rerun in August 2012 using a new toxicant provided by an accredited external proficiency testing provider and acceptable results were obtained.

TABLE 1-5

Summary of Crosschecks Completed in 2012

\begin{tabular}{|l|c|c|c|}
\hline \multicolumn{1}{|c|}{ Type } & $\begin{array}{c}\text { Number } \\
\text { Reported }\end{array}$ & $\begin{array}{c}\text { Number } \\
\text { Within } \\
\text { Acceptance } \\
\text { Limits }\end{array}$ & $\begin{array}{c}\text { Percent Within } \\
\text { Quality } \\
\text { Control Limits }\end{array}$ \\
\hline Radiological & 86 & 84 & $97.7 \%$ \\
\hline Non-radiological & 219 & 218 & $99.5 \%$ \\
\hline All types & 305 & 302 & $99.0 \%$ \\
\hline
\end{tabular}

\section{Data Management}

The Environmental Laboratory Information Management System (ELIMS) is a database system used at the WVDP to establish environmental sample identification numbers, maintain the sample data log, track samples, manage field and analytical data, and record data validation status and results. The ELIMS is used as a controlled-source database for generating reports and statistical evaluations of data sets to support environmental monitoring and surveillance activities. Subcontract laboratories are requested to provide data in electronic format for direct entry into the ELIMS by WVDP personnel.

All software packages used to generate data are verified and validated before use. All analytical data produced in the ELAB at the bench level are reviewed and signed off by a qualified person other than the one who performed the analysis. A similar in-house review is contractually required from subcontractor laboratories.

\section{Data Verification and Validation}

Data validation is the process by which analytical data from both on-site and off-site laboratories are reviewed to verify proper documentation of sample processing and data reporting, and to determine the data quality and usability. A graded approach is applied that, based upon data quality objectives, dictates the review rigor of the documentation associated with sample collection and/ or sample analysis. In the WVDP environmental program, data are validated per approved standard procedures before it is assigned approval status and made ready for data assessment.

\section{Data Assessment and Reporting}

Approved analytical data, field information, and historical project data are integrated and evaluated to determine whether the constituents of interest are actually present and, if so, at what concentrations. Data problems identified at this level are investigated and appropriately resolved.

Environmental monitoring program data are then evaluated to assess the effect, if any, of the site operations and activities on the environment and the public. Data from each sampling location are compared with historical results from that location, with comparable background measurements, and (if applicable) with regulatory limits or guidance standards. Standard statistical methods are used to evaluate the data. 


\section{Audits, Assessments, and Surveillances}

Audits, assessments, and surveillances are an important part of improving the WVDP's safety program. An integrated assessment council, made up of representatives from different departments, has been established to develop an annual integrated assessment schedule-based on past performance and the risk and hazards of upcoming work. Internal assessments, audits, and self-assessments are performed throughout the year to continuously improve safety programs. Issues discovered through the integrated assessment program are tracked in a centralized database, statused weekly with senior management, and trended via a quarterly performance analysis program.

Audits and assessments are conducted to verify compliance with, and effectiveness of, all aspects of the QA program, and to verify programmatic and functional compliance with site procedures, applicable local, state, and federal environmental regulations, and applicable DOE Directives. The WVDP environmental monitoring program is audited by external agencies and evaluated using internal self-assessments and audits.

An audit or assessment provides for objective and independent review of site functions to determine if they are operating within regulatory, programmatic, and procedural parameters. The focus and/or topics of an audit or assessment are selected from specific criteria taken from the protocol, procedure, or regulation against which the function is to be evaluated. Audit personnel (whether external or internal) are empowered and encouraged to bring safety-related issues to the immediate attention of management and, if serious enough, to stop work.

\section{EMS Audits}

Results of EMS Audits are described with respect to "nonconformance" defined as a deficiency in characteristic, documentation, or procedure which renders the quality of an item or activity unacceptable or indeterminate. "Major nonconformity" is an absence or complete breakdown of a system or element, or many minor nonconformities in one element. "Minor nonconformity" is a single observed nonconformity.

An "issue" is a condition that, if left uncorrected, could potentially lead to environmental, safety, operational, or reportability improvement or non-conforming conditions. Such conditions also require corrective action. If an issue cannot be corrected before the assessment report is completed, an Issue Report (IR) is initiated to document the condition that needs to be addressed, the required corrective action, and the timeline for completing the corrective action. IRs are tracked to closure in the WVDP open items tracking system. An "improvement action" or "opportunity for improvement" may be identified to enhance, improve, or add value to a process. Good practices (noteworthy practices) are identified when actions are above and beyond those required by procedural compliance.

External ISO 14001:2004 EMS Stage 1 Audit. During April 24-26, 2012, an external audit was conducted to determine if the CHBWV EMS was functional and ready for a full registration audit. Overall, the EMS was found to be functional and to meet the requirements of the ISO 14001 standard. Three minor nonconformities were identified and a corrective action plan was developed and approved by the EMS auditor. These nonconformities included the need to document the communication method of the site's environmental aspects to the public, revise the internal EMS assessment process, and complete a management review of the EMS status. These actions were entered into the OITS for tracking. The approved corrective actions have been completed and the open items in OITS have been closed out.

External ISO 14001:2004 EMS Registration Audit. During June 4-8, 2012, an external audit was conducted to determine if the CHBWV EMS was fully functional and meets the requirements of ISO 14001 . Overall, the EMS was found to be functional and to meet the requirements of ISO 14001 and CHBWV received ISO 14001 registration on July 31,2012 . Three minor nonconformities were identified and a corrective action plan was developed and approved by the EMS auditor. These nonconformities included expanding the list of environmental aspects to include minor aspects and beneficial aspects, improvements needed in the spill notification process, and the need to complete an internal EMS assessment. These actions were entered into the OITS for tracking. The approved corrective actions have been completed and the open items in OITS have been closed out.

Internal EMS Assessment. During December 15-31, 2012, an internal EMS assessment was conducted by QA to determine if the CHBWV EMS was fully functional and meets the requirements of ISO 14001 . While no major nonconformities were identified, three opportunities for improvement were noted. This included improved communications to the site workers on EMS objectives and targets, effectiveness of maintaining the site's environmental aspects, and polling other DOE site's on their methods of conducting internal EMS assessments. A corrective action plan was developed, actions were identified and entered into the OITS for tracking. 


\section{Other Environmental Audits and Assessments}

FY 2012 ISMS and QA Effectiveness Review. CHBWV assumed operation of the WVDP under the Phase 1 Decommissioning and Facility Disposition contract on July 1, 2011, and performed a limited effectiveness review for the performance period of August 29, 2011 through September 30, 2011. The effectiveness review time frame was extended to allow for contractor transition.

Work documents, event and injury reports, self-assessments, due diligence concerns, employee concerns, and external surveillances were reviewed to provide supportive details for comparison with the ISMS and QA effectiveness criterion. CHBWV concluded that adequate ISMS and QA programs are in place, and have been appropriately staffed for the near-term work associated with the Phase 1 Decommissioning and Facilities Disposition contract. A Safety Conscious Work Environment Program and Nuclear Safety Culture Program were initiated to ensure achievement of FY 2012 performance measures, objectives, and commitments.

NYSDOH ELAP Audit of the ELAB. NYSDOH did not perform an audit of the ELAB in 2012 because the ELAB ended its participation in the NYSDOH ELAP certification program in 2012.

CHBWV Audit of GEL Laboratories. CHBWV conducted an external QA audit of GEL on October 23-24, 2012. The focus of this audit was specific to DOE-STD-1112-98, "The Department of Energy Laboratory Accreditation Program for Radiobioassay", ASME NQA-I-2008, "Quality Assurance Program Requirements for Nuclear Facilities" with 2009 addenda and DOE Order 414.1D, "Quality Assurance." The audit team verified GEL's QA Program and procedures to ensure compliance with requirement documents and standards. There was sufficient objective evidence to support a mature and effective QA program. Within the scope of the audit, there were no issues.

DOE and CHBWV Audits and Assessments. During 2012, self-assessments were conducted to verify programmatic effectiveness and functional compliance with site procedures and applicable regulations.

For DOE audits and assessments, a "finding" is defined as a determination of an individual item which is a direct deviation to, is an omission of, or is in noncompliance with an established requirement and which requires correction. A response is required. A "concern" identified during a DOE audit or assessment is defined as a determination of a program breakdown or widespread problem supported by one or more findings. An immediate response is required.

DOE-WVDP Oversight Assessment of RCRA Hazardous Waste Shipments. From December 21, 2011 through February 14, 2012, DOE-WVDP performed an assessment of the mixed waste shipments relative to the STP FY 2011 Update and the WVDP 2011 Hazardous Waste Report. There were no concerns or findings identified.

DOE-WVDP Oversight Assessment of Process for Reporting Spills/Releases of Petroleum Products. From November 23, 2011 through January 24, 2012, DOEWVDP performed an assessment of the process for reporting spills/releases of petroleum products. There were three findings identified and a corrective action plan was developed and implemented. The findings related to the consistency for reporting and documenting minor petroleum spills from vehicles.

DOE-WVDP Oversight Audit of CHBWV Environmental Protection Programs, Surface Water, Drinking Water Quality, and Groundwater Monitoring Programs. From October 23, 2012 through November 6, 2012, DOE-WVDP performed an audit of the CHBWV environmental protection programs, surface water, drinking water quality, and groundwater monitoring programs. Three findings were identified and subsequently addressed. One finding related to the lack of documentation to show issues and associated corrective actions resulting from annual storm water outfall inspections. A new form was created to address this finding. The second finding related to not collecting storm water samples during qualifying storm events due to safety concerns such as nearby lightning. During 2013, a lightning detector was installed to track the presence of lightning storms near the WVDP to aid in determination of appropriate sheltering requirements. In addition, CHBWV revised WVDP-233, "Monitoring Plan for Storm Water Discharges at the West Valley Demonstration Project," to more clearly define criteria for qualifying and non-qualifying storm water events. The third finding related to the issuance of sampling results from a relocated outfall to NYSDEC. The sampling results from this outfall were subsequently submitted to NYSDEC.

DOE-WVDP Oversight Assessment of the SPDES Program. From January 25, 2012 through February 16, 2012, DOEWVDP performed an assessment of the SPDES program for the WVDP, evaluating compliance with the SPDES permit requirements. There were no concerns, one finding, 
and two comments associated with the assessment. The finding related to the SPDES Best Management Practices plan not specifically mentioning street sweeping as required by the permit. The plan was subsequently revised to add street sweeping. One comment related to the recommendation to inspect spill kits at the vehicle refueling station, which was subsequently incorporated on a monthly basis. The other comment was that a current copy of the SPDES permit was not readily available for reference at the WWTF. This was addressed and corrected immediately.

CHBWV Regulatory Strategy Assessment of RCRA Hazardous/Mixed Waste Container Storage Management. During March 19 to 21, 2012, Regulatory Strategy conducted assessments of RCRA hazardous/mixed waste containers stored in the interim status facilities, satellite accumulation areas, 90-day storage areas, and observed activities related to universal waste management. There were no concerns or findings identified.

CHBWV Regulatory Strategy Assessment of New SPDES Permit Compliance. This assessment was performed to evaluate and determine whether the compliance and reporting requirements for the WVDP SPDES permit (effective date July 1, 2011) have been met. There were no concerns or findings identified during the assessment.

\section{EMS Management Review}

A senior management review was conducted at an Executive Safety Review Board meeting on April 25, 2012 to review the site's environmental performance to ensure the continuing suitability, adequacy and effectiveness of the EMS. The following topics were presented:

- results of internal audits and evaluations of compliance with legal requirements and with other requirements to which the organization subscribes;

- communication(s) from external interested parties, including complaints;

- environmental performance of the organization;

- extent to which objectives and targets have been met;

- status of corrective and preventive actions;

- follow-up actions from previous management reviews;

- changing circumstances, including developments in legal and other requirements related to its environmental aspects; and

- recommendations for improvement.

\section{EMS Validation}

In 2012, a third-party audit of the EMS was conducted to determine if ISO 14001:2004 requirements were met. The audit concluded that the EMS was fully implemented and ISO:14001:2004 registration was granted on July 31, 2012. In addition, DOE-WVDP prepared and transmitted a declaration to DOE-HQ. This audit is required to be performed once every three years.

\section{EMS Experiences}

EMS Challenges. Since the major work of the current contract consists of demolishing radiologically contaminated facilities, a major challenge for the WVDP is maximizing the diversion of construction and demolition waste generated. Waste from radiologically contaminated areas cannot be recycled. It is difficult to obtain radiological clearance to send out materials from clean areas for recycling, but options are being evaluated.

EMS Best Practices/Lessons Learned. Near the end of FY 2011, the site's prime contract was transitioned to a new contractor with a new scope of work called Phase 1 Decommissioning. The new contractor revised the EMS to align the environmental aspects with the Phase 1 Decommissioning scope and to strengthen the WVDP's commitment to sustainability. CHBWV successfully obtained ISO 14001:2004 registration in July 2012. To accomplish this, the site's EMS program was aligned with EO 13514, DOE Order 436.1, and the DOE's SSPP. In addition, objectives and targets were established to assist in achieving the goals in the SSPP and SSP. A training program was developed to communicate the changes in the site's EMS program to both management and the workforce.

During the third Party ISO 14001 audit, the following strengths were noted: good understanding of environmental aspects and evaluation shown by managers of functional areas; environmental aspects reviewed on realtime basis utilizing the work control process; targets were clearly worded; project teams are performing mockups to ensure work instruction packages are written effectively; good training and awareness on EMS provided at all-hands meeting; plan of the day meetings show good communication on status of projects and involvement of the technical response team on environmental issues; good operator knowledge of risks and aspects; utilizing the "West Valley Chronicles" site newsletter to publicize the site's EMS; and strong QC and commitment to data integrity as shown by staff in the site's ELAB. Additional strengths noted were: spill reporting database is an excellent tool for documenting and tracking spills; 
management workplace visit program is an excellent preventative action measure; very robust activity hazards analysis program; and EMS issues are well managed, documented and monitored.

EMS Benefits to Agency Mission. The benefits of implementing an EMS at the WVDP are to maintain compliance, reduce operating costs, integrate environmental programs into the mission and overall safety culture, increase employee involvement, and reduce environmental impacts. These specifically include:

- minimizing the environmental impacts of $D \& D$ activities;

- reusing excess materials by transfer to other DOE facilities, federal and state agencies, various DOEsponsored programs, donation programs, auctions, and sales; and

- safe removal of asbestos from highly radiologically contaminated areas.

\section{DOE-WVDP SSP Goals and Performance}

The DOE-WVDP is committed to supporting the goals of DOE Order 436.1, "Departmental Sustainability," to:

- ensure that DOE carries out it's missions in a sustainable manner to address national energy security and global environmental challenges, and advances sustainable, efficient, and reliable energy for the future;

- institute wholesale cultural changes to factor sustainability and GHG reductions into all management decisions; and

- ensure DOE achieves the sustainability goals established in the SSPP pursuant to applicable laws, regulations and EOs, related performance scorecards, and sustainability initiatives.

The WVDP has a well-established culture of environmental stewardship. The WVDP's EMS promotes pollution prevention, waste minimization, and energy and water conservation. These are incorporated into the site's culture through standard practices, procedures, training, and encouragement of new ideas. The SSP for the WVDP was prepared and applicable goals were established to support the sustainability goals of the Order. Even though many of the DOE's sustainability goals do not apply to the WVDP, energy, water consumption, and GHG emissions will decrease as decommissioning activities progress and parts of the site footprint are reduced. Table 1-5 presents a summary of the WVDP's FY 2012 performance status and planned actions for FY 2013 for those sustainability goals that are applicable at the WVDP.

\section{Summary}

Although areas for improvement were identified in the course of audits and assessments, nothing was identified that would compromise the data quality in this report or the environmental monitoring program in general. 
TABLE 1-6

DOE - SSP Goal Summary and Performance Status

\begin{tabular}{|c|c|c|c|}
\hline $\begin{array}{c}\text { SSP } \\
\text { Goal \# }\end{array}$ & DOE Goal & $\begin{array}{c}\text { FY } 2012 \text { WVDP Performance } \\
\text { Status }\end{array}$ & $\begin{array}{l}\text { WVDP Planned Actions and } \\
\text { Contributions }\end{array}$ \\
\hline \multicolumn{4}{|c|}{ GOAL 1: GHG Reduction and Comprehensive GHG Inventory } \\
\hline 1.1 & $\begin{array}{l}28 \% \text { Scope } 1 \& 2 \text { GHG reduction by FY } 2020 \\
\text { from a FY } 2008 \text { baseline. }\end{array}$ & $\begin{array}{l}\text { FY } 2008 \text { baseline established. } \\
\text { Scope } 1 \text { and } 2 \text { GHG reduced by } \\
45.7 \% .\end{array}$ & $\begin{array}{l}\text { Cessation of operations and } \\
\text { demolition of buildings and } \\
\text { structures is underway and will } \\
\text { continue during the next five years. } \\
\text { Reduce fleet as appropriate. }\end{array}$ \\
\hline 1.2 & $\begin{array}{l}\text { 13\% Scope } 3 \text { GHG reduction by FY } 2020 \text { from a } \\
\text { FY } 2008 \text { baseline. }\end{array}$ & $\begin{array}{l}\text { FY } 2008 \text { baseline established. } \\
\text { Scope } 3 \text { GHG reduced by } 38.7 \% \text {. }\end{array}$ & $\begin{array}{l}\text { Continue to reduce as systems are } \\
\text { shutdown and site population } \\
\text { decreases. }\end{array}$ \\
\hline \multicolumn{4}{|c|}{ GOAL 2: Buildings, Energy Savings Performance Contract Initiative Schedule, and Regional \& Local Planning } \\
\hline 2.1 & $\begin{array}{l}30 \% \text { energy intensity (British thermal unit per } \\
\text { gross). }\end{array}$ & $\begin{array}{l}\text { Not applicable (NA) as buildings } \\
\text { are not owned by DOE. }\end{array}$ & NA \\
\hline 2.2 & $\begin{array}{l}\text { Energy Independence and Security Act Section } \\
432 \text { energy and water. }\end{array}$ & $\begin{array}{l}\text { NA as buildings are not owned } \\
\text { by DOE. }\end{array}$ & NA \\
\hline 2.3 & $\begin{array}{l}\text { Individual buildings or processes metering: } \\
\text { for } 90 \% \text { of electricity (by October 1, 2012); } \\
\text { for } 90 \% \text { of steam, natural gas, } \\
\text { and chilled water (by October 1, 2015). }\end{array}$ & $\begin{array}{l}\text { NA as buildings are not owned } \\
\text { by DOE. }\end{array}$ & NA \\
\hline 2.4 & $\begin{array}{l}\text { Cool roofs, unless uneconomical, for roof } \\
\text { replacements unless project already has CD-2 } \\
\text { approval. New roofs must have thermal } \\
\text { resistance of at least R-30. }\end{array}$ & $\begin{array}{l}\text { NA as buildings are not owned } \\
\text { by DOE. }\end{array}$ & NA \\
\hline 2.5 & $\begin{array}{l}15 \% \text { of existing buildings greater than 5,000 } \\
\text { gross } \mathrm{ft}^{2} \text { are compliant with guiding principles } \\
\text { of High Performance and Sustainable Building } \\
\text { by FY } 2015 .\end{array}$ & $\begin{array}{l}\text { NA as buildings are not owned } \\
\text { by DOE. }\end{array}$ & NA \\
\hline 2.6 & $\begin{array}{l}\text { All new construction, major renovations, and } \\
\text { alterations of buildings greater than } 5,000 \\
\text { gross } \mathrm{ft}^{2} \text { must comply with the guiding } \\
\text { principles. }\end{array}$ & $\begin{array}{l}\text { NA as DOE does not own the } \\
\text { facilities and no new } \\
\text { construction or major } \\
\text { renovations of buildings are } \\
\text { planned. }\end{array}$ & NA \\
\hline 2.7 & $\begin{array}{l}\text { 7.5\% of a site's annual electricity consumption } \\
\text { from renewable sources by FY } 2013 .\end{array}$ & $\begin{array}{l}10 \% \text { renewable energy credits } \\
(5 \% \text { old, } 5 \% \text { new }) \text {. }\end{array}$ & $\begin{array}{l}\text { Additional renewable energy credits } \\
\text { will be purchased as available. }\end{array}$ \\
\hline
\end{tabular}


TABLE 1-6 (continued)

DOE - SSP Goal Summary and Performance Status

\begin{tabular}{|c|c|c|c|}
\hline $\begin{array}{c}\text { SSP } \\
\text { Goal \# }\end{array}$ & DOE Goal & $\begin{array}{c}\text { FY } 2012 \text { WVDP Performance } \\
\text { Status }\end{array}$ & $\begin{array}{l}\text { WVDP Planned Actions and } \\
\text { Contributions }\end{array}$ \\
\hline \multicolumn{4}{|c|}{ GOAL 3: Fleet Management } \\
\hline 3.1 & $\begin{array}{l}10 \% \text { annual increase in fleet alternative fuel } \\
\text { (AF) consumption by FY } 2015 \text { relative to a FY } \\
2005 \text { baseline. }\end{array}$ & $\begin{array}{l}\text { AF not available; } \\
\text { Waiver approved for FY } 2012 .\end{array}$ & $\begin{array}{l}\text { Waiver approved for FY } 2013 \\
\text { Waivers will be requested as long } \\
\text { as AF is unavailable. }\end{array}$ \\
\hline 3.2 & $\begin{array}{l}\text { 2\% annual reduction in fleet petroleum } \\
\text { consumption by FY } 2020 \text { relative to a FY } 2005 \\
\text { baseline. }\end{array}$ & $\begin{array}{l}\text { Reduced fleet size by six } \\
\text { vehicles, } \\
37.2 \% \text { reduction from FY } 2005 .\end{array}$ & $\begin{array}{l}\text { AF not available; use of electric } \\
\text { carts will be encouraged; fuel } \\
\text { consumed primarily for short } \\
\text { distance, site activities. }\end{array}$ \\
\hline 3.3 & $\begin{array}{l}\text { 100\% of light duty vehicle purchases must } \\
\text { consist of alternative fuel vehicles (AFV) } \\
\text { by FY } 2015 \text { and thereafter (75\% FY 2000- } \\
2015) \text {. }\end{array}$ & $\begin{array}{l}45 \% \text { of fleet are AFV } \\
\text { Three vehicles were replaced in } \\
\text { FY 2012. All vehicles were leased } \\
\text { through General Services } \\
\text { Administration (GSA), however } \\
\text { AFV were not available. }\end{array}$ & $\begin{array}{l}\text { AFVs will be leased through GSA } \\
\text { if available as old stock is replaced. }\end{array}$ \\
\hline 3.4 & $\begin{array}{l}\text { Reduce fleet inventory of non-mission critical } \\
\text { vehicles by } 35 \% \text { by FY } 2013 \text { relative to a FY } \\
2005 \text { baseline. }\end{array}$ & $\begin{array}{l}\text { Non-mission critical fleet size in } \\
\text { FY } 2005=18 \text { vehicles. } \\
\text { Non-mission critical fleet size in } \\
\text { FY } 2012 \text { = } 9 \text { vehicles. } \\
50 \% \text { decrease. }\end{array}$ & $\begin{array}{l}\text { Opportunities for fleet reduction } \\
\text { will be evaluated. }\end{array}$ \\
\hline \multicolumn{4}{|c|}{ GOAL 4: Water Use Efficiency and Management } \\
\hline 4.1 & $\begin{array}{l}26 \% \text { potable water intensity (gal per gross ft }{ }^{2} \text { ) } \\
\text { reduction by FY } 2020 \text { from a FY } 2007 \text { baseline. }\end{array}$ & $\begin{array}{l}\text { NA as the WVDP does not } \\
\text { purchase water. }\end{array}$ & NA \\
\hline 4.2 & $\begin{array}{l}20 \% \text { water consumption (gal) reduction of } \\
\text { industrial, landscaping, and agricultural } \\
\text { water by FY } 2020 \text { from a } \\
\text { FY } 2010 \text { baseline. }\end{array}$ & $\begin{array}{l}\text { NA as the WVDP does not } \\
\text { purchase water. }\end{array}$ & NA \\
\hline \multicolumn{4}{|c|}{ GOAL 5: Pollution Prevention and Waste Reduction } \\
\hline 5.1 & $\begin{array}{l}\text { Divert at least } 50 \% \text { of non-hazardous solid } \\
\text { waste, excluding construction and demolition } \\
\text { debris, by FY } 2015 .\end{array}$ & $23 \%$ diverted in FY 2012. & $\begin{array}{l}\text { Continue to explore avenues to } \\
\text { increase recycling and diversion. }\end{array}$ \\
\hline 5.2 & $\begin{array}{l}\text { Divert at least } 50 \% \text { of construction and } \\
\text { demolition materials and debris by FY } 2015 .\end{array}$ & $\begin{array}{l}\text { There were minimal } \\
\text { construction or demolitions } \\
\text { activities in FY } 2012.100 \% \text { of } \\
\text { the materials generated were } \\
\text { diverted through metals } \\
\text { recycling. }\end{array}$ & $\begin{array}{l}\text { An issue regarding the } \\
\text { nonradioactive metals recycling is } \\
\text { being addressed. Material release } \\
\text { (unrestricted) surveys for recycling } \\
\text { in NYS are required to be performed } \\
\text { to demonstrate that the material } \\
\text { being presented for recycling does } \\
\text { not contain radioactivity outside of } \\
+2 \text { sigma above background ( } 95 \% \\
\text { confidence level). }\end{array}$ \\
\hline
\end{tabular}


TABLE 1-6 (concluded)

DOE - SSP Goal Summary and Performance Status

\begin{tabular}{|c|c|c|c|}
\hline $\begin{array}{c}\text { SSP } \\
\text { Goal \# }\end{array}$ & DOE Goal & $\begin{array}{c}\text { FY } 2012 \text { WVDP Performance } \\
\text { Status } \\
\end{array}$ & $\begin{array}{l}\text { WVDP Planned Actions and } \\
\text { Contributions }\end{array}$ \\
\hline \multicolumn{4}{|c|}{ GOAL 6: Sustainable Acquisition } \\
\hline 6.1 & $\begin{array}{l}\text { Procurements meet sustainability } \\
\text { requirements by including necessary } \\
\text { provisions and clauses (Sustainable } \\
\text { Procurements/Biobased Procurements). }\end{array}$ & $100 \%$ met in FY 2012. & Continue to meet goal. \\
\hline \multicolumn{4}{|c|}{ GOAL 7: Electronic Stewardship and Data Centers } \\
\hline 7.1 & $\begin{array}{l}\text { All data centers are metered to measure a } \\
\text { monthly power utilization effectiveness } \\
\text { of } 100 \% \text { by FY } 2015 \text {. }\end{array}$ & $\begin{array}{l}\text { NA as the WVDP does not have } \\
\text { data centers. }\end{array}$ & NA \\
\hline 7.2 & $\begin{array}{l}\text { Maximum annual weighted average power } \\
\text { utilization effectiveness of } 1.4 \text { by FY } 2015 \text {. }\end{array}$ & $\begin{array}{l}\text { NA as the WVDP does not have } \\
\text { data centers. }\end{array}$ & NA \\
\hline 7.3 & $\begin{array}{l}\text { Electronic Stewardship - } 100 \% \text { of eligible } \\
\text { personal computers, laptops, and monitors } \\
\text { with power management actively } \\
\text { implemented and in use by FY } 2012 \text {. }\end{array}$ & $95 \%$ enabled. & $\begin{array}{l}\text { Continue to provide guidance to } \\
\text { site personnel on importance of } \\
\text { using power saving options. }\end{array}$ \\
\hline \multicolumn{4}{|c|}{ GOAL 8: Innovation and Government Wide Support } \\
\hline 8.1 & Innovation and government-wide support. & \multicolumn{2}{|c|}{$\begin{array}{l}\text { Established routine conference calls with regulators to address } \\
\text { changes to permit conditions and other regulatory issues. } \\
\text { With facility ventilation systems and their associated air monitoring } \\
\text { equipment being taken out of service, the WVDP is replacing its air } \\
\text { monitoring and modeling approach with an ambient air monitoring } \\
\text { program consisting of } 16 \text { air monitoring stations at each compass } \\
\text { point. This system is currently installed and operating. } \\
\text { Developing methods and procedures to protect storm drains and } \\
\text { manage potentially contaminated water during D\&D activities. }\end{array}$} \\
\hline
\end{tabular}


This page intentionally left blank 


\section{ENVIRONMENTAL MONITORING}

\section{Monitoring Program}

The WVDP environmental monitoring program goal is to ensure that the public's health and safety and the environment continue to be protected with respect to releases from site activities. To achieve this goal, possible exposure pathways are monitored.

The monitoring program primarily focuses on surface water, air, and groundwater pathways, as these are the principal means by which potential contaminants are transported off site. Water, air, groundwater, and other environmental media samples are collected and measured for radiological and chemical constituents. A description of and schedule for the sampling program at each location and discussion of the environmental monitoring program drivers and rationale, as well maps showing the 2012 sampling locations, are presented in Appendix A. Groundwater monitoring data are discussed in Chapter 4. Monitoring data for all other media are discussed in this chapter. In accordance with DOE Order 458.1 (Change 2), the monitoring program includes both effluent monitoring and environmental surveillance.

Effluent Monitoring. Liquid effluents and air emissions are monitored by collecting samples at locations on site where radioactivity or chemical constituents are (or might be) released. Release points include discharge outfalls, storm water outfalls, site drainage points, and plant ventilation stacks. At some points, direct measurements (e.g., radioactivity or flow rates) are also collected. The WVDP maintains required permits and/or certificates from regulatory agencies applicable to releases to air and water, as listed in Table ECS-3.

Environmental Surveillance. Surface water, drinking water, air, sediment, soil, venison, fish, milk, and food crops are collected at locations where the highest concentrations of transported contaminants might be expected. Samples are also collected at remote locations to provide background data for comparison with data from on-site and near-site samples. Direct radiation is monitored on site, at the site perimeter, and at a remote background location.
Data Evaluation. Data are assessed to determine whether the constituents of interest are present and, if so, their concentrations. Data from each sampling location are compared with applicable regulatory or guidance limits. Guidance levels for evaluating radiological constituents in air and water dictated by the DOE were updated in April 2011. The new DCSs published in DOE-STD-1196-2011 replace the DOE derived concentration guides (DCGs) found in superseded DOE Order 5400.5. These DCSs are presented in Table UI-4 in the "Useful Information" section of this report, and are used throughout this ASER as comparative standards. Refer to the Environmental Compliance Summary (ECS) in this report for further discussion. Regulatory limits for chemical constituents in discharges to surface water, under the SPDES program, additional water quality standards, and potable water standards are listed in Appendix B-1. Regulatory standards for radiological and chemical constituents in soil and sediment are provided in Appendix F. Groundwater standards are discussed in Chapter 4.

Data from near-site locations are compared with background concentrations using standard statistical methods to assess possible site impacts to the environment. Results from each location are also compared to historical data from that location to determine if any trends, such as increasing constituent concentrations, are occurring. If indicated, follow-up actions are evaluated and implemented as warranted.

\section{Waterborne Effluent Monitoring}

The Project is drained by several small streams. Franks Creek enters from the south and receives drainage from the south plateau. As it flows northward, Franks Creek is joined by Erdman Brook, which receives effluent from the LLW2 (through the lagoon system) and the WWTF. After leaving the Project at the site security fence, Franks Creek receives drainage from the northeast swamp areas on the north plateau and from Quarry Creek, which receives drainage from the north swamp location WNSW74A. Franks Creek then flows into Buttermilk Creek, which, after flowing northward through the WNYNSC, enters Cattaraugus Creek and flows westward away from the WNYNSC. Cattaraugus Creek ultimately drains into Lake Erie, to the northwest. (See Figures A-2 and A-5.) 
Waterborne Radiological Releases. The primary sources of radionuclide releases to surface waters occur at two locations, the lagoon 3 weir at outfall 001 (WNSP001 on Figure A-2) and a natural drainage from the northeast swamp (monitoring point WNSWAMP on Figure A-2). Liquid releases from two other locations, the sewage treatment outfall [point WNSP007] and the north swamp [point WNSW74A] on the north plateau, are also evaluated each year. However, radiological releases to downstream surface water from these points are minor and are not included in this discussion. (Contributions to dose from these minor sources are addressed in Chapter 3, Dose Assessment.)
Discharge through the lagoon 3 weir at SPDES outfall WNSP001 into Erdman Brook is the primary controlled point source of liquid release from the Project. Five batch releases totaling about 8.3 million gal (31.6 million L) were discharged from WNSP001 in 2012. Natural drainage from the WNSWAMP location in CY 2012 was estimated to be approximately 13.5 million gal (51.2 million L). Flow weighted estimates of curies released from these two sources in 2012 and average radionuclide concentrations are summarized in Tables 2-1 and 2-2.

Concentrations from the WNSP001 outfall and WNSWAMP effluents are reported together with DCSs for comparison

TABLE 2-1

Total Radioactivity Discharged at Lagoon 3 (WNSP001) in 2012 and Comparison of Discharge Concentrations with DOE DCSs

\begin{tabular}{|c|c|c|c|c|c|}
\hline \multirow[t]{2}{*}{ Isotope ${ }^{a}$} & \multicolumn{2}{|c|}{ Discharge Activity ${ }^{b}$} & \multirow{2}{*}{$\begin{array}{c}\text { Average } \\
\text { Concentration } \\
(\mu \mathrm{Ci} / \mathrm{mL})\end{array}$} & \multirow{2}{*}{$\begin{array}{c}D C S^{d} \\
(\mu C i / m L)\end{array}$} & \multirow{2}{*}{$\begin{array}{c}\text { Ratio of } \\
\text { Concentration } \\
\text { to DCS }\end{array}$} \\
\hline & (Ci) & (Becquerels) $^{c}$ & & & \\
\hline Gross Alpha & $1.10 \pm 0.09 \mathrm{E}-03$ & $4.06 \pm 0.35 \mathrm{E}+07$ & $3.48 \pm 0.30 \mathrm{E}-08$ & $N A^{e}$ & NA \\
\hline Gross Beta & $1.31 \pm 0.02 \mathrm{E}-02$ & $4.84 \pm 0.08 \mathrm{E}+08$ & $4.14 \pm 0.07 E-07$ & $N A^{e}$ & NA \\
\hline $\mathrm{H}-3$ & $1.88 \pm 0.14 \mathrm{E}-02$ & $6.94 \pm 0.51 \mathrm{E}+08$ & $5.94 \pm 0.43 \mathrm{E}-07$ & $1.9 \mathrm{E}-03$ & 0.0003 \\
\hline C-14 & $0.21 \pm 4.14 \mathrm{E}-04$ & $0.08 \pm 1.53 \mathrm{E}+07$ & $0.07 \pm 1.31 \mathrm{E}-08$ & $6.2 \mathrm{E}-05$ & $<0.0002$ \\
\hline $\mathrm{K}-40$ & $-2.97 \pm 4.61 \mathrm{E}-04$ & $-1.10 \pm 1.70 \mathrm{E}+07$ & $-0.94 \pm 1.46 \mathrm{E}-08$ & $N A^{f}$ & NA \\
\hline Co-60 & $0.22 \pm 2.35 \mathrm{E}-05$ & $0.81 \pm 8.70 \mathrm{E}+05$ & $0.69 \pm 7.45 \mathrm{E}-10$ & $7.2 \mathrm{E}-06$ & $<0.0001$ \\
\hline Sr-90 & $5.93 \pm 0.14 \mathrm{E}-03$ & $2.19 \pm 0.05 E+08$ & $1.88 \pm 0.04 \mathrm{E}-07$ & $1.1 \mathrm{E}-06$ & 0.1709 \\
\hline Tc-99 & $5.48 \pm 0.37 \mathrm{E}-04$ & $2.03 \pm 0.14 \mathrm{E}+07$ & $1.74 \pm 0.12 \mathrm{E}-08$ & $4.4 \mathrm{E}-05$ & 0.0004 \\
\hline I-129 & $6.02 \pm 1.82 \mathrm{E}-05$ & $2.23 \pm 0.67 \mathrm{E}+06$ & $1.91 \pm 0.58 \mathrm{E}-09$ & $3.3 \mathrm{E}-07$ & 0.0058 \\
\hline Cs-137 & $1.25 \pm 0.06 \mathrm{E}-03$ & $4.61 \pm 0.23 \mathrm{E}+07$ & $3.95 \pm 0.20 \mathrm{E}-08$ & $3.0 \mathrm{E}-06$ & 0.0132 \\
\hline $\mathrm{U}-232^{g}$ & $2.33 \pm 0.09 \mathrm{E}-04$ & $8.62 \pm 0.34 \mathrm{E}+06$ & $7.38 \pm 0.29 \mathrm{E}-09$ & $9.8 \mathrm{E}-08$ & 0.0753 \\
\hline $\mathrm{U}-233 / 234^{g}$ & $1.68 \pm 0.08 \mathrm{E}-04$ & $6.22 \pm 0.30 \mathrm{E}+06$ & $5.32 \pm 0.26 \mathrm{E}-09$ & $6.6 \mathrm{E}-07^{h}$ & 0.0081 \\
\hline $\mathrm{U}-235 / 236^{g}$ & $5.77 \pm 1.47 \mathrm{E}-06$ & $2.14 \pm 0.55 \mathrm{E}+05$ & $1.83 \pm 0.47 \mathrm{E}-10$ & $7.2 \mathrm{E}-07$ & 0.0003 \\
\hline U-238 ${ }^{g}$ & $1.25 \pm 0.07 \mathrm{E}-04$ & $4.64 \pm 0.26 \mathrm{E}+06$ & $3.97 \pm 0.22 \mathrm{E}-09$ & $7.5 \mathrm{E}-07$ & 0.0053 \\
\hline Pu-238 & $2.40 \pm 0.31 \mathrm{E}-05$ & $8.88 \pm 1.14 \mathrm{E}+05$ & $7.60 \pm 0.98 \mathrm{E}-10$ & $1.5 \mathrm{E}-07$ & 0.0051 \\
\hline Pu-239/240 & $1.34 \pm 0.22 \mathrm{E}-05$ & $4.95 \pm 0.80 \mathrm{E}+05$ & $4.24 \pm 0.69 \mathrm{E}-10$ & $1.4 \mathrm{E}-07$ & 0.0030 \\
\hline Am-241 & $1.81 \pm 0.23 \mathrm{E}-05$ & $6.68 \pm 0.84 \mathrm{E}+05$ & $5.72 \pm 0.72 \mathrm{E}-10$ & $1.7 \mathrm{E}-07$ & 0.0034 \\
\hline \multicolumn{5}{|l|}{ Sum of Ratios } & 0.29 \\
\hline
\end{tabular}

NA - Not applicable.

${ }^{a}$ Half-lives are listed in Table UI-4.

${ }^{\mathrm{b}}$ Total volume released: $3.16 \mathrm{E}+10$ milliliters $(\mathrm{mL})(8.34 \mathrm{E}+06$ gal).

${ }^{c} 1$ curie $(\mathrm{Ci})=3.7 \mathrm{E}+10$ becquerels $(\mathrm{Bq}): 1 \mathrm{~Bq}=2.7 \mathrm{E}-11 \mathrm{Ci} ; 1$ microcurie $(\mu \mathrm{Ci})=1 \mathrm{E}-06 \mathrm{Ci}$.

${ }^{d}$ DCSs are used as reference values for the application of best available technology per DOE Order 458.1.

${ }^{\mathrm{e}} \mathrm{DCS} s$ do not exist for indicator parameters gross alpha and gross beta.

${ }^{f}$ The DCS is not applied to potassium-40 (K-40) activity because of its natural origin.

${ }^{\mathrm{g}}$ Total uranium $(\mathrm{g})=3.69 \pm 0.07 \mathrm{E}+02 ;$ Average uranium $[\mu \mathrm{g} / \mathrm{mL})=1.17 \pm 0.02 \mathrm{E}-02$.

${ }^{\mathrm{h}}$ The DCS for U-233 is used for this comparison. 
TABLE 2-2

Total Radioactivity Released at Northeast Swamp (WNSWAMP) in 2012 and Comparison of Discharge Concentrations with DOE DCSs

\begin{tabular}{|c|c|c|c|c|c|c|}
\hline \multirow{2}{*}{ Isotope ${ }^{a}$} & \multirow{2}{*}{$\boldsymbol{N}$} & \multicolumn{2}{|c|}{ Discharge Activity $^{b}$} & \multirow{2}{*}{$\begin{array}{c}\text { Average } \\
\text { Concentration } \\
(\mu \mathrm{Ci} / \mathrm{mL})\end{array}$} & \multirow{2}{*}{$\begin{array}{c}D_{C S}^{d} \\
(\mu \mathrm{Ci} / \mathrm{mL})\end{array}$} & \multirow{2}{*}{$\begin{array}{c}\text { Ratio of } \\
\text { Concentration } \\
\text { to DCS }\end{array}$} \\
\hline & & (Ci) & (Becquerels) $^{c}$ & & & \\
\hline Gross Alpha & 26 & $-2.26 \pm 4.59 \mathrm{E}-05$ & $-0.84 \pm 1.70 \mathrm{E}+06$ & $-4.40 \pm 8.95 \mathrm{E}-10$ & $N A^{e}$ & NA \\
\hline Gross Beta & 26 & $1.16 \pm 0.01 \mathrm{E}-01$ & $4.30 \pm 0.03 E+09$ & $2.27 \pm 0.02 \mathrm{E}-06$ & $N A^{e}$ & NA \\
\hline Tritium & 26 & $3.28 \pm 0.13 \mathrm{E}-03$ & $1.21 \pm 0.49 \mathrm{E}+08$ & $6.41 \pm 2.59 \mathrm{E}-08$ & $1.9 \mathrm{E}-03$ & 0.0001 \\
\hline C-14 & 2 & $3.06 \pm 9.83 \mathrm{E}-04$ & $1.13 \pm 3.64 \mathrm{E}+07$ & $0.60 \pm 1.92 \mathrm{E}-08$ & $6.2 \mathrm{E}-05$ & $<0.0003$ \\
\hline Sr-90 & 12 & $5.51 \pm 0.05 \mathrm{E}-02$ & $2.04 \pm 0.02 \mathrm{E}+09$ & $1.08 \pm 0.01 \mathrm{E}-06$ & $1.1 \mathrm{E}-06$ & 0.98 \\
\hline 1-129 & 2 & $-0.12 \pm 3.62 \mathrm{E}-05$ & $-0.04 \pm 1.34 \mathrm{E}+06$ & $-0.23 \pm 7.07 \mathrm{E}-10$ & $3.3 \mathrm{E}-07$ & $<0.0021$ \\
\hline Cs-137 & 12 & $-2.13 \pm 4.93 \mathrm{E}-05$ & $-0.79 \pm 1.82 \mathrm{E}+06$ & $-4.16 \pm 9.62 \mathrm{E}-10$ & $3.0 \mathrm{E}-06$ & $<0.0003$ \\
\hline $\mathrm{U}-232^{f}$ & 2 & $-0.20 \pm 1.71 \mathrm{E}-06$ & $-0.72 \pm 6.32 \mathrm{E}+04$ & $-0.38 \pm 3.34 \mathrm{E}-11$ & $9.8 \mathrm{E}-08$ & $<0.0003$ \\
\hline $\mathrm{U}-233 / 234^{f}$ & 2 & $7.97 \pm 3.35 \mathrm{E}-06$ & $2.95 \pm 1.24 \mathrm{E}+05$ & $1.56 \pm 0.65 \mathrm{E}-10$ & $6.6 \mathrm{E}-07^{\mathrm{g}}$ & 0.0002 \\
\hline $\mathrm{U}-235 / 236^{f}$ & 2 & $0.13 \pm 1.37 \mathrm{E}-06$ & $0.47 \pm 5.08 \mathrm{E}+04$ & $0.25 \pm 2.68 \mathrm{E}-11$ & $7.2 \mathrm{E}-07$ & $<0.0001$ \\
\hline U-238 & 2 & $4.10 \pm 2.55 \mathrm{E}-06$ & $1.52 \pm 0.94 \mathrm{E}+05$ & $8.00 \pm 4.98 \mathrm{E}-11$ & $7.5 \mathrm{E}-07$ & 0.0001 \\
\hline Pu-238 & 2 & $-1.79 \pm 9.85 \mathrm{E}-07$ & $-0.66 \pm 3.64 \mathrm{E}+04$ & $-0.35 \pm 1.92 \mathrm{E}-11$ & $1.5 \mathrm{E}-07$ & $<0.0001$ \\
\hline Pu-239/240 & 2 & $0.49 \pm 1.34 \mathrm{E}-06$ & $1.81 \pm 4.96 \mathrm{E}+04$ & $0.96 \pm 2.62 \mathrm{E}-11$ & $1.4 \mathrm{E}-07$ & $<0.0002$ \\
\hline Am-241 & 2 & $0.86 \pm 1.37 \mathrm{E}-06$ & $3.16 \pm 5.06 \mathrm{E}+04$ & $1.67 \pm 2.67 \mathrm{E}-11$ & $1.7 \mathrm{E}-07$ & $<0.0002$ \\
\hline \multicolumn{6}{|c|}{ Sum of Ratios } & 0.98 \\
\hline
\end{tabular}

Note: the average $\mathrm{pH}$ at this location was 7.10 Standard Units (SU).

$\mathrm{N}$ - Number of samples.

NA - Not applicable.

${ }^{\text {a }}$ Half-lives are listed in Table UI-4.

${ }^{\mathrm{b}}$ Total estimated volume released: $5.12 \mathrm{E}+10 \mathrm{~mL}$ (1.35E+07 gal).

${ }^{\mathrm{c}} 1 \mathrm{Ci}=3.7 \mathrm{E}+10 \mathrm{~Bq}: 1 \mathrm{~Bq}=2.7 \mathrm{E}-11 \mathrm{Ci}$.

${ }^{d}$ DCSs are used as reference values for the application of best available technology per DOE Order 458.1.

${ }^{\mathrm{e}}$ DCSs do not exist for indicator parameters gross alpha and gross beta.

${ }^{\mathrm{f}}$ Total Uranium $(\mathrm{g})=1.88 \pm 0.07 \mathrm{E}+01 ;$ Average Total Uranium $(\mu \mathrm{g} / \mathrm{mL})=3.67 \pm 0.13 \mathrm{E}-04$.

${ }^{\mathrm{g}}$ The DCS for Uranium-233 is used for this comparison.

purposes rather than regulatory compliance. DOESTD-1196-2011 defines DCSs as radionuclide concentrations that, under conditions of continuous exposure for one year by one exposure mode, would result in an effective dose equivalent of 100 mrem (1 millisievert [mSv]). Members of the public do not have access to the WVDP and therefore do not have any potential of direct exposure at outfall WNSPO01 and WNSWAMP. (Note that DCSs are not used for dose assessment. Methods for estimating dose from the liquid pathway are discussed in Chapter 3.)

To evaluate each radionuclide released with respect to the DCSs, each annual average radionuclide concentration was divided by its respective DCS and the ratios from all nuclides were summed. As a DOE policy, the sum of the ratios (also called the "sum of fractions") should not exceed 1.0, or otherwise expressed as the sum of percentages, should not exceed $100 \%$. Tables $2-1$ and $2-2$ list the sum of ratios for each release point.

The sum of ratios for the release from WNSP001 in 2012 was approximately 0.29 , well below the 1.0 criterion. The sum of ratios from WNSWAMP was 0.98 , slightly below the DOE-STD-1196-2011 criterion. This is the first year since 2004 that the sum of the ratios was below 1.0. The maximum sum of ratios at WNSWAMP to date was 2.67 in 2009.

As in past years, the relatively high sum of ratios at WNSWAMP was almost entirely attributable to strontium-90. Drainage at the WNSWAMP location largely 
consists of emergent groundwater. Elevated gross beta concentrations were first noted at this location in 1993. Subsequent investigations delineated a plume of strontium-90-contaminated groundwater on the north plateau that discharges to the surface water flowing through the WNSWAMP location. In November of 2010, a PTW designed to remove strontium-90 from the groundwater was installed upgradient of the WNSWAMP drainage ditch.

Flow weighted annual average strontium-90 concentrations at WNSWAMP, which first exceeded the strontium-90 DCS (1.1E-06 microcurie per milliliter $[\mu \mathrm{Ci} / \mathrm{mL}]$ ) in 1995, were slightly below the DCS in 2012. Monthly measured concentrations of strontium-90 were above the DCS from late June 2012 to mid-October, but decreased below the DCS in November and December 2012. (See Figure 4-8 in Chapter 4, "Groundwater Protection Program.") Activities to limit migration of the strontium-90 groundwater plume, including a description of the PTW, are discussed in Chapter 4.

Even though waters with elevated strontium-90 concentrations drain from WNSWAMP into Franks Creek, then into Buttermilk Creek, and ultimately into Cattaraugus Creek, strontium-90 and gross beta concentrations in water collected in 2012 from Cattaraugus Creek downstream of the WVDP at the first point of public access (at WFFELBR) continue to show little or no difference from background. (See Table B-5A in Appendix B-5.)

SPDES Permit-Required Monitoring. Liquid discharges from the WVDP are regulated for chemical constituents under a SPDES permit, as identified in Table ECS-3. The permit identifies compliance points from which liquid effluents are released to Erdman Brook (Figure A-2), and specifies the sampling and analytical requirements for each.

Effective July 1, 2011, NYSDEC issued a modified permit for the WVDP which removed two storm water outfalls (S02 and S40). An additional storm water location (S43) was added that was tentatively identified in 2006 and characterized in 2007 in a wetland near the Live-Fire Range on the WNYNSC. There were no modifications to the SPDES permit in 2012.

The conditions and requirements of the current SPDES permit are summarized in Appendix B-1. The permit identifies 23 outfalls and compliance points with monitoring requirements and discharge limits. The monitored outfalls include:
- outfall 001 (monitoring point WNSP001), discharge from the LLW2 through the lagoon system;

- outfall 007 (monitoring point WNSP007), discharge from the WWTF;

- outfall 116 (pseudo-monitoring point WNSP116, as noted on the permit), a location in Franks Creek that represents the confluence of outfalls WNSP001, WNSP007, and WNSP008 (which was capped in 2001, and was removed from the SPDES permit in 2011), as well as storm water runoff, groundwater seepage, and augmentation water. Samples from upstream sources are used to calculate total dissolved solids (TDS) at this location and to demonstrate compliance with the SPDES permit limit for this parameter;

- outfall 01B (monitoring point WNSP01B), an internal monitoring point for the liquid waste treatment system evaporator effluent, was historically monitored for flow and total mercury. No effluent was processed or released from this outfall in 2012; and

- nineteen storm water discharge outfalls that receive flows from other minor sources, such as fire hydrant testing and groundwater seepage, monitored on a rotational basis. Objectives of the SPDES permit requirements for monitoring storm water runoff are to determine the: (1) levels of water quality and specific chemicals in storm water discharges from specified WVDP locations, (2) amount of rainfall, (3) storm event duration, and (4) resulting flow at the outfalls. The 19 WVDP storm water outfalls are grouped into eight representative drainage basins that could potentially be influenced by industrial or construction activity runoff. One representative outfall from each of the eight outfall groups listed in Appendix A must be sampled on a semiannual basis.

The SPDES permit specifies the following conditions for a qualifying storm water event eligible for monitoring: (1) a period of 72 hours between the monitored event and the previous measurable event of 0.1 inches of precipitation; (2) a total rainfall of more than 0.1 inch; and (3) resultant storm discharge at the outfall.

During CY 2012, storm water samples were collected from all eight outfalls during both semiannual periods. Storm water outfalls that were collected on October 23, 2012, were performed sooner than the 72 hour protocol between the previous storm event due to oncoming winter 
weather. This decision was consistent with storm water sampling guidance and was documented.

Appendix B-2 presents process effluent data with SPDES permit limits provided for comparison. Appendix B-3 presents storm water runoff monitoring data for outfalls designated in the WVDP SPDES permit.

There were no SPDES effluent limit exceedances and two noncompliance events during 2012. The WWTF, temporarily shutdown in late 2011 due to a mercury SPDES permit exceedance, was restarted in February 2012 after corrective measures and confirmatory sampling. For additional information refer to "SPDES Permit Noncompliance Events" in the ECS.

\section{Airborne Effluent Monitoring}

Radiological Air Emissions. Federal law allows air containing small amounts of radioactivity to be released from plant ventilation stacks during normal operations. The releases must meet dose criteria specified in the NESHAP regulations to ensure that public health and safety and the environment are protected. At the WVDP in 2012, radiological releases have been measured and/or estimated from seven permitted emission points (see Table ECS-3), three non-permitted points, and two diffuse sources. The wastewater storage lagoons were the primary source of the diffuse radiological releases to air at the WVDP in 2012, with some additional contribution from stored waste in the high integrity containers. Estimated emissions from both of these diffuse sources are calculated for the purpose of annual NESHAP reports. Sampling locations for point source air emissions are shown on Figure A-6 in Appendix A.

Air releases are evaluated and reported to EPA in the annual NESHAP report. Measured radionuclide concentrations in air are also compared with DCSs (see Appendix C). Unlike NESHAP dose criteria, the DCSs are expressed in $\mu \mathrm{Ci} / \mathrm{mL}$ and can be directly compared with measurements from the monitoring program. The DCSs are used at the WVDP to evaluate airborne emissions at the release point. DCSs for radionuclides of interest at the WVDP are found in Table UI-4 in the "Useful Information" section of this report. When only gross alpha and beta measurements are available in WVDP air sample results, activity is usually assumed to come from plutonium-239/240 and strontium-90, respectively, because the DCSs for these radionuclides are the most limiting for major WVDP particulate emissions. No DCSs were exceeded by airborne emissions on an annualized basis during CY 2012. Locations with results statistically greater than background values are summarized in Table 2-4.

Ventilation and Emission Systems. Exhaust from each EPA-permitted ventilation system on the WVDP is continuously filtered and the permanent systems are monitored as air is released to the atmosphere. Because radionuclide concentrations in air emissions from the site are quite low, a large volume of facility air must be sampled to measure the radionuclide quantity released. Emissions are sampled for radioactivity in both particulate (e.g., strontium-90 and plutonium-239/240) and gaseous forms (e.g., tritium and iodine-129). The total release of each radionuclide varies from year to year in response to changing site activities. For instance, releases of iodine-129 dropped sharply after vitrification was completed in 2002. Over the years, the annual calculated dose from WVDP air emissions has remained a small fraction of the NESHAP standard. (See "Predicted Dose From Airborne Emissions" in Chapter 3.)

The MPPB Ventilation Stack. The primary controlled air emission point at the WVDP is the MPPB ventilation stack, ANSTACK, which vents to the atmosphere at a height of $208 \mathrm{ft}(63.4 \mathrm{~m})$. This stack has historically released ventilation exhaust from several MPPB facilities, including the liquid waste treatment system, the analytical laboratories, and off-gas from the former VIT system. In 2012, the MPPB stack continued to release ventilation exhaust from spaces within the MPPB. Emissions from the MPPB stack are an order of magnitude lower than they were during VIT operations in 2002.

Total curies released from the MPPB stack in 2012 are listed in Table 2-3, together with annual averages, maxima, and a comparison of average isotopic concentrations with the applicable DCSs. The sum of ratios for radiological concentrations from ANSTACK was 0.006 well, below the DOE guideline of 1.0. Airborne concentrations from the stack to the WVDP site boundary are further reduced by dispersion. Historical results from air samples taken near the site boundary have confirmed that WVDP operations have had no discernible effect on off-site air quality. (See "Ambient Air" monitoring results, later in this chapter.)

Unplanned Radiological Airborne Release. No unplanned radiological airborne releases occurred in 2012.

Although there were minor smoldering events in the VIT cell during 2012, it was found that no radiological air emissions resulted. 
Other On-Site Air Sampling Systems. Sampling systems similar to those of the MPPB are used to monitor airborne effluents from the former VIT heating ventilation and air conditioning system (ANVITSK), the supernatant treatment system/permanent ventilation system stack (ANSTSTK), the container sorting and packaging facility ventilation stack (ANCSPFK), and the RHWF stack (ANRHWFK) (Figure A-6). Ventilation from the contact size-reduction facility ventilation stack (ANCSRFK) was discontinued in 2011, and replaced by ventilation of this facility by a portable unit. Ventilation of the 01-14 building (ANCSSTK) was discontinued in October 2012 in preparation for building demolition.

Permitted outdoor ventilation enclosures (OVEs) with portable ventilation units are used to provide the ventilation necessary for personnel safety while working with radioactive materials in areas outside permanently ventilated facilities or in areas where permanent ventilation must be augmented. Air samples from OVEs are collected continuously while emission points are discharging, and the data collected are included in annual evaluations of airborne emissions.

Appendix C presents total radioactivity released for specific radionuclides at each on-site air sampling location. Isotopic results did not exceed the DCSs at any of the air emission sampling locations during 2012.

Nonradiological Air Emissions. Nonradiological air emissions at the WVDP are regulated under an air facility registration certificate that caps (limits) nitrogen and sulfur oxide emissions $\left(\mathrm{NO}_{\mathrm{X}}\right.$ and $\mathrm{SO}_{\mathrm{X}}$, respectively) from the facility at 49.5 tons per year each. (See Table ECS-3.) The certificate applies to two site utility steam boilers, which are the primary sources of $\mathrm{NO}_{\mathrm{X}}$ and $\mathrm{SO}_{\mathrm{X}}$ at the site. Based on natural gas usage, the boilers are estimated to have released about 0.09 tons of $\mathrm{NO}_{x}$ and no $\mathrm{SO}_{X}$ in 2012, only $0.19 \%$ of the capping limit.

Other units with the potential to emit non-radiological pollutants, such as generators listed in the certificate, are exempted with the understanding that each unit operates less than 500 hours per year.

\section{Ambient Air Monitoring Program}

New Ambient Air Network. Sixteen ambient air monitoring stations encircling the WVDP were installed on NYSERDA and private properties in 2012, located between the NYSERDA fence and the closest receptor in each sector (see Figure A-7). Monitoring from these stations was initiated in October 2012 for operational baselining and equipment testing. The new ambient air sampling program will provide environmental air sampling during demolition activities, as well as required data for regulatory compliance.

The off-site ambient air sampling system is intended to monitor air over a period of time, rather than providing instantaneous radiological results. The ambient air low volume samplers run continuously. Filter samples are collected biweekly for gross alpha and gross beta screening and charcoal cartridges are collected monthly for iodine-129 analysis. Samples collected on a biweekly basis are composited quarterly and analyzed for radioisotopes known to have been managed on the site. Samples of ambient air will include naturally occurring radioisotopes such as radon decay products which will be detected in the gross radioactivity analyses.

A high-volume sampler is included in the ambient air network located downwind in the prevailing wind direction, which is the direction of the hypothetical critical receptor (the historical MEOSI). This sampler operates at a flow rate more than five times the low-volume samplers and was installed to confirm the results of the lower volume sampling. Both high-volume and low-volume sampling systems are able to detect site-managed radioisotopes to less than $5 \%$ of each radioisotope's environmental regulatory compliance level. Continuous on-site air sampling is also performed close to the work area during demolition of all radiologically contaminated facilities for health and safety purposes by radiological engineering technicians. Samples collected from these local samplers are analyzed for gross radioactivity on a daily basis during demolition activities.

After a full year of monitoring with the new ambient air network, the current method of estimating dose using the "measure and model" approach will be compared to the "environmental measurement" approach using the new ambient air data. NESHAP regulations allow for either method to be used to demonstrate regulatory compliance. (For additional details on these alternate methods, refer to "EPA Interim Approval to Use Environmental Measurements for NESHAP Compliance" in the ECS.) As noted earlier in this chapter, the first quarter of baseline ambient air data collected from October to December 2012 indicated the sampling results were indistinguishable from background. 
TABLE 2-3

Total Radioactivity Released at Main Plant Stack (ANSTACK) in 2012 and Comparison of Discharge Concentrations with DOE DCSs

\begin{tabular}{|c|c|c|c|c|c|c|}
\hline Isotope $^{a}$ & $N$ & $\begin{array}{c}\text { Total } \\
\text { Activity Released }^{b} \\
\text { (Ci) }\end{array}$ & $\begin{array}{c}\text { Average } \\
\text { Concentration } \\
(\mu \mathrm{Ci} / \mathrm{mL})\end{array}$ & $\begin{array}{c}\text { Maximum } \\
\text { Concentration } \\
(\mu \mathrm{Ci} / \mathrm{mL})\end{array}$ & $\begin{array}{c}D C S^{c} \\
(\mu C i / m L)\end{array}$ & $\begin{array}{c}\text { Ratio of } \\
\text { Concentration } \\
\text { to DCS } \\
\end{array}$ \\
\hline Gross Alpha & 26 & $4.50 \pm 0.60 \mathrm{E}-07$ & $6.06 \pm 0.81 \mathrm{E}-16$ & $2.70 \mathrm{E}-15$ & $N A^{d}$ & NA \\
\hline Gross Beta & 26 & $8.87 \pm 0.21 \mathrm{E}-06$ & $1.24 \pm 0.03 \mathrm{E}-14$ & $6.43 E-14$ & $N A^{d}$ & NA \\
\hline $\mathrm{H}-3$ & 26 & $2.46 \pm 0.06 \mathrm{E}-03$ & $3.32 \pm 0.08 \mathrm{E}-12$ & $7.16 \mathrm{E}-12$ & $2.1 \mathrm{E}-07$ & $<0.0001$ \\
\hline Co-60 & 2 & $0.79 \pm 6.08 \mathrm{E}-08$ & $1.07 \pm 8.19 \mathrm{E}-17$ & $<1.46 \mathrm{E}-16$ & $3.6 \mathrm{E}-10$ & $<0.0001$ \\
\hline Sr-90 & 2 & $1.83 \pm 0.14 \mathrm{E}-06$ & $2.46 \pm 0.18 \mathrm{E}-15$ & $3.07 \mathrm{E}-15$ & $1.0 \mathrm{E}-10$ & $<0.0001$ \\
\hline I-129 & 2 & $2.09 \pm 0.17 \mathrm{E}-05$ & $2.82 \pm 0.22 \mathrm{E}-14$ & $3.49 \mathrm{E}-14$ & $1.0 \mathrm{E}-10$ & 0.0003 \\
\hline Cs-137 & 2 & $2.75 \pm 0.17 \mathrm{E}-06$ & $3.70 \pm 0.23 \mathrm{E}-15$ & $3.85 \mathrm{E}-15$ & $8.8 \mathrm{E}-10$ & $<0.0001$ \\
\hline Eu-154 & 2 & $0.00 \pm 1.84 \mathrm{E}-07$ & $0.00 \pm 2.48 \mathrm{E}-16$ & $<4.69 \mathrm{E}-16$ & $7.5 \mathrm{E}-11$ & $<0.0001$ \\
\hline $\mathrm{U}-232^{\mathrm{e}}$ & 2 & $-2.29 \pm 3.94 \mathrm{E}-09$ & $-3.08 \pm 5.32 E-18$ & $<8.07 \mathrm{E}-18$ & 4.7E-13 & $<0.0001$ \\
\hline $\mathrm{U}-233 / 234^{\mathrm{e}}$ & 2 & $1.57 \pm 0.75 \mathrm{E}-08$ & $2.12 \pm 1.01 \mathrm{E}-17$ & $2.27 \mathrm{E}-17$ & $1.0 \mathrm{E}-12^{\mathrm{f}}$ & $<0.0001$ \\
\hline $\mathrm{U}-235 / 236^{\mathrm{e}}$ & 2 & $-3.18 \pm 3.81 \mathrm{E}-09$ & $-4.28 \pm 5.13 E-18$ & $<7.46 \mathrm{E}-18$ & $1.2 \mathrm{E}-12$ & $<0.0001$ \\
\hline$U-238^{e}$ & 2 & $2.38 \pm 0.63 \mathrm{E}-08$ & $3.21 \pm 0.85 \mathrm{E}-17$ & $3.91 \mathrm{E}-17$ & $1.3 \mathrm{E}-12$ & $<0.0001$ \\
\hline $\mathrm{Pu}-238$ & 2 & $4.96 \pm 1.03 \mathrm{E}-08$ & $6.68 \pm 1.38 \mathrm{E}-17$ & $9.22 \mathrm{E}-17$ & $8.8 \mathrm{E}-14$ & 0.0008 \\
\hline Pu-239/240 & 2 & $9.82 \pm 1.40 \mathrm{E}-08$ & $1.32 \pm 0.19 \mathrm{E}-16$ & $1.67 \mathrm{E}-16$ & $8.1 \mathrm{E}-14$ & 0.0016 \\
\hline Am-241 & 2 & $2.04 \pm 0.25 \mathrm{E}-07$ & $2.75 \pm 0.34 \mathrm{E}-16$ & $3.14 \mathrm{E}-16$ & 9.7E-14 & 0.0028 \\
\hline Sum of Ratios & & & & & & 0.0060 \\
\hline
\end{tabular}

$\mathrm{N}$ - Number of samples.

NA - Not applicable.

${ }^{\text {a }}$ Half-lives are listed in table UI-4.

${ }^{\mathrm{b}}$ Total volume released at 50,000 cubic feet per minute $=7.44 \mathrm{E}+14 \mathrm{~mL} /$ year.

${ }^{c}$ DCSs are used as reference values for the application of best available technology per DOE Order 458.1.

${ }^{d}$ DCSs do not exist for indicator parameters gross alpha and gross beta.

${ }^{\mathrm{e}}$ Total uranium $=6.20 \pm 0.18 \mathrm{E}-02 \mathrm{~g}$; average $=8.36 \pm 0.24 \mathrm{E}-11 \mu \mathrm{g} / \mathrm{mL}$.

${ }^{f}$ DCS for uranium-233 used for this comparison.

\section{Environmental Surveillance}

Surface Water. On-site surface water drainage is routinely sampled at several points on the north and south plateaus, as shown in Appendix A, Figure A-2. Monitoring points are sited at locations where releases from possible source areas on the north and south plateaus could be detected. Appendices B-4 through B-6 present data for site surface drainage, subsurface drainage, contained water, ambient surface water, and potable (drinking) water monitoring locations. Off-site sampling locations are shown on Figure A-5. Results are presented in Appendix B-5. Also provided for side-by-side comparison with these data are reference values, where available, including background ambient water monitoring data and/or pertinent ambient water quality standards and guidelines.
Radiological and nonradiological results from surface water samples were compared with applicable water quality standards and guidelines. Radiological results from on-site and downstream locations on Franks and Buttermilk Creeks were also compared with results from the background location on Buttermilk Creek (WFBCBKG), upstream of the WVDP. (Chemical results were compared with historical background values from WFBCBKG, because sampling for chemical constituents was discontinued at this location in 2008.) Results from Cattaraugus Creek near Felton Bridge (sampling point WFFELBR), were compared with historical results from the upstream Cattaraugus Creek background at Bigelow Bridge (former sampling point WFBIGBR). Locations with results exceeding applicable limits and those with results statistically greater than background values are summarized in Table 2-4. 
TABLE 2-4

2012 Comparison of Environmental Monitoring Results with Applicable Limits and Backgrounds

\begin{tabular}{|c|c|c|c|c|}
\hline Sample Type & $\begin{array}{c}\text { Number of } \\
\text { Sampling } \\
\text { Locations }\end{array}$ & \begin{tabular}{|c|} 
Locations with \\
Results Greater than \\
Applicable Limits or \\
Screening Levels \\
(Constituent) \\
\end{tabular} & $\begin{array}{l}\text { Number of } \\
\text { Locations } \\
\text { with Results } \\
\text { Greater Than } \\
\text { Background } \\
\end{array}$ & $\begin{array}{l}\text { Locations with Results Statistically Greater than } \\
\text { Background (Constituent) }\end{array}$ \\
\hline \multicolumn{5}{|c|}{ Air (1 background location) } \\
\hline $\begin{array}{l}\text { On-site air } \\
\text { emission points }\end{array}$ & 7 & 0 & 5 & $\begin{array}{l}\text { ANSTACK (H-3, Sr-90, I-129, Cs-137, Pu-238, Pu- } \\
\text { 239/240, Am-241); } \\
\text { ANSTSTK (I-129); } \\
\text { ANCSPFK (I-129); } \\
\text { ANVITSK (I-129); } \\
\text { ANRHWFK (I-129) }\end{array}$ \\
\hline \multicolumn{5}{|c|}{ Surface water ( 2 background locations, one on Buttermilk Creek and one [historical] on Cattaraugus Creek) } \\
\hline $\begin{array}{l}\text { On-site controlled } \\
\text { effluents }\end{array}$ & 2 & 0 & 2 & $\begin{array}{l}\text { WNSP001 (Gross alpha, Gross beta, } \mathrm{H}-3 \text {, } \\
\text { Sr-90, Tc-99, I-129, Cs-137, U-232, U-233/234, } \\
\text { U-235/236, U-238, } \mathrm{Pu}-238, \mathrm{Pu}-239 / 240, \\
\text { Am-241, bromide, } \mathrm{SO}_{4}, \mathrm{NO}_{3}-\mathrm{N} \text {, total } \mathrm{B}, \\
\text { total } \mathrm{Hg} \text {, total antimony, total } \\
\text { dissolved solids [TDS]); } \\
\text { WNSP007 (Gross beta, TDS, oil and grease, total Hg) }\end{array}$ \\
\hline $\begin{array}{l}\text { On-site surface } \\
\text { water }\end{array}$ & 7 & $\begin{array}{l}\text { WNSWAMP } \\
\text { (Sr-90, Gross beta) } \\
\text { WNSP006 } \\
\text { (TDS) }\end{array}$ & 6 & $\begin{array}{l}\text { WNSP006 (Gross beta, Sr-90, U-232, U-233/234, U- } \\
\text { 238, TDS); } \\
\text { WNSP005 (Gross beta, Sr-90); } \\
\text { WNSWAMP (Gross beta, H-3, Sr-90); } \\
\text { WNSW74A (Gross beta, Sr-90); } \\
\text { WNNDADR (Gross beta, H-3, Sr-90); } \\
\text { WNERB53 (Gross beta); } \\
\text { WNFRC67 (Gross beta) }\end{array}$ \\
\hline $\begin{array}{l}\text { Off-site surface } \\
\text { water }\end{array}$ & 2 & $\begin{array}{l}\text { WFBCTCB }^{D} \\
\text { (total } \mathrm{Fe}^{c} \text { ) }\end{array}$ & 2 & $\begin{array}{l}\text { WFBCTCB (Gross beta); } \\
\text { WFFELBR (Gross beta) }\end{array}$ \\
\hline \multicolumn{5}{|l|}{ WNSP006 (TDS) } \\
\hline On-site drinking & 1 & 0 & 0 & None \\
\hline \multicolumn{5}{|c|}{ Soil (1 background location) } \\
\hline Off-site soil & 3 & 0 & 0 & None \\
\hline \multicolumn{5}{|c|}{ Sediment ( 2 background locations, one on Buttermilk Creek and one [historical] on Cattaraugus Creek) } \\
\hline $\begin{array}{l}\text { On-site } \\
\text { sediment/soil }\end{array}$ & 3 & $\begin{array}{l}\text { SNSWAMP } \\
\text { (Sr-90) } \\
\text { SNSP006 } \\
\text { (Cs-137) } \\
\end{array}$ & 3 & $\begin{array}{l}\text { SNSW74A (Cs-137); } \\
\text { SNSWAMP (Gross beta, Sr-90, Cs-137, Pu-238, Pu- } \\
\text { 239/240, Am-241); } \\
\text { SNSP006 (Gross beta, Sr-90, Cs-137) }\end{array}$ \\
\hline Off-site sediment & 3 & 0 & 3 & $\begin{array}{l}\text { SFTCSED (Cs-137); } \\
\text { SFSDSED (Cs-137); } \\
\text { SFCCSED (Cs-137) }\end{array}$ \\
\hline
\end{tabular}

NA = Not applicable; no regulatory, guidance, or screening limits are available.

${ }^{a}$ Applicable regulatory, guidance, or screening limits are listed in Table UI-4 (radionuclides in air and water), and Appendix B-1 (water).

${ }^{\mathrm{b}} \mathrm{NYS}$ Class $\mathrm{C}$ water quality standards were applied at WFBCTCB.

${ }^{c}$ Measurements at background location WFBCBKG have routinely exceeded the water quality standards. 
TABLE 2-4 (concluded)

2012 Comparison of Environmental Monitoring Results with Applicable Limits and Backgrounds

\begin{tabular}{|l|c|c|c|l|l|}
\hline \multicolumn{1}{|c|}{ Sample Type } & $\begin{array}{c}\text { Number of } \\
\text { Sampling } \\
\text { Locations }\end{array}$ & $\begin{array}{c}\text { Locations with } \\
\text { Results Greater than } \\
\text { Applicable Limits or } \\
\text { Screening Levels } \\
\text { (Constituent) }\end{array}$ & $\begin{array}{c}\text { Number of } \\
\text { Locations } \\
\text { with Results } \\
\text { Greater Than } \\
\text { Background }\end{array}$ & $\begin{array}{c}\text { Locations with Results Statistically Greater than } \\
\text { Background (Constituent) }\end{array}$ \\
\hline Biologicals (3 background deer; 1 background per matrix for remainder) \\
\hline Fish & $2^{\text {d }}$ & \multicolumn{2}{|c|}{0} & 0 & None \\
\hline Milk & 3 & 0 & 0 & None \\
\hline Deer & 3 & 0 & 1 & BFDNEAR (Cs-137) \\
\hline Vegetables/fruits & 3 & 0 & 0 & None \\
\hline Environmental dosimetry (1 background) & 0 & 3 & DNTLDs \#24, 38, 40 \\
\hline $\begin{array}{l}\text { On-site, near } \\
\text { facilities }\end{array}$ & 8 & 0 & 0 & None \\
\hline Perimeter & 17 & 0 & 0
\end{tabular}

NA = Not applicable; no regulatory, guidance, or screening limits are available.

${ }^{a}$ Applicable regulatory, guidance, or screening limits are listed in Table UI-4 (radionuclides in air and water), and Appendix B-1 (water)

${ }^{\mathrm{b}} \mathrm{NYS}$ Class $\mathrm{C}$ water quality standards were applied at WFBCTCB.

${ }^{c}$ Measurements at background location WFBCBKG have routinely exceeded the water quality standards.

${ }^{\mathrm{d}}$ Ten fish samples were obtained from each sampling location.

- South Plateau

Two inactive underground radioactive waste disposal areas (the NDA, under DOE's control, and the SDA, under NYSERDA's control), lie on the south plateau. These disposal sites are possible contaminant sources to surface water. The area southwest of the NDA, immediately west of the railroad tracks has been chosen as the storage location for the HLW canisters currently stored in the MPPB. These canisters will be encased in heavily shielded casks and stored on an engineered concrete slab. Nearby areas of the south plateau are being used to store the three radioactive vessels removed from the VIT facility and to temporarily store and stage containers of radioactive waste before they are shipped. Also located on the south plateau is the drum cell, a building formerly used to store drums of processed LLW. The drum cell has been empty since 2007, when the waste drums were shipped off site.

Surface water drainage downstream of the NDA is monitored at location WNNDADR, immediately north of the NDA, and further downstream at location WNERB53 on Erdman Brook. Some drainage from the western and northwestern portions of the SDA is also captured at WNNDADR and WNERB53. Although no radionuclide concentrations from these two locations are greater than (or even approach) DCSs, gross beta concentrations have routinely exceeded background concentrations at both WNNDADR and WNERB53, as have tritium and strontium-90 concentrations at WNNDADR. These exceedances were again observed in 2012. Residual soil contamination from past waste burial activities is thought to be the source.

As part of an IM to limit groundwater, surface water, and precipitation infiltration into the NDA, a geomembrane cap and slurry wall were constructed at the NDA. The IM was completed in December 2008. (See Chapter 4, "IM" under the discussion of "Groundwater Sampling Observations on the South Plateau: Weathered Lavery Till (WLT) and the NDA" for more detail.)

Figure 2-1 is a plot of average gross beta and strontium-90 concentrations in surface water at sample points WNNDADR and WNERB53 before and after completion of the IM. In CY 2012, average concentrations since the IM were $48 \%$ to $82 \%$ lower than historical concentrations, indicating the IM's effectiveness in 
reducing groundwater containment migration through the NDA, which affects surface water drainage at these points.

Tritium concentrations at WNNDADR in CY 2012, shown on Figure 2-2, remained above background concentrations with the annual average increasing slightly as compared to 2011. However, tritium concentrations at this location have been decreasing overall. Although the concentration in 2012 is slightly higher than 2011, the concentration in 2012 is lower than it was in 2010. Since tritium's half-life is slightly longer than 12 years, decreasing tritium concentrations may be partly attributable to radioactive decay. Residual soil contamination from past waste burial activities is also thought to be the source of this residual tritium.

Northeast of the SDA, Franks Creek is sampled to monitor drainage downstream of the drum cell and the eastern and southern borders of the SDA (point WNFRC67, on Figure A-2). In 2012, the gross beta concentrations at this point were statistically above background, but well below the DCSs.

\section{- North Plateau}

On the north plateau, possible contaminant sources that could affect surface water include the HLW tanks, MPPB, the lagoon system associated with the LLW2, waste handling and storage facilities, and seepage from the strontium-90 groundwater plume.

Besides the effluent and drainage locations discussed earlier in the liquid effluents section, a location on the east side of the MPPB (point WNSP005) monitors surface drainage on the north plateau. Annual average gross beta and strontium- 90 concentrations statistically exceeded background concentrations at this sampling location during CY 2012 but were well below DCSs. One other sample point, WNSP006, is sampled at Franks Creek at the security fence. WNSP006 is downgradient of the lagoon 3 outfall (point WNSP001). In 2012, as in previous years concentrations at WNSP006 exceeded background for gross beta, strontium-90, uranium-232, uranium-233/234, uranium-238, and TDS. The observed concentrations were all well below DCSs.

- Off-Site Surface Water

Surface water samples were collected at three off-site locations in 2012: one upstream background location on Buttermilk Creek, one downstream location on
Buttermilk Creek, and one downstream location on Cattaraugus Creek (see Figure A-5).

- Buttermilk Creek receives surface drainage from the WNYNSC. The background monitoring point is located upstream of the WVDP at Fox Valley Road (WFBCBKG) and the downstream location on Buttermilk Creek is located at Thomas Corners Bridge (WFBCTCB), just before Buttermilk Creek flows into Cattaraugus Creek.

- Further downstream of Thomas Corners Bridge, samples are collected from Cattaraugus Creek at Felton Bridge (WFFELBR), the first point of public access to surface water downstream of the WVDP.

- Until discontinuing sampling in 2008, background samples were also collected from Cattaraugus Creek at Bigelow Bridge, at Route 240, upstream of the confluence of Buttermilk Creek and Cattaraugus Creek (WFBIGBR). Historical data from this location from 1991 through 2007 have been used to establish an upstream background for Cattaraugus Creek for comparison to samples collected at WFFELBR (see Table B5-A). Sampling at WFBIGBR was discontinued in 2008.

Applicable guidance levels were exceeded at one of the three off-site surface water monitoring locations affected by the WVDP in 2012. The New York State Class C and D water quality limit for total iron, $0.3 \mathrm{mg} / \mathrm{L}$, was exceeded at location WFBCTCB, with a concentration of $0.6 \mathrm{mg} / \mathrm{L}$. However, the limit was also exceeded at background location WFBCBKG in eight of the 10 years of measurement before sampling for metals was discontinued in 2008. Historical background results at WFBCBKG ranged from $0.16 \mathrm{mg} / \mathrm{L}$ to $7.4 \mathrm{mg} / \mathrm{L}$. These fluctuating, elevated levels of iron are thought to reflect natural variability of stream conditions, and are not related to WVDP activities.

Consistent with historical data, concentrations of radiological constituents above background values, usually gross beta and strontium-90, were noted at several onsite surface water monitoring locations as summarized in Table 2-4. However, results from samples taken downstream at the first point of public access (WFFELBR) were statistically indistinguishable from background or, as with gross beta concentrations, only slightly higher than background, indicating limited Project influence downstream.

The highest average gross beta result at WFFELBR over the last 10 years $(5.99 \mathrm{E}-09 \mu \mathrm{Ci} / \mathrm{mL}$ in 2006) was about 
FIGURE 2-1

Average Gross Beta and Strontium-90 Concentrations in Surface Water

on the South Plateau at WNNDADR ${ }^{a}$ and WNERB53 ${ }^{b}$

Before and After the NDA Interim Measure (IM) was Installed

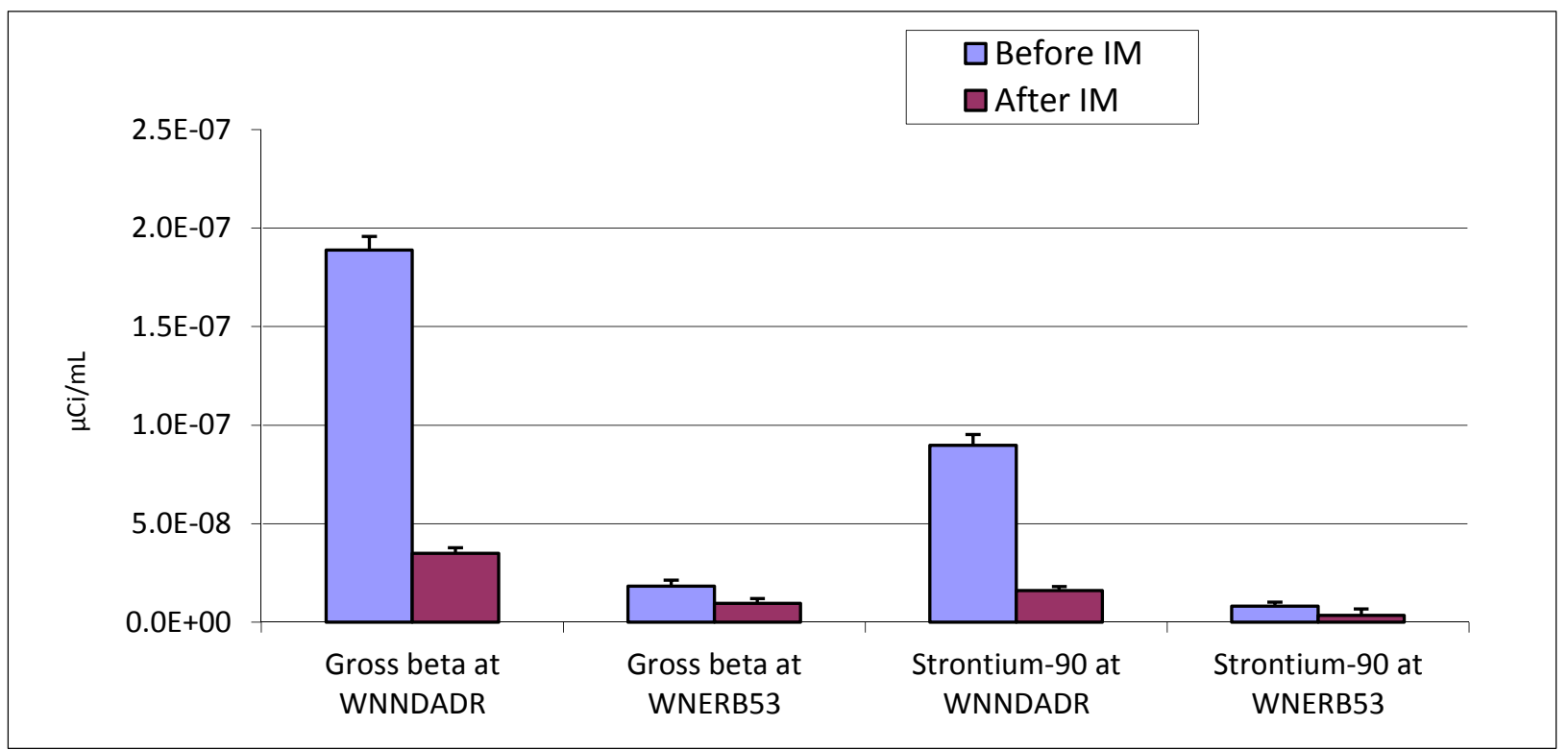

Note: The upper limit of the uncertainty term is indicated with each point. Average gross beta and strontium-90 background concentrations in Buttermilk Creek (WFBCBKG) in CY 2012 were 2.31 $\pm 1.53 \mathrm{E}-09$ and 0.97 $\pm 1.15 \mathrm{E}-09 \mu \mathrm{Ci} / \mathrm{mL}$, respectively.

${ }^{a}$ Sample point WNNDADR is located downstream, immediately north of the NDA.

${ }^{b}$ Sample point WNERB53 is located farther downstream, on Erdmann brook.

FIGURE 2-2

Average Concentration of Tritium in Surface Water at WNNDADR: 2003-2012

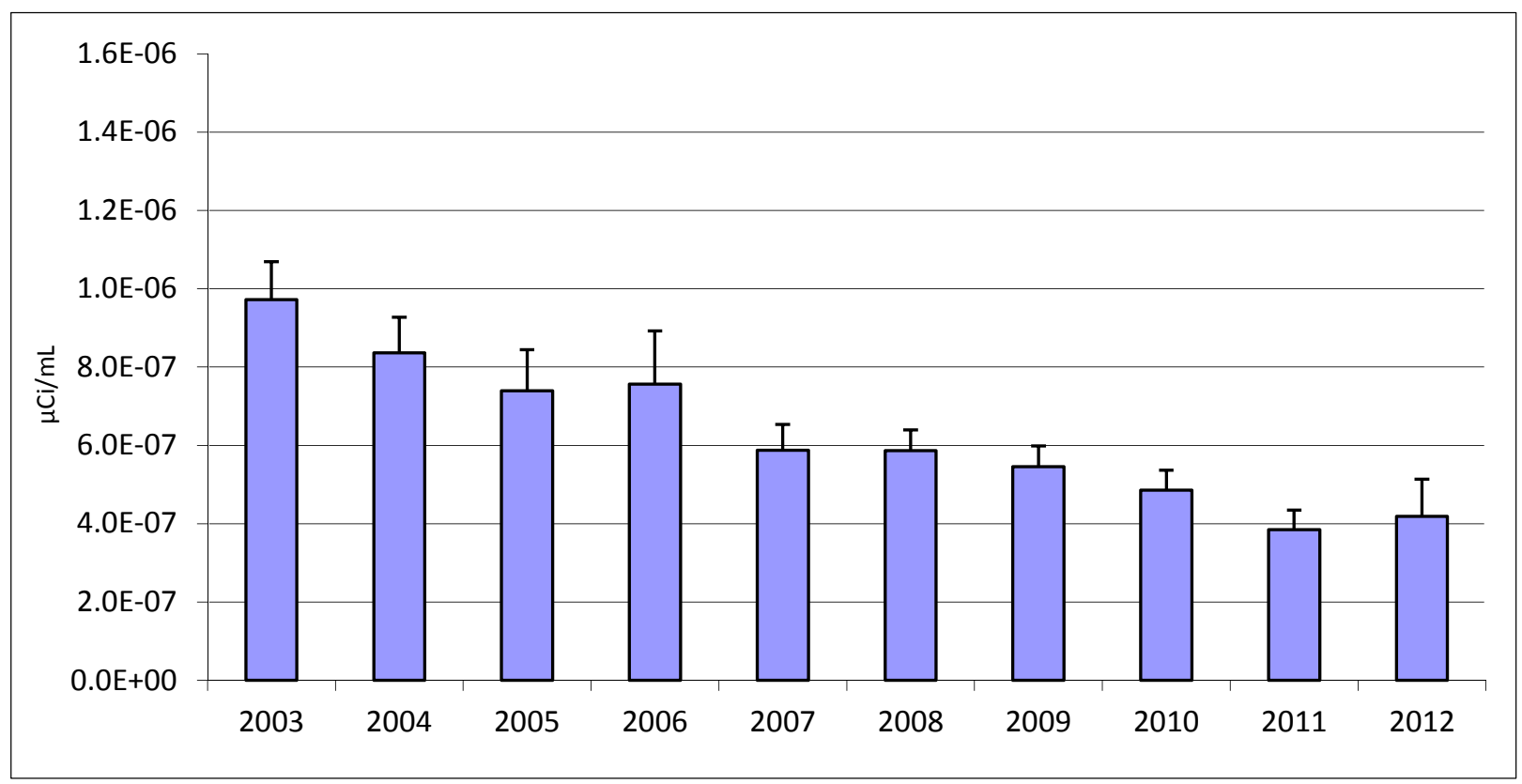

Note: The upper limit of the uncertainty term is indicated with each point. Average background tritium concentration in Buttermilk Creek (WFBCBKG) in CY 2012 was $<7.56 \mathrm{E}-08 \mu \mathrm{Ci} / \mathrm{mL}$. 
$0.6 \%$ of the DCS for strontium-90 $(1.1 \mathrm{E}-06 \mu \mathrm{Ci} / \mathrm{mL})$. The average result in $2012(3.85 \mathrm{E}-09 \mu \mathrm{Ci} / \mathrm{mL})$ was about $0.35 \%$ of the DCS.

Drinking Water. Project drinking (potable) water and utility water are drawn from two on-site surface water reservoirs. This water is sampled at select locations for both radiological and chemical constituents. It is monitored at the distribution entry point (WNDNKUR) and at other site tap water locations to verify compliance with EPA, NYSDOH, and Cattaraugus County Health Department regulations. Results from 2012 indicated that background levels of gross beta radioactivity were found in on-site drinking water, and that the Project's drinking water continued to remain below the local, state, and federal maximum contaminant levels and drinking water standards. The results are presented in Appendix B-6.

Ambient Air. Throughout 2012, samples for radionuclides in air continued to be collected at the background location at Great Valley (AFGRVAL), $18 \mathrm{mi}(29 \mathrm{~km}$ ) south of the WVDP. (See Figure A-13.) This location is considered representative of regional air with no potential to be affected by radiological releases from the WVDP.

As previously noted, during mid-CY 2012, an ambient air monitoring network was installed between the NYSERDA fence and the closest receptor in each of $16 \mathrm{sec}-$ tors around the site. The first quarter of ambient air data, collected from October to December 2012, indicated the results were indistinguishable from background. (See Tables C-10 and C-11). As previously described, the air sampling system is able to detect site-managed radioisotopes to less than $5 \%$ of each radioisotope's environmental compliance level. The first quarter of isotopic and gross radioactivity results from the ambient air samplers are similar to the concentrations measured at the Great Valley background sampling station during this same time period (see Table C-10). As the predominant potential source of air emissions on the site transitions from point sources (i.e., the Main Plant Stack) to diffuse sources, the use of ambient air monitoring samplers is a more appropriate method of demonstrating compliance with the NESHAP standards than the "measure and model" approach. Refer to "EPA Interim Approval to use Environmental Measurements for NESHAP Compliance" in the ECS.

Sediment and Soil. Airborne particulates may be deposited onto soil by wind or precipitation. Particulate matter in streams can adsorb radiological constituents in liquid effluents and settle on the stream bottom as sediment. Soils and sediment may subsequently be eroded or resuspended, especially during periods of high winds or high stream flow. The resuspended particles may provide a pathway for radiological constituents to reach humans either directly via exposure or indirectly through the food pathway.

As part of the monitoring program, on-site sediment/ soil samples are collected every five years at three locations on the north plateau where drainage has the potential to be contaminated. All of the soil and sediment samples were sampled and analyzed for radiological constituents in 2012. On-site soils are collected at SNSP006, SNSWAMP, and SNSW74A (see Figure A-2 with results summarized in Tables F-2A, F-2B, and F-2C.) Soil samples are also collected at one background location (SFGRVAL, shown on Figure A-13) and three former near-site air sampling locations (SFRSPRD, SFFXVRD, and SFRT240, shown on Figure A-5 with results summarized in Table F-2D). Additional off-site sediment samples are collected at one background location on Buttermilk Creek (SFBCSED) and at three downstream locations, one on Buttermilk Creek (SFTCSED) and two on Cattaraugus Creek (SFCCSED and SFSDSED) (see Figure A-5 and Table F-2E).

All three on-site sediment/soil locations and all three off-site sediment sampling locations had concentrations of cesium-137 statistically above the 10-year average background sediment/soil values. However, in the offsite soils, no cesium-137 was detected statistically above background. Samples from two of the on-site locations, SNSP006 and SNSWAMP, also contained strontium-90 and gross beta statistically above background. Gross beta at the third on-site location, SNSW74A, is in the same range as the current year background concentrations and statistically below the 10 -year average background result. Sr-90 was not detected at SNS74A and was not detected at any of the background locations. Additional isotopes, Plutonium-238, plutonium-239/240, americium-241, were detected at concentrations statistically above background at SNSWAMP.

The only location where soil or sediment samples exceeded several of the radionuclide comparison values for soils summarized in Table F-1A was SNSWAMP, the soil/sediment sampling location in the swamp ditch on the north plateau near where drainage exits the WVDP, where elevated strontium-90 was observed. The soil and sediment data are used in the biota dose modeling. Although some concentrations are elevated above background, they did not result in a dose level of concern (see "Dose to Biota" in Chapter 3). 
Food. Food samples are collected from locations near the site (Figure A-10) and from remote locations (Figure A-13). Milk and deer are collected every year. Fish, apples, beans, and corn are collected every five years, with 2012 being a collection year (2007 was the previous collection year). Fish and deer are collected during seasons when they would normally be taken by sportsmen. Corn, apples, and beans are collected at harvest time. Edible portions are analyzed for radionuclides. 2012 data are presented in Appendix E.

In 2012, milk, deer, and fish data continue to demonstrate that the Project has a minimal effect on local food sources. Strontium-90 and cesium-137 were detected at very low concentrations in some of the food crops in 2012; however, results were indistinguishable from background in 2012, with the exception of one near-site deer (of the three near-site deer analyzed). Concentrations of cesium-137 have been observed above background in near-site deer for many years. However, dose calculations based on results from food sources have consistently confirmed low dose estimates modeled on the basis of results from air and water monitoring. (See Chapter 3, "Dose Assessment.")
Environmental Radiation. TLDs are placed on site at waste management units, at the WVDP security fence, around the WNYNSC perimeter and the access road, and at a background location remote from the WVDP. The TLDs directly measure radiation in the environment. Generally, TLDs remain in the same location year-to-year. However in 2012 four off-site TLDs (DFTLD05, 08, 10, and 13) were moved from their historical locations to nearby new ambient air monitoring locations and two existing TLDs (DFTLD32 and DFTLD34) near the drum cell were put back in service in 2012. These two TLD sampling locations had not been monitored since 2005 .

Results at perimeter locations were statistically the same as results from the background TLDs (DNTLD23), indicating no measurable dose from Project activities at these locations. Figure 2-3 presents a graph of average annual exposure rates (in microroentgen per hour) over the last 10 years at background and perimeter locations. As shown, results at perimeter locations are comparable to background. In addition, no discernible trends over time are evident. Historical measurements at community locations (discontinued in 2008) have also shown no difference from background. Perimeter TLD locations (off-site)

FIGURE 2-3

10-Year Trends of Environmental Radiation Levels at Perimeter and Background Thermoluminescent Dosimeters (TLDs)

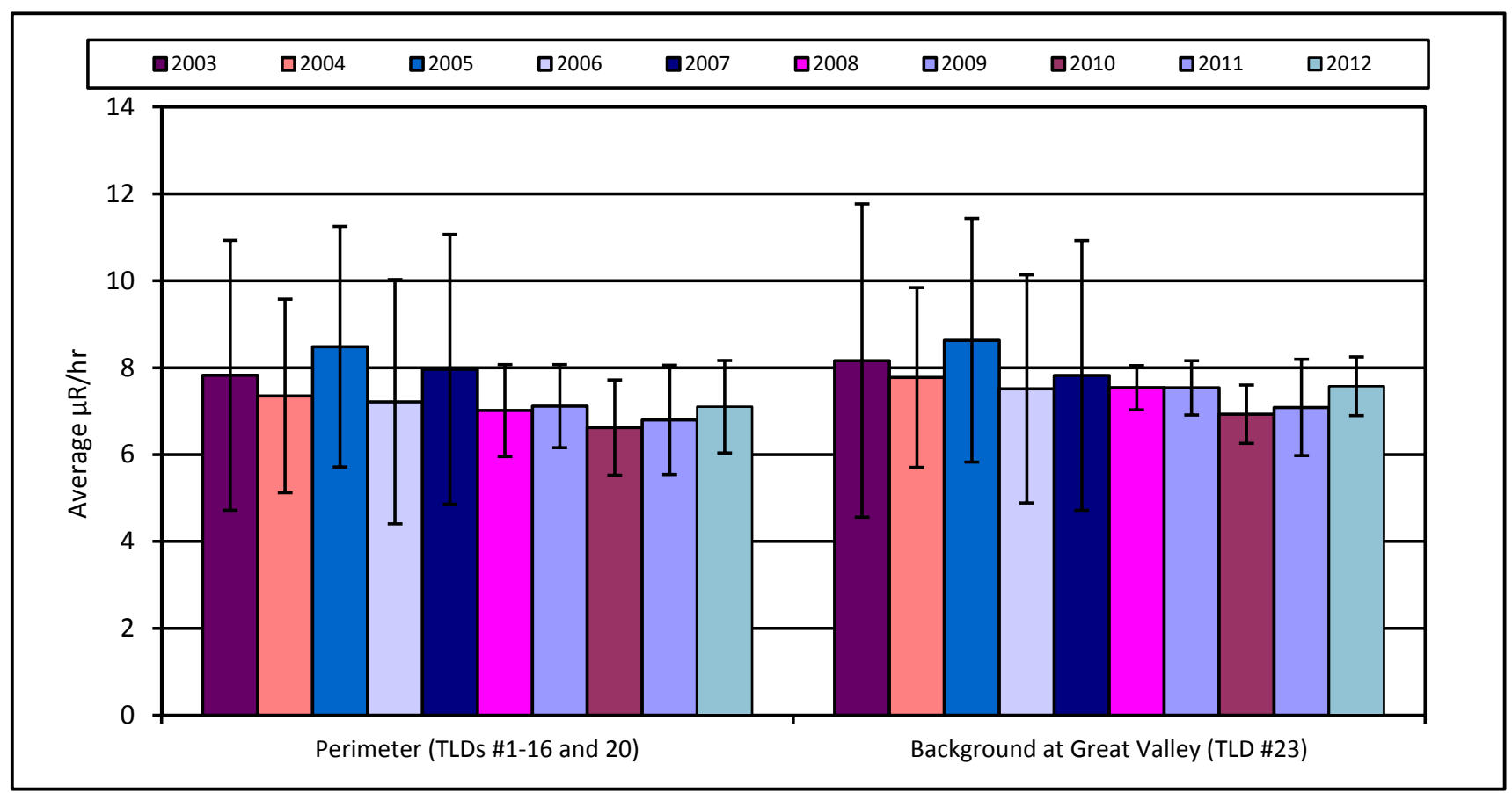

Note: The upper and lower limits of the uncertainty term are plotted with each result. 
TABLE 2-5

WVDP 2012 Monthly Precipitation Totals Compared with 10-Year Monthly Averages

\begin{tabular}{|l|c|c|}
\hline \multicolumn{1}{|c|}{ Month } & $\begin{array}{c}\mathbf{2 0 1 2} \\
\text { Monthly Total } \\
\text { (inches) }\end{array}$ & $\begin{array}{c}\text { 10-Year } \\
\text { Monthly } \\
\text { Average (2002 } \\
\text { through 2011) }\end{array}$ \\
\hline January & 4.04 & 3.01 \\
\hline February & 1.79 & 2.53 \\
\hline March & 2.75 & 2.97 \\
\hline April & 2.68 & 3.24 \\
\hline May & 1.89 & 3.33 \\
\hline June & 4.81 & 3.48 \\
\hline July & 3.29 & 4.44 \\
\hline August & 2.60 & 4.23 \\
\hline September & 3.04 & 3.70 \\
\hline October & 5.71 & 3.51 \\
\hline November & 1.79 & 3.73 \\
\hline December & 4.14 & 3.80 \\
\hline Total (inches) & 38.5 & 42.0 \\
\hline (Centimeters) & 97.9 & 106.6 \\
\hline
\end{tabular}

are shown on Figure A-12 in Appendix A, and the data are presented in Table G-1 in Appendix G.

Consistent with historical data, results from three TLDs (DNTLD24, DNTLD38, and DNTLD40) located near north plateau on-site waste storage facilities in 2012 were generally higher than background results as consistently observed in recent years. These locations are within the WNYNSC boundary and are not accessible by the public. On the south plateau, on-site TLD results remained at background levels. On-site TLD locations are shown on Figure A-11 in Appendix A, and the data are presented in Table G-2 in Appendix G.

Meteorological Monitoring. Meteorological monitoring at the WVDP provides representative and verifiable data that characterize the local climatology. These data are used to assess potential effects of routine and non-routine releases of airborne radioactivity and to provide input to dispersion models used to calculate dose to offsite residents. The on-site $197-\mathrm{ft}(60-\mathrm{m})$ meteorological tower (Figure A-1) continuously monitors wind speed, wind direction, and temperature at both the 197-ft (60$\mathrm{m})$ and 33-ft (10-m) elevations. Precipitation is monitored near the ELAB. Monthly CY 2012 precipitation totals compared with 10-year monthly averages are presented in Table 2-5.
Site barometric pressure is also measured. The meteorological tower supplies data to the primary digital and analog data acquisition systems on site.

The systems are provided with either uninterruptible or standby power backup in the event of site power failures. In 2012, the data recovery rate (the time valid data were logged versus the total elapsed time) was $93.3 \%$.

Documentation, such as meteorological system calibration records, site log books, and analog strip charts, is stored in protected archives. "Wind roses" showing the predominant wind direction as measured at the meteorological tower (60-m and $10-\mathrm{m}$ elevations) are shown on Figure 2-4. The wind measurements at the 60-m elevation are predominantly from the west-northwest or south-southeast and at the 10-m elevation are predominantly from the northwest or the south-southeast, apparently influenced by the orientation of the topography around the site. As expected, wind speeds measured at the $10-\mathrm{m}$ elevation were lower than those from the $60-\mathrm{m}$ elevation.

Because dispersive capabilities of the atmosphere are dependent upon wind speed, wind direction, and atmospheric stability (which includes a function of the difference in temperature between two elevations), these parameters are closely monitored and are available to the ERO at the WVDP. If an air release occurred, meteorological data would be used to predict the direction of plume migration.

\section{Special Projects}

Meteorological Station at the SDA and Stream Flow Monitoring. Meteorological instruments were installed by NYSERDA at the SDA in 2010 to measure total precipitation (i.e., rain, snow, and sleet); temperature, relative humidity; barometric pressure; and wind speed and direction. Data collection at SDA meteorological system have operated uninterrupted since October 1, 2010. In 2011, NYSERDA also installed a stage recorder on Buttermilk Creek at Thomas Corners Road Bridge (near the confluence with Cattaraugus Creek). NYSERDA maintains an interactive meteorological database for the SDA station on the internet at: http://v4.wqdata.com/webdblink/ nyserda.php. The data from these systems are ground only measurements. 


\section{Monitoring Program Changes}

Changes to the sampling program during 2012 were associated with ELAB analyses, the new ambient air monitoring network, the shutdown of ANCSSTK (01-14 building ventilation exhaust), the addition of two new TLDs, and the five-year sampling of biologicals, soils, and sediments.

- On June 30, 2012, as a cost savings, the ELAB relinquished its NYSDOH certifications allowing it to perform specific reportable analyses on site. Environmental Monitoring Program samples are now sent to offsite certified laboratories for these specific analyses. The ELAB maintains capabilities for select quick turnaround time analysis in support of site operations, for sample screening, and for tritium, gross alpha, gross beta, and iodine-129 in air.

- During the fourth quarter of 2012, 16 off-site ambient air monitoring locations were activated to collect one quarter of baseline data in preparation for future demonstration of compliance using ambient air measurements in accordance with 40 CFR 61, Subpart H, Section 61.93(b)(5), (pending final EPA approval).

- Air sampling location ANCSSTK was shut down on October 24, 2012, in preparation for the demolition of the 01-14 Building after the building ventilation was terminated.

- DNTLD32, located on drum cell road, and DNTLD34, located at drum cell south fence, were added back to the program in January 2012 to monitor activity in the area of the drum cell.

- The environmental monitoring program requires the collection of soils, aquatic sediments, milk, apples, beans, corn, and fish every five years. These parameters were currently sampled in 2012 and were previously sampled in 2007.

\section{Environmental Monitoring Summary}

As in the past, although concentrations of certain radiological and nonradiological constituents from samples collected within the security fence exceeded comparison levels or background concentrations, few results from near-site or downstream locations accessible to the public did. (See Table 2-4.)

Monitoring results from CY 2012 continued to demonstrate minimal or no adverse effects of the WVDP on the surrounding environment and confirmed the effectiveness of radiological control measures practiced at the WVDP. 
FIGURE 2-4

\section{Wind Frequency and Speed From the Meteorological Tower (10-m and 60-m Elevations)} January 1-December 31, 2012

Key:

Numbers indicate sector mean wind speed.

Sectors are directions from which the wind is blowing.

Wind Speed Range $(\mathrm{m} / \mathrm{sec})$

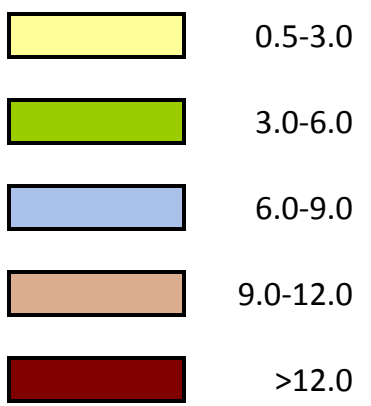

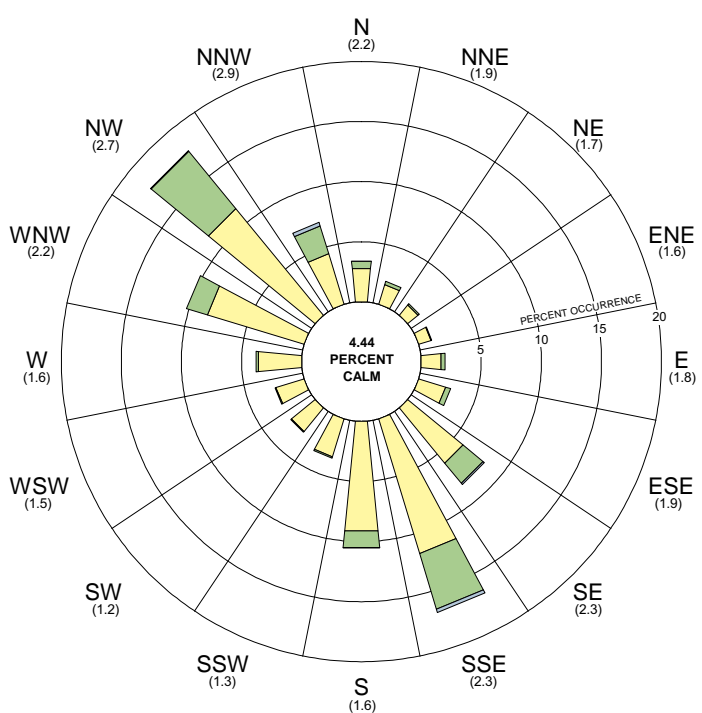

Meteorological Tower (10-m)

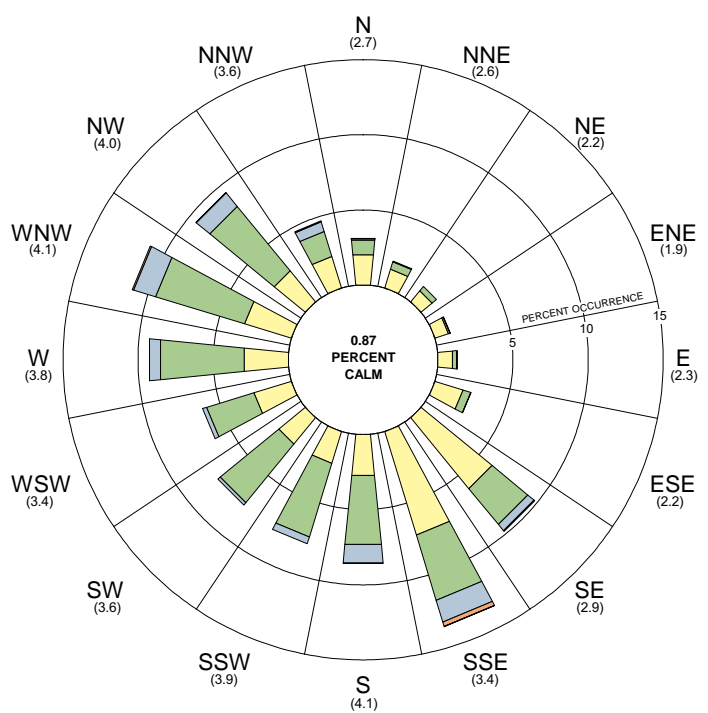

Meteorological Tower (60-m) 


\section{DOSE ASSESSMENT}

\section{Radiation Sources at the WVDP}

Members of the public are routinely exposed to natural and man-made sources of ionizing radiation. An individual living in the U.S. is estimated to receive an average annual effective dose equivalent (EDE) of about 620 mrem (6.2 mSv) (National Council on Radiation Protection and Measurements [NCRP] Report 160, 2009). NCRP Report No. 160, an update of NCRP Report No. 93 (1987), noted that the average member of the U.S. population was exposed to significantly more radiation from medical procedures than from any other source. (See the "Useful Information" section of this report for discussions of ionizing radiation. See the inset on page 3-3 for discussions of "Radiation Dose" and "Units of Dose Measurement.")

Half of the radiation dose to a member of the public, about $310 \mathrm{mrem} / \mathrm{year}$, is from natural background sources of cosmic and terrestrial origin (Figure 3-1). The other half is from man-made sources, including: diagnostic and therapeutic x-rays, tomography, and fluoroscopy; nuclear medicine; consumer products such as cigarettes and smoke detectors; fallout from nuclear weapons tests; industrial, research, and educational applications; and effluents from nuclear facilities.

Radioactive materials at the WVDP are residues from the commercial reprocessing of nuclear fuel by NFS in the 1960s and early 1970s. Each year, very small quantities of the radioactive materials remaining at the WVDP are released to the environment. Emissions and effluents are strictly controlled so that release quantities are kept ALARA.

\section{Exposure Pathways}

An exposure pathway consists of a route for contamination to be transported by an environmental medium from a source to a receptor. Table 3-1 summarizes the potential exposure pathways to the local off-site population and describes the rationale for including or excluding each pathway when calculating dose from the WVDP.

FIGURE 3-1

Comparison of Doses From Natural and Man-Made Sources to the Dose From 2012 WVDP Effluents

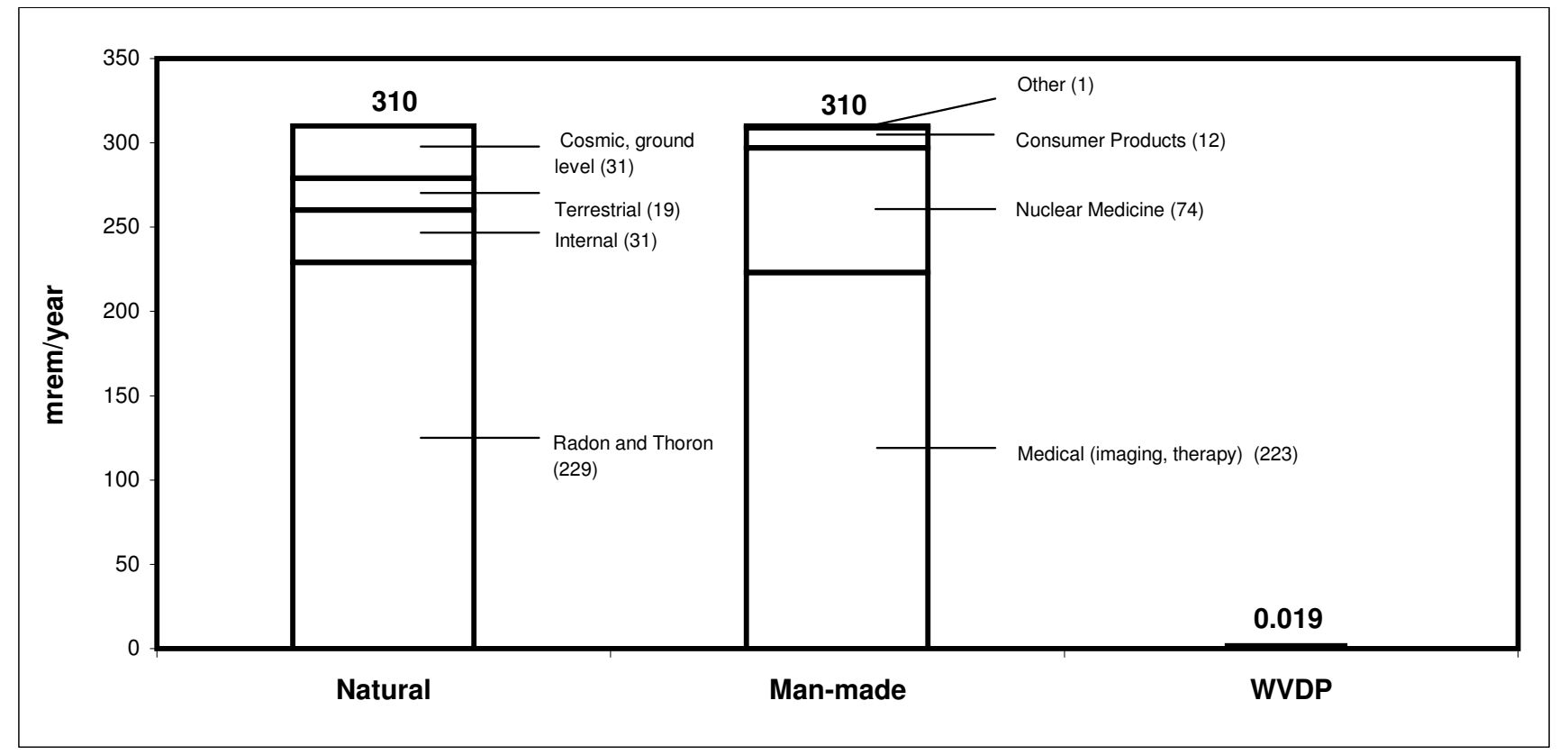


TABLE 3-1

Potential Exposure Pathways from the WVDP to the Local Off-Site Population

\begin{tabular}{|l|l|}
\hline \multicolumn{1}{|c|}{$\begin{array}{c}\text { Exposure Pathway and Transporting } \\
\text { Medium }\end{array}$} & \multicolumn{1}{c|}{ Reason for Including/Excluding } \\
\hline $\begin{array}{l}\text { Inhalation of gases and particulates in air } \\
\text { (included) }\end{array}$ & $\begin{array}{l}\text { Off-site transport of contaminants from stacks, vents, diffuse sources, } \\
\text { or resuspended particulates from soil or water. }\end{array}$ \\
\hline $\begin{array}{l}\text { Ingestion of vegetables, cultivated crops, } \\
\text { venison, milk, and fish (included) }\end{array}$ & $\begin{array}{l}\text { Local agricultural products irrigated with potentially contaminated } \\
\text { surface or groundwater; airborne deposition on leaves and uptake of } \\
\text { deposited contaminants; venison and milk from animals that have } \\
\text { inhaled or ingested contaminants; fish that have been exposed to or } \\
\text { ingested contaminants in surface water and sediment. }\end{array}$ \\
\hline $\begin{array}{l}\text { Ingestion of surface and groundwater } \\
\text { (excluded) }\end{array}$ & $\begin{array}{l}\text { No documented use of local surface water or downgradient } \\
\text { groundwater wells as drinking water by local residents. }\end{array}$ \\
\hline $\begin{array}{l}\text { External exposure to radiation from } \\
\text { particulates and gases directly from air or } \\
\text { surface water or indirectly from surface } \\
\text { deposition (included) }\end{array}$ & $\begin{array}{l}\text { Transport of air particulates and gases to off-site receptors; transport } \\
\text { of contaminants in surface water and direct exposure when swimming, } \\
\text { wading, boating, or fishing. }\end{array}$ \\
\hline
\end{tabular}

Potential exposure pathways that are considered include: inhalation of gases and particulates, ingestion of locally grown food products and game, and exposure to external penetrating radiation emitted from contaminated materials. Drinking water is not considered a pathway from the WVDP because surveys have determined that no public water supplies are drawn from downstream Cattaraugus Creek before Lake Erie or from groundwater in aquifers potentially affected by the WVDP.

\section{Land Use Survey and Population Data}

Population information is required when using computer models for annual dose assessments. Periodic surveys of local residents provide information about family size, and sources of food. Population around the WVDP by sector and distance from CY 2000 census is presented on Figure A-14. These data indicate an estimated 1.68 million people live within $50 \mathrm{mi}(80 \mathrm{~km})$ of the site. This total includes approximately 148,000 Canadians (Statistics Canada, 2001). The spatial distribution of population within the $50-\mathrm{mi}(80 \mathrm{~km})$ radius of the site is utilized in both the air and waterborne dose calculations.

Information from the most recent land use survey, conducted in early 2002, was used to update the residential locations nearest to the site. In 2008, a field verification of the residents closest to the site was conducted to confirm the location of the nearest receptor in each sector. The WVDP is in the process of updating its population files with the most recent 2010 U.S. and 2011 Canadian census data and will use this update for 2013 annual reporting.

\section{Dose Assessment Methodology}

Dose to the public is evaluated using a two-part method consistent with the requirements of DOE Order 458.1. First, measurements (and/or estimates) of radionuclide concentrations in liquid and air released from the Project are assembled from the CY of interest. The EPA- and DOE-approved models, or factors derived from those models, are then used to estimate the EDE to the MEOSI and the collective EDE to the population within a 50-mi $(80-\mathrm{km})$ radius. (See the inset on "Radiation Dose" and "Units of Dose Measurement.")

Second, radioactivity measurements in food from locations near the WVDP boundaries are taken to corroborate results from the modeled dose calculations. Vegetables, fruit, milk, venison, and fish samples from the WVDP vicinity are collected and analyzed for radiological constituents. (Biological sampling locations are shown on Figures A-10 and A-13.) Results are compared with similar measurements from samples collected at background locations to the WVDP. If any near-site results are higher than background results, dose calculations are performed. These results are used as an independent confirmation of (not added to) the computer-modeled dose estimates (Table 3-2) because the models already take into account contributions from all environmental pathways.

Determination of Radionuclide Concentrations in the Environment From Liquid and Airborne Releases. Because it is difficult to distinguish by direct measurement the small amount of radioactivity originating from the Project or from naturally occurring radiation in the 


\section{Radiation Dose}

The energy released from a radionuclide is eventually deposited in matter encountered along the path of the radiation. The radiation energy absorbed by a unit mass of material is referred to as the absorbed dose. The absorbing material can be either inanimate matter or living tissue.

Alpha particles leave a dense track of ionization as they travel through tissue and thus deliver the most dose per unit path-length. However, alpha particles are not penetrating and must be taken into the body by inhalation or ingestion to cause harm. Beta and gamma radiation can penetrate the protective dead skin layer of the body from the outside, resulting in exposure of the internal organs to radiation.

Because beta and gamma radiations deposit much less energy in tissue per unit path-length relative to alpha radiation, they produce fewer biological effects for the same absorbed dose. To allow for the different biological effects of different kinds of radiation, the absorbed dose is multiplied by a quality factor to yield a unit called the dose equivalent. A radiation dose expressed as a dose equivalent, rather than as an absorbed dose, permits the risks from different types of radiation exposure to be compared with each other (e.g., exposure to alpha radiation compared with exposure to gamma radiation). For this reason, regulatory agencies limit the dose to individuals in terms of total dose equivalent. Refer to the "Useful Information" section for discussion of ionizing radiation.

\section{Units of Dose Measurement}

The unit for dose equivalent in common use in the U.S. is the rem. The international unit of dose equivalent is the sievert (Sv), which is equal to 100 rem. The millirem and millisievert, used more frequently to report the low dose equivalents encountered in environmental exposures, are equal to one-thousandth of a rem or sievert, respectively. Other radioactivity unit conversions are found in the "Useful Information" section at the back of this report.

The effective dose equivalent (EDE), also expressed in units of rem or Sv, provides a means of combining unequal organ and tissue doses into a single "effective" whole body dose that represents a comparable risk probability. The probability that a given dose will result in the induction of a fatal cancer is referred to as the risk associated with that dose. For waterborne releases, the EDE is calculated by multiplying the organ dose equivalent by the organ-weighting factors developed by the International Commission on Radiological Protection in Publications 26 (1977) and 30 (1979). For airborne emissions, the EDE calculation is based upon factors in Federal Guidance Report 13, and National Council on Radiation Protection and Measurements (NCRP) report Number 123. The weighting factor is a ratio of the risk from a specific organ or tissue dose to the total risk resulting from an equal whole body dose. All organ-weighted dose equivalents are then summed to obtain the EDE.

The dose from internally deposited radionuclides calculated for a 50-year period following intake is called the 50 -year committed effective dose equivalent (CEDE). The CEDE sums the dose to an individual over 50 years to account for the biological retention of radionuclides in the body. The total EDE for one year of exposure to radioactivity is calculated by adding the CEDE to the dose equivalent from external, penetrating radiation received during the year. Unless otherwise specified, all doses discussed here are total EDE values, which include the CEDE for internal emitters.

A collective population dose is expressed in units of person-rem or person-sievert because the individual doses are summed over the entire potentially exposed population. The average individual dose can therefore be estimated by dividing the collective dose by the population. 
environment, computer codes are used to model the environmental dispersion of radionuclides that originate from on-site monitored ventilation stacks and liquid discharge points.

Actual data from air and water release monitoring samples are collected, together with annual weather measurements and the most recent demographic information for use in dose calculations. (See Appendices A, B, and C for details of the sampling program and for summaries of results in 2012.)

\section{Dose to the Public}

Each year an estimate is made of the potential radiological dose to the public that is attributable to WVDP operations and effluents during that CY. Estimates are calculated to confirm that no individual could have received a dose that exceeded the limits for protection of the public, as established by DOE or EPA.

Figure 3-1 shows the estimated (all pathway) maximum individual dose from the WVDP in CY 2012 as compared with the average annual dose a U.S. resident receives from man-made and natural background sources. As presented, the estimated dose from the WVDP would have contributed a very small amount (0.019 mrem [0.00019 $\mathrm{mSv}]$ ) of the total annual man-made radiation dose to the MEOSI. This is much less than the average dose received from consumer products and is insignificant compared with average dose from natural sources.

Estimated dose from the Project to an off-site resident is far below the federal standard of 100 mrem allowed from any DOE site operation in a $\mathrm{CY}$, confirming that efforts at the WVDP to minimize radiological releases are consistent with the ALARA philosophy of radiation protection.

\section{Predicted Dose From Airborne Emissions}

Airborne radionuclide emissions are regulated by EPA under the Clean Air Act and its implementing regulations. DOE facilities are subject to 40 CFR 61, Subpart H, NESHAP, which contains the national emission standards for radionuclides other than radon from DOE facilities. The applicable standard is a maximum of 10 mrem (0.1 mSv) EDE to any member of the public in any year.

Airborne radioactive materials released in 2012 from stacks and diffuse sources on the WVDP were modeled using the EPA-approved CAP88-PC computer code (Trinity Engineering, February 2013). This air dispersion code estimates EDEs for the ingestion, inhalation, air immersion, and ground surface pathways. (See "CAP88-PC Computer Code" in the "Useful Information" section.)

Site-specific data for CY 2012 (radionuclide releases in curies per year) were input into the CAP88-PC code, as were wind data collected from the on-site meteorological tower and information from the most recent local population survey. The output from the CAP88-PC code was then used to determine the total EDE from air emissions to the MEOSI and the collective EDE to the population within a $50-\mathrm{mi}(80-\mathrm{km})$ radius of the WVDP. Results are presented in Table 3-2. Although radon is specifically excluded from the NESHAP regulation, an estimate of dose from radon at the WVDP is also included in Table 3-2 for comparison purposes. (For a detailed discussion of radon in air emissions from the WVDP, see the inset on "Radon-220.")

Maximum Dose (Airborne) to an Off-Site Individual. Based on the nonradon airborne radioactivity released from all site sources during 2012 (i.e., permitted stacks, nonpermitted stacks, and nonpoint sources), it was estimated that a person living in the WVDP vicinity could have received a total EDE of $0.0027 \mathrm{mrem}(0.000027 \mathrm{mSv}$ ) from airborne releases. (See Table 3-2.) The computer model estimated that this MEOSI, who was assumed to eat only locally produced foods throughout the year, was located $1.2 \mathrm{mi}(1.9 \mathrm{~km})$ north-northwest of the site.

The dose from airborne sources is equal to about 5 minutes of natural background radiation received by an average member of the U.S. population, and is well below the 10-mrem (0.1 mSv) NESHAP limit established by EPA and mandated by DOE Order 458.1.

lodine-129, a long-lived radionuclide, has routinely been found in main stack emissions. During HLW VIT, iodine-129 releases increased because gaseous iodine was not as efficiently removed by the VIT process off-gas treatment system as were most other radionuclides. As more HLW was removed from the tanks and converted into glass, less waste was available to emit iodine-129 and the total emitted decreased. In 2012, iodine-129 concentrations remained at (or below) pre-VIT levels and accounted for about $37 \%$ of the dose to an off-site individual from airborne emissions. A comparison of dose proportions from various nuclides in air emissions is presented on the upper pie chart in Figure 3-2. Note that for this 2012 report, this figure presents the primary nuclides or nuclide groups for all airborne emissions, including diffuse sources. As work activities at the WVDP progress toward decommissioning and/or facility demolition, the importance of diffuse sources to dose estimates is expected to increase, and 
the number of point sources amendable to normal effluent monitoring will decrease. Although demolition of the 01-14 building began in 2012, only the asbestos roof and non-radiological portions of the building were removed in 2012. Therefore, there was no contribution to dose from building demolitions in 2012. The primary contribution to dose from diffuse sources in 2012 was from the LLW2 lagoons.

Collective Population Dose (Airborne). About 1.68 million people were estimated to reside in the U.S. and Canada within $50 \mathrm{mi}(80 \mathrm{~km}$ ) of the WVDP. (See Figure A-14.) This population received an estimated 0.0099 person-rem (0.000099 person-Sv) total EDE from radioactive non-radon airborne emissions released from WVDP point and diffuse sources during 2012. The resulting average EDE per individual was 0.0000059 mrem (0.000000059 mSv).

\section{Predicted Dose From Waterborne Releases}

Currently there are no EPA standards establishing limits on the radiation dose to members of the public from liquid effluents, except as applied in 40 CFR Parts 141 and 143, Drinking Water Guidelines (EPA, 1984a; 1984b). Corollary limits for community water supplies are set by the NYSDOH in the New York State Sanitary Code (10 NYCRR 5-1.52). Radionuclides are not regulated under the site's SPDES permit. However, special requirements in the permit specify that radionuclide concentrations in the discharge are subject to requirements of DOE Order 5400.5 (replaced by DOE Order 458.1, "Radiation Protection of the Public and the Environment.")

\section{Radon-220}

Radon-220, also known as thoron, is a naturally occurring gaseous decay product of thorium-232 present in the airborne emissions from the WVDP MPPB. Radon-220 is also associated with the thorium reduction extraction process-related thorium-232 and uranium-232 in the HLW.

As reported in Chapter 2 of the 1996 WVDP ASER (West Valley Nuclear Services Company [WVNSCO] and Dames \& Moore, June 1997), thoron levels were observed to increase during startup of the 1996 HLW VIT process. An estimate of thoron released during each waste concentration cycle was developed and used to determine a theoretical annual release. During the VIT phase, an average of about 12 curies per day were assumed to have been released. In 2012, with the VIT process completed, the average thoron release is conservatively estimated to be about three curies per day.

Although large numbers of curies were released relative to other radionuclides, the calculated dose from thoron is quite small because of its short decay half-life and other characteristics. The NESHAP rule specifically excludes thoron from air emission dose calculations, so a dose estimate using CAP88-PC was calculated separately. The theoretical dose to the MEOSI, located 1.2 mile (mi) (1.9 kilometer [km]) north-northwest of the site in 2012 , would have been 0.077 mrem $(0.00077 \mathrm{mSv})$, and the collective dose to the population within a $50-\mathrm{mi}(80-\mathrm{km})$ radius would have been 4.4 person-rem (0.044 person-Sv). (See Table 3-2.) These theoretical doses are within the same range as historical doses from the man-made radionuclides found in WVDP effluents.

With VIT completed, thoron releases have decreased to pre-VIT levels. The figure presented here provides a relative indication of recent trends in the estimated annual thoron releases.

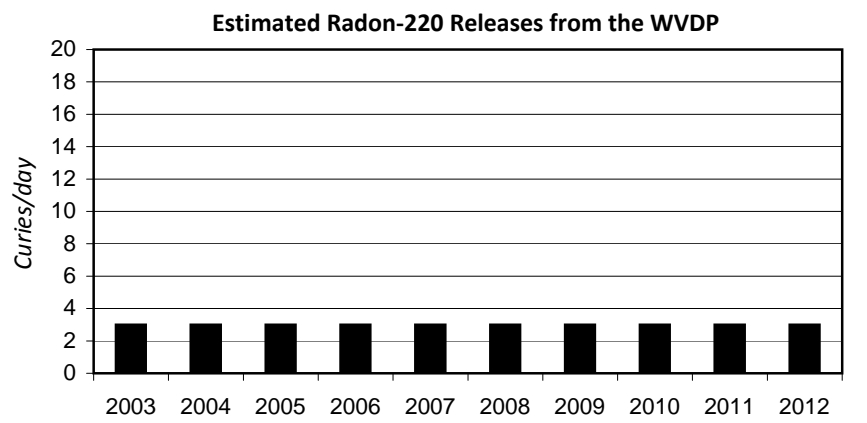


FIGURE 3-2

Dose Percent by Radionuclide in 2012

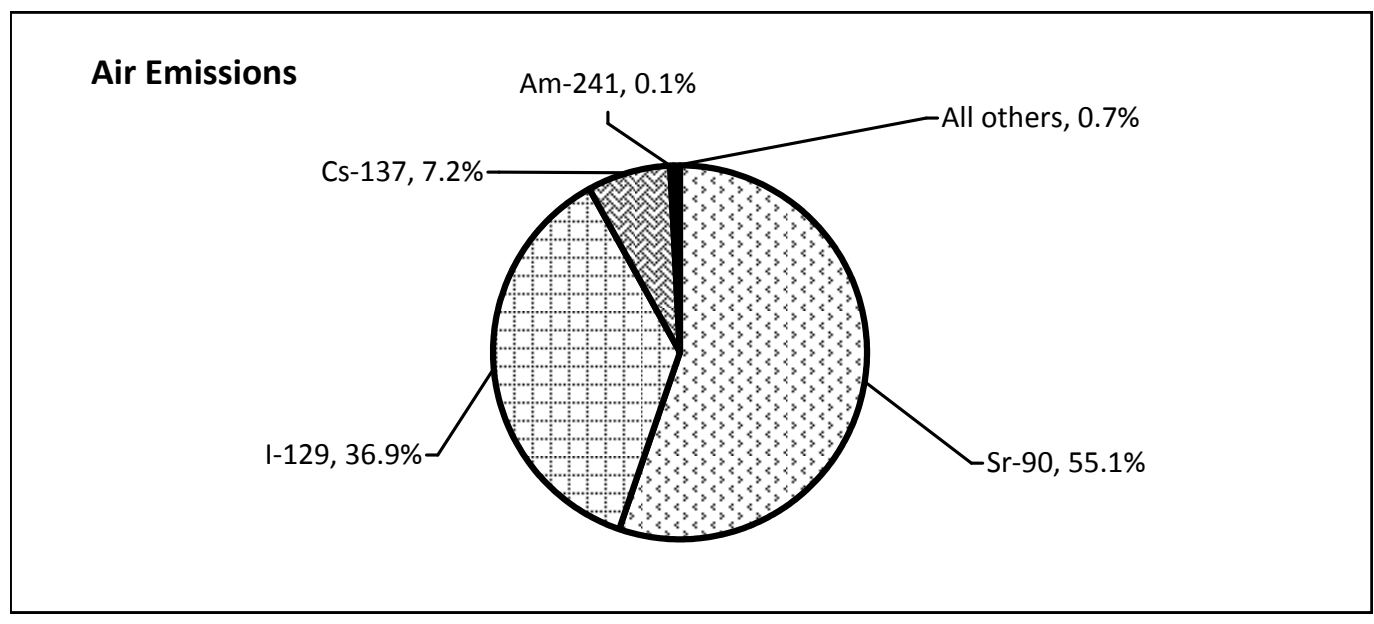

Water Releases
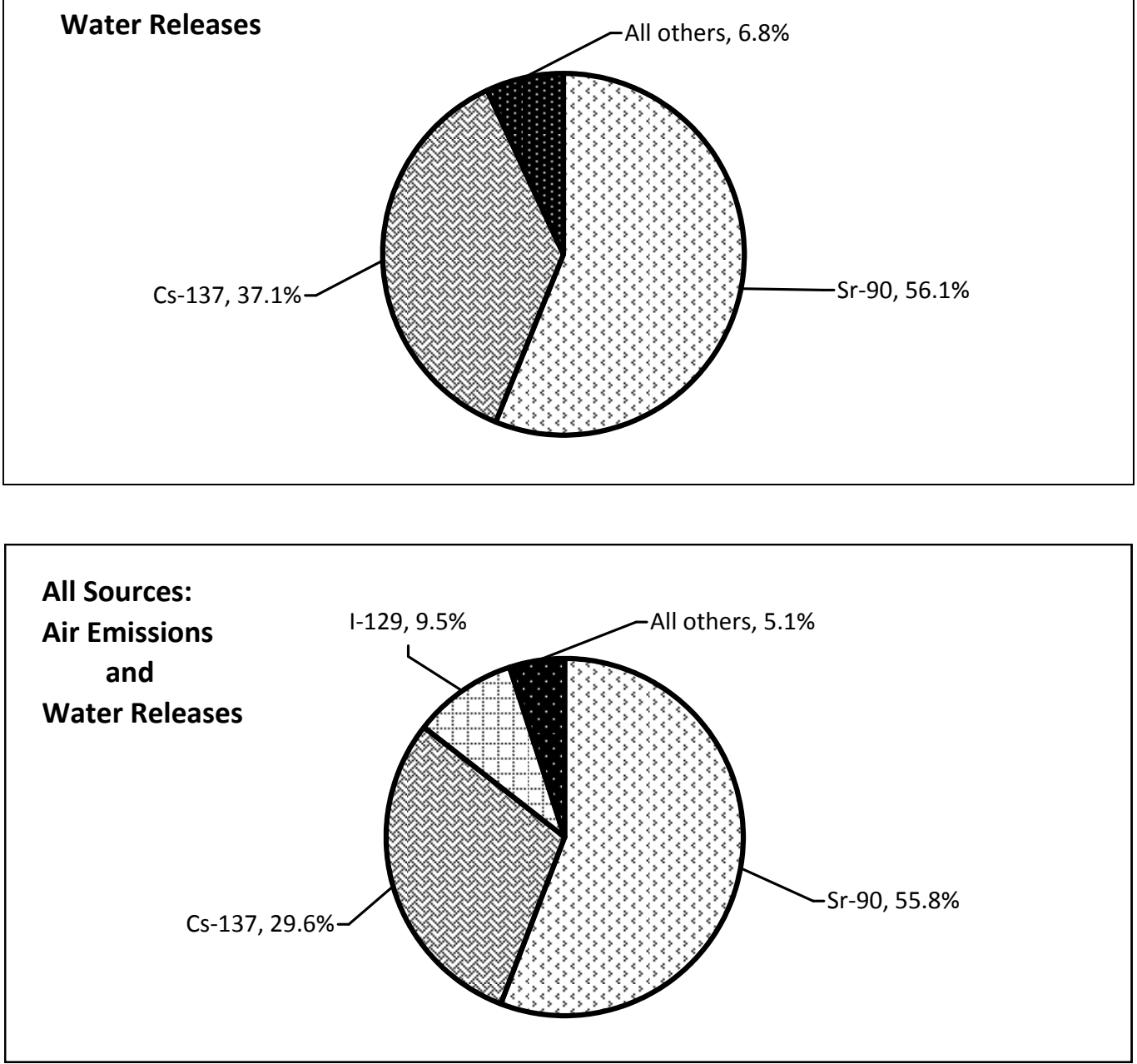
As shown in Table 3-1, the public water source and residential wells are located upgradient of the WVDP and therefore do not represent a potential source of exposure to radioactivity from Project activities. Cattaraugus Creek is not used as a drinking water supply; therefore, a comparison of estimated doses from this source with the 4-mrem/year (0.04-mSv/year) EPA and NYSDOH drinking water limits is not appropriate (although values are well below the drinking water limits). Population dose estimates are based on the presumption that radionuclides are even further diluted in Lake Erie before reaching any municipal water supplies.

Because the Project's liquid effluents eventually reach Cattaraugus Creek, the most important waterborne exposure pathway is the consumption of fish from the creek by local sportsmen and residents. Exposure to external radiation from shoreline contamination or in the water is also considered in the model for estimating radiation dose.

The computer codes GENII version 1.485 (Pacific Northwest Laboratory, 1988), which implements the models in the NRC Regulatory Guide 1.109 (NRC, 1977), and LADTAP II (Simpson and McGill, 1980) were used to calculate site-specific unit dose factors (UDFs) for routine waterborne releases and dispersion of these effluents. The UDFs derived from those codes are tabulated in the "Manual for Radiological Assessment of Environmental Releases at the WVDP," WVDP-065 (CHBWV, 2012).

Five batches of liquid effluents, totaling about 8.3 million gal (31.6 million L), were released from the lagoon 3 weir WNSP001 (SPDES point 001) during 2012. Measurements of the radioactivity discharged in these effluents were combined with the UDFs to calculate the EDE to the MEOSI and the collective EDE to the population living within a $50-\mathrm{mi}(80-\mathrm{km})$ radius of the WVDP. (See Table 3-2.)

In addition to measurements from WNSP001, radioactivity measurements from WWTF effluents (WNSP007) were included in the EDE calculations.

Besides the two controlled release points at WNSP001 and WNSP007, water from two natural drainage channels on the north plateau originating on the Project premises contain measurable concentrations of radioactivity: the northeast swamp (WNSWAMP) and north swamp (WNSW74A). Although releases from WNSWAMP and WNSW74A are not considered "controlled" releases, they are well characterized and are routinely sampled and monitored. Results from these monitoring points are included in the EDE calculations for the MEOSI and the collective population. A comparison of dose proportions attributable to specific waterborne radionuclides is shown on the middle pie chart on Figure 3-2. As presented, strontium-90 and cesium-137 account for almost all of the estimated waterborne dose, at $56.1 \%$ and $37.1 \%$, respectively, as shown by the middle pie chart in Figure 3-2.

There were no unplanned releases of waterborne radioactivity in 2012.

Maximum Dose (Waterborne) to an Off-Site Individual. Based on the radioactivity in liquid effluents discharged from the WVDP (lagoon 3 and the WWTF) during 2012, an off-site individual could have received a maximum EDE of 0.0074 mrem (0.000074 mSv). (See Table 3-2.) About $76 \%$ of this dose was from cesium-137. The MEOSI EDE due to drainage from the north plateau was 0.0090 mrem $(0.000090 \mathrm{mSv})$. About $92 \%$ of the north plateau dose was attributable to strontium-90, largely from the WNSWAMP drainage point.

The combined EDE to the MEOSI from liquid effluents and drainage was $0.016 \mathrm{mrem}$ (0.00016 mSv). This annual dose is very small in comparison to the 310-mrem (3.10 $\mathrm{mSv}$ ) dose that is received by an average member of the U.S. population from natural background radiation.

Collective Population Dose (Waterborne). As a result of radioactivity released in liquid effluents from the WVDP during 2012, the population living within $50 \mathrm{mi}(80 \mathrm{~km})$ of the site received an estimated collective EDE of 0.011 person-rem (0.00011 person-Sv). The collective dose to the population from the effluents plus the north plateau drainage was 0.062 person-rem (0.00062 person-Sv). The resulting average EDE per individual is 0.000046 mrem $(0.00000046 \mathrm{mSv})$, which is a very small percentage of the dose received by the average person from natural background radiation (310 mrem or $3.1 \mathrm{mSv}$ ).

\section{Predicted Dose From All Pathways}

The potential dose to the public from both airborne and liquid effluents released from the Project in 2012 is the sum of the individual dose contributions. (See Table 3-2 and the lower pie chart on Figure 3-2.) The calculated maximum EDE from all pathways to a nearby resident was $0.019 \mathrm{mrem}(0.00019 \mathrm{mSv})$. This dose is $0.019 \%$ of the 100-mrem (1-mSv) annual limit in DOE Order 458.1. As in past years, CY 2012 results continued to demonstrate WVDP compliance with applicable radiation standards for protection of the public and the environment. 
TABLE 3-2

Summary of Annual Effective Dose Equivalents (EDEs) to an Individual and Population From WVDP Releases in 2012

\begin{tabular}{|c|c|c|}
\hline \multirow[b]{2}{*}{ Exposure Pathways } & \multicolumn{2}{|c|}{ Annual EDE } \\
\hline & $\begin{array}{c}\text { MEOSI }^{a} \\
\text { mrem (mSv) }\end{array}$ & $\begin{array}{c}\text { Collective EDE } \\
\text { person-rem (person-Sv) }\end{array}$ \\
\hline Airborne Releases $^{c}$ & 2.7E-03 (2.7E-05) & 9.9E-03 (9.9E-05) \\
\hline \% EPA standard (10 mrem) & $0.027 \%$ & NA \\
\hline Waterborne Releases $^{d}$ & 1.6E-02 (1.6E-04) & $6.2 \mathrm{E}-02(6.2 \mathrm{E}-04)$ \\
\hline Effluents only & 7.4E-03 (7.4E-05) & $1.1 \mathrm{E}-02(1.1 \mathrm{E}-04)$ \\
\hline North plateau drainage & 9.0E-03 (9.0E-05) & 5.1E-02 (5.1E-04) \\
\hline Total From All Pathways & 1.9E-02 (1.9E-04) & 7.2E-02 (7.2E-04) \\
\hline $\begin{array}{l}\% \text { DOE standard (100 mrem) - } \\
\text { air and water combined }\end{array}$ & $0.019 \%$ & NA \\
\hline $\begin{array}{l}\% \text { of natural background } \\
\text { ( } 310 \text { mrem; } 522,000 \text { person-rem) - } \\
\text { received from air and water combined }\end{array}$ & $0.006 \%$ & $0.000014 \%$ \\
\hline Estimated Airborne Radon-220 ${ }^{e}$ & 7.7E-02 (7.7E-04) ${ }^{f}$ & $4.4 \mathrm{E}+00(4.4 \mathrm{E}-02)^{f}$ \\
\hline
\end{tabular}

Note: Summed values may not exactly match totals due to rounding.

NA - Not applicable. Numerical regulatory standards are not set for the collective EDE to the population.

${ }^{a}$ The maximum exposure to air discharges is estimated to occur at a residence $1.2 \mathrm{mi}(1.9 \mathrm{~km})$ north -northwest of the MPPB.

${ }^{\mathrm{b}}$ A population of 1.68 million is estimated to rside in the U.S. and Canada within $50 \mathrm{mi}(80 \mathrm{~km})$ of the site.

${ }^{\mathrm{c}}$ Releases are from atmospheric nonradon point and diffuse sources. Calculations use CAP88-PC to estimate individual and population doses. EPA and DOE limits for individual airborne dose are the same.

${ }^{d}$ Estimates are calculated using the methodolgy described in the "Manual for Radiological Assessment of Environmental Releases at the WVDP", WVDP-065 (CHBWV, 2012).

e Estimated airborne releases are based on indicator measurements and process knowledge. Dose estimates are calculated using CAP88-PC for the MPPB stack.

${ }^{\mathrm{f}}$ The estimated dose from radon-220 is specifically excluded by rule from NESHAP totals.

Table 3-3 presents the total curies released to air and water from all sources at the WVDP. As presented on the bottom pie chart on Figure 3-2, the largest proportion of estimated EDE to an off-site individual in 2012 was from strontium-90 via the waterborne pathway.

In CY 2012, the total collective EDE to the population within $50 \mathrm{mi}(80 \mathrm{~km})$ of the site was 0.072 person-rem (0.00072 person-Sv), with an average EDE of 0.000052 mrem (0.00000052 mSv) per individual.

Figure 3-3 shows the calculated annual dose to the hypothetical MEOSI over the last 10 years. As shown by this figure, the largest portion is due to waterborne contributions, which were approximately 62\% lower in 2012 than those in 2011.
Figure 3-4 shows the collective dose to the population over the last 10 years. Radioactivity in the human pathway represented by these data confirms the continued inconsequential addition to the natural background radiation dose that individuals and the nearby WVDP population receive from Project activities.

Calculated Dose From Food. Most radionuclide concentrations in near-site food samples were statistically indistinguishable from concentrations in background samples in 2012. One near-site deer sample exhibited cesium-137 concentrations above historical background. Conservative dose estimates due to consuming near-site deer, fish, milk, beans, corn, and apples were estimated to be about $0.22 \mathrm{mrem} /$ year ( $0.0022 \mathrm{mSv} /$ year), which is about $0.035 \%$ of the dose received by an average individual due 
TABLE 3-3

WVDP Radiological Dose and Release Summary

\begin{tabular}{|c|c|c|c|c|c|c|}
\hline \multicolumn{7}{|c|}{ WVDP Radiological Dose Reporting Table Calendar Year (CY) 2012} \\
\hline \multicolumn{2}{|c|}{$\begin{array}{l}\text { Dose to the } \\
\text { Maximally Exposed } \\
\text { Individual }\end{array}$} & \multirow{2}{*}{$\begin{array}{c}\begin{array}{c}\% \text { of DOE } \\
100 \text {-mrem } \\
\text { Limit }\end{array} \\
0.019\end{array}$} & \multicolumn{2}{|c|}{$\begin{array}{c}\text { Estimated } \\
\text { Population Dose }\end{array}$} & \multirow{2}{*}{\begin{tabular}{|c} 
Population \\
${\text { Within } 50 \text { Miles }^{a}}$ \\
(2000 census)
\end{tabular}} & \multirow{2}{*}{\begin{tabular}{|c|}
$\begin{array}{c}\text { Estimated Natura } \\
\text { Radiation } \\
\text { Population Dose }\end{array}$ \\
$\begin{array}{c}522,000 \\
\text { person-rem }\end{array}$ \\
\end{tabular}} \\
\hline $\begin{array}{l}0.019 \\
\text { mrem }\end{array}$ & $\begin{array}{c}0.00019 \\
(\mathrm{mSv})\end{array}$ & & $\begin{array}{c}0.072 \\
\text { person-rem }\end{array}$ & $\begin{array}{c}0.00072 \\
\text { (person-Sv) }\end{array}$ & & \\
\hline
\end{tabular}

\begin{tabular}{|c|c|c|c|c|c|c|c|c|c|c|}
\hline \multicolumn{11}{|c|}{ WVDP Radiological Atmospheric Emissions ${ }^{b}$ CY 2012 in Curies and Becquerels } \\
\hline Tritium & $\begin{array}{l}K r- \\
85\end{array}$ & $\begin{array}{l}\text { Noble Gases } \\
\left(T_{1 / 2}<40 \mathrm{dy}\right)\end{array}$ & $\begin{array}{c}\text { Short-Lived } \\
\text { Fission and } \\
\text { Activation } \\
\text { Products } \\
\left(\mathrm{T}_{1 / 2}<3 \mathrm{hr}\right)\end{array}$ & $\begin{array}{l}\text { Fission and } \\
\text { Activation } \\
\text { Products } \\
\left(\mathrm{T}_{1 / 2}>3 \mathrm{hr}\right)\end{array}$ & $\begin{array}{c}\text { Total Radio } \\
\text { iodine }\end{array}$ & $\begin{array}{l}\text { Total Radio } \\
\text { strontium }\end{array}$ & $\begin{array}{c}\text { Total } \\
\text { Uranium }^{c}\end{array}$ & $\begin{array}{c}\text { Total } \\
\text { Plutonium }\end{array}$ & $\begin{array}{c}\text { Total } \\
\text { Other } \\
\text { Actinides }\end{array}$ & $\begin{array}{c}\text { Other } \\
\text { (Rn-220) }\end{array}$ \\
\hline $\begin{array}{c}4.96 \mathrm{E}-03 \\
(1.84 \mathrm{E}+08)\end{array}$ & NA & NA & NA & $\begin{array}{c}8.97 \mathrm{E}-05 \\
(3.32 \mathrm{E}+06)\end{array}$ & $\begin{array}{c}3.85 \mathrm{E}-05 \\
(1.42 \mathrm{E}+06)\end{array}$ & $\begin{array}{c}1.26 \mathrm{E}-04 \\
(4.66 \mathrm{E}+06)\end{array}$ & $\begin{array}{c}1.53 \mathrm{E}-07 \\
(5.66 \mathrm{E}+03)\end{array}$ & $\begin{array}{c}1.59 \mathrm{E}-07 \\
(5.90 \mathrm{E}+03)\end{array}$ & $\begin{array}{c}2.11 \mathrm{E}-07 \\
(7.81 \mathrm{E}+03)\end{array}$ & $\begin{array}{c}1.10 \mathrm{E}+03 \\
(4.05 \mathrm{E}+13)\end{array}$ \\
\hline
\end{tabular}

\begin{tabular}{|c|c|c|c|c|c|c|}
\hline \multicolumn{7}{|c|}{ WVDP Liquid Effluent Releases ${ }^{d}$ of Radionuclide Material - CY 2012 in Curies and Becquerels } \\
\hline Tritium & $\begin{array}{l}\text { Fission and } \\
\text { Activation } \\
\text { Products } \\
\left(\mathrm{T}_{1 / 2}>3 \mathrm{hr}\right)\end{array}$ & $\begin{array}{c}\text { Total } \\
\text { Radioiodine }\end{array}$ & $\begin{array}{c}\text { Total } \\
\text { Radiostrontium }\end{array}$ & $\begin{array}{c}\text { Total } \\
\text { Uranium }^{e}\end{array}$ & $\begin{array}{c}\text { Total } \\
\text { Plutonium }\end{array}$ & $\begin{array}{c}\text { Total Other } \\
\text { Actinides }\end{array}$ \\
\hline $\begin{array}{c}2.30 \mathrm{E}-02 \\
(8.51 \mathrm{E}+08)\end{array}$ & $\begin{array}{c}3.33 \mathrm{E}-03 \\
(1.23 \mathrm{E}+08)\end{array}$ & $\begin{array}{c}8.84 \mathrm{E}-05 \\
(3.27 \mathrm{E}+06)\end{array}$ & $\begin{array}{c}6.13 \mathrm{E}-02 \\
(2.27 \mathrm{E}+09)\end{array}$ & $\begin{array}{c}5.48 \mathrm{E}-04 \\
(2.03 \mathrm{E}+07)\end{array}$ & $\begin{array}{c}3.79 \mathrm{E}-05 \\
(1.40 \mathrm{E}+06)\end{array}$ & $\begin{array}{c}2.25 E-05 \\
(8.32 E+05)\end{array}$ \\
\hline
\end{tabular}

Note: There are no known significant discharges of radioactive constituents from the site other than those reported in this table.

NA - Not applicable

${ }^{a}$ Total population includes the U.S. population from the 2000 census plus the Canadian population residing within a $50-\mathrm{mi}(80-\mathrm{km})$ radius (Statistics Canada, 2001).

${ }^{\mathrm{b}}$ Air releases are from point and diffuse sources.

${ }^{\mathrm{c}}$ Total uranium (airborne) $(\mathrm{g})=1.37 \mathrm{E}-01$

${ }^{\mathrm{d}}$ Water releases are from both controlled liquid effluent releases and from well-characterized site drainages.

${ }^{\mathrm{e}}$ Total uranium (waterborne) $(\mathrm{g})=3.94 \mathrm{E}+02$ 
FIGURE 3-3

Effective Dose Equivalent from Liquid and Airborne Effluents to a Maximally Exposed Individual Residing Near the WVDP

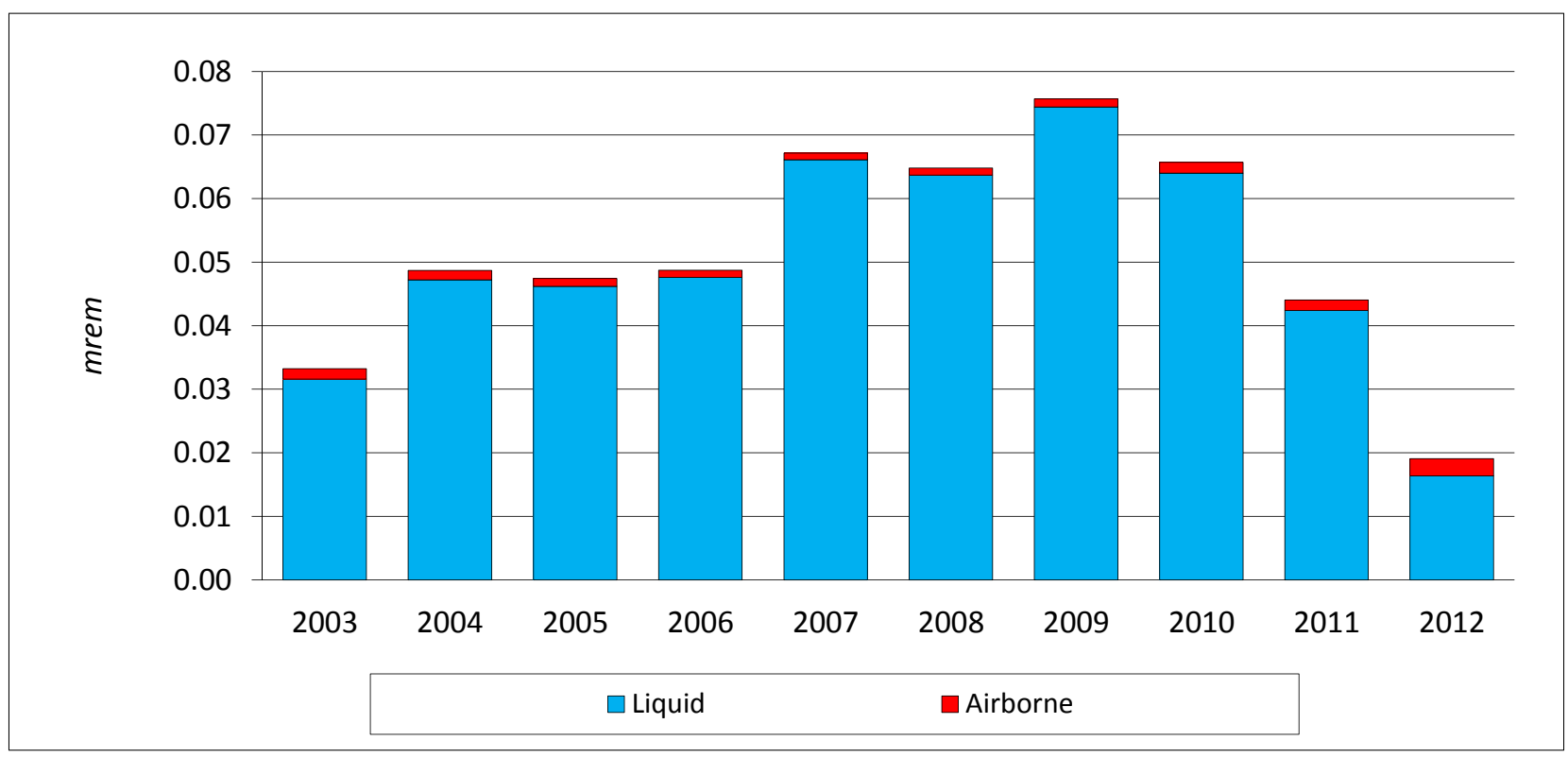

FIGURE 3-4

Collective Effective Dose Equivalent From Liquid and Air Effluents to the Population Residing Within 50 Miles $(80 \mathrm{~km})$ of the WVDP

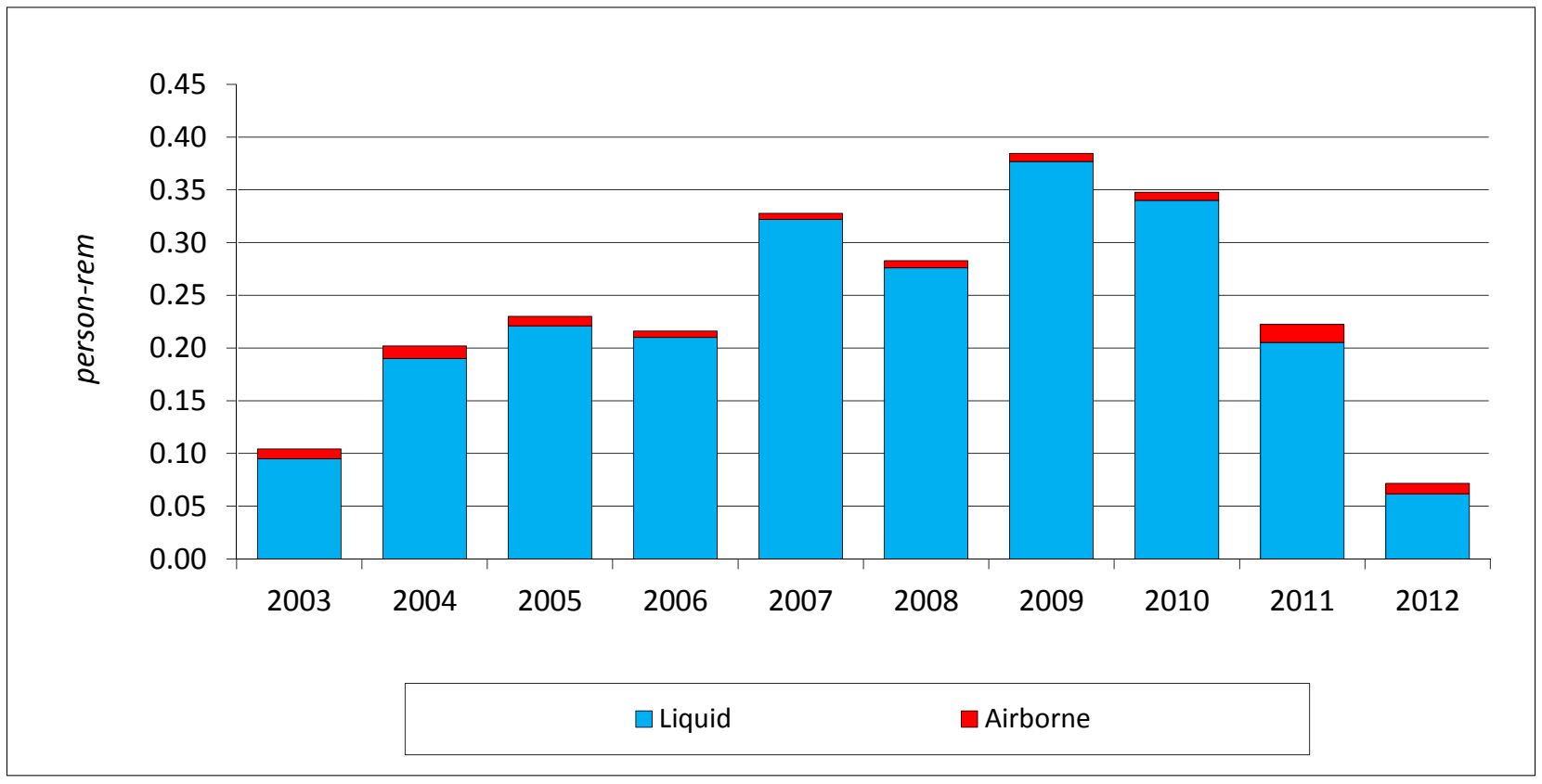


to natural and other man-made sources in 2012. (See Figure 3-1, "Comparison of Doses from Natural and ManMade Sources to the Dose from 2012 WVDP Effluents.") This estimate assumes the individual consumes the maximum quantities of each food item. These independent estimates confirmed the low modeled dose estimates based on air and water effluents, as summarized in Table 3-2.

\section{Risk Assessment}

Estimates of cancer risk from ionizing radiation have been presented by the NCRP (1987) and the National Research Council's Committee on Biological Effects of lonizing Radiation (1990).

The NCRP estimates that the probability of fatal cancer occurring is between one and five per 10,000 people who are each exposed to one rem (i.e., a risk coefficient of between 0.0001 and 0.0005$)$. DOE guidance has, in the past, recommended using a risk coefficient of 0.0005 (International Commission on Radiological Protection [ICRP], 1991) to estimate risk to a MEOSI. Recent DOE guidance recommends using the even more conservative risk coefficient of 0.0006 provided by the Interagency Steering Committee on Radiation Standards (January 2003). The estimated risk to the hypothetical individual residing near the WVDP from airborne and waterborne releases in 2012 was about 1 per 100 million (a risk of 0.00000001). This risk is well below the range of 0.000001 to 0.00001 per year considered by the ICRP to be a reasonable risk for any member of the public (ICRP Report Number 26, 1977).

\section{Release of Materials Containing Residual Radioactivity}

DOE ensures protection of the public and environment through the implementation of the standards and requirements set forth in DOE Order 458.1. In addition to discharges to the environment, the release of property containing residual radioactive materials is considered a potential contributor to dose received by the public.

In 2000, the Secretary of Energy placed a moratorium on the release of volumetrically contaminated metals, and suspended the unrestricted release of metals from radiological areas of DOE facilities for recycling. The moratorium and suspension currently remain in effect.

A graded approach is utilized by the WVDP for the release of equipment and materials to the public for unrestricted use. This approach considers the material use, the potential for internal contamination, the location the material was used, and process knowledge of the item(s) to be released. In accordance with WVDP radiological controls manuals and procedures, these criteria are assessed and documented, and the material(s) may be radiologically surveyed to verify the survey results are within the contamination limits presented in DOE Order 458.1, Requirements, Section 4.j. Records of released property are maintained.

Presently there are no approved criteria for releasing WVDP material to the public that may have been contaminated in depth or volume; therefore, no unrestricted release of scrap metal or other material of this type has occurred. Compliance with the Secretary of Energy's suspension of unrestricted release of scrap metal for recycle continues at the WVDP.

The Secretary does encourage efforts to promote reuse and recycling of excess property for use within the DOE complex. These transfers occur only when property is transferred to individuals authorized to use such material.

\section{Dose to Biota}

Radionuclides from both natural and man-made sources may be found in environmental media such as water, sediments, and soils. In the past, it has been assumed that if radiological controls are sufficient to protect humans, other living things are also likely to be sufficiently protected. This assumption is no longer considered adequate, because plant and animal populations residing in or near these media or taking food or water from these media may be exposed to a greater extent than are humans. Therefore, DOE prepared a technical standard that provides methods and guidance to be used to evaluate doses of ionizing radiation to populations of aquatic animals, riparian animals (i.e., those that live along banks of streams or rivers), terrestrial plants, and terrestrial animals.

Methods in this technical standard, "A Graded Approach for Evaluating Radiation Doses to Aquatic and Terrestrial Biota" (DOE-STD-1153-2002, July 2002), were used in 2012 to evaluate radiation doses to aquatic and terrestrial biota within the confines of the WNYNSC, which includes the WVDP. Doses were assessed for compliance with the limit in DOE Order 458.1 for native aquatic animal organisms ( $1 \mathrm{rad} / \mathrm{day}$ ) and for compliance with the thresholds for terrestrial plants (also $1 \mathrm{rad} /$ day) and for terrestrial animals (0.1 rad/day), as proposed in DOE-STD-1153-2002. 
Note that the absorbed dose unit (rad) is used for biota instead of the units used for indicating human risk (rem).

RESRAD-BIOTA for Windows ${ }^{\circledR}$ (November 2009), a calculation tool provided by DOE for implementing the technical standard, was used to compare existing radionuclide concentration data from environmental sampling with biota concentration guide (BCG) screening values and to estimate upper bounding doses to biota. Data were taken from surface water samples obtained in 2012 and sediments over the most recent five years of sediment sampling (2004-2007 and 2012). Soil data from the most recent 10 years (1995-2004) for which special on-site surface soil sampling was conducted and the most recent 10 years of routine on-site surface soil sampling (19992007 and 2012) were used. Differing time periods were used because radionuclide concentrations change more rapidly over time in surface waters than in sediments and soils, as reflected in their sampling frequencies (monthly or quarterly for water, every five years for sediment and surface soil).
Concentration data for radionuclides in each medium were entered into the RESRAD-BIOTA Code. The value for each radionuclide was automatically divided by its corresponding BCG to calculate a partial fraction for each nuclide in each medium. Partial fractions for each medium were added to produce a sum of fractions.

Exposures from the aquatic pathway may be assumed to be less than the aquatic dose limit from DOE Order 458.1 if the sum of fractions for the water medium plus that for the sediment medium is less than 1.0. Similarly, exposures from the terrestrial pathway may be assumed to be less than the proposed dose limits for both terrestrial plants and animals if the sum of fractions for the water medium plus that for the soil medium is less than 1.0.

It was found that the isotopes with the highest sums of fractions, the radionuclides that contributed the largest component of both aquatic and terrestrial dose to biota were strontium-90 and cesium-137. Per guidance in DOE-STD-1153-2002, the populations of organisms most

TABLE 3-4

2012 Evaluation of Dose to Aquatic and Terrestrial Biota

\begin{tabular}{|c|c|c|c|c|c|c|c|}
\hline \multicolumn{8}{|c|}{ AQUATIC SYSTEM EVALUATION } \\
\hline Nuclide & $\begin{array}{l}\text { Water } \\
\text { BCG }^{a} \\
\text { (pCi/L) }\end{array}$ & $\begin{array}{l}\text { Mean } \\
\text { Water } \\
\text { Value } \\
\text { (pCi/L) }\end{array}$ & Ratio & $\begin{array}{c}\text { Sediment } \\
\text { BCG }^{a} \\
\text { (pCi/g) }\end{array}$ & $\begin{array}{c}\text { Mean } \\
\text { Sediment } \\
\text { Value } \\
\text { (pCi/g) }\end{array}$ & Ratio & $\begin{array}{c}\text { Water and } \\
\text { Sediment Sum } \\
\text { of Fractions }\end{array}$ \\
\hline Cesium-137 & 42.7 & 2.61 & $6.11 \mathrm{E}-02$ & 3,130 & 5.49 & $1.76 \mathrm{E}-03$ & 0.063 \\
\hline Strontium-90 & 279 & 23.3 & $8.34 \mathrm{E}-02$ & 583 & 11.7 & $2.01 \mathrm{E}-02$ & 0.104 \\
\hline All Others & NA & NA & $4.68 \mathrm{E}-04$ & NA & NA & $4.72 \mathrm{E}-04$ & 0.001 \\
\hline \multicolumn{3}{|c|}{ Sum of Fractions } & $1.45 \mathrm{E}-01$ & & & $2.23 \mathrm{E}-02$ & 0.167 \\
\hline \multicolumn{8}{|c|}{ Estimated upper bounding dose to an aquatic animal $=0.0050 \mathrm{rad} / \mathrm{day}$; to a riparian animal $=0.017 \mathrm{rad} / \mathrm{day}$. } \\
\hline \multicolumn{8}{|c|}{ TERRESTRIAL SYSTEM EVALUATION } \\
\hline Nuclide & $\begin{array}{l}\text { Water } \\
\text { BCG }^{a} \\
(p C i / L)\end{array}$ & $\begin{array}{l}\text { Mean } \\
\text { Water } \\
\text { Value } \\
\text { (pCi/L) }\end{array}$ & Ratio & $\begin{array}{l}\text { Soil BCG }^{a} \\
\quad(p C i / g)\end{array}$ & $\begin{array}{c}\text { Mean Soil } \\
\text { Value } \\
\text { (pCi/g) }\end{array}$ & Ratio & $\begin{array}{c}\text { Water and Soil } \\
\text { Sum of } \\
\text { Fractions }\end{array}$ \\
\hline Cesium-137 & 599,000 & 2.61 & $4.36 \mathrm{E}-06$ & 20.8 & 4.57 & $2.20 \mathrm{E}-01$ & 0.220 \\
\hline Strontium-90 & 54,500 & 23.3 & 4.27E-04 & 22.5 & 5.16 & $2.30 \mathrm{E}-01$ & 0.230 \\
\hline All Others & NA & NA & $1.48 \mathrm{E}-06$ & NA & NA & $8.15 E-04$ & 0.001 \\
\hline \multicolumn{3}{|c|}{ Sum of Fractions } & $4.33 \mathrm{E}-04$ & & & $4.51 \mathrm{E}-01$ & 0.451 \\
\hline
\end{tabular}

NA - Not applicable

${ }^{a}$ The biota concentration guides (BCGs) are calculated values. Except for the sums of fractions and dose estimates, which are rounded to two signficant digits, all values are expressed to three signficant digits. 
sensitive to strontium-90 and cesium-137 in this evaluation; i.e., those most likely to be adversely affected via the aquatic and terrestrial pathways, were determined to be populations of riparian animals (such as the raccoon [aquatic dose]) and terrestrial animals (such as the deer mouse [terrestrial dose]). Populations of both animals are found on the WNYNSC.

In accordance with the graded approach described in DOE-STD-1153-2002, a general screening was first conducted using the maximum radionuclide concentrations from surface waters, sediments, and soils. Maximum radionuclide concentrations exceeded applicable BCG limits for both aquatic and terrestrial evaluations.

As recommended in DOE-STD-1153-2002, a site-specific screening was then done using estimates of average radionuclide concentrations derived from measurements in site-wide surface waters, sediments, and soils. Results are summarized in Table 3-4.

At the site-specific screening level, the sums of fractions for the aquatic and terrestrial evaluations were 0.167 and 0.451 , respectively. The sum of fractions for each assessment was less than 1.0, indicating that applicable BCGs were met for both the aquatic and terrestrial evaluations.

Upper bounding doses associated with the aquatic system evaluation were $0.0050 \mathrm{rad} /$ day to an aquatic animal and $0.017 \mathrm{rad} /$ day to a riparian animal, far below the 1 $\mathrm{rad} /$ day standard from DOE Order 458.1 for dose to a native aquatic animal. Upper bounding doses associated with the terrestrial system evaluation were $0.0036 \mathrm{rad} /$ day to a terrestrial animal and $0.045 \mathrm{rad} /$ day to a terrestrial plant, again well below the guidance thresholds $(0.1$ and $1 \mathrm{rad} /$ day, respectively).

It was therefore concluded that populations of aquatic and terrestrial biota (both plants and animals) on the WNYNSC are not being exposed to doses in excess of the existing DOE dose standard for native aquatic animals (DOE, February 1990) and the international standards for terrestrial organisms (International Atomic Energy Agency (IAEA), 1992).

\section{Summary}

Tables 3-2, 3-3, and 3-4 summarize radiological dose and release information for CY 2012.

Predictive computer modeling of airborne and waterborne releases resulted in estimated hypothetical doses to the maximally exposed individual that were orders of magnitude below all applicable EPA standards and DOE Orders that place limitations on the release of radioactive materials and dose to individual members of the public. The collective population dose was also assessed and found to be orders of magnitude below the natural background radiation dose. Additionally, estimates indicated that populations of biota at the WVDP are exposed at a fraction of DOE and IAEA guidelines for dose to biota.

Based on the overall dose assessment, the WVDP was found to be in compliance with applicable effluent radiological guidelines and standards during CY 2012. 
This page intentionally left blank 


\section{GROUNDWATER PROTECTION PROGRAM}

\section{Groundwater Monitoring Program (GMP)}

The GMP at the WVDP has been designed to comply with all applicable state and federal regulations and to meet the requirements of DOE Order 458.1, "Radiation Protection of the Public and the Environment," (including Change 2, June 6, 2011) and the RCRA $\S 3008$ (h) Administrative Order on Consent.

DOE Order 458.1, Section 4.i.2, states that "Groundwater must be protected from radiological contamination to ensure compliance with dose limits in the Consent Order and consistent with ALARA process requirements. To this end, DOE must ensure that: baseline conditions of the groundwater quality are documented; possible sources of, and potential for, radiological contamination are identified and assessed; strategies to control radiological contamination are documented and implemented; monitoring methodologies are documented and implemented; and groundwater monitoring activities are integrated with other environmental monitoring activities."

Compliance with the Consent Order and the conclusions in the RFI reports require routine monitoring of certain analytes at specified groundwater monitoring locations. (See the "RCRA 3008(h) Administrative Order on Consent" and the "RFI" section of the ECS.)

Environmental Surveillance. The WVDP EMS (Chapter 1) includes requirements for environmental monitoring to detect and evaluate changes in the environment resulting from Project, or pre-Project, activities and for assessing the effect of such changes on the public and the environment, including changes due to groundwater contamination. The WVDP EMS also implements a sitewide approach for groundwater protection; the "WVDP Groundwater Protection Management Program Plan" documents the Project's approach for groundwater protection from site activities.

The primary objectives of the groundwater monitoring plan are to identify, delineate, and monitor groundwater migration pathways that could transport contaminants off site and to support mitigative actions. To accomplish these goals, the GMP describes a groundwater monitoring well network designed to monitor groundwater conditions in subsurface geologic units that represent potential routes of contaminant migration. For a description of these geologic units refer to "Geology and Hydrogeology" later in this chapter.

Groundwater Use and History. Site groundwater is not used for drinking or operational purposes, nor is WVDP effluent discharged directly to groundwater. The majority of site groundwater eventually flows to Cattaraugus Creek and then to Lake Erie. Surveys have determined that no public water supplies are drawn from groundwater downgradient of the site or from Cattaraugus Creek downstream of the WVDP. However, upgradient of the site, groundwater is used as a public and private drinking water supply by local residents.

Highlights of the site groundwater monitoring history and the evolution of the GMP are summarized in Table 4-1. Groundwater monitoring to evaluate the performance of the full-scale PTW installed in November 2010 on the north plateau is discussed in detail later in this chapter.

\section{Geology and Hydrogeology}

The WNYNSC is situated upon a layered sequence of glacial-age sediments that fill a steep-sided bedrock valley composed of interbedded shales and siltstones (Rickard, 1975). (See Figure 4-1.) Erdman Brook bisects the WVDP into the north and south plateaus. The MPPB, WTF, and lagoons are located on the north plateau. The drum cell, NDA, and SDA are located on the south plateau. (See Figure A-1.)

The glacial sediments overlying the bedrock consist of a sequence of three silt- and clay-rich glacial tills of Lavery, Kent, and possibly Olean age. The tills are separated by stratified fluvio-lacustrine deposits (silty or silty/sandy lakebed sediments). The glacial sediments above the Kent till, which include the Kent recessional sequence, the WLT and unweathered Lavery till, the intra-Lavery till-sand, and the alluvial sand and gravel $(S \& G)$ unit, are generally regarded as the predominant routes for contaminant 
TABLE 4-1

Highlights of Groundwater Monitoring History at the WVDP and the WNYNSC

\begin{tabular}{|c|c|}
\hline Year & Highlight \\
\hline 1961-1980 & $\begin{array}{l}\text { From the time the WNYNSC was established in 1961, to passage of the WVDP Act in 1980, groundwater at } \\
\text { the WVDP was periodically sampled by NFS, the New York Geological Society, and the United States } \\
\text { Geological Survey during construction of the MPPB, for spill investigations, and for post-NFS research } \\
\text { studies. }\end{array}$ \\
\hline 1982 & Groundwater monitoring at the WVDP began in 1982 under DOE and the site subcontractor, WVNS. \\
\hline 1984 & By 1984, 40 wells provided groundwater monitoring coverage near the MPPB and the NDA. \\
\hline 1986 & Additional wells were installed to supplement the existing groundwater monitoring network. \\
\hline 1990-1991 & $\begin{array}{l}\text { Ninety-six wells were installed upgradient and downgradient of the WVDP SWMUs for DOE and RCRA } \\
\text { monitoring programs. (The total included wells at the SDA area). }\end{array}$ \\
\hline 1992 & The RCRA 3008(h) Order on Consent was signed. \\
\hline 1993 & $\begin{array}{l}\text { Elevated gross beta activity was discovered in groundwater from the sand and gravel (S\&G) unit on the } \\
\text { north plateau. Subsequent investigation delineated a plume of strontium-90-contaminated groundwater } \\
\text { originating beneath the MPPB, extending northeast. }\end{array}$ \\
\hline 1993-1994 & $\begin{array}{l}\text { An RFI expanded characterization program was conducted to assess potential releases of hazardous } \\
\text { constituents from on-site SWMUs. Results from the RFI influenced decisionmaking for the groundwater } \\
\text { monitoring program (GMP). }\end{array}$ \\
\hline 1994 & $\begin{array}{l}\text { A Geoprobe }{ }^{\circledast} \text { investigation of groundwater and soil beneath and downgradient of the MPPB was } \\
\text { performed to characterize the elevated gross beta activity in the S\&G unit. The presumed source was } \\
\text { found to be near the southwest corner of the MPPB. The primary isotopes responsible for the beta activity } \\
\text { were strontium- } 90 \text { and its daughter product yttrium- } 90 \text {. }\end{array}$ \\
\hline 1995 & $\begin{array}{l}\text { The GMP was evaluated and analytical constituents were tailored to each sampling point for a more } \\
\text { focused and cost-effective program. The NPGRS was installed near the leading edge of the main lobe of } \\
\text { the strontium-90 plume to minimize migration, which consisted of three extraction wells to recover } \\
\text { groundwater for treatment by ion exchange. }\end{array}$ \\
\hline 1996 & $\begin{array}{l}\text { Several groundwater seeps on the northeast edge of the north plateau were added to the monitoring } \\
\text { program. }\end{array}$ \\
\hline 1997 & $\begin{array}{l}\text { A Geoprobe }{ }^{\circledast} \text { soil and groundwater sampling program was conducted to delineate the leading edge of the } \\
\text { strontium- } 90 \text { plume. }\end{array}$ \\
\hline 1998 & $\begin{array}{l}\text { In response to recommendations from a } 1997 \text { external review of WVDP actions regarding the north } \\
\text { plateau, another Geoprobe }{ }^{\circledR} \text { soil and groundwater sampling program was carried out to further } \\
\text { characterize the core area of the plume. The new radiological data were compared to the } 1994 \text { data. }\end{array}$ \\
\hline 1999 & $\begin{array}{l}\text { A pilot-scale PTW was installed in the eastern lobe of the plume to test this passive in-situ remediation } \\
\text { technology. Well points were installed near the pilot-scale PTW. }\end{array}$ \\
\hline 2000-2001 & $\begin{array}{l}\text { Additional wells and well points were installed across the leading edge of the strontium-90 plume to } \\
\text { monitor the plume's movement and assess the effectiveness of the pilot PTW. }\end{array}$ \\
\hline 2003 & $\begin{array}{l}\text { Four new wells were installed to monitor groundwater upgradient and downgradient of the newly } \\
\text { constructed RHWF. }\end{array}$ \\
\hline 2005 & Number of analytes or sampling frequencies were reduced at 14 groundwater monitoring wells. \\
\hline 2007 & $\begin{array}{l}\text { The GMP was evaluated, considering current site conditions, activities, and environmental exposure } \\
\text { pathways. The analytes and sampling frequencies at } 20 \text { monitoring points were reduced and sampling at } \\
\text { four wells was discontinued. Off-site drinking water sampling was also discontinued after an evaluation of } \\
\text { historical data had confirmed that site operations had no impact on off-site downgradient groundwater. }\end{array}$ \\
\hline 2008 & $\begin{array}{l}\text { Two replacement wells, and } 21 \text { piezometers, were installed near the NDA during installation of a slurry } \\
\text { wall and geomembrane cover at the NDA. On the north plateau, three subsurface investigations were } \\
\text { performed upgradient, within, and downgradient of the strontium-90 plume. }\end{array}$ \\
\hline 2010 & $\begin{array}{l}\text { An approximately } 860 \text {-ft-long full-scale PTW was installed along the leading edges of the strontium-90 } \\
\text { plume. Sixty-six groundwater monitoring wells were installed upgradient, downgradient, and within the } \\
\text { PTW to monitor wall performance. Four new wells were installed downgradient of the MPPB to } \\
\text { supplement the strontium-90 source area monitoring. }\end{array}$ \\
\hline 2011-2012 & $\begin{array}{l}\text { Groundwater monitoring continued throughout CY } 2011 \text { and } 2012 \text { per the GMP, the "North Plateau } \\
\text { Groundwater Monitoring Plan," and the "North Plateau PTW Performance Monitoring Plan." There were } \\
\text { no changes to the programs and no wells were installed or decommissioned in } 2011 \text { or } 2012 .\end{array}$ \\
\hline
\end{tabular}


FIGURE 4-1

Geologic Cross Sections of the North and South Plateaus at the WVDP

J:/GIS/ArcMap/ASER/ASER 2010/ASER 2010 Fig4-1 20110602.mxd FJC/skw
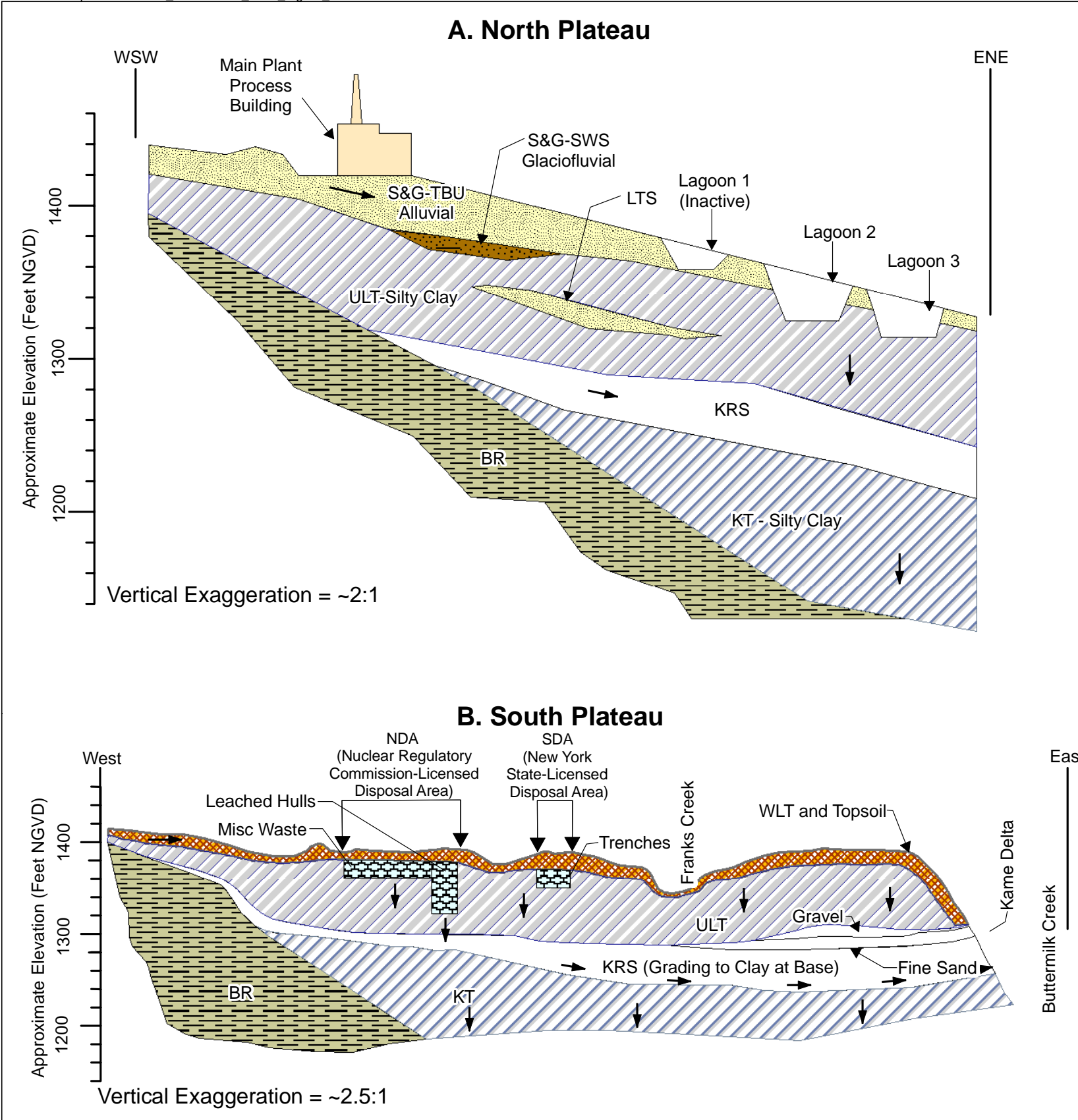

\section{Legend}

S\&G-TBU Sand and Gravel - Thick-Bedded Unit KT S\&G-SWS Sand and Gravel - Slackwater Sequence LTS

WLT

ULT

KRS
Lavery Till Sand

Weathered Lavery Till

Unweathered Lavery Till

Kent Recessional Sequence

\begin{tabular}{ll} 
KT & Kent Till \\
BR & Shale Bedrock \\
\hline ENE & Conceptual Groundwater Flow Direction \\
WSW & East-Northeast \\
(NGVD - National Geodetic Vertical Datum)
\end{tabular}

(NGVD - National Geodetic Vertical Datum) 
migration from the Project via groundwater. The Kent till has a relatively low permeability and does not provide a pathway for contaminant movement from the WVDP; therefore, it is not discussed here. The S\&G unit consists of two subunits: the thick-bedded unit and the slackwater sequence. It only exists on the Project's north plateau. See Table 4-2 for the descriptions and the geographic distribution of these units.

\section{Routine GMP}

Groundwater Monitoring Network. The WVDP groundwater monitoring network is a vital component to meet requirements of DOE Order 458.1. Groundwater is routinely monitored across the north and south plateaus and in the six hydrogeologic units described in Table 4-2. In CY 2012, groundwater samples were collected from 69 on -site, routine groundwater monitoring locations, including 63 monitoring wells and well points, five groundwater seepage points, and one trench sump (see Figures A-8 and A-9). Many of the wells monitor one or more of the SWMUs or SSWMUs per the Consent Order. Table 4-3 lists the wells in the routine groundwater monitoring network, the geologic units monitored, and the analytes measured in CY 2012. Table 4-4 identifies the analytical parameters defined in each analyte group.

The monitoring frequency and the constituents analyzed under the groundwater monitoring plan are a function of regulatory requirements, historical site activities, current operating practices, and ongoing groundwater data evaluations. Tables 4-5 and 4-6 provide an overview of groundwater monitoring performed during CY 2012, organized by geographic area and monitoring purpose.

Supplemental groundwater monitoring is also performed for evaluation of the PTW and the north plateau strontium-90 groundwater plume discussed later in this chapter.

Groundwater Elevation Monitoring. Groundwater elevations are measured at the monitoring network wells in conjunction with the quarterly analytical sampling. (See Figures A-8 and A-9 in Appendix A.) These data are used to produce maps depicting groundwater flow directions and gradients. Long-term trend graphs are used to illustrate variations in groundwater elevations over time, including seasonal fluctuations or changes resulting from installing water diversions, such as geomembrane covers, trenches, or slurry walls, and groundwater treatment systems (e.g., the north plateau pumping wells and the full-scale PTW).
Groundwater elevation mapping of the WLT on the south plateau helps evaluate the effectiveness of the NDA interceptor trench, the slurry wall, and geomembrane cover. (See "Groundwater Sampling Observations on the South Plateau: WLT and the NDA.")

Groundwater Trigger Level Evaluation. A computerized data-screening program uses "trigger levels," preset conservative values for chemical and radiological concentrations and groundwater elevation measurements, to promptly identify anomalies in monitoring results that may require further investigation. The trigger levels are statistically derived from historical results, are based on regulatory criteria, or are based on analytical detection limits.

Trigger level exceptions, defined as measurements above an upper trigger level or below a lower trigger level, may be the result of normal seasonal fluctuations, laboratory analytical problems, or changes in groundwater quality. Response actions are identified for each analytical result exceeding a trigger level. After each sampling event, the current trigger level exceptions are compiled, evaluated, and summarized with recommended response actions. RCRA trigger level exceptions are reported to NYSDEC.

In August 2012, groundwater trigger levels for selected chemical and radiological constituents were recalculated to incorporate data collected through December 2011. Trigger levels in areas that have seen a process change were calculated only on data that was collected after the change occurred. A process change may affect the analytical results collected from a monitoring location by altering the underlying physical conditions that are monitored at that sampling point. The upgradient NDA slurry wall and geomembrane cover installed in 2008 as an IM is an example of a process change that significantly altered the hydrogeologic conditions at monitoring points located on and downgradient of the NDA. The geomembrane cover and slurry wall have decreased water infiltration and migration into the NDA, which changes water levels in and downgradient of the NDA.

Groundwater Screening Levels (GSLs). In 2009, GSLs were developed during the CMS preparations as a tool to identify the presence of chemical and radiological constituents in groundwater above levels of concern (e.g., regulatory limits, guidance limits, or background). Methods used to develop the GSLs are discussed in detail in Appendix D. Analytical groundwater sampling results for 2012 were compared with applicable GSLs and background 
TABLE 4-2

Summary of Hydrogeology at the WVDP

\begin{tabular}{|c|c|c|c|c|}
\hline Geologic Unit & Description & $\begin{array}{c}\text { Groundwater Flow } \\
\text { Characteristics }\end{array}$ & $\begin{array}{c}\text { Hydraulic } \\
\text { Conductivity }^{a}\end{array}$ & Location \\
\hline $\begin{array}{l}\text { S\&G; Thick- } \\
\text { Bedded Unit } \\
\text { (TBU) }\end{array}$ & $\begin{array}{l}\text { Silty sand and gravel layer } \\
\text { composed of younger } \\
\text { Holocene alluvial deposits }\end{array}$ & $\begin{array}{l}\text { Flow is generally northeast } \\
\text { across the plateau toward } \\
\text { Franks Creek, with } \\
\text { groundwater near the } \\
\text { northwestern and } \\
\text { southeastern margins } \\
\text { flowing radially outward } \\
\text { toward Quarry Creek and } \\
\text { Erdman Brook. }\end{array}$ & $\begin{array}{l}9 \mathrm{ft} / \mathrm{day} \\
(3.2 \mathrm{E}-03 \text { centimeters } \\
[\mathrm{cm}] / \text { second }[\mathrm{sec}])\end{array}$ & $\begin{array}{l}\text { Surficial unit on the } \\
\text { north plateau }\end{array}$ \\
\hline $\begin{array}{c}\text { S\&G; } \\
\text { Slackwater } \\
\text { Sequence } \\
\text { (SWS) }\end{array}$ & $\begin{array}{l}\text { Interbedded silty sand and } \\
\text { gravel layers composed of } \\
\text { Pleistocene-age } \\
\text { glaciofluvial deposits } \\
\text { partially separated from } \\
\text { the S\&G-TBU by a } \\
\text { discontinuous silty clay } \\
\text { interval }\end{array}$ & $\begin{array}{l}\text { Flow is to the northeast } \\
\text { along gravel layers toward } \\
\text { Franks Creek. }\end{array}$ & $\begin{array}{l}17 \mathrm{ft} / \mathrm{day} \\
(5.9 \mathrm{E}-03 \mathrm{~cm} / \mathrm{sec})\end{array}$ & $\begin{array}{l}\text { Underlies a portion } \\
\text { of the north } \\
\text { plateau }\end{array}$ \\
\hline $\begin{array}{l}\text { Weathered } \\
\text { Lavery Till }\end{array}$ & $\begin{array}{l}\text { Upper zone of the Lavery } \\
\text { till which has been } \\
\text { exposed at the ground } \\
\text { surface; weathered and } \\
\text { fractured to a depth of } \\
3-16 \mathrm{ft}(0.9-4.9 \mathrm{~m}) \text {; brown } \\
\text { in color due to oxidation; } \\
\text { contains numerous } \\
\text { desiccation cracks and root } \\
\text { tubes }\end{array}$ & $\begin{array}{l}\text { Flow has both horizontal } \\
\text { and vertical components } \\
\text { allowing groundwater to } \\
\text { move laterally across the } \\
\text { south plateau before } \\
\text { moving downward into the } \\
\text { unweathered lavery till or } \\
\text { discharging to nearby } \\
\text { incised stream channels. }\end{array}$ & $\begin{array}{l}0.07 \mathrm{ft} / \mathrm{day} \\
(2.4 \mathrm{E}-05 \mathrm{~cm} / \mathrm{sec}) \\
\text { the highest } \\
\text { conductivities are } \\
\text { associated with } \\
\text { dense fracture zones } \\
\text { found within the } \\
\text { upper } 7 \mathrm{ft}(2 \mathrm{~m}) \text { of } \\
\text { the unit }\end{array}$ & $\begin{array}{l}\text { Surficial unit on the } \\
\text { south plateau }\end{array}$ \\
\hline $\begin{array}{c}\text { Unweathered } \\
\text { Lavery Till }\end{array}$ & $\begin{array}{l}\text { Olive gray silty clay with } \\
\text { intermittent lenses of silt } \\
\text { and sand; ranges up to } 130 \\
\mathrm{ft}(40 \mathrm{~m}) \text { in thickness }\end{array}$ & $\begin{array}{l}\text { Flow is vertically } \\
\text { downward at a relatively } \\
\text { slow rate; unit is } \\
\text { considered an aquitard. }\end{array}$ & $\begin{array}{l}0.002 \mathrm{ft} / \mathrm{day} \\
(8.1 \mathrm{E}-07 \mathrm{~cm} / \mathrm{sec})\end{array}$ & $\begin{array}{l}\text { Underlies both the } \\
\text { north and south } \\
\text { plateaus }\end{array}$ \\
\hline Lavery Till Sand & $\begin{array}{l}\text { Thin, sandy unit of limited } \\
\text { areal extent and variable } \\
\text { thickness within the Lavery } \\
\text { till. }\end{array}$ & $\begin{array}{l}\text { Flow is to the east- } \\
\text { southeast toward Erdman } \\
\text { Brook. }\end{array}$ & $\begin{array}{l}0.2 \mathrm{ft} / \mathrm{day} \\
(8.6 \mathrm{E}-05 \mathrm{~cm} / \mathrm{sec})\end{array}$ & $\begin{array}{l}\text { Primarily beneath } \\
\text { the southeastern } \\
\text { portion of the } \\
\text { north plateau }\end{array}$ \\
\hline $\begin{array}{c}\text { Kent } \\
\text { Recessional } \\
\text { Sequence }\end{array}$ & $\begin{array}{l}\text { Interbedded clay and silty } \\
\text { clay layers locally overlain } \\
\text { by coarser-grained sands } \\
\text { and gravels; pinches out } \\
\text { near the east side of Rock } \\
\text { Springs Road }\end{array}$ & $\begin{array}{l}\text { Flow is to the northeast; } \\
\text { recharge from the } \\
\text { overlying till and from } \\
\text { bedrock to the southwest; } \\
\text { discharges into Buttermilk } \\
\text { Creek. }\end{array}$ & $\begin{array}{l}0.01 \mathrm{ft} / \mathrm{day} \\
(4.3 \mathrm{E}-06 \mathrm{~cm} / \mathrm{sec})\end{array}$ & $\begin{array}{l}\text { Underlies most of } \\
\text { the Project, except } \\
\text { areas adjacent to } \\
\text { Rock Springs Road }\end{array}$ \\
\hline
\end{tabular}

Note: Hydrologic conditions of the site are more fully described in "Environmental Information Document,

Volume III: Hydrology, Part 4" (West Valley Nuclear Services Co. [WVNSCO], March 1996) and in the "RCRA

Facility Investigation Report (RFI) Vol. 1: Introduction and General Site Overview" (WVNSCO and Dames \&

Moore, July 1997).

${ }^{a}$ Hydraulic conductivities represent an average of testing results from 1991 through 2012. 
TABLE 4-3

WVDP Groundwater Monitoring Network Sorted by Geologic Unit

\begin{tabular}{|c|c|c|c|c|c|c|c|}
\hline Well ID & SSWMU & $\begin{array}{l}\text { Gradient } \\
\text { Position }\end{array}$ & $\begin{array}{l}\text { Analyte Group } \\
\text { (See Table 4-4) }\end{array}$ & Well ID & SSWMU & $\begin{array}{l}\text { Gradient } \\
\text { Position }\end{array}$ & $\begin{array}{l}\text { Analyte Group } \\
\text { (See Table 4-4) }\end{array}$ \\
\hline \multicolumn{8}{|c|}{ Sand and Gravel Wells } \\
\hline $103^{a}$ & 1,3 & $\mathrm{D}$ & $\mathrm{I}, \mathrm{RI}, \mathrm{V}$ & $803^{a}$ & 8 & $\mathrm{D}$ & $\mathrm{I}, \mathrm{RI}, \mathrm{SV}, \mathrm{V}$ \\
\hline 104 & 1 & $\mathrm{C}$ & $\mathrm{I}, \mathrm{RI}$ & $804^{a}$ & 8 & $\mathrm{D}$ & $\mathrm{I}, \mathrm{RI}, \mathrm{V}$ \\
\hline 105 & 1 & $\mathrm{C}$ & $\mathrm{I}, \mathrm{RI}$ & $1302^{b}$ & NA & $\mathrm{U}$ & $\mathrm{I}, \mathrm{RI}, \mathrm{M}$ \\
\hline 106 & 1 & $\mathrm{D}$ & $\mathrm{I}, \mathrm{RI}$ & $1304^{b}$ & NA & $\mathrm{U}$ & $\mathrm{I}, \mathrm{RI}, \mathrm{M}, \mathrm{R}$ \\
\hline $111^{a}$ & 1 & $\mathrm{D}$ & $\mathrm{I}, \mathrm{RI}, \mathrm{M}, \mathrm{SV}, \mathrm{V}$ & 8603 & 8 & $\mathrm{U}$ & $\mathrm{I}, \mathrm{RI}$ \\
\hline $116^{a}$ & 1,8 & $C, U$ & $\mathrm{I}, \mathrm{RI}, \mathrm{V}$ & 8604 & 1 & $\mathrm{C}$ & $\mathrm{I}, \mathrm{RI}$ \\
\hline 205 & 2 & $\mathrm{D}$ & $\mathrm{I}, \mathrm{RI}$ & $8605^{a}$ & 1,2 & $\mathrm{D}$ & $\mathrm{I}, \mathrm{RI}, \mathrm{M}, \mathrm{SV}, \mathrm{V}$ \\
\hline $301^{a}$ & 3 & $B, U$ & $\mathrm{I}, \mathrm{RI}$ & $8607^{a}$ & 4,6 & $\mathrm{D}, \mathrm{U}$ & $\mathrm{I}, \mathrm{RI}, \mathrm{V}$ \\
\hline 302 & 3 & $U$ & $\mathrm{I}, \mathrm{RI}$ & $8609^{a}$ & $3,4,6$ & $D, D, U$ & $\mathrm{I}, \mathrm{RI}, \mathrm{S}, \mathrm{V}$ \\
\hline $401^{a}$ & 3,4 & $\mathrm{~B}, \mathrm{U}$ & $\mathrm{I}, \mathrm{RI}, \mathrm{R}$ & $8612^{a}$ & 8 & $\mathrm{D}$ & $\mathrm{I}, \mathrm{RI}, \mathrm{SV}, \mathrm{V}$ \\
\hline 402 & 4 & $U$ & $\mathrm{I}, \mathrm{RI}$ & $\mathrm{MP}-01^{a}$ & 3 & $\mathrm{D}$ & $\mathrm{I}, \mathrm{RI}, \mathrm{M}, \mathrm{R}-\mathrm{MP}, \mathrm{SV}, \mathrm{V}, \mathrm{T}$ \\
\hline 403 & 4 & $U$ & $\mathrm{I}, \mathrm{RI}$ & $\mathrm{MP}-02^{a}$ & 3 & $\mathrm{D}$ & $\mathrm{I}, \mathrm{RI}, \mathrm{M}, \mathrm{R}-\mathrm{MP}, \mathrm{SV}, \mathrm{V}, \mathrm{T}$ \\
\hline $406^{a}$ & 4,6 & $\mathrm{D}, \mathrm{U}$ & $\mathrm{I}, \mathrm{RI}, \mathrm{R}, \mathrm{V}$ & $\mathrm{MP}-03^{a}$ & 3 & $\mathrm{D}$ & $\mathrm{I}, \mathrm{RI}, \mathrm{M}, \mathrm{R}-\mathrm{MP}, \mathrm{SV}, \mathrm{V}, \mathrm{T}$ \\
\hline $408^{a}$ & 3,4 & $\mathrm{D}$ & $\mathrm{I}, \mathrm{RI}, \mathrm{R}, \mathrm{V}$ & $\mathrm{MP}-04^{a}$ & 3 & $\mathrm{D}$ & $\mathrm{I}, \mathrm{RI}, \mathrm{M}, \mathrm{R}-\mathrm{MP}, \mathrm{SV}, \mathrm{V}, \mathrm{T}$ \\
\hline $501^{a}$ & 5 & $\mathrm{U}$ & $\mathrm{I}, \mathrm{RI}, \mathrm{S}, \mathrm{V}$ & $W P-A^{c}$ & NA & NA & $\mathrm{I}, \mathrm{RI}$ \\
\hline $502^{a}$ & 5 & $\bar{D}$ & $\mathrm{I}, \mathrm{RI}, \mathrm{S}, \mathrm{SM}, \mathrm{V}$ & $W P-C^{c}$ & NA & NA & $\mathrm{I}, \mathrm{RI}$ \\
\hline $602 \mathrm{~A}$ & 6 & $\mathrm{D}$ & $\mathrm{I}, \mathrm{RI}$ & $W P-H^{c}$ & NA & NA & $\mathrm{I}, \mathrm{RI}$ \\
\hline 604 & 6 & $\mathrm{D}$ & $\mathrm{I}, \mathrm{RI}$ & $\mathrm{SPO4}^{d}$ & NA & NA & $\mathrm{RI}$ \\
\hline 605 & 6 & $\mathrm{D}$ & $\mathrm{I}, \mathrm{RI}$ & $\mathrm{SPO6}^{d}$ & NA & NA & $\mathrm{RI}$ \\
\hline $706^{a}$ & 7 & $B, D$ & $\mathrm{I}, \mathrm{RI}, \mathrm{M}$ & $\mathrm{SP} 11^{d}$ & NA & NA & $\mathrm{RI}$ \\
\hline $801^{a}$ & 6,8 & $U, D$ & $\mathrm{I}, \mathrm{RI}, \mathrm{S}, \mathrm{V}$ & $\mathrm{SP} 12^{a, d}$ & 8 & $\mathrm{D}$ & $\mathrm{I}, \mathrm{RI}, \mathrm{V}$ \\
\hline 802 & 8 & $\mathrm{D}$ & $\mathrm{I}, \mathrm{RI}, \mathrm{V}$ & GSEEP $^{a, d}$ & 8 & C, D & $\mathrm{I}, \mathrm{RI}, \mathrm{V}$ \\
\hline \multicolumn{8}{|c|}{ Lavery Till Sand Wells } \\
\hline $204^{a}$ & 2,3 & $\mathrm{D}$ & $\mathrm{I}, \mathrm{RI}$ & 206 & 2 & $\mathrm{C}$ & $\mathrm{I}, \mathrm{RI}$ \\
\hline \multicolumn{8}{|c|}{ Weathered Lavery Till Wells } \\
\hline $906^{a}$ & 9 & $\mathrm{D}$ & $\mathrm{I}, \mathrm{RI}$ & $1005^{a}$ & 9,10 & $\mathrm{C}, \mathrm{U}$ & $\mathrm{I}, \mathrm{RI}$ \\
\hline $908 \mathrm{R}^{a}$ & 9 & $\mathrm{~B}, \mathrm{U}$ & $\mathrm{I}, \mathrm{RI}$ & $1006^{a}$ & 9,10 & C, D & $\mathrm{I}, \mathrm{RI}$ \\
\hline $909^{a}$ & 9 & $\mathrm{D}$ & $\mathrm{I}, \mathrm{RI}, \mathrm{M}, \mathrm{R}, \mathrm{SV}, \mathrm{V}$ & $1008 C^{a}$ & 9,10 & $\mathrm{~B}, \mathrm{U}$ & $\mathrm{I}, \mathrm{RI}$ \\
\hline NDATR $^{a}$ & 9 & $\mathrm{D}$ & $\mathrm{I}, \mathrm{RI}, \mathrm{M}, \mathrm{R}, \mathrm{SV}, \mathrm{V}$ & & & & \\
\hline \multicolumn{8}{|c|}{ Unweathered Lavery Till Wells } \\
\hline 107 & 1 & $\mathrm{D}$ & $\mathrm{I}, \mathrm{RI}$ & 704 & 7 & $\mathrm{D}$ & $\mathrm{I}, \mathrm{RI}$ \\
\hline 108 & 1 & $\mathrm{D}$ & $\mathrm{I}, \mathrm{RI}$ & 707 & 7 & $\mathrm{C}$ & $\mathrm{I}, \mathrm{RI}$ \\
\hline $110^{a}$ & 1 & $\mathrm{D}$ & $\mathrm{I}, \mathrm{RI}, \mathrm{V}$ & $910 \mathrm{R}^{a}$ & 9 & $\mathrm{D}$ & $\mathrm{I}, \mathrm{RI}$ \\
\hline 405 & 4 & $\mathrm{D}$ & $\mathrm{I}, \mathrm{RI}, \mathrm{M}$ & $1301^{b}$ & NA & $\mathrm{D}$ & $\mathrm{I}, \mathrm{RI}$ \\
\hline 409 & 4 & $\mathrm{D}$ & $\mathrm{I}, \mathrm{RI}$ & $1303^{b}$ & NA & $\mathrm{U}$ & $\mathrm{I}, \mathrm{RI}, \mathrm{M}$ \\
\hline \multicolumn{8}{|c|}{ Kent Recessional Sequence Wells } \\
\hline $901^{a}$ & 9 & $\mathrm{U}$ & $\mathrm{I}, \mathrm{RI}$ & $1008 \mathrm{~B}$ & 10 & $\mathrm{~B}, \mathrm{U}$ & $\mathrm{I}, \mathrm{RI}$ \\
\hline $902^{a}$ & 9 & $\mathrm{U}$ & $\mathrm{I}, \mathrm{RI}$ & $8610^{a}$ & 9 & $\mathrm{D}$ & $\mathrm{I}, \mathrm{RI}$ \\
\hline $903^{a}$ & 9 & $\mathrm{D}$ & $\mathrm{I}, \mathrm{RI}$ & $8611^{a}$ & 9 & $\mathrm{D}$ & $\mathrm{I}, \mathrm{RI}$ \\
\hline
\end{tabular}

Gradient Positions: B (background); C (crossgradient); D (downgradient); U (upgradient)

${ }^{a}$ Monitoring for certain parameters is required by the RCRA $\S 3008(\mathrm{~h})$ Consent Order.

${ }^{\mathrm{b}}$ Monitor upgradient and downgradient of the RHWF.

${ }^{c}$ Monitor north and east of the MPPB.

${ }^{d}$ Monitor groundwater emanating from seeps along the edge of the north plateau. 
TABLE 4-4

WVDP Groundwater Sampling and Analysis Agenda

\begin{tabular}{|c|c|}
\hline Analyte Group & Description of Parameters \\
\hline Indicator Parameters (I) & pH, specific conductance (field measurements) \\
\hline Radiological Indicator Parameters (RI) & Gross alpha, gross beta, tritium \\
\hline Volatile Organic Compounds (V) & 6 NYCRR Part 373-2 Appendix 33 Volatile Organic Compounds \\
\hline Semivolatile Organic Compounds (SV) & $\begin{array}{l}6 \text { NYCRR Part 373-2 Appendix } 33 \text { Semivolatile Organic Compounds } \\
\text { and tributyl phosphate }\end{array}$ \\
\hline Groundwater metals (M) & $\begin{array}{l}6 \text { NYCRR Part 373-2 Appendix } 33 \text { Metals (antimony, arsenic, barium, } \\
\text { beryllium, cadmium, chromium, cobalt, copper, lead, mercury, } \\
\text { nickel, selenium, silver, thallium, vanadium, zinc) }\end{array}$ \\
\hline $\begin{array}{l}\text { Special Monitoring Parameters for early } \\
\text { warning wells (SM) }\end{array}$ & $\begin{array}{l}\text { Aluminum, arsenic, barium, cadmium, chromium, cobalt, copper, } \\
\text { Iron, lead, manganese, mercury, nickel, selenium, silver, vanadium, } \\
\text { zinc }\end{array}$ \\
\hline $\begin{array}{l}\text { Radioisotopic Analyses: alpha-, beta-, and } \\
\text { gamma-emitters (R) }\end{array}$ & $\begin{array}{l}\text { Carbon-14, strontium-90, technetium-99, iodine-129, cesium-137, } \\
\text { radium-226, radium-228, uranium-232, uranium-233/234, uranium- } \\
\text { 235/236, uranium-238, total uranium }\end{array}$ \\
\hline Radioisotopic Analyses MPPB Area (R-MP) & $\begin{array}{l}\text { Carbon-14, potassium-40, cobalt-60, strontium-90, technetium-99, } \\
\text { iodine-129, cesium-137, europium-154, neptunium-237, plutonium- } \\
238 \text {, plutonium-239/240, plutonium-241, uranium-232, uranium- } \\
233 / 234 \text {, uranium-235/236, uranium-238, americium-241, curium- } \\
243 / 244\end{array}$ \\
\hline Strontium-90 (S) & Strontium-90 \\
\hline Turbidity $(\mathrm{T})$ & Turbidity \\
\hline
\end{tabular}

TABLE 4-5

2012 Groundwater Monitoring Overview by Geographic Area ${ }^{\text {a }}$

\begin{tabular}{|l|c|c|c|}
\hline \multicolumn{1}{|c|}{ Number of... } & Total WVDP & North Plateau & South Plateau \\
\hline Monitoring Points Sampled - Analytical & 69 & 55 & 14 \\
\hline Monitoring Points - Water Elevations Only & 73 & 34 & 39 \\
\hline Monitoring Events & 4 & 4 & 4 \\
\hline Analyses (analyses groups) & 1,029 & 872 & 157 \\
\hline Results (individual) & 7,213 & 5,844 & 1,369 \\
\hline Percent of Nondetectable Results & $83 \%$ & $82 \%$ & $87 \%$ \\
\hline Water Elevation Measurements & 536 & 324 & 212 \\
\hline
\end{tabular}

${ }^{\mathrm{a}}$ Does not include PTW monitoring.

TABLE 4-6

WVDP 2012 Groundwater Monitoring Overview by Monitoring Purpose

\begin{tabular}{|l|c|c|c|}
\hline \multicolumn{1}{|c|}{ Number of... } & Total & $\begin{array}{c}\text { Regulatory/ } \\
\text { Waste Management }\end{array}$ & $\begin{array}{c}\text { Environmental } \\
\text { Surveillance }\end{array}$ \\
\hline Monitoring Points Sampled - Analytical & 69 & 38 & 31 \\
\hline Monitoring Points - Water Elevations Only & 73 & 1 & 72 \\
\hline Monitoring Events & 4 & 4 & 4 \\
\hline Analyses (analyses groups) & 1,029 & 704 & 325 \\
\hline Results (individual) & 7,213 & 6,339 & 874 \\
\hline Percent of Nondetectable Results & $83 \%$ & $88 \%$ & $52 \%$ \\
\hline Water Elevation Measurements & 536 & 148 & 388 \\
\hline
\end{tabular}


levels. The results are summarized in Table 4-9 at the end of this chapter.

\section{North Plateau Strontium-90 Plume}

Elevated gross beta has been observed on the north plateau since 1993, and is predominantly confined to the S\&G unit, the shallowest hydrogeologic unit on the north plateau. (See the highlights for 1993 and 1994 in Table 4-1.) The routine groundwater monitoring plan network for the S\&G unit on the north plateau includes 44 monitoring locations, three well points, and five groundwater seepage locations.

In April 2011, DOE issued a new technical standard (DOESTD-1196-2011) that established a revised set of radiological concentration standards for radiological environmental protection programs at DOE facilities and sites. These DCSs were used to evaluate groundwater data collected in 2012. Because there is no DCS for gross beta in liquid effluents, the strontium-90 DCS (1.1E-06 $\mu \mathrm{Ci}$ / $\mathrm{mL}$ ) is used as a conservative basis for comparison where beta-emitting radionuclides are detected in groundwater. Historical monitoring has established that strontium-90 is the most predominant beta emitter found in site groundwater. The strontium-90 concentrations would be expected to be about one-half of the gross beta result because the beta includes strontium-90 and its daughter product, yttrium-90. Therefore, monitoring wells are routinely sampled for gross beta concentrations, supported by periodic sample measurement at select wells for strontium-90 analysis. For the purpose of the following discussions, the strontium-90 DCS is used for comparison with both gross beta and strontium-90. (See the "Useful Information" section for a discussion of DOE DCSs, and Table UI-4 for a list of the DCSs for radionuclides of interest at the WVDP.)

Figure 4-2 shows the extent of the strontium-90 plume as defined by the $1.0 \mathrm{E}-06-\mu \mathrm{Ci} / \mathrm{mL}$ gross beta isopleth, at three time intervals spanning 18 years (1994, 2002, and 2012). As shown, the plume's western boundary has remained relatively constant since 1994, but the plume's northern and eastern extents have spread to the northeast and east. The leading edge has divided into three small lobes because of the variable groundwater flow rate across the north plateau, due to the heterogeneous nature of the sediments within the S\&G unit. The uneven distribution of coarse and fine soils within the subsurface creates preferential pathways for groundwater flow. The GMP wells that monitor the plume and the measured gross beta concentrations are shown on the figure.
Gross beta concentration trends over the last 10 years at monitoring wells located within the plume and near former lagoon 1 are shown on Figures 4-3 through 4-7. These data are plotted on a log scale; therefore, an increase from one gridline to the next represents a 10 -fold increase in concentration. The log scale was used so that data from background locations (with concentrations in the $1.0 \mathrm{E}-09 \mu \mathrm{Ci} / \mathrm{mL}$ range) and data from the central plume (with concentrations in the $1.0 \mathrm{E}-04 \mu \mathrm{Ci} / \mathrm{mL}$ range, 100,000 times higher than background) could be plotted on the same graphs.

Figure 4-3 illustrates the gross beta concentrations in groundwater wells located immediately downgradient of the MPPB, the strontium-90 source area, and along the western edge of the plume (at well 8609). Well 408 and the four MPPB wells (MP-01, -02, -03, and -04, installed in CY 2010), located northeast of the MPPB closest to the source area, exhibit the highest gross beta concentrations (up to $3.48 \mathrm{E}-04 \mu \mathrm{Ci} / \mathrm{mL}$ in June 2012) of any routinely monitored wells in the GMP. Gross beta concentrations, remained relatively stable in CY 2012 at these six monitoring wells directly downgradient of the MPPB.

Figure 4-4 illustrates gross beta concentrations in wells 104, 501, 502, and 8604 centrally located within the plume area. Gross beta concentrations in these wells slightly decreased overall in 2012 compared with 2011.

Figure 4-5 illustrates gross beta concentrations at monitoring wells 105, 116, and 8603, upgradient of the PTW. The gross beta concentrations at these wells in 2012 are similar to the 2011 concentrations. Gross beta concentrations at wells 105 and 8603 decreased slightly whereas the gross beta concentration at well 116 exhibited a slight overall increase in 2012.

Figure 4-6 illustrates gross beta concentrations at monitoring wells $801,803,804$, and 8612 , downgradient of the PTW. The plume's leading edge had migrated past the PTW before it was installed in 2010 as indicated by increases in gross beta activity at wells 803 and 8612 since 2009. Gross beta concentrations at well 804 exhibited a slight increase from 2011 to 2012. Gross beta concentrations at wells 801,803 , and 8612 , also downgradient of the PTW, decreased from 2011 to 2012 . Continued monitoring will determine whether these recent decreases may be an indication of treated groundwater migrating out of the PTW. 


\section{FIGURE 4-2}

North Plateau Strontium-90 Plume Plotted by Beta Data: 1994, 2002, 2012

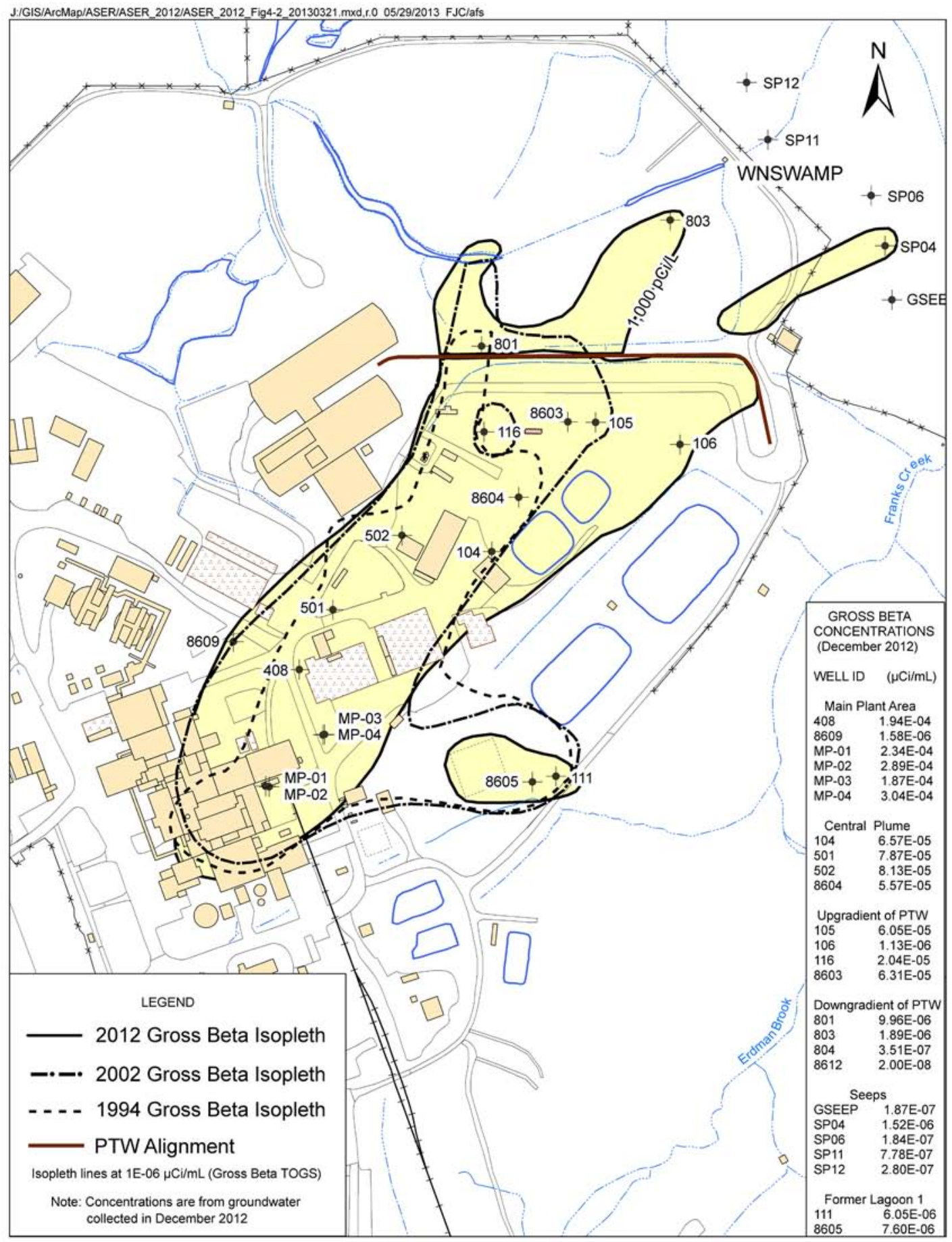


Monitoring at North Plateau Seeps. Groundwater is also monitored along the northeast edge of the north plateau, where it seeps from the steep banks incised by Erdman Brook and Franks Creek. The downgradient seepage locations (GSEEP, SP04, SP06, SP11, and SP12), located east of the CDDL outside of the WVDP fence line, monitor conditions on the edge of the north plateau where groundwater discharges to the surface. (See Figure A-8 in Appendix A.) Ten-year trends of gross beta concentrations at these five seep monitoring points are shown on Figure 4-7. Annual average gross beta concentrations were plotted against surface water background values because water from seepage points occasionally may include surface water (i.e., at seepage location SP11). Annual average concentrations at all five monitored seep locations increased during 2012.

The highest gross beta concentration among the seepage locations has been observed at SP04, which increased to an annual average of $1.46 \mathrm{E}-06-\mu \mathrm{Ci} / \mathrm{mL}$ in 2012 above the DOE DCS for strontium-90 of $1.10 \mathrm{E}-06-\mu \mathrm{Ci} / \mathrm{mL}$. However, the strontium-90 concentrations in the north plateau plume have been demonstrated to be approximately half of the gross beta concentrations, suggesting the DOE DCSs have not been exceeded at the seep locations. The second highest gross beta concentration at the seep sampling locations occurred at SP11, located within the discharge area of the swamp drainage ditch. The annual average 2012 concentration at SP11 represents approximately $57 \%$ of strontium-90 DCS. The gross beta activity detected as SP11 is believed to be the result of contaminated groundwater from the $S \& G$ unit that entered the northeast swamp drainage ditch, and percolated back into the ground.

Monitoring at the Northeast Swamp Drainage. The western and central lobes of the plume are partially intercepted by the northeast swamp drainage ditch flowing west to east across the plume's leading edge (see Figure 4-2 and Figure A-2 in Appendix A). The surface water flow rate in this ditch is measured biweekly. Surface water samples are collected monthly and analyzed for radiological constituents at sampling location WNSWAMP located at the WVDP property boundary. North plateau plume groundwater seeping into this ditch is believed to be the main source of the strontium-90 activity at WNSWAMP. Approximately 13.5 million gal (51 million L) of water flowed through this monitoring point in 2012. (See "Waterborne Effluent Monitoring" in Chapter 2.)

Gross beta and strontium-90 concentrations at WNSWAMP exhibit seasonal variability. As shown on
Figure 4-8, annual average strontium-90 concentrations at WNSWAMP have been close to or above the strontium-90 DCS for nine of the last 10 years. The 2012 average annual strontium-90 concentration shown on Figure 4-8 is a nonflow weighted average. This straight average of monthly concentrations was slightly above the DCSs, while the flow-weighted average shown in Table 2-2 is slightly below the DCS. Both estimates for the annual average strontium-90 at WNSWAMP show a decreasing trend for 2012. The strontium-90 released through WNSWAMP accounted for an annual estimated dose of 8.6E-3 mrem in 2012. See "Maximum Dose (Waterborne) to an Off-Site Individual" in Chapter 3.

Monitoring of surface water downstream of the WVDP at the first point of public access, Felton Bridge on Cattaraugus Creek (location WFFELBR), continued to show that strontium-90 concentrations in 2012 were similar to historical concentrations from the Cattaraugus Creek background surface water location at Bigelow Bridge (WFBIGBR).

\section{Strontium-90 Plume Remediation Activities}

Full-Scale PTW. In November 2010, an 860-ft-long fullscale PTW was installed to treat the north plateau strontium-90 plume. The PTW has operated now for over two full years. The overall average concentrations of strontium-90 immediately downgradient of the PTW are lower than they were when the wall was installed suggesting that the PTW is removing strontium-90 from the groundwater. A map view and cross-section of the PTW installation is shown on Figure 4-9.

The PTW was installed through the entire thickness of the S\&G unit (including the thick-bedded unit and the slackwater sequence, where present), and was keyed into the underlying, low-permeability unweathered Lavery till. Granular clinoptilolite (i.e., zeolite), a natural mineral with a porous structure that traps positively charged ions by ion exchange, including strontium, while allowing the groundwater to pass through, was used in the PTW. A lined storm water drainage ditch (Smart-Ditch ${ }^{\mathrm{TM}}$ ) was also installed in September 2010 south of the PTW to intercept storm water from upland site areas and route it around the PTW to Franks Creek.

The PTW was designed to address three remedial action objectives (RAOs): 
- RAO 1: Reduce or eliminate strontium-90 presence in groundwater seepage leaving or potentially exiting the north plateau to ALARA, with a goal to be less than the DCG of $1.0 \mathrm{E}-06 \mu \mathrm{Ci} / \mathrm{mL}$ (the RAOs for the PTW were determined before the DCGs were replaced by the DCSs);

- RAO 2: Minimize the future expansion of the strontium-90 plume beyond its current mapped limits; and

- RAO 3: Ensure that a technology selected for current containment of the strontium-90 plume does not preclude any strategies for addressing the plume during site decommissioning.

The PTW placement was chosen to not impact the CDDL, and consequently did not capture the plume's leading edge as it existed in November 2010. Strontium-90 concentrations that existed downgradient of the PTW prior to the PTW's installation were expected to increase for a period of time, and then eventually decrease when groundwater treated by the PTW begins to reach these downgradient areas. Recent north plateau monitoring shows evidence of treated groundwater exiting the PTW downgradient of the wall.

DOE continues to evaluate long-term strategies for plume management, including excavating subsurface soils from the source area beneath the MPPB. Removal of the MPPB and the plume source area are components of DOE's ROD for decommissioning and/or long-term stewardship of the WVDP and the WNYNSC.

PTW Performance Monitoring Plan (PTWPMP). The PTWPMP was developed and implemented immediately following the PTW installation. This plan describes the performance monitoring requirements for the PTW. Data collected during 2012 was reported in quarterly and annual PTW performance monitoring reports. The general objectives of the PTWPMP include:

- Monitoring the physical integrity of the PTW and its components;

- Assessing the movement of strontium-90-affected groundwater in the vicinity of the PTW; and

- Assessing the removal of strontium-90 from groundwater moving through the PTW.

Quarterly sampling and monthly inspections were performed throughout 2012. Manual monitoring of PTW water levels were performed monthly through October 2012, were stopped during November and December and monitored monthly again in early 2013. Continuous water level monitoring has been performed at five locations within the PTW since March 2011.

Monitoring data collected to date indicates:

- Groundwater flow patterns in the PTW area are similar to flow patterns observed prior to PTW construction, indicating that the PTW installation did not substantially alter groundwater flow conditions on the north plateau;

- Strontium-90 activity from groundwater wells inside the PTW typically is substantially lower than strontium-90 activity levels upgradient of the PTW;

- Geochemical differences were observed in groundwater that has migrated into or through the zeolite, indicating that cation exchange is occurring; and

- Strontium-90 activity in groundwater immediately downgradient of the PTW, as well as over 100 feet downgradient is steadily decreasing.

- Based on the January 2013 annual sampling results, there are no longer strontium-90 concentrations greater than $1.0 \mathrm{E}-05-\mu \mathrm{Ci} / \mathrm{mL}(10,000 \mathrm{pCi} / \mathrm{L})$ in the downgradient western or central lobes and no detected strontium-90 activities above $1.0 \mathrm{E}-06-\mu \mathrm{Ci} / \mathrm{mL}(1,000 \mathrm{pCi} / \mathrm{L})$ in the downgradient eastern lobe.

These observations indicate the ongoing processes within the PTW are currently achieving the RAOs and the functional requirements of the PTW defined in the PTWPMP.

North Plateau GMP (NPGMP). A supplementary NPGMP was also developed in 2010, in conjunction with completing the full-scale PTW. The primary objective of the NPGMP is to monitor the strontium-90 plume migration in groundwater farther upgradient and downgradient of the PTW than the areas monitored under the PTWPMP. This monitoring program, which includes quarterly gross beta sampling at 26 well locations and water level measurements at 40 well locations, was performed concurrent with the PTWPMP throughout 2012.

PTW Protection and Best Management Plan. The north plateau PTW protection and best management plan describe best management practices implemented to increase the effectiveness and longevity of the PTW. The 
practices include elimination of road-salt use near the PTW, storm water management via the upgradient SmartDitch $^{\mathrm{TM}}$, and monthly inspections.

NPGRS. In 1995, the NPGRS was installed to slow the advance of the strontium-90 plume. (See Figure 4-2.) The NPGRS consists of three wells used to extract contaminated groundwater. Extracted groundwater is transferred to the LLW2 for treatment by ion exchange to remove strontium-90. Treated water is ultimately discharged through the lagoon system to Erdman Brook via the SPDES-permitted outfall 001.

The NPGRS operated throughout 2012, processing about 2.9 million gal (10.9 million L) of water. The system has extracted and processed approximately 65.7 million gal (248.6 million L) since November 1995. One of the NPGRS wells was shut down in December 2012 and the second well was shutdown in April 2013. Should a determination be made that the system is no longer anticipated to be needed, closure will be performed in accordance with SPDES closure requirements.

Pilot-Scale PTW. A pilot-scale PTW was constructed in 1999 with a clinoptilolite, selected for its ability to adsorb strontium-90 ions from groundwater. The data collected during the testing of the pilot PTW helped determine that the PTW technology was an effective remediation method for strontium-90-contaminated groundwater. Three wells within the pilot-scale PTW were monitored in 2012 under the NPGMP to support delineation of flow and transport of the plume across the north plateau.

\section{Other Groundwater Sampling Observations on the North Plateau}

Monitoring Near Former Lagoon 1. Southeast of the strontium-90 plume, elevated gross beta concentrations are documented in groundwater downgradient of former lagoon 1, which was backfilled in 1984. (See Figure 4-2.) Gross beta concentrations in wells 8605 and 111 are consistently above the strontium-90 DCS and are remaining stable from year to year, as shown in the 10-year trend graph on Figure 4-10. The gross beta activity source is assumed to be the radiologically contaminated material used as backfill and the residual sediment within former lagoon 1.

Tritium in North Plateau Groundwater. On the north plateau, elevated tritium concentrations have historically been observed near the lag storage area, the lag storage hardstand, and adjacent to and downgradient of the lagoon system. Tritium concentrations sitewide have been consistently decreasing. Tritium has a relatively short halflife (about 12.3 years) and dilution from surface water infiltration and groundwater recharge contributes to the decrease. Residual tritium activity is attributed to former nuclear fuel reprocessing operations. No new source of tritium is suspected. As shown in Table 4-7, the maximum tritium concentration measured in groundwater from the north plateau in 2012, 3.12E-05 $\mu \mathrm{Ci} / \mathrm{mL}$, occurred at well point WP-C, downgradient of the MPPB (see Figure A-8 for the well point location). This concentration was approximately two orders of magnitude below the DCS for tritium of $1.9 \mathrm{E}-03 \mu \mathrm{Ci} / \mathrm{mL}$.

Radioisotopic Sampling Results on the North Plateau. In addition to being analyzed for gross alpha, gross beta, tritium, and strontium-90, samples from eight groundwater wells in the north plateau S\&G unit $(401,406,408$, 1304, and MP-01 through MP-04) were analyzed for specific radionuclides (see Tables 4-3 and 4-4). The maximum radionuclide concentrations measured at either the north or south plateau during 2012 are presented in Table 4-7.

The MPPB wells (MP-01, -02, -03, and -04) were also analyzed for radioisotopes not previously included in the WVDP groundwater analytical suites, including neptunium-237, plutonium-238, plutonium-239/240, plutonium-241, americium-241, and curium-243/244, to investigate their presence as a result of former MPPB operations. None of these radionuclides have been detected to date at the MPPB wells. (See Appendix D, Table D-2H.)

Two sampling locations in the south plateau (well 909 and the NDA sump [NDATR]) are also analyzed for specific radionuclides. Results are discussed later in this chapter. (Note that radium-226, radium-228, uranium-234, and uranium-238 occur naturally in the environment.) (See Appendix D-1.)

Results for Volatile and Semivolatile Organic Compounds (VOCs and SVOCs). Per the Consent Order, select wells within the S\&G unit are monitored for VOCs and SVOCS because concentrations of these compounds exceeding NYSDEC Technical and Operational Guidance Series (TOGS) 1.1.1 Class GA Groundwater Quality Standards were detected in some groundwater samples collected during the RFI.

Currently, the only S\&G unit monitoring location with consistent positive VOC detections is well 8612, located northeast and downgradient of the CDDL at the northeast edge of the north plateau. (See Table 4-8, and Figure A-8 
in Appendix A.) Figure 4-11 illustrates the concentration ranges of four VOCs detected at well 8612. Only one VOC (1,2-Dichloroethylene [total]) continues to be detected slightly above the TOGS 1.1.1 Class GA Groundwater Quality Standard; the concentration at well 8612 continued to decrease during 2012 from 8.3 micrograms per liter ( $\mu \mathrm{g} / \mathrm{L}$ ) in March to $7.9 \mu \mathrm{g} / \mathrm{L}$ in December. These concentrations are not significantly above the practical quantitation limit of $5.0 \mu \mathrm{g} / \mathrm{L}$. The VOCs detected in well 8612 are presumed to be from wastes buried in the CDDL.

TBP, an SVOC, has been continually detected in groundwater from well 8605, downgradient of former lagoon 1 since monitoring at this location began. The maximum concentration measured in $2012(162 \mu \mathrm{g} / \mathrm{L})$ was significantly lower than the historic high of $700 \mu \mathrm{g} / \mathrm{L}$ measured in December 1996. TBP has also been detected in well 111 , located near well 8605 , but at concentrations, close to the quantitation limit of $10 \mu \mathrm{g} / \mathrm{L}$. (See Figure 4-12.) TBP is thought to be residual contamination from liquid waste management activities in the former lagoon 1 area during nuclear fuel reprocessing. A TOGS 1.1.1 water quality standard has not been established for TBP.

A summary of maximum VOC and SVOC concentrations detected in WVDP groundwater wells in 2012, that exceeded TOGS 1.1 .1 criteria, is provided in Tables $4-8$ and 4-9.

Metals Sampling on the North Plateau. In 2005, 2007, and 2008, select groundwater wells were sampled to evaluate metals concentrations in groundwater impacted by the strontium-90 plume migrating from the MPPB source area. No metals have been determined to be associated with the strontium-90 plume.

During 2012, routine metals sampling continued to be performed, as outlined in the GMP. The sampling results were compared with the established GSLs and background levels (see Table 4-9). The only metals detected above background in groundwater in $\mathbf{2 0 1 2}$ were barium, chromium, and nickel. Barium was detected above background concentrations at wells 502 and MP-01. Nickel was detected at concentrations above the GSLs in wells 405, 502 and 706, and detected above background in well 1303. Chromium was detected above the GSL at wells 111, 502, 706, and MP-01 (see Appendix D-2G). Wells 405,502 , and 706 are stainless-steel wells that have historically shown evidence of corrosion. (For additional detail, refer to "Investigation of Chromium and Nickel in the S\&G Unit and Evaluation of Corrosion in Groundwater
Monitoring Wells" in previous ASERs.) The chromium detected at MP-01 was only marginally above the GSL during the June and September sampling events, but was below the detection limit in March and December 2012.

\section{Groundwater Sampling Observations on the South Plateau: Weathered Lavery Till (WLT) and the NDA}

Interim Measure (IM). In 1990, a trench system was constructed through the WLT along the northeast and northwest sides of the NDA to intercept and collect potentially contaminated groundwater. Sampling location NDATR is a sump at the lowest point of the interceptor trench. Groundwater is collected at NDATR and transferred to the LLW2 for processing. In 2012, no organic constituents were detected in groundwater from the NDA interceptor trench. Groundwater elevations are monitored quarterly in and around the interceptor trench to ensure that an inward gradient is maintained.

A second IM, to improve the stability of the earthen cap and to limit infiltration of surface water and precipitation into the NDA, was completed in December 2008. This included installing a geosynthetic cap over the NDA, a low-permeability upgradient slurry wall, and surface water drainage diversions. (See also "Interim Measure [IM]" under "RCRA 3008(h) Consent Order" in the ECS and "NDA Interceptor Trench and Pretreatment System" in Chapter 1.) Water level data from piezometers installed to monitor the slurry wall indicate that the slurry wall and geomembrane cover are causing the WLT to become dry in some areas. The reduced water volume extracted from the interceptor trench since the cap and barrier wall were installed is another indication that the IM is effectively reducing flow through the NDA. The total volume pumped annually from the NDA trench in 2012 (64,035 gal $[242,399$ L]) was approximately one-fifth of the volume pumped in CY 2007, before the IM. (See Figure 4-14.)

Refer to ECS “IM" under "RCRA §3008(h) Administrative Order on Consent" for further discussion of the NDA IMs.

Radioisotopic Sampling Results on the South Plateau. Gross beta, tritium, and several radioisotope concentrations in groundwater from NDATR (see Table 4-9, Figure 4-13, and Appendix A, Figure A-9) continued to be elevated with respect to GSLs or to concentrations in background monitoring locations on the south plateau. Gross beta concentrations at NDATR have decreased after the $2008 \mathrm{IM}$ to below the gross beta GSL of $1.00 \mathrm{E}-6 \mu \mathrm{Ci} / \mathrm{mL}$ 
TABLE 4-7

2012 Maximum Concentrations of Radionuclides ${ }^{a}$ in Groundwater at the WVDP Compared With WVDP Groundwater Screening Levels ${ }^{\text {b }}$ (GSLs)

\begin{tabular}{|c|c|c|c|c|c|c|c|}
\hline \multirow[b]{2}{*}{ Radionuclide } & \multicolumn{3}{|c|}{ Regulatory Compliance } & \multicolumn{3}{|c|}{ Environmental Surveillance } & \multirow[b]{2}{*}{$\begin{array}{c}G S L \\
(\mu \mathrm{Ci} / \mathrm{mL})\end{array}$} \\
\hline & $\begin{array}{c}\text { Well ID With } \\
\text { Maximum } \\
\text { Concentration }\end{array}$ & Flag $^{c}$ & $\begin{array}{c}\text { Maximum } \\
\text { Concentration } \\
(\mu \mathrm{Ci} / \mathrm{mL})\end{array}$ & $\begin{array}{c}\text { Well ID With } \\
\text { Maximum } \\
\text { Concentration }\end{array}$ & Flag $^{c}$ & $\begin{array}{c}\text { Maximum } \\
\text { Concentration } \\
(\mu \mathrm{Ci} / \mathrm{mL})\end{array}$ & \\
\hline Tritium & 909 & & 8.89E-07 & WP-C & & 3.12E-05 & $1.78 \mathrm{E}-07$ \\
\hline Strontium-90 & MP-02 & & $1.45 \mathrm{E}-04$ & - & & - & $5.90 \mathrm{E}-09$ \\
\hline Technetium-99 & MP-02 & & 4.50E-08 & - & & - & $5.02 \mathrm{E}-09$ \\
\hline lodine-129 & NDATR & & 2.30E-08 & - & & - & $9.61 \mathrm{E}-10$ \\
\hline Cesium-137 & - & & - & - & & - & $1.03 \mathrm{E}-08$ \\
\hline Radium-226 & 406 & $\mathrm{~J}$ & $6.05 \mathrm{E}-10$ & 1304 & & $3.38 \mathrm{E}-10$ & $1.33 \mathrm{E}-09$ \\
\hline Radium-228 & NDATR & $\mathrm{J}$ & 1.17E-09 & 1304 & & $3.85 \mathrm{E}-10$ & $2.16 \mathrm{E}-09$ \\
\hline Uranium-233/234 & NDATR & & $1.54 \mathrm{E}-09$ & - & & - & $6.24 \mathrm{E}-10$ \\
\hline Uranium-235/236 & MP-04 & & $1.40 \mathrm{E}-10$ & - & & - & 8.07E-11 \\
\hline Uranium-238 & MP-04 & & 1.00E-09 & - & & - & 4.97E-10 \\
\hline Total Uranium & NDATR & & $3.54 \mathrm{E}-03$ & 1304 & & $4.38 \mathrm{E}-04$ & $1.34 \mathrm{E}-03$ \\
\hline
\end{tabular}

Note: Bolding indicates that the radionuclide exceeds the GSL.

- indicates that none of the regulatory or environmental surveillance wells exhibited positive results for these radionuclides.

${ }^{a}$ The table presents the maximum concentrations of radioculides that were positively identified in groundwater wells at the WVDP, all other radionuclides were not positively identified, or were not analyzed.

${ }^{b}$ GSLs for radiological constituents are set equal to the larger of the background concentrations or NYSDEC Technical and Operational Guidance Series (TOGS) 1.1.1 Class GA Groundwater Quality Standards (see Table D-1A).

c The "J" flag indicates the result is an estimated value.

TABLE 4-8

2012 Summary of Maximum Concentrations of Organic Constituents in Select WVDP Groundwater Wells

\begin{tabular}{|c|c|c|c|}
\hline \multirow{2}{*}{ Constituent } & \multicolumn{2}{|c|}{$\begin{array}{c}\text { Regulatory/Waste Management } \\
\text { Monitoring Program }\end{array}$} & \multirow{2}{*}{$\begin{array}{c}\text { NYS } \\
\text { Class GA Groundwater Quality } \\
\text { Standards }^{a}(\mu \mathrm{g} / \mathrm{L})\end{array}$} \\
\hline & $\begin{array}{l}\text { Well with the Highest } \\
\text { Concentration }\end{array}$ & $\begin{array}{c}\text { Maximum } \\
\text { Concentration }(\mu \mathrm{g} / \mathrm{L})\end{array}$ & \\
\hline 1,2-Dichloroethylene (total) & 8612 & 8.3 & 5.0 \\
\hline Tributyl phosphate & 8605 & 162 & NA \\
\hline
\end{tabular}

NA - Not applicable

${ }^{a}$ Source: 6 NYCRR Part 703, Division of Water TOGS 1.1.1, NYS Groundwater Effluent Limitations (Class GA).

in 2012 from the maximum observed concentration of 1.75E-06 $\mu \mathrm{Ci} / \mathrm{L}$ in September 2009 after the $2008 \mathrm{IM}$. The increases immediately following the installation of the upgradient slurry wall and cap are believed to be attributable to less dilution of water collected in the trench because groundwater and surface water infiltration into the NDA was significantly reduced. Similar to the north plateau, strontium-90 is the predominant contributing radioisotope to the measured gross beta concentrations in the NDA trench water.

NDATR samples in 2012 also exhibited the highest concentrations for iodine-129. Elevated iodine-129 concentrations observed since the $2008 \mathrm{IM}$ are believed to be attributable to less dilution of the water that collects within the trench (See Table 4-7.). 
WLT well 909 also exhibited elevated tritium, iodine-129, strontium-90, and several uranium radioisotope concentrations above the GSL during 2012, consistent with historical values, as shown in Table 4-9 and Appendix D. Prior to replacement, ULT well 910 began to show increases in gross beta that were not representative of the groundwater in the ULT. A down-hole camera inspection determined there was a break in the well riser that allowed shallower legacy NDA contamination to enter the well. This well was therefore decommissioned and replaced in 2008, resulting in more representative gross beta concentrations in the ULT slightly above background. (See Figure 4-13).

Radionuclide concentrations in groundwater downgradient of the NDA are presumed to be associated with former waste burial operations.

\section{Additional Monitoring and Investigations}

Groundwater Monitoring Downgradient of the WTF. HLW in the underground tanks was removed and solidified through the VIT process in 2002. The underground waste tanks are being stabilized by a T\&VDS that began operating in December 2010. Two of the tanks are dry and liquid levels are decreasing in the other two. This system is successfully reducing the liquid volume in the tanks and vaults through evaporation. (See "WTF and the T\&VDS" in the ECS.)Throughout waste processing activities, groundwater controls were in place to (1) reduce the upward hydrostatic pressure on the tanks, and (2) to maintain an inward hydraulic gradient toward the tanks, thereby inhibiting potential leaks from the tanks. The natural inward hydraulic gradient is influenced by periodically pumping a dewatering well, located outside the vault, that also controls the hydrostatic pressure near the tanks.

Radioactivity in groundwater near the WTF is routinely monitored and evaluated. Elevated gross beta concentrations from well 8607 have been observed since 1994, with the maximum concentration measured in 2005. Gross beta activity has also been observed in the dewatering well and the tank 8D-2 pan. During 2012, gross beta concentrations at well 8607 were lower than 2011 concentrations and are near background levels.

\section{Summary}

Evaluation of groundwater results from 2012 continue to show that the most widespread area of groundwater contamination at the WVDP is the strontium-90 plume in the S\&G unit on the north plateau. Efforts to reduce contaminant levels in the downgradient portions of the north plateau plume included the 2010 installation of the full-scale PTW across the leading edge of the plume and installation of the NPGRS in 1996. Two years of post installation monitoring results indicate the PTW is removing strontium-90 from the groundwater exiting the wall. Other localized areas of groundwater contamination have been observed downgradient of former lagoon 1, also on the north plateau, and downgradient of the NDA on the south plateau. Measures to reduce and collect water moving through the NDA including the NDA trench installed in 1990 and the slurry wall and geomembrane cover installed in 2008 are reducing the water level in the NDA and thus the potential for groundwater contamination flowing out of the NDA. The T\&VDS is effectively drying out the waste tanks, further reducing the potential for groundwater contamination in the WTF.

As discussed in the ECS, longer-term measures to reduce potential groundwater contamination as described in Phase 1 of the EIS preferred alternative selected by DOE in the ROD (April 2010), include removing the MPPB, removing the lagoons, and remediating the source of the north plateau plume. 
TABLE 4-9

2012 Groundwater Monitoring Results Exceeding GSLs and Background Levels

\begin{tabular}{|c|c|c|c|c|c|c|c|c|}
\hline \multicolumn{9}{|c|}{ RADIOLOGICAL PARAMETERS } \\
\hline $\begin{array}{c}\text { Number of } \\
\text { exceeding } \\
\text { Backgrc }\end{array}$ & $\begin{array}{l}\text { ations } \\
s^{a} \text { or } \\
d^{b}\end{array}$ & $\begin{array}{c}\text { Geologic } \\
\text { Unit } \\
\text { (plateau) } \\
\end{array}$ & \multicolumn{6}{|c|}{ Groundwater Sampling Location } \\
\hline \multicolumn{9}{|l|}{ Gross Alpha } \\
\hline \multirow{3}{*}{$3>\mathrm{GSL}$} & \multirow{3}{*}{$6>\mathrm{BKG}$} & S\&G (NP) & 111 & 501 & 8605 & WP-H & & \\
\hline & & WLT (SP) & 906 & & & & & \\
\hline & & ULT (SP) & 910R & & & & & \\
\hline \multicolumn{9}{|l|}{ Gross Beta } \\
\hline \multirow{9}{*}{$20>$ GSL } & \multirow{9}{*}{$40>B K G$} & & GSEEP & 105 & 408 & 802 & 8609 & WP-C \\
\hline & & & SP04 & 106 & 501 & 803 & 8612 & WP-H \\
\hline & & & SP06 & 111 & 502 & 804 & MP-01 & \\
\hline & & S\&G (NP) & SP11 & 116 & $602 \mathrm{~A}$ & 8603 & MP-02 & \\
\hline & & & SP12 & 205 & 605 & 8604 & MP-03 & \\
\hline & & & 103 & 302 & 704 & 8605 & MP-04 & \\
\hline & & & 104 & 401 & 801 & 8607 & WP-A & \\
\hline & & ULT (NP) & 107 & & & & & \\
\hline & & WLT (SP) & NDATR & 909 & & & & \\
\hline \multicolumn{9}{|l|}{ Tritium } \\
\hline \multirow{5}{*}{$19>\mathrm{GSL}$} & \multirow{5}{*}{$19>\mathrm{BKG}$} & & GSEEP & 105 & 106 & 8604 & WP-A & \\
\hline & & $S \& G(N P)$ & SP04 & 106 & 801 & 8609 & WP-C & \\
\hline & & & 104 & $602 A$ & 8603 & MP-04 & WP-H & \\
\hline & & ULT (NP) & 108 & 110 & & & & \\
\hline & & WLT (SP) & NDATR & 909 & & & & \\
\hline \multicolumn{9}{|l|}{ Strontium-90 } \\
\hline \multirow{3}{*}{$11>$ GSL } & \multirow{3}{*}{$11>$ BKG } & S\&, (ND) & 408 & 502 & 8609 & MP-02 & MP-04 & \\
\hline & & $S \alpha U(I V P)$ & 501 & 801 & MP-01 & MP-03 & & \\
\hline & & WLT (SP) & NDATR & 909 & & & & \\
\hline \multicolumn{9}{|l|}{ Technetium-99 } \\
\hline $5>\mathrm{GSL}$ & $5>B K G$ & S\&G (NP) & 408 & MP-01 & MP-02 & MP-03 & MP-04 & \\
\hline \multicolumn{9}{|l|}{ lodine-129 } \\
\hline $2>\mathrm{GSL}$ & $2>B K G$ & WLT (SP) & NDATR & 909 & & & & \\
\hline \multicolumn{9}{|c|}{ Uranium-233/234 } \\
\hline \multirow{2}{*}{$5>\mathrm{GSL}$} & \multirow{2}{*}{$5>\mathrm{BKG}$} & S\&G (NP) & MP-02 & MP-03 & MP-04 & & & \\
\hline & & WLT (SP) & NDATR & 909 & & & & \\
\hline \multicolumn{9}{|c|}{ Uranium-235/236 } \\
\hline $1>\mathrm{GSL}$ & $1>\mathrm{BKG}$ & S\&G (NP) & MP-04 & & & & & \\
\hline \multicolumn{9}{|l|}{ Uranium-238 } \\
\hline \multirow{2}{*}{$5>\mathrm{GSL}$} & \multirow{2}{*}{$5>B K G$} & S\&G & 408 & MP-02 & MP-04 & & & \\
\hline & & WLT (SP) & NDATR & 909 & & & & \\
\hline \multicolumn{9}{|l|}{ Total Uranium } \\
\hline $2>G S L$ & $2>B K G$ & WLT (SP) & NDATR & 909 & & & & \\
\hline
\end{tabular}


TABLE 4-9 (concluded)

2012 Groundwater Monitoiring Results Exceeding GSLs and Background Levels

\begin{tabular}{|c|c|c|c|}
\hline \multicolumn{4}{|c|}{ METALS } \\
\hline $\begin{array}{c}\text { Number of Locations } \\
\text { exceeding GSLs }^{a} \text { or } \\
\text { Background }^{b}\end{array}$ & $\begin{array}{c}\text { Geologic } \\
\text { Unit } \\
\text { (plateau) }\end{array}$ & \multicolumn{2}{|r|}{ Groundwater Sampling Location } \\
\hline \multicolumn{4}{|l|}{ Barium } \\
\hline $2>B K G$ & $S \& G(N P)$ & 502 & MP-01 \\
\hline \multicolumn{4}{|l|}{ Chromium } \\
\hline $4>\mathrm{BKG}$ & S\&G (NP) & 111 & MP-01 \\
\hline \multicolumn{4}{|l|}{ Nickel } \\
\hline $4>B K G$ & $\begin{array}{l}\text { S\&G (NP) } \\
\text { ULT (NP) }\end{array}$ & $\begin{array}{c}405 \\
1303\end{array}$ & 502 \\
\hline \multicolumn{4}{|c|}{ ORGANICS } \\
\hline \multicolumn{4}{|l|}{ Chloroform } \\
\hline $0>$ TOGS & S\&G (NP) & 502 & MP-01 \\
\hline \multicolumn{4}{|l|}{ 1,2-Dichlorothene (total) } \\
\hline $1>$ TOGS & S\&G (NP) & 8612 & \\
\hline \multicolumn{4}{|l|}{ Tributyl phosphate } \\
\hline No TOGS ${ }^{\mathrm{C}}$ & S\&G (NP) & 111 & 8605 \\
\hline
\end{tabular}

Note: Bolded wells indicate 2012 results that exceed GSLs. Unbolded wells indicated 2012 results that exceeded background.

Key:
BKG - Background
SP - South Plateau
DL - Detection Limit
ULT - Unweathered Lavery Till
NP - North Plateau
WLT - Weathered Lavery Till

\footnotetext{
${ }^{a}$ The site-specific GSLs for radiological constituents were set equal to the larger of the WVDP background concentratrions or the NYSDEC TOGS 1.1.1 Class GA Groundwater Quality Standards as discussed on page D-1 and presented in Table D-1A. The GSLs for metals were set equal to the larger of the background concentration or NYSDEC TOGS 1.1.1 Class GA Groundwater Quality Standards as presented in Table D-1B. Organic constituents were compared directly with NYSDEC TOGS 1.1.1 Class GA Groundwater Quality Standards.

${ }^{b}$ The data used for the calculation of background values collected from 1991 through September 2009 were taken from background wells 301, 401, 706, and 1302 in the sand and gravel unit on the north plateau. The background concentration was set to the upper limit of the $95 \%$ confidence interval.

${ }^{c}$ No TOGS 1.1.1 standard has been established for tributyl phosphate.
} 
FIGURE 4-3

Annual Average Gross Beta Concentrations

at Monitoring Wells Downgradient of the North Plateau Strontium-90 Plume Source Area

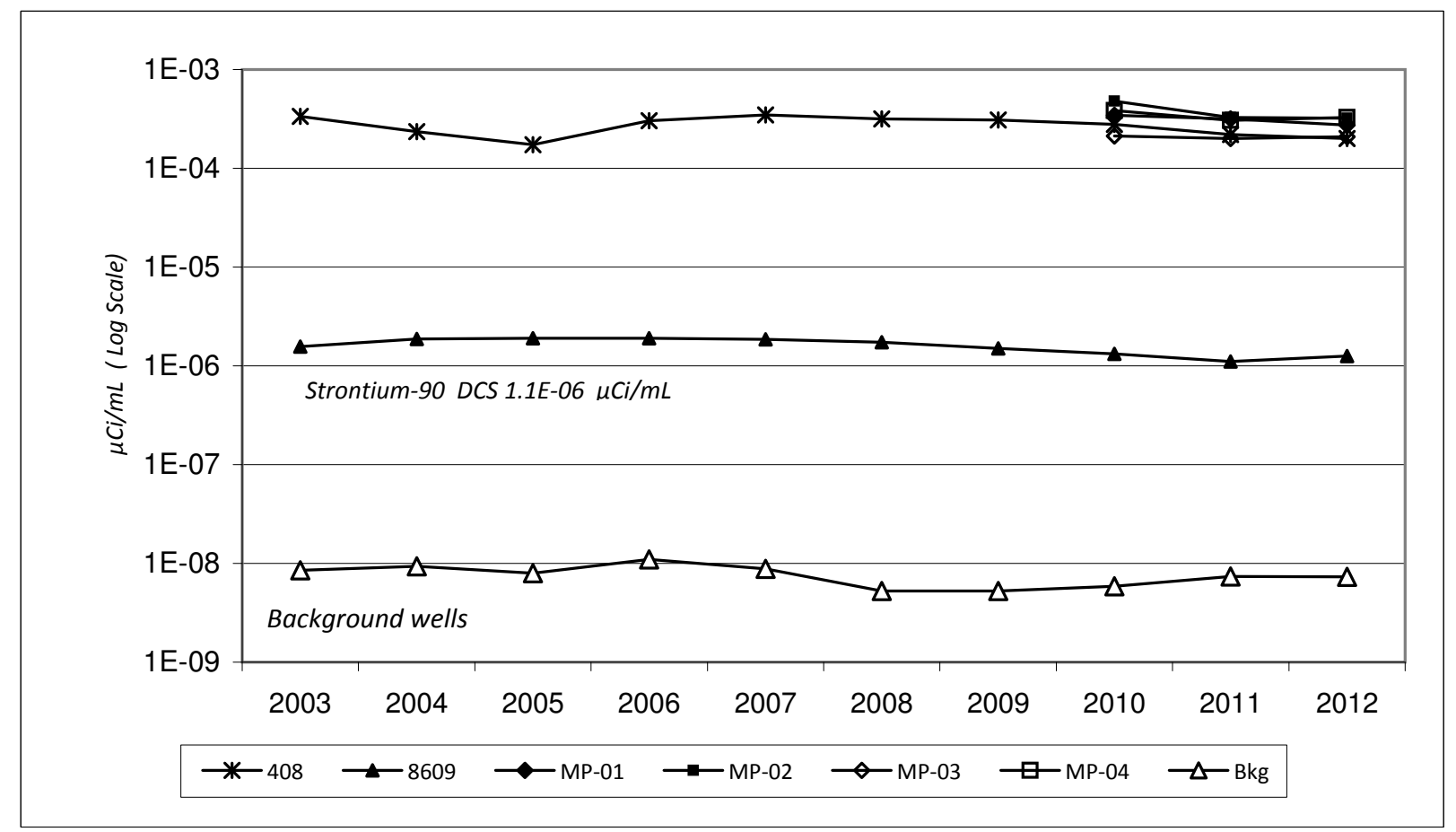

Note: S\&G background (Bkg) wells 301, 401, 706, and 1302 are averaged for this comparison.

FIGURE 4-4

Annual Average Gross Beta Concentrations

at Monitoring Wells Centrally Located Within the North Plateau Strontium-90 Plume

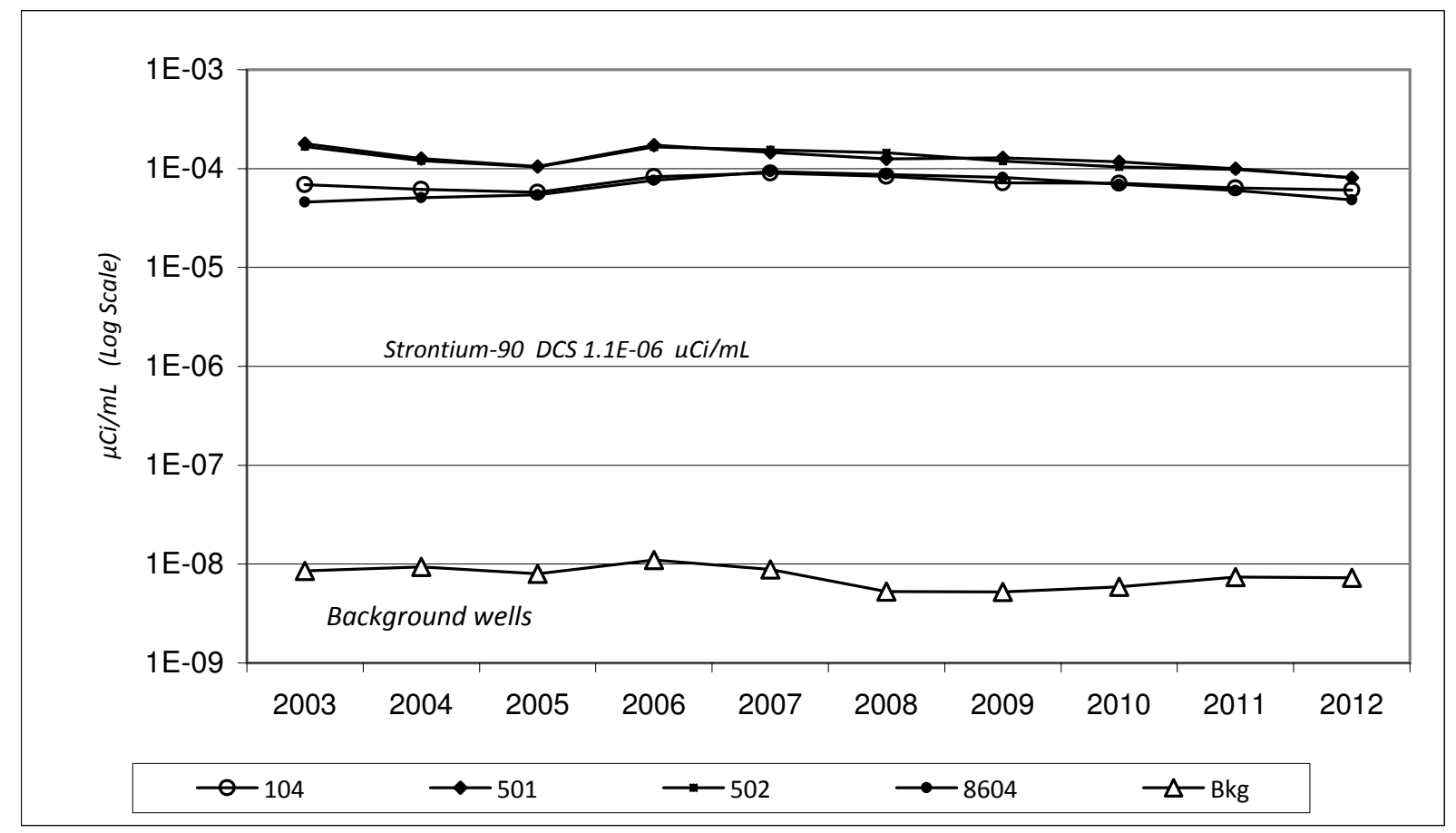

Note: S\&G background (Bkg) wells 301, 401, 706, and 1302 are averaged for this comparison. 
FIGURE 4-5

Annual Average Gross Beta at Monitoring Wells Upgradient of the PTW

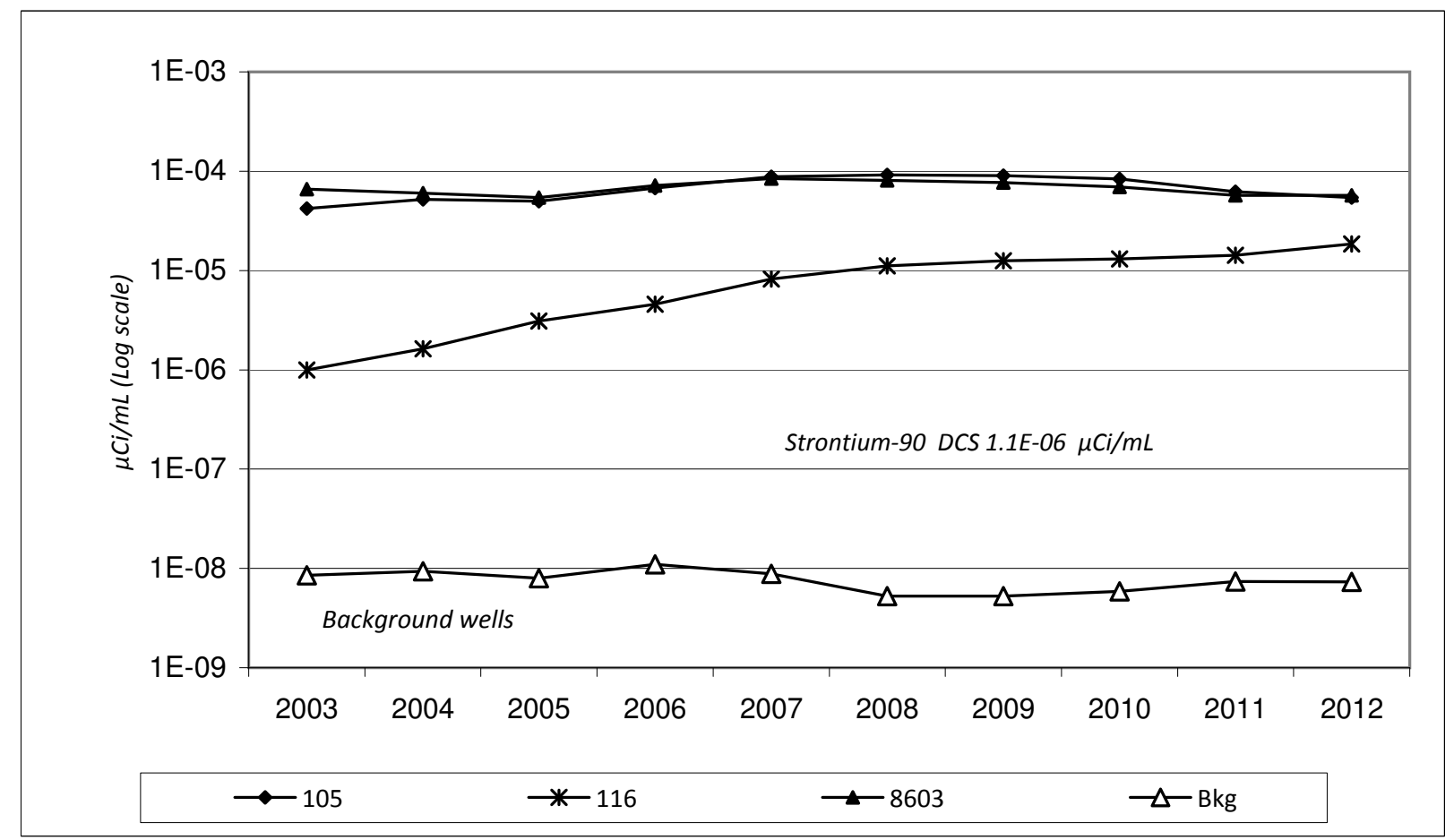

Note: S\&G background (Bkg) wells 301, 401, 706, and 1302 are averaged for this comparison.

FIGURE 4-6

Annual Average Gross Beta at Monitoring Wells Downgradient of the PTW

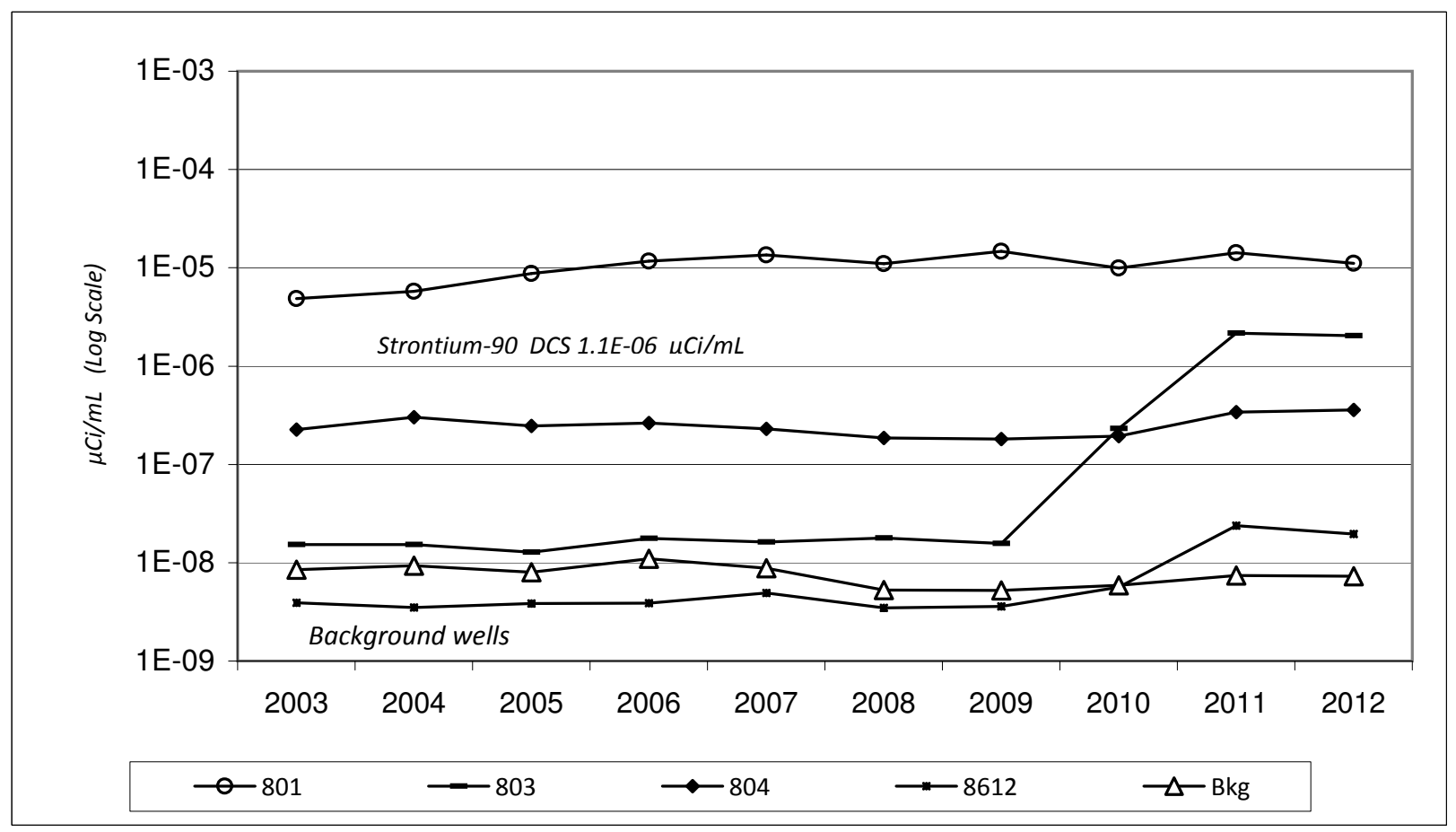

Note: S\&G background (Bkg) wells 301, 401, 706, and 1302 are averaged for this comparison. 
FIGURE 4-7

Annual Average Gross Beta Concentrations at Seeps

From the Northeast Edge of the North Plateau

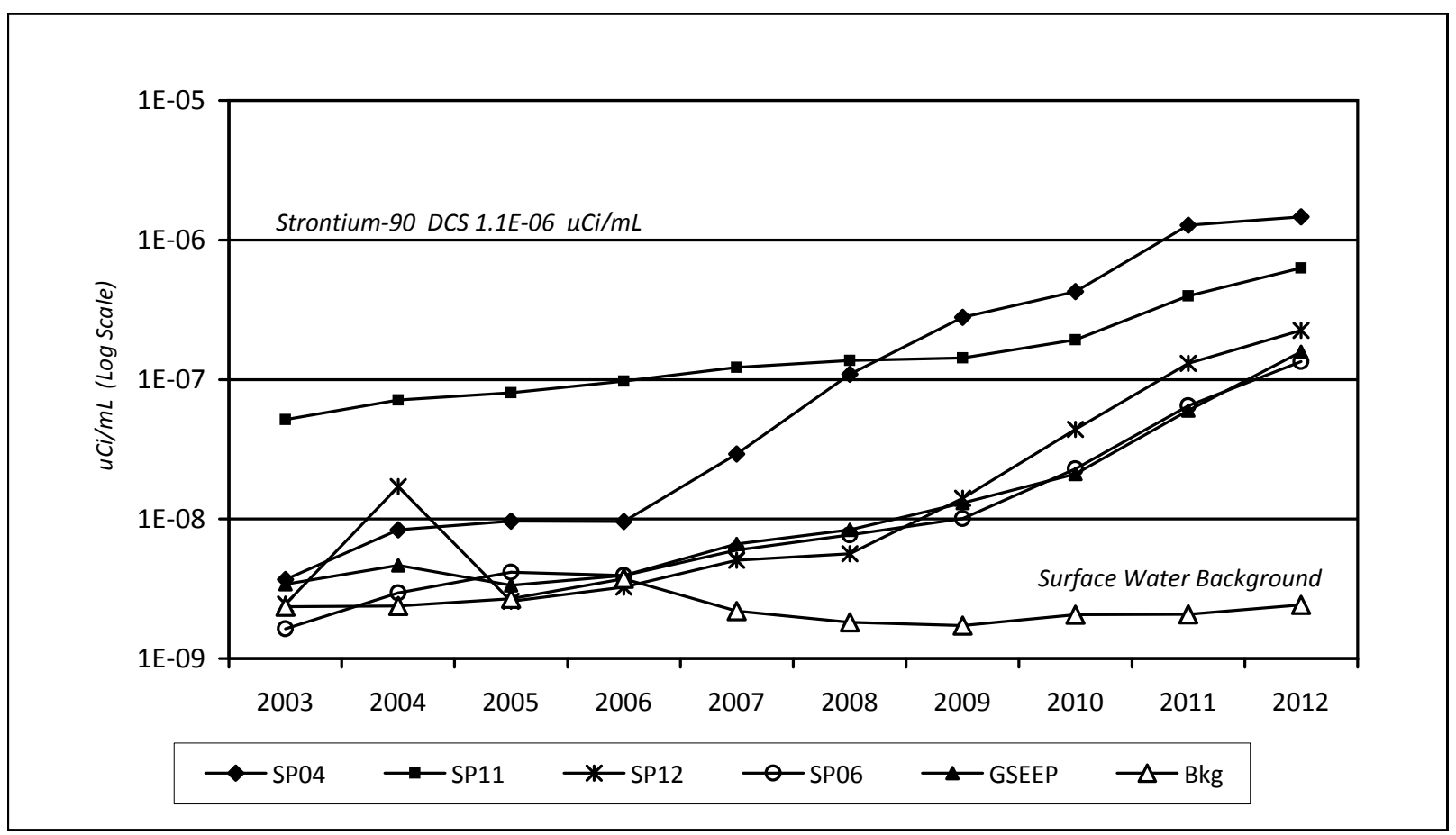

Note: Background (Bkg) from surface water sampling location WFBCBKG at Felton Bridge upgradient of the WVDP.

FIGURE 4-8

Annual Average Strontium-90 Concentrations at WNSWAMP

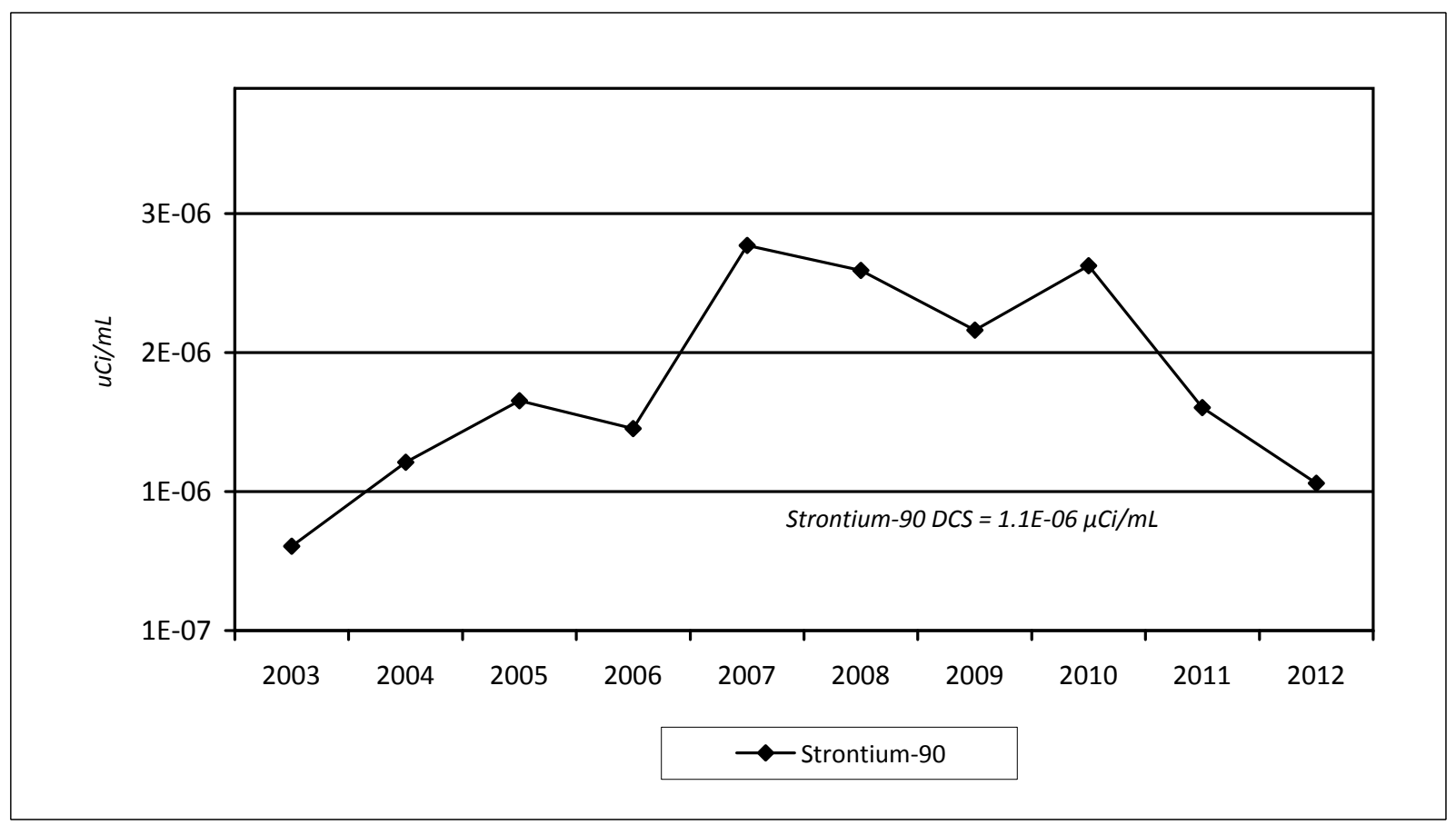

Note: Derived concentration standards (DCSs) are used as an evaluation tool for results from on-site locations as part of the routine environmental monitoring program. However, DOE DCSs are applicable only at locations accessible to members of the public. 
FIGURE 4-9

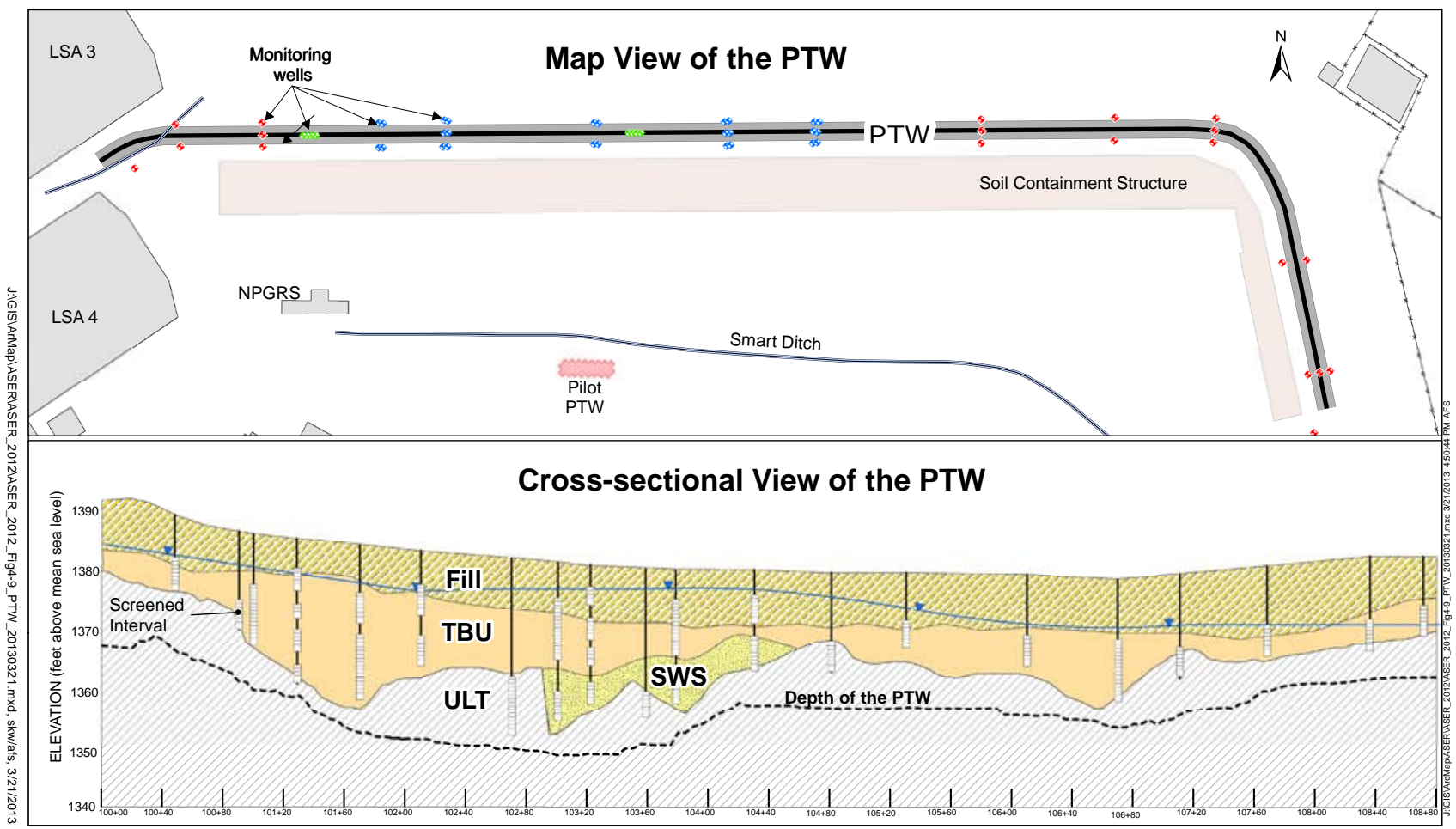

FIGURE 4-10

Annual Average Gross Beta Concentrations at Monitoring Wells Near Former Lagoon 1

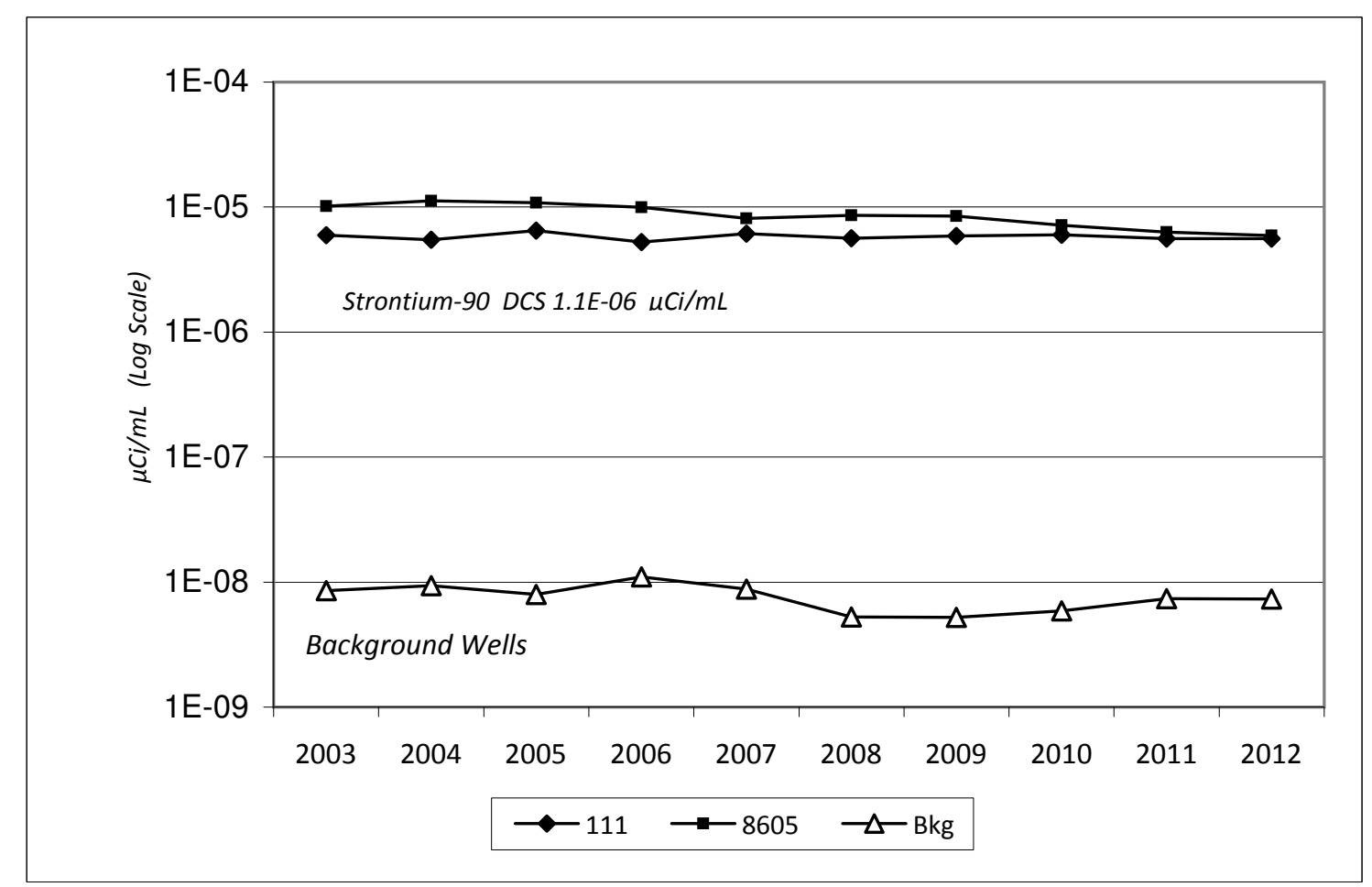

Note: S\&G background (Bkg) wells 301, 401, 706, and 1302 are averaged for this comparison. 
FIGURE 4-11

Concentrations of 1,2-DCE-t, 1,1,1-TCA, 1,1-DCA, and DCDFMeth

at Well 8612 in the S\&G Unit

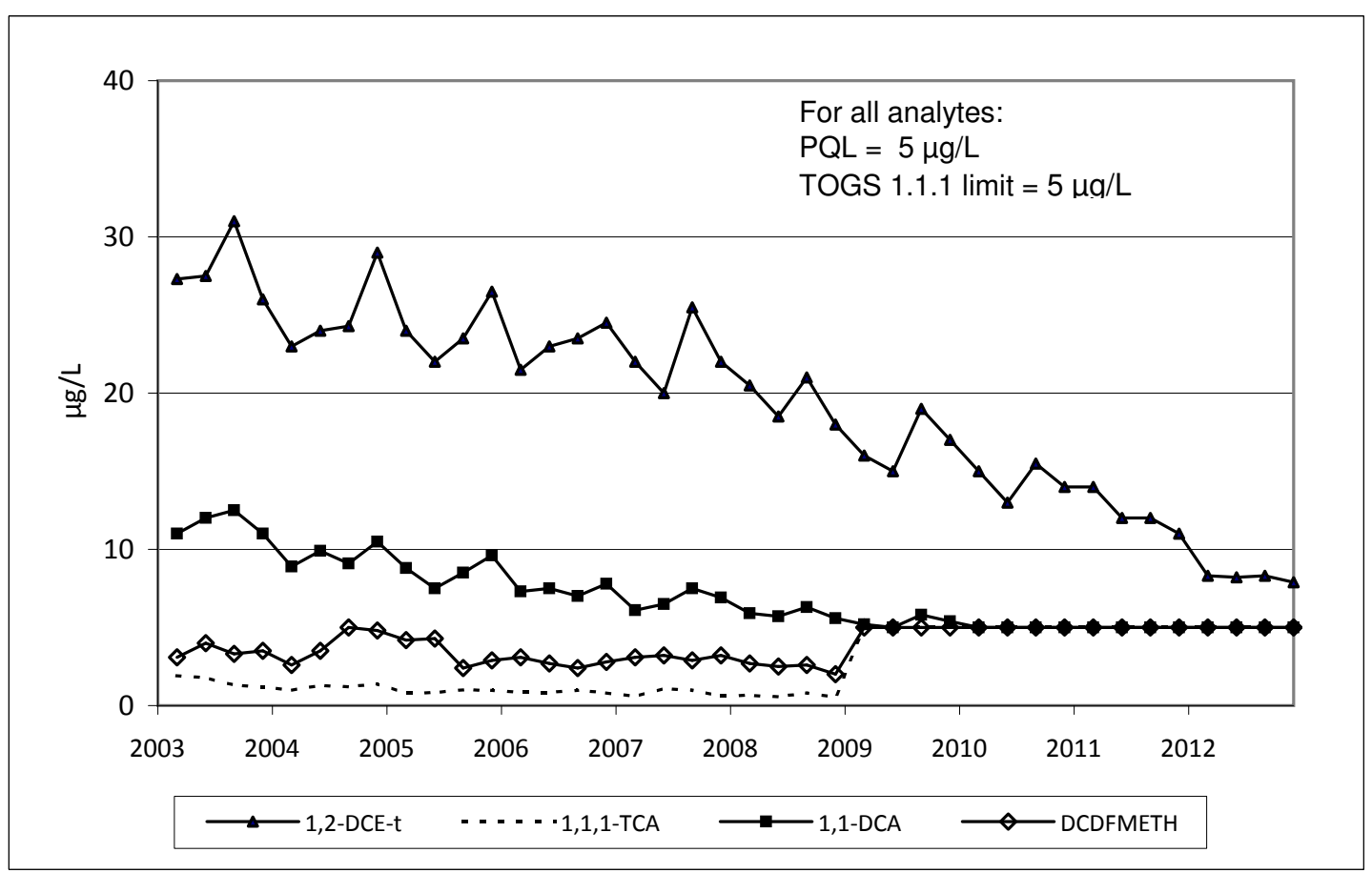

Note: $P Q L=$ Pracitcal Quantitation Limit $\quad$ 1,1-DCA = 1,1-Dichloroethane

1,2-DCE- $\mathrm{t}=1,2$-Dichloroethylene (total) $\quad$ DCDFMeth = Dichlorodifluroromethane

1,1,1-TCA = 1,1,1-Trichloroethane

FIGURE 4-12

Concentrations of Tributyl Phosphate at Monitoring Wells Near Former Lagoon 1

in the S\&G Unit

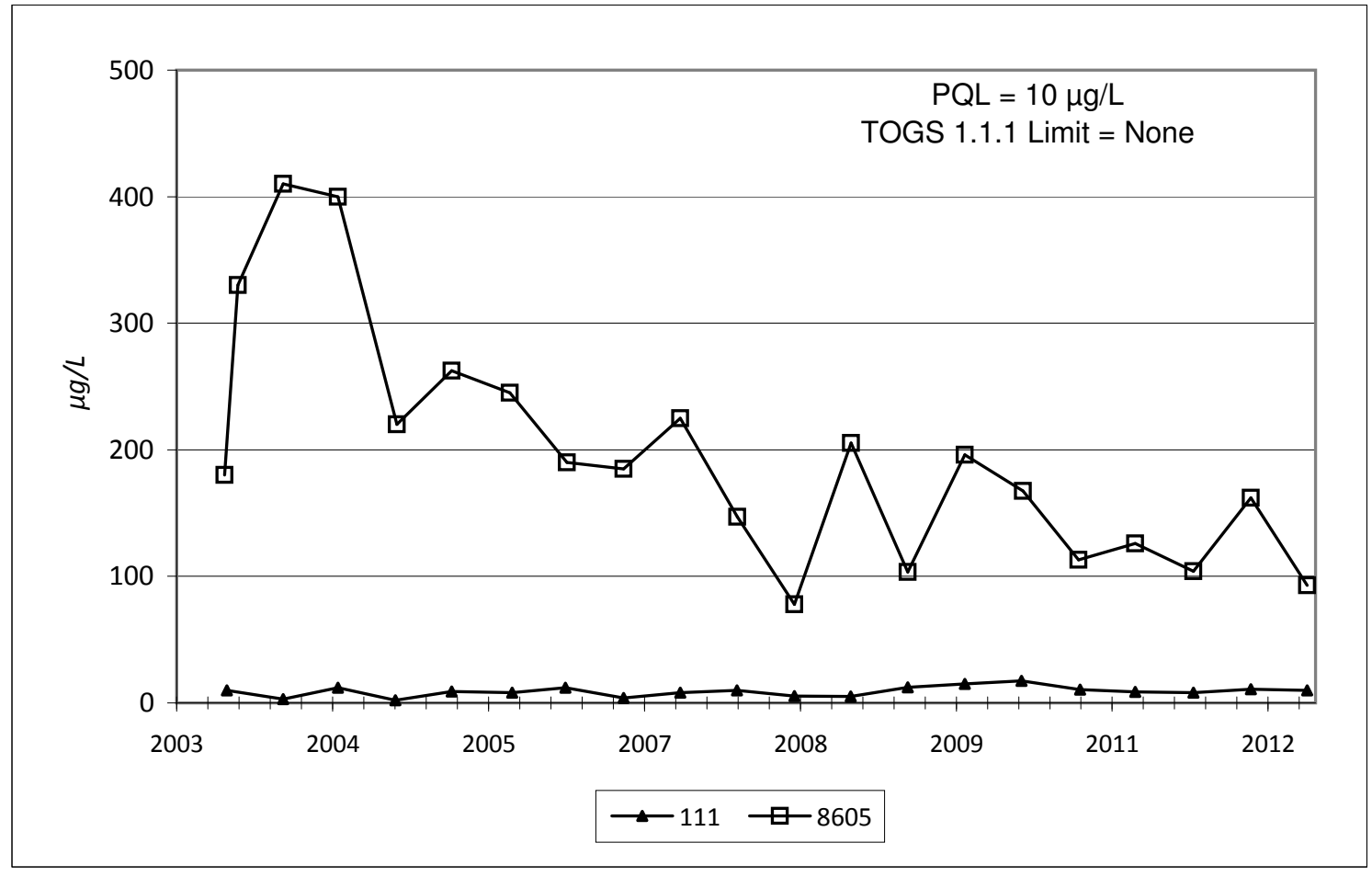


FIGURE 4-13

Annual Average Gross Beta Concentrations

at Monitoring Wells Downgradient of the NDA and at the NDA Trench

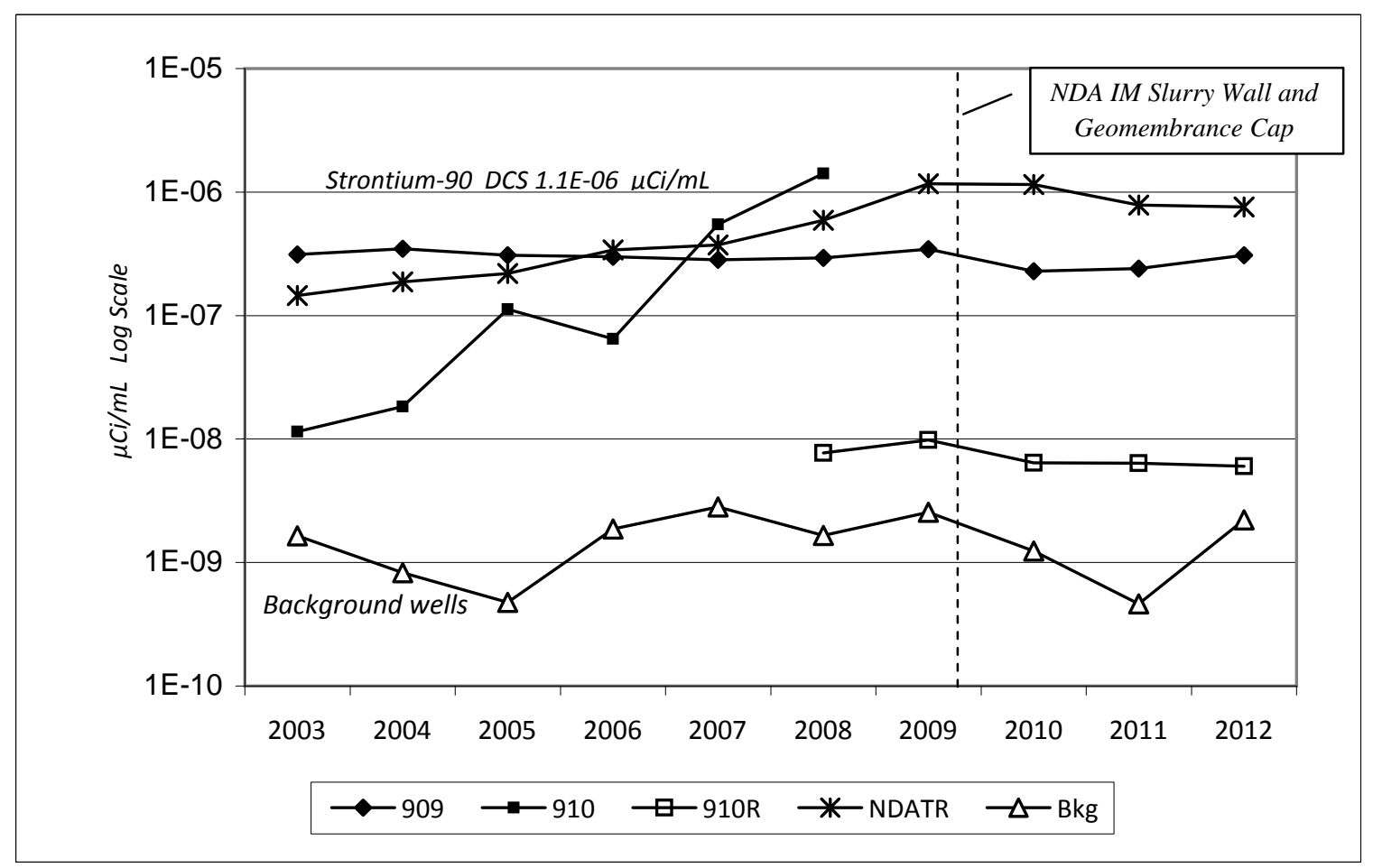

Notes: WLT background well for the south plateau is $1008 \mathrm{C}$.

In 2007, well 910 was determined to be damaged such that groundwater samples collected from this well were no longer representative of the ULT. Well 910 was therefore decommissioned in 2008 and replaced with well 910R. 
FIGURE 4-14

Volume of Water Pumped From the NDA Interceptor Trench

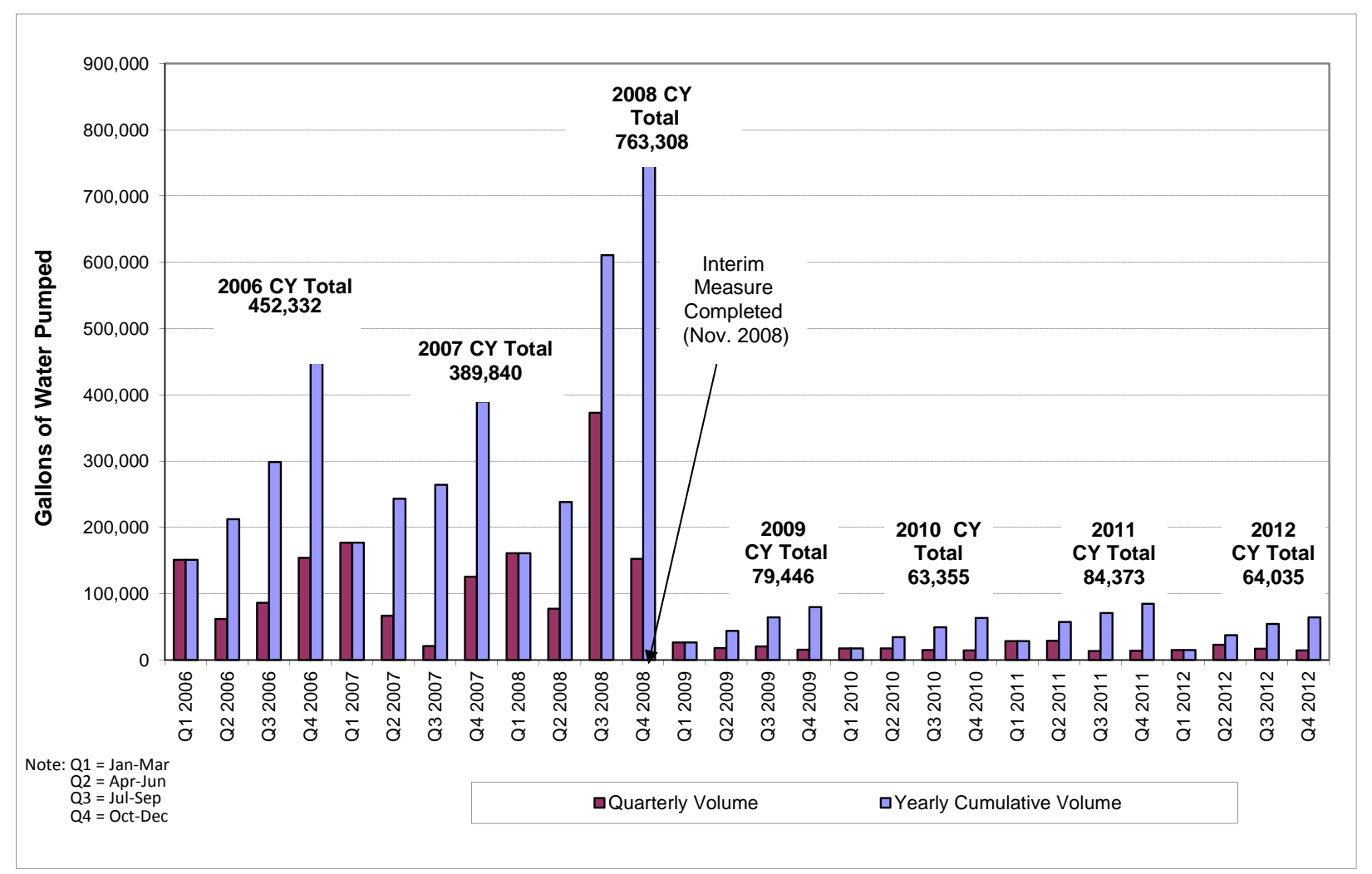




\section{USEFUL INFORMATION}

This section provides background information that may be useful to the reader in understanding and interpreting the results presented in this ASER. First, it presents brief summaries of concepts pertaining to radiation and radioactivity, including:

- radioactive decay;

- types of ionizing radiation;

- measurement of radioactivity;

- measurement of dose;

- background radiation; and

- potential health effects of radiation.

It describes how data are presented in the ASER, and presents tables of unit prefixes, units of measure, and conversion factors. It discusses limits applicable to air emissions and water effluents, and describes (and presents a table of) the dose-based DOE DCSs. It includes a discussion of CAP88-PC, the computer code used to evaluate compliance with the air dose standard. It also presents discussions of 1) water quality classifications, standards, and limits for ambient water; 2) potable water standards; 3 ) oil and sediment guidelines; and 4) evaluation of monitoring data with respect to limits.

\section{Radiation and Radioactivity}

Radioactivity is a property of atoms with unstable nuclei. The unstable nuclei spontaneously decay by emitting radiation in the form of energy (such as gamma rays) or particles (such as alpha and beta particles) (see inset on following page). If the emitted energy or particle has enough energy to break a chemical bond or to knock an electron loose from another atom, a charged particle (an "ion") may be created. This radiation is known as "ionizing radiation."

As used in this ASER, the term "radiation" refers only to ionizing radiation and does not include nonionizing forms of radiation such as visible light, radio waves, microwaves, infrared light, or ultraviolet light.

\section{Radioactive Decay}

An atom is the smallest particle of an element. It cannot be broken down by chemical means. An atom consists of a central core (the nucleus), composed of positively charged particles (protons) and particles with no charge (neutrons), surrounded by negatively charged particles (electrons) that revolve in orbits in the region surrounding the nucleus. The protons and neutrons are much more massive than the electrons; therefore, most of an atom's mass is in the nucleus.

An element is defined by the number of protons in its nucleus, its atomic number. For example, the atomic number of hydrogen is one (one proton), the atomic number of strontium is 38 ( 38 protons), and the atomic number of cesium is 55 ( 55 protons).

The mass number of an atom, its atomic weight, is equal to the total number of protons and neutrons in its nucleus. For example, although an atom of hydrogen will always have one proton in its nucleus, the number of neutrons may vary. Hydrogen atoms with zero, one, or two neutrons will have atomic weights of one, two, or three, respectively. These atoms are known as isotopes (or nuclides) of the element hydrogen. Elements may have many isotopes. For instance, the elements strontium and cesium have more than 30 isotopes each.

Isotopes may be stable or unstable. An atom from an unstable isotope will spontaneously change to another atom. The process by which this change occurs, that is, the spontaneous emission from the nucleus of alpha or beta particles, often accompanied by gamma radiation, is known as radioactive decay. Depending upon the type of radioactive decay, an atom may be transformed to another isotope of the same element or, if the number of protons in the nucleus has changed, to an isotope of another element.

Isotopes (nuclides) that undergo radioactive decay are called radioactive and are known as radioisotopes or radionuclides. Radionuclides are customarily referred to by their atomic weights. For instance, the radionuclides of hydrogen, strontium, and cesium measured at the WVDP are hydrogen-3 (also known as tritium), strontium-90, and cesium-137. For some radionuclides, such as cesium-137, a short-lived intermediate is formed that decays by gamma emission. This intermediate radionuclide may be designated by the letter " $\mathrm{m}$ " (for metastable) following 


\section{Some Types of lonizing Radiation}

Alpha Particles. An alpha particle is a positively charged particle consisting of two protons and two neutrons. Compared to beta particles, alpha particles are relatively large and heavy and do not travel very far when ejected by a decaying nucleus. Therefore, alpha radiation is easily stopped by a few centimeters of air or a thin layer of material, such as paper or skin. However, if radioactive material is ingested or inhaled, the alpha particles released inside the body can damage soft internal tissues because their energy can be absorbed by tissue cells in the immediate vicinity of the decay. An example of an alpha-emitting radionuclide is the uranium isotope with an atomic weight of 232 (uranium-232). Uranium-232 was in the HLW mixture at the WVDP as a result of a thorium-based nuclear fuel reprocessing campaign conducted by Nuclear Fuel Services, Inc. Uranium-232 has been detected in liquid waste streams.

Beta Particles. A beta particle is an electron emitted during the breakdown of a neutron in a radioactive nucleus. Compared to alpha particles, beta particles are smaller, have less of a charge, travel at a higher speed (close to the speed to light), and can be stopped by wood or a thin sheet of aluminum. If released inside the body, beta particles do much less damage than an equal number of alpha particles because beta particles deposit energy in tissue cells over a larger volume than alpha particles. Strontium-90, a fission product found in the liquids associated with the HLW, is an example of a beta emitting radionuclide.

Gamma Rays. Gamma rays are high-energy "packets" of electromagnetic radiation, called photons, that are emitted from the nucleus. Gamma rays are similar to x-rays, but are generally more energetic. If an alpha or beta particle released by a decaying nucleus does not carry off all the energy generated by the nuclear disintegration, the excess energy may be emitted as gamma rays. If the released energy is high, a very penetrating gamma ray is produced that can be effectively reduced only by shielding consisting of several inches of a dense material, such as lead, or of water or concrete several feet thick. Although large amounts of gamma radiation are dangerous, gamma rays are also used in lifesaving medical procedures. An example of a gamma-emitting radionuclide is barium-137m a short-lived daughter product of cesium-137. Both barium-137m and its precursor, cesium-137, are major constituents of the WVDP HLW.

the atomic weight. For cesium-137, the intermediate radionuclide is barium $-137 \mathrm{~m}$, with a half-life of less than three minutes.

The process of radioactive decay will continue until only a stable, nonradioactive isotope remains. Depending on the radionuclide, this process can take anywhere from less than a second to billions of years. The time required for half of the radioactivity to decay is called the radionuclide's half-life. Each radionuclide has a unique half-life. The half-life of hydrogen-3 is slightly more than 12 years, both strontium-90 and cesium-137 have half-lives of approximately 30 years, and plutonium-239 has a half-life of more than 24,000 years.

Knowledge of radionuclide half-lives is often used to estimate past and future inventories of radioactive material. For example, a 1.0 millicurie source of cesium-137 in 2006 would have measured 2.0 millicuries in 1976 and will be 0.5 millicuries in 2036. For a list of half-lives of radionuclides applicable to the WVDP, see Table UI-4.

\section{Measurement of Radioactivity}

As they decay, radionuclides emit one or more types of radiation at characteristic energies that can be measured and used to identify the radionuclide. Detection instruments measure the quantity of radiation emitted over a specified time. From this measurement, the number of decay events (nuclear transformations) over a fixed time can be calculated.

Radioactivity is measured in units of curies (Ci) or becquerels $(\mathrm{Bq})$. One $\mathrm{Ci}$ (based on the rate of decay of one gram of radium-226) is defined as the "quantity of any radionuclide that undergoes an average transformation rate of 37 billion transformations per second." In the International System of Units (SI), one Bq is equal to one transformation per second. In this ASER, radioactivity is customarily expressed in units of $\mathrm{Ci}$ followed by the equivalent SI unit in parentheses, as follows: $1 \mathrm{Ci}(3.7 \mathrm{E}+10 \mathrm{~Bq})$.

In this report, measurements of radioactivity in a defined volume of an environmental media, such as air or water, are presented in units of concentration. Since levels of 
radioactivity in the environment are typically very low, concentrations may be expressed in $\mu \mathrm{Ci} / \mathrm{mL}$, with $\mathrm{SI}$ units $(\mathrm{Bq} / \mathrm{L})$ in parentheses. (One microcurie is equal to one millionth of a curie.)

\section{Measurement of Dose}

The amount of energy absorbed by a material that receives radiation is measured in rads. A rad is 100 ergs of radiation energy absorbed per gram of material. (An erg is the approximate amount of energy necessary to lift a mosquito one-sixteenth of an inch.) "Dose" is a means of expressing the amount of energy absorbed, taking into account the effects of different kinds of radiation.

Alpha, beta, and gamma radiation affect the body to different degrees. Each type of radiation is given a quality factor that indicates the extent of human cell damage it can cause compared with equal amounts of other ionizing radiation energy. Alpha particles cause 20 times as much damage to internal tissues as $x$-rays, so alpha radiation has a quality factor of 20 , compared to gamma rays, $x$-rays, or beta particles, each of which have a quality factor of one.

The unit of dose measurement to humans is the rem. The number of rem is equal to the number of rads multiplied by the quality factor for each type of radiation. In the $\mathrm{SI}$ system, dose is expressed in sieverts. One Sv equals $100 \mathrm{rem}$. One rem equals 1,000 mrem, the unit used to express standards for dose to man from air and water sources, as applicable to this ASER. This ASER expresses dose in standard units, followed by equivalent SI units in parentheses, as follows: 1 mrem (0.01 millisievert [mSv]).

\section{Background Radiation}

Background radiation is always present, and everyone is constantly exposed to low levels of such radiation from both naturally occurring and man-made sources. In the U.S. the average total annual exposure to low-level background radiation is estimated to be about 620 mrem or $6.2 \mathrm{mSv}$. About one-half of this radiation, approximately 310 mrem (3.1 mSv), comes from natural sources. The other half (about 310 mrem [3.1 mSv]) comes from medical procedures, consumer products, and other man-made sources (NCRP Report Number 160, 2009). (See Figure 3-1 in Chapter 3.)

Background radiation includes cosmic rays; the decay of natural elements, such as potassium, uranium, thorium, and radon; and radiation from sources such as chemical fertilizers, smoke detectors, and cigarettes. Actual doses vary depending on such factors as geographic location, building ventilation, and personal health and habits.

\section{Potential Health Effects of Radiation}

The three primary pathways by which people may be exposed to radiation are (1) direct exposure, (2) inhalation, and (3) ingestion. Exposure from radiation may be from a source outside the body (external exposure) or from radioactive particles that have been taken in by breathing or eating and have become lodged inside the body (internal exposure). Radionuclides that are taken in are not distributed in the same way throughout the body. Radionuclides of strontium, plutonium, and americium concentrate in the skeleton, while radioisotopes of iodine concentrate in the thyroid. Radionuclides such as hydrogen-3 (tritium), carbon-14, or cesium-137, however, will be distributed uniformly throughout the body.

Living tissue in the human body can be damaged by ionizing radiation. The severity of the damage depends upon several factors, among them the amount of exposure (low or high), the duration of the exposure (long-term [chronic] or short-term [acute]), the type of radiation (alpha, beta, and gamma radiations of various energies), and the sensitivity of the human (or organ) receiving the radiation. The human body has mechanisms that repair damage from exposure to radiation; however, repair processes are not always successful.

Biological effects of exposure to radiation may be either somatic or genetic. Somatic effects are limited to the exposed individual. For example, a sufficiently high exposure could cause clouding of the eye lens or a decrease in the number of white blood cells. Genetic effects may show up in future generations. Radiation could damage chromosomes, causing them to break or join incorrectly with other chromosomes. Radiation-produced genetic defects and mutations in the offspring of an exposed parent, while not positively identified in humans, have been observed in some animal studies.

Assessing the biological damage from low-level radiation is difficult because other factors can cause the same symptoms as radiation exposure. Moreover, the body is able to repair damage caused by low-level radiation. Epidemiological studies have not demonstrated adverse health effects in individuals exposed to small doses (less than $10 \mathrm{rem}$ ) over a period of years. (For comparison, note that average natural background radiation in the U.S. is about $0.31 \mathrm{rem} /$ year, and estimated annual dose 
from activities at the WVDP in 2012 was calculated to be about $0.000019 \mathrm{rem} /$ year [0.019 mrem/year].)

The effect most often associated with exposure to relatively high levels of radiation appears to be an increased risk of cancer. However, scientists have not been able to demonstrate with certainty that exposure to low-level radiation causes an increase in injurious biological effects, nor have they been able to determine if there is a level of radiation exposure below which there are no adverse biological effects.

\section{Data Reporting}

In the ASER text, radiological units (e.g., rem, rad, curie) are presented first, followed by the $\mathrm{SI}$ equivalent in parentheses. Nonradiological measurements are presented in English units, followed by the metric unit equivalent in parentheses. See Tables UI-1, UI-2, and UI-3 for a summary of unit prefixes, units of measurement, and basic conversion factors used in this ASER.

Where results are very large or very small, scientific notation is used. Numbers greater than 10 are expressed with a positive exponent. To convert the number to its decimal form, the decimal point must be moved to the right by the number of places equal to the exponent. For example, 1.0E+06 would be expressed as 1,000,000 (one million). Numbers smaller than 1 are expressed with a negative exponent. For example, 1.0E-06 would be expressed as 0.000001 (one millionth).

Radiological data are reported as a result plus or minus $( \pm)$ an associated uncertainty, customarily the $95 \%$ confidence interval. The uncertainty is in part due to the random nature of radioactive decay. Generally, the relative uncertainty in a measurement increases as the amount of radioactivity being sampled decreases. For this reason,

TABLE UI-1

Unit Prefixes Used in this ASER

\begin{tabular}{crcc}
\multicolumn{2}{c}{ Multiplication factor } & & \\
Scientific notation & Decimal form & Prefix & Symbol \\
\hline $1.0 \mathrm{E}+06$ & 1000000 & mega & $\mathrm{M}$ \\
$1.0 \mathrm{E}+03$ & 1000 & kilo & $\mathrm{k}$ \\
$1.0 \mathrm{E}-02$ & 0.01 & centi & $\mathrm{C}$ \\
$1.0 \mathrm{E}-03$ & 0.001 & milli & $\mathrm{m}$ \\
$1.0 \mathrm{E}-06$ & 0.000001 & micro & $\mu$ \\
$1.0 \mathrm{E}-09$ & 0.000000001 & nano & $\mathrm{n}$ \\
$1.0 \mathrm{E}-12$ & 0.000000000001 & pico & $\mathrm{p}$
\end{tabular}

low-level environmental analyses for radioactivity are especially prone to significant uncertainty in comparison with the result. Radiological data are presented in the following manner:

Example: $1.04 \pm 0.54$ E-09

Where: $\begin{aligned} 1.04= & \text { the result } \\ \pm 0.54= & \begin{array}{l}\text { plus or minus the } \\ \text { associated uncertainty }\end{array} \\ \mathrm{E}-09= & \begin{array}{l}\text { times } 10 \text { raised to the } \\ \text { power }-09\end{array}\end{aligned}$

Sources of uncertainty may include random components (e.g., radiological counting statistics) or systematic components (e.g., sample collection and handling, measurement sensitivity, or bias). Radiological data in this report include both a result and uncertainty term. The uncertainty term represents only the uncertainty associated with the analytical measurement which for environmental samples is largely due to the random nature of radioactive decay. When such radiological data are used in calculations, such as estimating the total curies released from an air or water effluent point, the other parameter used in the calculation (e.g., air volumes, water volumes), typically do not have an associated uncertainty value available. As such, the uncertainties in this report for such calculated values only reflect the uncertainty associated with the radiological results used in the calculation. The actual (total propagated) uncertainty of such values would be larger if other components of uncertainty were available and included in these estimates.

Radiological results are calculated using both sample counts and background counts. If the background count is greater than the sample count, a negative result term will be reported. The constituent is considered to be detected if the result is larger than the associated uncertainty (i.e., a "positive" detection). Nonradiological data are not reported with an associated uncertainty.

In general, the detection limit is the minimum amount of a constituent that can be detected, or distinguished from background, by an instrument or a measurement technique. If a result is preceded by the symbol "<" (i.e., $<5$ parts per million [ppm]), the constituent was not measurable below the detection limit (in this example, $5 \mathrm{ppm}$ ). 
TABLE UI-2

Units of Measure Used in this ASER

\begin{tabular}{|c|c|c|c|c|c|}
\hline Type & Measurement & Symbol & Type & Measurement & Symbol \\
\hline \multirow[t]{6}{*}{ Length } & meter & $m$ & \multirow[t]{6}{*}{ Dose } & rad (absorbed dose) & rad \\
\hline & centimeter & $\mathrm{cm}$ & & rem (dose equivalent) & rem \\
\hline & kilometer & $\mathrm{km}$ & & millirem & mrem \\
\hline & inch & in & & sievert & Sv \\
\hline & foot & $\mathrm{ft}$ & & millisievert & $\mathrm{mSv}$ \\
\hline & mile & $\mathrm{mi}$ & & gray & Gy \\
\hline \multirow[t]{5}{*}{ Volume } & gallon & gal & \multirow[t]{3}{*}{ Exposure } & roentgen & $\mathrm{R}$ \\
\hline & liter & $\mathrm{L}$ & & milliroentgen & $\mathrm{mR}$ \\
\hline & milliliter & $\mathrm{mL}$ & & microroentgen & $\mu R$ \\
\hline & cubic meter & $\mathrm{m}^{3}$ & \multirow[t]{6}{*}{ Concentration } & parts per million & ppm \\
\hline & cubic feet & $\mathrm{ft}^{3}$ & & parts per billion & $\mathrm{ppb}$ \\
\hline \multirow[t]{4}{*}{ Area } & acre & ac & & parts per trillion & ppt \\
\hline & hectare & ha & & milligrams per L (ppm) & $\mathrm{mg} / \mathrm{L}$ \\
\hline & square meter & $m^{2}$ & & micrograms per L (ppb) & $\mu g / L$ \\
\hline & square foot & $\mathrm{ft}^{2}$ & & nanograms per L (ppt) & $\mathrm{ng} / \mathrm{L}$ \\
\hline \multirow[t]{2}{*}{ Temperature } & degrees Fahrenheit & ${ }^{\mathrm{o}} \mathrm{F}$ & & milligrams per kg (ppm) & $\mathrm{mg} / \mathrm{kg}$ \\
\hline & degrees Celsius & ${ }^{\circ} \mathrm{C}$ & & micrograms per g (ppm) & $\mu \mathrm{g} / \mathrm{g}$ \\
\hline \multirow[t]{8}{*}{ Mass } & gram & g & & micrograms per mL (ppm) & $\mu \mathrm{g} / \mathrm{mL}$ \\
\hline & kilogram & $\mathrm{kg}$ & & milliliters per mL & $\mathrm{mL} / \mathrm{L}$ \\
\hline & milligram & mg & & microcuries per $\mathrm{mL}$ & $\mu \mathrm{Ci} / \mathrm{mL}$ \\
\hline & microgram & $\mu g$ & & picocuries per $\mathrm{L}$ & $\mathrm{pCi} / \mathrm{L}$ \\
\hline & nanogram & $\mathrm{ng}$ & & microcuries per $\mathrm{g}$ & $\mu \mathrm{Ci} / \mathrm{g}$ \\
\hline & pound & $\mathrm{lb}$ & & becquerels per $\mathrm{L}$ & $\mathrm{Bq} / \mathrm{L}$ \\
\hline & tonne (metric ton) & $\mathrm{t}$ & & nephelometric turbidity units & NTU \\
\hline & ton, short & $\mathrm{T}$ & & standard units $(\mathrm{pH})$ & SU \\
\hline \multirow[t]{6}{*}{ Radioactivity } & curie & $\mathrm{Ci}$ & \multirow[t]{6}{*}{ Flow rate } & gallons per day & gpd \\
\hline & millicurie & $\mathrm{mCi}$ & & gallons per minute & gpm \\
\hline & microcurie & $\mu \mathrm{Ci}$ & & million gallons per day & mgd \\
\hline & nanocurie & $\mathrm{nCi}$ & & cubic feet per minute & $\mathrm{cfm}$ \\
\hline & picocurie & $\mathrm{pCi}$ & & liters per minute & Ipm \\
\hline & becquerel & $\mathrm{Bq}$ & & meters per second & $\mathrm{m} / \mathrm{sec}$ \\
\hline
\end{tabular}

TABLE UI-3

Conversion Factors Used in this ASER

\begin{tabular}{llc} 
To convert from & to & Multiply by \\
\hline miles & kilometers & 1.609344 \\
feet & meters & 0.3048 \\
inches & centimeters & 2.54 \\
acres & hectares & 0.4046873 \\
pounds & kilograms & 0.45359237 \\
gallons & liters & 3.785412 \\
curies & becquerels & $3.7 \mathrm{E}+10$ \\
rad & gray & 0.01 \\
rem & sievert & 0.01 \\
\hline \hline
\end{tabular}


The number of significant digits reported depends on the precision of the measurement technique. Integer counts are reported without rounding. Calculated values are customarily reported to three significant figures. Dose estimates are usually reported to two significant figures. All calculations are completed before values are rounded.

\section{Limits Applicable to Environmental Media}

Dose Standards. The two dose standards against which releases at the WVDP are assessed are those established by EPA for air emissions and that established by DOE regarding all exposure modes from DOE activities.

Radiological air emissions other than radon from DOE facilities are regulated by EPA under the NESHAP regulation (40 CFR 61, Subpart H), which establishes a standard of $10 \mathrm{mrem} / \mathrm{year}$ effective dose equivalent to any member of the public. See "CAP88-PC Computer Code" in inset.

DOE Order 458.1 sets the DOE primary standard of $100 \mathrm{mrem} /$ year effective dose equivalent to members of the public considering all exposure modes from DOE activities. (Currently there are no EPA standards establish- ing limits on the radiation dose to members of the public from liquid effluents.)

Note that EPA establishes a drinking water limit of 4-mrem/year (0.04-mSv/year) (40 CFR Parts 141 and 143, Drinking Water Guidelines). Corollary limits for community water supplies are set by the NYSDOH in the NYS Sanitary Code (10 NYCRR 5-152). These limits are not applicable at the WVDP because no drinking water sources within the Cattaraugus Creek drainage basin are affected by the WVDP.

DOE DCS. A DCS is defined as the concentration of a radionuclide in air or water that, under conditions of continuous exposure by one exposure mode (i.e., ingestion of water, immersion in air, or inhalation) for one year, would result in an EDE of 100 mrem ( $1 \mathrm{mSv}$ ) to a "reference man" (DOE Order 458.1). DCSs for radionuclides measured at the WVDP are listed in Table UI-4. At the WVDP, DCSs are used as a screening tool for evaluating liquid effluents and airborne emissions. (DCSs are not used to estimate dose.)

SPDES Permit Requirements. On July 1, 2011, a modified SPDES permit became effective for the WVDP, and requirements of the $C Y 2011$ SPDES permit are summarized in Appendix B-1. The site's SPDES permit defines points where sampling must be conducted, sampling fre-

\section{CAP88-PC Computer Code}

The WVDP ASER summarizes the airborne radioactivity released (see Appendix C) and the effect from those releases (Chapter 3) in a manner consistent with that required by EPA. The computer code Clean Air Act Assessment Package-1988 for personal computers (CAP88-PC), Version 3.0, first approved in 2006, is used to perform radiation dose and risk calculations from WVDP airborne releases. According to EPA website from whence the most recent release can be obtained, any approved version of the code can be used for compliance.

Version 3.0 of CAP88-PC (Trinity Engineering Associates, Inc., most recent release, February 2013) was first approved by EPA for use in February 2006 to demonstrate compliance with the 10-mrem/year NESHAP standard. Version 3.0 incorporates updated scientific methods to calculate radiation dose and risk. Version 3.0 also considers age and gender factors not considered in earlier versions. This version used weighting factors that consider the sensitivity of various human organs to radiation. The model also calculates how long radioactive material will remain in a particular organ or system. Together, these factors are used to calculate dose and cancer risk. The net effect is that dose and risk estimates summarized in the ASER from using CAP88-PC Version 2.0 and Version 3.0 are slightly different, even if the radioactivity released from WVDP and meteorology both remain constant. However, test calculations with both versions have resulted in estimated doses far below the compliance limit.

At this juncture, EPA accepts the use of any of the three approved versions of CAP88 for compliance purposes. The WVDP used Version 2.0 in 2009 for airborne dose assessment and has used the recommended Version 3.0 code since 2010. 
quency, the type of samples to be collected, nonradiological constituents for which samples must be analyzed, and the limits applicable to these constituents. Results are reported monthly to the NYSDEC in DMRs.

Radionuclides are not regulated under the SPDES permit. However, special requirements in the permit specify that the concentration of radionuclides in the discharge is subject to requirements of DOE Order 458.1 (including Change 2), "Radiation Protection of the Public and the Environment."

Water Quality Classifications, Standards, and Limits for Ambient Water. The objective of the Clean Water Act (CWA) of 1972 is to restore and maintain the integrity of the nation's waters and ensure that, wherever attainable, waters be made useful for fishing and swimming. To achieve this goal, NYS is delegated with authority under Sections 118,303 , and 510 of the CWA to (1) classify and designate the best uses for receiving waters, such as streams and rivers, within its jurisdiction, and (2) establish and assign water quality standards - goals for achieving the designated best uses for these classified waters.

The definitions for best usage classification of New York's jurisdictional waters and the water quality standard goals for these classifications are provided in 6 NYCRR Parts 701-704. Mapping of the Cattaraugus Creek drainage basin and assignment of best usage designations and classification to each receiving water segment within this drainage basin are described in 6 NYCRR Part 838.

According to these regulations, Franks Creek, Quarry Creek, and segments of Buttermilk Creek under the influence of water effluents from the WVDP are identified as Class " $C$ " receiving waters with a minimum designated best usage for fishing with conditions suitable for fish propagation and survival.

Cattaraugus Creek, in the immediate downstream vicinity of the WNYNSC, is identified as a Class " $\mathrm{B}$ " receiving water with best designated usages for swimming and fishing. All fresh (nonsaline) groundwaters within New York are assigned a "GA" classification with a designated best usage as a potable water supply source.

Refer to Appendix B for a summary of the water quality standards, guidelines, and MCLs assigned to these water classifications for those constituents that are included in the WVDP environmental monitoring program for ambient water.
Potable Water Standards. In addition to achieving CWA goals for fishing and swimming, the NYSDOH and EPA have further classified its jurisdictional waters and established ambient water standards, guidelines, and maximum contaminant levels (MCLs) or MCL goals to achieve objectives under the Safe Drinking Water Act for drinking water. These standards serve as the basis for periodic evaluation of the integrity of the receiving waters and identification of needed controls. These standards are expressed as MCLs or MCL goals. See Appendix B-1 for a summary of these levels.

Soil and Sediment Concentration Guidelines. Contaminants in soil are potential sources for contamination of groundwater, surface water, ambient air, and plants and animals. Routine soil and sediment sampling is performed every five years.

The Nuclear Regulatory Commission (NRC) and the EPA, in a 2002 memorandum of understanding pertaining to decommissioning and decontamination of contaminated sites, agreed upon concentrations of residual radioactivity in soil that would trigger consultation between the two agencies. Consultation "trigger" levels for radioactive contamination in both residential and industrial soil are listed in Appendix F for nuclides applicable to the WVDP.

In 2006, the NRC, in a decommissioning guidance document (NUREG-1757, Vol. 2, 2006), provided concentration screening values for common radionuclides in soil that could result in a dose of $25 \mathrm{mrem} /$ year. For summary tables of screening levels for radionuclides of interest at the WVDP, see Appendix F.

In 2009, soil cleanup goals were developed from site-specific data for the "Phase I Decommissioning Plan for the WVDP," rev. 2, December 2009. These criteria are presented in Table 5-14 of the DP.

\section{Evaluation of Monitoring Data with Respect to Limits}

Monitoring data for this report were evaluated against the limits presented in Table UI-4, and in Appendices B, $D$, and $F$. Those locations with results exceeding the limits are listed in Chapter 2, Table 2-4, and in Chapter 4, Table 4-9. 
TABLE UI-4

U.S. Department of Energy Derived Concentration Standards (DCSs) ${ }^{\text {a }}$ for Inhaled Air or Ingested Water $(\mu \mathrm{Ci} / \mathrm{mL})$

\begin{tabular}{|c|c|c|c|}
\hline Radionuclide & Half-life (years) ${ }^{b}$ & DCSs in Inhaled Air ${ }^{c}$ & $\begin{array}{c}\text { DCSs in Ingested } \\
\text { Water }\end{array}$ \\
\hline Gross Alpha $^{d}$ & NA & $\begin{array}{c}8.1 \mathrm{E}-14 \\
\text { (as Pu-239/240) }\end{array}$ & $\begin{array}{c}9.8 \mathrm{E}-08 \\
\text { (as U-232) }\end{array}$ \\
\hline Gross Beta $^{d}$ & NA & $\begin{array}{c}1.0 \mathrm{E}-10 \\
\text { (as Sr-90) }\end{array}$ & $\begin{array}{c}1.1 \mathrm{E}-06 \\
\text { (as Sr-90) }\end{array}$ \\
\hline Tritium (H-3) & $1.23 \mathrm{E}+01$ & $2.1 \mathrm{E}-07^{\mathrm{e}}$ & $1.9 \mathrm{E}-03$ \\
\hline Carbon-14 (C-14) & $5.70 \mathrm{E}+03$ & $6.1 \mathrm{E}-07^{f}$ & $6.2 \mathrm{E}-05$ \\
\hline Potassium-40 (K-40) & $1.25 \mathrm{E}+09$ & $2.6 \mathrm{E}-10$ & $4.8 \mathrm{E}-06$ \\
\hline Cobalt-60 (Co-60) & $5.27 \mathrm{E}+00$ & $3.6 \mathrm{E}-10$ & $7.2 \mathrm{E}-06$ \\
\hline Strontium-90 (Sr-90) & $2.89 \mathrm{E}+01$ & $1.0 \mathrm{E}-10$ & $1.1 \mathrm{E}-06$ \\
\hline Technetium-99 (Tc-99) & $2.11 \mathrm{E}+05$ & $9.2 \mathrm{E}-10$ & $4.4 \mathrm{E}-05$ \\
\hline lodine-129 (I-129) & $1.57 \mathrm{E}+07$ & $1.0 \mathrm{E}-10$ & $3.3 \mathrm{E}-07$ \\
\hline Cesium-137 (Cs-137) & $3.00 \mathrm{E}+01$ & $8.8 \mathrm{E}-10$ & $3.0 \mathrm{E}-06$ \\
\hline Europium-154 (Eu-154) & $8.59 \mathrm{E}+00$ & $7.5 \mathrm{E}-11$ & $1.5 \mathrm{E}-05$ \\
\hline Uranium-232 (U-232) & $6.89 \mathrm{E}+01$ & $4.7 \mathrm{E}-13$ & $9.8 \mathrm{E}-08$ \\
\hline Uranium-233 (U-233) & $1.59 \mathrm{E}+05$ & $1.0 \mathrm{E}-12$ & $6.6 \mathrm{E}-07$ \\
\hline Uranium-234 (U-234) & $2.46 \mathrm{E}+05$ & $1.1 \mathrm{E}-12$ & $6.8 \mathrm{E}-07$ \\
\hline Uranium-235 (U-235) & $7.04 \mathrm{E}+08$ & $1.2 \mathrm{E}-12$ & $7.2 \mathrm{E}-07$ \\
\hline Uranium-236 (U-236) & $2.34 \mathrm{E}+07$ & $1.2 \mathrm{E}-12$ & $7.2 \mathrm{E}-07$ \\
\hline Uranium-238 (U-238) & $4.47 \mathrm{E}+09$ & $1.3 \mathrm{E}-12$ & $7.5 \mathrm{E}-07$ \\
\hline Plutonium-238 (Pu-238) & $8.77 \mathrm{E}+01$ & $8.8 \mathrm{E}-14$ & $1.5 \mathrm{E}-07$ \\
\hline Plutonium-239 (Pu-239) & $2.41 \mathrm{E}+04$ & $8.1 \mathrm{E}-14$ & $1.4 \mathrm{E}-07$ \\
\hline Plutonium-240 (Pu-240) & $6.56 \mathrm{E}+03$ & $8.1 \mathrm{E}-14$ & $1.4 \mathrm{E}-07$ \\
\hline Americium-241 (Am-241) & $4.32 \mathrm{E}+02$ & $9.7 \mathrm{E}-14$ & $1.7 \mathrm{E}-07$ \\
\hline
\end{tabular}

${ }^{a}$ DCSs are defined as the concentration of a radionuclide that, under conditions of continuous exposure for one year. by one exposure mode, would result in an effective dose equivalent of $100 \mathrm{mrem}(1 \mathrm{mSv})$.

${ }^{b}$ Nuclear Wallet Cards. April 2005. National Nuclear Data Center. Brookhaven National Laboratory. Upton, New York.

' The DCS selection for air utilized the default type lung absorption rates for each nuclide, based on guidance from ICRP-72 for particulate aerosols when no specific chemical information is available.

${ }^{d}$ Because there are no DCSs for gross alpha and gross beta concentrations, the values for the most restrictive alpha and beta emitters at the WVDP (Pu-239/240 for alpha in air, U-232 for alpha in water, and Sr-90 for both air and water gross beta concentrations) are used as a conservative basis for comparison at locations for which there are no radionuclide-specific data, in which case a more appropriate DCS may be applied.

${ }^{\mathrm{e}}$ The DCS for tritium represents the water vapor standard, selected from Table 5, DOE-STD-1196-2011.

${ }^{\dagger}$ The DCS for carbon-14 represents the dioxide chemical form, selected from Table 5, DOE-STD-1996-2011. 


\section{GLOSSARY}

A

accuracy - The degree of agreement between a measurement and its true value. The accuracy of a data set is assessed by evaluating results from standards or sample spikes containing known quantities of an analyte.

action plan - An action plan addresses assessment findings and root causes that have been identified in an audit or an assessment report. It is intended to define specific actions that the responsible group will undertake to remedy deficiencies. The plan includes a timetable and resource requirements for implementation of the planned activities.

aquifer - A water-bearing unit of permeable rock or soil that will yield water in usable quantities via wells. Confined aquifers are bounded above and below by less permeable layers. Groundwater in a confined aquifer may be under a pressure greater than the atmospheric pressure. Unconfined aquifers are bounded below by less permeable material, but are not bounded above. The pressure on the groundwater at the surface of an unconfined aquifer is equal to that of the atmosphere.

aquitard - A low-permeability geologic unit that can store groundwater and can transmit groundwater at a very slow rate.

as low as reasonably achievable (ALARA) - An approach to radiation protection that advocates controlling or managing exposures (both individual and collective) to the work force and the general public and releases of radioactive material to the environment as low as social, technical, economic, practical, and public policy considerations permit. As used in United States (U.S.) Department of Energy (DOE) Order 5400.5, ALARA is not a dose limit but, rather, a process that has as its objective the attainment of dose levels as far below the applicable limits of the Order as practicable.
B

background radiation - Natural and man-made radiation such as: cosmic radiation, radiation from naturally radioactive elements, and radiation from commercial sources and medical procedures.

becquerel $(\mathbf{B q})$ - A unit of radioactivity equal to one nuclear transformation per second.

C

categorical exclusion (CX) - A proposed action that the DOE has determined does not individually or cumulatively have a significant effect on the human environment. See 10 Code of Federal Regulations (CFR) 1021.410.

Class A, B, and C low-level waste - Waste classifications from the Nuclear Regulatory Commission's 10 CFR Part 61 rule. Maximum concentration limits are set for specific isotopes. Class A waste disposal is minimally restricted with respect to the form of the waste. Class B waste must meet more rigorous requirements to ensure physical stability after disposal. Higher radionuclide concentration limits are set for Class C waste (the most radioactive), which also must meet physical stability requirements. Moreover, special measures must be taken at the disposal facility to protect against inadvertent intrusion.

compliance findings - Conditions that may not satisfy applicable environmental or safety and health regulations, DOE Orders and memoranda, enforcement actions, agreements with regulatory agencies, or permit conditions.

confidence interval - The range of values within which some parameter may be expected to lie with a stated degree of confidence. For example, a value of 10 with an uncertainty of 5 calculated at the $95 \%$ confidence level $(10 \pm 5)$ indicates there is a $95 \%$ probability that the true value of that parameter lies between 5 and 15 . 
consistency - The condition of showing steady conformity to practices. In the environmental monitoring program, approved procedures are in place so that data collection activities are carried out in a uniform manner to minimize variability.

Core Team - The "core team approach" is a formalized, consensus-based process in which those individuals with decision-making authority, including the DOE, the U.S. Environmental Protection Agency (EPA), and State remedial project managers, work together to reach agreement on key remediation decisions (DOE/EH-413-9911, October 1999). In August 2006, the DOE-West Valley Demonstration Project (DOE-WVDP) requested that the New York State Department of Health (NYSDOH), the U.S. Nuclear Regulatory Commission (NRC), the EPA (region 2), the New York State Department of Environmental Conservation (NYSDEC), and the New York State Energy Research and Development Authority (NYSERDA) participate in a collaborative process (i.e., Core Team) to resolve technical issues associated with the "Draft Environmental Impact Statement for Decommissioning and/or Long-Term Stewardship at the West Valley Demonstration Project and Western New York Nuclear Service Center" (DEIS).

cosmic radiation - High-energy subatomic particles from outer space that bombard the earth's atmosphere. Cosmic radiation is part of natural background radiation.

curie (Ci) - A unit of radioactivity equal to 37 billion (3.7 $\mathrm{x}$ $10^{10}$ ) nuclear transformations per second.

D

data set - A group of data (e.g., factual information such as measurements or statistics) used as a basis for reasoning, discussion, or calculation.

decay (radioactive) - Disintegration of the nucleus of an unstable nuclide by spontaneous emission of charged particles and/or photons or by spontaneous fission.

derived concentration standard (DCS) - The concentration of a radionuclide in air and water that, under conditions of continuous human exposure for one year by one exposure mode (i.e., ingestion of water, inhalation, or immersion in a gaseous cloud), would result in an effective dose equivalent of 100 millirem (mrem) (1 millisievert [mSv]). See Table UI-4 in the "Useful Information" section of this report. detection limit or level (DL) - This term may also be expressed as "method detection limit" (MDL). The smallest amount of a substance that can be distinguished in a sample by a given measurement procedure at a given confidence level. (See lower limit of detection.)

dispersion (airborne) - The process whereby particulates or gases are spread and diluted in air as they move away from a source.

dispersion (groundwater) - The process whereby solutes are spread or mixed as they are transported by groundwater as it moves through the subsurface.

dosimeter - A portable device for measuring the total accumulated exposure to ionizing radiation.

downgradient - The direction of water flow from a reference point to a selected point of interest at a lower elevation than the reference point. (See gradient.)

E

effective dose - (See effective dose equivalent under radiation dose.)

effluent - Any treated or untreated air emission or liquid discharge to the environment.

effluent monitoring - Sampling or measuring specific liquid or gaseous effluent streams for the presence of pollutants to determine compliance with applicable standards, permit requirements, and administrative controls.

environmental assessment (EA) - An evaluation that provides sufficient evidence and analysis for determining whether an environmental impact statement is required or a finding of no significant impact should be issued. See 10 CFR 1021.

environmental impact statement (EIS) - A detailed statement that includes the environmental impact of the proposed action, any adverse environmental effects that cannot be avoided should the proposal be implemented, and alternatives to the proposed action. Detailed information may be found in Section 10 CFR 1021.

environmental management system (EMS) - The systematic application of business management practices to environmental issues, including defining the organizational structure, planning for activities, identifying responsibil- 
ities, and defining practices, procedures, processes, and resources.

environmental monitoring - The collection and analysis of samples or the direct measurement of environmental media. Environmental monitoring consists of two major activities: effluent monitoring and environmental surveillance.

environmental surveillance - The collection and analysis of samples or the direct measurement of air, water, soil, foodstuff, and biota in the environs of a facility of interest to determine compliance with applicable standards and to detect trends and environmental pollutant transport.

exposure - The subjection of a target (usually living tissue) to radiation.

$\mathbf{F}$

fallout - The settling to earth of radioactive materials mixed into the earth's atmosphere.

finding - A DOE compliance term. A finding is a statement of fact concerning a condition in the Environmental, Safety, and Health program that was investigated during an appraisal. Findings include best management practice findings, compliance findings, and noteworthy practices. A finding may be a simple statement of proficiency or a description of deficiency (i.e., a variance from procedures or criteria). (See also self-assessment.)

fission - The act or process of splitting into parts. A nuclear reaction in which an atomic nucleus splits into fragments (i.e., fission products, usually fragments of comparable mass) with the evolution of approximately 100 million to several hundred million electron volts of energy.

\section{G}

gamma isotopic (also gamma scan) - An analytical method by which the quantity of several gamma ray-emitting radioactive isotopes may be determined simultaneously. Typical nuclear fuel cycle isotopes determined by this method include, but are not limited to, cobalt-60, zirconium-95, ruthenium-106, silver-110m, antimony-125, cesium-134, cesium-137, and europium-154. Naturally occurring isotopes for which samples may be analyzed are beryllium-7, potassium-40, radium-224, and radium-226.

gradient - Change in value of one variable with respect to another variable, such as a vertical change over a horizontal distance. groundwater - Subsurface water in the pore spaces and fractures of soil and bedrock units.

H

half-life - The time in which half the atoms of a radionuclide disintegrate into another nuclear form. The half-life may vary from a fraction of a second to billions of years.

hazardous waste - A waste or combination of wastes that because of quantity, concentration, or physical, chemical, or infectious characteristics may: a) cause or significantly contribute to an increase in mortality or an increase in serious irreversible or incapacitating reversible illness; or (b) pose a substantial present or potential hazard to human health or the environment when improperly treated, stored, transported, disposed of, or otherwise managed.

high-level radioactive waste (HLW) - The highly radioactive waste material that results from the reprocessing of spent nuclear fuel, including liquid waste produced directly in reprocessing and solid waste derived from the liquid, that contains a combination of transuranic waste and fission products in concentrations sufficient to require permanent isolation. (See also transuranic waste.)

hydraulic conductivity - The ratio of flow velocity to driving force for viscous flow under saturated conditions of a specified liquid in a porous medium; the ratio describing the rate at which water can move through a permeable medium.

\section{I}

integrated safety management system (ISMS) - A process that describes the programs, policies, and procedures used at the WVDP to ensure the establishment of a safe workplace for the employees, the public, and the environment. The guiding principles of ISMS are line management responsibility for safety; clear roles and responsibilities; competence commensurate with responsibilities; balanced priorities; identification of safety standards and requirements; hazard controls; and operations authorization.

interim status - The status of any currently existing facility that becomes subject to the requirement to have a Resource Conservation and Recovery Act (RCRA) permit because of a new statutory or regulatory amendment to RCRA.

ion - An atom or group of atoms with an electric charge. 
ion exchange - The reversible exchange of ions contained in solution with other ions that are part of the ion-exchange material.

ISO (International Organization for Standardization) An international network of nongovernmental standards institutes that forms a bridge between the public and private sectors, and is the largest standards organization in the world. ISO enables a consensus to be reached on solutions that meet both the requirements of business and the broader needs of society.

ISO 14001:2004 - A standard for an EMS, which requires an organization to:

- Determine the organization's impact on the environment and relevant regulations to the operations of the business;

- Create a plan to control the organization's processes to minimize the environmental impact;

- Monitor the effectiveness of the system at meeting objectives, as well as legal and other; and

- Continually analyze the results and improve the organization's systems.

isotope - Different forms of the same chemical element that are distinguished by having the same number of protons but a different number of neutrons in the nucleus. An element can have many isotopes. For example, the three isotopes of hydrogen are protium, deuterium, and tritium, with one, two, and three neutrons in the nucleus, respectively.

\section{K}

knickpoint - A term in geomorphology to describe a location in a river or channel where there is a sharp change in channel slope resulting from differential rates of erosion.

\section{$\mathbf{L}$}

land disposal restrictions (LDR) - Regulations promulgated by the EPA (and by NYSDEC in New York State) governing the land disposal of hazardous wastes. The wastes must be treated using the best demonstrated available technology or must meet certain treatment standards before being disposed. lower limit of detection (LLD) - The lowest limit of a given parameter that an instrument is capable of detecting. A measurement of analytical sensitivity.

low-level radioactive waste (LLW) - Radioactive waste not classified as high-level radioactive waste, transuranic waste, spent fuel, or uranium mill tailings. (See Class $A, B$, and (low-level waste.)

\section{M}

maximally exposed individual (MEI) - On-site (occupational) or off-site (nonoccupational) person that receives the highest dose from a release scenario.

maximally exposed off-site individual (MEOSI) - Member of the general public receiving the highest dose from the effluent release.

mean - The average value of a series of measurements.

metric ton - (See ton, metric.)

millirem (mrem) - A unit of radiation dose equivalent that is equal to one one-thousandth of a rem. An individual member of the public can receive up to 100 mrem per year according to DOE standards. This limit does not include the roughly $310 \mathrm{mrem}$, on average, that people in the U.S. receive annually from natural background radiation.

minimum detectable concentration (MDC) or method detection limit (MDL) - Depending on the sample medium, the smallest amount or concentration of a radioactive or nonradioactive analyte that can be reliably detected using a specific analytical method. Calculations of the minimum detectable concentrations are based on the lower limit of detection.

mixed waste (MW) - A waste that is both radioactive and RCRA hazardous.

\section{$\mathbf{N}$}

n-Dodecane/tributyl phosphate - An organic solution composed of $30 \%$ tributyl phosphate (TBP) dissolved in n-dodecane used to first separate the uranium and plutonium from the fission products in dissolved nuclear fuel and then to separate the uranium from the plutonium. 
neutron - An electrically neutral subatomic particle in the baryon family with a mass 1,839 times that of an electron, stable when bound in an atomic nucleus, and having a mean lifetime of approximately 16.6 minutes as a free particle.

Nitrocision ${ }^{\circledR}$ - A robotically controlled, pressurized, liquid nitrogen tooling system used to remove high-activity fixed contamination from cell and equipment surfaces.

notice of violation (NOV) - Generally, an official notification from a regulatory agency of noncompliance with permit requirements. (An example would be a letter of notice from a regional water engineer in response to an instance of significant noncompliance with a State Pollutant Discharge Elimination System [SPDES] permit.)

nucleus - The positively-charged central region of an atom, made up of protons and neutrons and containing almost all of the mass of the atom.

0

outfall - The discharge end of a drain or pipe that carries wastewater or other liquid effluents into a ditch, pond, or river.

\section{$\mathbf{P}$}

parameter - Any of a set of physical properties whose values determine the characteristics or behavior of something (e.g., temperature, pressure, density of air). In relation to environmental monitoring, a monitoring parameter is a constituent of interest. Statistically, the term "parameter" is a calculated quantity, such as a mean or variance, that describes a statistical population.

particulates - Solid particles and liquid droplets small enough to become airborne.

person-rem - The sum of the individual radiation dose equivalents received by members of a certain group or population. It may be calculated by multiplying the average dose per person by the number of persons exposed. For example, a thousand people each exposed to one millirem would have a collective dose of one person-rem.

plume - The distribution of a pollutant in air or water after being released from a source.

practical quantitation limits (PQLs) - The PQL is the minimum concentration of an analyte that can be measured within specified limits of precision during routine laboratory operations (NYSDEC, 1991).

precision - The degree of reproducibility of a measurement under a given set of conditions. Precision in a data set is assessed by evaluating results from duplicate field or analytical samples.

proton - A stable, positively-charged subatomic particle in the baryon family with a mass 1,836 times that of an electron.

pseudo-monitoring point - A theoretical monitoring location rather than an actual physical location; a calculation based on analytical test results of samples obtained from other associated, tributary, monitored locations. (Point 116 at the WVDP is classified as a "pseudo" monitoring point because samples are not physically collected at that location. Rather, using analytical results from samples collected from "real" upstream outfall locations, compliance with the total dissolved solids limit in the WVDP's SPDES permit is calculated for this theoretical point.)

\section{Q}

quality factor (QF) - The extent of tissue damage caused by different types of radiation of the same energy. The greater the damage, the higher the quality factor. More specifically, the factor by which absorbed doses are multiplied to obtain a quantity that indicates the degree of biological damage produced by ionizing radiation. (See radiation dose.) The factor is dependent upon radiation type (alpha, beta, gamma, or x-ray) and exposure (internal or external).

\section{$\mathbf{R}$}

rad - Radiation absorbed dose. One hundred ergs of energy absorbed per gram of solid material.

radiation - The process of emitting energy in the form of rays or particles that are thrown off by disintegrating atoms. The rays or particles emitted may consist of alpha, beta, or gamma radiation.

alpha radiation - The least penetrating type of radiation. Alpha radiation (similar to a helium nucleus) can be stopped by a sheet of paper or the outer dead layer of skin.

beta radiation - Electrons emitted from a nucleus during fission and nuclear decay. Beta radiation can be stopped by an inch of wood or a thin sheet of aluminum. 
gamma radiation - A form of electromagnetic, high-energy radiation emitted from a nucleus. Gamma rays are essentially the same as $x$-rays and require heavy shielding such as lead, concrete, or steel to be effectively attenuated.

internal radiation - Radiation originating from a source within the body as a result of the inhalation, ingestion, or implantation of natural or man-made radionuclides in body tissues.

\section{radiation dose:}

absorbed dose - The amount of energy absorbed per unit mass in any kind of matter from any kind of ionizing radiation. Absorbed dose is measured in rads or grays.

collective dose equivalent - The sum of the dose equivalents for all the individuals comprising a defined population. The per capita dose equivalent is the quotient of the collective dose equivalent divided by the population. The unit of collective dose equivalent is person-rem or person-sievert.

collective effective dose equivalent - The sum of the effective dose equivalents for the individuals comprising a defined population. Units of measurement are person-rem or person-sievert. The per capita effective dose equivalent is obtained by dividing the collective dose equivalent by the population. Units of measurement are rem or sievert.

committed dose equivalent - A measure of internal radiation. The predicted total dose equivalent to a tissue or organ over a 50-year period after a known intake of a radionuclide into the body. It does not include contributions from sources of external penetrating radiation. Committed dose equivalent is measured in rem or sievert.

committed effective dose equivalent - The sum of the committed dose equivalents to various tissues in the body, each multiplied by the appropriate weighting factor. Committed effective dose equivalent is measured in rem or sievert.

total effective dose equivalent - The summation of the products of the dose equivalent received by specified tissues of the body and the appropriate weighting factors. It includes the dose from radiation sources internal and/or external to the body. The effective dose equivalent is expressed in units of rem or seivert.

radioactivity - A property possessed by some elements (such as uranium) whereby alpha, beta, or gamma rays are spontaneously emitted.

radioisotope - A radioactive isotope of a specified element. Carbon-14 is a radioisotope of carbon. Tritium is a radioisotope of hydrogen. (See isotope.)

radionuclide - A radioactive nuclide. Radionuclides are variations (isotopes) of elements. They have the same number of protons and electrons but different numbers of neutrons, resulting in different atomic masses. There are hundreds of known nuclides, both man-made and naturally occurring.

reference man - A hypothetical aggregation of human physical and physiological characteristics arrived at by international consensus. These characteristics may be used by researchers and public health workers to standardize results of experiments and to relate biological insult to a common base.

rem - An acronym for Roentgen Equivalent Man. A unit of radiation exposure that indicates the potential effect of radiation on human cells.

remote-handled waste - At the WVDP, waste that has an external surface dose rate that exceeds 100 millirem per hour or a high level of alpha and/or beta surface contamination and, therefore, must be handled in such a manner that it does not come into physical contact with workers.

roentgen - A unit of exposure to ionizing radiation. It is that quantity of gamma or x-rays required to produce ions carrying one electrostatic unit of electrical charge in one cubic centimeter of dry air under standard conditions. The unit is named after Wilhelm Roentgen, German scientist who discovered x-rays in 1895.

\section{S}

self-assessment - Appraisals of work at the WVDP by individuals, groups, or organizations responsible for overseeing and/or performing the work. Self-assessments are intended to provide an internal review of performance to determine that specific functional areas are in program- 
matic and site-specific compliance with applicable DOE directives, WVDP procedures, and regulations.

finding - A direct and significant violation of applicable DOE, regulatory, or other procedural or programmatic requirements. A finding requires documented corrective action.

observation - A condition that, while not a direct and significant violation of applicable DOE, regulatory, or other procedural or programmatic requirements, could result in a finding if not corrected. An observation requires documented corrective action.

good practice - A statement of proficiency or confirmed excellence worthy of documenting.

sievert - A unit of dose equivalent from the International System of Units (Systeme Internationale). Equal to one joule per kilogram.

solid waste management unit (SWMU) - Any discernible unit at which solid wastes have been placed at any time, irrespective of whether the unit was intended for the management of solid or hazardous waste. Such units include any area at a facility at which solid wastes have been routinely and systematically released or created. (See also super solid waste management unit.)

spent fuel - Nuclear fuel that has been used in a nuclear reactor; this fuel contains uranium, activation products, fission products, and plutonium.

spill - A spill or release is defined as "any spilling, leaking, pumping, pouring, emitting, emptying, discharging, injecting, escaping, leaching, dumping, or otherwise disposing of substances from the ordinary containers employed in the normal course of storage, transfer, processing, or use," outside of the intended procedural action.

stakeholder - A person or group that has an investment, share, or interest in something. At the WVDP stakeholders include Project management, scientists, other employees, politicians, regulatory agencies, local and national interest groups, and members of the general public.

standard deviation - An indication of the dispersion of a set of results around their average.

super solid waste management unit (SSWMU) - Individual solid waste management units that have been grouped and ranked into larger units - super solid waste management units - because some individual units are contiguous or so close together as to make monitoring of separate units impractical. This terminology is unique to the WVDP, and is not an official regulatory term. (See also solid waste management unit.)

surface water - Water that is exposed to the atmospheric conditions of temperature, pressure, and chemical composition at the surface of the earth.

surveillance - The act of monitoring or observing a process or activity to verify conformance with specified requirements.

$T$

thermoluminescent dosimeter (TLD) - A device that luminesces upon heating after being exposed to radiation. The amount of light emitted is proportional to the amount of radiation to which the luminescent material has been exposed.

ton, metric (also tonne) - A unit of mass equal to 1,000 kilograms. (See also Table UI-2, "Units of Measure Used in This ASER.")

ton (short ton) - A unit of weight equal to 2,000 pounds or 907.1847 kilograms. (See also Table UI-2, "Units of Measure Used in This ASER.)

transuranic (TRU) waste - Waste containing transuranic elements, that is, those elements with an atomic number greater than 92, including neptunium, plutonium, americium, and curium.

U

universal wastes - Wastes subject to special management provisions that are intended to ease the management burden and facilitate recycling of such materials. Four types of waste are currently covered under the universal waste regulations: hazardous waste batteries, hazardous waste pesticides that are either recalled or collected in waste pesticide collection programs, hazardous waste thermostats, and hazardous waste lamps.

upgradient - Referring to the flow of water or air, "upgradient" is analogous to upstream. Upgradient is a point that is "before" an area of study and that is used as a baseline for comparison with downstream or downgradient data. (See gradient and downgradient.) 
V

vitrification - A waste treatment process that encapsulates or immobilizes radioactive wastes in a glassy matrix to prevent them from reacting in disposal sites. Vitrification involves adding chemicals, glass formers, and waste to a heated vessel and melting the mixture into a glass that is then poured into a canister.

W

watershed - The area contained within a drainage divide above a specified point on a stream or river.

water table - The upper surface in a body of groundwater; the surface in an unconfined aquifer or confining bed at which the pore water pressure is equal to atmospheric pressure.

well point - A small-diameter well that is hammer-driven rather than placed into a pre-drilled borehole.

$\mathbf{X}$

x-ray - Penetrating electromagnetic radiations having wave lengths shorter than those of visible light. They are usually produced by bombarding a metallic target with fast electrons in a high vacuum. In nuclear reactions it is customary to refer to photons originating in the nucleus as gamma rays and those originating in the extranuclear part of the atom as $\mathrm{x}$-rays. These rays are sometimes called Roentgen rays after their discoverer, W.C. Roentgen. 


\section{ACRONYMS AND ABBREVIATIONS}

\section{Note: For abbreviations of units of measure, see Table UI-2, "Units of Measure Used in This ASER," in the "Useful Information" section.}

A

ACM - Asbestos-Containing Material

AEA - Atomic Energy Act

AF - Alternate Fuel

AFV - Alternate Fuel Vehicles

ALARA - As Low As Reasonably Achievable

alpha-BHC - alpha-hexachlorocyclohexane

ASER - Annual Site Environmental Report

ASME - American Society of Mechanical Engineers

AST - Aboveground Storage Tank

B

BCG - Biota Concentration Guide

BOD $_{5}$ - Biological Oxygen Demand (5-day)

BOSF - Balance of Site Facilities

Bq - Becquerels

C

C-O-C - Chain of Custody

CBS - Chemical Bulk Storage

CCHD - Cattaraugus County Health Department

CD - Compact Disk

CDDL - Construction and Demolition Debris Landfill

CEDE - Committed Effective Dose Equivalent

CERCLA - Comprehensive Environmental Response, Compensation, and Liability Act

CFC - Chlorofluorocarbon

CFMT - Concentrator Feed Makeup Tank

CFR - Code of Federal Regulations

CHBWV - CH2M HILL •B\&W West Valley, LLC

CMS - Corrective Measures Study

CSAP - Characterization Sampling and Analysis Plan

CSRF - Contact Size-Reduction Facility
CWA - Clean Water Act

CX - Categorical Exclusion

CY - Calendar Year

D

D\&D - Decontamination and Decommissioning

DCS - Derived Concentration Standard

DEIS - Draft Environmental Impact Statement

DCG - Derived Concentration Guide

DMR - Discharge Monitoring Report

DO - Dissolved Oxygen

DOE - (U.S.) Department of Energy

DOE-HQ - Department of Energy, Headquarters Office DOE-WVDP - Department of Energy, West Valley Demonstration Project (title as of June 2006)

DP - Decommissioning Plan

$\mathbf{E}$

EA - Environmental Assessment

ECL - (New York State) Environmental Conservation Law

ECS - Environmental Compliance Summary

EDE - Effective Dose Equivalent

EIS - Environmental Impact Statement

ELAB - (WVDP) Environmental Laboratory

ELAP - Environmental Laboratory Approval Program

ELIMS - Environmental Laboratory Information Management System

EMS - Environmental Management System

EO - Executive Order

EOC - Emergency Operations Center

EPEAT - Electronic Product Environmental Assessment Tool

EPA - (U.S.) Environmental Protection Agency

EPCRA - Emergency Planning and Community Right-toKnow Act 
ERO - Emergency Response Organization

ESH\&Q - Environmental, Safety, Health, and Quality

EWG - Erosion Work Group

$\mathbf{F}$

FEIS - Final Environmental Impact Statement

FFCA - Federal Facilities Compliance Act

FONSI - Finding of No Significant Impact

FR - Federal Register

FRS - Fuel Receiving and Storage

FSSP - Final Status Survey Plan

FY - Fiscal Year

G

GEL - General Engineering Laboratories LLC

GET - General Employee Training

GHG - Greenhouse Gas

GMP - Groundwater Monitoring Program

GSA - General Services Administration

GSL - (Site-Specific) Groundwater Screening Levels

GTCC - Greater Than Class C

H

ha - Hectare

HEPA - High-Efficiency Particulate Air (filter)

HLW - High-Level (radioactive) Waste

HP/BBS - Human Performance/Behavior-Based Safety

HVAC - Heating, Ventilation, and Air Conditioning

HWSL - Hazardous Waste Storage Locker

1

IAEA - International Atomic Energy Agency

IAP - Integrated Assessment Program

ICRP - International Commission on Radiological

Protection

IM - Interim Measure

INEEL - Idaho National Engineering and Environmental Laboratory (historical)

IR - Issue Report

ISMS - Integrated Safety Management System

ISO - International Organization for Standardization

ISP - Independent Scientific Panel

$\mathbf{L}$

LAS - Linear Alkylate Sulfonate
LLW - Low-Level (radioactive) Waste

LLW2 - Low-Level (liquid) Waste Treatment Facility

LLWTF - Low-Level Waste Treatment Facility (historical)

LOA - Letter of Agreement

LPS - Liquid Pretreatment System

LTS - Lavery Till Sand

LWTS - Liquid Waste Treatment System

$\mathbf{M}$

MAPEP - Mixed Analyte Performance Evaluation

Program

MCL - Maximum Contaminant Level

MCLG - Maximum Contaminant Level Goal

MEOSI - Maximally Exposed Off-Site Individual

MFHT - Melter Feed Hold Tank

MGD - Million Gallons per Day

MOU - Memorandum of Understanding

MPPB - Main Plant Process Building

$\mathbf{N}$

NA - Not Applicable

NCRP - National Council on Radiation Protection and Measurements

NDA - Nuclear Regulatory Commission (NRC)-Licensed Disposal Area

NEPA - National Environmental Policy Act

NESHAP - National Emission Standards for Hazardous Air Pollutants

NFS - Nuclear Fuel Services, Inc.

$\mathrm{NH}_{3}$ - Ammonia

NOI - Notice of Intent

$\mathrm{NO}_{2}-\mathrm{N}$ - Nitrite (as N)

$\mathrm{NO}_{3}-\mathbf{N}$ - Nitratte (as $\mathrm{N}$ )

$\mathrm{NO}_{\mathbf{x}}$ - Nitrogen Oxides

NPGMP - North Plateau Groundwater Monitoring Plan

NPGRS - North Plateau Groundwater Recovery System

NPOC - Nonpurgeable Organic Carbon

NQA-1 - Nuclear Quality Assurance, Level 1

NRC - (U.S.) Nuclear Regulatory Commission

NTS - Nevada Test Site

NTU - Nephelometric Turbidity Unit

NUREG - (U.S.) NRC Regulation

NYCRR - New York Official Compilation of Codes, Rules, and Regulations

NYS - New York State

NYSDEC - New York State Department of Environmental Conservation

NYSDOH - New York State Department of Health

NYSDOL - New York State Department of Labor 
NYSERDA - New York State Energy Research and Development Authority

0

OAD - Office of Atomic Development

OITS - Open Items Tracking System

OSHA - Occupational Safety and Health Administration

OVE - Outdoor Ventilated Enclosure

$\mathbf{P}$

PAS - Potential Areas of Study

PBS - Petroleum Bulk Storage

PCB - Polychlorinated Biphenyl

PEIS - Programmatic Environmental Impact Statement

PNL - Pacific Northwest Laboratory

POC - Principal Organic Contaminant

PPM - Parts Per Million

PQL - Practical Quantitation Limit

PTW - Permeable Treatment Wall

PTWPMP - Permeable Treatment Wall Performance Monitoring Plan

PVS - Permanent Ventilation System

PVU - Portable Ventilation Unit

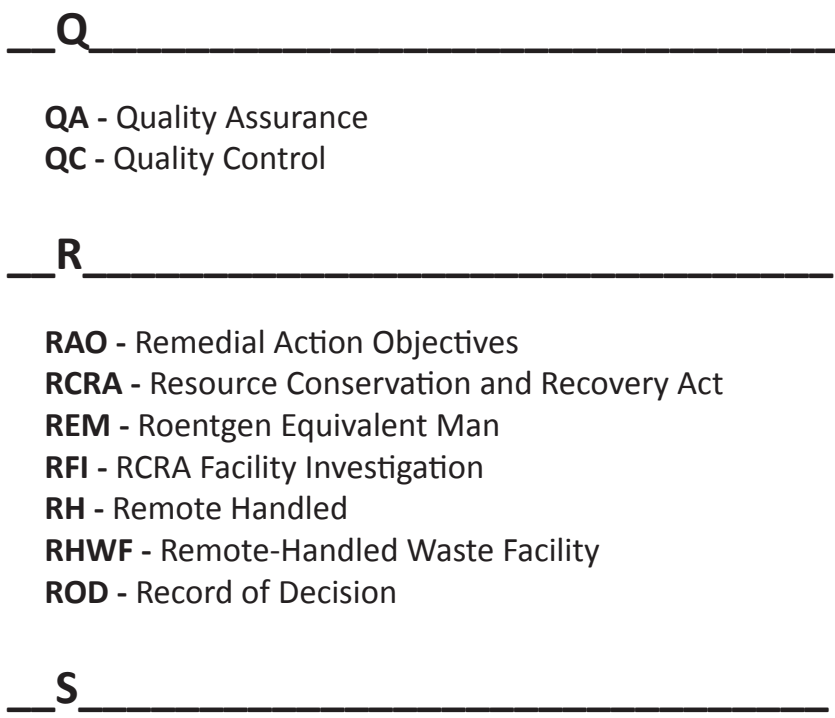

S\&G - Sand and Gravel Unit

SARA - Superfund Amendments and Reauthorization Act

SDA - (New York) State-Licensed Disposal Area

SEC - Safety and Ecology Corporation

SEQR - (New York) State Environmental Quality Review Act

SI - Systeme Internationale (International System of Units)
SME - Subject Matter Expert

SO $_{\mathbf{x}}$ - Sulfur Oxides

SPDES - (New York) State Pollutant Discharge Elimination System

SSP - Site Sustainability Plan

SSPP - Strategic Sustainability Performance Plan

SSWMU - Super Solid Waste Management Unit

STP - Site Treatment Plan

STS - Supernatant Treatment System

SU - Standard Unit

SVOC - Semivolatile Organic Compound

SWMU - Solid Waste Management Unit

SWS - Slack Water Sequence

$\mathbf{T}$

T\&VDS - Tank and Vault Drying System

TBP - Tributyl Phosphate

TBU - Thick-Bedded Unit

TDS - Total Dissolved Solids

TER - Technical Evaluation Report

TKN - Total Kjeldahl Nitrogen

TLD - Thermoluminescent Dosimeter

TOC - Total Organic Carbon

TOGS - Technical and Operational Guidance Series

TOX - Total Organic Halides

TRU - Transuranic

TSS - Total Suspended Solids

U

U.S. - United States

UDF - Unit Dose Factor

ULT - Unweathered Lavery Till

UOD - Ultimate Oxygen Demand

URS - URS - Energy \& Construction Division

USACE - U.S. Army Corps of Engineers

USC - United States Code

UST - Underground Storage Tank

V

VIT - Vitrification

VOC - Volatile Organic Compound

W

WET - Whole Effluent Toxicity

WIR - Waste-Incidental-to-Reprocessing

WLT - Weathered Lavery Till 
WNYNSC - Western New York Nuclear Service Center

WTC - Water Treatment Chemical

WTF - Waste Tank Farm

WVDP - West Valley Demonstration Project

WVES - West Valley Environmental Services LLC (histor-

ical)

WVNS - West Valley Nuclear Services (historical)

WVNSCO - West Valley Nuclear Services Company (his-

torical)

WWTF - Wastewater Treatment Facility 


\section{REFERENCES AND BIBLIOGRAPHY}

(For a bibliographical listing that includes basis documents not specifically cited in the text, see the WVDP Annual Site Environmental Report for 2003. [Available on the DOE-WVDP website at www.wv.doe.gov])

American National Standards Institute, Inc. August 20, 1975. American National Standard: Performance Testing, and Procedural Specifications for Thermoluminescent Dosimetry (Environmental Applications). ANSI N545-1975.

American Society of Mechanical Engineers. 1989. Quality Assurance Program Requirements for Nuclear Facilities. ASMENQA-1. New York: The American Society of Mechanical Engineers.

Brookhaven National Laboratory. April 2005. Nuclear Wallet Cards. National Nuclear Data Center. Upton, New York.

CHBWV. April 26, 2012. Manual for Radiological Assessment of Environmental Releases at the WVDP. Current revision. WVDP-065. WVDP-200.

May 1, 2012. West Valley Demonstration Project (WVDP) Waste Acceptance Manual. Current revision.

May 2, 2012. Clean Water Act/State Pollutant Discharge Elimination System Best Management Practices and Storm Water Pollution Prevention Plan for the West Valley Demonstration Project. Current revision. WVDP-206.

May 30, 2012. Waste Minimization/Pollution Prevention Awareness Plan. Current revision. WVDP-087.

July 24, 2012. Groundwater Monitoring Plan. Current revision. WVDP-239.

October 31, 2012. Low-Level Waste Management Program Plan. Current revision. WVDP-019.

December 13, 2012. WVDP Integrated Safety Management System (ISMS) Description. WVDP-310, including Addendum 1, WVDP Worker Safety and Health Plan, Current revision, April 19, 2012.

. December 20, 2012. Environmental Monitoring Program Plan. Current revision. WVDP-098.

January 8, 2013. Letter CHBWV to NYSDEC. "Predischarge Radiological Analysis of Lagoon 3 and Lagoon 4 - December 26, 2012, State Pollutant Discharge Elimination System (SPDES) Permit No. NY-000000973, U.S. DOE, WVDP. WR:2013:0006.

. January 10, 2013. WVDP Site Treatment Plan: Fiscal Year 2012 Update. Current revision. WVDP-299.

2012.

. February 2013. New York State Department of Environmental Conservation Hazardous Waste Report for

. February 25, 2013. Monitoring Plan for Storm Water Discharges at the West Valley Demonstration

Project. Current revision. WVDP-233. 
April 17, 2013. CHBWV Environmental Management System. Current revision. WV-980.

Citizen Task Force. July 29, 1998. West Valley Citizen Task Force Final Report.

Executive Order 11988. May 24, 1977. Floodplain Management. 42 FR 26951.

Executive Order 11990. May 25, 1977. Protection of Wetlands. 42 FR 26961.

Executive Order 13101. September 16, 1998. Greening the Government Through Waste Prevention, Recycling, and Federal Acquisition. 63 FR 49643. (Revoked by Executive Order 13423, January 24, 2007.)

Executive Order 13148. April 26, 2000. Greening the Government Through Leadership in Environmental Management. 65 FR 24595. (Revoked by Executive Order 13423, January 24, 2007.)

Executive Order 13423. January 24, 2007. Strengthening Federal Environmental, Energy, and Transportation Management. 72 FR 3919.

Executive Order 13514. October 5, 2009. Federal Leadership in Environmental, Energy, and Economic Performance. 74 FR 52117.

Federal Guidance Report 13. (FGR 13, EPA99)

International Atomic Energy Agency (IAEA). 1992. Effects of Ionizing Radiation on Plants and Animals at Levels Implied by Current Radiation Protection Standards. Technical Report Series No. 332, IAEA, Vienna, Austria.

International Commission on Radiological Protection. 1977. Recommendations of the International Commission on Radiological Protection. ICRP Publication 26. Oxford: Pergamon Press.

1979. Recommendations of the International Commission on Radiological Protection - Limits for Intakes of Radionuclides by Workers. ICRP Publication 30. Oxford: Pergamon Press.

1991. Recommendations of the International Commission on Radiological Protection. ICRP Publication 60, Pergamon Press, New York.

International Organization for Standardization. 1996. Environmental Management Systems. ISO 14001:2004.

Long, E.R., and L.G. Morgan. 1990. The Potential for Biological Effects of Sediment-Sorbed Contaminants Tested in the National States and Trends Program. National Oceanic Atmospheric Administration (NOAA) Technical Memorandum No. 5, OMA52, NOAA National Ocean Service, Seattle, Washington.

Mitrey, R.J. October 28, 1986. Correspondence from New York State Department of Environmental Conservation to J.P. Hamric, Department of Energy, Idaho Operations Office, West Valley Project Office, regarding the construction landfill.

National Council on Radiation Protection and Measurements. 1987. Ionizing Radiation Exposure of the Population of the United States. NCRP-93. Bethesda, Maryland.

National Council on Radiation Protection and Measurements. 2009. Ionizing Radiation Exposure of the Population of the United States. NCRP Report No. 160. Bethesda, Maryland.

National Environmental Laboratory Accreditation Conference (NELAC) Standard. June 2003, effective July 2005. 
National Research Council. 1990. Health Effects of Exposure to Low Levels of Ionizing Radiation. Biological Effects of Ionizing Radiation (BEIR) V. Washington: National Academy Press.

National Oceanic and Atmospheric Administration. 1919 through 2010 Buffalo area climate data. http://www.wbuf.noaa. gov. (also NOAA data at http://nowdata.rec-acis.org/BUF/pubACIS_results).

New York State. nd. Environmental Conservation Law (ECL). Article 27, Collection, Treatment, and Disposal of Refuse and Other Solid Waste. Title 9. Industrial Hazardous Waste Management.

. nd. ECL. Article 15. Water Resources. Title 5. Protection of Water.

nd. ECL. Article 15. Water Resources. Title 33. Water Withdrawal Reporting.

nd. ECL. Article 17. Water Pollution Control. Title 8. State Pollutant Discharge Elimination System.

. nd. ECL. Article 24. Freshwater Wetlands Act.

. nd. ECL. Article 40. Hazardous Substances Bulk Storage Act.

nd. Navigation Law. Article 12. Oil Spill Prevention, Control, and Compensation.

nd. Public Health Law. Article 5. Laboratories. Section 502. Laboratories; Examinations; Certificates of

Approval.

New York State Department of Environmental Conservation. nd. Title 6, New York Codes, Rules, and Regulations (6 NYCRR). Environmental Conservation Rules and Regulations.

. nd. Hazardous Waste Management Facilities. 6 NYCRR Subpart 373.

. nd. Management of Specific Hazardous Waste. 6 NYCRR Subpart 374.

. nd. Solid Waste Management Facilities. 6 NYCRR Part 360.

nd. Title 6 NYCRR, Subchapter D, Water Regulation, Parts 595 (Releases of Hazardous Substances Reporting, Response and Corrective Action); 596 (Hazardous Substance Bulk Storage Regulations), 597 (List of Hazardous Substances), 598 (Handling and Storage of Hazardous Substances); and 599 (Standards for New or Modified Hazardous Substance Storage Facilities).

. December 27, 1985 (amended February 12, 1992). Title 6 NYCRR Parts 612 (Registration of Petroleum Storage Facilities), 613 (Handling and Storage of Petroleum), and 614 (Standards for New and Substantially Modified Petroleum Storage Facilities).

. December 31, 1988 (last revised May 12, 2006). Used Oil. 6 NYCRR Subpart 360-14.

. January 24, 1994. Determination of Soil Cleanup Objectives and Cleanup Levels. Technical and Administrative Guidance Memorandum (TAGM) \#4046. (Rescinded by NYSDEC, December 3, 2010 and replaced with CP-51/Soil Cleanup Guidance).

1995. Appendix 33 - Groundwater Monitoring List. Title 6 NYCRR Subpart 373-2.

. January 1, 1996. State Environmental Quality Review. Title 6 NYCRR, Part 617. 
. September 3, 1996. Federal Facility Compliance Act: Order on Consent.

. June 1998. Ambient Water Quality Standards and Guidance Values and Groundwater Effluent Limitations.

Technical and Operational Guidance Series (TOGS) 1.1.1.

. January 25, 1999. Technical Guidance for Screening Contaminated Sediments.

March 19, 1999. Stipulation of Agreement Pursuant to Section 17-0303 of the Environmental Conservation Law and Section 176 of the Navigation Law.

. March 10, 2003 (amended May 12, 2006). 6 NYCRR Part 364, Waste Transportation, Subpart 364.9. Standards for the Tracking and Management of Medical Waste.

. February 1, 2004 and modification dates January 1, 2005 and September 1, 2006. State Pollutant Discharge Elimination System (SPDES) Discharge Permit NY0000973.

. October 21, 2004. Air Facility Registration Certificate in accordance with 6 NYCRR Part 201-4.

November 2004. Draft Technical and Operational Guidance Series (TOGS) \#5.1.9. In-Water and Riparian Management of Sediment and Dredge Material.

September 5, 2006. Hazardous Waste Manifest System and Related Standards for Generators, Transporters, and Facilities. 6 NYCRR Subpart 372.

. September 5, 2006. Identification and Listing of Hazardous Wastes. 6 NYCRR Subpart 371.

. September 5, 2006. Interim Status Standards for Owners and Operators of Hazardous Waste Facilities. 6 NYCRR Subpart 373-3.

. September 6, 2006. Final Status Standards for Owners and Operators of Hazardous Waste Treatment, Storage, and Disposal Facilities. 6 NYCRR Subpart 373-2.

September 6, 2006. Hazardous Waste Management System - General. 6 NYCRR Subpart 370.

. December 5, 2006. Land Disposal Restrictions. 6 NYCRR Subpart 376.

. October 21, 2010. CP-51/Soil Cleanup Guidance. 6NYCRR Part 375 Standards (as basis).

New York State Department of Health. nd. Environmental Laboratory Approval Program (ELAP) Certification Manual.

. nd. Title 10, New York Code, Rules, and Regulations (10 NYCRR). Sources of Water Supply. Part 5 (Drinking Water Supplies) and Part 170 (Sources of Water Supply).

New York State Energy Research and Development Authority. May 12, 2010. State Environmental Quality Review Findings Statement.

Pacific Northwest Laboratory (PNL). November 1988. Napier, B.A., Strenge, D.L., Pelequin, R.A., and Ramsdell, J.V. GENII The Hanford Environmental Radiation Dosimetry Software System. Version 1.485, PNL-6584.

Parks B.L. March 1992. User's Guide for CAP88-PC. Version 1.0. Las Vegas, NV: U.S. Environmental Protection Agency Office of Radiation Programs. 402-B-92-001. 
. June 1997. CAP88-PC Version 2.0 User's Guide. Germantown, Maryland. U.S. Department of Energy.

Persaud, D., Jaagumagi, R., and A. Hayton. 1992. Guidelines for the Protection and Management of Aquatic Sediment Quality in Ontario. Ontario Ministry of the Environment, Queen's Printer for Ontario.

Rickard, L.V. 1975. Correlation of the Silurian and Devonian Rocks in New York State. New York State Museum and Science Service Map and Chart Series No. 24.

Simpson, D.B., and B.L. McGill. 1980. LADTAP II: A Computer Program for Calculating Radiation Exposure to Man from Routine Release of Nuclear Reactor Liquid Effluents. Technical Data Management Center. ORNL/NUREG/TDMC-1.

Standish, P.N. 1985. Closure of the Construction Landfill Site. Letter (WD:85:0434) to W.H. Hannum, Department of Energy, West Valley Project Office.

Statistics Canada. 2001. Population and Dwelling Counts for Canada, Provinces and Territories, and Census Subdivisions (Municipalities), 2001 and 1996 censuses -- 100\% data, and topic-based tabulations. <http://www.statcan.ca/english/ census01/products/standard>

Trinity Engineering Associates, Inc. February 2013. CAP88-PC Version 3.0 User Guide.

U.S. Congress. 1918. Migratory Bird Treaty Act. 16 United States Code (USC) §703 et seq.

1954. Atomic Energy Act of 1954. 42 USC $§ 2011$ et seq.

1966. National Historic Preservation Act of 1966. 16 USC $§ 470$ et seq.

1969. National Environmental Policy Act of 1969. 42 USC $\$ 4321$ et seq.

1970. Clean Air Act of 1970. 42 USC $\S 7401$ et seq.

1973. Endangered Species Act of 1973. 16 USC $\$ 1531$ et seq.

1974. Safe Drinking Water Act. 42 USC §300f et seq.

1976. Resource Conservation and Recovery Act of 1976. Public Law 94-580, 90 Stat. 2795, 42 USC §6901

et seq.

1976. Toxic Substances Control Act. 15 USC $\$ 2601$ et seq.

1977. Federal Water Pollution Control Act of 1977. 33 USC §1251 et seq. (Also known as the Clean Water

Act)

. October 1, 1980. An Act to Authorize the Department of Energy to Carry Out a High-Level Liquid Nuclear Waste Management Demonstration Project at the Western New York Service Center in West Valley, New York. Public Law 96-368 [S. 2443]. Congressional Record, Vol. 126. (Also known as the WVDP Act)

1980. Comprehensive Environmental Response, Compensation, and Liability Act of 1980. Public Law 96510, 42 USC $§ 9601$ et seq.

1986. Emergency Planning and Community Right-to-Know Act of 1986. 42 USC $§ 11001$ et seq. 
. October 17, 1986. Superfund Amendments and Reauthorization Act (SARA) of 1986. Public Law 99-499, 100 Stat. 1613 , Title 10.

1992. Federal Facilities Compliance Act of 1992. Amendment to Section 6001 of the Solid Waste Disposal Act (42 USC 6961). 1996. Federal Insecticide, Fungicide, and Rodenticide Act. 7 USC $§ 136$ et seq.

U.S. Department of Commerce. U.S. Census Bureau. Census 2000.

U.S. Department of Energy. nd. National Environmental Policy Act Implementing Procedures. 10 CFR Part 1021. Subpart D, Typical Classes of Actions. Appendix B, Categorical Exclusions Applicable to Specific Agency Actions. B6-1, Small-scale, short-term cleanup actions under RCRA, Atomic Energy Act, or other authorities.

nd. Quality Assurance Criteria. 10 CFR 830.122.

1981. West Valley Demonstration Project Memorandum of Understanding Between the U.S. Department of Energy and the U.S. Nuclear Regulatory Commission.

. July 1981. A Guide for Environmental Radiological Surveillance at U.S. Department of Energy Installations. DOE/EP-0023. Washington, D.C.

. June 1982. Final Environmental Impact Statement: Long-Term Management of Liquid High-Level Radioactive Wastes Stored at the Western New York Nuclear Service Center, West Valley. DOE/EIS-0081.

. July 1983. A Guide for Effluent Radiological Measurements at DOE Installations. DOE/EP-0096. Washington, D.C.

. January 1991. Environmental Regulatory Guide for Radiological Effluent Monitoring and Environmental Surveillance. DOE/EH-0173T. Washington, D.C.

. May 1997. Final Waste Management Programmatic Environmental Impact Statement for Managing Treatment, Storage, and Disposal of Radioactive and Hazardous Waste. DOE/EIS-0200-F.

. July 9, 1999. Radioactive Waste Management. DOE Order 435.1, including Change 1 (August 28, 2001). Washington, D.C.

. August 26, 1999. Record of Decision for the Department of Energy's Waste Management Program: Storage of High-Level Radioactive Waste. 64 FR 46661.

. October 1999. Expediting Cleanup Through a Core Team Approach. DOE/EH-413-9911.

. February 25, 2000. Record of Decision for the Department of Energy's Waste Management Program: Treatment and Disposal of Low-Level Waste and Mixed Low-Level Waste; Amendment of the Record of Decision for the Nevada Test Site. 65 FR 10061.

. October 26, 2000. National Environmental Policy Act Compliance Program. DOE Order 451.1B, including Change 3 (January 19, 2012). Washington, D.C.

March 26, 2001. Revised Strategy for the Environmental Impact Statement for Completion of the West Valley Demonstration Project and Closure or Long-Term Management of Facilities at the Western New York Nuclear Service Center and Solicitation of Scoping Comments. 66 FR 16447. 
. May 2, 2001. Department of Energy Management of Cultural Resources. DOE Policy 141.1.

. November 6, 2001. Advance Notice of Intent to Prepare an Environmental Impact Statement to Evaluate Decommissioning and/or Long-Term Stewardship at the West Valley Demonstration Project and Western New York Nuclear Service Center. 66 FR 56090.

. July 2002. DOE Standard: A Graded Approach for Evaluating Radiation Doses to Aquatic and Terrestrial Biota. DOE-STD-1153-2002. Washington, D.C.

. January 2003. Estimating Radiation Risk from Total Effective Dose Equivalent (TEDE). Interagency Steering Committee on Radiation Standards (ISCORS) Technical Report No. 1. DOE/EH-412/0015/0502, Rev. 1.

. March 13, 2003. Notice of Intent to Prepare an Environmental Impact Statement for Decommissioning and/or Long-Term Stewardship at the West Valley Demonstration Project and Western New York Nuclear Services Center. 68 FR 12044.

. May 16, 2003. Notice of Availability of the West Valley Demonstration Project Draft Waste Management Environmental Impact Statement. 68 FR 26587.

. December 2003. West Valley Demonstration Project Waste Management Environmental Impact Statement. DOE/EIS-0337F.

January 2004. Users Guide: RESRAD-BIOTA: A Tool for Implementing a Graded Approach to Biota Dose Evaluation. Version 1. DOE/EH-0676. (ISCORS Technical Report 2004-2).

. June 16, 2005. Record of Decision for WVDP Waste Management Activities. 70 FR 35073.

. February 2006. Worker Safety and Health Program. 10 CFR 851.

. September 14, 2006. Environmental Assessment for the Decontamination, Demolition, and Removal of Certain Facilities at the West Valley Demonstration Project. DOE/EA-1552. West Valley, New York.

. June 4, 2008. Radioactive Material Transportation Practices Manual. DOE M 460.2-1.

December 5, 2008. Notice of Availability of the Revised Draft Environmental Impact Statement for Decommissioning and/or Long-Term Stewardship at the West Valley Demonstration Project and Western New York Nuclear Service Center. 73 FR 74160.

. December 5, 2008. Proposed Phase 1 Decommissioning Plan for the West Valley Demonstration Project, West Valley, New York. 73 FR 74162.

. December 2008, March 2009, and December 2009. Phase 1 Decommissioning Plan for the West Valley Demonstration Project. Revs. 0, 1, and 2. Prepared by: Washington Safety Management Solutions - URS Washington Division and Science Applications International Corporation.

November 18, 2009. RESRAD-BIOTA for Windows. Argonne National Laboratory, with support from U.S. EPA and U.S. NRC.

. April 14, 2010. Record of Decision: Final Environmental Impact Statement for Decommissioning and/or Long-Term Stewardship at the West Valley Demonstration Project and Western New York Nuclear Service Center. 
. February 11, 2011. Radiation Protection of the Public and the Environment. DOE Order 458.1, including Change 2 (June 6, 2011). Washington, D.C. (Canceled DOE O 5400.5.)

April 2011. DOE Standard Derived Concentration Technical Standard. DOE-STD-1196-2011. Washington, D.C. (Replaced DOE DCGs.)

April 25, 2011. Integrated Safety Management DOE O 450.2 for Use with Integrated Safety Management Policy DOE P 450.4A.

April 25, 2011. Quality Assurance. DOE Order 414.1D.

May 2011. Rev. 1. Phase I Final Status Survey Plan. West Valley Demonstration Project. Prepared by Argonne National Laboratory, Environmental Science Division, Argonne, Illinois.

. May 2, 2011. Departmental Sustainability. DOE Order 436.1 (canceled DOE O 450.1A and 430.2B).

. June 2011. Rev. 1. Phase I Characterization Sampling and Analysis Plan. West Valley Demonstration Project. Rev. 0. Prepared by Argonne National Laboratory, Environmental Science Division, Argonne, Illinois.

June 17, 2011. Worker Protection Management for DOE Federal and Contractor Employees. DOE Order 440.1B including Change 1 (March 22, 2013). Washington, D.C.

June 27, 2011. Environment, Safety, and Health Reporting. DOE Order 231.1B. Washington, D.C.

. September 2012. West Valley Demonstration Project Annual Site Environmental Report. Calendar Year 2011. Prepared by CH2M HILL • B\&W West Valley, LLC.

February 2012. Waste-Incidental-to-Reprocessing Evaluation for the West Valley Demonstration Project Vitrification Melter.

U.S. Department of Energy and New York State Energy Research and Development Authority. 1981. Cooperative Agreement between United States Department of Energy and New York State Energy Research and Development Authority on the Western New York Nuclear Service Center at West Valley, New York, effective October 1, 1980, as amended September 18, 1981.

October 1, 1990. Supplemental Agreement to the Cooperative Agreement Between the United States Department of Energy and the New York State Energy Research and Development Authority Setting Forth Procedures and Responsibilities for the Preparation of a Joint Environmental Impact Statement for the Decommissioning and/or Long-Term Stewardship at the West Valley Demonstration Project and Western New York Nuclear Service Center.

. December 2008. Revised Draft Environmental Impact Statement for Decommissioning and/or Long-Term Stewardship at the West Valley Demonstration Project and Western New York Nuclear Service Center. DOE/EIS0226-D (Revised).

. January 29, 2010. Final Environmental Impact Statement for Decommissioning and/or Long-Term Stewardship at the West Valley Demonstration Project and Western New York Nuclear Service Center. Prepared by DOE and the New York State Energy Research and Development Authority (NYSERDA). DOE/EIS-0226. 
. March 14, 2011. Second Supplemental Agreement to the Cooperative Agreement Between the United States Department of Energy and the New York State Energy Research and Development Authority Setting Forth Special Provisions for the Identification, Implementation, and Management of the Phase 1 Studies for the Decommissioning and/or Long-Term Stewardship at the West Valley Demonstration Project and Western New York Nuclear Service Center.

U.S. Department of Transportation. nd. 49 CFR Chapter 1, Pipeline and Hazardous Materials Safety Administration, Department of Transportation. Part 172. Hazardous Materials Table, Special Provisions, Hazardous Materials Communications, Emergency Response Information, and Training Requirements.

U.S. Environmental Protection Agency. nd. 40 Code of Federal Regulations, Protection of the Environment, Chapter 1 , Environmental Protection Agency.

March 1983. Mercury, Method 245.1 (Manual Cold Vapor Technique). Methods for Chemical Analysis of Water and Wastes. Environmental Monitoring and Support Laboratory. Cincinnati, Ohio.

1984a. Drinking Water Guidelines. 40 CFR 141, National Secondary Drinking Water Regulations, Subpart B, Maximum Contaminant Levels.

1984b. Drinking Water Guidelines. 40 CFR 143, National Secondary Drinking Water Regulations, Section 143.3, Secondary Maximum Contaminant Levels.

. December 15, 1989. National Emission Standards for Hazardous Air Pollutants: Standards for Radionuclides. 40 CFR 61, including update of September 9, 2002. Subpart H. National Emission Standards for Emissions of Radionuclides Other Than Radon From Department of Energy Facilities. Washington, D.C.: U.S. Government Printing Office, as amended.

1992. Region II Administrative Order on Consent. Docket No. II RCRA 3008(h) -92-0202. In the Matter of: Western New York Nuclear Service Center.

. March 17, 1994. Communication from P.A. Giardina, Chief Radiation Branch, U.S. EPA Region II, to T.J. Rowland, Director, U.S DOE. NESHAP Compliance Approval for (1) Periodic Confirmatory Measurements and (2) HVAC Stack Effluent Monitoring Changes.

1995. Comprehensive Procurement Guidelines for Products Containing Recovered Material. 40 CFR 247.

. October 16, 1996. Code of Environmental Management Principles. 61 FR 54062.

August 2002. Method 1631, Revision E: Mercury in Water by Oxidation, Purge and Trap, and Cold Vapor Atomic Fluorescence Spectrometry. EPA-821-R-02-019.

October 9, 2002. Memorandum of Understanding Between the Environmental Protection Agency and the Nuclear Regulatory Commission. Consultation and Finality on Decommissioning and Decontamination of Contaminated Sites.

July 9, 2009. Communication from R. Borsellino, Acting Director, EPA Division of Environmental Planning and Protection, to B.C. Bower, Director U.S. DOE-WVDP. Approval to implement environmental measurements for rad-NESHAP compliance and to modify the MPPB stack. 
July 14, 2011. Communication from K. Bricke, Acting Director, EPA Division of Environmental Planning and Protection, to B.C. Bower, Director U.S. DOE-WVDP. Approval request to grant a 24-month extension of the interim approval to use ambient measurements to demonstrate RAD-NESHAP Compliance to modify the MPPB stack.

U.S. General Accounting Office. May 2001. Nuclear Waste Agreement Among Agencies Responsible for the West Valley Site is Critically Needed. Report to Congressional Requestors. GAO-01-314.

U.S. Nuclear Regulatory Commission. October 1977. Regulatory Guide 1.109: Calculation of Annual Doses to Man from Routine Releases of Reactor Effluents for the Purpose of Evaluating Compliance with 10 CFR Part 50, Appendix I.

. July 1997. Radiological Criteria for License Termination. 10 CFR Part 20, Appendix E.

. February 1, 2002. Decommissioning Criteria for the West Valley Demonstration Project (M-32) at the West Valley Site; Final Policy Statement. 67 FR 5003.

September 2006. Consolidated Decommissioning Guidance: Characterization, Survey, and Determination of Radiological Criteria. NUREG-1757, Vol. 2.

. February 25, 2010. U.S. Nuclear Regulatory Commission Technical Evaluation Report on the U.S. Department of Energy Phase 1 Decommissioning Plan for the West Valley Demonstration Project.

URS Group, Inc. April 8, 2002. Land Use Survey. Rev. 0. AR \#2002-171.

West Valley Environmental Services LLC. March 24, 2004 and May 3, 2010. TRU Waste Management Program Plan. Rev. 0 and Rev. 1. WVDP-417.

October 15, 2008. Characterization Plan for the Mitigation of the Leading Edge of the WVDP North Plateau Strontium-90 Plume. Rev. 1. WVDP-489.

December 23, 2008. WVDP Groundwater Protection Management Program Plan. Current revision. WVDP-091.

. April 28, 2009. West Valley Demonstration Project North Plateau Plume Area Characterization Report. Rev. 0. WVDP-494.

. July 23, 2009. Asbestos Management Plan. Current revision. WVDP-072.

. June 28, 2010. CY 2009 Annual Status Report for the Hazardous Waste Reduction Plan.

. September 14, 2010. North Plateau Permeable Treatment Wall Protection and Best Management Plan.

Current revision. WVDP-516.

. October 7, 2010. North Plateau Groundwater Monitoring Plan. Current revision. WVDP-518.

. March 15, 2011. North Plateau Permeable Treatment Wall Performance Monitoring Plan. Rev. 1. WVDP512.

West Valley Nuclear Services Co., Inc. May 1, 1995. Subsurface Probing Investigation on the North Plateau at the West Valley Demonstration Project. Rev. 0. WVDP-220.

. March 1996. Environmental Information Document, Volume III: Hydrology, Part 4. WVDP-EIS-009. 
. June 11, 1999. 1998 Geoprobe ${ }^{\circledast}$ Investigation in the Core Area of the North Plateau Groundwater Plume. Rev. 0. WVDP-346.

November 17, 2005. PCB and PCB-Contaminated Material Management Plan. Rev. 8. WVDP-080.

WVDP-462.

. January 2007. Corrective Measures Study Work Plan for the West Valley Demonstration Project. Rev. 0.

August 16, 2007. Sampling and Analysis Plan for Background Subsurface Soil on the North Plateau. Current revision. WVDP-466.

August 16, 2007. Sampling and Analysis Plan for the North Plateau Plume Area. Current revision. WVDP465.

West Valley Nuclear Services Co., Inc. and Dames \& Moore. June 1997. West Valley Demonstration Project Site Environmental Report, Calendar Year 1996.

. July 1997. Resource Conservation and Recovery Act Facility Investigation Report, Vol.1: Introduction and General Site Overview. WVDP-RFI-017.

. June 1998. Final Report: Evaluation of the Pilot Program to Investigate Chromium and Nickel Concentrations in Groundwater in the Sand and Gravel Unit.

West Valley Nuclear Services Co. and URS Group, Inc. January 2001. Results of Corrosion Evaluation in Selected Stainless Steel Monitoring Wells on the North Plateau and Recommendations for Long-Term Management. 
This page intentionally left blank 


\section{DISTRIBUTION}

\section{Recipient}

\section{Federal Organization}

DOE Office of Scientific and Technical Information

$\begin{array}{ll}\text { W. Eckroade } & \text { DOE - HQ } \\ \text { D. Geiser } & \text { DOE - HQ } \\ \text { R. Hardwick } & \text { DOE - HQ } \\ \text { F. Marcinowski } & \text { DOE - HQ } \\ \text { R. Natoli } & \text { DOE - HQ } \\ \text { G. Podonsky } & \text { DOE - HQ } \\ \text { J. Rhoderick } & \text { DOE - HQ } \\ \text { W. Roege } & \text { DOE - HQ } \\ \text { A. Williams } & \text { DOE - HQ } \\ & \\ \text { L. Camper } & \text { NRC - HQ } \\ \text { C. Glenn } & \text { NRC - HQ } \\ \text { M. Norato } & \text { NRC - HQ } \\ \text { D. Persinko } & \text { NRC - HQ } \\ \text { M. Roberts } & \text { NRC - Region 1 }\end{array}$

\section{A. Everett}

P. Giardina

A. Park

O. Povetko

W. Kappel

C. Collins

B. Higgins

L. Slaughter

T. Reed

K. Gillibrand

C. Schumer
U.S. EPA - Region II

U.S. EPA - Region II

U.S. EPA - Region II

U.S. EPA - Region II

USGS

U.S. Congress, 26th Dist.

U.S. Congress, 27th Dist.

U.S. Congress, 28th Dist.

U.S. Congress, 29th Dist.

U.S. Senate, New York

U.S. Senate, New York $\underline{\text { Recipient }}$

T. Hoffman

E. Schneiderman

M. Cruden

J. Harrington

T. Killeen

D. Lightsey

D. O'Hehir

T. Rice

J. Weidman

P. Concannon

M. Jackson

K. Martin

J. Strickland

D. Weiss

T. Semkow

L. Sturman

R. Snyder

F. Murray

A. Zipp

A. Peterson

P. Bembia

E. Lowes

A. Mellon

D. Gabryszak

S. Ryan

K. Smardz

D. Burling

J. Giglio

C. Young

T. Kennedy

P. Gallivan
State Organization

NYSAttorney General's Office

NYS Attorney Generals Office

NYSDEC - Albany

NYSDEC - Albany

NYSDEC - Albany

NYSDEC - Albany

NYSDEC - Albany

NYSDEC - Albany

NYSDEC - Albany

NYSDEC - Region 9

NYSDEC - Region 9

NYSDEC - Region 9

NYSDEC - Region 9

NYSDEC - Region 9

NYSDOH - Albany

NYSDOH - Albany

NYSDOH - Troy

NYSERDA - Albany (President)

NYSERDA - General Counsel

NYSERDA - Albany

NYSERDA

NYSERDA

NYSERDA

New York Assembly, 143rd Dist. New York Assembly, 144th Dist. New York Assembly, 146th Dist. New York Assembly, 147th Dist. New York Assembly, 149th Dist. New York Senate, 57th Dist. New York Senate, 58th Dist. New York Senate, 59th Dist. 


\begin{tabular}{|c|c|c|c|}
\hline$\underline{\text { Recipient }}$ & Local Organization & $\underline{\text { Recipient }}$ & Local Organization \\
\hline Dr. K. Watkins & Director, Catt. County Health Dept. & E. Lawton & Superintendent, West Valley \\
\hline C. Crawford & Cattaraugus County Health Dept. & & Central School \\
\hline S. Dayton & Cattaraugus County Health Dept. & D. McCauley & West Valley Central School Board \\
\hline B. Hastings & Cattaraugus County Health Dept. & & of Education \\
\hline E. Wohlers & Cattaraugus County Health Dept. & & \\
\hline J. Boser & Cattaraugus County Legislature & R. Porter & $\begin{array}{l}\text { President, Seneca Nation of } \\
\text { Indians }\end{array}$ \\
\hline C. Edwards & Cattaraugus County Legislature & D. John & Seneca Nation of Indians \\
\hline G. Felton & Cattaraugus County Legislature & & Energy Planner \\
\hline D. Hale & Cattaraugus County Legislature & A. Stevens & Seneca Nation of Indians \\
\hline R. Klancer & Cattaraugus County Legislature & & Environmental Protection \\
\hline D. Koch & Cattaraugus County Legislature & & Department \\
\hline N. Marsh & Cattaraugus County Legislature & & \\
\hline P. Murphy & Cattaraugus County Legislature & W. Krebs & Mayor, Village of Springville \\
\hline W. Sprague & Cattaraugus County Legislature & T. Skelton & Village of Springville \\
\hline H. VanRensselaer & Cattaraugus County Legislature & C. Gerwitz & Supervisor, Town of Ashford \\
\hline D. Vickman & Cattaraugus County Legislature & P. Dashnaw & Town Clerk, Town of Ashford \\
\hline \multirow[t]{2}{*}{ W. Weller } & \multirow[t]{2}{*}{ Cattaraugus County Legislature } & G. Eppolito & Supervisor, Town of Concord \\
\hline & & C. Davis & Council, Town of Ashford \\
\hline \multirow[t]{3}{*}{ D. Rivet } & Cattaraugus County DPW & T. Engels & Council, Town of Ashford \\
\hline & \multirow[t]{2}{*}{ Commissioner } & W. Heim & Council, Town of Ashford \\
\hline & & J. Pfeffer & Council, Town of Ashford \\
\hline \multirow[t]{3}{*}{ J. Williams } & Cattaraugus County Economic & W. Snyder & Council, Town of Concord \\
\hline & Development, Planning, and & & \\
\hline & Tourism & C. Couture & West Valley Chamber of Commerce \\
\hline Dr. G.R. Burstein & Erie County Health Department & \multirow[t]{2}{*}{ L. Lambert } & League of Women Voters \\
\hline \multirow{2}{*}{ K. Konst } & Commissioner, Erie County & & \\
\hline & $\begin{array}{l}\text { Department of Environment and } \\
\text { Planning }\end{array}$ & \multirow{2}{*}{\multicolumn{2}{|c|}{ West Valley Volunteer Hose Co., Inc. }} \\
\hline P. Kranz & $\begin{array}{l}\text { Erie County Department of } \\
\text { Environment and Planning }\end{array}$ & & \\
\hline E. Giardini & Laborers Local \#621, Olean & & \\
\hline D. Rychnowski & $\begin{array}{l}\text { Southern Tier West Development } \\
\text { Foundation }\end{array}$ & & \\
\hline
\end{tabular}

Citizen Task Force Membership and Alternates

Notice of public availability

Springville Journal, Springville, New York

Olean Times Herald, Olean, New York 


\section{ACKNOWLEDGMENTS}

This report was compiled and edited by A.F. Steiner (team leader), M.P. Pendl, and J.T. Kelly of the URS West Valley Demonstration Project staff. R.L. Werchowski, provided desktop publishing services. Other technical preparers and reviewers are listed below.

Bennett, L.E.

Biedermann, C.A.

Bridges, N.L.

Dogal, T.D.

Dukes, H.H.

Fox, J.R.

Hoch, J.J.

Jeffery, B.N.

Kean, W.N.

Klenk, D.P.

Krentz, M.P.

Love, R.D.

Maloney, M.N.
Meess, D.C.

Mellon, A.L.

Mitchell, R.M.

O'Leary, J.

Pendl, M.P.

Rendall, J.D.

Ruszczyk, D.M.

Shagula, B.P.

Steiner, R.E.

Szalinski, S.J.

Troescher, P.

Vincent, G.

Wedvik, S.K.

Wrotniak, C.M. 
This page intentionally left blank 


\section{APPENDIX A 2012 Environmental Monitoring Program}

\section{Environmental Monitoring Program Drivers and Sampling Rationale}

The following schedule represents the WVDP routine environmental monitoring program for 2012. This schedule met or exceeded the requirements of DOE Order 458.1, "Radiation Protection of the Public and the Environment," and DOE/EH-0173T, "Environmental Regulatory Guide for Radiological Effluent Monitoring and Environmental Surveillance." Specific methods and monitoring program elements were based on DOE/EP-0096, "A Guide for Effluent Radiological Measurements at DOE Installations," and DOE/EP-0023, "A Guide for Environmental Radiological Surveillance at U.S. Department of Energy Installations." Additional monitoring was mandated by air and water discharge permits (under the NESHAP regulations in 40 CFR 61, Subpart H, and the SPDES, respectively). Specific groundwater monitoring is required by the RCRA $\S 3008(\mathrm{~h})$ Administrative Order on Consent.

Permits, agreements, and/or programs may require formal reports of monitoring results. Radiological air emissions from the WVDP are reported annually in the NESHAP report to EPA. Nonradiological releases in water effluent and storm water drainage points covered under the SPDES permit are reported monthly to NYSDEC in a DMR. Groundwater monitoring results are reported quarterly to NYSDEC. Annual results from the monitoring program, as a whole, are evaluated and discussed in this ASER, which is prepared as directed in DOE Order 231.1B, "Environment, Safety, and Health Reporting," and associated guidance.

Table A-1 summarizes programmatic drivers and guidance applicable to each environmental medium measured or sampled as part of the WVDP Environmental Monitoring Program.

\section{Sampling Schedule}

Sampling locations are assigned a specific identifier, the location code, which is used to schedule sampling, track samples, and trace analytical results. This appendix details the sampling schedule conducted at each location in 2012. Routine sampling locations are shown on Figures
A-2 through A-12. Table headings in the sampling schedule described in Table A-2 are as follows:

- Sample Location Code. This code describes the physical location where the sample is collected. The code consists of seven or eight characters: The first character identifies the sample medium as Air, Water, Soil/sediment, Biological, or Direct measurement. The second character specifies oN-site or off-site. The remaining characters describe the specific location (e.g., AFGRVAL is Air off-site at GReat VALley). Distances noted at sampling locations are as measured in a straight line from the ventilation stack of the MPPB on site. Groundwater and storm water sampling points (e.g., WNW0408, WNNDATR, WNSO04) are often abbreviated in figures or data tables (i.e., "408," “NDATR," "S04").

- Sampling Type/Medium. Describes the collection method and the physical characteristics of the medium or sample.

- Collection Frequency/Total Annual Samples. Indicates how often the samples are collected or retrieved and the total number of each type of sample processed in one year.

- Measurements/Analyses. Notes the type of measurement taken from the sampling medium and/or the constituents of interest, and (in some instances) the type of analysis conducted. 
TABLE A-1

WVDP Environmental Program Drivers and Sampling Rationale

\begin{tabular}{|c|c|}
\hline Programmatic Drivers & Sampling Rationale \\
\hline \multicolumn{2}{|c|}{ On-Site Air Emissions } \\
\hline $\begin{array}{l}40 \text { CFR } 61 \text {, Subpart H (radiological air emissions); } \\
\text { DOE Order 458.1, Change } 2\end{array}$ & $\begin{array}{l}\text { DOE/EH-0173T, Chapter } 3.0 \text { (air effluent monitoring); } \\
\text { DOE/EP-0096, Section } 3.3 \text { (criteria for effluent } \\
\text { measurements) }\end{array}$ \\
\hline \multicolumn{2}{|r|}{ Ambient Air } \\
\hline DOE Order 458.1, Change 2 & $\begin{array}{l}\text { DOE/EH-0173T, Section 5.7.4 (environmental surveillance, } \\
\text { air sampling locations); } \\
\text { DOE/EP-0023, Section 4.2.3 (air sampling locations and } \\
\text { measurement techniques) }\end{array}$ \\
\hline \multicolumn{2}{|c|}{ On-Site Liquid Effluents and Storm Water } \\
\hline $\begin{array}{l}\text { New York State SPDES Permit No. NY } 0000973 \\
\text { (nonradiological; specified points only), } \\
\text { DOE Order 458.1, Change } 2 \text { (radiological) }\end{array}$ & $\begin{array}{l}\text { DOE/EH-0173T, Section 2.3.3 (sampling locations for effluent } \\
\text { monitoring); } \\
\text { New York State Department of Health (NYSDOH) } \\
\text { Environmental Laboratory Approval Program (ELAP) } \\
\text { certification for nonpotable water }\end{array}$ \\
\hline \multicolumn{2}{|c|}{ Surface Water } \\
\hline DOE Order 458.1, Change 2 & $\begin{array}{l}\text { DOE/EH-0173T, Section 5.10.1 (environmental } \\
\text { surveillance water sampling locations and methods); } \\
\text { NYSDOH ELAP certification for nonpotable water }\end{array}$ \\
\hline \multicolumn{2}{|c|}{ Potable (Drinking) Water } \\
\hline DOE Order 458.1, Change 2 & $\begin{array}{l}\text { DOE/EH-0173T, Section } 5.10 \text { (basis and guidance for } \\
\text { environmental surveillance, water); } \\
\text { NYSDOH ELAP certification for potable water }\end{array}$ \\
\hline \multicolumn{2}{|c|}{ On-Site Groundwater } \\
\hline $\begin{array}{l}\text { RCRA } \S 3008(h) \text { Order on Consent (nonradiological); } \\
\text { DOE Order 458.1, Change } 2 \text { (radiological) }\end{array}$ & $\begin{array}{l}\text { DOE/EH-0173T, Section } 5.10 \text { (basis for environmental } \\
\text { surveillance, water); } \\
\text { NYSDOH ELAP certification for nonpotable water }\end{array}$ \\
\hline \multicolumn{2}{|c|}{ Soil and Sediment } \\
\hline DOE Order 458.1, Change 2 & $\begin{array}{l}\text { DOE EH-0173T, Sections } 5.9 \text { (environmental surveillance soil } \\
\text { sampling locations and methods) and } \\
5.12 \text { (sediment sampling locations and methods) }\end{array}$ \\
\hline \multicolumn{2}{|r|}{ Biological } \\
\hline DOE Order 458.1, Change 2 & $\begin{array}{l}\text { DOE/EH-0173T, Sections } 5.8 \text { (environmental surveillance, } \\
\text { terrestrial foodstuffs) and } 5.11 \text { (aquatic foodstuffs) }\end{array}$ \\
\hline \multicolumn{2}{|c|}{ Direct Radiation } \\
\hline DOE Order 458.1, Change 2 & $\begin{array}{l}\text { DOE/EH-0173T, Section } 5.5 \text { (environmental surveillance } \\
\text { external radiation measurement locations and frequency); } \\
\text { DOE/EP-0023, Section } 4.6 \text { (external radiation) }\end{array}$ \\
\hline
\end{tabular}




\section{Index of Environmental Monitoring Program Sample Points}

Air Effluent (Figure A-6 [p. A-24]) $\quad$ Page

$\begin{array}{lll}\text { ANSTACK } & \text { Main Plant Process Building A-7 } & \text { A-7 } \\ \text { ANSTSTK } & \text { Supernatant Treatment System_A } & A-7 \\ \text { ANCSSTK } & \text { 01-14 Building A-7 } & \text { A-7 } \\ \text { ANCSRFK } & \text { Contact Size-Reduction Facility } & \text { A-7 } \\ \text { ANCSPFK } & \text { Container Sorting and Packaging Facility } & A-7 \\ \text { ANVITSK } & \text { Vitrification Heating, Ventilation, and Air Conditioning } & A-7\end{array}$

Liquid Effluent, On-Site Water, and Storm Water Outfalls (Figures A-2 through A-4 [pp. A-20 through A-22])

WNSP001

WNSP01B $^{a}$

WNSP116

WNSP007

WNURRAW $^{a}$

WNSP006
Lagoon 3 Weir Point

Internal Process Monitoring Point

Pseudo-Monitoring Point Outfall 116

Sanitary Waste Discharge

Utility Room Raw Water

Facility Main Drainage, Franks Creek at Security Fence
A-8

A-8

A-8

A-9

A-9

A-9

\section{WNSO-Series Storm Water Outfalls}

GROUP 1

WNSO04

North Swamp Drainage (WNSW74A) A-9

$\underline{\text { GROUP } 2}$

WNSO06

Northeast Swamp Drainage (WNSWAMP)

A-9

WNSO33

LAG Storage Drainage

GROUP 3

WNSO09

WNSO12

Smartditch ${ }^{\circledast}$

A-10

South Facility Drainage (WNSP005) A-10

GROUP 4

WNSO34

Rail Spur Culvert A-10

GROUP 5

WNSO14

NDA Service Road

Drainage North

A-10

WNSO17

NDA Service Road Drainage South

A-10

WNSO28

Drum Cell West Road A-10

a Not detailed on map 
Liquid Effluent, On-Site Water, and Storm Water Outfalls (Figures A-2 through A-4) (concluded)

\begin{tabular}{l} 
GROUP 6 \\
\hline WNSO36 \\
WNSO37 \\
WNSO38 \\
WNSO39 \\
WNSO41 \\
WNSO42 \\
WNSO43
\end{tabular}

Live-Fire Range Wetland Drainage

A-10

Pump House Roadway

A-10

Lake Two Roadway North

A-10

Lake Two Roadway South

A-10

Lake One Roadway

A-10

Pre-Railroad Spur Wetland Area (Near WFBCBKG) ___ A-10

Live-Fire Range Drainage East ___ A-10

$\underline{\text { GROUP } 7}$

WNSO20

Disposal Area Drainage (WNNDADR)

A-10

$\underline{\text { GROUP } 8}$

WNSO27

Drum Cell Drainage West

A-11

WNSO35

Drum Cell Drainage East A-11

WNSWR01

Storm Water Precipitation pH Measurement Location Near the Site Rain Gauge

A-10

On Site Surface Water WNSWAMP

WNSW74A

WNSP005

WNFRC67

WNERB53

WNNDADR

Northeast Swamp Drainage Point

A-11

North Swamp Drainage Point A-11

South Facility Drainage A-11

Franks Creek East A-11

Erdman Brook A-11

Disposal Area Drainage A-11

WNDNK Series

Site Potable Water A-11

WNDFILTR

WNDNKMP

Utility Room Potable Water (Entry Point 2) A-11

Main Plant Drinking water A-11

WNDNKEL

ELAB Drinking Water A-11 
On-Site Groundwater and Seeps (Figures A-8 and A-9 [pp. A-26 and A-27])

Page

SSWMU \#1

LLW2 Wells A-12

SSWMU \#2

Miscellaneous Small Units Wells A-12

SSWMU \#3 LWTS A-12

SSWMU \#4 HLW Storage and Processing Tank Wells A-12

SSWMU \#5 Maintenance Shop Leach Field Wells A-12

SSWMU \#6

SSWMU \#7

LLW Storage Area Wells A-12

SSWMU \#8

Chemical Process Cell - Waste Storage Area Wells A-12

CDDL Wells A-12

SSWMU \#9

SSWMU \#10

RHWF

NDA Unit Wells and NDATR A-12

IRTS Drum Cell Wells _ A

RHWF Wells

A-12

MPPB Wells

MPPB Downgradient Wells

A-13

North Plateau Seeps

Northeastern Edge of North Plateau A-13

PTWPMP Wells

PTW Platform and Full Network Wells A-13

Miscellaneous

Monitoring Locations (not in a SWMU: Well Points WP-A, WP-C, WP-H) A-13

Surface Elevation Points

SDA (SSWMU \#11)

Surface Water Elevation Points A-13

SDA Unit Wells A-13

Soil and Sediment (Figures A-2, A-5, and A-13 [pp. A-20, A-23, and A-31])

\begin{tabular}{cl} 
SN Soil Series: & On-Site Soil/Sediment \\
SNSW74A & Soil/Sediment at North Swamp Drainage Point__ A-13 \\
SNSWAMP & Soil/Sediment at Northeast Swamp Drainage Point A-13 \\
SNSP006 & Soil/Sediment at Facility Main Drainage A-13 \\
SF Soil Series: & Off-Site Soil Collected at Air Samplers A-13 \\
\hline SFFXVRD & Surface Soil South-Southeast at Fox Valley \\
SFRT240 & Surface Soil Northeast on Route 240_13 \\
SFRSPRD & Surface Soil Northwest on Rock Springs Road \\
SFGRVAL & Surface Soil South at Great Valley, Background A-13 \\
SF Sediment Series: & Off-Site Sediment A-13 \\
\hline SFCCSED & Cattaraugus Creek at Felton Bridge, Sediment \\
SFSDSED & Cattaraugus Creek at Springville Dam, Sediment A-13 \\
SFTCSED & Buttermilk Creek at Thomas Corners, Sediment A-14 \\
SFBCSED & Buttermilk Creek at Fox Valley Road, Background Sediment
\end{tabular}

\section{Off-Site Surface Water (Figure A-5 [p. A-23])}

WFBCBKG

WFFELBR

WFBCTCB
Buttermilk Creek near Fox Valley, Background A-14

Cattaraugus Creek at Felton Bridge

Buttermilk Creek at Thomas Corners
A-14

A-14 
Off-Site Ambient Air (Figure A-7 [p. A-25])

\begin{tabular}{|c|c|c|}
\hline AF01_N & Bond Road & $A-15$ \\
\hline AF02_NNE & Route 240 & $A-15$ \\
\hline AF03_NE & Route 240 & A-15 \\
\hline AF04_ENE & Route 240 & $A-15$ \\
\hline AF05_E & Heinz Road & $A-15$ \\
\hline AF06_ESE & Buttermilk Road & $A-15$ \\
\hline AF07_SE & Fox Valley Road & A-15 \\
\hline AF08_SSE & Fox Valley Road & $A-15$ \\
\hline AF09_S & Rock Springs Road & $A-15$ \\
\hline AF10_SSW & Dutch Hill Road & $A-15$ \\
\hline AF11_SW & Dutch Hill Road & $A-15$ \\
\hline AF12_WSW & Dutch Hill Road & $A-15$ \\
\hline AF13_W & Dutch Hill Road & A-15 \\
\hline AF14_WNW & Boberg Road & $A-15$ \\
\hline AF15_NW & Rock Springs Road & $A-15$ \\
\hline AF16_NNW & Rock Springs Road & $A-15$ \\
\hline AF16HNNW & MEOSI location & A-16 \\
\hline AFGRVAL & Great Valley Sampler, Background & A-16 \\
\hline
\end{tabular}

Off-Site Biological (Figures A-10 and A-13 [pp. A-28 and A-31])

BFMFLDMN

BFMCTLS

BFMBLSY

BFMSCHT

BFDNEAR

BFDCTRL

BFVNEAR $^{a}$

BFVCTRL $^{a}$

BFFCATC

BFFCATD

BFFCTRL
Southeast Milk, Near-Site

A-16

Control Milk, South

Milk, West-Northwest

Milk, South

Venison, Near-Site

Venison, Background

Produce, Near-Site

Produce, Background

Cattaraugus Creek Fish, Downstream

Cattaraugus Creek Fish, Downstream of Springville Dam

Cattaraugus Creek Fish, Background

Direct Measurement Dosimetry (Figures A-11 through A-13 [pp. A-29 through A-31])

DFTLD Series

Off-Site Direct Radiation

A-17

DNTLD Series

On-Site Direct Radiation

\footnotetext{
a Near site and background produce samples (corn, apples, and beans) are identified specifically as follows:
} corn = BFVNEAC and BFVCTRC; apples = BFVNEAAF and BFVCTRA; beans = BFVNEAB and BFVCTRB. 
TABLE A-2

2012 Environmental Monitoring Program

\begin{tabular}{|c|c|c|c|}
\hline Sample Location Code & $\begin{array}{c}\text { Sampling Type/ } \\
\text { Medium }\end{array}$ & $\begin{array}{l}\text { Collection Frequency/ } \\
\text { Total Annual Samples }\end{array}$ & Measurements/Analyses \\
\hline \multicolumn{4}{|c|}{ On-Site Air Emissions } \\
\hline $\begin{array}{l}\text { ANSTACK }^{a} \\
\text { MPPB ventilation exhaust } \\
\text { stack }\end{array}$ & $\begin{array}{l}\text { Continuous on-line air } \\
\text { particulate monitors }\end{array}$ & $\begin{array}{l}\text { Continuous measurement of } \\
\text { fixed filter; replaced biweekly; } \\
\text { held as backup }\end{array}$ & Real-time monitoring - CAM \\
\hline \multirow{2}{*}{$\begin{array}{l}\text { ANSTSTK }^{a} \\
\text { STS ventilation exhaust } \\
\text { ANCSSTK }^{a, c} \\
\text { 01-14 building ventilation } \\
\text { exhaust }\end{array}$} & $\begin{array}{l}\text { Continuous off-line air } \\
\text { particulate filters }\end{array}$ & Biweekly; 26 each location & $\begin{array}{l}\text { Gross alpha/beta, gamma isotopic }{ }^{b} \text { upon } \\
\text { collection, flow }\end{array}$ \\
\hline & $\begin{array}{l}\text { Composite of biweekly } \\
\text { particulate filters }\end{array}$ & Semiannually; 2 each location & $\begin{array}{l}\text { Sr-90, U-232, U-233/234, U-235/236, } \\
\text { U-238, total U, Pu-238, Pu-239/240, } \\
\text { Am-241, gamma isotopic, flow }\end{array}$ \\
\hline $\begin{array}{l}\text { ANCSRFK }^{a, d} \\
\text { Contact size-reduction } \\
\text { facility exhaust } \\
\text { ANCSPFK }^{a} \\
\text { Container sorting and } \\
\text { packaging facility exhaust }\end{array}$ & $\begin{array}{l}\text { Continuous off-line } \\
\text { desiccant columns for } \\
\text { collection of water } \\
\text { vapor }\end{array}$ & $\begin{array}{l}\text { Biweekly; } 26 \text { each at ANSTACK } \\
\text { and ANSTSTK only }\end{array}$ & $H-3$, flow \\
\hline \multicolumn{3}{|l|}{$\begin{array}{l}\text { ANVITSK }^{a} \\
\text { VIT heating, ventilation, } \\
\text { and air conditioning } \\
\text { exhaust }\end{array}$} & I-129 \\
\hline \multicolumn{4}{|l|}{$\begin{array}{l}\text { ANRHWFK }^{a} \\
\text { RHWF exhaust }^{-}\end{array}$} \\
\hline \multirow{2}{*}{$\begin{array}{l}\text { OVEs/PVUs }{ }^{a} \\
\text { Outdoor ventilated } \\
\text { enclosures/portable } \\
\text { ventilation units }\end{array}$} & $\begin{array}{l}\text { Continuous off-line air } \\
\text { particulate filter }\end{array}$ & $\begin{array}{l}\text { Collected as required by } \\
\text { project }\end{array}$ & $\begin{array}{l}\text { Gross alpha/beta, gamma isotopic }{ }^{b} \text { upon } \\
\text { collection, flow }\end{array}$ \\
\hline & Composite of filters & Semiannually; 2 each location & $\begin{array}{l}\text { Sr-90, U-232, U-233/234, U-235/236, } \\
\text { U-238, total U, Pu-238, Pu-239/240, } \\
\text { Am-241, gamma isotopic, flow }\end{array}$ \\
\hline
\end{tabular}

${ }^{a}$ Required by 40 CFR 61, Subpart H. Results reported in the Annual NESHAP Report and evaluated in the ASER.

${ }^{b}$ Gamma isotopic analysis done only if gross alpha/beta activity rises significantly.

${ }^{c}$ Operation of the 01-14 building stack was discontinued in October 2012 in preparation for demolition.

${ }^{d}$ Operation of the contact size-reduction stack was discontinued in July 2005. 
TABLE A-2 (continued)

2012 Monitoring Program

\begin{tabular}{|c|c|c|c|}
\hline Sample Location Code & $\begin{array}{l}\text { Sampling Type/ } \\
\text { Medium } \\
\end{array}$ & $\begin{array}{l}\text { Collection Frequency/ } \\
\text { Total Annual Samples }\end{array}$ & Measurements/Analyses \\
\hline \multicolumn{4}{|c|}{ On-Site Liquid Effluents } \\
\hline \multirow[t]{13}{*}{$\begin{array}{l}\text { WNSPO01 }^{a} \\
\text { Lagoon } 3 \text { discharge weir }\end{array}$} & Continuous & $\begin{array}{l}\text { Daily during discharge. Lagoon } \\
3 \text { is discharged } 4 \text { to } 8 \text { times } \\
\text { per year, averaging } 6 \text { to } 7 \\
\text { days per discharge; } 24-56 \\
\text { days per year }\end{array}$ & $\begin{array}{l}\text { Daily flow, hold for flow-weighted } \\
\text { composite }\end{array}$ \\
\hline & Grab & $\begin{array}{l}\text { Twice during discharge; } 8-16 \\
\text { per year }\end{array}$ & $\begin{array}{l}\text { Gross alpha/beta, H-3, Sr-90, gamma } \\
\text { isotopic }\end{array}$ \\
\hline & $\begin{array}{l}\text { Flow-weighted } \\
\text { composite of daily } \\
\text { samples for each } \\
\text { discharge }\end{array}$ & 4 to 8 per year & $\begin{array}{l}\text { Gross alpha/beta, H-3, C-14, Sr-90, Tc-99, } \\
\text { I-129, gamma isotopic, U-232, } \\
\text { U-233/234, U-235/236, U-238, total U, } \\
\text { Pu-238, Pu-239/240, Am-241 }\end{array}$ \\
\hline & Grab & $\begin{array}{l}\text { Twice during discharge; } 8-16 \\
\text { per year }\end{array}$ & $\begin{array}{l}\text { Settleable solids, TDS, Dissolved Oxygen } \\
\text { (DO) }\end{array}$ \\
\hline & 24-hour composite & $\begin{array}{l}\text { Twice during discharge; } 8-16 \\
\text { per year }\end{array}$ & $\begin{array}{l}\text { 5-day Biological Oxygen Demand }\left(\mathrm{BOD}_{5}\right) \text {, } \\
\text { Total Suspended Solids (TSS), } \mathrm{NH}_{3}, \mathrm{TKN} \text {, } \\
\text { total Fe }\end{array}$ \\
\hline & Grab & $\begin{array}{l}\text { Once during discharge; } 4-8 \\
\text { per year }\end{array}$ & $\begin{array}{l}\text { Total } \mathrm{Hg}, \mathrm{pH} \text {, total recoverable } \mathrm{Co}, \mathrm{Se}, \mathrm{V} \text {, } \\
\text { total residual chlorine, oil \& grease, } \\
\text { surfactant (as LAS) }\end{array}$ \\
\hline & 24-hour composite & $\begin{array}{l}\text { Once during discharge; } 4-8 \\
\text { per year }\end{array}$ & $\begin{array}{l}\text { Total Al, total recoverable As, dissolved } \\
\text { sulfide, } \mathrm{NO}_{3}-\mathrm{N}, \mathrm{NO}_{2}-\mathrm{N}, \mathrm{SO}_{4}\end{array}$ \\
\hline & 24-hour composite & $\begin{array}{l}\text { Quarterly; } 4 \text { per year for the } \\
\text { first year }{ }^{b}\end{array}$ & Whole Effluent Toxicity (WET) Testing \\
\hline & Grab & Semiannually; 2 per year & $\begin{array}{l}\text { Cyanide amenable to chlorination, } \\
\text { Heptachlor }\end{array}$ \\
\hline & 24-hour composite & Semiannually; 2 per year & $\begin{array}{l}\text { Bromide, } \mathrm{B} \text {, total } \mathrm{Mn}, \mathrm{Ni} \text {, total } \\
\text { recoverable } \mathrm{Cu}, \mathrm{Cr}, \mathrm{Pb}, \mathrm{Ti}, \mathrm{Zn}\end{array}$ \\
\hline & Grab & Annually; 1 per year & $\begin{array}{l}\text { Total recoverable } \mathrm{Cr}+6, \\
\text { Dichlorodifluoromethane, } \\
\text { trichlorofluoromethane, 3,3- } \\
\text { dichlorobenzidine, tributyl phosphate, } \\
\text { xylene, hexachlorobenzene, 2-butanone, } \\
\text { alpha-BHC, chloroform }\end{array}$ \\
\hline & 24-hour composite & Annually; 1 per year & Total $\mathrm{Ba}, \mathrm{Sb}$, total recoverable $\mathrm{Cd}$ \\
\hline & $\begin{array}{l}\text { Calculated from BOD5 } \\
\text { and TKN }\end{array}$ & $\begin{array}{l}\text { Twice during discharge; } 8-16 \\
\text { per year }\end{array}$ & Ultimate Oxygen Demand (UOD) \\
\hline \multirow{2}{*}{\begin{tabular}{|l|} 
WNSPO1B $^{a}$ \\
Internal process monitoring \\
point
\end{tabular}} & Continuous & Recorded when operating & Total flow, elapsed flow time \\
\hline & Grab liquid & $\begin{array}{l}\text { Twice per month when } \\
\text { operating; 0-24 per year }\end{array}$ & Total Hg \\
\hline $\begin{array}{l}\text { WNSP116 } \\
\text { Pseudo-monitoring point } \\
\text { outfall } 116\end{array}$ & Calculated & $\begin{array}{l}\text { Twice per lagoon discharge; } \\
\text { 8-16 per year }\end{array}$ & TDS \\
\hline
\end{tabular}

${ }^{a}$ Required by SPDES Permit \#NY0000973. Results reported in the SPDES DMR and evaluated in this ASER.

${ }^{\mathrm{b}}$ WET testing shall be performed quarterly for the first year, and repeat the quarterly sampling every five years. 
TABLE A-2 (continued)

2012 Monitoring Program

\begin{tabular}{|c|c|c|c|}
\hline Sample Location Code & $\begin{array}{l}\text { Sampling Type/ } \\
\text { Medium }\end{array}$ & $\begin{array}{l}\text { Collection Frequency/ } \\
\text { Total Annual Samples }\end{array}$ & Measurements/Analyses \\
\hline \multicolumn{4}{|c|}{ On-Site Liquid Effluents } \\
\hline \multirow[t]{10}{*}{$\begin{array}{l}\text { WNSPOO7 }^{a} \\
\text { Sanitary waste discharge }\end{array}$} & $\begin{array}{l}\text { 24-hour composite } \\
\text { liquid }\end{array}$ & 1 per month; 12 per year & Gross alpha/beta, H-3 \\
\hline & $\begin{array}{l}\text { Composite of monthly } \\
\text { samples }\end{array}$ & Annually; 1 per year & Sr-90, gamma isotopic \\
\hline & Grab & 2 per month; 24 per year & $\begin{array}{l}\mathrm{pH} \text {, settleable solids, TDS, DO, oil \& } \\
\text { grease }\end{array}$ \\
\hline & 24-hour composite & 2 per month; 24 per year & TSS, $\mathrm{BOD}_{5}, \mathrm{NH}_{3}$, total Fe \\
\hline & Grab & Monthly; 12 per year & Total residual chlorine, total $\mathrm{Hg}$ \\
\hline & 24-hour composite & Monthly; 12 per year & TKN (as N), $\mathrm{NO}_{2}-\mathrm{N}$, \\
\hline & 24-hour composite & 3 per month, 36 per year & Flow rate (gpm) \\
\hline & $\begin{array}{l}\text { Calculated from } \mathrm{BOD}_{5} \\
\text { and TKN }\end{array}$ & Monthly; 12 per year & UOD \\
\hline & 24-hour composite & $\begin{array}{l}\text { Quarterly; } 4 \text { per year for the } \\
\text { first year }^{b}\end{array}$ & WET Testing \\
\hline & Grab & Annually; 1 per year & Chloroform \\
\hline \multirow{2}{*}{$\begin{array}{l}\text { WNURRAW }^{a} \\
\text { Utility room raw water }\end{array}$} & Composite & Weekly; 52 per year & Total Fe \\
\hline & $\mathrm{Grab}^{c}$ & Monthly; 12 per year & Total Organic Carbon (TOC), alkalinity \\
\hline \multirow[t]{4}{*}{$\begin{array}{l}\text { WNSP006 } \\
\text { Franks Creek at the security } \\
\text { fence }\end{array}$} & $\begin{array}{l}\text { Timed continuous } \\
\text { composite }\end{array}$ & $\begin{array}{l}\text { Weekly during lagoon } \\
\text { discharge, otherwise } \\
\text { biweekly; 26-34 per year }\end{array}$ & Gross alpha/beta, H-3 \\
\hline & $\begin{array}{l}\text { Composite of weekly } \\
\text { and biweekly samples }\end{array}$ & Monthly; 12 per year & Sr-90 and gamma isotopic \\
\hline & $\begin{array}{l}\text { Composite of weekly } \\
\text { and biweekly samples }\end{array}$ & Quarterly; 4 per year & $\begin{array}{l}\text { C-14, Tc-99, I-129, U-232, U-233/234, } \\
\text { U-235/236, U-238, total U, Pu-238, } \\
\text { Pu-239/240, Am-241 }\end{array}$ \\
\hline & Grab & $\begin{array}{l}\text { Three per lagoon discharge: } \\
\text { pre-discharge, near beginning, } \\
\text { at end, } 12-24 \text { per year }\end{array}$ & TDS, flow rate \\
\hline \multicolumn{4}{|c|}{ Storm Water Outfalls } \\
\hline \multirow[t]{2}{*}{$\frac{\text { Group 1 }^{a}}{\text { WNSO04 (S04) }}$} & First flush grab & Semiannually; 2 per year & $\begin{array}{l}\mathrm{pH} \text {, oil \& grease, } \mathrm{BOD}_{5}, \mathrm{TSS}, \mathrm{TDS} \text {, total } \mathrm{P}, \\
\mathrm{Al}, \mathrm{Fe} \text {, total recoverable } \mathrm{Cu}, \mathrm{Pb}, \mathrm{Zn}, \mathrm{Cd} \text {, } \\
\mathrm{Cr}, \mathrm{Cr}+6, \mathrm{Se}, \mathrm{V}, \mathrm{TKN} \text {, ammonia (as } \mathrm{NH}_{3} \text { ), } \\
\mathrm{NO}_{3}-\mathrm{N}, \mathrm{NO}_{2}-\mathrm{N} \text {, total nitrogen (as } \mathrm{N} \text { ) }\end{array}$ \\
\hline & $\begin{array}{l}\text { Flow-weighted } \\
\text { composite }\end{array}$ & Semiannually; 2 per year & $\begin{array}{l}\text { Maximum flow, total flow, plus all of the } \\
\text { above constituents except for } \mathrm{pH} \text { and oil } \\
\text { \& grease }\end{array}$ \\
\hline \multirow[t]{2}{*}{\begin{tabular}{|l}
$\frac{\text { Group 2 }^{a}}{\text { WNSO06 (S06) }}$ \\
WNSO33 (S33)
\end{tabular}} & First flush grab & Semiannually; 2 per year & $\begin{array}{l}\mathrm{pH} \text {, oil \& grease, } \mathrm{BOD}_{5}, \mathrm{TSS}, \mathrm{TDS} \text {, total } \mathrm{P} \text {, } \\
\mathrm{Al} \text {, Fe, total recoverable } \mathrm{Cu}, \mathrm{Pb}, \mathrm{Zn}, \\
\text { surfactant (as LAS) }\end{array}$ \\
\hline & $\begin{array}{l}\text { Flow-weighted } \\
\text { composite }\end{array}$ & Semiannually; 2 per year & $\begin{array}{l}\text { Maximum flow, total flow, plus all of the } \\
\text { above constituents except for } \mathrm{pH} \text { and oil } \\
\text { \& grease }\end{array}$ \\
\hline
\end{tabular}

${ }^{a}$ Required by SPDES Permit \#NY0000973. Results reported in the SPDES DMR and evaluated in this ASER.

${ }^{\mathrm{b}}$ WET testing shall be performed quarterly for the first year, and repeat the quarterly sampling every five years.

${ }^{c}$ Results are reported to the CCHD. 
TABLE A-2 (continued)

2012 Monitoring Program

\begin{tabular}{|c|c|c|c|}
\hline Sample Location Code & $\begin{array}{l}\text { Sampling Type/ } \\
\text { Medium }\end{array}$ & $\begin{array}{l}\text { Collection Frequency/ } \\
\text { Total Annual Samples }\end{array}$ & Measurements/Analyses \\
\hline \multicolumn{4}{|c|}{ Storm Water Outfalls } \\
\hline \multirow{4}{*}{$\begin{array}{l}{\text { Group } 3^{a}}^{\text {WNSO09 (S09) }} \\
\text { WNSO12 (S12) }\end{array}$} & First flush grab & Semiannually; 2 per year & $\mathrm{pH}$, oil \& grease, $\mathrm{BOD}_{5}, \mathrm{TSS}, \mathrm{TDS}$, total $\mathrm{P}$ \\
\hline & & & $\mathrm{Al}, \mathrm{Fe}, \mathrm{Hg}$, total recoverable $\mathrm{Cu}, \mathrm{Pb}, \mathrm{Zn}$, \\
\hline & & & $\begin{array}{l}\mathrm{TKN} \text {, ammonia (as } \mathrm{NH}_{3} \text { ), } \mathrm{NO}_{3}-\mathrm{N}, \mathrm{NO}_{2}-\mathrm{N} \text {, } \\
\text { alpha-BHC, total nitrogen (as } \mathrm{N} \text { ) }\end{array}$ \\
\hline & $\begin{array}{l}\text { Flow-weighted } \\
\text { composite }\end{array}$ & Semiannually; 2 per year & $\begin{array}{l}\text { Maximum flow, total flow, plus all of the } \\
\text { above constituents except for } \mathrm{pH} \text { and oil } \\
\text { \& grease }\end{array}$ \\
\hline \multirow{3}{*}{$\frac{\text { Group 4 }}{\text { WNSO34 (S34) }}^{a}$} & First flush grab & Semiannually; 2 per year & $\mathrm{pH}$, oil \& grease, $\mathrm{BOD}_{5}, \mathrm{TSS}, \mathrm{TDS}$, total P, \\
\hline & & & $\begin{array}{l}\text { Al, Fe, total recoverable } \mathrm{Cu}, \mathrm{Pb}, \mathrm{Zn} \text {, } \\
\text { surfactant (as LAS) }\end{array}$ \\
\hline & $\begin{array}{l}\text { Flow-weighted } \\
\text { composite }\end{array}$ & Semiannually; 2 per year & $\begin{array}{l}\text { Maximum flow, total flow, plus all of the } \\
\text { above constituents except for } \mathrm{pH} \text { and oil } \\
\text { \& grease }\end{array}$ \\
\hline \multirow{5}{*}{$\begin{array}{l}\text { Group 5 }^{a} \\
\text { WNSO14 (S14) } \\
\text { WNSO17 (S17) } \\
\text { WNSO28 (S28) }\end{array}$} & First flush grab & Semiannually; 2 per year & $\mathrm{pH}$, oil \& grease, $\mathrm{BOD}_{5}, \mathrm{TSS}, \mathrm{TDS}$, total $\mathrm{P}$ \\
\hline & & & $\mathrm{Al}, \mathrm{Fe}$, total recoverable $\mathrm{Cu}, \mathrm{Pb}, \mathrm{Zn}, \mathrm{V}$, \\
\hline & & & TKN, ammonia (as $\mathrm{NH}_{3}$ ), $\mathrm{NO}_{3}-\mathrm{N}, \mathrm{NO}_{2}-\mathrm{N}$, \\
\hline & & & $\begin{array}{l}\text { surfactant (as LAS), sulfide, settleable } \\
\text { solids, total nitrogen (as N) }\end{array}$ \\
\hline & $\begin{array}{l}\text { Flow-weighted } \\
\text { composite }\end{array}$ & Semiannually; 2 per year & $\begin{array}{l}\text { Maximum flow, total flow, plus all of the } \\
\text { above constituents except for } \mathrm{pH} \text { and oil } \\
\text { \& grease }\end{array}$ \\
\hline \multirow{7}{*}{$\begin{array}{l}\frac{\text { Group 6 }^{\text {a }}}{\text { WNSO36 (S36) }} \\
\text { WNSO37 (S37) } \\
\text { WNSO38 (S38) } \\
\text { WNSO39 (S39) } \\
\text { WNSO41 (S41) } \\
\text { WNSO42 (S42) } \\
\text { WNSO43 (S43) }\end{array}$} & First flush grab & Semiannually; 2 per year & $\mathrm{pH}$, oil \& grease, $\mathrm{BOD}_{5}, \mathrm{TSS}, \mathrm{TDS}$, total $\mathrm{P}$ \\
\hline & & & $\mathrm{Al}, \mathrm{Fe}$, total recoverable $\mathrm{Cu}, \mathrm{Pb}, \mathrm{Zn}, \mathrm{V}$ \\
\hline & & & TKN, ammonia (as $\mathrm{NH}_{3}$ ), $\mathrm{NO}_{3}-\mathrm{N}, \mathrm{NO}_{2}-\mathrm{N}$, \\
\hline & & & surfactant (as LAS), sulfide, settleable \\
\hline & & & solids, total nitrogen (as N) \\
\hline & S43 only, grab & Semiannually; 2 per year & Total recoverable $\mathrm{Pb}$ \\
\hline & $\begin{array}{l}\text { Flow-weighted } \\
\text { composite }\end{array}$ & $\begin{array}{l}\text { Semiannually; } 2 \text { locations per } \\
\text { group per year }^{\text {b }}\end{array}$ & $\begin{array}{l}\text { Maximum flow, total flow, plus all of the } \\
\text { above constituents except for } \mathrm{pH} \text { and oil } \\
\text { \& grease }\end{array}$ \\
\hline \multirow{3}{*}{$\begin{array}{l}\text { Group 7 }^{a} \\
\text { WNSO20 (S20) }^{\prime}\end{array}$} & First flush grab & Semiannually; 2 per year & $\mathrm{pH}$, oil \& grease, $\mathrm{BOD}_{5}, \mathrm{TSS}, \mathrm{TDS}$, total $\mathrm{P}$ \\
\hline & & & $\begin{array}{l}\text { Al, Fe, total recoverable } \mathrm{Cu}, \mathrm{Pb}, \mathrm{Zn}, \mathrm{TKN} \text {, } \\
\text { ammonia (as } \mathrm{NH}_{3} \text { ), } \mathrm{NO}_{3}-\mathrm{N}, \mathrm{NO}_{2}-\mathrm{N}, \\
\text { surfactant (as } \mathrm{LAS} \text { ), sulfide, total nitrogen } \\
\text { (as } \mathrm{N} \text { ) }\end{array}$ \\
\hline & $\begin{array}{l}\text { Flow-weighted } \\
\text { composite }\end{array}$ & Semiannually; 2 per year & $\begin{array}{l}\text { Maximum flow, total flow, plus all of the } \\
\text { above constituents except for } \mathrm{pH} \text { and oil } \\
\text { \& grease }\end{array}$ \\
\hline
\end{tabular}

a Required by SPDES Permit \# NY0000973. Results reported in the monthly SPDES DMR and evaluated in this ASER.

${ }^{\mathrm{b}}$ One location per group sampled semiannually. 
TABLE A-2 (continued)

2012 Environmental Monitoring Program

\begin{tabular}{|c|c|c|c|}
\hline Sample Location Code & $\begin{array}{l}\text { Sampling Type/ } \\
\text { Medium }\end{array}$ & $\begin{array}{l}\text { Collection Frequency/ } \\
\text { Total Annual Samples }\end{array}$ & Measurements/Analyses \\
\hline \multicolumn{4}{|c|}{ Storm Water Outfalls (continued) } \\
\hline \multirow[t]{2}{*}{$\begin{array}{l}\frac{\text { Group }^{a}}{\text { WNSO27 (S27) }} \\
\text { WNSO35 (S35) }\end{array}$} & First flush grab & Semiannually; 2 per year & $\begin{array}{l}\mathrm{pH} \text {, oil \& grease, } \mathrm{BOD}_{5}, \mathrm{TSS}, \mathrm{TDS} \text {, total } \mathrm{P} \text {, } \\
\mathrm{Al}, \mathrm{Fe} \text {, total recoverable } \mathrm{Cu}, \mathrm{Pb}, \mathrm{Zn}, \mathrm{TKN}, \\
\text { ammonia (as } \mathrm{NH}_{3} \text { ), } \mathrm{NO}_{3}-\mathrm{N}, \mathrm{NO}_{2}-\mathrm{N}, \\
\text { surfactant (as LAS), total nitrogen (as } \mathrm{N} \text { ) }\end{array}$ \\
\hline & $\begin{array}{l}\text { Flow-weighted } \\
\text { composite }\end{array}$ & Semiannually; 2 per year & $\begin{array}{l}\text { Maximum flow, total flow, plus all of the } \\
\text { above constituents except for } \mathrm{pH} \text { and oil } \\
\text { \& grease }\end{array}$ \\
\hline $\begin{array}{l}\text { WNSWRO1 } \\
\text { Site rain gauge }\end{array}$ & $\begin{array}{l}\text { Field measurement of } \\
\text { precipitation }\end{array}$ & $\begin{array}{l}1 \text { each storm water sampling } \\
\text { event }\end{array}$ & $\mathrm{pH}$ \\
\hline \multicolumn{4}{|c|}{ On-Site Surface Water } \\
\hline \multirow[t]{3}{*}{$\begin{array}{l}\text { WNSWAMP } \\
\text { Northeast swamp drainage }\end{array}$} & $\begin{array}{l}\text { Timed continuous } \\
\text { composite liquid }\end{array}$ & Biweekly; 26 per year & $\begin{array}{l}\text { Gross alpha/beta, } \mathrm{H}-3, \mathrm{pH} \text {, flow (at } \\
\text { WNSWAMP only) }\end{array}$ \\
\hline & $\begin{array}{l}\text { Composite of biweekly } \\
\text { samples }\end{array}$ & Monthly; 12 per year & Sr-90 and gamma isotopic \\
\hline & $\begin{array}{l}\text { Composite of biweekly } \\
\text { samples }\end{array}$ & Semiannually; 2 per year & $\begin{array}{l}\mathrm{C}-14, \mathrm{I}-129, \mathrm{U}-232, \mathrm{U}-233 / 234 \\
\mathrm{U}-235 / 236, \mathrm{U}-238, \text { total U, } \\
\text { Pu-238, Pu-239/240, Am-241 }\end{array}$ \\
\hline $\begin{array}{l}\text { WNSP005 } \\
\text { Facility yard drainage }\end{array}$ & $\begin{array}{l}\text { Composite of quarterly } \\
\text { samples }\end{array}$ & Semiannually; 2 per year & Sr-90 and gamma isotopic \\
\hline \multirow[t]{2}{*}{$\begin{array}{l}\text { WNFRC67 } \\
\text { Franks Creek east of the } \\
\text { SDA }\end{array}$} & Grab liquid & $\begin{array}{l}\text { Quarterly; } 4 \text { per year } \\
\text { (collected at same time as } \\
\text { WNNDADR) }\end{array}$ & Gross alpha/beta, $\mathrm{H}-3, \mathrm{pH}$ \\
\hline & $\begin{array}{l}\text { Composite of quarterly } \\
\text { samples }\end{array}$ & Semiannually; 2 per year & Sr-90 and gamma isotopic \\
\hline $\begin{array}{l}\text { WNERB53 } \\
\text { Erdman Brook north of } \\
\text { disposal areas }\end{array}$ & Grab liquid & $\begin{array}{l}\text { Quarterly; } 4 \text { per year } \\
\text { (collected at same time as } \\
\text { WNNDADR) }\end{array}$ & Gross alpha/beta, $\mathrm{H}-3, \mathrm{pH}$ \\
\hline $\begin{array}{l}\text { WNNDADR } \\
\text { Drainage between NDA and }\end{array}$ & $\begin{array}{l}\text { Timed continuous } \\
\text { composite liquid }\end{array}$ & Biweekly; 26 per year & Hold for composite \\
\hline \multirow[t]{2}{*}{ SDA } & $\begin{array}{l}\text { Composite of biweekly } \\
\text { samples }\end{array}$ & Monthly; 12 per year & Gross alpha/beta, H-3, gamma isotopic \\
\hline & $\begin{array}{l}\text { Composite of biweekly } \\
\text { samples }\end{array}$ & Semiannually; 2 per year & Sr-90 and $\mathrm{I}-129$ \\
\hline \multicolumn{4}{|c|}{ On-Site Potable (Drinking) Water } \\
\hline $\begin{array}{l}\text { WNDFLTR } \\
\text { Utility room (entry point } \\
\text { [EP-02]) potable water } \\
\text { storage tank }\end{array}$ & $\begin{array}{l}\text { Grab liquid }^{b} \\
\text { Grab }^{c}\end{array}$ & $\begin{array}{l}\text { Annually; } 1 \text { per year } \\
\text { Quarterly; } 4 \text { per year }\end{array}$ & $\begin{array}{l}\text { As, } \mathrm{Ba}, \mathrm{Be}, \mathrm{Cd}, \mathrm{Cr}, \mathrm{Hg}, \mathrm{Ni}, \mathrm{Sb}, \mathrm{Se}, \mathrm{Tl}, \\
\text { cyanide, fluoride } \\
\text { TOC }\end{array}$ \\
\hline $\begin{array}{l}\text { WNDNKMP } \\
\text { Main plant drinking water }\end{array}$ & Grab liquid & Annually; 1 per year & Gross alpha/beta, H-3 \\
\hline $\begin{array}{l}\text { WNDNKEL } \\
\text { Environmental Laboratory } \\
\text { drinking water }\end{array}$ & Grab liquid $^{d}$ & Annually; 1 per year & $\begin{array}{l}\text { Total haloacetic acids, total } \\
\text { trihalomethanes }\end{array}$ \\
\hline
\end{tabular}

Note: $\mathrm{Pb}$ and $\mathrm{Cu}$ are sampled at various drinking water locations once every three years, based on CCHD guidance. Three locations were sampled in CY 2012. The CCHD collects monthly distribution system samples for total coliform and residual chlorine, and reports to the WVDP.

${ }^{a}$ Required by SPDES Permit \# NY0000973. Results reported in the monthly SPDES DMR and evaluated in this ASER.

${ }^{b}$ Primary inorganic chemical results are reported to the CCHD. A sample for $\mathrm{NO}_{3}$ (as total nitrate) is collected by the CCHD.

${ }^{\mathrm{c}}$ Total organic carbon is sampled monthly and reported to the CCHD.

${ }^{d}$ Disinfection byproducts are sampled annually and reported to the CCHD. 
TABLE A-2 (continued)

2012 Environmental Monitoring Program

\begin{tabular}{|c|c|c|c|}
\hline Sample Location Code & $\begin{array}{c}\text { Sampling Type/ } \\
\text { Medium }\end{array}$ & $\begin{array}{l}\text { Collection Frequency/ } \\
\text { Total Annual Samples }\end{array}$ & Measurements/Analyses \\
\hline \multicolumn{4}{|c|}{ On-Site Groundwater } \\
\hline $\begin{array}{l}\text { LLW2: SSWMU \#1 } \\
\text { (wells 103, 104, 105, 106, } \\
\text { 107, 108, 110, 111, 116, } \\
8604,8605 \text { ) } \\
\text { Miscellaneous small units: } \\
\text { SSWMU \#2 } \\
\text { (wells 204, 205, 206) } \\
\text { LWTS: SSWMU \#3 } \\
\text { (wells 301, 302) } \\
\text { HLW and processing tank: } \\
\text { SSWMU \#4 } \\
\text { (wells 401, 402, 403, 405, } \\
406,408,409 \text { ) } \\
\text { Maintenance shop leach } \\
\text { field: SSWMU \#5 } \\
\text { (wells 501, 502) } \\
\text { LLW storage area: SSWMU } \\
\# 6 \\
\text { (wells 602A, 604, 605, }\end{array}$ & Grab liquid & $\begin{array}{l}\text { Quarterly during the fiscal } \\
\text { year (generally }{ }^{a} \text { ); } 4 \text { per year }\end{array}$ & 10 \\
\hline $\begin{array}{l}8607,8609) \\
\text { Chemical process cell } \\
\text { waste storage area: } \\
\text { SSWMU \#7 } \\
\text { (wells 704, 706, 707) } \\
\text { CDDL: SSWMU \#8 } \\
\text { (wells 801, 802, 803, 804, } \\
8603,8612 \text { ) }\end{array}$ & 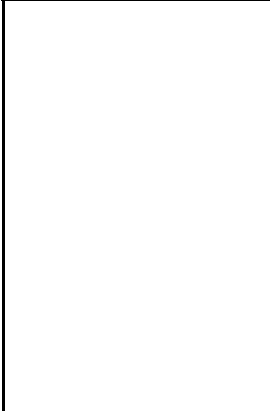 & 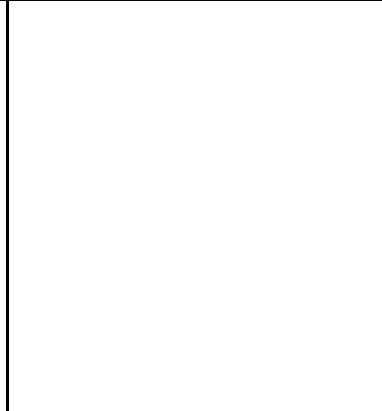 & 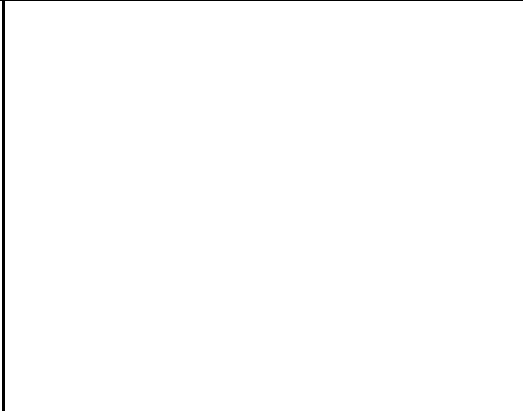 \\
\hline $\begin{array}{l}\text { NDA: SSWMU \#9 } \\
\text { (wells 901, 902, 903, 906, } \\
\text { 908, 908R, 909, 910R, } \\
\text { 8610, 8611, trench NDATR) } \\
\text { IRTS drum cell: } \\
\text { SSWMU \#10 } \\
\text { (wells 1005, 1006, 1008B, } \\
\text { 1008C) } \\
\text { RHWF (not in a SSWMU): } \\
\text { (wells 1301, 1302, 1303, } \\
\text { 1304) }\end{array}$ & $\begin{array}{l}\text { Direct field } \\
\text { measurement }\end{array}$ & $\begin{array}{l}\text { Twice each sampling event; } \\
8 \text { per year for wells sampled } \\
\text { quarterly }\end{array}$ & Conductivity, $\mathrm{pH}$ \\
\hline
\end{tabular}

${ }^{\mathrm{a}}$ Sampling frequency and analyses vary from point to point. 
TABLE A-2 (continued)

2012 Environmental Monitoring Program

\begin{tabular}{|c|c|c|c|}
\hline Sample Location Code & $\begin{array}{c}\text { Sampling Type/ } \\
\text { Medium }\end{array}$ & $\begin{array}{l}\text { Collection Frequency/ } \\
\text { Total Annual Samples }\end{array}$ & Measurements/Analyses \\
\hline \multicolumn{4}{|c|}{ On-Site Groundwater } \\
\hline \multirow{2}{*}{$\begin{array}{l}\text { MPPB downgradient wells } \\
\text { (installed in 2010): (wells } \\
\text { MP-01, MP-02, MP-03, MP- } \\
\text { 04) }\end{array}$} & Grab liquid & $\begin{array}{l}\text { Quarterly during the fiscal } \\
\text { year (generally }{ }^{a} \text { ); } 4 \text { per year }\end{array}$ & $\begin{array}{l}\text { Gross alpha/beta, H-3, Radioisotopic } \\
\text { analyses, VOCs, SVOCs, metals, and } \\
\text { turbidity }\end{array}$ \\
\hline & $\begin{array}{l}\text { Direct field } \\
\text { measurement }\end{array}$ & $\begin{array}{l}\text { Twice each sampling event; } 8 \\
\text { per year for wells sampled } \\
\text { quarterly }\end{array}$ & Conductivity, $\mathrm{pH}$ \\
\hline \multirow{2}{*}{$\begin{array}{l}\text { North plateau seeps (not } \\
\text { in a SSWMU): (points } \\
\text { GSEEP, SP04, SP06, SP11, } \\
\text { SP12) }\end{array}$} & Grab liquid & $\begin{array}{l}\text { Semiannually (quarterly at } \\
\text { GSEEP); } 2 \text { (or 4) per year }\end{array}$ & $\begin{array}{l}\text { Gross alpha/beta, H-3 (also VOCs at } \\
\text { GSEEP and SP12) }\end{array}$ \\
\hline & $\begin{array}{l}\text { Direct field } \\
\text { measurement of } \\
\text { sampled water } \\
\end{array}$ & $\begin{array}{l}\text { Semiannually at SP12 } \\
\text { (quarterly at GSEEP); } 2 \text { (or 4) } \\
\text { per year }\end{array}$ & $\mathrm{pH}$, conductivity \\
\hline \multirow{3}{*}{$\begin{array}{l}\text { PTWPMP wells: (66 PTW } \\
\text { platform wells at stations 1- } \\
\text { 12, installed in } 2010 \text { [i.e. } \\
\text { PTW-S1A, PTW-S1B and } \\
\text { PTW-S1C] and } 21 \text { pre- } \\
\text { existing full network wells } \\
\text { (i.e. WP02, MW-5) }\end{array}$} & Grab liquid & $\begin{array}{l}\text { Quarterly (annually at full } \\
\text { network wells); } 4 \text { (or 1) per } \\
\text { year at each location }\end{array}$ & Strontim-90 \\
\hline & Grab liquid & $\begin{array}{l}\text { Annually; } 1 \text { per year at each } \\
\text { location }\end{array}$ & $\begin{array}{l}\text { Geochemical parameters: } \mathrm{Na}, \mathrm{K}, \mathrm{Ca}, \mathrm{Mg} \text {, } \\
\text { carbonate, bicarbonate, } \mathrm{SO}_{4}, \mathrm{Cl}\end{array}$ \\
\hline & $\begin{array}{l}\text { Direct field } \\
\text { measurement }\end{array}$ & $\begin{array}{l}\text { Quarterly (annually at full } \\
\text { network wells); } 4 \text { (or } 1 \text { ) per } \\
\text { year at each location }\end{array}$ & $\begin{array}{l}\text { Conductivity, } \mathrm{pH} \text {, temperature, oxidation- } \\
\text { reduction potential, } \\
\text { dissolved oxygen, and turbidity }\end{array}$ \\
\hline \multirow{2}{*}{$\begin{array}{l}\text { Miscellaneous monitoring } \\
\text { locations (not in a } \\
\text { SSWMU): Well points WP- } \\
\text { A, WP-C, WP-H }\end{array}$} & Grab liquid & $\begin{array}{l}\text { Annually (quarterly at NB1S); } \\
1 \text { (or 4) per year }\end{array}$ & Gross alpha/beta, H-3 \\
\hline & $\begin{array}{l}\text { Direct field } \\
\text { measurement of } \\
\text { sampled water }\end{array}$ & $\begin{array}{l}\text { Annually (quarterly at NB1S); } \\
1 \text { (or 4) per year }\end{array}$ & $\mathrm{pH}$, conductivity \\
\hline $\begin{array}{l}\text { Surface water elevation } \\
\text { points: (SE007, SE008, } \\
\text { SE009, SE011) }\end{array}$ & $\begin{array}{l}\text { Direct field } \\
\text { measurement }\end{array}$ & $\begin{array}{l}\text { Quarterly; } 4 \text { per year at each } \\
\text { location }\end{array}$ & Water level \\
\hline SDA (SSWMU \#11) & \multicolumn{3}{|c|}{$\begin{array}{l}\text { Groundwater wells in SSWMU \#11 are sampled by NYSERDA under a separate program. For } \\
\text { information, see the NYSERDA website at www.nyserda.ny.gov. }\end{array}$} \\
\hline \multicolumn{4}{|c|}{ On-Site Soil/Sediment } \\
\hline $\begin{array}{l}\text { SN on-site soil series; } \\
\text { SNSW74A (near } \\
\text { WNSW74A), SNSWAMP } \\
\text { (near WNSWAMP), and } \\
\text { SNSP006 (near WNSP006) }\end{array}$ & $\begin{array}{l}\text { Surface plug composite } \\
\text { soil/sediment }\end{array}$ & $\begin{array}{l}1 \text { each location every five } \\
\text { years (sampled in current year } \\
\text { and previously sampled in } \\
2007 \text { ) }\end{array}$ & $\begin{array}{l}\text { Gross alpha/beta, gamma isotopic, } \\
\text { Sr-90, U-232, U-233/234, U-235/236, } \\
\text { U-238, total U, Pu-238, Pu-239/240, } \\
\text { Am-241 }\end{array}$ \\
\hline \multicolumn{4}{|c|}{ Off-Site Soil } \\
\hline $\begin{array}{l}\text { SF off-site soil series } \\
\text { (collected at historical air } \\
\text { sampling location[s]); } \\
\text { SFFXVRD, SFRT240, } \\
\text { SFRSPRD, SFGRVAL }\end{array}$ & $\begin{array}{l}\text { Surface plug composite } \\
\text { soil }\end{array}$ & $\begin{array}{l}1 \text { each location every five } \\
\text { years (sampled in current year } \\
\text { and previously sampled in } \\
2007 \text { ) }\end{array}$ & $\begin{array}{l}\text { Gross alpha/beta, Sr-90, gamma isotopic, } \\
\text { Pu-238, Pu-239/240, } \\
\text { Am-241. At nearest site (SFRSPRD) and } \\
\text { background (SFGRVAL), also } \\
\text { U-232, U-233/234, U-235/236, U-238, } \\
\text { and total U }\end{array}$ \\
\hline
\end{tabular}

${ }^{\mathrm{a} S a m p l i n g ~ f r e q u e n c y ~ a n d ~ a n a l y s e s ~ v a r y ~ f r o m ~ p o i n t ~ t o ~ p o i n t . ~}$ 
TABLE A-2 (continued)

2012 Environmental Monitoring Program

\begin{tabular}{|c|c|c|c|}
\hline Sample Location Code & $\begin{array}{l}\text { Sampling Type/ } \\
\text { Medium }\end{array}$ & $\begin{array}{l}\text { Collection Frequency/ } \\
\text { Total Annual Samples }\end{array}$ & Measurements/Analyses \\
\hline \multicolumn{4}{|c|}{ Off-Site Sediment } \\
\hline \begin{tabular}{|l|} 
SFCCSED \\
Cattaraugus Creek at Felton \\
Bridge \\
SFSDSED \\
Cattaraugus Creek at \\
Springville Dam \\
SFTCSED \\
Buttermilk Creek at Thomas \\
Corners Road \\
SFBCSED \\
Buttermilk Creek at Fox Valley \\
Road (background)
\end{tabular} & Grab stream sediment & $\begin{array}{l}1 \text { each location every five years } \\
\text { (sampled in current year and } \\
\text { previously sampled in 2007) }\end{array}$ & $\begin{array}{l}\text { Gross alpha/beta, gamma isotopic, Sr-90, } \\
\text { U-232, U-233/234, U-235/236, U-238, total U, } \\
\text { Pu-238, Pu-239/240, Am-241 }\end{array}$ \\
\hline \multicolumn{4}{|c|}{ Off-Site Surface Water } \\
\hline \multirow{3}{*}{$\begin{array}{l}\text { WFBCBKG } \\
\text { Buttermilk Creek near Fox } \\
\text { Valley (background) }\end{array}$} & $\begin{array}{l}\text { Timed continuous } \\
\text { composite liquid }\end{array}$ & Biweekly; 26 per year & Hold for composite \\
\hline & $\begin{array}{l}\text { Composite of biweekly } \\
\text { samples }\end{array}$ & Monthly; 12 per year & Gross alpha/beta, $\mathrm{H}-3$ \\
\hline & $\begin{array}{l}\text { Composite of biweekly } \\
\text { samples }\end{array}$ & Semiannually; 2 per year & $\begin{array}{l}\text { C-14, Sr-90, Tc-99, I-129, U-232, U-233/234, } \\
\text { U-235/236, U-238, total U, Pu-238, } \\
\text { Pu-239/240, Am-241, gamma isotopic }\end{array}$ \\
\hline \multirow{2}{*}{$\begin{array}{l}\text { WFFELBR } \\
\text { Cattaraugus Creek at Felton } \\
\text { Bridge (downstream of } \\
\text { confluence with Buttermilk } \\
\text { Creek); nearest point of public } \\
\text { access to waters receiving } \\
\text { WVDP effluents }\end{array}$} & $\begin{array}{l}\text { Timed continuous } \\
\text { composite liquid }\end{array}$ & $\begin{array}{l}\text { Weekly during lagoon } 3 \\
\text { discharge, otherwise biweekly; }\end{array}$ & Gross alpha/beta, $\mathrm{H}-3, \mathrm{pH}$, flow \\
\hline & $\begin{array}{l}\text { Flow-weighted composite } \\
\text { of weekly and biweekly } \\
\text { samples }\end{array}$ & Monthly; 12 per year & $\begin{array}{l}\text { Gross alpha/beta, } \mathrm{H}-3, \mathrm{Sr}-90 \text {, and gamma } \\
\text { isotopic }\end{array}$ \\
\hline \multirow{5}{*}{$\begin{array}{l}\text { WFBCTCB } \\
\text { Buttermilk Creek at Thomas } \\
\text { Corners Road, downstream of } \\
\text { WVDP and upstream of } \\
\text { confluence with Cattaraugus } \\
\text { Creek }\end{array}$} & $\begin{array}{l}\text { Composite of biweekly } \\
\text { samples }\end{array}$ & Monthly; 12 per year & Gross alpha/beta, $\mathrm{H}-3$ \\
\hline & $\begin{array}{l}\text { Composite of biweekly } \\
\text { samples }\end{array}$ & Semiannually; 2 per year & Sr-90, gamma isotopic \\
\hline & Grab liquid & Monthly; 12 per year & Hardness ( $\mathrm{Ca}$ and $\mathrm{Mg}$ ) \\
\hline & Grab liquid & Semiannually; 2 per year ${ }^{a}$ & $\begin{array}{l}\text { Temperature (field), pH (field), dissolved } \\
\text { oxygen (field), TOX, oil \& grease, } \\
\text { Hg (method 1631) }\end{array}$ \\
\hline & $\begin{array}{l}\text { 24-hour timed } \\
\text { continuous composite }\end{array}$ & Semiannually; 2 per year ${ }^{a}$ & $\begin{array}{l}\text { TSS, TDS, NPOC, } \mathrm{NH}_{3} \text { (as N), } \mathrm{NO}_{3} \text { (as N), } \mathrm{NO}_{2} \\
\text { (as N), bromide, fluoride, sulfate, total } \\
\text { sulfide, surfactant (as LAS), alpha-BHC, B, Ba, } \\
\mathrm{Co}, \mathrm{Fe}, \mathrm{Na}, \mathrm{Mn}, \mathrm{Sb}, \mathrm{Ti}, \mathrm{Tl}, \mathrm{V} \text {, dissolved } \mathrm{Al}, \mathrm{As} \text {, } \\
\mathrm{Cd}, \mathrm{Cr}, \mathrm{Cu}, \mathrm{Ni}, \mathrm{Pb}, \mathrm{Se}, \mathrm{Zn}\end{array}$ \\
\hline
\end{tabular}

${ }^{\mathrm{a}}$ Samples are collected when point WNSP001 is discharging. 
TABLE A-2 (continued)

2012 Environmental Monitoring Program

\begin{tabular}{|c|c|c|c|}
\hline Sample Location Code & $\begin{array}{c}\text { Sampling Type/ } \\
\text { Medium }\end{array}$ & $\begin{array}{l}\text { Collection Frequency/ } \\
\text { Total Annual Samples }\end{array}$ & Measurements/Analyses \\
\hline \multicolumn{4}{|c|}{ Off-Site Ambient Air } \\
\hline $\begin{array}{l}\text { AF01_N } \\
\text { North at Bond Road } \\
\text { AF02_NNE } \\
\text { North-northeast at Rt. } 240 \\
\text { AF03_NE } \\
\text { Northeast at Rt. } 240 \\
\text { AF04_ENE } \\
\text { East-northeast at Rt. } 240\end{array}$ & $\begin{array}{l}\text { Glass fiber filters for air } \\
\text { particulates }\end{array}$ & Biweekly; 26 per year & $\begin{array}{l}\text { Gross alpha/beta screening, flow; } \\
\text { Hold for composite }\end{array}$ \\
\hline $\begin{array}{l}\text { AF05_E } \\
\text { East at Heinz Road } \\
\text { AF06_ESE } \\
\text { East-southeast at Buttermilk } \\
\text { Road } \\
\text { AF07_SE } \\
\text { Southeast } \\
\text { at Fox Valley Road } \\
\text { AF08_SSE } \\
\text { South-southeast } \\
\text { at Fox Valley Road }\end{array}$ & $\begin{array}{l}\text { Charcoal cartridge for } \\
\text { iodine }\end{array}$ & Monthly; 12 per year & $\begin{array}{l}\text { I-129 screening, flow; } \\
\text { Hold for composite }\end{array}$ \\
\hline $\begin{array}{l}\text { AF09_S } \\
\text { South } \\
\text { at Rock Springs Road } \\
\text { AF10_SSW } \\
\text { South-southwest } \\
\text { at Dutch Hill Road } \\
\text { AF11_SW } \\
\text { Southwest } \\
\text { at Dutch Hill Road } \\
\text { AF12_WSW } \\
\text { West-southwest } \\
\text { at Dutch Hill Road }\end{array}$ & $\begin{array}{l}\text { Composite of biweekly } \\
\text { glass fiber filters }\end{array}$ & Quarterly; 4 per year & $\begin{array}{l}\text { Sr-90, Cs-137, U-232, Pu-238, Pu-239/240, } \\
\text { Am-241, flow }\end{array}$ \\
\hline $\begin{array}{l}\text { AF13_W } \\
\text { West } \\
\text { at Dutch Hill Road } \\
\text { AF14_WNW } \\
\text { West-northwest } \\
\text { at Boberg Road } \\
\text { AF15_NW } \\
\text { Northwest } \\
\text { at Rock Springs Road } \\
\text { AF16_NNW } \\
\text { North-northwest } \\
\text { at Rock Springs Road }\end{array}$ & $\begin{array}{l}\text { Composite of monthly } \\
\text { charcoal }\end{array}$ & Quarterly; 4 per year & I-129, flow \\
\hline
\end{tabular}


TABLE A-2 (continued)

2012 Environmental Monitoring Program

\begin{tabular}{|c|c|c|c|}
\hline Sample Location Code & $\begin{array}{l}\text { Sampling Type/ } \\
\text { Medium }\end{array}$ & $\begin{array}{l}\text { Collection Frequency/ } \\
\text { Total Annual Samples }\end{array}$ & Measurements/Analyses \\
\hline \multicolumn{4}{|c|}{ Off-Site Ambient Air } \\
\hline \multirow{2}{*}{$\begin{array}{l}\text { AF16HNNW } \\
\text { High-volume sampler at } \\
\text { presumed MEOSI location } \\
\text { north-northwest }\end{array}$} & $\begin{array}{l}\text { Glass fiber filters for air } \\
\text { particulates }\end{array}$ & Biweekly; 26 per year & $\begin{array}{l}\text { Gross alpha/beta screening, flow; } \\
\text { Hold for composite }\end{array}$ \\
\hline & $\begin{array}{l}\text { Composite of biweekly } \\
\text { glass fiber filters }\end{array}$ & Quarterly; 4 per year & $\begin{array}{l}\text { Sr-90, Cs-137, U-232, Pu-238, Pu-239/240, } \\
\text { Am-241, flow }\end{array}$ \\
\hline \multirow{4}{*}{$\begin{array}{l}\text { AFGRVAL } \\
29 \text { km south at Great Valley } \\
\text { (background) }\end{array}$} & $\begin{array}{l}\text { Glass fiber filter for air } \\
\text { particulates }\end{array}$ & Biweekly; 26 per year & $\begin{array}{l}\text { Gross alpha/beta screening, flow; Hold for } \\
\text { composite }\end{array}$ \\
\hline & $\begin{array}{l}\text { Charcoal cartridge for } \\
\text { iodine }\end{array}$ & Monthly; 12 per year & $\begin{array}{l}\text { I-129 screening, flow; } \\
\text { Hold for composite }\end{array}$ \\
\hline & $\begin{array}{l}\text { Composite of monthly } \\
\text { charcoal }\end{array}$ & Quarterly; 4 per year & I-129, flow \\
\hline & $\begin{array}{l}\text { Composite of biweekly } \\
\text { glass fiber filters }\end{array}$ & Quarterly; 4 per year & $\begin{array}{l}\text { Sr-90, gamma isotopic, U-232, U-233/234, } \\
\text { U-235/236, U-238, total U, Pu-238, } \\
\text { Pu-239/240, Am-241, flow }\end{array}$ \\
\hline \multicolumn{4}{|c|}{ Off-Site Biological } \\
\hline $\begin{array}{l}\text { BFMFLDMN } \\
\text { Dairy farm } 5.1 \mathrm{~km} \text { southeast } \\
\text { of WVDP }\end{array}$ & Grab milk sample & Annual; 1 per year & Sr-90, I-129, gamma isotopic \\
\hline $\begin{array}{l}\text { BFMCTLS } \\
\text { Control location } 22 \mathrm{~km} \text { south } \\
\text { (background) } \\
\text { BFMBLSY } \\
\text { Dairy farm } 5.5 \mathrm{~km} \\
\text { west-northwest } \\
\text { BFMSCHT } \\
\text { Dairy farm } 4.9 \mathrm{~km} \text { south }\end{array}$ & Grab milk sample & $\begin{array}{l}\text { Each location once every five } \\
\text { years (sampled in current year } \\
\text { and previously sampled in 2007) }\end{array}$ & Sr-90, I-129, gamma isotopic \\
\hline $\begin{array}{l}\text { BFDNEAR } \\
\text { Deer in the vicinity of the } \\
\text { WVDP } \\
\text { BFDCTRL } \\
\text { Control deer } 16 \mathrm{~km} \text { or more } \\
\text { from the WVDP }\end{array}$ & $\begin{array}{l}\text { Individual collection of } \\
\text { venison samples, usually } \\
\text { from deer killed in } \\
\text { collisions with vehicles }\end{array}$ & $\begin{array}{l}\text { Six deer collected annually } \\
\text { during hunting season } \\
\text { ( } 3 \text { near-site, } 3 \text { background) }\end{array}$ & $\begin{array}{l}\text { Gamma isotopic and } \mathrm{Sr}-90 \text { in edible portions } \\
\text { of meat, \% moisture, } \mathrm{H}-3 \text { in free moisture }\end{array}$ \\
\hline $\begin{array}{l}\text { BFVNEAR } \\
\text { Apples, beans, and corn from } \\
\text { locations near the WVDP } \\
\text { BFVCTRL } \\
\text { Control apples, beans, and } \\
\text { corn from locations far from } \\
\text { the WVDP }\end{array}$ & Grab biological & $\begin{array}{l}\text { Each food crop and background, } \\
\text { once every five years at time of } \\
\text { harvest (sampled in current year } \\
\text { and previously sampled in 2007) }\end{array}$ & $\begin{array}{l}\text { Gamma isotopic and } \mathrm{Sr}-90 \text { in edible portions, } \\
\% \text { moisture, } \mathrm{H}-3 \text { in free moisture }\end{array}$ \\
\hline
\end{tabular}


TABLE A-2 (concluded)

2012 Environmental Monitoring Program

\begin{tabular}{|c|c|c|c|}
\hline Sample Location Code & $\begin{array}{l}\text { Sampling Type/ } \\
\text { Medium }\end{array}$ & $\begin{array}{l}\text { Collection Frequency/ } \\
\text { Total Annual Samples }\end{array}$ & Measurements/Analyses \\
\hline \multicolumn{4}{|c|}{ Off-Site Biological } \\
\hline $\begin{array}{l}\text { BFFCATC } \\
\text { Fish from Cattaraugus Creek } \\
\text { downstream of its confluence } \\
\text { with Buttermilk Creek } \\
\text { BFFCATD } \\
\text { Fish from Cattaraugus Creek } \\
\text { downstream of the Springville } \\
\text { Dam } \\
\text { BFFCTRL } \\
\text { Control fish sample from } \\
\text { nearby stream not affected by } \\
\text { WVDP ( } 7 \text { km or more } \\
\text { upstream of site effluent } \\
\text { point); background }\end{array}$ & $\begin{array}{l}\text { Individual collection of } \\
\text { fish }\end{array}$ & $\begin{array}{l}\text { Once every } 5 \text { years; } 10 \text { fish from } \\
\text { each location (sampled in } \\
\text { current year and previously } \\
\text { sampled in 2007) }\end{array}$ & $\begin{array}{l}\text { Gamma isotopic and } \mathrm{Sr}-90 \text { in edible portions, } \\
\% \text { moisture }\end{array}$ \\
\hline \multicolumn{4}{|c|}{ Off-Site Direct Radiation } \\
\hline $\begin{array}{l}\text { DFTLD Series: Off-site } \\
\text { environmental } \\
\text { thermoluminescent } \\
\text { dosimeters (TLDs): \#1 through } \\
\# 16 \text {, at each of } 16 \text { compass } \\
\text { sectors at nearest accessible } \\
\text { perimeter point } \\
\# 20: 1,500 \text { m northwest } \\
\text { (downwind receptor) } \\
\text { \#23: } 29 \text { km south, Great } \\
\text { Valley (background) }\end{array}$ & Integrating TLD & $\begin{array}{l}\text { Semiannually; } 2 \text { per year at each } \\
\text { location }\end{array}$ & Gamma radiation exposure \\
\hline \multicolumn{4}{|c|}{ On-Site Direct Radiation } \\
\hline $\begin{array}{l}\text { DNTLD Series: On-site TLDs } \\
\# 33 \text { : Corner of the SDA } \\
\# 24, \text { \#28: Security fence } \\
\text { around the WVDP } \\
\text { \#32, \#34, \#35, \#36: Drum Cell } \\
\text { road and Drum Cell south } \\
\text { fence } \\
\# 38, \text { \#40: Near operational } \\
\text { areas on-site } \\
\# 43: \text { SDA west perimeter } \\
\text { fence }\end{array}$ & Integrating TLD & $\begin{array}{l}\text { Semiannually; } 2 \text { per year at each } \\
\text { location }\end{array}$ & Gamma radiation exposure \\
\hline
\end{tabular}




\title{
Summary of Monitoring Program Changes in 2012
}

\author{
Description of Changes
}

Changes to the sampling program during 2012 were associated with ELAB analyses, the new ambient air monitoring network, the shutdown of ANCSSTK (01-14 building ventilation exhaust), the addition of two new thermoluminescent dosimeters (TLD), and the five-year sampling of biologicals, soils, and sediments.

On June 30, 2012 the CHBWV environmental laboratory relinquished its NYSDOH certifications which allowed it to perform specific reportable analyses. The samples are now sent to off-site certified laboratories for specific analyses. The ELAB continues to analyze samples for site operations, for screening and for gross alpha, gross beta, and iodine-129 in air.

During the fourth quarter of 2012, 16 off-site ambient air monitoring locations were activated to collect baseline data in preparation for future demonstration of compliance using ambient air measurements in accordance with 40 Code of Federal Regulations (CFR) 61, Subpart H, Section 61.93 (b)(5), pending final EPA approval.

Air sampling location ANCSSTK was shut down on October 24, 2012 in preparation for the demolition of the 01-14 building.

DNTLD32, located on drum cell road and TLD34 located at drum cell south fence were added back to the program in January 2012 to monitor activity from the drum cell.

The environmental monitoring program requires the collection of soils, aquatic sediments, milk, apples, beans, corn, and fish every five years. These parameters were all sampled in 2012; prior to this year they were last sampled in 2007. 
FIGURE A-1

West Valley Demonstration Project Base Map

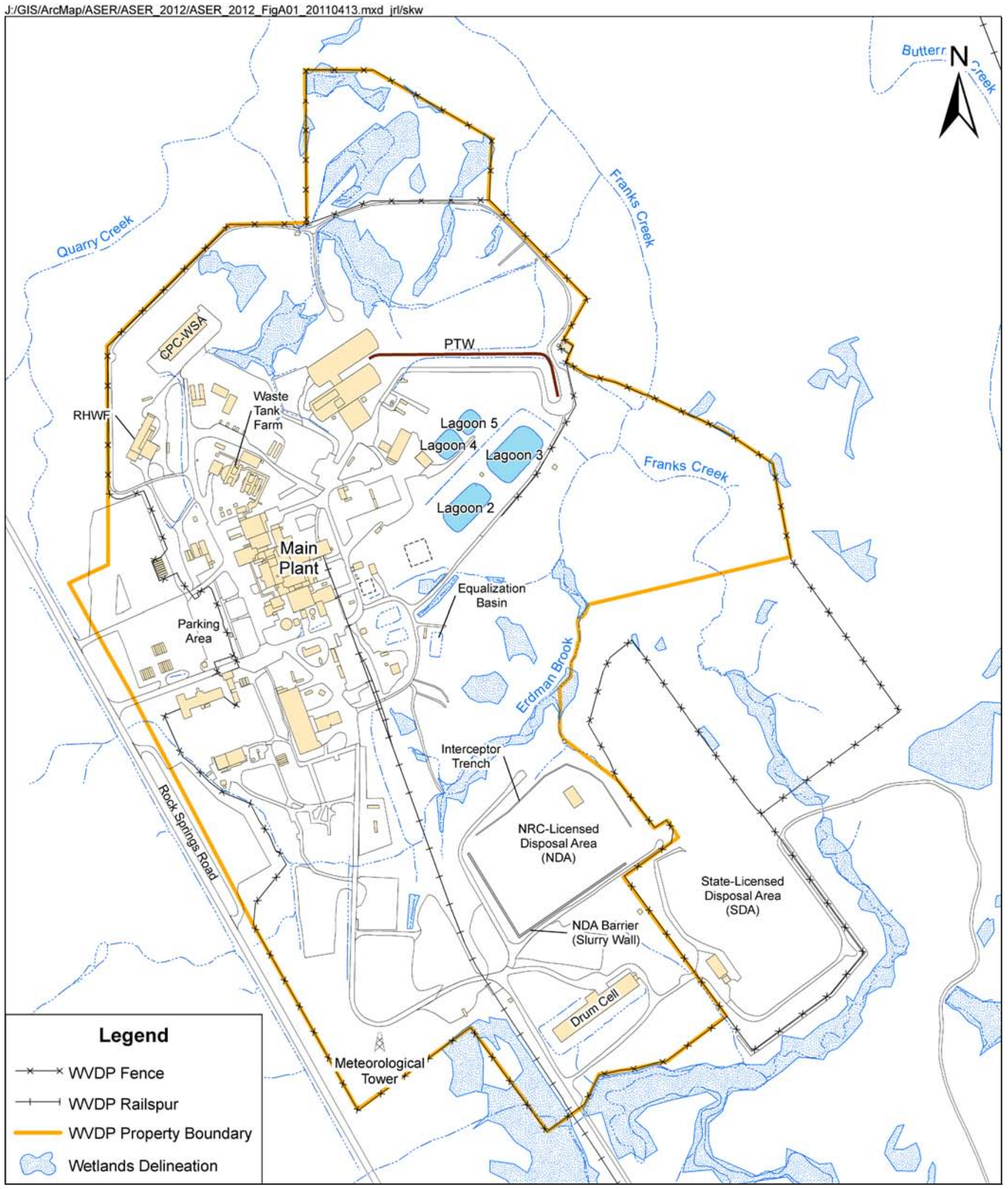


FIGURE A-2

On-Site Surface Water, Drinking Water, and Soil/Sediment Sampling Locations

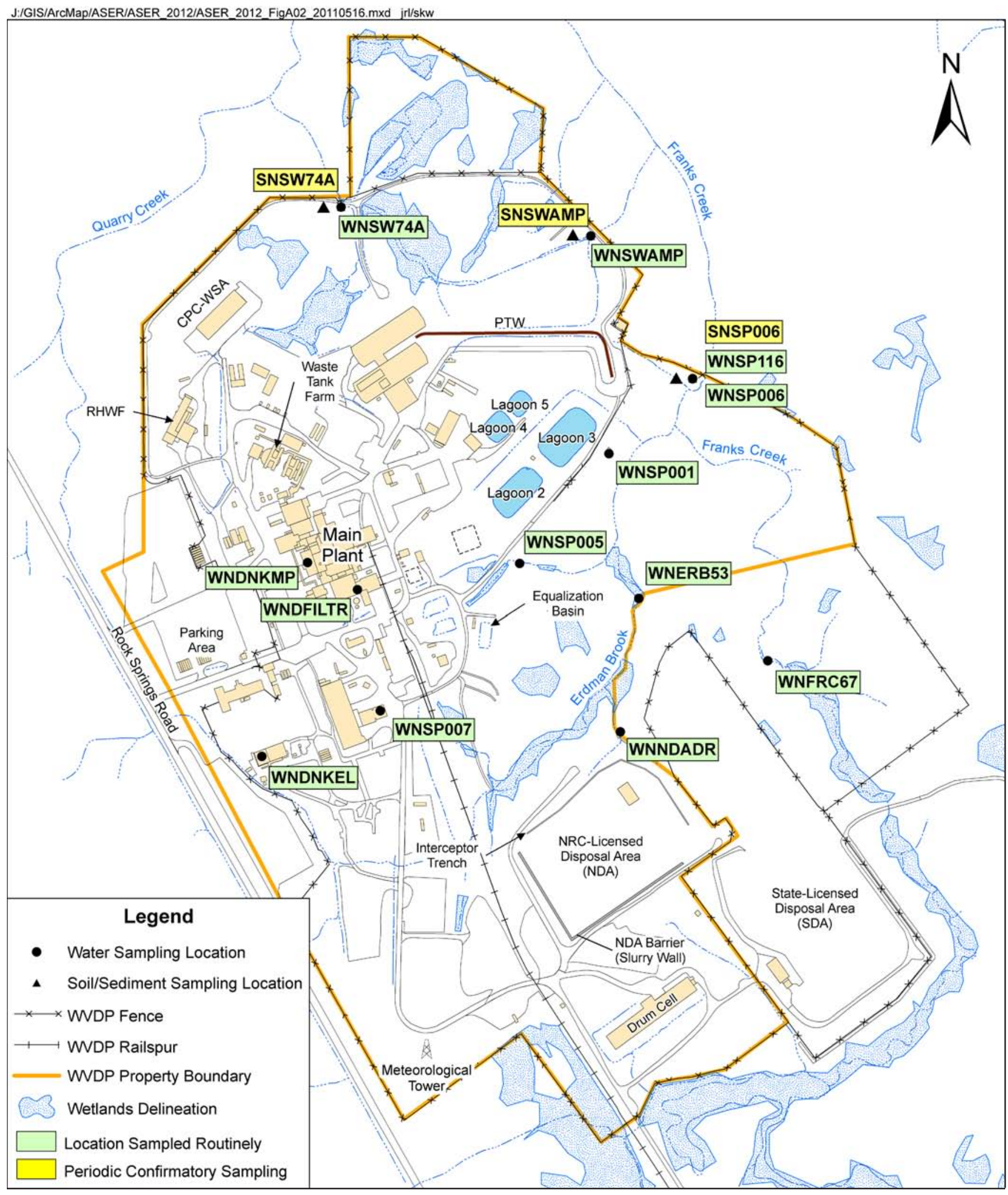


FIGURE A-3

On-Site Storm Water Outfalls

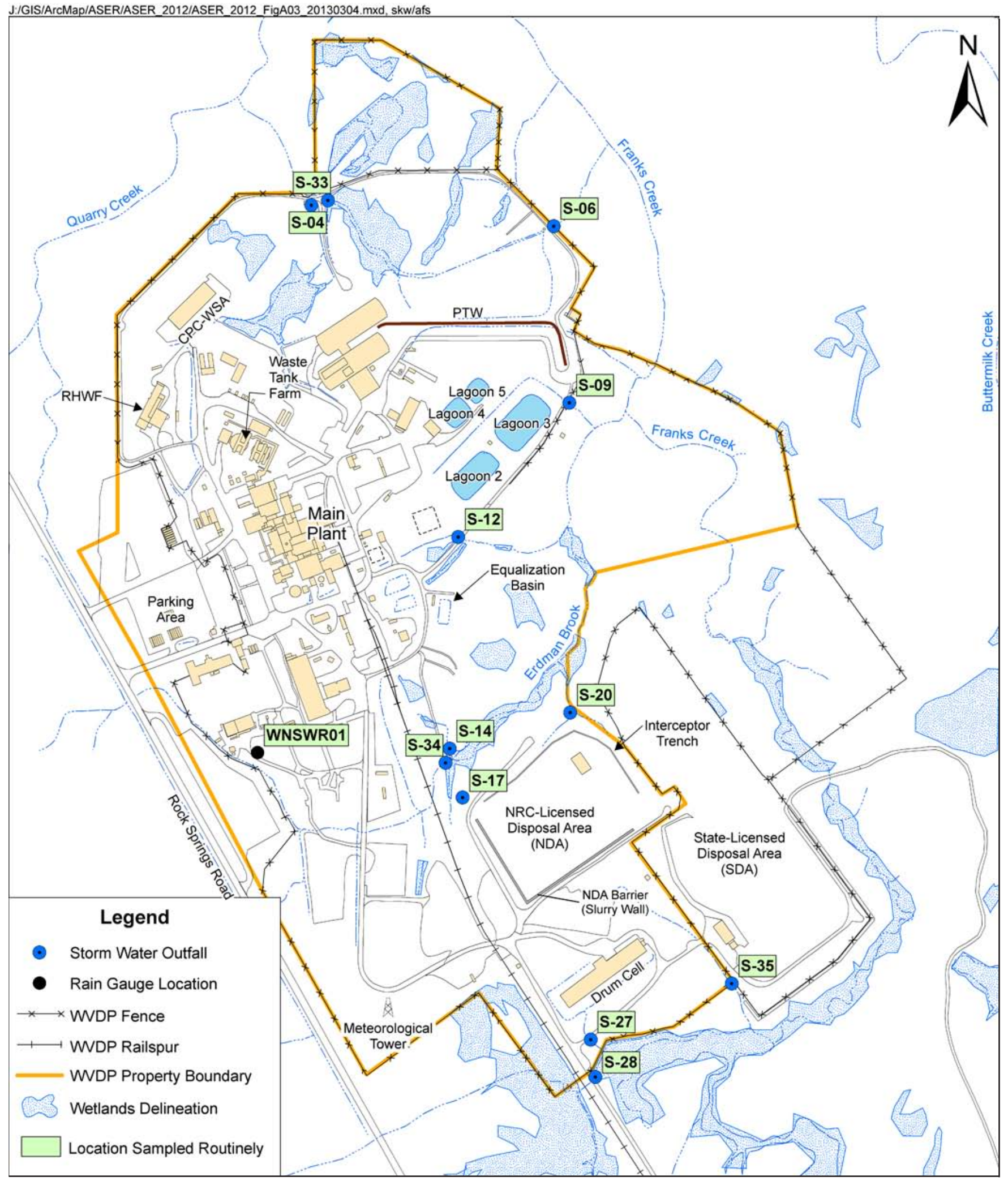


FIGURE A-4

Rail Spur Storm Water Outfalls

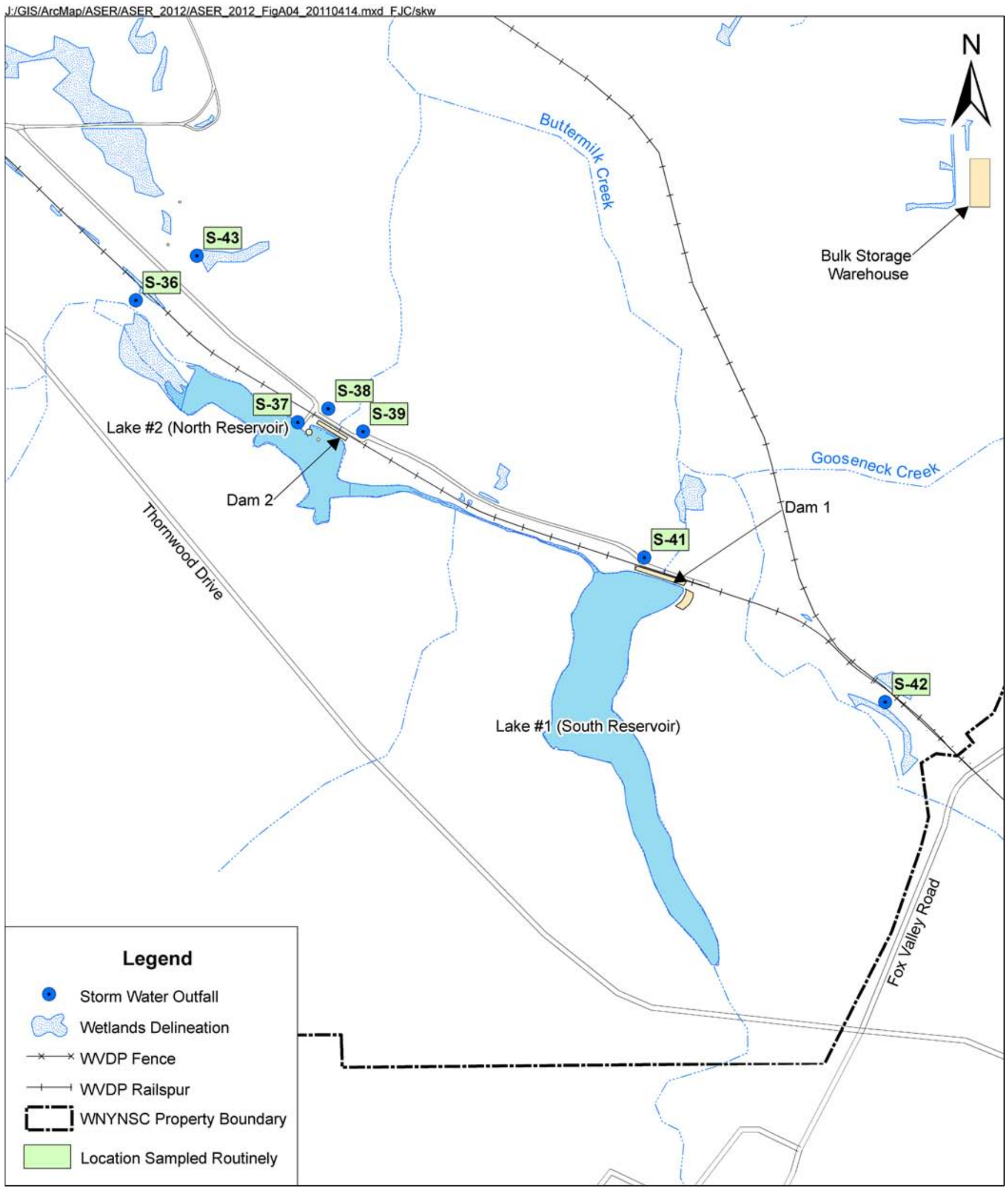


FIGURE A-5

Off-Site Surface Water and Soil/Sediment Sampling Locations

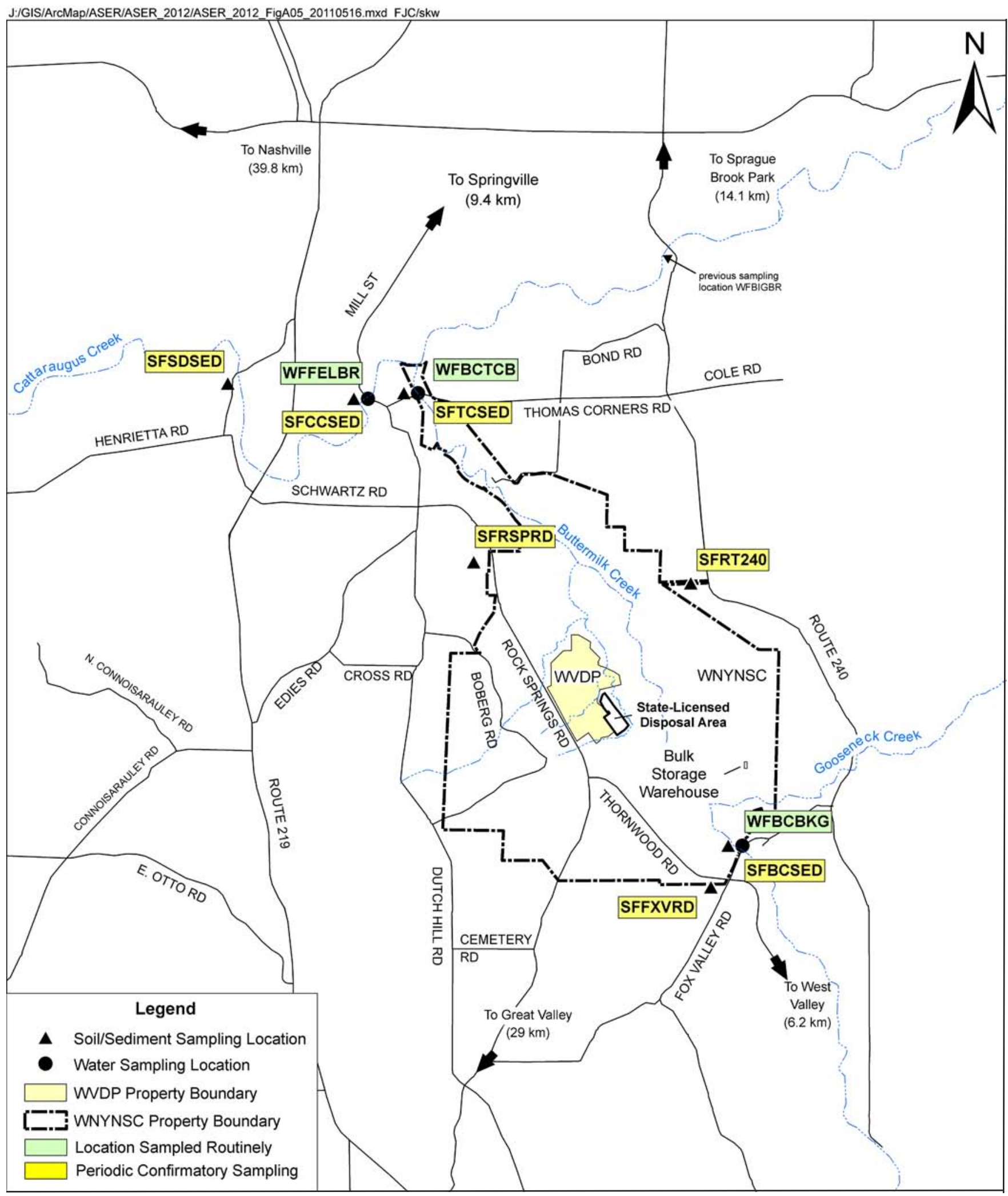


FIGURE A-6

On-Site Air Monitoring and Sampling Locations

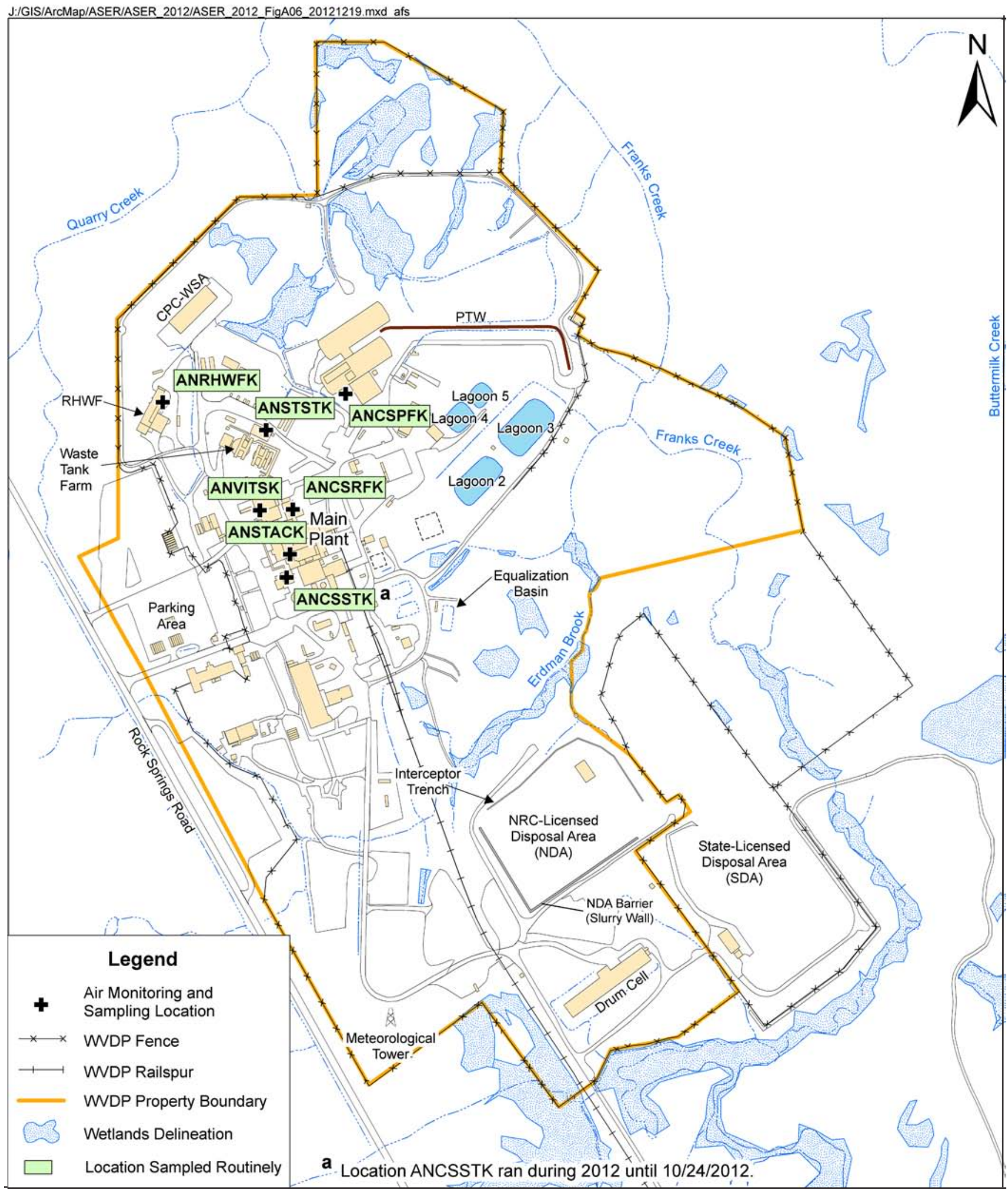


FIGURE A-7

Off-Site Ambient Air Monitoring and Sampling Locations

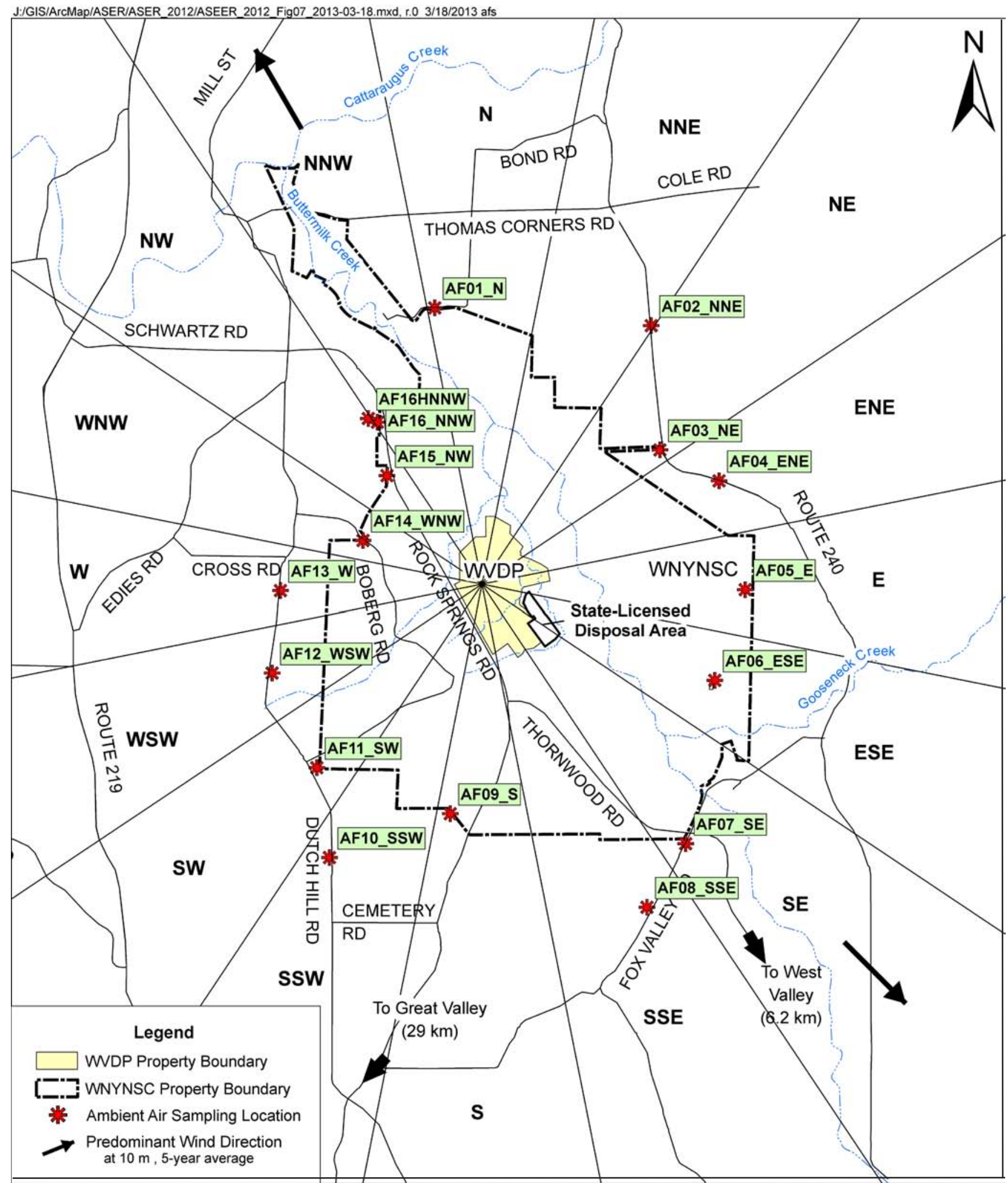


FIGURE A-8

North Plateau Groundwater Monitoring Network

(includes Wells Used for Water-Level Measurements)

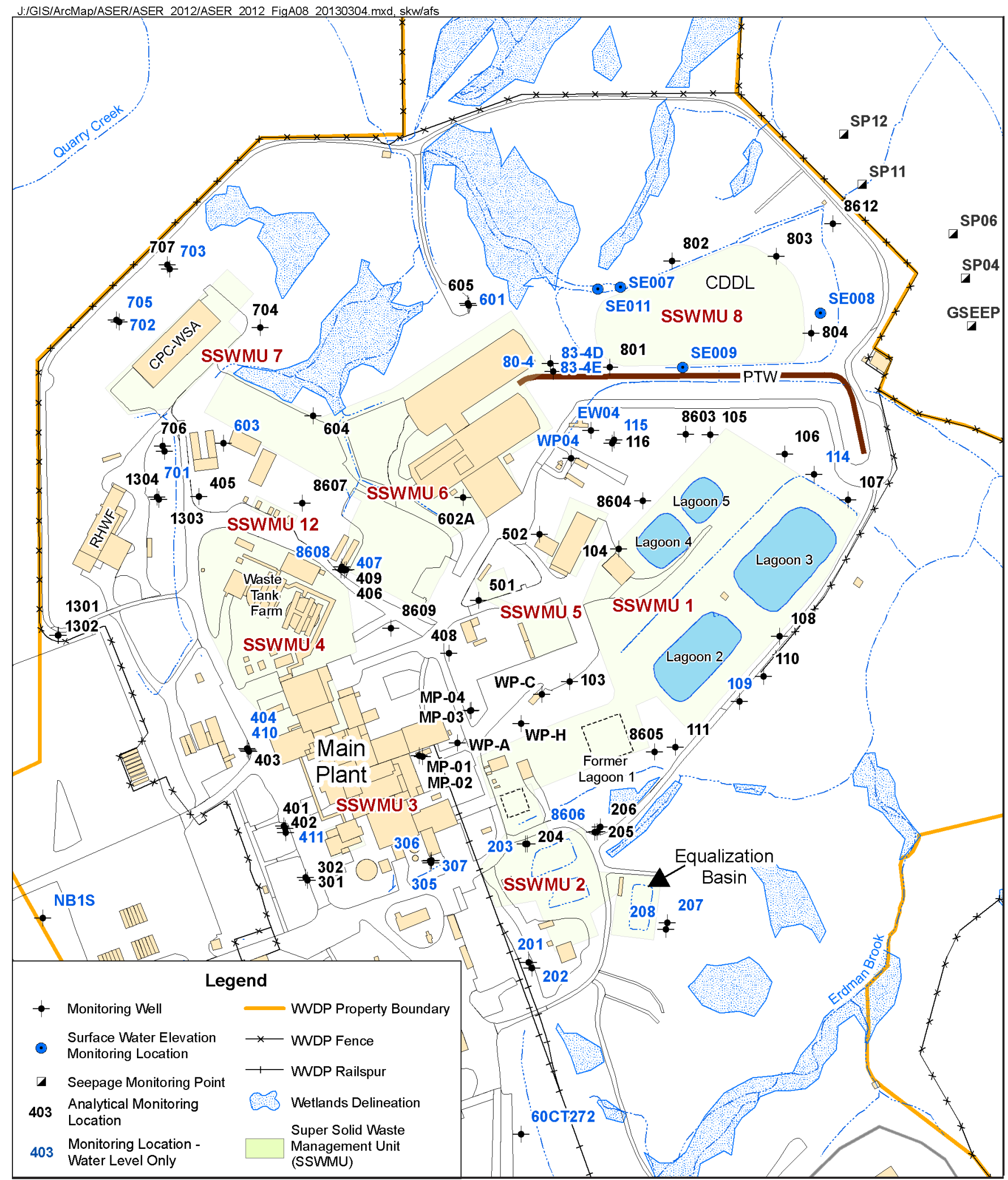


FIGURE A-9

South Plateau Groundwater Monitoring Network

(Includes Wells Used for Water-Level Measurements)

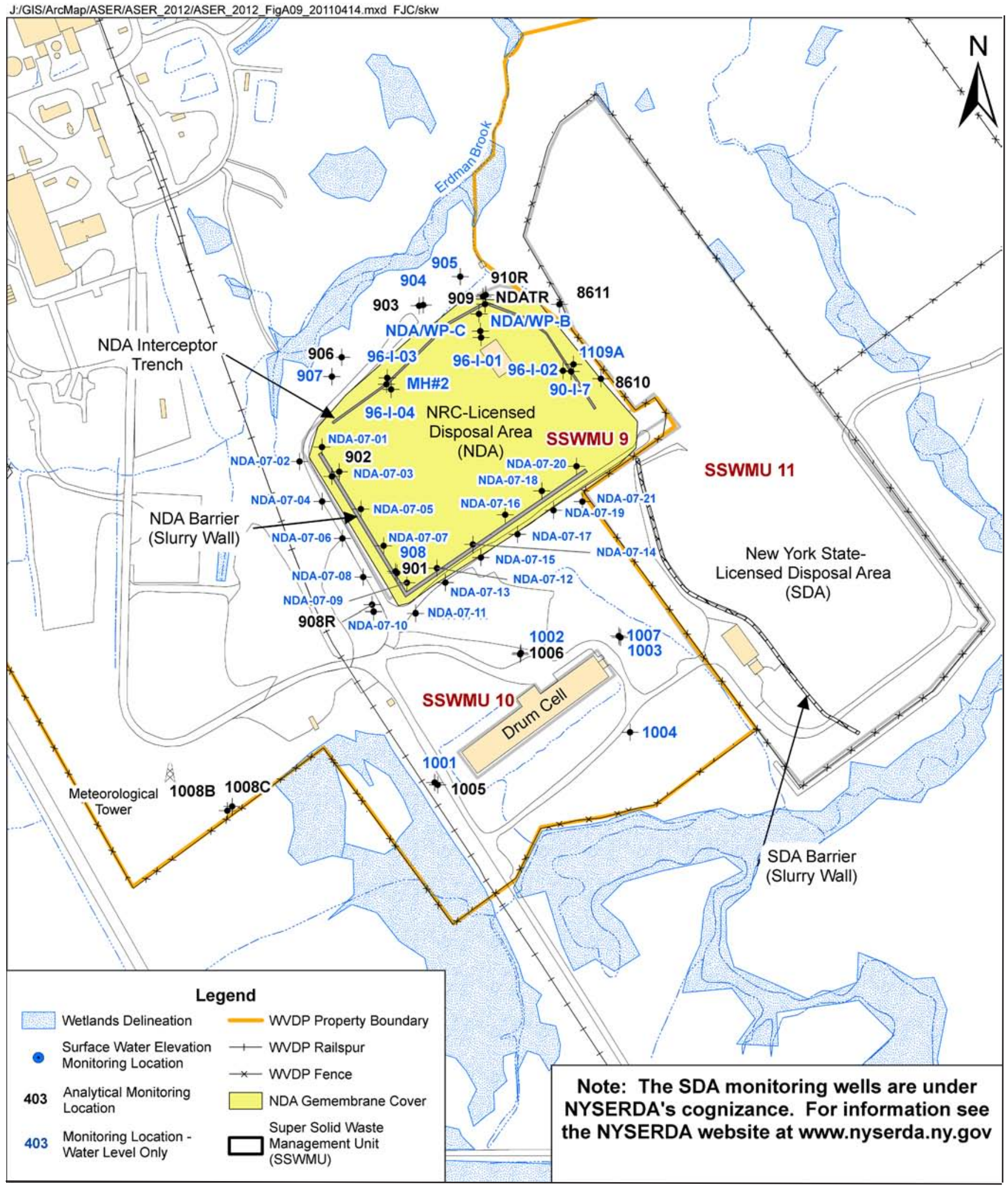


FIGURE A-10

Biological Sampling Locations

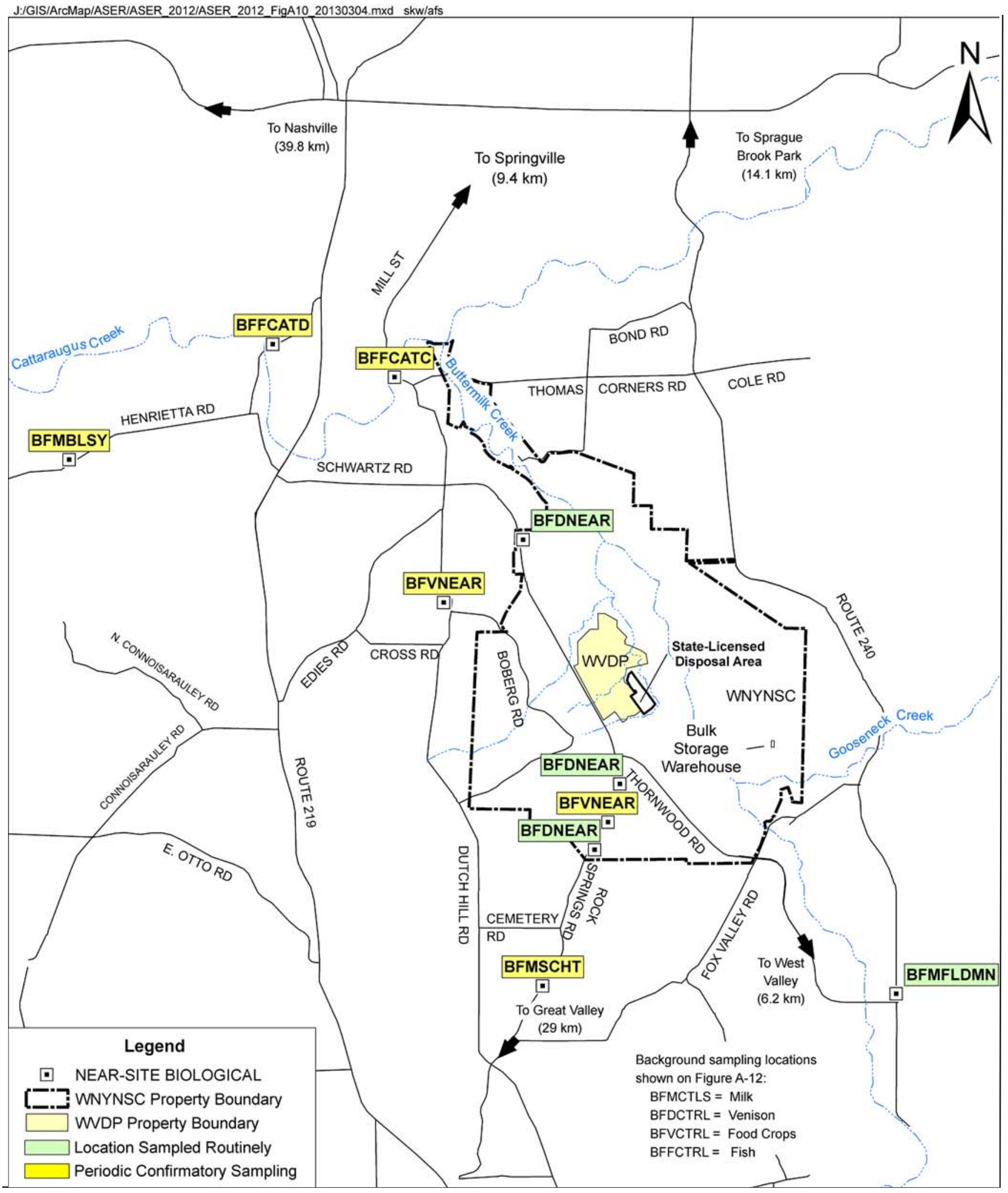


FIGURE A-11

Location of On-Site Thermoluminescent Dosimeters (TLDs)

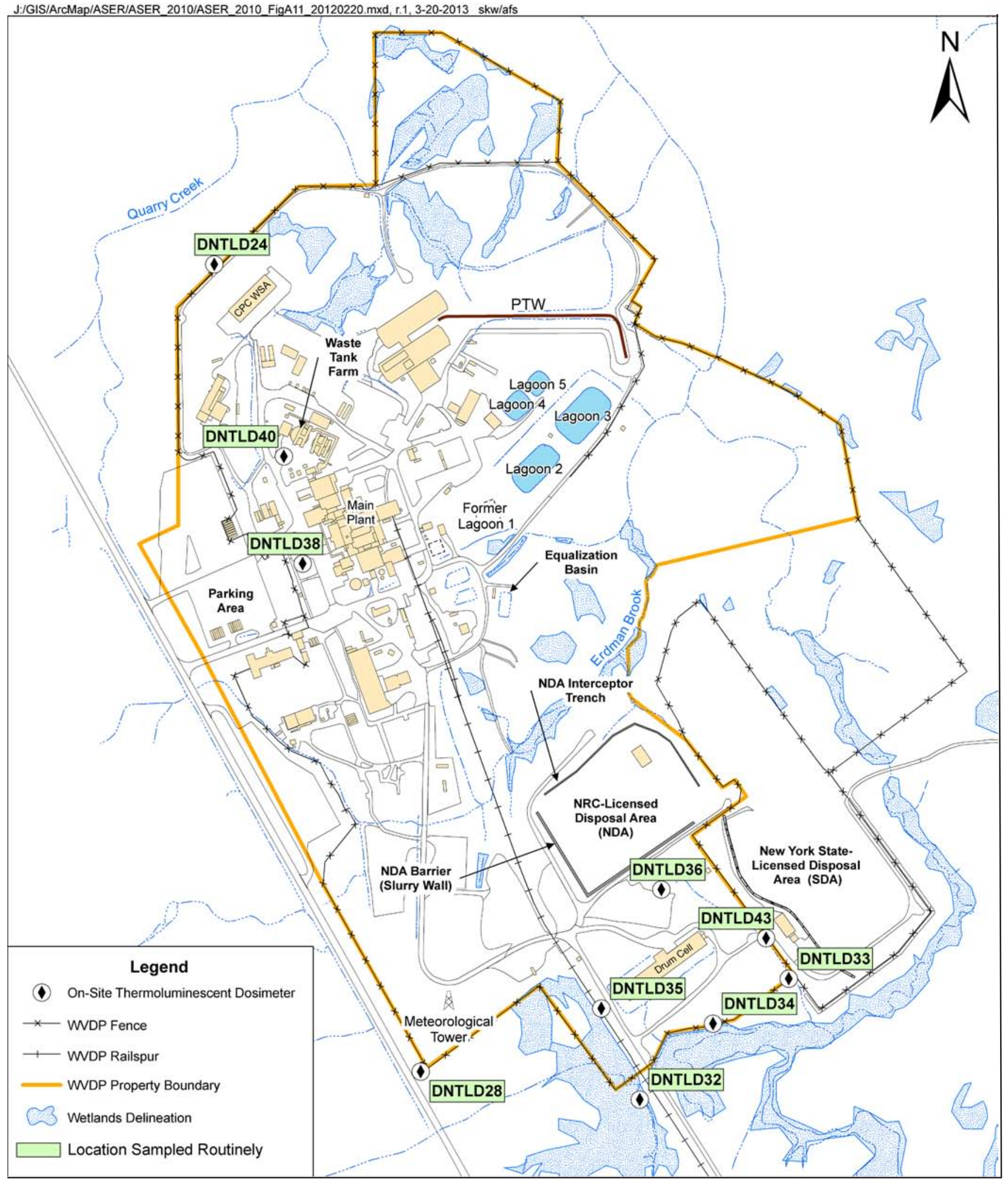


FIGURE A-12

Location of Off-Site Thermoluminescent Dosimeters (TLDs) Within 5 Kilometers of the WVDP

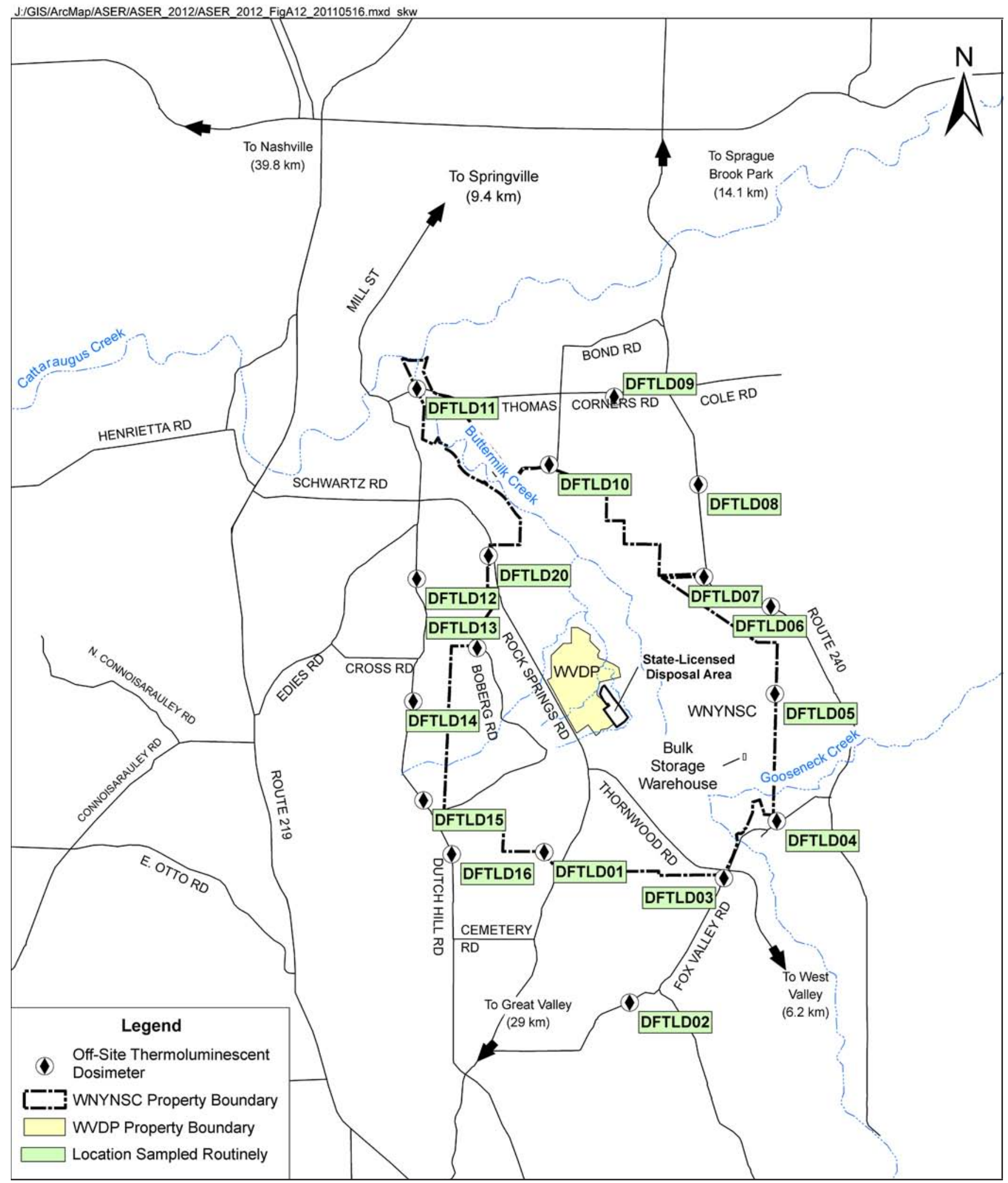


FIGURE A-13

Environmental Sampling Locations More Than 5 Kilometers From the WVDP

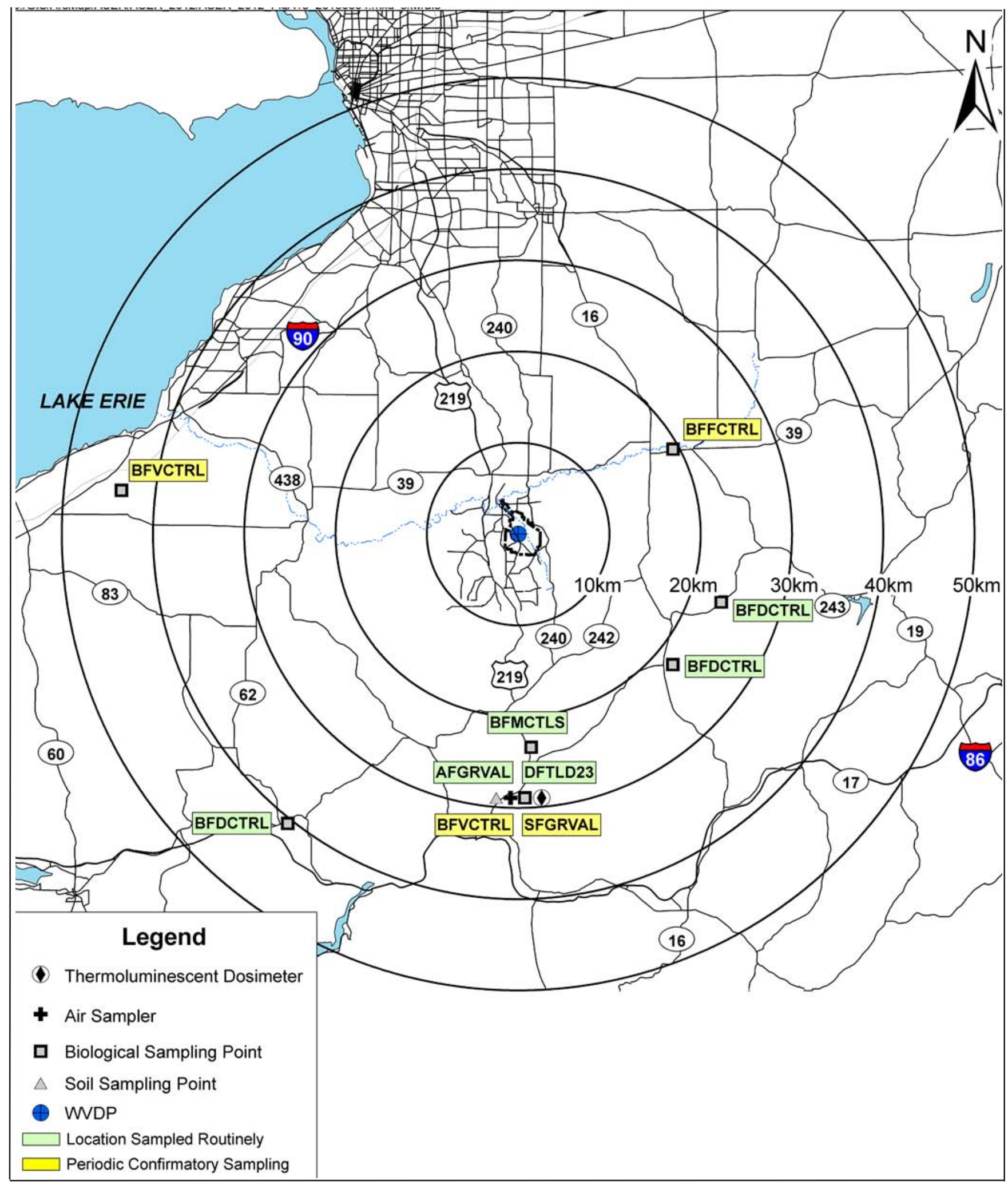


FIGURE A-14

Population by Sector Within 80 Kilometers of the WVDP (2002 Estimate)

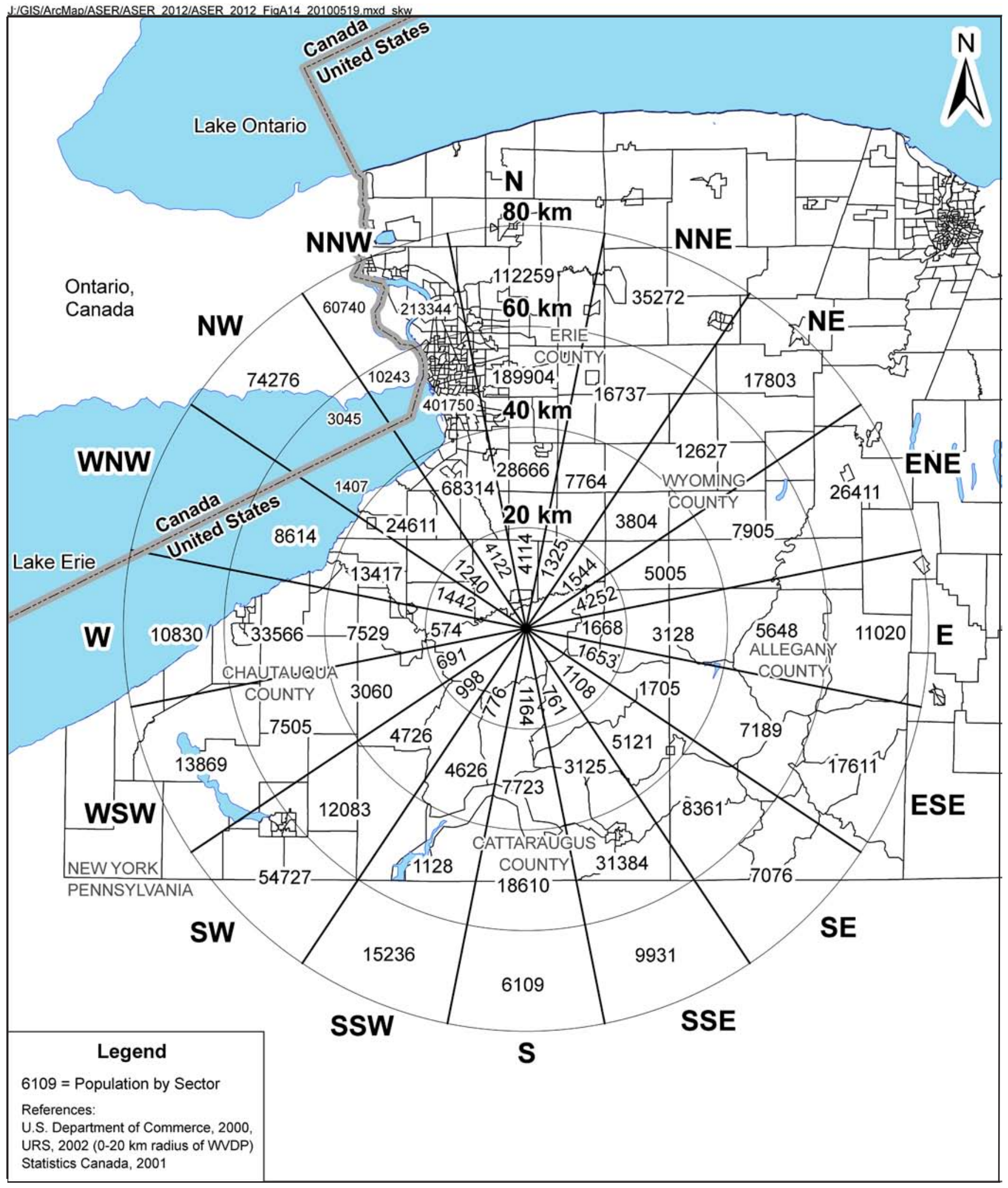




\section{APPENDIX B-1}

Summary of Water Limits, Guidelines, and Standards

TABLE B-1A

West Valley Demonstration Project

State Pollutant Discharge Elimination System (SPDES) Sampling Program

\begin{tabular}{|c|c|c|c|}
\hline Outfall 001 & Parameter & Effluent Limit & Sample Frequency \\
\hline $\begin{array}{l}\text { 001; Process and } \\
\text { Storm Wastewater }\end{array}$ & 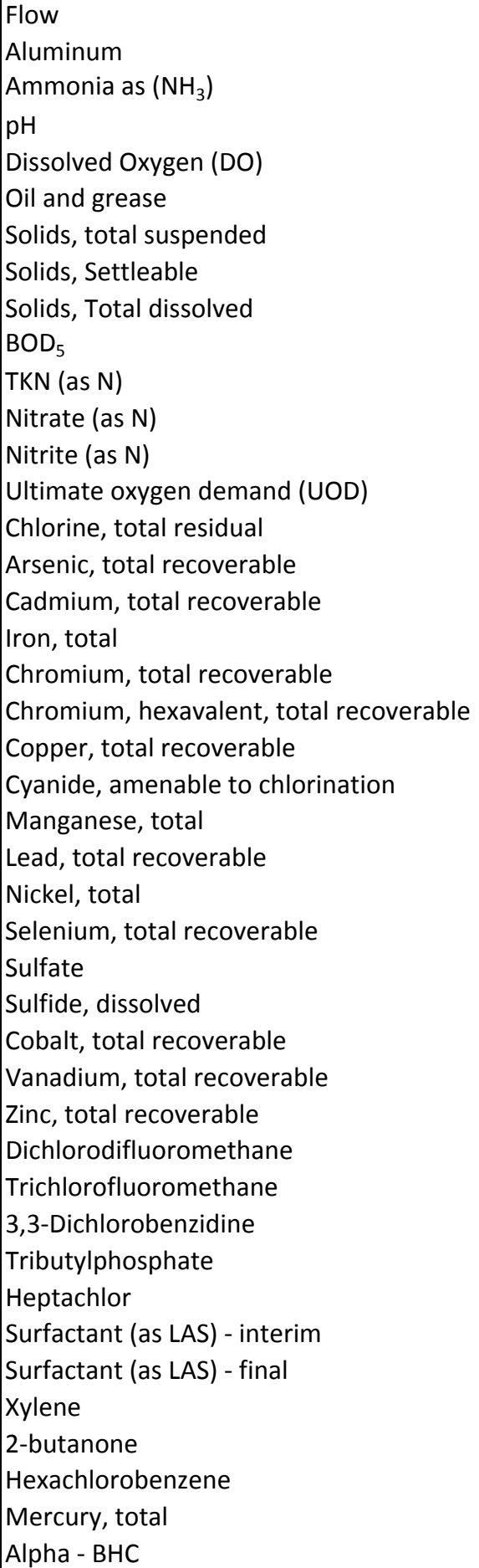 & $\begin{array}{l}\text { Monitor - MGD } \\
4.0 \mathrm{mg} / \mathrm{L} \\
2.1 \mathrm{mg} / \mathrm{L} \\
6.5-8.5 \mathrm{SU} \\
3.0 \mathrm{mg} / \mathrm{L} \text { (minimum) } \\
15.0 \mathrm{mg} / \mathrm{L} \\
45 \mathrm{mg} / \mathrm{L} \\
0.3 \mathrm{ml} / \mathrm{L} \\
\text { Monitor } \\
10.0 \mathrm{mg} / \mathrm{L} \\
\text { Monitor } \\
\text { Monitor } \\
0.1 \mathrm{mg} / \mathrm{L} \\
22.0 \mathrm{mg} / \mathrm{L} \\
0.1 \mathrm{mg} / \mathrm{L} \\
0.15 \mathrm{mg} / \mathrm{L} \\
0.002 \mathrm{mg} / \mathrm{L} \\
\text { Monitor } \\
0.11 \mathrm{mg} / \mathrm{L} \\
0.011 \mathrm{mg} / \mathrm{L} \\
0.014 \mathrm{mg} / \mathrm{L} \\
0.005 \mathrm{mg} / \mathrm{L} \\
2.0 \mathrm{mg} / \mathrm{L} \\
0.006 \mathrm{mg} / \mathrm{L} \\
0.079 \mathrm{mg} / \mathrm{L} \\
0.004 \mathrm{mg} / \mathrm{L} \\
\text { Monitor } \\
0.4 \mathrm{mg} / \mathrm{L} \\
0.005 \mathrm{mg} / \mathrm{L} \\
0.014 \mathrm{mg} / \mathrm{L} \\
0.13 \mathrm{mg} / \mathrm{L} \\
0.01 \mathrm{mg} / \mathrm{L} \\
0.01 \mathrm{mg} / \mathrm{L} \\
0.01 \mathrm{mg} / \mathrm{L} \\
0.1 \mathrm{mg} / \mathrm{L} \\
0.01 \mathrm{Hg} / \mathrm{L} \\
\text { Monitor } \\
0.04 \mathrm{mg} / \mathrm{L} \\
0.05 \mathrm{mg} / \mathrm{L} \\
0.5 \mathrm{mg} / \mathrm{L} \\
0.2 \mu \mathrm{Lg} / \mathrm{L} \\
50 \mathrm{ng} / \mathrm{L} \\
0.01 \mathrm{Hg} / \mathrm{L} \\
\end{array}$ & $\begin{array}{l}\text { Continuous } \\
\text { 1/batch } \\
\text { 2/batch } \\
\text { 1/batch } \\
\text { 2/batch } \\
\text { 1/batch } \\
\text { 2/batch } \\
\text { 2/batch } \\
\text { 2/batch } \\
\text { 2/batch } \\
\text { 2/batch } \\
\text { 1/batch } \\
\text { 1/batch } \\
\text { 2/batch } \\
\text { 1/batch } \\
\text { 1/batch } \\
\text { 1/year } \\
\text { 2/batch } \\
\text { 2/year } \\
\text { 1/year } \\
\text { 2/year } \\
\text { 2/year } \\
\text { 2/year } \\
\text { 1/year } \\
\text { 1/year } \\
\text { 2/year } \\
\text { 1/batch } \\
\text { 1/batch } \\
\text { 1/batch } \\
\text { 1/batch } \\
\text { 1/batch } \\
\text { 2/year } \\
\text { 1/year } \\
\text { 1/year } \\
\text { 1/year } \\
\text { 1/year } \\
\text { 1/year } \\
\text { 1/batch } \\
\text { 1/bar }\end{array}$ \\
\hline
\end{tabular}


TABLE B-1A (continued)

West Valley Demonstration Project

State Pollutant Discharge Elimination System (SPDES) Sampling Program

\begin{tabular}{|c|c|c|c|}
\hline Outfall 001 & Parameter & Action Levels & Sample Frequency \\
\hline \multirow{11}{*}{$\begin{array}{l}\text { 001; Process and } \\
\text { Storm Wastewater }\end{array}$} & Antimony & $1.0 \mathrm{mg} / \mathrm{L}$ & 1/year \\
\hline & Barium & $0.5 \mathrm{mg} / \mathrm{L}$ & 1/year \\
\hline & Boron & $2.0 \mathrm{mg} / \mathrm{L}$ & 2/year \\
\hline & Bromide & $5.0 \mathrm{mg} / \mathrm{L}$ & 2/year \\
\hline & Chloroform & $0.3 \mathrm{mg} / \mathrm{L}$ & 1/year \\
\hline & Titanium & $0.65 \mathrm{mg} / \mathrm{L}$ & 2/year \\
\hline & \multicolumn{3}{|c|}{ Whole Effluent Toxicity (WET) Testing } \\
\hline & WET - Acute Invertebrate & $0.3 \mathrm{TUa}$ & 4/year \\
\hline & WET - Acute Vertebrate & 0.3 TUa & 4/year \\
\hline & WET - Chronic Invertebrate & 1.0 TUc & 4/year \\
\hline & WET - Chronic Vertebrate & 1.0 TUc & 4/year \\
\hline
\end{tabular}

\begin{tabular}{|c|c|c|c|}
\hline Outfall 007 & Parameter & Effluent Limit & Sample Frequency \\
\hline \multirow{22}{*}{$\begin{array}{l}\text { 007; Sanitary and } \\
\text { Utility Wastewater }\end{array}$} & $\mathrm{pH}$ & $6.5-8.5 \mathrm{SU}$ & 2/month \\
\hline & Dissolved oxygen (DO) & 3.0 mg/L (minimum) & 2/month \\
\hline & Flow & Monitor - MGD & $1 /$ month \\
\hline & Oil and Grease & $15.0 \mathrm{mg} / \mathrm{L}$ & 2/month \\
\hline & Solids, total suspended & $45 \mathrm{mg} / \mathrm{L}$ & $2 /$ month \\
\hline & Solids, settleable & $0.3 \mathrm{ml} / \mathrm{L}$ & $2 /$ month \\
\hline & Solids, total dissolved & Monitor & 2/month \\
\hline & $\mathrm{BOD}_{5}$ & $10.0 \mathrm{mg} / \mathrm{L}$ & $2 /$ month \\
\hline & Ammonia (as $\mathrm{NH}_{3}$ ) & $2.1 \mathrm{mg} / \mathrm{L}$ & $2 /$ month \\
\hline & TKN (as N) & Monitor & $1 /$ month \\
\hline & Nitrite (as N) & $0.1 \mathrm{mg} / \mathrm{L}$ & $1 /$ month \\
\hline & Ultimate oxygen demand (UOD) & $22.0 \mathrm{mg} / \mathrm{L}$ & $1 /$ month \\
\hline & Iron, total & Monitor & $2 /$ month \\
\hline & Chlorine, total residual & $0.1 \mathrm{mg} / \mathrm{L}$ & $1 /$ month \\
\hline & Mercury, total - interim limit & $200 \mathrm{ng} / \mathrm{L}$ & $1 /$ month \\
\hline & Mercury, total - final limit & $50 \mathrm{ng} / \mathrm{L}$ & $1 /$ month \\
\hline & Chloroform & $0.20 \mathrm{mg} / \mathrm{L}$ & 1/year \\
\hline & \multicolumn{3}{|c|}{ Whole Effluent Toxicity (WET) Testing } \\
\hline & WET - Acute Invertebrate & 0.3 TUa & 4/year \\
\hline & WET - Acute Vertebrate & 0.3 TUa & 4/year \\
\hline & WET - Chronic Invertebrate & 1.0 Tuc & 4/year \\
\hline & WET - Chronic Vertebrate & 1.0 TUc & 4/year \\
\hline
\end{tabular}

\begin{tabular}{|c|l|l|c|}
\hline Outfall 01B & \multicolumn{1}{|c|}{ Parameter } & \multicolumn{1}{|c|}{ Action Levels } & Sample Frequency \\
\hline 01B; Mercury Pre- & Flow & Monitor - MGD & Continuous \\
Treatment Process & Mercury, total & Monitor - 50 ng/L & $2 /$ batch \\
\hline
\end{tabular}

\begin{tabular}{|c|l|l|c|}
\hline Sum of Outfalls & \multicolumn{1}{|c|}{ Parameter } & Action Levels & Sample Frequency \\
\hline $\mathbf{0 0 1}$ and $\mathbf{0 0 7}$ & Iron, total & Monitor $-1.0 \mathrm{mg} / \mathrm{L}$ & $1 / \mathrm{month}$ \\
\hline
\end{tabular}


TABLE B-1A (concluded)

West Valley Demonstration Project

State Pollutant Discharge Elimination System (SPDES) Sampling Program

\begin{tabular}{|c|c|c|c|}
\hline Monitoring Point & Parameter & Action Levels & Sample Frequency \\
\hline 116 & Solids, total dissolved & Monitor - $500 \mathrm{mg} / \mathrm{L}$ & 2/discharge event \\
\hline Monitoring Point & Parameter & Compliance Limit & Sample Frequency \\
\hline $\begin{array}{l}\text { Stormwater } \\
\text { Outfalls (AII) }\end{array}$ & Oil \& grease & $<15 \mathrm{mg} / \mathrm{L}$ & 1/event \\
\hline Outfall S43 & Lead, total recoverable & $0.006 \mathrm{mg} / \mathrm{L}$ & 1/event \\
\hline
\end{tabular}


TABLE B-1B

New York State Water Quality Standards and Guidelines ${ }^{\mathrm{a}}$

\begin{tabular}{|c|c|c|c|c|c|c|}
\hline Parameter & Units & Class A & Class B & Class C & Class D & Class GA \\
\hline Gross Alpha $^{b}$ & $\mathrm{pCi} / \mathrm{L}(\mu \mathrm{Ci} / \mathrm{mL})$ & 15 (1.5E-08) & -- & -- & -- & 15 (1.5E-08) \\
\hline Gross Beta $^{c}$ & $\mathrm{pCi} / \mathrm{L}(\mu \mathrm{Ci} / \mathrm{mL})$ & $1,000(1 \mathrm{E}-06)$ & -- & $\begin{array}{ll}- \\
--\end{array}$ & $\begin{array}{ll}- \\
--\end{array}$ & $1,000(1 \mathrm{E}-06)$ \\
\hline Tritium (H-3) & $\mathrm{pCi} / \mathrm{L}(\mu \mathrm{Ci} / \mathrm{mL})$ & 20,000 (2E-05) & -- & -- & -- & -- \\
\hline Strontium-90 & $\mathrm{pCi} / \mathrm{L}(\mu \mathrm{Ci} / \mathrm{mL})$ & 8 (8E-09) & -- & -- & -- & -- \\
\hline Alpha BHC & $\mathrm{mg} / \mathrm{L}$ & 0.000002 & 0.000002 & 0.000002 & 0.000002 & 0.00001 \\
\hline Aluminum, Dissolved & $\mathrm{mg} / \mathrm{L}$ & 0.10 & 0.10 & 0.10 & -- & -- \\
\hline Aluminum, Total & $\mathrm{mg} / \mathrm{L}$ & -- & -- & -- & -- & -- \\
\hline Ammonia, Total as $\mathbf{N}$ & $\mathrm{mg} / \mathrm{L}$ & $0.09-2.1$ & $0.09-2.1$ & $0.09-2.1$ & $0.67-29$ & 2.0 \\
\hline Antimony, Total & $\mathrm{mg} / \mathrm{L}$ & 0.003 & -- & -- & -- & 0.003 \\
\hline Arsenic, Dissolved & $\mathrm{mg} / \mathrm{L}$ & 0.050 & 0.150 & 0.150 & 0.340 & -- \\
\hline Arsenic, Total & $\mathrm{mg} / \mathrm{L}$ & 0.050 & -- & -- & -- & 0.025 \\
\hline Barium, Total & $\mathrm{mg} / \mathrm{L}$ & 1.00 & -- & -- & -- & 1.00 \\
\hline Beryllium, Total & $\mathrm{mg} / \mathrm{L}$ & 0.003 & $\bar{d}$ & $d$ & -- & 0.003 \\
\hline Boron, Total & $\mathrm{mg} / \mathrm{L}$ & 10.0 & 10.0 & 10.0 & -- & 1.00 \\
\hline Bromide & $\mathrm{mg} / \mathrm{L}$ & 2.00 & -- & -- & -- & 2.00 \\
\hline Cadmium, Dissolved $^{e}$ & $\mathrm{mg} / \mathrm{L}$ & -- & -- & -- & -- & -- \\
\hline Cadmium, Total & $\mathrm{mg} / \mathrm{L}$ & 0.005 & -- & -- & -- & 0.005 \\
\hline Calcium, Total & $\mathrm{mg} / \mathrm{L}$ & -- & -- & -- & -- & -- \\
\hline Chloride & $\mathrm{mg} / \mathrm{L}$ & 250 & -- & -- & -- & 250 \\
\hline Chromium, Dissolved $^{e}$ & $\mathrm{mg} / \mathrm{L}$ & -- & -- & -- & -- & -- \\
\hline Chromium, Total & $\mathrm{mg} / \mathrm{L}$ & 0.05 & -- & -- & -- & 0.05 \\
\hline Cobalt, Totalf & $\mathrm{mg} / \mathrm{L}$ & 0.005 & 0.005 & 0.005 & 0.110 & -- \\
\hline Conductivity & $\mu \mathrm{mhos} / \mathrm{cm} @ 25^{\circ} \mathrm{C}$ & -- & -- & -- & -- & -- \\
\hline Copper, Dissolved $^{e}$ & $\mathrm{mg} / \mathrm{L}$ & -- & -- & -- & -- & -- \\
\hline Copper, Total & $\mathrm{mg} / \mathrm{L}$ & 0.20 & -- & -- & -- & 0.20 \\
\hline Cyanide & $\mathrm{mg} / \mathrm{L}$ & 0.0052 & 0.0052 & 0.0052 & 0.22 & 0.200 \\
\hline Dissolved Oxygen (minimum) & $\mathrm{mg} / \mathrm{L}$ & 4.0 & 4.0 & 4.0 & 3.0 & -- \\
\hline Fluoride $^{e}$ & $\mathrm{mg} / \mathrm{L}$ & -- & -- & -- & -- & 1.5 \\
\hline Hardness & $\mathrm{mg} / \mathrm{L}$ & -- & -- & -- & -- & -- \\
\hline Iron and Manganese (sum) & $\mathrm{mg} / \mathrm{L}$ & -- & -- & -- & -- & 0.500 \\
\hline Iron, Total & $\mathrm{mg} / \mathrm{L}$ & 0.30 & 0.30 & 0.30 & 0.30 & 0.30 \\
\hline
\end{tabular}

-- No applicable guideline or reference standard available.

Note: All water quality and metals standards are presented in $\mathrm{mg} / \mathrm{L}(\mathrm{ppm})$ to provide consistency in comparisons.

a Source: 6 NYCRR Part 702 - 704; The most stringent applicable pathway (e.g.,wildlife, aquatic, human health)

values are reported.

${ }^{\mathrm{b}}$ Gross alpha standard includes radium-226 but excludes radon and uranium, however WVDP results include these isotopes.

${ }^{c}$ Gross beta standard excludes strontium-90 and alpha emitters, however WVDP results include these isotopes.

d Beryllium standard for classes "B" and "C" are based on stream hardness values.

${ }^{\mathrm{e}}$ Standards for these constituents vary according to stream location hardness values.

${ }^{f}$ Standards for cobalt, thallium, and vanadium are applicable to the acid soluable fraction.

${ }^{\mathrm{g}}$ Applies to the sum of those organic substances which have individual human health water source standards listed at $0.100 \mathrm{mg} / \mathrm{L}$ or less in 6 NYCRR Part 703.5.

${ }^{\mathrm{h}} \mathrm{pH}$ shall not be lower than 6.5 or the $\mathrm{pH}$ of natural groundwater, whichever is lower, nor shall $\mathrm{pH}$ be greater than 8.5 or the $\mathrm{pH}$ of the natural groundwater, whichever is greater. 
TABLE B-1B (concluded)

New York State Water Quality Standards and Guidelines ${ }^{a}$

\begin{tabular}{|c|c|c|c|c|c|c|}
\hline Parameter & Units & Class A & Class B & Class C & Class D & Class GA \\
\hline Lead, Dissolved $^{e}$ & $\mathrm{mg} / \mathrm{L}$ & -- & -- & -- & -- & -- \\
\hline Lead, Total & $\mathrm{mg} / \mathrm{L}$ & 0.050 & -- & -- & -- & 0.025 \\
\hline Magnesium, Total & $\mathrm{mg} / \mathrm{L}$ & 35.0 & - & -- & - & 35.0 \\
\hline Manganese, Total & $\mathrm{mg} / \mathrm{L}$ & 0.30 & -- & -- & -- & 0.30 \\
\hline Mercury, Dissolved & $\mathrm{mg} / \mathrm{L}$ & 0.0000007 & 0.0000007 & 0.0000007 & 0.0000007 & -- \\
\hline Mercury, Total & $\mathrm{mg} / \mathrm{L}$ & 0.0007 & -- & -- & -- & 0.0007 \\
\hline Nickel, Dissolved $^{e}$ & $\mathrm{mg} / \mathrm{L}$ & -- & -- & -- & -- & -- \\
\hline Nickel, Total & $\mathrm{mg} / \mathrm{L}$ & 0.10 & -- & -- & -- & 0.10 \\
\hline Nitrate-N & $\mathrm{mg} / \mathrm{L}$ & 10.0 & -- & -- & -- & 10.0 \\
\hline Nitrate + Nitrite & $\mathrm{mg} / \mathrm{L}$ & 10.0 & 10.0 & 10.0 & 10.0 & 10.0 \\
\hline Nitrite-N & $\mathrm{mg} / \mathrm{L}$ & 0.10 & 0.10 & 0.10 & -- & 1.00 \\
\hline NPOC $^{g}$ & $\mathrm{mg} / \mathrm{L}$ & 0.10 & -- & -- & - & - \\
\hline Oil \& Grease & $\mathrm{mg} / \mathrm{L}$ & -- & -- & -- & -- & -- \\
\hline pH & SU & $6.5-8.5^{h}$ & $6.5-8.5^{h}$ & $6.5-8.5^{h}$ & $6.0-9.5$ & $6.5-8.5^{h}$ \\
\hline Potassium, Total & $\mathrm{mg} / \mathrm{L}$ & -- & -- & -- & - & -- \\
\hline Selenium, Dissolved & $\mathrm{mg} / \mathrm{L}$ & 0.0046 & 0.0046 & 0.0046 & -- & -- \\
\hline Selenium, Total & $\mathrm{mg} / \mathrm{L}$ & 0.01 & -- & -- & -- & 0.01 \\
\hline Silver, Total & $\mathrm{mg} / \mathrm{L}$ & 0.05 & -- & -- & -- & 0.05 \\
\hline Sodium, Total & $\mathrm{mg} / \mathrm{L}$ & -- & -- & -- & -- & 20.0 \\
\hline Solids, Total Dissolved & $\mathrm{mg} / \mathrm{L}$ & 500 & 500 & 500 & -- & 500 \\
\hline Solids, Total Suspended & $\mathrm{mg} / \mathrm{L}$ & - & -- & -- & - & -- \\
\hline Sulfate & $\mathrm{mg} / \mathrm{L}$ & 250 & -- & -- & -- & 250 \\
\hline Sulfide (undissociated form) & $\mathrm{mg} / \mathrm{L}$ & 0.002 & 0.002 & 0.002 & -- & 0.050 (as HS) \\
\hline Surfactants (as LAS) & $\mathrm{mg} / \mathrm{L}$ & 0.04 & 0.04 & 0.04 & - & -- \\
\hline 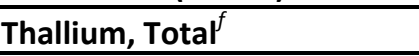 & $\mathrm{mg} / \mathrm{L}$ & 0.0005 & 0.008 & 0.008 & 0.020 & 0.0005 \\
\hline Titanium, Total & $\mathrm{mg} / \mathrm{L}$ & -- & -- & -- & -- & -- \\
\hline TOX (total organic halides) ${ }^{g}$ & $\mathrm{mg} / \mathrm{L}$ & 0.10 & -- & - & - & -- \\
\hline Vanadium, Totalf & $\mathrm{mg} / \mathrm{L}$ & 0.014 & 0.014 & 0.014 & 0.190 & -- \\
\hline Zinc, Dissolved $^{e}$ & $\mathrm{mg} / \mathrm{L}$ & -- & -- & -- & -- & -- \\
\hline Zinc, Total & $\mathrm{mg} / \mathrm{L}$ & 2.00 & -- & -- & -- & 2.00 \\
\hline
\end{tabular}

-- No applicable guideline or reference standard available.

Note: All water quality and metals standards are presented in $\mathrm{mg} / \mathrm{L}(\mathrm{ppm})$ to provide consistency in comparisons.

a Source: 6 NYCRR Part 702 - 704; The most stringent applicable pathway (e.g.,wildlife, aquatic, human health) values are reported.

${ }^{\mathrm{b}}$ Gross alpha standard includes radium-226 but excludes radon and uranium, however WVDP results include these isotopes.

c Gross beta standard excludes strontium-90 and alpha emitters, however WVDP results include these isotopes.

'Beryllium standard for classes "B" and "C" are based on stream hardness values.

${ }^{\mathrm{e}}$ Standards for these constituents vary according to stream location hardness values.

${ }^{f}$ Standards for cobalt, thallium, and vanadium are applicable to the acid soluable fraction.

${ }^{\mathrm{g}}$ Applies to the sum of those organic substances which have individual human health water source standards listed at $0.100 \mathrm{mg} / \mathrm{L}$ or less in 6 NYCRR Part 703.5 .

${ }^{\mathrm{h}} \mathrm{pH}$ shall not be lower than 6.5 or the $\mathrm{pH}$ of natural groundwater, whichever is lower, nor shall $\mathrm{pH}$ be greater than 8.5 or the $\mathrm{pH}$ of the natural groundwater, whichever is greater. 
TABLE B-1C

New York State Department of Health/U.S. EPA

Potable Water MCLs, MCLGs and Raw Water Standards

\begin{tabular}{|c|c|c|c|c|}
\hline Parameter & Units & $\begin{array}{l}\text { NYSDOH or } \\
\text { EPA MCL }^{a}\end{array}$ & EPA MCLG ${ }^{b}$ & $\begin{array}{c}\text { NYSDOH Raw } \\
\text { Water Standards }^{c}\end{array}$ \\
\hline Gross Alpha & $\mathrm{pCi} / \mathrm{L}(\mu \mathrm{Ci} / \mathrm{mL})$ & $15(1.5 \mathrm{E}-08)^{d}$ & 0 & -- \\
\hline Gross Beta & $\mathrm{pCi} / \mathrm{L}(\mu \mathrm{Ci} / \mathrm{mL})$ & $50(5 \mathrm{E}-08)^{e}$ & 0 & $1,000(1 \mathrm{E}-06)$ \\
\hline Tritium (H-3) & $\mathrm{pCi} / \mathrm{L}(\mu \mathrm{Ci} / \mathrm{mL})$ & $20,000(2 \mathrm{E}-05)$ & -- & -- \\
\hline Strontium-90 & $\mathrm{pCi} / \mathrm{L}(\mu \mathrm{Ci} / \mathrm{mL})$ & $8(8 \mathrm{E}-09)$ & -- & $10(1 \mathrm{E}-08)$ \\
\hline Antimony, Total & $\mathrm{mg} / \mathrm{L}$ & 0.006 & 0.006 & -- \\
\hline Arsenic, Total & $\mathrm{mg} / \mathrm{L}$ & 0.05 & -- & 0.05 \\
\hline Barium, Total & $\mathrm{mg} / \mathrm{L}$ & 2.00 & 2.00 & 1.0 \\
\hline Beryllium, Total & $\mathrm{mg} / \mathrm{L}$ & 0.004 & 0.004 & -- \\
\hline Cadmium, Total & $\mathrm{mg} / \mathrm{L}$ & 0.005 & 0.005 & 0.01 \\
\hline Chromium, Total & $\mathrm{mg} / \mathrm{L}$ & 0.10 & 0.10 & -- \\
\hline Conductivity & $\mu \mathrm{mhos} / \mathrm{cm} @ 25^{\circ} \mathrm{C}$ & -- & -- & -- \\
\hline Copper, Total & $\mathrm{mg} / \mathrm{L}$ & 1.3 & 1.3 & $<0.2$ \\
\hline Cyanide & $\mathrm{mg} / \mathrm{L}$ & 0.2 & 0.2 & $<0.1$ \\
\hline E. Coli & NA & one positive sample & 0 & -- \\
\hline Fluoride & $\mathrm{mg} / \mathrm{L}$ & 2.2 & -- & $<1.5$ \\
\hline Free Residual Chlorine & $\mathrm{mg} / \mathrm{L}$ & $0.02(\min ) \quad 4.0(\max )$ & -- & -- \\
\hline Haloacetic Acids-Five (5) & $\mathrm{mg} / \mathrm{L}$ & 0.060 & -- & -- \\
\hline Iron, Total & $\mathrm{mg} / \mathrm{L}$ & 0.3 & -- & -- \\
\hline Lead, Total & $\mathrm{mg} / \mathrm{L}$ & 0.015 & 0 & 0.05 \\
\hline Mercury, Total & $\mathrm{mg} / \mathrm{L}$ & 0.002 & 0.002 & 0.005 \\
\hline Nickel, Total & $\mathrm{mg} / \mathrm{L}$ & -- & -- & -- \\
\hline Nitrate-N & $\mathrm{mg} / \mathrm{L}$ & 10 & 10 & -- \\
\hline pH & SU & -- & -- & $6.5-8.5$ \\
\hline POC (Principle Organic Contaminant) & $\mathrm{mg} / \mathrm{L}$ & -- & 0.0005 & -- \\
\hline Selenium, Total & $\mathrm{mg} / \mathrm{L}$ & 0.05 & 0.05 & 0.01 \\
\hline Solids, Total Dissolved & $\mathrm{mg} / \mathrm{L}$ & -- & -- & 500 \\
\hline Thallium, Total & $\mathrm{mg} / \mathrm{L}$ & 0.002 & 0.0005 & -- \\
\hline Total Coliform & NA & $\begin{array}{c}2 \text { or more } \\
\text { positive samples }\end{array}$ & 0 & -- \\
\hline Total Trihalomethanes & $\mathrm{mg} / \mathrm{L}$ & 0.080 & -- & -- \\
\hline Turbidity & $\overline{N T U}$ & 1 (max) & -- & -- \\
\hline
\end{tabular}

-- No applicable guideline or reference standard available.

Note: All water quality and metals standards are presented in $\mathrm{mg} / \mathrm{L}(\mathrm{ppm})$ to provide consistency in comparisons.

NA - Not applicable.

${ }^{a} \mathrm{MCL}$ - Listed is NYSDOH or EPA Maximum Contaminant Levels. Sources:40 CFR Part 141and/or10 NYCRR part 5,

Subpart 5-1, Section 5-1.52, whichever is most stringent.

${ }^{b}$ MCLG - Maximum Contaminant Level Goal (non-enforceable) as listed in 40 CFR Part 141.

c Source: 10 NYCRR Part 170.4

d Alpha guideline includes radium-226 but excludes radon and uranium, however WVDP results include these isotopes.

e Average annual concentration assumed to produce a total bodv organ dose of $4 \mathrm{mrem} / \mathrm{vr}$. 
TABLE B-1D

Department of Energy (DOE)

Derived Concentration Standards (DCSs) ${ }^{\mathrm{a}}$ in Ingested Water

\begin{tabular}{|l|l|l|}
\hline \multicolumn{1}{|c|}{ Radionuclide } & Units & $\begin{array}{c}\text { Concentration in Ingested } \\
\text { Water }\end{array}$ \\
\hline Gross Alpha (as U-232) & $\mu \mathrm{Ci} / \mathrm{mL}$ & $9.8 \mathrm{E}-08$ \\
\hline Gross Beta (as Sr-90) & $\mu \mathrm{Ci} / \mathrm{mL}$ & $1.1 \mathrm{E}-06$ \\
\hline Tritium (H-3) & $\mu \mathrm{Ci} / \mathrm{mL}$ & $1.9 \mathrm{E}-03$ \\
\hline Carbon-14 (C-14) & $\mu \mathrm{Ci} / \mathrm{mL}$ & $6.2 \mathrm{E}-05$ \\
\hline Potassium-40 (K-40) & $\mu \mathrm{Ci} / \mathrm{mL}$ & $4.8 \mathrm{E}-06$ \\
\hline Cobalt-60 (Co-60) & $\mu \mathrm{Ci} / \mathrm{mL}$ & $7.2 \mathrm{E}-06$ \\
\hline Strontium-90 (Sr-90) & $\mu \mathrm{Ci} / \mathrm{mL}$ & $1.1 \mathrm{E}-06$ \\
\hline Technetium-99 (Tc-99) & $\mu \mathrm{Ci} / \mathrm{mL}$ & $4.4 \mathrm{E}-05$ \\
\hline lodine-129 (I-129) & $\mu \mathrm{Ci} / \mathrm{mL}$ & $3.3 \mathrm{E}-07$ \\
\hline Cesium-137 (Cs-137) & $\mu \mathrm{Ci} / \mathrm{mL}$ & $3.0 \mathrm{E}-06$ \\
\hline Europium-154 (Eu-154) & $\mu \mathrm{Ci} / \mathrm{mL}$ & $1.5 \mathrm{E}-05$ \\
\hline Uranium-232 (U-232) & $\mu \mathrm{Ci} / \mathrm{mL}$ & $9.8 \mathrm{E}-08$ \\
\hline Uranium-233 (U-233) & $\mu \mathrm{Ci} / \mathrm{mL}$ & $6.6 \mathrm{E}-07$ \\
\hline Uranium-234 (U-234) & $\mu \mathrm{Ci} / \mathrm{mL}$ & $6.8 \mathrm{E}-07$ \\
\hline Uranium-235 (U-235) & $\mu \mathrm{Ci} / \mathrm{mL}$ & $7.2 \mathrm{E}-07$ \\
\hline Uranium-236 (U-236) & $\mu \mathrm{Ci} / \mathrm{mL}$ & $7.2 \mathrm{E}-07$ \\
\hline Uranium-238 (U-238) & $\mu \mathrm{Ci} / \mathrm{mL}$ & $7.5 \mathrm{E}-07$ \\
\hline Plutonium-238 (Pu-238) & $\mu \mathrm{Ci} / \mathrm{mL}$ & $1.5 \mathrm{E}-07$ \\
\hline Plutonium-239 (Pu-239) & $\mu \mathrm{Ci} / \mathrm{mL}$ & $1.4 \mathrm{E}-07$ \\
\hline Plutonium-240 (Pu-240) & $\mu \mathrm{Ci} / \mathrm{mL}$ & $1.4 \mathrm{E}-07$ \\
\hline Americium-241 (Am-241) & $\mu \mathrm{Ci} / \mathrm{mL}$ & $1.7 \mathrm{E}-07$ \\
\hline
\end{tabular}

${ }^{\text {a }}$ DCS: Derived Concentation Standard. DCSs are established in DOE-STD-1196-2011 and are defined as the concentration of a radiobuclide that, under conditions of continuous exposure for one year by one exposure mode, would result in an effective dose equivalent of $100 \mathrm{mrem}(1 \mathrm{mSv})$.

${ }^{b}$ Because there are no DCSs for gross alpha and gross beta concentrations, the DCSs for the most restrictive alpha and beta emitters in water at the WVDP, uranium-232 and strontium-90

(9.8E-08 and $1.1 \mathrm{E}-06 \mathrm{uCi} / \mathrm{mL}$, respectively) are used as a conservative basis for comparison at locations for which there are no radionuclide-specific data, in which case a more appropriate DCS may be applied. 
This page intentionally left blank 


\section{APPENDIX B-2 \\ Process Effluent Data}

TABLE B-2A

Comparison of 2012 Lagoon 3 (WNSP001) Liquid Effluent Radioactivity Concentrations With U.S. DOE-Derived Conentration Standards (DCSs)

\begin{tabular}{|c|c|c|c|c|c|}
\hline \multirow[t]{2}{*}{ Isotope $^{a}$} & \multicolumn{2}{|c|}{ Discharge Activity $^{b}$} & \multirow{2}{*}{$\begin{array}{c}\text { Average } \\
\text { Concentration } \\
(\mu \mathrm{Ci} / \mathrm{mL})\end{array}$} & \multirow{2}{*}{$\begin{array}{c}D_{C S}^{d} \\
(\mu C i / m L)\end{array}$} & \multirow{2}{*}{$\begin{array}{c}\text { Ratio of } \\
\text { Concentration } \\
\text { to DCS }\end{array}$} \\
\hline & (Ci) & (Becquerels) $^{c}$ & & & \\
\hline Gross Alpha & $1.10 \pm 0.09 \mathrm{E}-03$ & $4.06 \pm 0.35 \mathrm{E}+07$ & $3.48 \pm 0.30 \mathrm{E}-08$ & $\mathrm{NA}^{e}$ & NA \\
\hline Gross Beta & $1.31 \pm 0.02 \mathrm{E}-02$ & $4.84 \pm 0.08 E+08$ & $4.14 \pm 0.07 E-07$ & $\mathrm{NA}^{e}$ & NA \\
\hline $\mathrm{H}-3$ & $1.88 \pm 0.14 \mathrm{E}-02$ & $6.94 \pm 0.51 E+08$ & $5.94 \pm 0.43 E-07$ & 1.9E-03 & 0.0003 \\
\hline C-14 & $0.21 \pm 4.14 \mathrm{E}-04$ & $0.08 \pm 1.53 E+07$ & $0.07 \pm 1.31 \mathrm{E}-08$ & $6.2 \mathrm{E}-05$ & $<0.0002$ \\
\hline K-40 & $-2.97 \pm 4.61 \mathrm{E}-04$ & $-1.10 \pm 1.70 E+07$ & $-0.94 \pm 1.46 \mathrm{E}-08$ & $\mathrm{NA}^{f}$ & NA \\
\hline Co-60 & $0.22 \pm 2.35 \mathrm{E}-05$ & $0.81 \pm 8.70 \mathrm{E}+05$ & $0.69 \pm 7.45 \mathrm{E}-10$ & 7.2E-06 & $<0.0001$ \\
\hline Sr-90 & $5.93 \pm 0.14 \mathrm{E}-03$ & $2.19 \pm 0.05 E+08$ & $1.88 \pm 0.04 \mathrm{E}-07$ & $1.1 \mathrm{E}-06$ & 0.1709 \\
\hline Tc-99 & $5.48 \pm 0.37 \mathrm{E}-04$ & $2.03 \pm 0.14 \mathrm{E}+07$ & $1.74 \pm 0.12 \mathrm{E}-08$ & 4.4E-05 & 0.0004 \\
\hline I-129 & $6.02 \pm 1.82 \mathrm{E}-05$ & $2.23 \pm 0.67 E+06$ & $1.91 \pm 0.58 \mathrm{E}-09$ & $3.3 \mathrm{E}-07$ & 0.0058 \\
\hline Cs-137 & $1.25 \pm 0.06 \mathrm{E}-03$ & $4.61 \pm 0.23 E+07$ & $3.95 \pm 0.20 \mathrm{E}-08$ & 3.0E-06 & 0.0132 \\
\hline $\mathbf{U}-232^{g}$ & $2.33 \pm 0.09 E-04$ & $8.62 \pm 0.34 \mathrm{E}+06$ & $7.38 \pm 0.29 E-09$ & $9.8 \mathrm{E}-08$ & 0.0753 \\
\hline $\mathrm{U}-233 / 234^{g}$ & $1.68 \pm 0.08 \mathrm{E}-04$ & $6.22 \pm 0.30 \mathrm{E}+06$ & $5.32 \pm 0.26 \mathrm{E}-09$ & $6.6 \mathrm{E}-07^{h}$ & 0.0081 \\
\hline $\mathrm{U}-235 / 236^{g}$ & $5.77 \pm 1.47 \mathrm{E}-06$ & $2.14 \pm 0.55 \mathrm{E}+05$ & $1.83 \pm 0.47 \mathrm{E}-10$ & $7.2 \mathrm{E}-07$ & 0.0003 \\
\hline $\mathrm{U}-238^{g}$ & $1.25 \pm 0.07 \mathrm{E}-04$ & $4.64 \pm 0.26 \mathrm{E}+06$ & $3.97 \pm 0.22 \mathrm{E}-09$ & $7.5 \mathrm{E}-07$ & 0.0053 \\
\hline Pu-238 & $2.40 \pm 0.31 \mathrm{E}-05$ & $8.88 \pm 1.14 \mathrm{E}+05$ & $7.60 \pm 0.98 \mathrm{E}-10$ & $1.5 \mathrm{E}-07$ & 0.0051 \\
\hline $\mathrm{Pu}-239 / 240$ & $1.34 \pm 0.22 \mathrm{E}-05$ & $4.95 \pm 0.80 E+05$ & $4.24 \pm 0.69 \mathrm{E}-10$ & $1.4 \mathrm{E}-07$ & 0.0030 \\
\hline Am-241 & $1.81 \pm 0.23 \mathrm{E}-05$ & $6.68 \pm 0.84 \mathrm{E}+05$ & $5.72 \pm 0.72 \mathrm{E}-10$ & 1.7E-07 & 0.0034 \\
\hline \multicolumn{5}{|l|}{ Sum of Ratios } & 0.29 \\
\hline
\end{tabular}

NA - Not applicable.

${ }^{a}$ Half-lives are listed in Table UI-4.

${ }^{\mathrm{b}}$ Total volume released: $3.16 \mathrm{E}+10$ milliliters $(\mathrm{mL})(8.34 \mathrm{E}+06$ gal).

${ }^{c} 1$ curie $(\mathrm{Ci})=3.7 \mathrm{E}+10$ becquerels $(\mathrm{Bq}): 1 \mathrm{~Bq}=2.7 \mathrm{E}-11 \mathrm{Ci} ; 1$ microcurie $(\mu \mathrm{Ci})=1 \mathrm{E}-06 \mathrm{Ci}$.

${ }^{d}$ DCSs are used as reference values for the application of best available technology per DOE Order 458.1.

${ }^{\mathrm{e}} \mathrm{DCS}$ do not exist for indicator parameters gross alpha and gross beta.

${ }^{\mathrm{f}}$ The DCS is not applied to potassium-40 (K-40) activity because of its natural origin.

${ }^{\mathrm{g}}$ Total uranium $(\mathrm{g})=3.69 \pm 0.07 \mathrm{E}+02 ;$ Average uranium $[\mu \mathrm{g} / \mathrm{mL})=1.17 \pm 0.02 \mathrm{E}-02$.

${ }^{\mathrm{h}}$ The DCS for U-233 is used for this comparison. 
TABLE B-2B

2012 SPDES Results for Outfall 001 (WNSP001): Water Quality

\begin{tabular}{|c|c|c|c|c|c|c|c|c|}
\hline \multirow[t]{2}{*}{ Permit Limit } & \multicolumn{2}{|c|}{$\begin{array}{c}\text { Ammonia (as } \mathrm{NH}_{3} \text { ) } \\
\text { (mg/L) }\end{array}$} & \multicolumn{2}{|c|}{$\begin{array}{c}B O D_{5} \text { day } \\
(\mathrm{mg} / \mathrm{L})\end{array}$} & \multicolumn{2}{|c|}{$\begin{array}{c}\text { Discharge Rate } \\
\text { (MGD) }\end{array}$} & \multirow{2}{*}{\multicolumn{2}{|c|}{$\begin{array}{c}\text { Chlorine, } \\
\text { Total Redisual } \\
\text { (mg/L) } \\
0.1 \mathrm{mg} / \mathrm{L} \text { daily } \\
\text { maximum }\end{array}$}} \\
\hline & \multicolumn{2}{|c|}{$\begin{array}{l}2.1 \mathrm{mg} / \mathrm{L} \text { daily } \\
\text { maximum }\end{array}$} & \multicolumn{2}{|c|}{$\begin{array}{l}10.0 \mathrm{mg} / \mathrm{L} \text { daily } \\
\text { maximum }\end{array}$} & \multicolumn{2}{|c|}{ Monitor } & & \\
\hline Month & Avg & Max & Avg & Max & Avg & $\operatorname{Max}$ & Avg & Max \\
\hline January $^{a}$ & -- & -- & -- & -- & -- & -- & -- & -- \\
\hline February & 0.34 & 0.36 & $<2.0$ & $<2.0$ & 0.287 & 0.363 & 0.04 & 0.04 \\
\hline March & 0.14 & 0.14 & $<2.0$ & $<2.0$ & 0.194 & 0.236 & 0.03 & 0.03 \\
\hline April $^{a}$ & -- & -- & -- & -- & -- & -- & -- & -- \\
\hline May & 0.18 & 0.23 & $<2.4$ & 2.8 & 0.216 & 0.301 & 0.07 & 0.07 \\
\hline June $^{a}$ & -- & -- & -- & -- & -- & -- & -- & -- \\
\hline July & 0.039 & 0.054 & 2.9 & 3.0 & 0.195 & 0.207 & 0.01 & 0.01 \\
\hline August $^{a}$ & -- & -- & -- & -- & -- & -- & -- & -- \\
\hline September $^{a}$ & -- & -- & -- & -- & -- & -- & -- & -- \\
\hline October $^{a}$ & -- & -- & -- & -- & -- & -- & -- & -- \\
\hline November & $<0.013$ & 0.017 & 3.4 & 4.5 & 0.185 & 0.235 & 0.03 & 0.03 \\
\hline December $^{a}$ & -- & -- & -- & -- & -- & -- & -- & -- \\
\hline
\end{tabular}

\begin{tabular}{|c|c|c|c|c|c|c|c|c|}
\hline \multirow{3}{*}{$\begin{array}{l}\text { Permit Limit } \\
\text { Month } \\
\end{array}$} & \multirow{2}{*}{\multicolumn{2}{|c|}{$\begin{array}{c}\begin{array}{c}\text { Dissolved Oxygen } \\
\text { (mg/L) }\end{array} \\
3.0 \mathrm{mg} / \mathrm{L} \text { minimum }\end{array}$}} & \multirow{2}{*}{\multicolumn{2}{|c|}{$\begin{array}{c}\text { Nitrogen, total } \\
\text { Kjeldahl } \\
\text { (as } \mathrm{N})(\mathrm{mg} / \mathrm{L}) \\
\text { Monitor }\end{array}$}} & \multirow{2}{*}{\multicolumn{2}{|c|}{$\begin{array}{c}\begin{array}{c}\text { Nitrate (as N) } \\
(\mathrm{mg} / \mathrm{L})\end{array} \\
\text { Monitor }\end{array}$}} & \multirow{2}{*}{\multicolumn{2}{|c|}{$\begin{array}{c}\begin{array}{c}\text { Nitrite (as } N) \\
(\mathrm{mg} / \mathrm{L})\end{array} \\
0.1 \mathrm{mg} / \mathrm{L} \text { daily } \\
\text { maximum }\end{array}$}} \\
\hline & & & & & & & & \\
\hline & Min & Max & Avg & $\operatorname{Max}$ & Avg & Max & Avg & $\operatorname{Max}$ \\
\hline January $^{a}$ & -- & -- & -- & -- & -- & -- & -- & -- \\
\hline February & 13 & 13 & 1.1 & 1.3 & 0.80 & 0.80 & $<0.02$ & $<0.02$ \\
\hline March & 11 & 13 & 0.75 & 0.79 & 0.96 & 0.96 & $<0.02$ & $<0.02$ \\
\hline April $^{a}$ & -- & -- & -- & -- & -- & -- & -- & -- \\
\hline May & 8.02 & 8.13 & 0.82 & 1.2 & 0.12 & 0.12 & 0.02 & 0.02 \\
\hline June $^{a}$ & -- & -- & -- & -- & -- & -- & -- & -- \\
\hline July & 4.3 & 5.6 & 1.0 & 1.4 & $<0.011$ & $<0.011$ & $<0.02$ & $<0.02$ \\
\hline August $^{a}$ & -- & -- & -- & -- & -- & -- & -- & -- \\
\hline September ${ }^{a}$ & -- & -- & -- & -- & -- & -- & -- & -- \\
\hline October $^{a}$ & -- & -- & -- & -- & -- & -- & -- & -- \\
\hline November & 12 & 13 & 0.91 & 1.0 & 0.037 & 0.037 & $<0.02$ & $<0.02$ \\
\hline December $^{a}$ & -- & -- & -- & -- & -- & -- & -- & -- \\
\hline
\end{tabular}

Note: No results exceeded the permit limits.

MGD - Million gallons per day.

${ }^{a}$ There was no discharge from outfall 001 during this month in 2012. 
TABLE B-2B (continued)

2012 SPDES Results for Outfall 001 (WNSP001); Water Quality

\begin{tabular}{|c|c|c|c|c|c|c|c|c|}
\hline \multirow{3}{*}{\begin{tabular}{|l} 
Permit Limit \\
Month
\end{tabular}} & \multirow{2}{*}{\multicolumn{2}{|c|}{$\begin{array}{c}\begin{array}{c}\text { Oil \& Grease } \\
(\mathrm{mg} / \mathrm{L})\end{array} \\
\begin{array}{c}15.0 \mathrm{mg} / \mathrm{L} \text { daily } \\
\text { maximum }\end{array}\end{array}$}} & \multirow{2}{*}{\multicolumn{2}{|c|}{$\begin{array}{c}\begin{array}{c}p H \\
\text { (standard units) }\end{array} \\
6.5 \text { to } 8.5\end{array}$}} & \multirow{2}{*}{\multicolumn{2}{|c|}{$\begin{array}{c}\text { Solids, } \\
\text { Settleable } \\
\text { (mL/L) } \\
0.3 \mathrm{~mL} / \mathrm{L} \text { daily } \\
\text { maximum }\end{array}$}} & \multirow{2}{*}{\multicolumn{2}{|c|}{$\begin{array}{c}\text { Solids, } \\
\begin{array}{c}\text { Total Dissolved } \\
\text { (mg/L) }\end{array} \\
\text { Monitor }\end{array}$}} \\
\hline & & & & & & & & \\
\hline & Avg & Max & Min & Max & Avg & Max & Avg & Max \\
\hline January $^{a}$ & -- & -- & -- & -- & - & -- & -- & - \\
\hline February & $<1.5$ & $<1.5$ & 7.4 & 7.4 & 0.1 & 0.1 & 883 & 887 \\
\hline March & $<1.4$ & $<1.4$ & 7.0 & 7.0 & $<0.1$ & $<0.1$ & 816 & 846 \\
\hline April $^{a}$ & -- & -- & -- & -- & -- & -- & -- & -- \\
\hline May & $<1.4$ & $<1.4$ & 7.5 & 7.5 & $<0.1$ & $<0.1$ & 849 & 908 \\
\hline June ${ }^{a}$ & -- & -- & -- & -- & -- & -- & -- & -- \\
\hline July & $<1.4$ & $<1.4$ & 6.7 & 6.7 & $<0.1$ & $<0.1$ & 1040 & 1040 \\
\hline August $^{a}$ & -- & -- & -- & -- & -- & -- & -- & -- \\
\hline September ${ }^{a}$ & -- & -- & -- & -- & -- & -- & -- & -- \\
\hline October $^{a}$ & -- & -- & -- & -- & -- & -- & - & - \\
\hline November & 3.0 & 3.0 & 7.5 & 7.5 & $<0.1$ & $<0.1$ & 944 & 954 \\
\hline December $^{a}$ & - & -- & - & - & - & - & - & - \\
\hline
\end{tabular}

\begin{tabular}{|c|c|c|c|c|c|c|c|c|}
\hline \multirow{3}{*}{\begin{tabular}{|l} 
Permit Limit \\
Month \\
\end{tabular}} & \multirow{2}{*}{\multicolumn{2}{|c|}{$\begin{array}{c}\begin{array}{c}\text { Solids, } \\
\text { Total Suspended } \\
\text { (mg/L) }\end{array} \\
45 \mathrm{mg} / \mathrm{L} \text { daily } \\
\text { maximum }\end{array}$}} & \multirow{2}{*}{\multicolumn{2}{|c|}{$\begin{array}{c}\begin{array}{c}\text { Sulfate (as S) } \\
\text { (mg/L) }\end{array} \\
\text { Monitor }\end{array}$}} & \multirow{2}{*}{\multicolumn{2}{|c|}{$\begin{array}{c}\text { Sulfide, (as S) } \\
\text { Dissolved } \\
\text { (mg/L) }\end{array}$}} & \multicolumn{2}{|c|}{$\begin{array}{c}\text { Surfactant (as LAS) } \\
(\mathrm{mg} / \mathrm{L})\end{array}$} \\
\hline & & & & & & & \multicolumn{2}{|c|}{ Monitor } \\
\hline & Avg & Max & Avg & Max & Avg & Max & Avg & Max \\
\hline January $^{a}$ & -- & -- & -- & -- & - & -- & -- & -- \\
\hline February & $<4.0$ & $<4.0$ & 60 & 60 & $<0.05$ & $<0.05$ & 0.036 & 0.036 \\
\hline March & $<4.0$ & $<4.0$ & 64 & 64 & $<0.05$ & $<0.05$ & 0.013 & 0.013 \\
\hline April $^{a}$ & -- & -- & -- & -- & -- & -- & -- & -- \\
\hline May & $<4.0$ & 4.0 & 53 & 53 & $<0.05$ & $<0.05$ & $<0.013$ & $<0.013$ \\
\hline June ${ }^{a}$ & -- & -- & -- & -- & -- & -- & -- & -- \\
\hline July & $<4.0$ & $<4.0$ & 100 & 100 & $<0.05$ & $<0.05$ & 0.0595 & 0.0595 \\
\hline August $^{a}$ & -- & -- & -- & -- & -- & -- & -- & -- \\
\hline September ${ }^{a}$ & -- & -- & -- & -- & -- & -- & -- & -- \\
\hline October $^{a}$ & -- & -- & -- & -- & -- & -- & -- & -- \\
\hline November & $<4.0$ & $<4.0$ & 88 & 88 & $<0.05$ & $<0.05$ & 0.039 & 0.039 \\
\hline December $^{a}$ & -- & -- & -- & -- & -- & -- & -- & -- \\
\hline
\end{tabular}

Note: No results exceeded the permit limits.

LAS - linear alkylate sulfonate.

${ }^{a}$ There was no discharge from outfall 001 during this month in 2012. 
Table B-2B (concluded)

2012 SPDES Results for Outfall 001 (WNSP001): Water Quality

\begin{tabular}{|c|c|c|}
\hline \multirow[t]{2}{*}{ Permit Limit } & \multicolumn{2}{|c|}{$\begin{array}{l}\text { Ultimate Oxygen Demand } \\
\text { (UOD) } \\
\text { (mg/L) }\end{array}$} \\
\hline & \multicolumn{2}{|c|}{$\begin{array}{c}22.0 \mathrm{mg} / \mathrm{L} \text { daily } \\
\text { maximum }\end{array}$} \\
\hline Month & Avg & $\operatorname{Max}$ \\
\hline January $^{a}$ & -- & -- \\
\hline February & $<8.12$ & $<8.94$ \\
\hline March & $<6.40$ & $<6.61$ \\
\hline April $^{a}$ & -- & -- \\
\hline May & $<7.35$ & 9.68 \\
\hline June ${ }^{a}$ & -- & -- \\
\hline July & 8.82 & 10.5 \\
\hline August $^{a}$ & -- & -- \\
\hline September $^{a}$ & -- & -- \\
\hline October $^{a}$ & -- & -- \\
\hline November & 9.24 & 11.3 \\
\hline December $^{a}$ & -- & -- \\
\hline
\end{tabular}

Note: No results exceeded the permit limits.

${ }^{a}$ There was no discharge from outfall 001 during this month in 2012. 
TABLE B-2C

2012 SPDES Results for Outfall 001 (WNSP001): Metals

\begin{tabular}{|c|c|c|c|c|c|c|c|c|}
\hline \multirow{3}{*}{$\begin{array}{l}\text { Permit Limit } \\
\text { Month } \\
\end{array}$} & \multirow{2}{*}{\multicolumn{2}{|c|}{$\begin{array}{c}\text { Aluminum, } \\
\text { Total } \\
\text { (mg/L) }\end{array}$}} & \multirow{2}{*}{\multicolumn{2}{|c|}{$\begin{array}{c}\text { Arsenic, } \\
\text { Total Recoverable } \\
\text { (mg/L) } \\
0.15 \mathrm{mg} / \mathrm{L} \text { daily } \\
\text { maximum }\end{array}$}} & \multirow{2}{*}{\multicolumn{2}{|c|}{$\begin{array}{c}\text { Cobalt, } \\
\text { Total Recoverable } \\
\text { (mg/L) } \\
0.005 \mathrm{mg} / \mathrm{L} \text { daily } \\
\text { maximum }\end{array}$}} & \multirow{2}{*}{\multicolumn{2}{|c|}{$\begin{array}{c}\begin{array}{c}\text { Iron, } \\
\text { Total } \\
\text { (mg/L) }\end{array} \\
\text { Monitor }\end{array}$}} \\
\hline & & & & & & & & \\
\hline & Avg & $\operatorname{Max}$ & Avg & $\operatorname{Max}$ & Avg & $\operatorname{Max}$ & Avg & $\operatorname{Max}$ \\
\hline January $^{a}$ & -- & -- & -- & -- & -- & -- & -- & -- \\
\hline February & 0.32 & 0.32 & 0.002 & 0.002 & $<0.0006$ & $<0.0006$ & 0.480 & 0.517 \\
\hline March & 0.30 & 0.30 & 0.0016 & 0.0016 & $<0.0006$ & $<0.0006$ & 0.329 & 0.348 \\
\hline April $^{a}$ & -- & -- & -- & -- & -- & -- & -- & -- \\
\hline May & 0.25 & 0.25 & 0.0016 & 0.0016 & $<0.0006$ & $<0.0006$ & 0.58 & 0.77 \\
\hline June ${ }^{a}$ & -- & -- & -- & -- & -- & -- & -- & -- \\
\hline July & 0.38 & 0.38 & 0.0031 & 0.0031 & 0.0006 & 0.0006 & 1.8 & 2.0 \\
\hline August $^{a}$ & -- & -- & -- & -- & -- & -- & -- & -- \\
\hline September $^{a}$ & -- & -- & -- & -- & -- & -- & -- & -- \\
\hline October $^{a}$ & - & -- & - & - & -- & -- & -- & -- \\
\hline November & 0.45 & 0.45 & 0.0029 & 0.0029 & $<0.0006$ & $<0.0006$ & 0.44 & 0.48 \\
\hline December $^{a}$ & -- & -- & -- & -- & -- & -- & -- & -- \\
\hline
\end{tabular}

\begin{tabular}{|c|c|c|c|c|c|c|}
\hline \multirow{3}{*}{\begin{tabular}{|l} 
Permit Limit \\
Month \\
\end{tabular}} & \multirow{2}{*}{\multicolumn{2}{|c|}{$\begin{array}{c}\text { Mercury, } \\
\text { Total } \\
\text { (ng/L) }\end{array}$}} & \multirow{2}{*}{\multicolumn{2}{|c|}{$\begin{array}{c}\text { Selenium, } \\
\text { Total Recoverable } \\
\text { (mg/L) }\end{array}$}} & \multirow{2}{*}{\multicolumn{2}{|c|}{$\begin{array}{c}\text { Vanadium, } \\
\text { Total Recoverable } \\
(\mathrm{mg} / \mathrm{L})\end{array}$}} \\
\hline & & & & & & \\
\hline & Avg & Max & Avg & $\operatorname{Max}$ & Avg & $\operatorname{Max}$ \\
\hline January $^{a}$ & -- & -- & -- & -- & -- & - \\
\hline February & 42 & 42 & 0.0006 & 0.0006 & 0.0011 & 0.0011 \\
\hline March & 25 & 25 & $<0.0004$ & $<0.0004$ & $<0.0015$ & $<0.0015$ \\
\hline April $^{a}$ & -- & -- & -- & -- & -- & -- \\
\hline May & 9.08 & 9.08 & 0.0006 & 0.0006 & $<0.0015$ & $<0.0015$ \\
\hline June ${ }^{a}$ & -- & -- & -- & -- & -- & -- \\
\hline July & 5.63 & 5.63 & $<0.0004$ & $<0.0004$ & $<0.0015$ & $<0.0015$ \\
\hline August $^{a}$ & -- & -- & -- & -- & -- & -- \\
\hline September ${ }^{a}$ & -- & -- & -- & -- & -- & -- \\
\hline October $^{a}$ & -- & -- & -- & -- & -- & -- \\
\hline November & 5.49 & 5.49 & $<0.0004$ & $<0.0004$ & $<0.0015$ & $<0.0015$ \\
\hline December $^{a}$ & -- & -- & - & -- & -- & -- \\
\hline
\end{tabular}

Note: No results exceeded the permit limits.

${ }^{a}$ There was no discharge from outfall 001 during this month in 2012. 
TABLE B-2D

2012 SPDES Results for Outfall 007 (WNSP007): Water Quality and Iron

\begin{tabular}{|c|c|c|c|c|c|c|c|c|c|c|}
\hline \multirow{3}{*}{$\begin{array}{l}\text { Permit Limit } \\
\text { Month } \\
\end{array}$} & \multirow{2}{*}{\multicolumn{2}{|c|}{$\begin{array}{l}\text { Ammonia } \\
\left(a s \mathrm{NH}_{3}\right) \\
(\mathrm{mg} / \mathrm{L}) \\
1 \mathrm{mg} / \mathrm{L} \text { daily } \\
\text { maximum } \\
\end{array}$}} & \multirow{2}{*}{\multicolumn{2}{|c|}{$\begin{array}{l}\mathrm{BOD}_{5} \\
(\mathrm{mg} / \mathrm{L}) \\
0 \mathrm{mg} / \mathrm{L} \text { daily } \\
\text { maximum }\end{array}$}} & \multirow{2}{*}{\multicolumn{2}{|c|}{$\begin{array}{c}\text { Chlorine, } \\
\text { Total Residual } \\
\text { (mg/L) } \\
0.1 \mathrm{mg} / \mathrm{L} \text { daily } \\
\text { maximum }\end{array}$}} & \multicolumn{2}{|c|}{$\begin{array}{c}\text { Discharge Rate } \\
\text { (MGD) }\end{array}$} & \multirow{2}{*}{\multicolumn{2}{|c|}{$\begin{array}{c}\begin{array}{c}\text { Dissolved } \\
\text { Oxygen } \\
(\mathrm{mg} / \mathrm{L})\end{array} \\
3.0 \mathrm{mg} / \mathrm{L} \text { daily } \\
\text { minimum }\end{array}$}} \\
\hline & & & & & & & \multicolumn{2}{|c|}{ Monitor } & & \\
\hline & Avg & Max & Avg & Max & Avg & Max & Avg & $\operatorname{Max}$ & Min & Max \\
\hline January $^{a}$ & -- & -- & -- & -- & -- & -- & -- & -- & -- & -- \\
\hline February & 0.10 & 0.15 & $<2.3$ & 2.5 & 0.01 & 0.01 & 0.004 & 0.007 & 12 & 12 \\
\hline March & 0.058 & 0.073 & $<2.0$ & 2.0 & 0.01 & 0.01 & 0.006 & 0.011 & 12 & 14 \\
\hline April & 0.046 & 0.058 & $<2.0$ & $<2.0$ & 0.02 & 0.02 & 0.005 & 0.008 & 12 & 12 \\
\hline May & 0.032 & 0.044 & $<2.0$ & $<2.0$ & 0.01 & 0.01 & 0.005 & 0.008 & 11 & 14 \\
\hline June & 0.036 & 0.040 & $<2.2$ & 2.3 & 0.01 & 0.01 & 0.004 & 0.010 & 8.7 & 9.4 \\
\hline July & 0.039 & 0.049 & $<2.0$ & $<2.0$ & 0.02 & 0.02 & 0.003 & 0.008 & 9.4 & 9.7 \\
\hline August & 0.027 & 0.027 & $<2.0$ & $<2.0$ & 0.02 & 0.02 & 0.006 & 0.009 & 8.2 & 8.2 \\
\hline September $^{a}$ & -- & -- & -- & -- & -- & - & -- & -- & -- & -- \\
\hline October & 0.033 & 0.041 & $<2.0$ & $<2.0$ & 0.02 & 0.02 & 0.009 & 0.015 & 9.0 & 9.7 \\
\hline November & 0.020 & 0.030 & $<2.6$ & 3.1 & 0.01 & 0.01 & 0.008 & 0.020 & 10 & 11 \\
\hline December & 0.031 & 0.031 & 3.3 & 3.4 & 0.02 & 0.02 & 0.010 & 0.019 & 11 & 12 \\
\hline
\end{tabular}

\begin{tabular}{|c|c|c|c|c|c|c|c|c|c|c|}
\hline \multirow{3}{*}{\begin{tabular}{|l} 
Permit Limit \\
\\
Month \\
\end{tabular}} & \multirow{2}{*}{\multicolumn{2}{|c|}{$\begin{array}{c}\begin{array}{c}\text { Iron, } \\
\text { Total } \\
\text { (mg/L) }\end{array} \\
\text { Monitor }\end{array}$}} & \multirow{2}{*}{\multicolumn{2}{|c|}{$\begin{array}{c}\text { Mercury, Total } \\
\text { (as Hg) } \\
\text { (ng/L) } \\
200 \text { ng/L daily } \\
\text { maximum }\end{array}$}} & \multirow{2}{*}{\multicolumn{2}{|c|}{\begin{tabular}{|c}
$\begin{array}{c}\text { Nitrogen, Total } \\
\text { Kjeldahl } \\
\text { (as } \mathrm{N})(\mathrm{mg} / \mathrm{L})\end{array}$ \\
Monitor
\end{tabular}}} & \multirow{2}{*}{\multicolumn{2}{|c|}{$\begin{array}{l}\text { Nitrite } \\
\text { (as } \mathrm{N}) \\
\text { (mg/L) } \\
1 \mathrm{mg} / \mathrm{L} \text { daily } \\
\text { maximum }\end{array}$}} & \multirow{2}{*}{\multicolumn{2}{|c|}{$\begin{array}{c}\begin{array}{c}\text { Oil \& Grease } \\
(\mathrm{mg} / \mathrm{L})\end{array} \\
\begin{array}{c}15.0 \mathrm{mg} / \mathrm{L} \text { daily } \\
\text { maximum }\end{array}\end{array}$}} \\
\hline & & & & & & & & & & \\
\hline & Avg & Max & Avg & $\operatorname{Max}$ & Avg & $\operatorname{Max}$ & Avg & Max & Avg & $\operatorname{Max}$ \\
\hline January $^{a}$ & -- & -- & -- & -- & -- & -- & -- & -- & -- & -- \\
\hline February & 0.126 & 0.128 & 74.4 & 74.4 & $<0.15$ & $<0.15$ & 0.04 & 0.04 & $<1.4$ & $<1.4$ \\
\hline March & 0.0809 & 0.115 & 13.6 & 13.6 & 0.17 & 0.17 & $<0.02$ & $<0.02$ & $<2.9$ & 4.3 \\
\hline April & 0.044 & 0.050 & 9.71 & 9.71 & $<0.15$ & $<0.15$ & $<0.02$ & $<0.02$ & $<1.4$ & $<1.4$ \\
\hline May & 0.032 & 0.036 & 7.75 & 7.75 & $<0.15$ & $<0.15$ & $<0.02$ & $<0.02$ & $<1.8$ & 2.2 \\
\hline June & 0.045 & 0.050 & 15.5 & 15.5 & $<0.15$ & $<0.15$ & $<0.02$ & $<0.02$ & $<1.4$ & $<1.4$ \\
\hline July & $<0.026$ & 0.032 & 10.9 & 10.9 & $<0.15$ & $<0.15$ & $<0.02$ & $<0.02$ & $<1.4$ & $<1.4$ \\
\hline August & 0.027 & 0.027 & 12.7 & 12.7 & $<0.15$ & $<0.15$ & $<0.02$ & $<0.02$ & $<1.4$ & $<1.4$ \\
\hline September $^{a}$ & -- & -- & -- & -- & -- & -- & -- & -- & -- & -- \\
\hline October & 0.077 & 0.11 & 17.1 & 17.1 & $<3.0$ & $<3.0$ & 0.037 & 0.037 & $<1.4$ & $<1.4$ \\
\hline November & 0.030 & 0.037 & 20.8 & 20.8 & $<0.15$ & $<0.15$ & 0.04 & 0.04 & $<1.4$ & $<1.4$ \\
\hline December & 0.079 & 0.13 & 18.7 & 18.7 & 0.47 & 0.47 & $<0.02$ & $<0.02$ & $<3.4$ & 5.4 \\
\hline
\end{tabular}

Note: No results exceeded the permit limits.

MGD - Million gallons per day.

${ }^{a}$ There was no discharge from outfall 007 during January and September 2012, and only one discharge in August 2012. 
TABLE B-2D (concluded)

2012 SPDES Results for Outfall 007 (WNSP007): Water Quality

\begin{tabular}{|c|c|c|c|c|c|c|c|c|c|c|}
\hline \multirow{3}{*}{$\begin{array}{l}\text { Permit Limit } \\
\text { Month } \\
\end{array}$} & \multirow{2}{*}{\multicolumn{2}{|c|}{\begin{tabular}{|c}
$p H$ \\
(standard units) \\
$\begin{array}{l}6.5 \text { to } 8.5 \\
\text { maximum }\end{array}$
\end{tabular}}} & \multirow{2}{*}{\multicolumn{2}{|c|}{$\begin{array}{c}\text { Solids } \\
\text { Settleable } \\
(\mathrm{mL} / \mathrm{L})\end{array}$}} & \multirow{2}{*}{\multicolumn{2}{|c|}{$\begin{array}{c}\text { Solids } \\
\text { Total Dissolved } \\
(\mathrm{mg} / \mathrm{L})\end{array}$}} & \multirow{2}{*}{\multicolumn{2}{|c|}{$\begin{array}{c}\text { Solids } \\
\text { Total Suspended } \\
\text { (mg/L) } \\
45 \mathrm{mg} / \mathrm{L} \text { daily } \\
\text { maximum }\end{array}$}} & \multirow{2}{*}{\multicolumn{2}{|c|}{$\begin{array}{c}\text { Ultimate Oxygen } \\
\text { Demand } \\
\text { (mg/L) } \\
22.0 \mathrm{mg} / \mathrm{L} \text { daily } \\
\text { maximum }\end{array}$}} \\
\hline & & & & & & & & & & \\
\hline & Min & $\operatorname{Max}$ & Avg & $\operatorname{Max}$ & Avg & $\operatorname{Max}$ & Avg & $\operatorname{Max}$ & Avg & $\operatorname{Max}$ \\
\hline January $^{a}$ & -- & -- & -- & -- & -- & -- & -- & -- & -- & -- \\
\hline February & 6.7 & 7.7 & $<0.1$ & $<0.1$ & 1240 & 1260 & $<4.0$ & $<4.0$ & $<4.44$ & $<4.44$ \\
\hline March & 7.5 & 8.0 & $<0.1$ & $<0.1$ & 959 & 1210 & $<4.0$ & $<4.0$ & 3.78 & 3.78 \\
\hline April & 7.9 & 8.1 & $<0.1$ & $<0.1$ & 828 & 944 & $<4.0$ & $<4.0$ & $<3.69$ & $<3.69$ \\
\hline May & 7.5 & 8.0 & $<0.1$ & $<0.1$ & 967 & 994 & $<4.0$ & $<4.0$ & $<3.69$ & $<3.69$ \\
\hline June & 7.5 & 7.7 & $<0.1$ & $<0.1$ & 989 & 1220 & $<4.0$ & $<4.0$ & $<3.69$ & $<3.69$ \\
\hline July & 7.3 & 7.5 & $<0.1$ & $<0.1$ & 691 & 778 & $<4.0$ & $<4.0$ & $<3.69$ & $<3.69$ \\
\hline August & 7.7 & 7.7 & $<0.1$ & $<0.1$ & 452 & 452 & $<4.0$ & $<4.0$ & $<3.69$ & $<3.69$ \\
\hline September ${ }^{a}$ & -- & -- & -- & -- & -- & -- & -- & -- & -- & -- \\
\hline October & 8.1 & 8.2 & $<0.1$ & $<0.1$ & 972 & 994 & $<4.0$ & $<4.0$ & $<16.7$ & $<16.7$ \\
\hline November & 6.8 & 6.8 & $<0.1$ & $<0.1$ & 628 & 730 & $<4.0$ & $<4.0$ & $<5.34$ & $<5.34$ \\
\hline December & 6.6 & 6.7 & $<0.1$ & $<0.1$ & 443 & 469 & $<4.0$ & $<4.0$ & 7.25 & 7.25 \\
\hline
\end{tabular}

Note: No results exceeded the permit limits.

a There was no discharge from outfall 007 during January and September 2012 and only one discharge in August 2012. 
TABLE B-2E

2012 SPDES Results for Sums of Outfalls 001, 007, and 116: Water Quality

\begin{tabular}{|l|c|c|}
\hline \multirow{2}{*}{ Permit Limit } & \multicolumn{2}{|c|}{$\begin{array}{c}\text { Iron Total }^{a} \\
\text { Net Effluent Limitation }\end{array}$} \\
\cline { 2 - 3 } & \multicolumn{2}{|c|}{$\begin{array}{c}\text { 1.0 } \text { mg/L } \\
\text { daily maximum }\end{array}$} \\
\hline Month & Avg & Max \\
\hline January & 0.00 & 0.00 \\
\hline February & 0.20 & 0.20 \\
\hline March & 0.01 & 0.01 \\
\hline April & 0.00 & 0.00 \\
\hline May & 0.33 & 0.33 \\
\hline June & 0.00 & 0.00 \\
\hline July & $<0.86$ & $<0.86$ \\
\hline August & 0.00 & 0.00 \\
\hline September & 0.00 & 0.00 \\
\hline October & 0.00 & 0.00 \\
\hline November & 0.23 & 0.23 \\
\hline December & 0.00 & 0.00 \\
\hline
\end{tabular}

${ }^{\mathrm{a}}$ Sum of Outfalls 001 and 007.

\begin{tabular}{|l|c|c|}
\hline \multirow{2}{*}{ Permit Limit } & \multicolumn{2}{|c|}{$\begin{array}{c}\text { Total Dissolved Solids } \\
\text { (mg/L) }\end{array}$} \\
\cline { 2 - 3 } & \multicolumn{2}{|c|}{$\begin{array}{c}\text { 500 mg/L daily } \\
\text { maximum }\end{array}$} \\
\hline Month & Avg & Max \\
\hline January $^{c}$ & -- & -- \\
\hline February $^{*}$ & 336 & 387 \\
\hline March $^{c}$ & 317 & 336 \\
\hline April $^{c}$ & -- & -- \\
\hline May $^{c}$ & 355 & 386 \\
\hline June $^{c}$ & -- & -- \\
\hline July $^{*}$ & 469 & 471 \\
\hline August $^{c}$ & -- & -- \\
\hline September $^{c}$ & -- & -- \\
\hline October $^{c}$ & -- & -- \\
\hline November $^{c}$ & 305 & 317 \\
\hline December $^{c}$ & -- & -- \\
\hline
\end{tabular}

${ }^{\mathrm{b}}$ Outfall 116 only.

c There was no discharge from outfall 001 during this month in 2012, therefore, a calculated TDS at 116 is not required. 
TABLE B-2F

2012 Annual and Semiannual SPDES Results for Outfall 001:

Metals, Water Quality and Organic Compounds

\begin{tabular}{|c|c|c|c|c|}
\hline Permit Limit Parameters & Permit Limit & $\begin{array}{l}\text { Monitoring } \\
\text { Frequency }\end{array}$ & $\begin{array}{c}\text { Sample } \\
\text { Date }\end{array}$ & $\begin{array}{l}\text { Maximum } \\
\text { Measured }\end{array}$ \\
\hline 2-Butanone & $\begin{array}{c}0.5 \mathrm{mg} / \mathrm{L} \\
\text { daily maximum }\end{array}$ & Annual & March 2012 & $<0.002$ \\
\hline 3,3-Dichlorobenzidine & $\begin{array}{c}0.01 \mathrm{mg} / \mathrm{L} \\
\text { daily maximum }\end{array}$ & Annual & March 2012 & $<0.0008$ \\
\hline Alpha-BHC & $\begin{array}{c}0.01 \mathrm{ug} / \mathrm{L} \\
\text { daily maximum }\end{array}$ & Annual & March 2012 & $<0.007$ \\
\hline Cadmium, Total Recoverable & $\begin{array}{c}0.002 \mathrm{mg} / \mathrm{L} \\
\text { daily maximum }\end{array}$ & Annual & March 2012 & $<0.00002$ \\
\hline Chromium VI, Total Recoverable & $\begin{array}{c}0.011 \mathrm{mg} / \mathrm{L} \\
\text { daily maximum }\end{array}$ & Annual & March 2012 & 0.0061 \\
\hline Chromium, Total Recoverable & $\begin{array}{c}0.11 \mathrm{mg} / \mathrm{L} \\
\text { daily maximum }\end{array}$ & Semiannual & $\begin{array}{c}\text { February } 2012 \\
\text { July } 2012\end{array}$ & $\begin{array}{l}0.0015 \\
0.0015\end{array}$ \\
\hline Copper, Total Recoverable & $\begin{array}{c}0.014 \mathrm{mg} / \mathrm{L} \\
\text { daily maximum }\end{array}$ & Semiannual & $\begin{array}{c}\text { February } 2012 \\
\text { July } 2012\end{array}$ & $\begin{array}{l}0.0068 \\
0.0043 \\
\end{array}$ \\
\hline Cyanide, Amenable to chlorination & $\begin{array}{c}0.005 \mathrm{mg} / \mathrm{L} \\
\text { daily maximum }\end{array}$ & Semiannual & $\begin{array}{c}\text { February } 2012 \\
\text { July } 2012 \\
\end{array}$ & $\begin{array}{l}<0.005 \\
<0.005\end{array}$ \\
\hline Dichlorodifluoromethane & $\begin{array}{c}0.01 \mathrm{mg} / \mathrm{L} \\
\text { daily maximum }\end{array}$ & Annual & February 2012 & $<0.0003$ \\
\hline Heptachlor & $\begin{array}{c}0.01 \mathrm{ug} / \mathrm{L} \\
\text { daily maximum }\end{array}$ & Semiannual & $\begin{array}{c}\text { February } 2012 \\
\text { July } 2012\end{array}$ & $\begin{array}{l}<0.006 \\
<0.007\end{array}$ \\
\hline Hexachlorobenzene & $\begin{array}{c}0.2 \mathrm{ug} / \mathrm{L} \\
\text { daily maximum }\end{array}$ & Annual & February 2012 & $<0.01$ \\
\hline Lead, Total Recoverable & $\begin{array}{c}0.006 \mathrm{mg} / \mathrm{L} \\
\text { daily maximum }\end{array}$ & Semiannual & $\begin{array}{c}\text { February } 2012 \\
\text { July } 2012\end{array}$ & $\begin{array}{l}0.003 \\
0.002 \\
\end{array}$ \\
\hline Manganese, Total & $\begin{array}{c}2.0 \mathrm{mg} / \mathrm{L} \\
\text { daily maximum }\end{array}$ & Semiannual & $\begin{array}{c}\text { February } 2012 \\
\text { July } 2012\end{array}$ & $\begin{array}{c}0.023 \\
0.20\end{array}$ \\
\hline Nickel, Total & $\begin{array}{c}0.079 \mathrm{mg} / \mathrm{L} \\
\text { daily maximum }\end{array}$ & Semiannual & $\begin{array}{c}\text { February } 2012 \\
\text { July } 2012 \\
\end{array}$ & $\begin{array}{l}0.0033 \\
0.0048 \\
\end{array}$ \\
\hline Tributyl phosphate & $\begin{array}{c}0.1 \mathrm{mg} / \mathrm{L} \\
\text { daily maximum }\end{array}$ & Annual & March 2011 & $<0.0008$ \\
\hline Trichlorofluoromethane & $\begin{array}{c}0.01 \mathrm{mg} / \mathrm{L} \\
\text { daily maximum }\end{array}$ & Annual & March 2012 & $<0.0005$ \\
\hline Xylene & $\begin{array}{c}0.05 \mathrm{mg} / \mathrm{L} \\
\text { daily maximum }\end{array}$ & Annual & March 2012 & $<0.001$ \\
\hline Zinc, Total Recoverable & $\begin{array}{c}0.13 \mathrm{mg} / \mathrm{L} \\
\text { daily maximum }\end{array}$ & Semiannual & $\begin{array}{c}\text { February } 2012 \\
\text { July } 2012\end{array}$ & $\begin{array}{c}0.011 \\
0.0074\end{array}$ \\
\hline
\end{tabular}


TABLE B-2G

2012 SPDES Action Level Requirement Monitoring Results for Outfalls 001 and 007 Metals and Water Quality

\begin{tabular}{|c|c|c|c|c|c|}
\hline Outfall & $\begin{array}{l}\text { Action Level } \\
\text { Parameters }\end{array}$ & Action Level & $\begin{array}{l}\text { Monitoring } \\
\text { Frequency }\end{array}$ & $\begin{array}{c}\text { Sampling } \\
\text { Date }\end{array}$ & $\begin{array}{c}\text { Maximum } \\
\text { Measured }(\mathrm{mg} / \mathrm{L})\end{array}$ \\
\hline \multirow{6}{*}{001} & Antimony, Total & $\begin{array}{c}1.0 \mathrm{mg} / \mathrm{L} \text { daily } \\
\text { maximum }\end{array}$ & Annual & March 2012 & $<0.0068$ \\
\hline & Barium, Total & $\begin{array}{c}0.5 \mathrm{mg} / \mathrm{L} \text { daily } \\
\text { maximum }\end{array}$ & Annual & March 2012 & 0.01 \\
\hline & Boron, Total & $\begin{array}{c}2.0 \mathrm{mg} / \mathrm{L} \text { daily } \\
\text { maximum }\end{array}$ & Semiannual & $\begin{array}{c}\text { February } 2012 \\
\text { July } 2012 \\
\end{array}$ & $\begin{array}{l}0.058 \\
0.047 \\
\end{array}$ \\
\hline & Bromide, Total & $\begin{array}{l}5.0 \mathrm{mg} / \mathrm{L} \text { daily } \\
\text { maximum }\end{array}$ & Semiannual & $\begin{array}{c}\text { February } 2012 \\
\text { July } 2012 \\
\end{array}$ & $\begin{array}{l}0.28 \\
0.52 \\
\end{array}$ \\
\hline & Chloroform & $\begin{array}{c}0.3 \mathrm{mg} / \mathrm{L} \text { daily } \\
\text { maximum }\end{array}$ & Annual & March 2012 & $<0.0005$ \\
\hline & Titanium, Total & $\begin{array}{c}0.65 \mathrm{mg} / \mathrm{L} \text { daily } \\
\text { maximum }\end{array}$ & Semiannual & $\begin{array}{c}\text { February } 2012 \\
\text { July } 2012 \\
\end{array}$ & $\begin{array}{l}0.0062 \\
0.0063 \\
\end{array}$ \\
\hline 007 & Chloroform & $\begin{array}{c}0.3 \mathrm{mg} / \mathrm{L} \text { daily } \\
\text { maximum }\end{array}$ & Annual & July 2012 & 0.06 \\
\hline
\end{tabular}

TABLE B-2H

2012 SPDES Results for Outfall 01B (WNSP01B): Water Quality

Internal process monitoring point did not operate during 2012 
TABLE B-2I

2012 PARAQUAT DICHLORIDE ${ }^{a}$ Data for Storm Water Discharge Monitoring

Sampling for herbicides was not required in 2012.

${ }^{a}$ The site did not apply any of the herbicide Paraquat Dichloride at the WVDP in 2012. Therefore, in accordance with the SPDES permit, no sampling from the drainage basins potentially affected by the application of herbicide is required.

TABLE B-2J

2012 Radioactivity Results for Sewage Treatment Outfall (WNSP007)

\begin{tabular}{|c|c|c|c|c|c|c|}
\hline \multirow{2}{*}{ Isotope $^{a}$} & \multirow{2}{*}{$N^{b}$} & \multicolumn{2}{|c|}{ Discharge Activity ${ }^{b}$} & \multirow{2}{*}{$\begin{array}{c}\text { Average } \\
\text { Concentration } \\
(\mu \mathrm{Ci} / \mathrm{mL})\end{array}$} & \multirow{2}{*}{$\begin{array}{c}D C S \\
(\mu \mathrm{Ci} / \mathrm{mL})\end{array}$} & \multirow{2}{*}{$\begin{array}{c}\text { Ratio of } \\
\text { Concentration } \\
\text { to DCS }\end{array}$} \\
\hline & & (Ci) & (Becquerels) $^{c}$ & & & \\
\hline Gross Alpha & 10 & $3.34 \pm 5.69 \mathrm{E}-06$ & $1.24 \pm 2.10 \mathrm{E}+05$ & $0.73 \pm 1.25 \mathrm{E}-09$ & $N A^{e}$ & NA \\
\hline Gross Beta & 10 & $7.38 \pm 0.50 \mathrm{E}-05$ & $2.73 \pm 0.19 \mathrm{E}+06$ & $1.62 \pm 0.11 \mathrm{E}-08$ & $N A^{e}$ & NA \\
\hline Tritium & 10 & $1.19 \pm 1.37 \mathrm{E}-04$ & $4.39 \pm 5.08 \mathrm{E}+06$ & $2.60 \pm 3.01 \mathrm{E}-08$ & $1.9 \mathrm{E}-03$ & $<0.00002$ \\
\hline Sr-90 & 1 & $4.69 \pm 5.38 \mathrm{E}-06$ & $1.74 \pm 1.99 \mathrm{E}+05$ & $1.03 \pm 1.18 \mathrm{E}-09$ & $1.1 \mathrm{E}-06$ & $<0.0011$ \\
\hline Cs-137 & 1 & $0.00 \pm 1.74 \mathrm{E}-05$ & $0.00 \pm 6.44 \mathrm{E}+05$ & $0.00 \pm 3.82 \mathrm{E}-09$ & $3.0 \mathrm{E}-06$ & $<0.0013$ \\
\hline \multicolumn{6}{|l|}{ Sum of Ratios } & $<0.0024$ \\
\hline
\end{tabular}

$\mathrm{N}$-Number of samples.

NA - Not applicable.

${ }^{\text {a }}$ Half-lives are listed in Table UI-4.

${ }^{\mathrm{b}}$ Discharge from the sewage treatment outfall was discontinued and secured in October, 2011 due to a mercury permit exceedence. Discharge from the outfall was restarted on February 14, 2012. There are ten samples because there was also no discharge in September 2012.

${ }^{\mathrm{C}}$ Total volume released; $1.20 \mathrm{E}+06 \mathrm{gal},(4.56 \mathrm{E}+09 \mathrm{~mL})$.

${ }^{\mathrm{d}} 1$ curie $(\mathrm{Ci})=3.7 \mathrm{E}+10$ becquerels $(\mathrm{Bq}) ; 1 \mathrm{~Bq}=2.7 \mathrm{E}-11 \mathrm{Ci}$.

${ }^{\mathrm{e}} \mathrm{DOE}$ derived concentration standards (DCSs) do not exist for indicator parameters gross alpha and beta. 
This page intentionally left blank 


\section{APPENDIX B-3}

\section{SPDES-Permitted Storm Water Outfall Discharge Data}

TABLE B-3A

2012 Storm Water Discharge Monitoring Data for Outfall Group 1

STORM WATER OUTFALL SO4

\begin{tabular}{|c|c|c|c|c|}
\hline \multirow[t]{2}{*}{ Analyte } & \multirow[t]{2}{*}{ Units } & \multirow[t]{2}{*}{$N$} & \multirow{2}{*}{$\begin{array}{c}\text { First Flush Grab } \\
03 / 08 / 12\end{array}$} & \multirow{2}{*}{$\begin{array}{c}\begin{array}{c}\text { Flow-weighteo } \\
\text { Composite }\end{array} \\
03 / 08 / 12 \\
\end{array}$} \\
\hline & & & & \\
\hline Aluminum, Total & $\mathrm{mg} / \mathrm{L}$ & 2 & 1.7 & 0.49 \\
\hline Ammonia (as $\mathrm{NH}_{3}$ ) & $\mathrm{mg} / \mathrm{L}$ & 2 & $<0.0090$ & 0.020 \\
\hline $\mathrm{BOD}_{5}$ & $\mathrm{mg} / \mathrm{L}$ & 2 & $<2.0$ & $<2.0$ \\
\hline Cadmium, Total Recoverable & $\mathrm{mg} / \mathrm{L}$ & 2 & $<0.000018$ & $<0.000090$ \\
\hline Chromium, Total Recoverable & $\mathrm{mg} / \mathrm{L}$ & 2 & 0.0012 & $<0.0010$ \\
\hline Chromium, Hexavalent, Total Recoverable & $\mathrm{mg} / \mathrm{L}$ & 2 & $<0.0050$ & $<0.0050$ \\
\hline Copper, Total Recoverable & $\mathrm{mg} / \mathrm{L}$ & 2 & 0.011 & 0.020 \\
\hline Iron, Total & $\mathrm{mg} / \mathrm{L}$ & 2 & 3.7 & 0.58 \\
\hline Lead, Total Recoverable & $\mathrm{mg} / \mathrm{L}$ & 2 & 0.0040 & 0.0017 \\
\hline Nitrogen, Nitrate (as N) & $\mathrm{mg} / \mathrm{L}$ & 2 & 0.47 & 0.22 \\
\hline Nitrogen, Nitrite (as N) & $\mathrm{mg} / \mathrm{L}$ & 2 & $<0.020$ & $<0.020$ \\
\hline Nitrogen, Total (as N) & $\mathrm{mg} / \mathrm{L}$ & 2 & $<0.82$ & $<1.0$ \\
\hline Nitrogen, Total Kjeldahl & $\mathrm{mg} / \mathrm{L}$ & 2 & 0.33 & 0.80 \\
\hline Oil \& Grease $^{a}$ & $\mathrm{mg} / \mathrm{L}$ & 1 & 11.5 & NR \\
\hline $\mathrm{pH}$ & SU & 1 & 8.0 & NR \\
\hline Phosphorous, Total & $\mathrm{mg} / \mathrm{L}$ & 2 & 0.11 & 0.056 \\
\hline Selenium, Total Recoverable & $\mathrm{mg} / \mathrm{L}$ & 2 & $<0.00044$ & $<0.00044$ \\
\hline Solids, Total Dissolved & $\mathrm{mg} / \mathrm{L}$ & 2 & 1710 & 4620 \\
\hline Solids, Total Suspended & $\mathrm{mg} / \mathrm{L}$ & 2 & 120 & 18 \\
\hline Vanadium, Total Recoverable & $\mathrm{mg} / \mathrm{L}$ & 2 & 0.0027 & $<0.0015$ \\
\hline Zinc, Total Recoverable & $\mathrm{mg} / \mathrm{L}$ & 2 & 0.039 & 0.016 \\
\hline \multicolumn{5}{|c|}{ Rain Event Summary } \\
\hline pH of Rainfall During Sampling Event & SU & 1 & \multicolumn{2}{|c|}{7.0} \\
\hline Rainfall During Sampling Event & inches & -- & \multicolumn{2}{|c|}{0.18} \\
\hline Total Flow During Sampling Event & gallons & -- & \multicolumn{2}{|c|}{220,000} \\
\hline Maximum Flow Rate During Sampling Event & gpm & -- & \multicolumn{2}{|c|}{1,400} \\
\hline
\end{tabular}

gpm - gallons per minute.

$\mathrm{N}$ - Number of samples.

NR - Not required by permit.

${ }^{a}$ The SPDES permit specifies that oil and grease concentration shall not exceed $15 \mathrm{mg} / \mathrm{L}$. 
TABLE B-3A (concluded)

2012 Storm Water Discharge Monitoring Data for Outfall Group 1

STORM WATER OUTFALL SO4

\begin{tabular}{|c|c|c|c|c|}
\hline \multirow[t]{2}{*}{ Analyte } & \multirow[t]{2}{*}{ Units } & \multirow[t]{2}{*}{$N$} & \multirow{2}{*}{$\begin{array}{c}\text { First Flush Grab } \\
10 / 23 / 12\end{array}$} & \multirow{2}{*}{$\begin{array}{c}\begin{array}{c}\text { Flow-weighted } \\
\text { Composite }\end{array} \\
10 / 23 / 12 \\
\end{array}$} \\
\hline & & & & \\
\hline Aluminum, Total & $\mathrm{mg} / \mathrm{L}$ & 3 & $0.31 / 0.41$ & 0.74 \\
\hline Ammonia (as $\mathrm{NH}_{3}$ ) & $\mathrm{mg} / \mathrm{L}$ & 3 & $<0.009 /<0.009$ & $<0.009$ \\
\hline $\mathrm{BOD}_{5}$ & $\mathrm{mg} / \mathrm{L}$ & 3 & $<2.0 /<2.0$ & 2.2 \\
\hline Cadmium, Total Recoverable & $\mathrm{mg} / \mathrm{L}$ & 3 & $<0.000018 /<0.000027$ & $<0.000095$ \\
\hline \begin{tabular}{|l} 
Chromium, Total Recoverable \\
\end{tabular} & $\mathrm{mg} / \mathrm{L}$ & 3 & $0.00052 / 0.00057$ & 0.00098 \\
\hline Chromium, Hexavalent, Total Recoverable & $\mathrm{mg} / \mathrm{L}$ & 3 & $0.0051 /<0.005$ & $<0.005$ \\
\hline Copper, Total Recoverable & $\mathrm{mg} / \mathrm{L}$ & 3 & $0.0014 / 0.0014$ & 0.0023 \\
\hline Iron, Total & $\mathrm{mg} / \mathrm{L}$ & 3 & $0.35 / 0.50$ & 0.92 \\
\hline Lead, Total Recoverable & $\mathrm{mg} / \mathrm{L}$ & 3 & $0.0010 / 0.0012$ & 0.0013 \\
\hline Nitrogen, Nitrate (as N) & $\mathrm{mg} / \mathrm{L}$ & 3 & $<0.011 / 0.12$ & 0.089 \\
\hline Nitrogen, Nitrite (as N) & $\mathrm{mg} / \mathrm{L}$ & 3 & $<0.020 /<0.020$ & $<0.020$ \\
\hline Nitrogen, Total (as N) & $\mathrm{mg} / \mathrm{L}$ & 3 & $<0.30 /<0.36$ & $<0.53$ \\
\hline Nitrogen, Total Kjeldahl & $\mathrm{mg} / \mathrm{L}$ & 3 & $0.27 / 0.22$ & 0.42 \\
\hline Oil \& Grease ${ }^{a}$ & $\mathrm{mg} / \mathrm{L}$ & 2 & $<1.4 /<1.4$ & NR \\
\hline $\mathrm{pH}$ & SU & 1 & 7.1 & NR \\
\hline Phosphorous, Total & $\mathrm{mg} / \mathrm{L}$ & 3 & $0.098 / 0.033$ & 0.022 \\
\hline Selenium, Total Recoverable & $\mathrm{mg} / \mathrm{L}$ & 3 & $<0.00044 /<0.00044$ & $<0.00044$ \\
\hline Solids, Total Dissolved & $\mathrm{mg} / \mathrm{L}$ & 3 & $352 / 354$ & 195 \\
\hline Solids, Total Suspended & $\mathrm{mg} / \mathrm{L}$ & 3 & $7.6 / 8.0$ & 21 \\
\hline Vanadium, Total Recoverable & $\mathrm{mg} / \mathrm{L}$ & 3 & $0.00034 / 0.00035$ & 0.0013 \\
\hline Zinc, Total Recoverable & $\mathrm{mg} / \mathrm{L}$ & 3 & $0.0058 / 0.0080$ & 0.012 \\
\hline \multicolumn{5}{|c|}{ Rain Event Summary } \\
\hline pH of Rainfall During Sampling Event & SU & 1 & \multicolumn{2}{|c|}{6.1} \\
\hline Rainfall During Sampling Event & inches & -- & \multicolumn{2}{|c|}{0.89} \\
\hline Total Flow During Sampling Event & gallons & -- & \multicolumn{2}{|c|}{$1,300,000$} \\
\hline Maximum Flow Rate During Sampling Event & gpm & -- & \multicolumn{2}{|c|}{13,000} \\
\hline
\end{tabular}

Note: The first flush grab samples were sampled and analyzed in duplicate.

gpm - gallons per minute.

$\mathrm{N}$ - Number of samples.

NR - Not required by permit.

${ }^{a}$ The SPDES permit specifies that oil and grease concentration shall not exceed $15 \mathrm{mg} / \mathrm{L}$. 
TABLE B-3B

2012 Storm Water Discharge Monitoring Data for Outfall Group 2

STORM WATER OUTFALL S06

\begin{tabular}{|c|c|c|c|c|}
\hline \multirow[t]{2}{*}{ Analyte } & \multirow[t]{2}{*}{ Units } & \multirow[t]{2}{*}{$N$} & \multirow{2}{*}{$\begin{array}{c}\text { First Flush Grab } \\
05 / 08 / 12\end{array}$} & \multirow{2}{*}{$\begin{array}{c}\text { Flow-weighteo } \\
\text { Composite }\end{array}$} \\
\hline & & & & \\
\hline Aluminum, Total & $\mathrm{mg} / \mathrm{L}$ & 2 & $<0.068$ & 0.20 \\
\hline $\mathrm{BOD}_{5}$ & $\mathrm{mg} / \mathrm{L}$ & 2 & 9.2 & 18 \\
\hline Copper, Total Recoverable & $\mathrm{mg} / \mathrm{L}$ & 2 & 0.00056 & 0.00095 \\
\hline Iron, Total & $\mathrm{mg} / \mathrm{L}$ & 2 & 0.15 & 2.2 \\
\hline Lead, Total Recoverable & $\mathrm{mg} / \mathrm{L}$ & 2 & $<0.00050$ & $<0.00050$ \\
\hline Oil \& Grease $^{a}$ & $\mathrm{mg} / \mathrm{L}$ & 1 & $<1.5$ & NR \\
\hline $\mathrm{pH}$ & SU & 1 & 6.8 & NR \\
\hline Phosphorous, Total & $\mathrm{mg} / \mathrm{L}$ & 2 & 0.062 & 0.059 \\
\hline Solids, Total Dissolved & $\mathrm{mg} / \mathrm{L}$ & 2 & 451 & 541 \\
\hline Solids, Total Suspended & $\mathrm{mg} / \mathrm{L}$ & 2 & $<2.3$ & 8.5 \\
\hline Surfactant (as LAS) & $\mathrm{mg} / \mathrm{L}$ & 2 & $<0.016$ & $<0.016$ \\
\hline Zinc, Total Recoverable & $\mathrm{mg} / \mathrm{L}$ & 2 & 0.0058 & 0.013 \\
\hline \multicolumn{5}{|c|}{ Rain Event Summary } \\
\hline pH of Rainfall During Sampling Event & SU & 1 & \multicolumn{2}{|c|}{7.7} \\
\hline Rainfall During Sampling Event & inches & -- & \multicolumn{2}{|c|}{0.51} \\
\hline Total Flow During Sampling Event & gallons & -- & \multicolumn{2}{|c|}{20,000} \\
\hline Maximum Flow Rate During Sampling Event & gpm & -- & \multicolumn{2}{|c|}{170} \\
\hline
\end{tabular}

gpm - gallons per minute.

$\mathrm{N}$ - Number of samples.

NR - Not required by permit.

${ }^{a}$ The SPDES permit specifies that oil and grease concentration shall not exceed $15 \mathrm{mg} / \mathrm{L}$. 
TABLE B-3B (concluded)

2012 Storm Water Discharge Monitoring Data for Outfall Group 2

STORM WATER OUTFALL S33

\begin{tabular}{|c|c|c|c|c|}
\hline \multirow[t]{2}{*}{ Analyte } & \multirow[t]{2}{*}{ Units } & \multirow[t]{2}{*}{$N$} & \multirow{2}{*}{$\begin{array}{c}\text { First Flush Grab } \\
10 / 23 / 12\end{array}$} & \multirow{2}{*}{$\begin{array}{c}\text { Flow-weighted } \\
\text { Composite }\end{array}$} \\
\hline & & & & \\
\hline Aluminum, Total & $\mathrm{mg} / \mathrm{L}$ & 2 & 0.12 & 0.096 \\
\hline $\mathrm{BOD}_{5}$ & $\mathrm{mg} / \mathrm{L}$ & 2 & 2.1 & 2.1 \\
\hline Copper, Total Recoverable & $\mathrm{mg} / \mathrm{L}$ & 2 & 0.00085 & 0.00071 \\
\hline Iron, Total & $\mathrm{mg} / \mathrm{L}$ & 2 & 2.6 & 1.6 \\
\hline Lead, Total Recoverable & $\mathrm{mg} / \mathrm{L}$ & 2 & 0.00023 & 0.00013 \\
\hline Oil \& Grease ${ }^{a}$ & $\mathrm{mg} / \mathrm{L}$ & 1 & $<1.4$ & NR \\
\hline $\mathrm{pH}$ & SU & 1 & 7.1 & NR \\
\hline Phosphorous, Total & $\mathrm{mg} / \mathrm{L}$ & 2 & 0.14 & 0.047 \\
\hline Solids, Total Dissolved & $\mathrm{mg} / \mathrm{L}$ & 2 & 313 & 280 \\
\hline Solids, Total Suspended & $\mathrm{mg} / \mathrm{L}$ & 2 & 14 & 6.0 \\
\hline Surfactant (as LAS) & $\mathrm{mg} / \mathrm{L}$ & 2 & 0.031 & $<0.013$ \\
\hline Zinc, Total Recoverable & $\mathrm{mg} / \mathrm{L}$ & 2 & 0.0052 & 0.0032 \\
\hline \multicolumn{5}{|c|}{ Rain Event Summary } \\
\hline pH of Rainfall During Sampling Event & SU & 1 & \multicolumn{2}{|c|}{6.1} \\
\hline Rainfall During Sampling Event & inches & -- & \multicolumn{2}{|c|}{0.90} \\
\hline Total Flow During Sampling Event & gallons & -- & \multicolumn{2}{|c|}{250,000} \\
\hline Maximum Flow Rate During Sampling Event & gpm & -- & \multicolumn{2}{|c|}{1,800} \\
\hline
\end{tabular}

gpm - gallons per minute.

$\mathrm{N}$ - Number of samples.

NR - Not required by permit.

${ }^{\mathrm{a}}$ The SPDES permit specifies that oil and grease concentration shall not exceed $15 \mathrm{mg} / \mathrm{L}$. 
TABLE B-3C

2012 Storm Water Discharge Monitoring Data for Outfall Group 3

STORM WATER OUTFALL S12

\begin{tabular}{|c|c|c|c|c|}
\hline \multirow[t]{2}{*}{ Analyte } & \multirow[t]{2}{*}{ Units } & \multirow[t]{2}{*}{$N$} & \multirow{2}{*}{$\begin{array}{c}\text { First Flush Grab } \\
05 / 08 / 12\end{array}$} & \multirow{2}{*}{$\begin{array}{c}\text { Flow-weighted } \\
\text { Composite }\end{array}$} \\
\hline & & & & \\
\hline Alpha-BHC & $\mathrm{mg} / \mathrm{L}$ & 3 & $\begin{array}{l}<0.0000067 \\
<0.0000067\end{array}$ & $<0.0000067$ \\
\hline Aluminum, Total & $\mathrm{mg} / \mathrm{L}$ & 3 & $3.3 / 3.3$ & 3.9 \\
\hline Ammonia (as $\mathrm{NH}_{3}$ ) & $\mathrm{mg} / \mathrm{L}$ & 3 & $0.034 / 0.035$ & 0.030 \\
\hline $\mathrm{BOD}_{5}$ & $\mathrm{mg} / \mathrm{L}$ & 3 & $<2.0 /<2.0$ & $<2.0$ \\
\hline Copper, Total Recoverable & $\mathrm{mg} / \mathrm{L}$ & 3 & $0.013 / 0.011$ & 0.011 \\
\hline Iron, Total & $\mathrm{mg} / \mathrm{L}$ & 3 & $4.2 / 4.3$ & 5.1 \\
\hline Lead, Total Recoverable & $\mathrm{mg} / \mathrm{L}$ & 3 & $0.0045 / 0.0042$ & 0.0054 \\
\hline Mercury, Total $^{\mathrm{a}}$ (1631E) & $\mathrm{ng} / \mathrm{L}$ & 1 & 45.7 & NR \\
\hline Nitrogen, Nitrate (as N) & $\mathrm{mg} / \mathrm{L}$ & 3 & $0.14 / 0.16$ & 0.012 \\
\hline Nitrogen, Nitrite (as N) & $\mathrm{mg} / \mathrm{L}$ & 3 & $0.051 / 0.048$ & 0.046 \\
\hline Nitrogen, Total (as N) & $\mathrm{mg} / \mathrm{L}$ & 3 & $0.55 / 0.39$ & 0.41 \\
\hline Nitrogen, Total Kjeldahl & $\mathrm{mg} / \mathrm{L}$ & 3 & $0.36 / 0.18$ & 0.35 \\
\hline Oil \& Grease & $\mathrm{mg} / \mathrm{L}$ & 2 & $<1.4 /<1.4$ & NR \\
\hline $\mathrm{pH}$ & SU & 2 & $6.5 / 6.5$ & NR \\
\hline Phosphorous, Total & $\mathrm{mg} / \mathrm{L}$ & 3 & $0.31 / 0.26$ & 0.27 \\
\hline Solids, Total Dissolved & $\mathrm{mg} / \mathrm{L}$ & 3 & $185 / 201$ & 271 \\
\hline Solids, Total Suspended & $\mathrm{mg} / \mathrm{L}$ & 3 & $124 / 125$ & 140 \\
\hline Zinc, Total Recoverable & $\mathrm{mg} / \mathrm{L}$ & 3 & $0.058 / 0.054$ & 0.051 \\
\hline \multicolumn{5}{|c|}{ Rain Event Summary } \\
\hline $\mathrm{pH}$ of Rainfall During Sampling Event & SU & 1 & \multicolumn{2}{|c|}{7.7} \\
\hline Rainfall During Sampling Event & inches & -- & \multicolumn{2}{|c|}{0.51} \\
\hline Total Flow During Sampling Event & gallons & -- & \multicolumn{2}{|c|}{60,000} \\
\hline Maximum Flow Rate During Sampling Event & gpm & -- & \multicolumn{2}{|c|}{660} \\
\hline
\end{tabular}

Note: The first flush grab samples were sampled and analyzed in duplicate.

gpm - gallons per minute.

$\mathrm{N}$ - Number of samples.

NR - Not required by permit.

${ }^{a}$ The SPDES permit requires that Group 3 outfalls be analyzed for mercury as part of the Mercury Minimization Program.

${ }^{b}$ The SPDES permit specifies that oil and grease concentration shall not exceed $15 \mathrm{mg} / \mathrm{L}$. 
TABLE B-3C (concluded)

2012 Storm Water Discharge Monitoring Data for Outfall Group 3

STORM WATER OUTFALL SO9

\begin{tabular}{|c|c|c|c|c|}
\hline \multirow[t]{2}{*}{ Analyte } & \multirow[t]{2}{*}{ Units } & \multirow[t]{2}{*}{$\mathbf{N}$} & \multirow{2}{*}{$\begin{array}{c}\text { First Flush Grab } \\
11 / 12 / 12\end{array}$} & \multirow{2}{*}{$\begin{array}{c}\text { Flow-weighted } \\
\text { Composite }\end{array}$} \\
\hline & & & & \\
\hline Alpha-BHC & $\mathrm{mg} / \mathrm{L}$ & 2 & $<0.0000067$ & $<0.0000067$ \\
\hline Aluminum, Total & $\mathrm{mg} / \mathrm{L}$ & 2 & 4.9 & 10 \\
\hline Ammonia (as $\mathrm{NH}_{3}$ ) & $\mathrm{mg} / \mathrm{L}$ & 2 & 0.30 & 0.11 \\
\hline $\mathrm{BOD}_{5}$ & $\mathrm{mg} / \mathrm{L}$ & 2 & 6.8 & 3.5 \\
\hline Copper, Total Recoverable & $\mathrm{mg} / \mathrm{L}$ & 2 & 0.015 & 0.015 \\
\hline Iron, Total & $\mathrm{mg} / \mathrm{L}$ & 2 & 5.5 & 11 \\
\hline Lead, Total Recoverable & $\mathrm{mg} / \mathrm{L}$ & 2 & 0.0065 & 0.0061 \\
\hline Mercury, Total ${ }^{\mathrm{a}}$ (1631E) & $\mathrm{ng} / \mathrm{L}$ & 1 & 14.0 & NR \\
\hline Nitrogen, Nitrate (as N) & $\mathrm{mg} / \mathrm{L}$ & 2 & 0.84 & 0.40 \\
\hline Nitrogen, Nitrite (as N) & $\mathrm{mg} / \mathrm{L}$ & 2 & $<0.020$ & $<0.020$ \\
\hline Nitrogen, Total (as N) & $\mathrm{mg} / \mathrm{L}$ & 2 & $<2.1$ & $<1.0$ \\
\hline Nitrogen, Total Kjeldahl & $\mathrm{mg} / \mathrm{L}$ & 2 & 1.2 & 0.59 \\
\hline Oil \& Grease ${ }^{b}$ & $\mathrm{mg} / \mathrm{L}$ & 1 & $<1.4$ & NR \\
\hline $\mathrm{pH}$ & SU & 1 & 8.7 & NR \\
\hline Phosphorous, Total & $\mathrm{mg} / \mathrm{L}$ & 2 & 0.13 & 0.12 \\
\hline Solids, Total Dissolved & $\mathrm{mg} / \mathrm{L}$ & 2 & 567 & 77 \\
\hline Solids, Total Suspended & $\mathrm{mg} / \mathrm{L}$ & 2 & 163 & 165 \\
\hline Zinc, Total Recoverable & $\mathrm{mg} / \mathrm{L}$ & 2 & 0.18 & 0.094 \\
\hline \multicolumn{5}{|c|}{ Rain Event Summary } \\
\hline pH of Rainfall During Sampling Event & SU & 1 & \multicolumn{2}{|c|}{7.4} \\
\hline Rainfall During Sampling Event & inches & -- & \multicolumn{2}{|c|}{0.56} \\
\hline Total Flow During Sampling Event & gallons & -- & \multicolumn{2}{|c|}{120,000} \\
\hline Maximum Flow Rate During Sampling Event & gpm & -- & \multicolumn{2}{|c|}{1,200} \\
\hline
\end{tabular}

gpm - gallons per minute.

$\mathrm{N}$ - Number of samples.

NR - Not required by permit.

${ }^{a}$ The SPDES permit requires that Group 3 outfalls be analyzed for mercury as part of the Mercury Minimization Program.

${ }^{\mathrm{b}}$ The SPDES permit specifies that oil and grease concentration shall not exceed $15 \mathrm{mg} / \mathrm{L}$. 
TABLE B-3D

2012 Storm Water Discharge Monitoring Data for Outfall Group 4

STORM WATER OUTFALL S34

\begin{tabular}{|c|c|c|c|c|}
\hline \multirow[t]{2}{*}{ Analyte } & \multirow[t]{2}{*}{ Units } & \multirow[t]{2}{*}{$N$} & \multirow{2}{*}{$\begin{array}{c}\text { First Flush Grab } \\
03 / 08 / 12\end{array}$} & \multirow{2}{*}{$\begin{array}{c}\text { Flow-weighted } \\
\text { Composite } \\
03 / 08 / 12\end{array}$} \\
\hline & & & & \\
\hline Aluminum, Total & $\mathrm{mg} / \mathrm{L}$ & 2 & 1.5 & 0.8 \\
\hline $\mathrm{BOD}_{5}$ & $\mathrm{mg} / \mathrm{L}$ & 2 & 2.2 & $<2.0$ \\
\hline Copper, Total Recoverable & $\mathrm{mg} / \mathrm{L}$ & 2 & 0.0064 & 0.015 \\
\hline Iron, Total & $\mathrm{mg} / \mathrm{L}$ & 2 & 2.0 & 1.4 \\
\hline Lead, Total Recoverable & $\mathrm{mg} / \mathrm{L}$ & 2 & 0.0019 & 0.0041 \\
\hline Oil \& Grease ${ }^{a}$ & $\mathrm{mg} / \mathrm{L}$ & 1 & 5.6 & NR \\
\hline $\mathrm{pH}$ & SU & 1 & 7.7 & NR \\
\hline Phosphorous, Total & $\mathrm{mg} / \mathrm{L}$ & 2 & 0.019 & 0.017 \\
\hline Solids, Total Dissolved & $\mathrm{mg} / \mathrm{L}$ & 2 & 811 & 1960 \\
\hline Solids, Total Suspended & $\mathrm{mg} / \mathrm{L}$ & 2 & 76 & 110 \\
\hline Surfactant (as LAS) & $\mathrm{mg} / \mathrm{L}$ & 2 & 0.095 & 0.031 \\
\hline Zinc, Total Recoverable & $\mathrm{mg} / \mathrm{L}$ & 2 & 0.038 & 0.059 \\
\hline \multicolumn{5}{|c|}{ Rain Event Summary } \\
\hline pH of Rainfall During Sampling Event & SU & 1 & \multicolumn{2}{|c|}{7.0} \\
\hline Rainfall During Sampling Event & inches & -- & \multicolumn{2}{|c|}{0.18} \\
\hline Total Flow During Sampling Event & gallons & -- & \multicolumn{2}{|c|}{250,000} \\
\hline Maximum Flow Rate During Sampling Event & gpm & -- & \multicolumn{2}{|c|}{1,500} \\
\hline
\end{tabular}

gpm - gallons per minute.

$\mathrm{N}$ - Number of samples.

NR - Not required by permit.

${ }^{a}$ The SPDES permit specifies that oil and grease concentration shall not exceed $15 \mathrm{mg} / \mathrm{L}$. 
TABLE B-3D (concluded)

2012 Storm Water Discharge Monitoring Data for Outfall Group 4

STORM WATER OUTFALL S34

\begin{tabular}{|c|c|c|c|c|}
\hline \multirow[t]{2}{*}{ Analyte } & \multirow[t]{2}{*}{ Units } & \multirow[t]{2}{*}{$N$} & \multirow{2}{*}{$\begin{array}{c}\text { First Flush Grab } \\
10 / 23 / 12 \\
\end{array}$} & \multirow{2}{*}{$\begin{array}{c}\text { Flow-weighted } \\
\text { Composite }\end{array}$} \\
\hline & & & & \\
\hline Aluminum, Total & $\mathrm{mg} / \mathrm{L}$ & 2 & 0.57 & 2.1 \\
\hline $\mathrm{BOD}_{5}$ & $\mathrm{mg} / \mathrm{L}$ & 2 & $<2.0$ & 2.6 \\
\hline Copper, Total Recoverable & $\mathrm{mg} / \mathrm{L}$ & 2 & 0.0032 & 0.0044 \\
\hline Iron, Total & $\mathrm{mg} / \mathrm{L}$ & 2 & 0.93 & 3.2 \\
\hline Lead, Total Recoverable & $\mathrm{mg} / \mathrm{L}$ & 2 & 0.0012 & 0.0027 \\
\hline Oil \& Grease $^{a}$ & $\mathrm{mg} / \mathrm{L}$ & 1 & $<1.4$ & NR \\
\hline $\mathrm{pH}$ & SU & 1 & 7.6 & NR \\
\hline Phosphorous, Total & $\mathrm{mg} / \mathrm{L}$ & 2 & 0.011 & 0.062 \\
\hline Solids, Total Dissolved & $\mathrm{mg} / \mathrm{L}$ & 2 & 247 & 134 \\
\hline Solids, Total Suspended & $\mathrm{mg} / \mathrm{L}$ & 2 & 44 & 120 \\
\hline Surfactant (as LAS) & $\mathrm{mg} / \mathrm{L}$ & 2 & 0.043 & 0.033 \\
\hline Zinc, Total Recoverable & $\mathrm{mg} / \mathrm{L}$ & 2 & 0.047 & 0.073 \\
\hline \multicolumn{5}{|c|}{ Rain Event Summary } \\
\hline $\mathrm{pH}$ of Rainfall During Sampling Event & SU & 1 & \multicolumn{2}{|c|}{6.1} \\
\hline Rainfall During Sampling Event & inches & -- & \multicolumn{2}{|c|}{0.89} \\
\hline Total Flow During Sampling Event & gallons & -- & \multicolumn{2}{|c|}{990,000} \\
\hline Maximum Flow Rate During Sampling Event & gpm & -- & \multicolumn{2}{|c|}{8,700} \\
\hline
\end{tabular}

gpm - gallons per minute.

$\mathrm{N}$ - Number of samples.

NR - Not required by permit.

${ }^{a}$ The SPDES permit specifies that oil and grease concentration shall not exceed $15 \mathrm{mg} / \mathrm{L}$. 
TABLE B-3E

2012 Storm Water Discharge Monitoring Data for Outfall Group 5

STORM WATER OUTFALL S17

\begin{tabular}{|c|c|c|c|c|}
\hline \multirow[t]{2}{*}{ Analyte } & \multirow[t]{2}{*}{ Units } & \multirow[t]{2}{*}{$N$} & \multirow{2}{*}{$\begin{array}{c}\text { First Flush Grab } \\
05 / 08 / 12\end{array}$} & \multirow{2}{*}{$\begin{array}{c}\text { Flow-weighted } \\
\text { Composite }\end{array}$} \\
\hline & & & & \\
\hline Aluminum, Total & $\mathrm{mg} / \mathrm{L}$ & 2 & 2.0 & 6.8 \\
\hline Ammonia (as $\mathrm{NH}_{3}$ ) & $\mathrm{mg} / \mathrm{L}$ & 2 & 0.025 & 0.061 \\
\hline $\mathrm{BOD}_{5}$ & $\mathrm{mg} / \mathrm{L}$ & 2 & 2.6 & $<2.0$ \\
\hline Copper, Total Recoverable & $\mathrm{mg} / \mathrm{L}$ & 2 & 0.0044 & 0.0057 \\
\hline Iron, Total & $\mathrm{mg} / \mathrm{L}$ & 2 & 1.2 & 4.0 \\
\hline Lead, Total Recoverable & $\mathrm{mg} / \mathrm{L}$ & 2 & 0.0023 & 0.0082 \\
\hline Nitrogen, Nitrate (as N) & $\mathrm{mg} / \mathrm{L}$ & 2 & $<0.011$ & 0.059 \\
\hline Nitrogen, Nitrite (as N) & $\mathrm{mg} / \mathrm{L}$ & 2 & 0.020 & $<0.020$ \\
\hline Nitrogen, Total (as N) & $\mathrm{mg} / \mathrm{L}$ & 2 & $<0.85$ & $<0.49$ \\
\hline Nitrogen, Total Kjeldahl & $\mathrm{mg} / \mathrm{L}$ & 2 & 0.82 & 0.41 \\
\hline Oil \& Grease G $^{a}$ & $\mathrm{mg} / \mathrm{L}$ & 1 & $<1.4$ & NR \\
\hline $\mathrm{pH}$ & SU & 1 & 7.5 & NR \\
\hline Phosphorous, Total & $\mathrm{mg} / \mathrm{L}$ & 2 & 0.54 & 0.088 \\
\hline Solids, Settleable & $\mathrm{ml} / \mathrm{L}$ & 2 & 0.3 & 0.2 \\
\hline Solids, Total Dissolved & $\mathrm{mg} / \mathrm{L}$ & 2 & 389 & 216 \\
\hline Solids, Total Suspended & $\mathrm{mg} / \mathrm{L}$ & 2 & 34 & 141 \\
\hline Sulfide & $\mathrm{mg} / \mathrm{L}$ & 2 & $<0.052$ & 0.16 \\
\hline Surfactant (as LAS) & $\mathrm{mg} / \mathrm{L}$ & 2 & $<0.013$ & $<0.013$ \\
\hline Vanadium, Total Recoverable & $\mathrm{mg} / \mathrm{L}$ & 2 & 0.0021 & 0.011 \\
\hline Zinc, Total Recoverable & $\mathrm{mg} / \mathrm{L}$ & 2 & 0.013 & 0.026 \\
\hline \multicolumn{5}{|c|}{ Rain Event Summary } \\
\hline pH of Rainfall During Sampling Event & SU & 1 & \multicolumn{2}{|c|}{7.7} \\
\hline Rainfall During Sampling Event & inches & -- & \multicolumn{2}{|c|}{0.51} \\
\hline Total Flow During Sampling Event & gallons & -- & \multicolumn{2}{|c|}{140,000} \\
\hline Maximum Flow Rate During Sampling Event & gpm & -- & \multicolumn{2}{|c|}{1,200} \\
\hline
\end{tabular}

gpm - gallons per minute.

$\mathrm{N}$ - Number of samples.

NR -Not required by permit.

${ }^{a}$ The SPDES permit specifies that oil and grease concentration shall not exceed $15 \mathrm{mg} / \mathrm{L}$. 
TABLE B-3E (concluded)

2012 Storm Water Discharge Monitoring Data for Outfall Group 5

STORM WATER OUTFALL S28

\begin{tabular}{|c|c|c|c|c|}
\hline \multirow[t]{2}{*}{ Analyte } & \multirow[t]{2}{*}{ Units } & \multirow[t]{2}{*}{$N$} & \multirow{2}{*}{$\begin{array}{c}\text { First Flush Grab } \\
10 / 23 / 12\end{array}$} & \multirow{2}{*}{$\begin{array}{c}\begin{array}{c}\text { Flow-weighted } \\
\text { Composite }\end{array} \\
10 / 23 / 12 \\
\end{array}$} \\
\hline & & & & \\
\hline Aluminum, Total & $\mathrm{mg} / \mathrm{L}$ & 2 & 0.56 & 1.1 \\
\hline Ammonia (as $\mathrm{NH}_{3}$ ) & $\mathrm{mg} / \mathrm{L}$ & 2 & 0.024 & $<0.009$ \\
\hline $\mathrm{BOD}_{5}$ & $\mathrm{mg} / \mathrm{L}$ & 2 & 2.7 & 3.1 \\
\hline Copper, Total Recoverable & $\mathrm{mg} / \mathrm{L}$ & 2 & 0.0036 & 0.0031 \\
\hline Iron, Total & $\mathrm{mg} / \mathrm{L}$ & 2 & 0.60 & 1.3 \\
\hline Lead, Total Recoverable & $\mathrm{mg} / \mathrm{L}$ & 2 & 0.00071 & 0.0015 \\
\hline Nitrogen, Nitrate (as N) & $\mathrm{mg} / \mathrm{L}$ & 2 & 0.053 & 0.093 \\
\hline Nitrogen, Nitrite (as N) & $\mathrm{mg} / \mathrm{L}$ & 2 & $<0.020$ & $<0.020$ \\
\hline Nitrogen, Total (as N) & $\mathrm{mg} / \mathrm{L}$ & 2 & $<0.75$ & $<0.51$ \\
\hline Nitrogen, Total Kjeldahl & $\mathrm{mg} / \mathrm{L}$ & 2 & 0.68 & 0.40 \\
\hline Oil \& Grease ${ }^{a}$ & $\mathrm{mg} / \mathrm{L}$ & 1 & $<1.4$ & NR \\
\hline $\mathrm{pH}$ & SU & 1 & 6.9 & NR \\
\hline Phosphorous, Total & $\mathrm{mg} / \mathrm{L}$ & 2 & 0.033 & 0.015 \\
\hline Solids, Settleable & $\mathrm{ml} / \mathrm{L}$ & 2 & $<0.1$ & 0.2 \\
\hline Solids, Total Dissolved & $\mathrm{mg} / \mathrm{L}$ & 2 & 267 & 224 \\
\hline Solids, Total Suspended & $\mathrm{mg} / \mathrm{L}$ & 2 & 11 & 32 \\
\hline Sulfide & $\mathrm{mg} / \mathrm{L}$ & 2 & $<0.052$ & $<0.052$ \\
\hline Surfactant (as LAS) & $\mathrm{mg} / \mathrm{L}$ & 2 & 0.031 & 0.016 \\
\hline Vanadium, Total Recoverable & $\mathrm{mg} / \mathrm{L}$ & 2 & 0.00098 & 0.0020 \\
\hline Zinc, Total Recoverable & $\mathrm{mg} / \mathrm{L}$ & 2 & 0.013 & 0.014 \\
\hline \multicolumn{5}{|c|}{ Rain Event Summary } \\
\hline pH of Rainfall During Sampling Event & SU & 1 & \multicolumn{2}{|c|}{6.1} \\
\hline Rainfall During Sampling Event & inches & -- & \multicolumn{2}{|c|}{0.89} \\
\hline Total Flow During Sampling Event & gallons & -- & \multicolumn{2}{|c|}{260,000} \\
\hline Maximum Flow Rate During Sampling Event & gpm & -- & \multicolumn{2}{|c|}{2,200} \\
\hline
\end{tabular}

gpm - gallons per minute.

$\mathrm{N}$ - Number of samples.

NR - Not required by permit.

${ }^{\mathrm{a}}$ The SPDES permit specifies that oil and grease concentration shall not exceed $15 \mathrm{mg} / \mathrm{L}$. 
TABLE B-3F

2012 Storm Water Discharge Monitoring Data for Outfall Group 6 STORM WATER OUTFALL S37

\begin{tabular}{|c|c|c|c|c|}
\hline \multirow[t]{2}{*}{ Analyte } & \multirow[t]{2}{*}{ Units } & \multirow[t]{2}{*}{$N$} & \multirow{2}{*}{$\begin{array}{c}\text { First Flush Grab } \\
05 / 29 / 12 \\
\end{array}$} & \multirow{2}{*}{$\begin{array}{c}\text { Flow-weighted } \\
\text { Composite }\end{array}$} \\
\hline & & & & \\
\hline Aluminum, Total & $\mathrm{mg} / \mathrm{L}$ & 2 & 1.5 & 0.32 \\
\hline Ammonia $\left(\right.$ as $\mathrm{NH}_{3}$ ) & $\mathrm{mg} / \mathrm{L}$ & 2 & 0.032 & $<0.009$ \\
\hline $\mathrm{BOD}_{5}$ & $\mathrm{mg} / \mathrm{L}$ & 2 & 14.1 & 5.1 \\
\hline Copper, Total Recoverable & $\mathrm{mg} / \mathrm{L}$ & 2 & 0.0054 & 0.0025 \\
\hline Iron, Total & $\mathrm{mg} / \mathrm{L}$ & 2 & 1.4 & 0.32 \\
\hline Lead, Total Recoverable & $\mathrm{mg} / \mathrm{L}$ & 2 & 0.0013 & 0.00026 \\
\hline Nitrogen, Nitrate (as N) & $\mathrm{mg} / \mathrm{L}$ & 2 & 0.27 & 0.023 \\
\hline \begin{tabular}{|l|} 
Nitrogen, Nitrite (as N) \\
\end{tabular} & $\mathrm{mg} / \mathrm{L}$ & 2 & $<0.020$ & $<0.020$ \\
\hline Nitrogen, Total (as N) & $\mathrm{mg} / \mathrm{L}$ & 2 & $<2.0$ & $<0.69$ \\
\hline Nitrogen, Total Kjeldahl & $\mathrm{mg} / \mathrm{L}$ & 2 & 1.7 & 0.65 \\
\hline Oil \& Grease $^{a}$ & $\mathrm{mg} / \mathrm{L}$ & 1 & $<1.4$ & NR \\
\hline $\mathrm{pH}$ & SU & 1 & 8.1 & NR \\
\hline Phosphorous, Total & $\mathrm{mg} / \mathrm{L}$ & 2 & 0.088 & $<0.0050$ \\
\hline Solids, Settleable & $\mathrm{ml} / \mathrm{L}$ & 2 & 0.5 & 0.1 \\
\hline Solids, Total Dissolved & $\mathrm{mg} / \mathrm{L}$ & 2 & 307 & 233 \\
\hline Solids, Total Suspended & $\mathrm{mg} / \mathrm{L}$ & 2 & 123 & 9.6 \\
\hline Sulfide & $\mathrm{mg} / \mathrm{L}$ & 2 & 0.10 & 0.053 \\
\hline Surfactant (as LAS) & $\mathrm{mg} / \mathrm{L}$ & 2 & $<0.013$ & $<0.013$ \\
\hline Vanadium, Total Recoverable & $\mathrm{mg} / \mathrm{L}$ & 2 & 0.0014 & 0.00032 \\
\hline Zinc, Total Recoverable & $\mathrm{mg} / \mathrm{L}$ & 2 & 0.016 & 0.0054 \\
\hline \multicolumn{5}{|c|}{ Rain Event Summary } \\
\hline pH of Rainfall During Sampling Event & SU & 1 & \multicolumn{2}{|c|}{4.5} \\
\hline Rainfall During Sampling Event & inches & -- & \multicolumn{2}{|c|}{0.52} \\
\hline Total Flow During Sampling Event & gallons & -- & \multicolumn{2}{|c|}{1,700} \\
\hline Maximum Flow Rate During Sampling Event & gpm & -- & \multicolumn{2}{|c|}{15} \\
\hline
\end{tabular}

gpm - gallons per minute.

$\mathrm{N}$ - Number of samples.

NR - Not required by permit.

${ }^{a}$ The SPDES permit specifies that oil and grease concentration shall not exceed $15 \mathrm{mg} / \mathrm{L}$.

NOTE: Stormwater outfall S43 in outfall group 6 was also analyzed for total recordable lead during this sampling event. The total recordable lead result for S43 in May $2012=0.0015 \mathrm{mg} / \mathrm{L}$ (Action Level $=0.006 \mathrm{mg} / \mathrm{L}$ ). 
TABLE B-3F (concluded)

2012 Storm Water Discharge Monitoring Data for Outfall Group 6

STORM WATER OUTFALL S38

\begin{tabular}{|c|c|c|c|c|}
\hline \multirow[t]{2}{*}{ Analyte } & \multirow[t]{2}{*}{ Units } & \multirow[t]{2}{*}{$N$} & \multirow{2}{*}{$\begin{array}{c}\text { First Flush Grab } \\
10 / 23 / 12\end{array}$} & \multirow{2}{*}{$\begin{array}{c}\text { Flow-weighted } \\
\text { Composite }\end{array}$} \\
\hline & & & & \\
\hline Aluminum, Total & $\mathrm{mg} / \mathrm{L}$ & 2 & 0.75 & 2.4 \\
\hline Ammonia (as $\mathrm{NH}_{3}$ ) & $\mathrm{mg} / \mathrm{L}$ & 2 & 0.012 & 0.015 \\
\hline $\mathrm{BOD}_{5}$ & $\mathrm{mg} / \mathrm{L}$ & 2 & $<2.0$ & $<2.0$ \\
\hline Copper, Total Recoverable & $\mathrm{mg} / \mathrm{L}$ & 2 & 0.0070 & 0.0052 \\
\hline Iron, Total & $\mathrm{mg} / \mathrm{L}$ & 2 & 0.83 & 2.3 \\
\hline Lead, Total Recoverable & $\mathrm{mg} / \mathrm{L}$ & 2 & 0.0069 & 0.0045 \\
\hline Nitrogen, Nitrate (as N) & $\mathrm{mg} / \mathrm{L}$ & 2 & 0.29 & 0.25 \\
\hline \begin{tabular}{|l|} 
Nitrogen, Nitrite (as N) \\
\end{tabular} & $\mathrm{mg} / \mathrm{L}$ & 2 & 0.041 & 0.063 \\
\hline Nitrogen, Total (as N) & $\mathrm{mg} / \mathrm{L}$ & 2 & 0.61 & 0.66 \\
\hline Nitrogen, Total Kjeldahl & $\mathrm{mg} / \mathrm{L}$ & 2 & 0.28 & 0.35 \\
\hline Oil \& Grease G $^{a}$ & $\mathrm{mg} / \mathrm{L}$ & 1 & $<1.4$ & NR \\
\hline $\mathrm{pH}$ & SU & 1 & 7.5 & NR \\
\hline Phosphorous, Total & $\mathrm{mg} / \mathrm{L}$ & 2 & 0.078 & 0.049 \\
\hline Solids, Settleable & $\mathrm{ml} / \mathrm{L}$ & 2 & 0.2 & 0.3 \\
\hline Solids, Total Dissolved & $\mathrm{mg} / \mathrm{L}$ & 2 & 391 & 371 \\
\hline Solids, Total Suspended & $\mathrm{mg} / \mathrm{L}$ & 2 & 221 & 186 \\
\hline Sulfide & $\mathrm{mg} / \mathrm{L}$ & 2 & $<0.052$ & $<0.052$ \\
\hline Surfactant (as LAS) & $\mathrm{mg} / \mathrm{L}$ & 2 & 0.013 & $<0.013$ \\
\hline Vanadium, Total Recoverable & $\mathrm{mg} / \mathrm{L}$ & 2 & 0.0065 & 0.0049 \\
\hline Zinc, Total Recoverable & $\mathrm{mg} / \mathrm{L}$ & 2 & 0.032 & 0.023 \\
\hline \multicolumn{5}{|c|}{ Rain Event Summary } \\
\hline pH of Rainfall During Sampling Event & SU & 1 & \multicolumn{2}{|c|}{6.1} \\
\hline Rainfall During Sampling Event & inches & -- & \multicolumn{2}{|c|}{0.91} \\
\hline Total Flow During Sampling Event & gallons & -- & \multicolumn{2}{|c|}{140,000} \\
\hline Maximum Flow Rate During Sampling Event & gpm & -- & \multicolumn{2}{|c|}{950} \\
\hline
\end{tabular}

gpm - gallons per minute.

$\mathrm{N}$ - Number of samples.

NR - Not required by permit.

${ }^{a}$ The SPDES permit specifies that oil and grease concentration shall not exceed $15 \mathrm{mg} / \mathrm{L}$.

NOTE: Stormwater outfall S43 in outfall group 6 was also analyzed for total recordable lead during this sampling event. The total recordable lead result for S43 in October $2012=0.0009 \mathrm{mg} / \mathrm{L}$ (Action Level $=0.006 \mathrm{mg} / \mathrm{L}$ ). 
TABLE B-3G

2012 Storm Water Discharge Monitoring Data for Outfall Group 7

STORM WATER OUTFALL S2O

\begin{tabular}{|c|c|c|c|c|}
\hline \multirow[t]{2}{*}{ Analyte } & \multirow[t]{2}{*}{ Units } & \multirow[t]{2}{*}{$\boldsymbol{N}$} & \multirow{2}{*}{$\begin{array}{c}\text { First Flush Grab } \\
03 / 08 / 12\end{array}$} & \multirow{2}{*}{$\begin{array}{c}\begin{array}{c}\text { Flow-weighted } \\
\text { Composite }\end{array} \\
03 / 08 / 12\end{array}$} \\
\hline & & & & \\
\hline Aluminum, Total & $\mathrm{mg} / \mathrm{L}$ & 2 & 0.75 & 0.27 \\
\hline Ammonia (as $\mathrm{NH}_{3}$ ) & $\mathrm{mg} / \mathrm{L}$ & 2 & 0.15 & 0.063 \\
\hline $\mathrm{BOD}_{5}$ & $\mathrm{mg} / \mathrm{L}$ & 2 & 3.6 & $<2.0$ \\
\hline Copper, Total Recoverable & $\mathrm{mg} / \mathrm{L}$ & 2 & 0.0032 & 0.00088 \\
\hline Iron, Total & $\mathrm{mg} / \mathrm{L}$ & 2 & 2.0 & 0.36 \\
\hline Lead, Total Recoverable & $\mathrm{mg} / \mathrm{L}$ & 2 & 0.0025 & 0.00044 \\
\hline Nitrogen, Nitrate (as N) & $\mathrm{mg} / \mathrm{L}$ & 2 & 0.42 & 0.24 \\
\hline Nitrogen, Nitrite (as N) & $\mathrm{mg} / \mathrm{L}$ & 2 & $<0.020$ & $<0.020$ \\
\hline Nitrogen, Total (as N) & $\mathrm{mg} / \mathrm{L}$ & 2 & $<0.79$ & $<0.41$ \\
\hline Nitrogen, Total Kjeldahl & $\mathrm{mg} / \mathrm{L}$ & 2 & 0.35 & $<0.15$ \\
\hline Oil \& Grease ${ }^{a}$ & $\mathrm{mg} / \mathrm{L}$ & 1 & $<1.4$ & NR \\
\hline $\mathrm{pH}$ & SU & 1 & 8.1 & NR \\
\hline Phosphorous, Total & $\mathrm{mg} / \mathrm{L}$ & 2 & 0.049 & 0.058 \\
\hline Solids, Total Dissolved & $\mathrm{mg} / \mathrm{L}$ & 2 & 39 & 31 \\
\hline Solids, Total Suspended & $\mathrm{mg} / \mathrm{L}$ & 2 & 76 & 8.8 \\
\hline Sulfide & $\mathrm{mg} / \mathrm{L}$ & 2 & $<0.052$ & $<0.052$ \\
\hline Surfactant (as LAS) & $\mathrm{mg} / \mathrm{L}$ & 2 & 0.071 & 0.043 \\
\hline Zinc, Total Recoverable & $\mathrm{mg} / \mathrm{L}$ & 2 & 0.033 & 0.0060 \\
\hline \multicolumn{5}{|c|}{ Rain Event Summary } \\
\hline pH of Rainfall During Sampling Event & SU & 1 & \multicolumn{2}{|c|}{7.0} \\
\hline Total Rainfall During Sampling Event & inches & -- & \multicolumn{2}{|c|}{0.17} \\
\hline Total Flow During SamplingEvent & gallons & -- & \multicolumn{2}{|c|}{71,000} \\
\hline Maximum Flow Rate During Sampling Event & gpm & -- & \multicolumn{2}{|c|}{430} \\
\hline
\end{tabular}

gpm - gallons per minute.

$\mathrm{N}$ - Number of samples.

NR - Not required by permit.

${ }^{\mathrm{a}}$ The SPDES permit specifies that oil and grease concentration shall not exceed $15 \mathrm{mg} / \mathrm{L}$. 
TABLE B-3G (concluded)

2012 Storm Water Discharge Monitoring Data for Outfall Group 7

STORM WATER OUTFALL S2O

\begin{tabular}{|c|c|c|c|c|}
\hline \multirow[t]{2}{*}{ Analyte } & \multirow[t]{2}{*}{ Units } & \multirow[t]{2}{*}{$N$} & \multirow{2}{*}{$\begin{array}{c}\text { First Flush Grab } \\
09 / 04 / 12\end{array}$} & \multirow{2}{*}{$\begin{array}{c}\text { Flow-weighted } \\
\text { Composite }\end{array}$} \\
\hline & & & & \\
\hline Aluminum, Total & $\mathrm{mg} / \mathrm{L}$ & 2 & 0.97 & 0.58 \\
\hline Ammonia (as $\mathrm{NH}_{3}$ ) & $\mathrm{mg} / \mathrm{L}$ & 2 & 0.24 & 0.046 \\
\hline $\mathrm{BOD}_{5}$ & $\mathrm{mg} / \mathrm{L}$ & 2 & 5.3 & $<2.0$ \\
\hline Copper, Total Recoverable & $\mathrm{mg} / \mathrm{L}$ & 2 & 0.0013 & 0.0014 \\
\hline Iron, Total & $\mathrm{mg} / \mathrm{L}$ & 2 & 0.76 & 0.52 \\
\hline Lead, Total Recoverable & $\mathrm{mg} / \mathrm{L}$ & 2 & 0.00048 & 0.00024 \\
\hline Nitrogen, Nitrate (as N) & $\mathrm{mg} / \mathrm{L}$ & 2 & 0.45 & 0.38 \\
\hline Nitrogen, Nitrite (as N) & $\mathrm{mg} / \mathrm{L}$ & 2 & $<0.020$ & $<0.020$ \\
\hline Nitrogen, Total (as N) & $\mathrm{mg} / \mathrm{L}$ & 2 & $<1.2$ & $<0.87$ \\
\hline Nitrogen, Total Kjeldahl & $\mathrm{mg} / \mathrm{L}$ & 2 & 0.68 & 0.47 \\
\hline Oil \& Grease $^{a}$ & $\mathrm{mg} / \mathrm{L}$ & 1 & $<1.4$ & NR \\
\hline $\mathrm{pH}$ & SU & 1 & 7.4 & NR \\
\hline Phosphorous, Total & $\mathrm{mg} / \mathrm{L}$ & 2 & 0.054 & 0.0063 \\
\hline Solids, Total Dissolved & $\mathrm{mg} / \mathrm{L}$ & 2 & 10 & 52 \\
\hline Solids, Total Suspended & $\mathrm{mg} / \mathrm{L}$ & 2 & 16 & 5.2 \\
\hline Sulfide & $\mathrm{mg} / \mathrm{L}$ & 2 & $<0.052$ & $<0.052$ \\
\hline Surfactant (as LAS) & $\mathrm{mg} / \mathrm{L}$ & 2 & $<0.013$ & $<0.013$ \\
\hline Zinc, Total Recoverable & $\mathrm{mg} / \mathrm{L}$ & 2 & 0.0084 & 0.0040 \\
\hline \multicolumn{5}{|c|}{ Rain Event Summary } \\
\hline pH of Rainfall During Sampling Event & SU & 1 & \multicolumn{2}{|c|}{5.7} \\
\hline Total Rainfall During Sampling Event & inches & -- & \multicolumn{2}{|c|}{0.30} \\
\hline Total Flow During SamplingEvent & gallons & -- & \multicolumn{2}{|c|}{67,000} \\
\hline Maximum Flow Rate During Sampling Event & gpm & -- & \multicolumn{2}{|c|}{660} \\
\hline
\end{tabular}

gpm - gallons per minute.

$\mathrm{N}$ - Number of samples.

NR - Not required by permit.

${ }^{a}$ The SPDES permit specifies that oil and grease concentration shall not exceed $15 \mathrm{mg} / \mathrm{L}$. 
TABLE B-3H

2012 Storm Water Discharge Monitoring Data for Outfall Group 8

STORM WATER OUTFALL S27

\begin{tabular}{|c|c|c|c|c|}
\hline \multirow[t]{2}{*}{ Analyte } & \multirow[t]{2}{*}{ Units } & \multirow[t]{2}{*}{$N$} & \multirow{2}{*}{$\begin{array}{c}\text { First Flush Grab } \\
05 / 08 / 12\end{array}$} & \multirow{2}{*}{$\begin{array}{c}\text { Flow-weighted } \\
\text { Composite }\end{array}$} \\
\hline & & & & \\
\hline Aluminum, Total & $\mathrm{mg} / \mathrm{L}$ & 2 & 3.7 & 3.1 \\
\hline Ammonia (as $\mathrm{NH}_{3}$ ) & $\mathrm{mg} / \mathrm{L}$ & 2 & 0.019 & 0.031 \\
\hline $\mathrm{BOD}_{5}$ & $\mathrm{mg} / \mathrm{L}$ & 2 & $<2.0$ & $<2.0$ \\
\hline Copper, Total Recoverable & $\mathrm{mg} / \mathrm{L}$ & 2 & 0.0061 & 0.0038 \\
\hline Iron, Total & $\mathrm{mg} / \mathrm{L}$ & 2 & 2.2 & 1.8 \\
\hline Lead, Total Recoverable & $\mathrm{mg} / \mathrm{L}$ & 2 & 0.0073 & 0.0029 \\
\hline Nitrogen, Nitrate (as N) & $\mathrm{mg} / \mathrm{L}$ & 2 & 0.064 & $<0.011$ \\
\hline Nitrogen, Nitrite (as N) & $\mathrm{mg} / \mathrm{L}$ & 2 & 0.056 & 0.032 \\
\hline Nitrogen, Total (as N) & $\mathrm{mg} / \mathrm{L}$ & 2 & 0.57 & $<0.73$ \\
\hline Nitrogen, Total Kjeldahl & $\mathrm{mg} / \mathrm{L}$ & 2 & 0.45 & 0.69 \\
\hline Oil \& Grease ${ }^{a}$ & $\mathrm{mg} / \mathrm{L}$ & 1 & 1.9 & NR \\
\hline $\mathrm{pH}$ & SU & 1 & 7.7 & NR \\
\hline Phosphorous, Total & $\mathrm{mg} / \mathrm{L}$ & 2 & 0.15 & 0.23 \\
\hline Solids, Total Dissolved & $\mathrm{mg} / \mathrm{L}$ & 2 & 221 & 162 \\
\hline Solids, Total Suspended & $\mathrm{mg} / \mathrm{L}$ & 2 & 124 & 44 \\
\hline Surfactant (as LAS) & $\mathrm{mg} / \mathrm{L}$ & 2 & $<0.013$ & $<0.013$ \\
\hline Zinc, Total Recoverable & $\mathrm{mg} / \mathrm{L}$ & 2 & 0.024 & 0.011 \\
\hline \multicolumn{5}{|c|}{ Rain Event Summary } \\
\hline pH of Rainfall During Sampling Event & SU & 1 & \multicolumn{2}{|c|}{7.7} \\
\hline Rainfall During Sampling Event & inches & -- & \multicolumn{2}{|c|}{0.51} \\
\hline Total Flow During Sampling Event & gallons & -- & \multicolumn{2}{|c|}{35,000} \\
\hline Maximum Flow Rate During Sampling Event & gpm & -- & \multicolumn{2}{|c|}{250} \\
\hline
\end{tabular}

gpm - gallons per minute.

$\mathrm{N}$ - Number of samples.

NR - Not required by permit.

${ }^{a}$ The SPDES permit specifies that oil and grease concentration shall not exceed $15 \mathrm{mg} / \mathrm{L}$. 
TABLE B-3H (concluded)

2012 Storm Water Discharge Monitoring Data for Outfall Group 8

STORM WATER OUTFALL S35

\begin{tabular}{|c|c|c|c|c|}
\hline \multirow[t]{2}{*}{ Analyte } & \multirow[t]{2}{*}{ Units } & \multirow[t]{2}{*}{$N$} & \multirow{2}{*}{$\begin{array}{c}\text { First Flush Grab } \\
10 / 23 / 12\end{array}$} & \multirow{2}{*}{$\begin{array}{c}\begin{array}{c}\text { Flow-weighted } \\
\text { Composite }\end{array} \\
10 / 23 / 12\end{array}$} \\
\hline & & & & \\
\hline Aluminum, Total & $\mathrm{mg} / \mathrm{L}$ & 2 & 1.3 & 1.2 \\
\hline Ammonia (as $\mathrm{NH}_{3}$ ) & $\mathrm{mg} / \mathrm{L}$ & 2 & 0.016 & $<0.009$ \\
\hline $\mathrm{BOD}_{5}$ & $\mathrm{mg} / \mathrm{L}$ & 2 & $<2.0$ & 4.6 \\
\hline Copper, Total Recoverable & $\mathrm{mg} / \mathrm{L}$ & 2 & 0.0036 & 0.0033 \\
\hline Iron, Total & $\mathrm{mg} / \mathrm{L}$ & 2 & 1.2 & 1.1 \\
\hline Lead, Total Recoverable & $\mathrm{mg} / \mathrm{L}$ & 2 & 0.0064 & 0.0039 \\
\hline Nitrogen, Nitrate (as N) & $\mathrm{mg} / \mathrm{L}$ & 2 & 0.17 & 0.078 \\
\hline Nitrogen, Nitrite (as N) & $\mathrm{mg} / \mathrm{L}$ & 2 & 0.033 & $<0.020$ \\
\hline Nitrogen, Total (as N) & $\mathrm{mg} / \mathrm{L}$ & 2 & 0.63 & $<0.65$ \\
\hline Nitrogen, Total Kjeldahl & $\mathrm{mg} / \mathrm{L}$ & 2 & 0.43 & 0.55 \\
\hline Oil \& Grease ${ }^{a}$ & $\mathrm{mg} / \mathrm{L}$ & 1 & $<1.4$ & NR \\
\hline $\mathrm{pH}$ & SU & 1 & 7.6 & NR \\
\hline Phosphorous, Total & $\mathrm{mg} / \mathrm{L}$ & 2 & 0.022 & 0.020 \\
\hline Solids, Total Dissolved & $\mathrm{mg} / \mathrm{L}$ & 2 & 303 & 250 \\
\hline Solids, Total Suspended & $\mathrm{mg} / \mathrm{L}$ & 2 & 81 & 56 \\
\hline Surfactant (as LAS) & $\mathrm{mg} / \mathrm{L}$ & 2 & 0.022 & 0.024 \\
\hline Zinc, Total Recoverable & $\mathrm{mg} / \mathrm{L}$ & 2 & 0.035 & 0.030 \\
\hline \multicolumn{5}{|c|}{ Rain Event Summary } \\
\hline pH of Rainfall During Sampling Event & SU & 1 & \multicolumn{2}{|c|}{6.1} \\
\hline Rainfall During Sampling Event & inches & -- & \multicolumn{2}{|c|}{0.89} \\
\hline Total Flow During Sampling Event & gallons & -- & \multicolumn{2}{|c|}{160,000} \\
\hline Maximum Flow Rate During Sampling Event & gpm & -- & \multicolumn{2}{|c|}{1100} \\
\hline
\end{tabular}

gpm - gallons per minute.

$\mathrm{N}$ - Number of samples.

NR - Not required by permit.

${ }^{a}$ The SPDES permit specifies that oil and grease concentration shall not exceed $15 \mathrm{mg} / \mathrm{L}$. 


\section{APPENDIX B-4
Site Surface Drainage, subsurface Drainage, \\ APPENDIX B-4
Site Surface Drainage, Subsurface Drainage, and Contained Water Data}

TABLE B-4A

2012 Radioactivity and pH in Surface Water at Facillity Yard Drainage (WNSP005)

\begin{tabular}{|c|c|c|c|c|c|c|}
\hline \multirow{2}{*}{ Analyte } & \multirow{2}{*}{ Units } & \multirow{2}{*}{$N$} & \multicolumn{3}{|c|}{ WNSP005 Concentrations } & \multirow{2}{*}{$\begin{array}{c}\text { Guideline }^{a} \text { or } \\
\text { Standard }^{b}\end{array}$} \\
\hline & & & Minimum & Average & Maximum & \\
\hline Gross Alpha & $\mu \mathrm{Ci} / \mathrm{mL}$ & 4 & $<2.99 \mathrm{E}-09$ & $2.30 \pm 3.76 \mathrm{E}-09$ & $4.02 \mathrm{E}-09$ & $9.8 \mathrm{E}-08^{c}$ \\
\hline Gross Beta & $\mu \mathrm{Ci} / \mathrm{mL}$ & 4 & $8.92 \mathrm{E}-08$ & $3.42 \pm 0.14 \mathrm{E}-07$ & $7.61 \mathrm{E}-07$ & $1.1 \mathrm{E}-06^{d}$ \\
\hline Tritium & $\mu \mathrm{Ci} / \mathrm{mL}$ & 4 & $<4.69 \mathrm{E}-08$ & $1.88 \pm 7.71 \mathrm{E}-08$ & $<1.02 \mathrm{E}-07$ & 1.9E-03 \\
\hline Sr-90 & $\mu \mathrm{Ci} / \mathrm{mL}$ & 2 & $7.28 \mathrm{E}-08$ & $1.72 \pm 0.11 \mathrm{E}-07$ & $2.71 \mathrm{E}-07$ & $1.1 \mathrm{E}-06$ \\
\hline Cs-137 & $\mu \mathrm{Ci} / \mathrm{mL}$ & 2 & $<1.13 \mathrm{E}-09$ & $0.41 \pm 1.90 \mathrm{E}-09$ & $<2.44 \mathrm{E}-09$ & $3.0 \mathrm{E}-06$ \\
\hline $\mathrm{pH}$ & SU & 4 & 7.12 & 7.38 & 8.06 & $6.0-9.5$ \\
\hline
\end{tabular}

$\mathrm{N}$ - Number of samples.

${ }^{a}$ DOE ingestion-based DCSs for $100 \mathrm{mrem} / \mathrm{yr}$ dose limit are provided as a guideline for radiological results.

${ }^{\mathrm{b}}$ New York State Water Quality Standards for Class "D" as a comparative reference for non-radiological results.

${ }^{c}$ Alpha as U-232.

${ }^{d}$ Beta as Sr-90. 
TABLE B-4B

Comparison of 2012 Radioactivity Concentrations in Surface Water at the North Swamp (WNSW74A) With U.S. DOE-Derived Concentration Standards (DCSs)

RADIOACTIVE CONSTITUENTS

\begin{tabular}{|c|c|c|c|c|c|c|}
\hline \multirow{2}{*}{ Isotope $^{a}$} & \multirow{2}{*}{$N$} & \multicolumn{2}{|c|}{ Discharge Activity ${ }^{b}$} & \multirow{2}{*}{$\begin{array}{c}\text { Average } \\
\text { Concentration } \\
(\mu \mathrm{Ci} / \mathrm{mL})\end{array}$} & \multirow{2}{*}{$\begin{array}{c}D_{C S}^{d} \\
(\mu C i / m L)\end{array}$} & \multirow{2}{*}{$\begin{array}{c}\text { Ratio of } \\
\text { Concentration } \\
\text { to DCS }\end{array}$} \\
\hline & & (Ci) & (Becquerels) $^{c}$ & & & \\
\hline Gross Alpha & 26 & $0.59 \pm 3.86 \mathrm{E}-05$ & $0.22 \pm 1.43 \mathrm{E}+06$ & $1.26 \pm 8.25 \mathrm{E}-10$ & $N A^{e}$ & NA \\
\hline Gross Beta & 26 & $5.52 \pm 0.32 \mathrm{E}-04$ & $2.04 \pm 0.12 \mathrm{E}+07$ & $1.18 \pm 0.07 E-08$ & $N A^{e}$ & NA \\
\hline Tritium & 26 & $0.79 \pm 1.09 E-03$ & $2.93 \pm 4.02 E+07$ & $1.69 \pm 2.32 \mathrm{E}-08$ & 1.9E-03 & $<0.0001$ \\
\hline C-14 & 2 & $-0.57 \pm 1.06 \mathrm{E}-03$ & $-2.10 \pm 3.92 E+07$ & $-1.21 \pm 2.26 \mathrm{E}-08$ & $6.2 \mathrm{E}-05$ & $<0.0004$ \\
\hline Sr-90 & 12 & $2.46 \pm 0.28 \mathrm{E}-04$ & $9.10 \pm 1.03 \mathrm{E}+06$ & $5.25 \pm 0.59 \mathrm{E}-09$ & $1.1 \mathrm{E}-06$ & 0.0048 \\
\hline I-129 & 2 & $2.93 \pm 3.24 \mathrm{E}-05$ & $1.08 \pm 1.20 \mathrm{E}+06$ & $6.26 \pm 6.91 \mathrm{E}-10$ & $3.3 \mathrm{E}-07$ & $<0.0021$ \\
\hline Cs-137 & 12 & $2.47 \pm 3.46 \mathrm{E}-05$ & $0.92 \pm 1.28 \mathrm{E}+06$ & $5.28 \pm 7.38 \mathrm{E}-10$ & $3.0 \mathrm{E}-06$ & $<0.0002$ \\
\hline $\mathrm{U}-232^{f}$ & 2 & $0.64 \pm 1.88 \mathrm{E}-06$ & $2.37 \pm 6.94 \mathrm{E}+04$ & $1.37 \pm 4.01 \mathrm{E}-11$ & $9.8 \mathrm{E}-08$ & $<0.0004$ \\
\hline $\mathrm{U}-233 / 234^{f}$ & 2 & $2.01 \pm 2.75 \mathrm{E}-06$ & $0.74 \pm 1.02 \mathrm{E}+05$ & $4.29 \pm 5.87 \mathrm{E}-11$ & $6.6 \mathrm{E}-07^{\mathrm{g}}$ & $<0.0001$ \\
\hline $\mathrm{U}-235 / 236^{f}$ & 2 & $-0.30 \pm 1.58 \mathrm{E}-06$ & $-1.10 \pm 5.84 \mathrm{E}+04$ & $-0.63 \pm 3.37 \mathrm{E}-11$ & $7.2 \mathrm{E}-07$ & $<0.0001$ \\
\hline U-238 ${ }^{f}$ & 2 & $2.12 \pm 2.13 \mathrm{E}-06$ & $7.85 \pm 7.90 \mathrm{E}+04$ & $4.53 \pm 4.56 \mathrm{E}-11$ & $7.5 \mathrm{E}-07$ & $<0.0001$ \\
\hline Pu-238 & 2 & $-1.00 \pm 5.84 \mathrm{E}-07$ & $-0.37 \pm 2.16 \mathrm{E}+04$ & $-0.21 \pm 1.25 \mathrm{E}-11$ & $1.5 \mathrm{E}-07$ & $<0.0001$ \\
\hline Pu-239/240 & 2 & $2.55 \pm 6.09 E-07$ & $0.94 \pm 2.25 \mathrm{E}+04$ & $0.54 \pm 1.30 \mathrm{E}-11$ & $1.4 \mathrm{E}-07$ & $<0.0001$ \\
\hline Am-241 & 2 & $0.20 \pm 1.65 E-06$ & $0.74 \pm 6.10 \mathrm{E}+04$ & $0.43 \pm 3.52 E-11$ & $1.7 \mathrm{E}-07$ & $<0.0002$ \\
\hline \multicolumn{6}{|l|}{ Sum of Ratios } & 0.008 \\
\hline
\end{tabular}

Note: The average $\mathrm{pH}$ at this location was $7.34 \mathrm{SU}$.

$\mathrm{N}$ - Number of samples.

NA - Not applicable.

${ }^{\text {a }}$ Half-lives are listed in Table UI-4.

${ }^{\mathrm{b}}$ Total estimated volume released; $4.68 \mathrm{E}+10 \mathrm{~mL}(1.24 \mathrm{E}+07$ gal).

${ }^{c} 1$ curie $(\mathrm{Ci})=3.7 \mathrm{E}+10$ becquerels $(\mathrm{Bq}) ; 1 \mathrm{~Bq}=2.7 \mathrm{E}-11 \mathrm{Ci}$.

${ }^{d}$ DCSs are used as reference values for the application of best available technology per DOE Order 458.1.

${ }^{\mathrm{e}}$ DCSs do not exist for indicator parameters gross alpha and gross beta.

${ }^{\mathrm{f}}$ Total Uranium $=6.42 \pm 0.52 \mathrm{E}+00(\mathrm{~g}) ;$ Average Total Uranium $=1.37 \pm 0.11 \mathrm{E}-04(\mu \mathrm{g} / \mathrm{mL})$.

${ }^{\mathrm{g}}$ The DCS for U-233 is used for this comparison. 
TABLE B-4C

Comparison of 2012 Radioactivity Concentrations in Surface Water at the Northeast Swamp (WNSWAMP) With U.S. DOE-Derived Concentration Standards (DCSs)

\begin{tabular}{|c|c|c|c|c|c|c|}
\hline \multirow{2}{*}{ Isotope $^{a}$} & \multirow{2}{*}{$\mathbf{N}$} & \multicolumn{2}{|c|}{ Discharge Activity $^{b}$} & \multirow{2}{*}{$\begin{array}{c}\text { Average } \\
\text { Concentration } \\
(\mu \mathrm{Ci} / \mathrm{mL})\end{array}$} & \multirow{2}{*}{$\begin{array}{c}D C S^{d} \\
(\mu \mathrm{Ci} / \mathrm{mL})\end{array}$} & \multirow{2}{*}{$\begin{array}{c}\text { Ratio of } \\
\text { Concentration } \\
\text { to DCS }\end{array}$} \\
\hline & & (Ci) & (Becquerels) $^{c}$ & & & \\
\hline Gross Alpha & 26 & $-2.26 \pm 4.59 \mathrm{E}-05$ & $-0.84 \pm 1.70 E+06$ & $-4.40 \pm 8.95 \mathrm{E}-10$ & $\mathrm{NA}^{e}$ & NA \\
\hline Gross Beta & 26 & $1.16 \pm 0.01 \mathrm{E}-01$ & $4.30 \pm 0.03 E+09$ & $2.27 \pm 0.02 E-06$ & $N A^{e}$ & NA \\
\hline Tritium & 26 & $3.28 \pm 0.13 E-03$ & $1.21 \pm 0.49 \mathrm{E}+08$ & $6.41 \pm 2.59 \mathrm{E}-08$ & $1.9 \mathrm{E}-03$ & 0.0001 \\
\hline C-14 & 2 & $3.06 \pm 9.83 E-04$ & $1.13 \pm 3.64 \mathrm{E}+07$ & $0.60 \pm 1.92 \mathrm{E}-08$ & $6.2 \mathrm{E}-05$ & $<0.0003$ \\
\hline Sr-90 & 12 & $5.51 \pm 0.05 E-02$ & $2.04 \pm 0.02 E+09$ & $1.08 \pm 0.01 E-06$ & $1.1 \mathrm{E}-06$ & 0.98 \\
\hline $\mathrm{I}-129$ & 2 & $-0.12 \pm 3.62 E-05$ & $-0.04 \pm 1.34 \mathrm{E}+06$ & $-0.23 \pm 7.07 E-10$ & $3.3 \mathrm{E}-07$ & $<0.0021$ \\
\hline Cs-137 & 12 & $-2.13 \pm 4.93 E-05$ & $-0.79 \pm 1.82 E+06$ & $-4.16 \pm 9.62 \mathrm{E}-10$ & $3.0 \mathrm{E}-06$ & $<0.0003$ \\
\hline $\mathrm{U}-232^{f}$ & 2 & $-0.20 \pm 1.71 E-06$ & $-0.72 \pm 6.32 E+04$ & $-0.38 \pm 3.34 \mathrm{E}-11$ & $9.8 \mathrm{E}-08$ & $<0.0003$ \\
\hline $\mathrm{U}-233 / 234^{f}$ & 2 & $7.97 \pm 3.35 \mathrm{E}-06$ & $2.95 \pm 1.24 \mathrm{E}+05$ & $1.56 \pm 0.65 \mathrm{E}-10$ & $6.6 \mathrm{E}-07^{\mathrm{g}}$ & 0.0002 \\
\hline $\mathrm{U}-235 / 236^{f}$ & 2 & $0.13 \pm 1.37 \mathrm{E}-06$ & $0.47 \pm 5.08 \mathrm{E}+04$ & $0.25 \pm 2.68 \mathrm{E}-11$ & $7.2 \mathrm{E}-07$ & $<0.0001$ \\
\hline $\mathbf{U}-238^{f}$ & 2 & $4.10 \pm 2.55 \mathrm{E}-06$ & $1.52 \pm 0.94 \mathrm{E}+05$ & $8.00 \pm 4.98 \mathrm{E}-11$ & $7.5 \mathrm{E}-07$ & 0.0001 \\
\hline Pu-238 & 2 & $-1.79 \pm 9.85 E-07$ & $-0.66 \pm 3.64 E+04$ & $-0.35 \pm 1.92 \mathrm{E}-11$ & $1.5 \mathrm{E}-07$ & $<0.0001$ \\
\hline $\mathrm{Pu}-239 / 240$ & 2 & $0.49 \pm 1.34 \mathrm{E}-06$ & $1.81 \pm 4.96 \mathrm{E}+04$ & $0.96 \pm 2.62 \mathrm{E}-11$ & $1.4 \mathrm{E}-07$ & $<0.0002$ \\
\hline Am-241 & 2 & $0.86 \pm 1.37 \mathrm{E}-06$ & $3.16 \pm 5.06 \mathrm{E}+04$ & $1.67 \pm 2.67 \mathrm{E}-11$ & $1.7 \mathrm{E}-07$ & $<0.0002$ \\
\hline \multicolumn{6}{|l|}{ Sum of Ratios } & 0.98 \\
\hline
\end{tabular}

Note: the average $\mathrm{pH}$ at this location was 7.10 Standard Units (SU).

$\mathrm{N}$ - Number of samples.

NA - Not applicable.

${ }^{a}$ Half-lives are listed in Table UI-4.

${ }^{\mathrm{b}}$ Total estimated volume released: $5.12 \mathrm{E}+10 \mathrm{~mL}$ (1.35E+07 gal).

${ }^{\mathrm{c}} 1 \mathrm{Ci}=3.7 \mathrm{E}+10 \mathrm{~Bq}: 1 \mathrm{~Bq}=2.7 \mathrm{E}-11 \mathrm{Ci}$.

${ }^{d}$ DCSs are used as reference values for the application of best available technology per DOE Order 458.1.

${ }^{\mathrm{e}}$ DCSs do not exist for indicator parameters gross alpha and gross beta.

${ }^{\mathrm{f}}$ Total Uranium $(\mathrm{g})=1.88 \pm 0.07 \mathrm{E}+01 ;$ Average Total Uranium $(\mu \mathrm{g} / \mathrm{mL})=3.67 \pm 0.13 \mathrm{E}-04$.

${ }^{\mathrm{g}}$ The DCS for Uranium-233 is used for this comparison.

TABLE B-4D

2012 Radioactivity in Surface Water Drainage Between the NDA and SDA (WNNDADR)

\begin{tabular}{|c|c|c|c|c|c|}
\hline \multirow{2}{*}{ Analyte } & \multirow{2}{*}{ Units } & \multirow{2}{*}{$N$} & \multicolumn{3}{|c|}{ WNNDADR Concentrations } \\
\hline & & & Minimum & Average & Maximum \\
\hline Gross Alpha & $\mu \mathrm{Ci} / \mathrm{mL}$ & 12 & $<5.67 \mathrm{E}-10$ & $1.23 \pm 1.22 \mathrm{E}-09$ & $4.22 \mathrm{E}-09$ \\
\hline Gross Beta & $\mu \mathrm{Ci} / \mathrm{mL}$ & 12 & 3.00E-09 & $3.49 \pm 0.29 E-08$ & $5.48 \mathrm{E}-08$ \\
\hline Tritium & $\mu \mathrm{Ci} / \mathrm{mL}$ & 12 & $3.08 \mathrm{E}-07$ & $4.19 \pm 0.95 E-07$ & $5.80 \mathrm{E}-07$ \\
\hline Sr-90 & $\mu \mathrm{Ci} / \mathrm{mL}$ & 2 & $1.37 \mathrm{E}-08$ & $1.60 \pm 0.22 \mathrm{E}-08$ & $1.82 \mathrm{E}-08$ \\
\hline I-129 & $\mu \mathrm{Ci} / \mathrm{mL}$ & 2 & $<1.03 \mathrm{E}-09$ & $0.62 \pm 1.06 \mathrm{E}-09$ & $<1.09 \mathrm{E}-09$ \\
\hline Cs-137 & $\mu \mathrm{Ci} / \mathrm{mL}$ & 12 & $<1.10 \mathrm{E}-09$ & $-0.34 \pm 2.29 E-09$ & $<3.53 \mathrm{E}-09$ \\
\hline
\end{tabular}

$\mathrm{N}$ - Number of samples. 
This page intentionally left blank 


\section{APPENDIX B-5 Ambient Surface Water Data}

TABLE B-5A

2012 Radioactivity and pH in Surface Water Downstream of the WVDP in Cattaraugus Creek at Felton Bridge (WFFELBR)

\begin{tabular}{|c|c|c|c|c|c|c|c|}
\hline \multirow{3}{*}{ Analyte } & \multirow{3}{*}{ Units } & \multirow{3}{*}{$N$} & \multirow{2}{*}{\multicolumn{2}{|c|}{$\begin{array}{c}\text { WFFELBR } \\
\text { Concentrations }\end{array}$}} & \multirow{3}{*}{$N$} & \multicolumn{2}{|c|}{ Reference Values } \\
\hline & & & & & & \multirow{2}{*}{$\begin{array}{c}\text { WFBIGBR } \\
\text { Background Range }\end{array}$} & \multirow{2}{*}{\begin{tabular}{|c} 
Guideline $^{a}$ or \\
Standard $^{b}$
\end{tabular}} \\
\hline & & & Average & Maximum & & & \\
\hline Gross Alpha & $\mu \mathrm{Ci} / \mathrm{mL}$ & 12 & $1.74 \pm 1.46 \mathrm{E}-09$ & $4.21 \mathrm{E}-09$ & 98 & $<3.59 \mathrm{E}-10-4.62 \mathrm{E}-09$ & $9.8 \mathrm{E}-08^{d}$ \\
\hline Gross Beta & $\mu \mathrm{Ci} / \mathrm{mL}$ & 12 & $3.85 \pm 1.66 \mathrm{E}-09$ & $6.41 E-09$ & 98 & $<9.03 \mathrm{E}-10-1.37 \mathrm{E}-08$ & $1.1 \mathrm{E}-06^{e}$ \\
\hline Tritium & $\mu \mathrm{Ci} / \mathrm{mL}$ & 12 & $1.34 \pm 7.09 \mathrm{E}-08$ & $6.53 \mathrm{E}-08$ & 98 & $<4.46 \mathrm{E}-08-2.65 \mathrm{E}-07$ & $1.9 \mathrm{E}-03$ \\
\hline Sr-90 & $\mu \mathrm{Ci} / \mathrm{mL}$ & 12 & $0.51 \pm 1.19 \mathrm{E}-09$ & $1.55 \mathrm{E}-09$ & 98 & $<3.57 \mathrm{E}-10-1.10 \mathrm{E}-08$ & $1.1 \mathrm{E}-06$ \\
\hline Cs-137 & $\mu \mathrm{Ci} / \mathrm{mL}$ & 12 & $0.89 \pm 2.36 \mathrm{E}-09$ & $2.09 E-09$ & 98 & $<1.34 \mathrm{E}-09-5.29 \mathrm{E}-09$ & $3.0 \mathrm{E}-06$ \\
\hline $\mathrm{pH}$ & SU & 33 & \multicolumn{2}{|c|}{ Range: $7.3-8.4$} & 98 & $5.80-8.34$ & $6.5-8.5$ \\
\hline
\end{tabular}

Note: Historical background data are from Bigelow Bridge, on Cattaraugus Creek upstream of WFFELBR. Sampling at WFBIGBR was discontinued in 2008. Range was calculated from the most recent 10 years of sampling, 1998-2007.

$\mathrm{N}$ - Number of samples.

${ }^{a}$ DOE ingestion-based DCSs for $100 \mathrm{mrem} / \mathrm{yr}$ dose limit are provided as a guideline for radiological results in the absence of water quality standards.

${ }^{\mathrm{b}}$ New York Water Quality Standards for Class "B" as a comparative reference for non-radiological results.

${ }^{c}$ Values represent composite concentrations weighted to monthly stream flow.

${ }^{\mathrm{d}}$ Alpha as U-232.

${ }^{\mathrm{e}}$ Beta as Sr-90.

TABLE B-5B

2012 Water Quality of Surface Water Downstream of the WVDP in Buttermilk Creek at Thomas Corners Bridge (WFBCTCB)

\section{RADIOACTIVITY CONCENTRATIONS}

\begin{tabular}{|c|c|c|c|c|c|c|c|}
\hline \multirow{3}{*}{ Analyte } & \multirow{3}{*}{ Units } & \multirow{3}{*}{$N$} & \multirow{2}{*}{\multicolumn{2}{|c|}{$\begin{array}{c}\text { WFBCTCB } \\
\text { Concentrations }\end{array}$}} & \multirow{3}{*}{$N$} & \multicolumn{2}{|c|}{ Reference Values } \\
\hline & & & & & & \multirow{2}{*}{$\begin{array}{c}\text { WFBCBKG }^{a} \\
\text { Background Range }\end{array}$} & \multirow{2}{*}{ Guideline $^{b}$} \\
\hline & & & Average & Maximum & & & \\
\hline Gross Alpha & $\mu \mathrm{Ci} / \mathrm{mL}$ & 12 & $1.62 \pm 1.28 \mathrm{E}-09$ & $5.56 \mathrm{E}-09$ & 12 & $<5.10 \mathrm{E}-10-2.80 \mathrm{E}-09$ & $9.8 \mathrm{E}-08^{C}$ \\
\hline Gross Beta & $\mu \mathrm{Ci} / \mathrm{mL}$ & 12 & $7.29 \pm 1.85 E-09$ & $1.12 \mathrm{E}-08$ & 12 & 1.73E-09-4.15E-09 & $1.1 \mathrm{E}-06^{d}$ \\
\hline Tritium & $\mu \mathrm{Ci} / \mathrm{mL}$ & 12 & $1.51 \pm 7.42 \mathrm{E}-08$ & $<9.80 \mathrm{E}-08$ & 12 & $<4.67 \mathrm{E}-08-1.07 \mathrm{E}-07$ & $1.9 \mathrm{E}-03$ \\
\hline Sr-90 & $\mu \mathrm{Ci} / \mathrm{mL}$ & 2 & $1.56 \pm 1.21 \mathrm{E}-09$ & $1.98 \mathrm{E}-09$ & 2 & $<1.14 \mathrm{E}-09-<1.16 \mathrm{E}-09$ & $1.1 \mathrm{E}-06$ \\
\hline Cs-137 & $\mu \mathrm{Ci} / \mathrm{mL}$ & 2 & $1.74 \pm 3.34 \mathrm{E}-09$ & $<4.10 \mathrm{E}-09$ & 2 & $<2.87 \mathrm{E}-09-3.44 \mathrm{E}-09$ & $3.0 \mathrm{E}-06$ \\
\hline
\end{tabular}

$\mathrm{N}$ - Number of samples.

${ }^{a}$ Background location.

${ }^{b}$ DOE ingestion based derived consentration standards (DCSs) for $100 \mathrm{mrem} / \mathrm{yr}$ dose limit are provided as a guideline for radiological results.

${ }^{c}$ Alpha as U-232.

d Beta as Sr-90. 
TABLE B-5B (continued)

2012 Water Quality of Surface Water Downstream of the WVDP in Buttermilk Creek at Thomas Corners Bridge (WFBCTCB)

\section{CHEMICAL CONSTITUENTS}

\begin{tabular}{|c|c|c|c|c|c|}
\hline \multirow[t]{2}{*}{ Analyte } & \multirow[t]{2}{*}{ Units } & \multirow[t]{2}{*}{$N$} & \multicolumn{2}{|c|}{$\begin{array}{c}\text { WFBCTCB } \\
\text { Concentration }\end{array}$} & \multirow[t]{2}{*}{ Standard $^{\circ}$} \\
\hline & & & Average & Maximum & \\
\hline Alpha-BHC & $\mu g / L$ & 2 & $<0.009$ & $<0.009$ & 0.002 \\
\hline Aluminum, Dissolved & $\mathrm{mg} / \mathrm{L}$ & 2 & $<0.100$ & $<0.100$ & 0.10 \\
\hline Ammonia-N & $\mathrm{mg} / \mathrm{L}$ & 2 & $<0.05$ & $<0.05$ & $0.09-2.1$ \\
\hline Antimony, Total & $\mathrm{mg} / \mathrm{L}$ & 2 & $<0.003$ & $<0.003$ & -- \\
\hline Arsenic, Dissolved & $\mathrm{mg} / \mathrm{L}$ & 2 & $<0.005$ & $<0.005$ & 0.150 \\
\hline Barium, Total & $\mathrm{mg} / \mathrm{L}$ & 2 & 0.07 & 0.08 & -- \\
\hline Boron, Total & $\mathrm{mg} / \mathrm{L}$ & 2 & 0.02 & 0.03 & 10.0 \\
\hline Bromide & $\mathrm{mg} / \mathrm{L}$ & 2 & $<0.50$ & $<0.50$ & -- \\
\hline Cadmium, Dissolved & $\mathrm{mg} / \mathrm{L}$ & 2 & $<0.001$ & $<0.001$ & $0.0031^{b}$ \\
\hline Calcium, Total & $\mathrm{mg} / \mathrm{L}$ & 12 & 38.4 & 53.3 & -- \\
\hline Chloride & $\mathrm{mg} / \mathrm{L}$ & 2 & 27 & 32 & -- \\
\hline Chromium, Dissolved & $\mathrm{mg} / \mathrm{L}$ & 2 & $<0.01$ & $<0.01$ & $0.113^{b}$ \\
\hline Cobalt, Total & $\mathrm{mg} / \mathrm{L}$ & 2 & $<0.005$ & $<0.005$ & $0.005^{c}$ \\
\hline Copper, Dissolved & $\mathrm{mg} / \mathrm{L}$ & 2 & $<0.005$ & $<0.005$ & $0.014^{b}$ \\
\hline Dissolved Oxygen & $\mathrm{mg} / \mathrm{L}$ & 2 & 10.5 & 12.3 & 4.0 (min) \\
\hline Fluoride & $\mathrm{mg} / \mathrm{L}$ & 2 & $<0.10$ & $<0.10$ & $3.39^{b}$ \\
\hline Hardness & $\mathrm{mg} / \mathrm{L}$ & 12 & 121 & 168 & -- \\
\hline Iron, Total & $\mathrm{mg} / \mathrm{L}$ & 2 & 0.54 & 0.60 & 0.30 \\
\hline Lead, Dissolved & $\mathrm{mg} / \mathrm{L}$ & 2 & $<0.0005$ & $<0.0005$ & $0.0066^{b}$ \\
\hline Magnesium, Total & $\mathrm{mg} / \mathrm{L}$ & 12 & 6.13 & 8.65 & -- \\
\hline Manganese, Total & $\mathrm{mg} / \mathrm{L}$ & 2 & 0.02 & 0.02 & -- \\
\hline \begin{tabular}{|} 
Mercury, Total, \\
Method 1631 \\
\end{tabular} & $\mu \mathrm{g} / \mathrm{L}$ & 2 & 0.000819 & 0.000964 & $0.0007^{d}$ \\
\hline Nickel, Dissolved & $\mathrm{mg} / \mathrm{L}$ & 2 & $<0.04$ & $<0.04$ & $0.081^{b}$ \\
\hline Nitrate-N & $\mathrm{mg} / \mathrm{L}$ & 2 & 0.16 & 0.16 & -- \\
\hline Nitrite-N & $\mathrm{mg} / \mathrm{L}$ & 2 & $<0.02$ & $<0.02$ & 0.10 \\
\hline NPOC & $\mathrm{mg} / \mathrm{L}$ & 2 & 2.6 & 3.2 & -- \\
\hline
\end{tabular}

$\mathrm{N}$ - Number of samples.

-- No Reference Standard available for this analyte.

a New York Water Quality Standards for Class "C" as a comparative reference for non-radiological results.

b Calculated from maximum measurement of hardness of surface water stream at WFBCTCB.

c Standards for cobalt, thallium and vanadium are applicable to the acid soluble fraction.

d Standard is for dissolved mercury. 
TABLE B-5B (concluded)

2012 Water Quality of Surface Water Downstream of the WVDP in Buttermilk Creek at Thomas Corners Bridge (WFBCTCB)

CHEMICAL CONSTITUENTS (concluded)

\begin{tabular}{|c|c|c|c|c|c|}
\hline \multirow[t]{2}{*}{ Analyte } & \multirow[t]{2}{*}{ Units } & \multirow[t]{2}{*}{$\mathbf{N}$} & \multicolumn{2}{|c|}{$\begin{array}{c}\text { WFBCTCB } \\
\text { Concentration }\end{array}$} & \multirow[t]{2}{*}{ Standard } \\
\hline & & & Average & Maximum & \\
\hline Oil \& Grease & $\mathrm{mg} / \mathrm{L}$ & 2 & $<5$ & $<5$ & -- \\
\hline pH & SU & 2 & 7.95 & 7.99 & $6.5-8.5$ \\
\hline Selenium, Dissolved & $\mathrm{mg} / \mathrm{L}$ & 2 & $<0.001$ & $<0.001$ & 0.0046 \\
\hline Sodium, Total & $\mathrm{mg} / \mathrm{L}$ & 2 & 19.2 & 23.6 & -- \\
\hline Solids, Total Dissolved & $\mathrm{mg} / \mathrm{L}$ & 2 & 210 & 242 & 500 \\
\hline Solids, Total Suspended & $\mathrm{mg} / \mathrm{L}$ & 2 & $<9.6$ & 15 & -- \\
\hline Sulfate & $\mathrm{mg} / \mathrm{L}$ & 2 & 23.6 & 27.9 & -- \\
\hline Sulfide & $\mathrm{mg} / \mathrm{L}$ & 2 & $<0.05$ & $<0.05$ & 0.002 \\
\hline Surfactants & $\mathrm{mg} / \mathrm{L}$ & 2 & $<0.02$ & $<0.02$ & 0.04 \\
\hline Thallium, Total & $\mathrm{mg} / \mathrm{L}$ & 2 & $<0.008$ & $<0.008$ & $0.008^{c}$ \\
\hline Titanium, Total & $\mathrm{mg} / \mathrm{L}$ & 2 & $<0.05$ & $<0.05$ & -- \\
\hline TOX & $\mathrm{mg} / \mathrm{L}$ & 1 & 0.01 & 0.01 & -- \\
\hline Vanadium, Total & $\mathrm{mg} / \mathrm{L}$ & 2 & $<0.01$ & $<0.01$ & $0.014^{c}$ \\
\hline Zinc, Dissolved & $\mathrm{mg} / \mathrm{L}$ & 2 & $<0.02$ & $<0.02$ & $0.128^{b}$ \\
\hline
\end{tabular}

$\mathrm{N}$ - Number of samples.

-- No Reference Standard available for this analyte.

${ }^{a}$ New York Water Quality Standards for Class "C" as a comparative reference for non-radiological results.

${ }^{\mathrm{b}}$ Calculated from maximum measurement of hardness of surface water stream at WFBCTCB.

${ }^{\mathrm{c}}$ Standards for cobalt, thallium and vanadium are applicable to the acid soluble fraction. 
TABLE B-5C

2012 Radioactivity of Surface Water Downstream of the WVDP at Franks Creek (WNSP006)

\begin{tabular}{|c|c|c|c|c|c|c|c|}
\hline \multirow{3}{*}{ Analyte } & \multirow{3}{*}{ Units } & \multirow{3}{*}{$\mathbf{N}$} & \multirow{2}{*}{\multicolumn{2}{|c|}{$\begin{array}{c}\text { WNSP006 } \\
\text { Concentrations }\end{array}$}} & \multirow{3}{*}{$N$} & \multicolumn{2}{|c|}{ Reference Values } \\
\hline & & & & & & \multirow{2}{*}{$\begin{array}{c}\text { WFBCBKG }^{a} \\
\text { Background Range }\end{array}$} & \multirow{2}{*}{ Guideline $^{b}$} \\
\hline & & & Average & Maximum & & & \\
\hline Gross Alpha & $\mu \mathrm{Ci} / \mathrm{mL}$ & 33 & $1.89 \pm 1.48 \mathrm{E}-09$ & $9.40 \mathrm{E}-09$ & 12 & $<5.10 \mathrm{E}-10-2.80 \mathrm{E}-09$ & $9.8 \mathrm{E}-08^{c}$ \\
\hline Gross Beta & $\mu \mathrm{Ci} / \mathrm{mL}$ & 33 & $5.08 \pm 0.33 \mathrm{E}-08$ & $1.58 \mathrm{E}-07$ & 12 & 1.73E-09-4.15E-09 & $1.1 \mathrm{E}-06^{d}$ \\
\hline Tritium & $\mu \mathrm{Ci} / \mathrm{mL}$ & 33 & $5.41 \pm 7.99 \mathrm{E}-08$ & $1.69 \mathrm{E}-07$ & 12 & $<4.67 \mathrm{E}-08-1.07 \mathrm{E}-07$ & $1.9 \mathrm{E}-03$ \\
\hline C-14 & $\mu \mathrm{Ci} / \mathrm{mL}$ & 4 & $0.25 \pm 3.48 \mathrm{E}-08$ & $<3.85 \mathrm{E}-08$ & 2 & $<2.98 \mathrm{E}-08-<3.40 \mathrm{E}-08$ & $6.2 \mathrm{E}-05$ \\
\hline Sr-90 & $\mu \mathrm{Ci} / \mathrm{mL}$ & 12 & $1.93 \pm 0.25 \mathrm{E}-08$ & $6.21 \mathrm{E}-08$ & 2 & $<1.14 \mathrm{E}-09-<1.16 \mathrm{E}-09$ & $1.1 \mathrm{E}-06$ \\
\hline Tc-99 & $\mu \mathrm{Ci} / \mathrm{mL}$ & 4 & $-0.61 \pm 2.19 \mathrm{E}-09$ & $<2.43 \mathrm{E}-09$ & 2 & $<1.98 \mathrm{E}-09-<2.32 \mathrm{E}-09$ & $4.4 \mathrm{E}-05$ \\
\hline I-129 & $\mu \mathrm{Ci} / \mathrm{mL}$ & 4 & $1.52 \pm 8.68 \mathrm{E}-10$ & $<1.09 \mathrm{E}-09$ & 2 & $<7.85 \mathrm{E}-10-<9.60 \mathrm{E}-10$ & $3.3 \mathrm{E}-07$ \\
\hline Cs-137 & $\mu \mathrm{Ci} / \mathrm{mL}$ & 12 & $2.06 \pm 2.76 \mathrm{E}-09$ & $6.93 \mathrm{E}-09$ & 2 & $<2.87 \mathrm{E}-09-3.44 \mathrm{E}-09$ & $3.0 \mathrm{E}-06$ \\
\hline U-232 & $\mu \mathrm{Ci} / \mathrm{mL}$ & 4 & $1.83 \pm 1.20 \mathrm{E}-10$ & 2.43E-10 & 2 & $<4.30 \mathrm{E}-11-<4.35 \mathrm{E}-11$ & $9.8 \mathrm{E}-08$ \\
\hline U-233/234 & $\mu \mathrm{Ci} / \mathrm{mL}$ & 4 & $3.52 \pm 1.67 \mathrm{E}-10$ & $5.33 \mathrm{E}-10$ & 2 & $<7.15 \mathrm{E}-11-<7.39 \mathrm{E}-11$ & $6.6 \mathrm{E}-07^{e}$ \\
\hline $\mathrm{U}-235 / 236$ & $\mu \mathrm{Ci} / \mathrm{mL}$ & 4 & $1.80 \pm 4.65 \mathrm{E}-11$ & $<6.03 \mathrm{E}-11$ & 2 & $<3.33 \mathrm{E}-11-<4.19 \mathrm{E}-11$ & $7.2 \mathrm{E}-07$ \\
\hline U-238 & $\mu \mathrm{Ci} / \mathrm{mL}$ & 4 & $2.70 \pm 1.36 \mathrm{E}-10$ & $4.34 \mathrm{E}-10$ & 2 & $<6.23 \mathrm{E}-11-1.04 \mathrm{E}-10$ & 7.5E-07 \\
\hline Total U & $\mu \mathrm{g} / \mathrm{mL}$ & 4 & $7.63 \pm 0.39 \mathrm{E}-04$ & $9.66 \mathrm{E}-04$ & 2 & $2.48 \mathrm{E}-04-2.90 \mathrm{E}-04$ & -- \\
\hline Pu-238 & $\mu \mathrm{Ci} / \mathrm{mL}$ & 4 & $0.94 \pm 3.79 \mathrm{E}-11$ & $<5.14 \mathrm{E}-11$ & 2 & $<1.93 \mathrm{E}-11-<1.94 \mathrm{E}-11$ & $1.5 \mathrm{E}-07$ \\
\hline Pu-239/240 & $\mu \mathrm{Ci} / \mathrm{mL}$ & 4 & $2.25 \pm 3.96 \mathrm{E}-11$ & $3.51 \mathrm{E}-11$ & 2 & $<2.85 \mathrm{E}-11-3.24 \mathrm{E}-11$ & $1.4 \mathrm{E}-07$ \\
\hline Am-241 & $\mu \mathrm{Ci} / \mathrm{mL}$ & 4 & $1.32 \pm 4.01 \mathrm{E}-11$ & $<4.55 \mathrm{E}-11$ & 2 & $<3.12 \mathrm{E}-11-<3.75 \mathrm{E}-11$ & 1.7E-07 \\
\hline
\end{tabular}

$\mathrm{N}$ - Number of samples.

-- No Guideline or standard available for these analytes.

${ }^{\text {a }}$ Background location.

${ }^{\mathrm{b}}$ DOE ingestion-based DCSs for $100 \mathrm{mrem} / \mathrm{yr}$ dose limit are provided as a guideline for radiological results.

${ }^{c}$ Alpha as U-232.

${ }^{\mathrm{d}}$ Beta as Sr-90.

${ }^{\mathrm{e}}$ DCS for U-233 is used for this comparison.

TABLE B-5D

2012 Radioactivity and pH in Surface Water at Erdman Brook (WNERB53)

\begin{tabular}{|c|c|c|c|c|c|c|c|}
\hline \multirow{3}{*}{ Analyte } & \multirow{3}{*}{ Units } & \multirow{3}{*}{$N$} & \multirow{2}{*}{\multicolumn{2}{|c|}{$\begin{array}{c}\text { WNERB53 } \\
\text { Concentrations }\end{array}$}} & \multirow{3}{*}{$N$} & \multicolumn{2}{|c|}{ Reference Values } \\
\hline & & & & & & \multirow{2}{*}{$\begin{array}{c}\text { WFBCBKG }^{a} \\
\text { Background Range }\end{array}$} & \multirow{2}{*}{$\begin{array}{c}\text { Guideline }^{b} \text { or } \\
\text { Standard }^{c}\end{array}$} \\
\hline & & & Average & Maximum & & & \\
\hline Gross Alpha & $\mu \mathrm{Ci} / \mathrm{mL}$ & 4 & $0.77 \pm 1.53 E-09$ & $2.34 \mathrm{E}-09$ & 12 & $<5.10 \mathrm{E}-10-2.80 \mathrm{E}-09$ & $9.8 \mathrm{E}-08^{d}$ \\
\hline Gross Beta & $\mu \mathrm{Ci} / \mathrm{mL}$ & 4 & $9.61 \pm 2.38 \mathrm{E}-09$ & $1.25 \mathrm{E}-08$ & 12 & 1.73E-09-4.15E-09 & $1.1 \mathrm{E}-06^{e}$ \\
\hline Tritium & $\mu \mathrm{Ci} / \mathrm{mL}$ & 4 & $4.98 \pm 7.82 \mathrm{E}-08$ & $1.62 \mathrm{E}-07$ & 12 & $<4.67 \mathrm{E}-08-1.07 \mathrm{E}-07$ & $1.9 \mathrm{E}-03$ \\
\hline Sr-90 & $\mu \mathrm{Ci} / \mathrm{mL}$ & 2 & $2.12 \pm 3.39 E-09$ & $3.71 \mathrm{E}-09$ & 2 & $<1.14 \mathrm{E}-09-<1.16 \mathrm{E}-09$ & $1.1 \mathrm{E}-06$ \\
\hline Cs-137 & $\mu \mathrm{Ci} / \mathrm{mL}$ & 2 & $0.13 \pm 2.32 \mathrm{E}-09$ & $<3.07 \mathrm{E}-09$ & 2 & $<2.87 \mathrm{E}-09-3.44 \mathrm{E}-09$ & $3.0 \mathrm{E}-06$ \\
\hline pH & SU & 4 & \multicolumn{2}{|c|}{ Range: $7.3-7.9$} & 292 & $6.4-8.7$ & $6.0-9.5$ \\
\hline
\end{tabular}

$\mathrm{N}$ - Number of samples.

a Background data are from Buttermilk Creek, upstream of the WVDP. Sampling for nonradiological data was discontinued. at this location in 2008. The $\mathrm{pH}$ range was calculated from the most recent 10 years of sampling, 1998-2007.

${ }^{b}$ DOE ingestion-based DCSs for $100 \mathrm{mrem} / \mathrm{yr}$ dose limit are provided as a guideline for radiological results.

c New York State Water Quality Standards for surface waters Class "D" as a standard for non-radiological results.

${ }^{d}$ Alpha as U-232.

e Beta as Sr-90. 
TABLE B-5E

2012 Radioactivity and pH in Surface Water at Franks Creek (WNFRC67)

\begin{tabular}{|c|c|c|c|c|c|c|c|}
\hline \multirow{3}{*}{ Analyte } & \multirow{3}{*}{ Units } & \multirow{3}{*}{$N$} & \multirow{2}{*}{\multicolumn{2}{|c|}{$\begin{array}{c}\text { WNFRC67 } \\
\text { Concentrations }\end{array}$}} & \multirow{3}{*}{$\mathbf{N}$} & \multicolumn{2}{|c|}{ Reference Values } \\
\hline & & & & & & \multirow{2}{*}{$\begin{array}{c}\text { WFBCBKG }{ }^{a} \\
\text { Background Range }\end{array}$} & \multirow{2}{*}{\begin{tabular}{|c} 
Guideline $^{b}$ or \\
Standard $^{c}$
\end{tabular}} \\
\hline & & & Average & Maximum & & & \\
\hline Gross Alpha & $\mu \mathrm{Ci} / \mathrm{mL}$ & 4 & $4.66 \pm 8.23 \mathrm{E}-10$ & $1.32 \mathrm{E}-09$ & 12 & $<5.10 \mathrm{E}-10-2.80 \mathrm{E}-09$ & $9.8 \mathrm{E}-08^{d}$ \\
\hline Gross Beta & $\mu \mathrm{Ci} / \mathrm{mL}$ & 4 & $3.31 \pm 1.59 \mathrm{E}-09$ & 4.17E-09 & 12 & 1.73E-09-4.15E-09 & $1.1 \mathrm{E}-06^{e}$ \\
\hline Tritium & $\mu \mathrm{Ci} / \mathrm{mL}$ & 4 & $5.07 \pm 7.87 \mathrm{E}-08$ & $1.23 \mathrm{E}-07$ & 12 & $<4.67 \mathrm{E}-08-1.07 \mathrm{E}-07$ & $1.90 \mathrm{E}-03$ \\
\hline Sr-90 & $\mu \mathrm{Ci} / \mathrm{mL}$ & 2 & $1.65 \pm 3.29 E-09$ & $<4.54 \mathrm{E}-09$ & 2 & $<1.14 \mathrm{E}-09-<1.16 \mathrm{E}-09$ & $1.10 \mathrm{E}-06$ \\
\hline Cs-137 & $\mu \mathrm{Ci} / \mathrm{mL}$ & 2 & $-0.70 \pm 1.95 E-09$ & $<2.53 \mathrm{E}-09$ & 2 & $<2.87 \mathrm{E}-09-3.44 \mathrm{E}-09$ & $3.00 \mathrm{E}-06$ \\
\hline $\mathrm{pH}$ & SU & 4 & \multicolumn{2}{|c|}{ Range: $6.52-8.1$} & 292 & $6.4-8.7$ & $6.0-9.5$ \\
\hline
\end{tabular}

$\mathrm{N}$ - Number of samples.

a Background data are from Buttermilk Creek, upstream of the WVDP. Sampling for nonradiological data was discontinued.

at this location in 2008. The pH range was calculated from the most recent 10 years of sampling, 1998-2007.

${ }^{b}$ DOE ingestion-based DCSs for $100 \mathrm{mrem} / \mathrm{yr}$ dose limit are provided as a guideline for radiological results.

c New York State Water Quality Standards for Class "D" surface waters as a standard for non-radiological results.

${ }^{\mathrm{d}}$ Alpha as U-232.

e Beta as Sr-90.

TABLE B-5F

Historical Radioactivity and pH in Surface Water at Bigelow Bridge Cattaraugus Creek Background (WFBIGBR)

\begin{tabular}{|c|c|c|c|c|c|}
\hline \multirow[t]{2}{*}{ Analyte } & \multirow[t]{2}{*}{ Units } & \multirow[t]{2}{*}{$N$} & \multicolumn{2}{|c|}{$\begin{array}{c}\text { WFBIGBR } \\
\text { Concentrations }\end{array}$} & \multirow{2}{*}{$\begin{array}{c}\text { Reference Values } \\
\text { Guideline }^{b} \\
\text { or Standard }^{c}\end{array}$} \\
\hline & & & Average & Maximum & \\
\hline Gross Alpha & $\mu \mathrm{Ci} / \mathrm{mL}$ & 98 & $0.45 \pm 1.05 E-09$ & $4.62 \mathrm{E}-09$ & $9.8 \mathrm{E}-08^{d}$ \\
\hline Gross Beta & $\mu \mathrm{Ci} / \mathrm{mL}$ & 98 & $2.64 \pm 1.35 \mathrm{E}-09$ & $1.37 \mathrm{E}-08$ & $1.1 \mathrm{E}-06^{e}$ \\
\hline Tritium & $\mu \mathrm{Ci} / \mathrm{mL}$ & 98 & $0.71 \pm 7.79 \mathrm{E}-08$ & $2.65 \mathrm{E}-07$ & $1.9 \mathrm{E}-03$ \\
\hline Sr-90 & $\mu \mathrm{Ci} / \mathrm{mL}$ & 98 & $1.27 \pm 1.46 \mathrm{E}-09$ & $1.10 \mathrm{E}-08$ & $1.1 \mathrm{E}-06$ \\
\hline Cs-137 & $\mu \mathrm{Ci} / \mathrm{mL}$ & 98 & $0.59 \pm 3.27 E-09$ & $5.29 \mathrm{E}-09$ & $3 \mathrm{E}-06$ \\
\hline $\mathrm{pH}$ & SU & 98 & \multicolumn{2}{|c|}{ Range: $5.80-8.34$} & $6.5-8.5$ \\
\hline
\end{tabular}

$\mathrm{N}$ - Number of samples.

a Sampling was discontinued in 2008. Data represent measurements from the most recent 10 years of sampling, 1998 through 2007.

${ }^{b}$ DOE ingestion-based DCSs for $100 \mathrm{mrem} / \mathrm{yr}$ dose limit are provided as a guideline for radiological results.

c The New York Water Quality Standard for Class "B" is provided as a comparative reference for $\mathrm{pH}$.

d Alpha as U-232.

${ }^{\mathrm{e}}$ Beta as Sr-90. 
TABLE B-5G

2012 Radioactivity and pH in Surface Water at Fox Valley Road

Buttermilk Creek Background (WFBCBKG)

\begin{tabular}{|c|c|c|c|c|c|}
\hline \multirow[t]{2}{*}{ Analyte } & \multirow[t]{2}{*}{ Units } & \multirow[t]{2}{*}{$N$} & \multicolumn{2}{|c|}{$\begin{array}{c}\text { WFBCBKG }^{a} \\
\text { Concentrations }\end{array}$} & \multirow{2}{*}{$\begin{array}{c}\text { Reference Values } \\
\text { Guideline }^{b} \\
\text { or Standard }^{c}\end{array}$} \\
\hline & & & Average & Maximum & \\
\hline Gross Alpha & $\mu \mathrm{Ci} / \mathrm{mL}$ & 12 & $1.02 \pm 1.07 E-09$ & $2.80 \mathrm{E}-09$ & $9.8 \mathrm{E}-08^{d}$ \\
\hline Gross Beta & $\mu \mathrm{Ci} / \mathrm{mL}$ & 12 & $2.36 \pm 1.57 \mathrm{E}-09$ & $4.15 E-09$ & $1.1 \mathrm{E}-06^{e}$ \\
\hline Tritium & $\mu \mathrm{Ci} / \mathrm{mL}$ & 12 & $2.60 \pm 7.56 \mathrm{E}-08$ & $1.07 \mathrm{E}-07$ & $1.9 \mathrm{E}-03$ \\
\hline C-14 & $\mu \mathrm{Ci} / \mathrm{mL}$ & 2 & $0.55 \pm 3.20 \mathrm{E}-08$ & $<3.40 \mathrm{E}-08$ & $6.2 \mathrm{E}-05$ \\
\hline Sr-90 & $\mu \mathrm{Ci} / \mathrm{mL}$ & 2 & $0.96 \pm 1.15 \mathrm{E}-09$ & $<1.16 \mathrm{E}-09$ & $1.1 \mathrm{E}-06$ \\
\hline Tc-99 & $\mu \mathrm{Ci} / \mathrm{mL}$ & 2 & $-1.07 \pm 2.15 \mathrm{E}-09$ & $<2.32 \mathrm{E}-09$ & $4.4 \mathrm{E}-05$ \\
\hline I-129 & $\mu \mathrm{Ci} / \mathrm{mL}$ & 2 & $-2.60 \pm 8.77 \mathrm{E}-10$ & $<9.60 \mathrm{E}-10$ & $3.3 \mathrm{E}-07$ \\
\hline Cs-137 & $\mu \mathrm{Ci} / \mathrm{mL}$ & 2 & $1.90 \pm 2.68 \mathrm{E}-09$ & $3.44 \mathrm{E}-09$ & $3.0 \mathrm{E}-06$ \\
\hline$U-232$ & $\mu \mathrm{Ci} / \mathrm{mL}$ & 2 & $-1.77 \pm 4.32 \mathrm{E}-11$ & $<4.35 \mathrm{E}-11$ & $9.8 \mathrm{E}-08$ \\
\hline U-233/234 & $\mu \mathrm{Ci} / \mathrm{mL}$ & 2 & $5.06 \pm 7.27 \mathrm{E}-11$ & $<7.39 \mathrm{E}-11$ & $6.6 \mathrm{E}-07^{f}$ \\
\hline U-235/236 & $\mu \mathrm{Ci} / \mathrm{mL}$ & 2 & $1.03 \pm 3.78 \mathrm{E}-11$ & $<4.19 \mathrm{E}-11$ & $7.2 \mathrm{E}-07$ \\
\hline U-238 & $\mu \mathrm{Ci} / \mathrm{mL}$ & 2 & $7.86 \pm 7.32 \mathrm{E}-11$ & $1.04 \mathrm{E}-10$ & $7.5 \mathrm{E}-07$ \\
\hline Total U & $\mu \mathrm{g} / \mathrm{mL}$ & 2 & $2.69 \pm 0.23 \mathrm{E}-04$ & $2.90 \mathrm{E}-04$ & -- \\
\hline Pu-238 & $\mu \mathrm{Ci} / \mathrm{mL}$ & 2 & $-0.90 \pm 1.94 \mathrm{E}-11$ & $<1.94 \mathrm{E}-11$ & $1.5 \mathrm{E}-07$ \\
\hline $\mathrm{Pu}-239 / 240$ & $\mu \mathrm{Ci} / \mathrm{mL}$ & 2 & $1.82 \pm 3.01 \mathrm{E}-11$ & $3.24 \mathrm{E}-11$ & $1.4 \mathrm{E}-07$ \\
\hline Am-241 & $\mu \mathrm{Ci} / \mathrm{mL}$ & 2 & $-0.51 \pm 3.45 E-11$ & $<3.75 E-11$ & $1.7 \mathrm{E}-07$ \\
\hline $\mathrm{pH}$ & SU & 292 & Range & & $6.0-9.5$ \\
\hline
\end{tabular}

$\mathrm{N}$ - Number of samples.

-- No Guideline or standard available for these analytes.

${ }^{a}$ Radiological data are from samples collected in CY 2012. Sampling for nonradiological constituents was discontinued in 2008. The $\mathrm{pH}$ values represent measurements from the most recent 10 years of sampling, 1998 through 2007.

${ }^{b}$ DOE ingestion-based DCSs for $100 \mathrm{mrem} / \mathrm{yr}$ dose limit are provided as a guideline for radiological results.

c The New York Water Quality Standard for Class "D" is provided as a comparative reference for $\mathrm{pH}$.

${ }^{d}$ Alpha as U-232.

e Beta as Sr-90.

${ }^{f}$ DCS for U-233 used for this comparison. 


\section{APPENDIX B-6 \\ Potable Water (Drinking Water) Data}

TABLE B-6A

2012 Water Quality Results in Potable Water at the WVDP

\begin{tabular}{|l|c|c|c|c|c|}
\hline \multicolumn{1}{|c|}{ Analyte } & Units & $\boldsymbol{N}$ & WNDNKMP & \multirow{2}{*}{ WNDNKEL $^{*}$ Standard $^{a}$} \\
\hline Gross Alpha & $\mu \mathrm{Ci} / \mathrm{mL}$ & 1 & $-1.28 \pm 3.07 \mathrm{E}-10$ & NA & $1.5 \mathrm{E}-08$ \\
\hline Gross Beta & $\mu \mathrm{Ci} / \mathrm{mL}$ & 1 & $2.01 \pm 0.87 \mathrm{E}-09$ & NA & $5 \mathrm{E}-08$ \\
\hline Tritium & $\mu \mathrm{Ci} / \mathrm{mL}$ & 1 & $-3.45 \pm 3.31 \mathrm{E}-08$ & $\mathrm{NA}$ & $2 \mathrm{E}-05$ \\
\hline Haloacetic Acids-Five $(5)$ & $\mathrm{mg} / \mathrm{L}$ & 1 & $\mathrm{NA}$ & 0.024 & 0.06 \\
\hline Total Trihalomethanes & $\mathrm{mg} / \mathrm{L}$ & 1 & $\mathrm{NA}$ & 0.05 & 0.08 \\
\hline
\end{tabular}

$\mathrm{N}$ - Number of samples.

NA - Not applicable, constituent not analyzed.

${ }^{\text {a }}$ New York State Department of Health MCLs for drinking water used as a comparative reference.

TABLE B-6B

2012 Water Quality Results in Utility Room Potable Water (Entry Point 002)

\begin{tabular}{|c|c|c|c|c|c|}
\hline \multirow{2}{*}{ Analyte } & \multirow{2}{*}{ Units } & \multirow{2}{*}{$N$} & \multicolumn{2}{|c|}{ Utility Room Concentrations } & \multirow{2}{*}{$\begin{array}{c}\text { Standard or } \\
\text { Guideline }^{a}\end{array}$} \\
\hline & & & Minimum & Maximum & \\
\hline Antimony, Total & $\mathrm{mg} / \mathrm{L}$ & 1 & NA & 0.00064 & 0.006 \\
\hline Arsenic, Total & $\mathrm{mg} / \mathrm{L}$ & 1 & NA & $<0.0014$ & 0.010 \\
\hline Barium, Total & $\mathrm{mg} / \mathrm{L}$ & 1 & NA & 0.0369 & 2.00 \\
\hline Beryllium, Total & $\mathrm{mg} / \mathrm{L}$ & 1 & NA & $<0.0003$ & 0.004 \\
\hline Cadmium, Total & $\mathrm{mg} / \mathrm{L}$ & 1 & NA & $<0.001$ & 0.005 \\
\hline Chromium, Total & $\mathrm{mg} / \mathrm{L}$ & 1 & NA & $<0.007$ & 0.10 \\
\hline Cyanide, Total & $\mathrm{mg} / \mathrm{L}$ & 1 & NA & $<0.020$ & 0.2 \\
\hline Fluoride & $\mathrm{mg} / \mathrm{L}$ & 1 & NA & $<0.20$ & 2.2 \\
\hline Free Residual Chlorine & $\mathrm{mg} / \mathrm{L}$ & 1,098 & 0.4 & 2.80 & $0.2-4.0$ \\
\hline Iron, Total & $\mathrm{mg} / \mathrm{L}$ & 1 & NA & $<0.050$ & 0.3 \\
\hline Manganese, Total & $\mathrm{mg} / \mathrm{L}$ & 1 & NA & 0.0182 & 0.3 \\
\hline Mercury, Total & $\mathrm{mg} / \mathrm{L}$ & 1 & NA & $<0.0002$ & 0.002 \\
\hline Nickel, Total & $\mathrm{mg} / \mathrm{L}$ & 1 & NA & $<0.005$ & -- \\
\hline TOC & $\mathrm{mg} / \mathrm{L}$ & 5 & 1.0 & 1.9 & -- \\
\hline Selenium, Total & $\mathrm{mg} / \mathrm{L}$ & 1 & NA & $<0.002$ & 0.05 \\
\hline Thallium, Total & $\mathrm{mg} / \mathrm{L}$ & 1 & NA & $<0.0003$ & 0.002 \\
\hline Turbidity & NTU & 2,142 & 0.1 & 0.6 & $1.0^{b}$ \\
\hline Zinc, Total & $\mathrm{mg} / \mathrm{L}$ & 1 & NA & $<0.010$ & 5.0 \\
\hline
\end{tabular}

Note: Chemical constituent sampling is required by, and reported to the Cattaraugus County Department of Health. $\mathrm{N}$ - Number of samples.

NA - Not applicable, constituents sampled annually.

-- No guideline or standard available for these analytes.

${ }^{a}$ New York State Department of Health MCLs for drinking water.

${ }^{\mathrm{b}} \mathrm{A}$ treatment standard of $0.3 \mathrm{NTU}$ applies to the 95 th percentile on a monthly basis. 
TABLE B-6C

2012 Water Quality Results in Utility Room Raw (Untreated) Water

\begin{tabular}{|l|c|c|c|c|c|}
\hline \multirow{2}{*}{ Analyte } & \multirow{2}{*}{ Units } & \multirow{2}{*}{$\boldsymbol{N}$} & \multicolumn{3}{c|}{ Untreated Raw Water Concentrations } \\
\cline { 4 - 6 } & & & Minimum & Average & Maximum \\
\hline Alkalinity & $\mathrm{mg} / \mathrm{L}$ & 5 & 44.0 & 73.6 & 118 \\
\hline Iron, Total & $\mathrm{mg} / \mathrm{L}$ & 52 & 0.226 & 0.661 & 3.23 \\
\hline Solids, Total Dissolved & $\mathrm{mg} / \mathrm{L}$ & 15 & 34 & 102 & 151 \\
\hline TOC & $\mathrm{mg} / \mathrm{L}$ & 5 & 1.5 & 2.2 & 3.2 \\
\hline
\end{tabular}

Note: Chemical constituent sampling is required by, and reported to the Cattaraugus County Department of Health. $\mathrm{N}$ - Number of samples.

TOC - Total organic carbon.

TABLE B-6D

2012 Biological and Chlorine Results From Various Site Tap Water Locations (Analyzed by Cattaraugus County Department of Health)

\begin{tabular}{|l|c|c|c|c|}
\hline \multicolumn{1}{|c|}{ Analyte } & Units & $\mathbf{N}$ & $\begin{array}{c}\text { Various Site Tap Water Locations } \\
\text { Results }\end{array}$ & Standard $^{a}$ \\
\hline E. coli & NA & 12 & Negative & one positive sample \\
\hline Free Residual Chlorine & $\mathrm{mg} / \mathrm{L}$ & 12 & Range: $0.10-1.19$ & 4.0 (max) \\
\hline Total Coliform & NA & 12 & Negative & two or more positive samples \\
\hline
\end{tabular}

$\mathrm{N}$ - Number of samples.

NA - Not applicable.

${ }^{a}$ New York State Department of Health MCLs for drinking water or EPA MCLGs, whichever is more stringent.

TABLE B-6E

2012 Nitrate Results From the Utility Room Raw Tap Water

(Analyzed by Cattaraugus County Department of Health)

\begin{tabular}{|l|c|c|c|c|c|}
\hline \multicolumn{1}{|c|}{ Analyte } & Units & $\mathbf{N}$ & Date Collected & Annual Concentration & Standard $^{a}$ \\
\hline Nitrate-N & $\mathrm{mg} / \mathrm{L}$ & 1 & $3 / 1 / 2012$ & $<1.0$ & 10 \\
\hline
\end{tabular}

$\mathrm{N}$ - Number of samples.

${ }^{a}$ New York State Department of Health MCLs for drinking water. 


\section{APPENDIX C \\ Summary of Air Monitoring Data}

TABLE C-1

Total Radioactivity Released at Main Plant Stack (ANSTACK) in 2012

and Comparison of Discharge Concentrations with U.S. DOE-Derived Concentration Standards (DCSs)

\begin{tabular}{|c|c|c|c|c|c|c|}
\hline Isotope ${ }^{a}$ & $N$ & $\begin{array}{c}\text { Total } \\
\text { Activity Released }^{b} \\
\text { (Ci) }\end{array}$ & $\begin{array}{c}\text { Average } \\
\text { Concentration } \\
(\mu \mathrm{Ci} / \mathrm{mL})\end{array}$ & $\begin{array}{c}\text { Maximum } \\
\text { Concentration } \\
(\mu \mathrm{Ci} / \mathrm{mL})\end{array}$ & $\begin{array}{c}D_{C S}{ }^{c} \\
(\mu C i / m L) \\
\end{array}$ & $\begin{array}{c}\text { Ratio of } \\
\text { Concentration } \\
\text { to DCS } \\
\end{array}$ \\
\hline Gross Alpha & 26 & $4.50 \pm 0.60 \mathrm{E}-07$ & $6.06 \pm 0.81 \mathrm{E}-16$ & $2.70 \mathrm{E}-15$ & $N A^{d}$ & NA \\
\hline Gross Beta & 26 & $8.87 \pm 0.21 \mathrm{E}-06$ & $1.24 \pm 0.03 \mathrm{E}-14$ & $6.43 \mathrm{E}-14$ & $N A^{d}$ & NA \\
\hline $\mathrm{H}-3$ & 26 & $2.46 \pm 0.06 \mathrm{E}-03$ & $3.32 \pm 0.08 \mathrm{E}-12$ & $7.16 \mathrm{E}-12$ & $2.1 \mathrm{E}-07$ & $<0.0001$ \\
\hline Co-60 & 2 & $0.79 \pm 6.08 \mathrm{E}-08$ & $1.07 \pm 8.19 \mathrm{E}-17$ & $<1.46 \mathrm{E}-16$ & $3.6 \mathrm{E}-10$ & $<0.0001$ \\
\hline Sr-90 & 2 & $1.83 \pm 0.14 \mathrm{E}-06$ & $2.46 \pm 0.18 \mathrm{E}-15$ & $3.07 \mathrm{E}-15$ & $1.0 \mathrm{E}-10$ & $<0.0001$ \\
\hline I-129 & 2 & $2.09 \pm 0.17 \mathrm{E}-05$ & $2.82 \pm 0.22 E-14$ & $3.49 \mathrm{E}-14$ & $1.0 \mathrm{E}-10$ & 0.0003 \\
\hline Cs-137 & 2 & $2.75 \pm 0.17 \mathrm{E}-06$ & $3.70 \pm 0.23 E-15$ & $3.85 \mathrm{E}-15$ & $8.8 \mathrm{E}-10$ & $<0.0001$ \\
\hline Eu-154 & 2 & $0.00 \pm 1.84 \mathrm{E}-07$ & $0.00 \pm 2.48 \mathrm{E}-16$ & $<4.69 \mathrm{E}-16$ & 7.5E-11 & $<0.0001$ \\
\hline $\mathrm{U}-232^{\mathrm{e}}$ & 2 & $-2.29 \pm 3.94 \mathrm{E}-09$ & $-3.08 \pm 5.32 E-18$ & $<8.07 \mathrm{E}-18$ & 4.7E-13 & $<0.0001$ \\
\hline $\mathrm{U}-233 / 234^{\mathrm{e}}$ & 2 & $1.57 \pm 0.75 \mathrm{E}-08$ & $2.12 \pm 1.01 \mathrm{E}-17$ & $2.27 \mathrm{E}-17$ & $1.0 \mathrm{E}-12^{f}$ & $<0.0001$ \\
\hline $\mathrm{U}-235 / 236^{\mathrm{e}}$ & 2 & $-3.18 \pm 3.81 E-09$ & $-4.28 \pm 5.13 E-18$ & $<7.46 \mathrm{E}-18$ & $1.2 \mathrm{E}-12$ & $<0.0001$ \\
\hline $\mathrm{U}-238^{\mathrm{e}}$ & 2 & $2.38 \pm 0.63 \mathrm{E}-08$ & $3.21 \pm 0.85 \mathrm{E}-17$ & $3.91 \mathrm{E}-17$ & $1.3 \mathrm{E}-12$ & $<0.0001$ \\
\hline Pu-238 & 2 & $4.96 \pm 1.03 \mathrm{E}-08$ & $6.68 \pm 1.38 \mathrm{E}-17$ & $9.22 \mathrm{E}-17$ & $8.8 \mathrm{E}-14$ & 0.0008 \\
\hline Pu-239/240 & 2 & $9.82 \pm 1.40 \mathrm{E}-08$ & $1.32 \pm 0.19 E-16$ & $1.67 \mathrm{E}-16$ & $8.1 \mathrm{E}-14$ & 0.0016 \\
\hline Am-241 & 2 & $2.04 \pm 0.25 \mathrm{E}-07$ & $2.75 \pm 0.34 \mathrm{E}-16$ & $3.14 \mathrm{E}-16$ & $9.7 \mathrm{E}-14$ & 0.0028 \\
\hline Sum of Ratios & & & & & & 0.0060 \\
\hline
\end{tabular}

$\mathrm{N}$ - Number of samples.

NA - Not applicable.

${ }^{a}$ Half-lives are listed in table UI-4.

${ }^{\mathrm{b}}$ Total volume released at 50,000 cubic feet per minute $=7.44 \mathrm{E}+14 \mathrm{~mL} / \mathrm{year}$.

${ }^{C}$ DCSs are used as reference values for the application of best available technology per DOE Order 458.1.

${ }^{d}$ DCSs do not exist for indicator parameters gross alpha and gross beta.

e Total Uranium $=6.20 \pm 0.18 \mathrm{E}-02 \mathrm{~g}$; average $=8.36 \pm 0.24 \mathrm{E}-11 \mu \mathrm{g} / \mathrm{mL}$.

${ }^{f}$ DCS for Uranium-233 used for this comparison. 
TABLE C-2

2012 Effluent Airborne Radioactivity at Vitrification System HVAC (ANVITSK)

\begin{tabular}{|c|c|c|c|c|c|}
\hline Isotope & $N$ & $\begin{array}{c}\text { Total } \\
\text { Activity Released } \\
\text { (Ci) }\end{array}$ & $\begin{array}{c}\text { Average } \\
\text { Concentration } \\
(\mu \mathrm{Ci} / \mathrm{mL})\end{array}$ & $\begin{array}{c}\text { Maximum } \\
\text { Concentration } \\
(\mu \mathrm{Ci} / \mathrm{mL})\end{array}$ & $\begin{array}{c}D_{C S}^{a} \\
(\mu C i / m L)\end{array}$ \\
\hline Gross Alpha & 26 & $-1.36 \pm 1.41 E-08$ & $-3.68 \pm 3.79 E-17$ & $<2.93 \mathrm{E}-16$ & $N A^{b}$ \\
\hline Gross Beta & 26 & $1.34 \pm 3.93 E-08$ & $0.36 \pm 1.06 \mathrm{E}-16$ & $4.80 \mathrm{E}-16$ & $N A^{b}$ \\
\hline Co-60 & 2 & $0.92 \pm 2.43 E-08$ & $2.48 \pm 6.54 \mathrm{E}-17$ & $<1.04 \mathrm{E}-16$ & $3.6 \mathrm{E}-10$ \\
\hline Sr-90 & 2 & $1.05 \pm 1.96 \mathrm{E}-08$ & $2.84 \pm 5.27 \mathrm{E}-17$ & $<8.43 \mathrm{E}-17$ & $1.0 \mathrm{E}-10$ \\
\hline I-129 & 2 & $5.55 \pm 1.23 \mathrm{E}-07$ & $1.50 \pm 0.33 \mathrm{E}-15$ & $1.61 \mathrm{E}-15$ & $1.0 \mathrm{E}-10$ \\
\hline Cs-137 & 2 & $-0.28 \pm 1.75 E-08$ & $-0.76 \pm 4.71 E-17$ & $8.45 \mathrm{E}-17$ & $8.8 \mathrm{E}-10$ \\
\hline Eu-154 & 2 & $3.15 \pm 4.97 \mathrm{E}-08$ & $0.85 \pm 1.34 \mathrm{E}-16$ & $<2.17 \mathrm{E}-16$ & 7.5E-11 \\
\hline $\mathrm{U}-232^{\mathrm{c}}$ & 2 & $-0.40 \pm 1.61 E-09$ & $-1.07 \pm 4.34 \mathrm{E}-18$ & $<7.13 \mathrm{E}-18$ & 4.7E-13 \\
\hline$U-233 / 234^{c}$ & 2 & $5.36 \pm 2.84 \mathrm{E}-09$ & $1.45 \pm 0.76 \mathrm{E}-17$ & $2.21 \mathrm{E}-17$ & $1.0 \mathrm{E}-12^{\mathrm{d}}$ \\
\hline U-235/236 ${ }^{c}$ & 2 & $0.89 \pm 1.26 \mathrm{E}-09$ & $2.39 \pm 3.40 \mathrm{E}-18$ & $5.49 \mathrm{E}-18$ & $1.2 \mathrm{E}-12$ \\
\hline$U-238^{\mathrm{C}}$ & 2 & $9.63 \pm 2.88 \mathrm{E}-09$ & $2.59 \pm 0.77 \mathrm{E}-17$ & $3.02 \mathrm{E}-17$ & $1.3 \mathrm{E}-12$ \\
\hline Pu-238 & 2 & $-0.26 \pm 1.34 \mathrm{E}-09$ & $-0.70 \pm 3.60 \mathrm{E}-18$ & $<6.46 \mathrm{E}-18$ & $8.8 \mathrm{E}-14$ \\
\hline Pu-239/240 & 2 & $0.30 \pm 1.24 \mathrm{E}-09$ & $0.82 \pm 3.34 \mathrm{E}-18$ & $<5.74 \mathrm{E}-18$ & 8.1E-14 \\
\hline Am-241 & 2 & $0.46 \pm 1.84 \mathrm{E}-09$ & $1.25 \pm 4.96 \mathrm{E}-18$ & $<7.95 \mathrm{E}-18$ & 9.7E-14 \\
\hline
\end{tabular}

$\mathrm{N}$ - Number of samples.

NA - Not applicable.

${ }^{a}$ DOE-derived concentration standards (DCS's) are used as reference values for the application of best available technology per DOE Order 458.1.

${ }^{\mathrm{b}}$ DCSs do not exist for indicator parameters gross alpha and gross beta.

${ }^{c}$ Total Uranium $=2.52 \pm 0.07 \mathrm{E}-02 \mathrm{~g}$; average $=6.80 \pm 0.19 \mathrm{E}-11 \mu \mathrm{g} / \mathrm{mL}$.

${ }^{d}$ DCS for Uranium-233 used for this comparison.

TABLE C-3

2012 Effluent Airborne Radioactivity at 01-14 Building (ANCSSTK)

\begin{tabular}{|c|c|c|c|c|c|}
\hline Isotope & $\mathbf{N}$ & $\begin{array}{c}\text { Total } \\
\text { Activity Released } \\
\text { (Ci) }\end{array}$ & $\begin{array}{c}\text { Average } \\
\text { Concentration } \\
(\mu \mathrm{Ci} / \mathrm{mL})\end{array}$ & $\begin{array}{c}\text { Maximum } \\
\text { Concentration } \\
(\mu \mathrm{Ci} / \mathrm{mL})\end{array}$ & $\begin{array}{c}D_{C S}^{a} \\
(\mu C i / m L)\end{array}$ \\
\hline Gross Alpha & 22 & $0.75 \pm 5.89 \mathrm{E}-09$ & $0.62 \pm 4.84 \mathrm{E}-17$ & $<3.94 \mathrm{E}-16$ & $N A^{b}$ \\
\hline Gross Beta & 22 & $-0.43 \pm 1.54 \mathrm{E}-08$ & $-0.36 \pm 1.27 \mathrm{E}-16$ & $<1.07 \mathrm{E}-15$ & $N A^{b}$ \\
\hline Co-60 & 2 & $7.78 \pm 7.87 \mathrm{E}-09$ & $6.39 \pm 6.46 \mathrm{E}-17$ & $<1.01 \mathrm{E}-16$ & $3.6 \mathrm{E}-10$ \\
\hline Sr-90 & 2 & $8.01 \pm 9.52 \mathrm{E}-09$ & $6.57 \pm 7.81 \mathrm{E}-17$ & $<9.24 \mathrm{E}-17$ & $1.0 \mathrm{E}-10$ \\
\hline I-129 & 2 & $8.36 \pm 4.17 \mathrm{E}-08$ & $6.86 \pm 3.43 E-16$ & $9.53 \mathrm{E}-16$ & $1.0 \mathrm{E}-10$ \\
\hline Cs-137 & 2 & $0.48 \pm 7.08 \mathrm{E}-09$ & $0.39 \pm 5.81 \mathrm{E}-17$ & $8.74 \mathrm{E}-17$ & $8.8 \mathrm{E}-10$ \\
\hline Eu-154 & 2 & $-0.70 \pm 2.43 \mathrm{E}-08$ & $-0.58 \pm 1.99 \mathrm{E}-16$ & $<3.10 \mathrm{E}-16$ & $7.5 \mathrm{E}-11$ \\
\hline $\mathrm{U}-232^{\mathrm{c}}$ & 2 & $4.55 \pm 8.00 \mathrm{E}-10$ & $3.74 \pm 6.57 \mathrm{E}-18$ & $<9.44 \mathrm{E}-18$ & 4.7E-13 \\
\hline $\mathrm{U}-233 / 234^{\mathrm{C}}$ & 2 & $5.83 \pm 1.49 \mathrm{E}-09$ & $4.79 \pm 1.22 \mathrm{E}-17$ & $9.19 \mathrm{E}-17$ & $1.0 \mathrm{E}-12^{\mathrm{d}}$ \\
\hline $\mathrm{U}-235 / 236^{\mathrm{c}}$ & 2 & $3.30 \pm 3.94 \mathrm{E}-10$ & $2.71 \pm 3.23 \mathrm{E}-18$ & $5.32 \mathrm{E}-18$ & $1.2 \mathrm{E}-12$ \\
\hline $\mathrm{U}-238^{\mathrm{C}}$ & 2 & $5.06 \pm 1.39 \mathrm{E}-09$ & $4.16 \pm 1.14 \mathrm{E}-17$ & $7.02 \mathrm{E}-17$ & $1.3 \mathrm{E}-12$ \\
\hline Pu-238 & 2 & $-3.38 \pm 4.09 E-10$ & $-2.78 \pm 3.36 \mathrm{E}-18$ & $<6.27 \mathrm{E}-18$ & $8.8 \mathrm{E}-14$ \\
\hline $\mathrm{Pu}-239 / 240$ & 2 & $2.56 \pm 3.54 \mathrm{E}-10$ & $2.10 \pm 2.91 \mathrm{E}-18$ & $<5.66 \mathrm{E}-18$ & $8.1 \mathrm{E}-14$ \\
\hline Am-241 & 2 & $1.04 \pm 6.14 \mathrm{E}-10$ & $0.85 \pm 5.04 \mathrm{E}-18$ & $<8.52 \mathrm{E}-18$ & 9.7E-14 \\
\hline
\end{tabular}

$\mathrm{N}$ - Number of samples. NA - Not applicable.

${ }^{a}$ DOE-derived concentration standards (DCS's) are used as reference values for the application of best available

technology per DOE Order 458.1.

${ }^{\mathrm{b}}$ DCSs do not exist for indicator parameters gross alpha and gross beta.

${ }^{\mathrm{c}}$ Total Uranium $=1.79 \pm 0.06 \mathrm{E}-02 \mathrm{~g}$; average $=1.47 \pm 0.05 \mathrm{E}-10 \mu \mathrm{g} / \mathrm{mL}$.

${ }^{\mathrm{d}}$ DCS for Uranium-233 used for this comparison.

Note: Operation of the 01-14 building stack was discontinued at the end of October 2012 to prepare for demolition. 
TABLE C-4

2012 Airborne Radioactivity at Contact Size-Reduction Facility (ANCSRFK)

Ventilation Off;

System Did Not Operate During CY 2012

TABLE C-5

2012 Effluent Airborne Radioactivity at Supernatant Treatment System (ANSTSTK)

\begin{tabular}{|c|c|c|c|c|c|}
\hline Isotope & $N$ & $\begin{array}{c}\text { Total } \\
\text { Activity Released } \\
\text { (Ci) }\end{array}$ & $\begin{array}{c}\text { Average } \\
\text { Concentration } \\
(\mu \mathrm{Ci} / \mathrm{mL})\end{array}$ & $\begin{array}{c}\text { Maximum } \\
\text { Concentration } \\
(\mu \mathrm{Ci} / \mathrm{mL})\end{array}$ & $\begin{array}{c}\operatorname{DCS}^{a} \\
(\mu \mathrm{Ci} / \mathrm{mL})\end{array}$ \\
\hline Gross Alpha & 26 & $-3.25 \pm 2.86 \mathrm{E}-09$ & $-4.86 \pm 4.28 \mathrm{E}-17$ & $<2.86 \mathrm{E}-16$ & $N A^{b}$ \\
\hline Gross Beta & 26 & $1.62 \pm 0.84 \mathrm{E}-08$ & $2.42 \pm 1.26 \mathrm{E}-16$ & $4.84 \mathrm{E}-15$ & $N A^{b}$ \\
\hline $\mathrm{H}-3$ & 26 & $1.67 \pm 0.50 \mathrm{E}-05$ & $2.50 \pm 0.75 \mathrm{E}-13$ & $1.26 \mathrm{E}-12$ & $2.1 \mathrm{E}-07$ \\
\hline Co-60 & 2 & $-0.37 \pm 4.11 \mathrm{E}-09$ & $-0.55 \pm 6.15 \mathrm{E}-17$ & $<9.96 \mathrm{E}-17$ & $3.6 \mathrm{E}-10$ \\
\hline Sr-90 & 2 & $0.32 \pm 4.67 \mathrm{E}-09$ & $0.49 \pm 6.99 \mathrm{E}-17$ & $<1.13 \mathrm{E}-16$ & $1.0 \mathrm{E}-10$ \\
\hline $\mathrm{I}-129$ & 2 & $7.85 \pm 0.39 \mathrm{E}-06$ & $1.17 \pm 0.06 \mathrm{E}-13$ & $1.41 \mathrm{E}-13$ & $1.0 \mathrm{E}-10$ \\
\hline Cs-137 & 2 & $1.99 \pm 0.64 \mathrm{E}-08$ & $2.98 \pm 0.95 \mathrm{E}-16$ & 4.23E-16 & $8.8 \mathrm{E}-10$ \\
\hline Eu-154 & 2 & $-0.26 \pm 1.10 \mathrm{E}-08$ & $-0.40 \pm 1.65 \mathrm{E}-16$ & $<2.62 \mathrm{E}-16$ & 7.5E-11 \\
\hline U-232 ${ }^{c}$ & 2 & $-1.41 \pm 3.77 E-10$ & $-2.11 \pm 5.65 \mathrm{E}-18$ & $<8.31 \mathrm{E}-18$ & 4.7E-13 \\
\hline $\mathrm{U}-233 / 234^{\mathrm{C}}$ & 2 & $6.64 \pm 5.27 \mathrm{E}-10$ & $9.94 \pm 7.89 \mathrm{E}-18$ & $1.05 \mathrm{E}-17$ & $1.0 \mathrm{E}-12^{\mathrm{d}}$ \\
\hline U-235/236 ${ }^{\mathrm{c}}$ & 2 & $2.73 \pm 2.59 \mathrm{E}-10$ & $4.09 \pm 3.89 E-18$ & 5.17E-18 & $1.2 \mathrm{E}-12$ \\
\hline $\mathrm{U}-238^{\mathrm{C}}$ & 2 & $1.51 \pm 0.53 \mathrm{E}-09$ & $2.26 \pm 0.79 \mathrm{E}-17$ & $2.43 \mathrm{E}-17$ & $1.3 \mathrm{E}-12$ \\
\hline Pu-238 & 2 & $0.35 \pm 2.54 \mathrm{E}-10$ & $0.52 \pm 3.81 E-18$ & $<5.69 \mathrm{E}-18$ & $8.8 \mathrm{E}-14$ \\
\hline $\mathrm{Pu}-239 / 240$ & 2 & $0.05 \pm 2.24 \mathrm{E}-10$ & $0.07 \pm 3.35 \mathrm{E}-18$ & $<5.66 \mathrm{E}-18$ & $8.1 \mathrm{E}-14$ \\
\hline Am-241 & 2 & $-0.05 \pm 2.66 \mathrm{E}-10$ & $-0.07 \pm 3.99 E-18$ & $<5.88 \mathrm{E}-18$ & 9.7E-14 \\
\hline
\end{tabular}

$\mathrm{N}$ - Number of samples.

NA - Not applicable.

${ }^{a}$ DOE-derived concentration standards (DCS's) are used as reference values for the application of best available technology per DOE Order 458.1.

${ }^{\mathrm{b}}$ DCSs do not exist for indicator parameters gross alpha and gross beta.

${ }^{\mathrm{c}}$ Total Uranium $=4.56 \pm 0.15 \mathrm{E}-03 \mathrm{~g}$; average $=6.83 \pm 0.22 \mathrm{E}-11 \mu \mathrm{g} / \mathrm{mL}$.

${ }^{\mathrm{d}}$ DCS for Uranium-233 used for this comparison. 
TABLE C-6

2012 Effluent Airborne Radioactivity at Container Sorting and Packaging Facility (ANCSPFK)

\begin{tabular}{|c|c|c|c|c|c|}
\hline Isotope & $N$ & $\begin{array}{c}\text { Total } \\
\text { Activity Released } \\
\text { (Ci) }\end{array}$ & $\begin{array}{c}\text { Average } \\
\text { Concentration } \\
(\mu \mathrm{Ci} / \mathrm{mL})\end{array}$ & $\begin{array}{c}\text { Maximum } \\
\text { Concentration } \\
(\mu \mathrm{Ci} / \mathrm{mL})\end{array}$ & $\begin{array}{c}D_{C S}^{a} \\
(\mu C i / m L)\end{array}$ \\
\hline Gross Alpha & 26 & $-3.78 \pm 7.60 \mathrm{E}-10$ & $-2.13 \pm 4.27 \mathrm{E}-17$ & $<3.07 \mathrm{E}-16$ & $N A^{b}$ \\
\hline Gross Beta & 26 & $4.18 \pm 2.13 \mathrm{E}-09$ & $2.35 \pm 1.20 \mathrm{E}-16$ & $9.24 \mathrm{E}-16$ & $N A^{b}$ \\
\hline Co-60 & 2 & $-1.25 \pm 1.46 \mathrm{E}-09$ & $-7.02 \pm 8.22 \mathrm{E}-17$ & $<1.19 \mathrm{E}-16$ & $3.6 \mathrm{E}-10$ \\
\hline Sr-90 & 2 & $5.68 \pm 9.37 \mathrm{E}-10$ & $3.19 \pm 5.26 \mathrm{E}-17$ & $<8.79 \mathrm{E}-17$ & $1.0 \mathrm{E}-10$ \\
\hline I-129 & 2 & $7.37 \pm 0.62 \mathrm{E}-08$ & $4.14 \pm 0.35 \mathrm{E}-15$ & $5.46 \mathrm{E}-15$ & $1.0 \mathrm{E}-10$ \\
\hline Cs-137 & 2 & $4.89 \pm 9.17 \mathrm{E}-10$ & $2.74 \pm 5.15 \mathrm{E}-17$ & $<7.32 \mathrm{E}-17$ & $8.8 \mathrm{E}-10$ \\
\hline Eu-154 & 2 & $-1.48 \pm 3.54 \mathrm{E}-09$ & $-0.83 \pm 1.99 E-16$ & $<2.94 \mathrm{E}-16$ & $7.5 \mathrm{E}-11$ \\
\hline $\mathrm{U}-232^{\mathrm{c}}$ & 2 & $-1.14 \pm 0.86 \mathrm{E}-10$ & $-6.43 \pm 4.86 E-18$ & $<8.44 \mathrm{E}-18$ & $4.7 \mathrm{E}-13$ \\
\hline $\mathrm{U}-233 / 234^{\mathrm{c}}$ & 2 & $2.98 \pm 1.36 \mathrm{E}-10$ & $1.68 \pm 0.76 \mathrm{E}-17$ & $1.82 \mathrm{E}-17$ & $1.0 \mathrm{E}-12^{\mathrm{d}}$ \\
\hline $\mathrm{U}-235 / 236^{\mathrm{c}}$ & 2 & $1.14 \pm 5.76 \mathrm{E}-11$ & $0.64 \pm 3.24 \mathrm{E}-18$ & $4.90 \mathrm{E}-18$ & $1.2 \mathrm{E}-12$ \\
\hline$U-238^{\mathrm{c}}$ & 2 & $2.94 \pm 1.26 \mathrm{E}-10$ & $1.65 \pm 0.71 \mathrm{E}-17$ & $1.72 \mathrm{E}-17$ & $1.3 \mathrm{E}-12$ \\
\hline Pu-238 & 2 & $-3.31 \pm 5.33 \mathrm{E}-11$ & $-1.86 \pm 2.99 \mathrm{E}-18$ & $<4.72 \mathrm{E}-18$ & $8.8 \mathrm{E}-14$ \\
\hline Pu-239/240 & 2 & $2.64 \pm 6.54 \mathrm{E}-11$ & $1.48 \pm 3.67 \mathrm{E}-18$ & $<5.42 \mathrm{E}-18$ & $8.1 \mathrm{E}-14$ \\
\hline Am-241 & 2 & $2.22 \pm 1.48 \mathrm{E}-10$ & $1.25 \pm 0.83 \mathrm{E}-17$ & $1.82 \mathrm{E}-17$ & 9.7E-14 \\
\hline
\end{tabular}

$\mathrm{N}$ - Number of samples.

NA - Not applicable.

${ }^{\mathrm{a}}$ DOE-derived concentration standards (DCS's) are used as reference values for the application of best available technology per DOE Order 458.1.

${ }^{\mathrm{b}}$ DCSs do not exist for indicator parameters gross alpha and gross beta.

${ }^{\mathrm{c}}$ Total Uranium $=1.02 \pm 0.03 \mathrm{E}-03 \mathrm{~g}$; average $=6.76 \pm 0.19 \mathrm{E}-11 \mu \mathrm{g} / \mathrm{mL}$.

${ }^{d}$ DCS for Uranium-233 used for this comparison.

TABLE C-7

2012 Effluent Airborne Radioactivity at Outdoor Ventilation Enclosures/ Portable Ventilation Units (OVEs/PVUs)

\begin{tabular}{|c|c|c|c|c|c|}
\hline Isotope & $N$ & $\begin{array}{c}\text { Total } \\
\text { Activity Released } \\
\text { (Ci) }\end{array}$ & $\begin{array}{c}\text { Average } \\
\text { Concentration } \\
(\mu \mathrm{Ci} / \mathrm{mL})\end{array}$ & $\begin{array}{c}\text { Maximum } \\
\text { Concentration } \\
(\mu \mathrm{Ci} / \mathrm{mL})\end{array}$ & $\begin{array}{c}D_{C S}{ }^{a} \\
(\mu C i / m L)\end{array}$ \\
\hline Gross Alpha & 154 & $-4.97 \pm 3.17 \mathrm{E}-09$ & $-3.37 \pm 2.15 E-17$ & $2.36 \mathrm{E}-16$ & $N A^{b}$ \\
\hline Gross Beta & 154 & $0.32 \pm 8.98 \mathrm{E}-09$ & $0.22 \pm 6.08 \mathrm{E}-17$ & $1.99 \mathrm{E}-15$ & $N A^{b}$ \\
\hline Co-60 & 2 & $0.01 \pm 2.78 \mathrm{E}-09$ & $0.004 \pm 1.89 \mathrm{E}-17$ & $<3.13 \mathrm{E}-17$ & $3.6 \mathrm{E}-10$ \\
\hline Sr-90 & 2 & $-1.03 \pm 1.85 \mathrm{E}-09$ & $-0.70 \pm 1.25 \mathrm{E}-17$ & $<1.92 \mathrm{E}-17$ & $1.0 \mathrm{E}-10$ \\
\hline Cs-137 & 2 & $-0.22 \pm 2.79 E-09$ & $-0.15 \pm 1.89 \mathrm{E}-17$ & $<3.17 \mathrm{E}-17$ & $8.8 \mathrm{E}-10$ \\
\hline Eu-154 & 2 & $1.08 \pm 7.40 \mathrm{E}-09$ & $0.73 \pm 5.01 \mathrm{E}-17$ & $<8.55 \mathrm{E}-17$ & $7.5 \mathrm{E}-11$ \\
\hline U-232 ${ }^{c}$ & 2 & $0.51 \pm 1.35 \mathrm{E}-10$ & $3.45 \pm 9.11 \mathrm{E}-19$ & $<1.57 \mathrm{E}-18$ & 4.7E-13 \\
\hline U-233/234 & 2 & $3.32 \pm 0.47 \mathrm{E}-09$ & $2.25 \pm 0.32 \mathrm{E}-17$ & $2.46 \mathrm{E}-17$ & $1.0 \mathrm{E}-12^{\mathrm{C}}$ \\
\hline$U-235 / 236^{c}$ & 2 & $2.05 \pm 1.52 \mathrm{E}-10$ & $1.39 \pm 1.03 \mathrm{E}-18$ & $2.29 \mathrm{E}-18$ & $1.2 \mathrm{E}-12$ \\
\hline U-238 ${ }^{\mathrm{C}}$ & 2 & $3.48 \pm 0.46 \mathrm{E}-09$ & $2.36 \pm 0.31 \mathrm{E}-17$ & $2.40 \mathrm{E}-17$ & $1.3 \mathrm{E}-12$ \\
\hline Pu-238 & 2 & $-0.98 \pm 1.18 \mathrm{E}-10$ & $-6.65 \pm 8.01 \mathrm{E}-19$ & $<1.53 \mathrm{E}-18$ & $8.8 \mathrm{E}-14$ \\
\hline Pu-239/240 & 2 & $6.15 \pm 9.44 \mathrm{E}-11$ & $4.17 \pm 6.39 \mathrm{E}-19$ & $<9.19 \mathrm{E}-19$ & $8.1 \mathrm{E}-14$ \\
\hline Am-241 & 2 & $2.43 \pm 2.11 \mathrm{E}-10$ & $1.65 \pm 1.43 \mathrm{E}-18$ & $<2.34 \mathrm{E}-18$ & $9.7 \mathrm{E}-14$ \\
\hline
\end{tabular}

$\mathrm{N}$ - Number of samples.

NA - Not applicable.

${ }^{a}$ DOE-derived concentration standards (DCS's) are used as reference values for the application of best available technology per DOE Order 458.1.

${ }^{\mathrm{b}}$ DCSs do not exist for indicator parameters gross alpha and gross beta.

${ }^{\mathrm{c}}$ Total Uranium $=1.15 \pm 0.05 \mathrm{E}-02 \mathrm{~g}$; average $=7.78 \pm 0.37 \mathrm{E}-11 \mu \mathrm{g} / \mathrm{mL}$.

${ }^{\mathrm{d}}$ DCS for Uranium-233 used for this comparison. 
TABLE C-8

2012 Effluent Airborne Radioactivity at Remote-Handled Waste Facility (ANRHWFK)

\begin{tabular}{|c|c|c|c|c|c|}
\hline Isotope & $N$ & $\begin{array}{c}\text { Total } \\
\text { Activity Released } \\
\text { (Ci) } \\
\end{array}$ & $\begin{array}{c}\text { Average } \\
\text { Concentration } \\
(\mu \mathrm{Ci} / \mathrm{mL})\end{array}$ & $\begin{array}{c}\text { Maximum } \\
\text { Concentration } \\
(\mu \mathrm{Ci} / \mathrm{mL})\end{array}$ & $\begin{array}{c}D_{C S}^{a} \\
(\mu C i / m L)\end{array}$ \\
\hline Gross Alpha & 26 & $-1.40 \pm 8.62 \mathrm{E}-09$ & $-1.16 \pm 7.13 \mathrm{E}-17$ & $<5.32 \mathrm{E}-16$ & $N A^{b}$ \\
\hline Gross Beta & 26 & $-1.48 \pm 2.25 \mathrm{E}-08$ & $-1.23 \pm 1.86 \mathrm{E}-16$ & $<1.05 \mathrm{E}-15$ & $N A^{b}$ \\
\hline Co-60 & 2 & $0.54 \pm 1.27 \mathrm{E}-08$ & $0.45 \pm 1.05 \mathrm{E}-16$ & $<1.53 \mathrm{E}-16$ & $3.6 \mathrm{E}-10$ \\
\hline Sr-90 & 2 & $1.83 \pm 9.84 \mathrm{E}-09$ & $1.51 \pm 8.14 \mathrm{E}-17$ & $<1.28 \mathrm{E}-16$ & $1.0 \mathrm{E}-10$ \\
\hline$I-129$ & 2 & $1.06 \pm 0.07 E-06$ & $8.75 \pm 0.55 \mathrm{E}-15$ & $1.45 \mathrm{E}-14$ & $1.0 \mathrm{E}-10$ \\
\hline Cs-137 & 2 & $1.10 \pm 1.11 \mathrm{E}-08$ & $9.11 \pm 9.19 \mathrm{E}-17$ & $<1.48 \mathrm{E}-16$ & $8.8 \mathrm{E}-10$ \\
\hline Eu-154 & 2 & $-0.32 \pm 3.63 \mathrm{E}-08$ & $-0.26 \pm 3.00 E-16$ & $<4.73 \mathrm{E}-16$ & $7.5 \mathrm{E}-11$ \\
\hline $\mathrm{U}-232^{\mathrm{c}}$ & 2 & $-5.27 \pm 9.39 \mathrm{E}-10$ & $-4.36 \pm 7.77 \mathrm{E}-18$ & $<1.19 \mathrm{E}-17$ & $4.7 \mathrm{E}-13$ \\
\hline $\mathrm{U}-233 / 234^{\mathrm{C}}$ & 2 & $3.34 \pm 1.83 \mathrm{E}-09$ & $2.76 \pm 1.51 \mathrm{E}-17$ & $3.73 \mathrm{E}-17$ & $1.0 \mathrm{E}-12^{\mathrm{C}}$ \\
\hline $\mathrm{U}-235 / 236^{\mathrm{c}}$ & 2 & $1.89 \pm 7.25 \mathrm{E}-10$ & $1.56 \pm 5.99 \mathrm{E}-18$ & $<8.81 \mathrm{E}-18$ & $1.2 \mathrm{E}-12$ \\
\hline $\mathrm{U}-238^{\mathrm{C}}$ & 2 & $3.83 \pm 1.39 \mathrm{E}-09$ & $3.16 \pm 1.15 \mathrm{E}-17$ & $3.49 \mathrm{E}-17$ & $1.3 \mathrm{E}-12$ \\
\hline Pu-238 & 2 & $0.25 \pm 6.17 \mathrm{E}-10$ & $0.21 \pm 5.11 \mathrm{E}-18$ & $<8.20 \mathrm{E}-18$ & $8.8 \mathrm{E}-14$ \\
\hline $\mathrm{Pu}-239 / 240$ & 2 & $0.56 \pm 4.98 \mathrm{E}-10$ & $0.47 \pm 4.12 \mathrm{E}-18$ & $<7.10 \mathrm{E}-18$ & $8.1 \mathrm{E}-14$ \\
\hline Am-241 & 2 & $2.20 \pm 9.50 \mathrm{E}-10$ & $1.82 \pm 7.86 \mathrm{E}-18$ & $<1.36 \mathrm{E}-17$ & $9.7 \mathrm{E}-14$ \\
\hline
\end{tabular}

$\mathrm{N}$ - Number of samples.

NA - Not applicable.

${ }^{a}$ DOE-derived concentration standards (DCS's) are used as reference values for the application of best available technology per DOE Order 458.1.

${ }^{\mathrm{b}}$ DCSs do not exist for indicator parameters gross alpha and gross beta.

${ }^{c}$ Total Uranium $=1.44 \pm 0.04 \mathrm{E}-02 \mathrm{~g}$; average $=1.19 \pm 0.03 \mathrm{E}-10 \mu \mathrm{g} / \mathrm{mL}$.

${ }^{\mathrm{d}}$ DCS for Uranium-233 used for this comparison.

TABLE C-9

2012 Ambient Airborne Radioactivity at Background Great Valley Location (AFGRVAL)

\begin{tabular}{|c|c|c|c|}
\hline \multirow[t]{2}{*}{ Isotope } & \multirow[t]{2}{*}{$\mathbf{N}^{a}$} & \multicolumn{2}{|c|}{$\begin{array}{c}\text { AFGRVAL } \\
\mu \mathrm{Ci} / \mathrm{mL}\end{array}$} \\
\hline & & Average & Maximum \\
\hline Gross Alpha & 26 & $8.13 \pm 3.97 \mathrm{E}-16$ & $1.65 \mathrm{E}-15$ \\
\hline Gross Beta & 26 & $1.75 \pm 0.15 \mathrm{E}-14$ & $2.84 \mathrm{E}-14$ \\
\hline $\mathrm{K}-40$ & 3 & $0.66 \pm 1.73 \mathrm{E}-15$ & $1.68 \mathrm{E}-15$ \\
\hline Co-60 & 3 & $0.20 \pm 1.20 \mathrm{E}-16$ & $<1.35 \mathrm{E}-16$ \\
\hline Sr-90 & 3 & $0.93 \pm 1.15 \mathrm{E}-16$ & $1.56 \mathrm{E}-16$ \\
\hline I-129 & 3 & $-0.70 \pm 1.58 \mathrm{E}-16$ & $<2.44 \mathrm{E}-16$ \\
\hline Cs-137 & 3 & $-0.10 \pm 1.21 \mathrm{E}-16$ & $<1.59 \mathrm{E}-16$ \\
\hline Eu-154 & 3 & $-0.12 \pm 3.35 E-16$ & $<3.67 \mathrm{E}-16$ \\
\hline $\mathrm{U}-232^{b}$ & 3 & $0.63 \pm 7.89 \mathrm{E}-18$ & $<8.99 \mathrm{E}-18$ \\
\hline U-233/234 ${ }^{b}$ & 3 & $7.46 \pm 2.34 \mathrm{E}-17$ & $1.25 \mathrm{E}-16$ \\
\hline U-235/236 ${ }^{b}$ & 3 & $3.36 \pm 8.68 \mathrm{E}-18$ & $<1.01 \mathrm{E}-17$ \\
\hline $\mathrm{U}-238^{b}$ & 3 & $9.49 \pm 2.40 \mathrm{E}-17$ & $1.64 \mathrm{E}-16$ \\
\hline Pu-238 & 3 & $-0.61 \pm 5.28 \mathrm{E}-18$ & $<6.45 \mathrm{E}-18$ \\
\hline Pu-239/240 & 3 & $1.30 \pm 7.96 \mathrm{E}-18$ & $<9.08 \mathrm{E}-18$ \\
\hline Am-241 & 3 & $1.67 \pm 6.97 \mathrm{E}-18$ & $<8.62 \mathrm{E}-18$ \\
\hline
\end{tabular}

$\mathrm{N}$ - Number of samples.

${ }^{a}$ The sampling frequencey at AFGRVAL was changed from semiannually to quarterly after the June 2012 semiannual sample was collected.

${ }^{\mathrm{b}}$ Total Uranium: AFGRVAL average $=2.60 \pm 0.13 \mathrm{E}-10 \mu \mathrm{g} / \mathrm{mL}$. 
TABLE C-10

2012 Gross Alpha and Gross Beta Radioactivity at Nearsite Ambient Air Sampling Locations and at Background Great Valley Location (AFGRVAL)

\begin{tabular}{|c|c|c|c|c|c|}
\hline \multirow{2}{*}{$\begin{array}{c}\text { Monitoring } \\
\text { Location }\end{array}$} & \multirow[t]{2}{*}{$N$} & \multicolumn{2}{|c|}{$\begin{array}{c}\text { Gross Alpha } \\
\mu \mathrm{Ci} / \mathrm{mL}\end{array}$} & \multicolumn{2}{|c|}{$\begin{array}{c}\text { Gross Beta } \\
\mu \mathrm{Ci} / \mathrm{mL}\end{array}$} \\
\hline & & Average & Maximum & Average & Maximum \\
\hline AF01_N & 7 & $1.05 \pm 0.19 E-15$ & $1.44 \mathrm{E}-15$ & $1.89 \pm 0.07 E-14$ & $2.55 \mathrm{E}-14$ \\
\hline AF02_NNE & 7 & $1.07 \pm 0.19 \mathrm{E}-15$ & $1.66 \mathrm{E}-15$ & $1.90 \pm 0.07 \mathrm{E}-14$ & $2.64 \mathrm{E}-14$ \\
\hline AF03_NE & 7 & $1.11 \pm 0.19 \mathrm{E}-15$ & $1.47 \mathrm{E}-15$ & $1.99 \pm 0.07 E-14$ & $2.72 \mathrm{E}-14$ \\
\hline AF04_ENE & 7 & $1.15 \pm 0.20 \mathrm{E}-15$ & $1.47 \mathrm{E}-15$ & $1.97 \pm 0.07 \mathrm{E}-14$ & 2.69E-14 \\
\hline AF05_E & 7 & $1.02 \pm 0.20 \mathrm{E}-15$ & $1.40 \mathrm{E}-15$ & $1.96 \pm 0.07 E-14$ & $2.74 \mathrm{E}-14$ \\
\hline AF06_ESE & 7 & $1.10 \pm 0.20 \mathrm{E}-15$ & $1.55 \mathrm{E}-15$ & $1.98 \pm 0.07 E-14$ & 2.67E-14 \\
\hline AF07_SE & 7 & $1.08 \pm 0.20 \mathrm{E}-15$ & $1.36 \mathrm{E}-15$ & $1.94 \pm 0.07 \mathrm{E}-14$ & $2.54 \mathrm{E}-14$ \\
\hline AF08_SSE & 7 & $1.11 \pm 0.20 \mathrm{E}-15$ & $1.53 \mathrm{E}-15$ & $1.93 \pm 0.07 \mathrm{E}-14$ & $2.59 \mathrm{E}-14$ \\
\hline AF09_S & 7 & $1.06 \pm 0.19 E-15$ & $1.48 \mathrm{E}-15$ & $2.03 \pm 0.07 E-14$ & $2.76 \mathrm{E}-14$ \\
\hline AF10_SSW & 7 & $1.09 \pm 0.19 \mathrm{E}-15$ & $1.60 \mathrm{E}-15$ & $1.92 \pm 0.07 \mathrm{E}-14$ & $2.66 \mathrm{E}-14$ \\
\hline AF11_SW & 7 & $9.89 \pm 1.88 \mathrm{E}-16$ & $1.64 \mathrm{E}-15$ & $1.94 \pm 0.07 E-14$ & $2.72 \mathrm{E}-14$ \\
\hline AF12_WSW & 7 & $1.05 \pm 0.19 \mathrm{E}-15$ & $1.52 \mathrm{E}-15$ & $2.00 \pm 0.07 E-14$ & $2.74 \mathrm{E}-14$ \\
\hline AF13_W & 7 & $1.15 \pm 0.20 \mathrm{E}-15$ & $1.70 \mathrm{E}-15$ & $1.95 \pm 0.07 E-14$ & $2.71 \mathrm{E}-14$ \\
\hline AF14_WNW ${ }^{a}$ & 6 & $1.03 \pm 0.19 E-15^{a}$ & $1.51 \mathrm{E}-15$ & $2.08 \pm 0.07 E-14^{a}$ & $2.71 \mathrm{E}-14$ \\
\hline AF15_NW & 7 & $1.17 \pm 0.20 \mathrm{E}-15$ & $1.48 \mathrm{E}-15$ & $1.92 \pm 0.07 \mathrm{E}-14$ & $2.66 \mathrm{E}-14$ \\
\hline AF16_NNW & 7 & $1.08 \pm 0.19 E-15$ & $1.64 \mathrm{E}-15$ & $1.95 \pm 0.07 E-14$ & $2.68 \mathrm{E}-14$ \\
\hline AF16HNNW & 7 & $1.78 \pm 0.31 \mathrm{E}-15 \mathrm{~J}$ & $6.20 \mathrm{E}-15$ & $3.13 \pm 0.11 \mathrm{E}-14 \mathrm{~J}$ & 1.10E-13 \\
\hline AFGRVAL & 26 & $8.13 \pm 3.97 E-16$ & $1.65 \mathrm{E}-15$ & $1.75 \pm 0.15 \mathrm{E}-14$ & $2.84 \mathrm{E}-14$ \\
\hline
\end{tabular}

$\mathrm{N}$ - Number of samples.

New Ambient air network went online in October 2012.

${ }^{a}$ The duration of the first sample collected at AF14_WNW was less than one day and it is excluded from the average of the remaining six biweekly samples.

$\mathrm{J}$ - High volume sampling results have more variability than the other sampling locations due to uncertainty in the flow values measured during the first quarter of operation - the fourth quarter of 2012. 
TABLE C-11

2012 Ambient Airborne Radioisotope Activity and Background Great Valley Location (AFGRVAL)

\begin{tabular}{|c|c|c|c|c|c|}
\hline $\begin{array}{c}\text { Monitoring } \\
\text { Location }\end{array}$ & $N$ & $\begin{array}{c}S r-90 \\
\mu \mathrm{Ci} / \mathrm{mL}\end{array}$ & $\begin{array}{c}I-129 \\
\mu C i / m L\end{array}$ & $\begin{array}{l}C s-137 \\
\mu C i / m L\end{array}$ & $\begin{array}{c}U-232 \\
\mu C i / m L\end{array}$ \\
\hline AF01_N & 1 & $1.74 \pm 1.32 \mathrm{E}-16 \quad \mathrm{~b}$ & $1.00 \pm 0.72 E-16$ & $0.09 \pm 1.00 \mathrm{E}-16$ & $0.00 \pm 8.19 \mathrm{E}-18$ \\
\hline AF02_NNE & 1 & $-3.05 \pm 6.64 \mathrm{E}-17$ & $0.77 \pm 7.43 \mathrm{E}-17$ & $0.15 \pm 1.08 \mathrm{E}-16$ & $0.51 \pm 1.00 \mathrm{E}-17$ \\
\hline AF03_NE & 1 & $0.79 \pm 1.33 \mathrm{E}-16$ & $1.77 \pm 6.98 \mathrm{E}-17$ & $-0.73 \pm 1.18 \mathrm{E}-16$ & $2.97 \pm 6.99 \mathrm{E}-18$ \\
\hline AF04_ENE & 1 & $0.21 \pm 1.43 \mathrm{E}-16$ & $2.61 \pm 8.39 \mathrm{E}-17$ & $1.98 \pm 8.22 \mathrm{E}-17$ & $-0.41 \pm 1.06 \mathrm{E}-17$ \\
\hline AF05_E & 1 & $1.16 \pm 1.25 \mathrm{E}-16$ & $5.32 \pm 9.42 \mathrm{E}-17$ & $8.27 \pm 8.80 \mathrm{E}-17$ & $-5.76 \pm 6.77 \mathrm{E}-18$ \\
\hline AF06_ESE & 1 & $5.51 \pm 9.88 \mathrm{E}-17$ & $0.95 \pm 7.51 \mathrm{E}-17$ & $-0.06 \pm 1.40 \mathrm{E}-16$ & $0.00 \pm 8.92 \mathrm{E}-18$ \\
\hline AF07_SE & 1 & $-0.31 \pm 1.16 \mathrm{E}-16$ & $4.61 \pm 8.56 \mathrm{E}-17$ & $-2.26 \pm 9.75 \mathrm{E}-17$ & $-2.17 \pm 7.96 \mathrm{E}-18$ \\
\hline AF08_SSE & 1 & $-0.16 \pm 1.13 \mathrm{E}-16$ & $0.00 \pm 1.26 \mathrm{E}-16$ & $2.86 \pm 9.86 \mathrm{E}-17$ & $0.74 \pm 1.03 \mathrm{E}-17$ \\
\hline AF09_S & 1 & $1.05 \pm 1.35 \mathrm{E}-16$ & $6.32 \pm 8.07 \mathrm{E}-17$ & $0.19 \pm 1.28 \mathrm{E}-16$ & $2.17 \pm 7.95 \mathrm{E}-18$ \\
\hline AF10_SSW & 1 & $0.60 \pm 1.28 \mathrm{E}-16$ & $3.25 \pm 7.20 \mathrm{E}-17$ & $-0.97 \pm 1.08 \mathrm{E}-16$ & $0.59 \pm 1.16 \mathrm{E}-17$ \\
\hline AF11_SW & 1 & $2.04 \pm 1.50 \mathrm{E}-16$ & $3.07 \pm 8.16 \mathrm{E}-17$ & $0.32 \pm 1.09 \mathrm{E}-16$ & $0.00 \pm 1.04 \mathrm{E}-17$ \\
\hline AF12_WSW & 1 & $0.68 \pm 1.25 \mathrm{E}-16$ & $-1.01 \pm 9.06 \mathrm{E}-17$ & $-0.51 \pm 1.07 \mathrm{E}-16$ & $0.34 \pm 1.12 \mathrm{E}-17$ \\
\hline AF13_W & 1 & $0.93 \pm 1.28 \mathrm{E}-16$ & $-5.31 \pm 7.56 \mathrm{E}-17$ & $0.41 \pm 1.16 \mathrm{E}-16$ & $-7.29 \pm 9.43 \mathrm{E}-18$ \\
\hline AF14_WNW & 1 & $1.58 \pm 1.40 \mathrm{E}-16$ & $-0.03 \pm 1.04 \mathrm{E}-16$ & $0.54 \pm 1.25 \mathrm{E}-16$ & $-1.23 \pm 8.00 \mathrm{E}-18$ \\
\hline AF15_NW & 1 & $0.38 \pm 1.15 \mathrm{E}-16$ & $-0.26 \pm 1.01 \mathrm{E}-16$ & $-0.14 \pm 1.08 \mathrm{E}-16$ & $0.81 \pm 1.06 \mathrm{E}-17$ \\
\hline AF16_NNW & 1 & $0.31 \pm 1.09 \mathrm{E}-16$ & $-4.25 \pm 7.19 \mathrm{E}-17$ & $-1.63 \pm 8.45 \mathrm{E}-17$ & $-4.47 \pm 7.59 \mathrm{E}-18$ \\
\hline AF16HNNW $^{\mathrm{a}}$ & 1 & $4.28 \pm 2.86 \mathrm{E}-17 \mathrm{~J} \quad \mathrm{~b}$ & NA & $0.68 \pm 3.96 \mathrm{E}-17 \mathrm{~J}$ & $-0.74 \pm 2.32 \mathrm{E}-18 \mathrm{~J}$ \\
\hline AFGRVAL (range) & 3 & $<7.73 \mathrm{E}-17-1.56 \mathrm{E}-16$ & $<5.02 \mathrm{E}-17-<2.44 \mathrm{E}-16$ & $<9.11 \mathrm{E}-17-<1.59 \mathrm{E}-16$ & $<5.95 \mathrm{E}-18-<8.99 \mathrm{E}-18$ \\
\hline \multicolumn{2}{|c|}{$\begin{array}{l}5 \% \text { of NESHAP } \\
\text { Compliance Limit }\end{array}$} & $9.50 \mathrm{E}-16$ & $4.55 \mathrm{E}-16$ & $9.50 \mathrm{E}-16$ & $6.50 \mathrm{E}-17$ \\
\hline
\end{tabular}

\begin{tabular}{|l|c|c|c|c|}
\hline \multicolumn{1}{|c|}{$\begin{array}{c}\text { Monitoring } \\
\text { Location }\end{array}$} & $\boldsymbol{N}$ & $\begin{array}{c}\text { Pu-238 } \\
\mu \mathrm{Ci} / \mathrm{mL}\end{array}$ & $\begin{array}{c}\text { Pu-239/240 } \\
\mu \mathrm{Ci} / \mathrm{mL}\end{array}$ & $\begin{array}{c}\text { Am-241 } \\
\mu \mathrm{Ci} / \mathrm{mL}\end{array}$ \\
\hline AF01_N & 1 & $0.00 \pm 4.28 \mathrm{E}-18$ & $-1.97 \pm 5.07 \mathrm{E}-18$ & $7.25 \pm 8.11 \mathrm{E}-18$ \\
\hline AF02_NNE & 1 & $2.15 \pm 6.33 \mathrm{E}-18$ & $-2.20 \pm 7.63 \mathrm{E}-18$ & $-0.05 \pm 7.57 \mathrm{E}-18$ \\
\hline AF03_NE & 1 & $-1.05 \pm 4.99 \mathrm{E}-18$ & $3.10 \pm 7.61 \mathrm{E}-18$ & $-0.02 \pm 5.21 \mathrm{E}-18$ \\
\hline AF04_ENE & 1 & $0.00 \pm 5.29 \mathrm{E}-18$ & $1.19 \pm 7.47 \mathrm{E}-18$ & $8.06 \pm 9.04 \mathrm{E}-18$ \\
\hline AF05_E & 1 & $0.00 \pm 5.30 \mathrm{E}-18$ & $1.20 \pm 7.49 \mathrm{E}-18$ & $2.72 \pm 6.67 \mathrm{E}-18$ \\
\hline AF06_ESE & 1 & $1.09 \pm 6.84 \mathrm{E}-18$ & $2.17 \pm 8.36 \mathrm{E}-18$ & $3.27 \pm 5.79 \mathrm{E}-18$ \\
\hline AF07_SE & 1 & $0.00 \pm 4.86 \mathrm{E}-18$ & $3.31 \pm 8.13 \mathrm{E}-18$ & $3.17 \pm 7.79 \mathrm{E}-18$ \\
\hline AF08_SSE & 1 & $0.00 \pm 4.45 \mathrm{E}-18$ & $-2.05 \pm 5.28 \mathrm{E}-18$ & $0.87 \pm 7.04 \mathrm{E}-18$ \\
\hline AF09_S & 1 & $-2.12 \pm 5.46 \mathrm{E}-18$ & $0.00 \pm 4.60 \mathrm{E}-18$ & $-0.85 \pm 6.76 \mathrm{E}-18$ \\
\hline AF10_SSW & 1 & $-0.02 \pm 6.59 \mathrm{E}-18$ & $-1.02 \pm 4.86 \mathrm{E}-18$ & $-0.75 \pm 4.95 \mathrm{E}-18$ \\
\hline AF11_SW & 1 & $1.13 \pm 9.14 \mathrm{E}-18$ & $0.58 \pm 1.12 \mathrm{E}-17$ & $0.74 \pm 7.22 \mathrm{E}-18$ \\
\hline AF12_WSW & 1 & $0.00 \pm 4.46 \mathrm{E}-18$ & $-0.02 \pm 6.62 \mathrm{E}-18$ & $1.46 \pm 6.73 \mathrm{E}-18$ \\
\hline AF13_W & 1 & $0.99 \pm 6.22 \mathrm{E}-18$ & $-1.03 \pm 6.81 \mathrm{E}-18$ & $-2.50 \pm 8.12 \mathrm{E}-18$ \\
\hline AF14_WNW & 1 & $1.17 \pm 7.30 \mathrm{E}-18$ & $1.17 \pm 7.30 \mathrm{E}-18$ & $-3.83 \pm 7.20 \mathrm{E}-18$ \\
\hline AF15_NW & 1 & $-3.04 \pm 5.59 \mathrm{E}-18$ & $-0.02 \pm 6.53 \mathrm{E}-18$ & $-2.33 \pm 6.67 \mathrm{E}-18$ \\
\hline AF16_NNW & 1 & $1.99 \pm 5.87 \mathrm{E}-18$ & $3.98 \pm 7.04 \mathrm{E}-18$ & $0.00 \pm 3.26 \mathrm{E}-18$ \\
\hline AF16HNNW ${ }^{\text {a }}$ & 1 & $-0.01 \pm 1.68 \mathrm{E}-18 \mathrm{~J}$ & $0.26 \pm 1.60 \mathrm{E}-18 \mathrm{~J}$ & $1.04 \pm 1.63 \mathrm{E}-18 \mathrm{~J}$ \\
\hline AFGRVAL (range) & 3 & $<4.38 \mathrm{E}-18-<6.45 \mathrm{E}-18$ & $<5.63 \mathrm{E}-18-<9.08 \mathrm{E}-18$ & $<4.74 \mathrm{E}-18-<8.62 \mathrm{E}-18$ \\
\hline \multicolumn{1}{|c|}{ 5\% of NESHAP } & & $1.05 \mathrm{E}-16$ & $1.00 \mathrm{E}-16$ & $9.50 \mathrm{E}-17$ \\
\hline Compliance Limit & & & & \\
\hline
\end{tabular}

$\mathrm{N}$ - Number of samples.

NA - Parameter (I-129) is not sampled for at this location.

${ }^{a}$ Location AF16HNNW is the high volume sampler at the same location as AF16_NNW.

${ }^{b}$ Although result is greater than the uncertainty, the result is below the Minimum Detectable Activity (MDA). 
This page intentionally left blank 


\section{APPENDIX D-1 \\ Summary of Groundwater Screening Levels and Practical Quantitation Limits}

\section{Groundwater Sampling Methodology}

Groundwater samples are collected from monitoring wells using either dedicated Teflon well bailers or bladder pumps. Bailers are used in low-yield wells; bladder pumps are used in wells with good water-yielding characteristics. This sampling equipment is dedicated to an individual well to reduce the likelihood of sample contamination from external materials or cross contamination.

To ensure that only representative groundwater is sampled, three well volumes are removed (purged) from the well before the actual samples are collected. In low-yield wells, pumping or bailing to dryness provides sufficient purging. Conductivity and $\mathrm{pH}$ are measured before and after sampling to confirm the geochemical stability of the groundwater during sampling.

The bailer, a tube with a check valve at the bottom, is lowered slowly into the well to minimize agitation of the water column. The bailer containing the groundwater is then withdrawn from the well and emptied into a sample container. Bladder pumps use compressed air to gently squeeze a Teflon bladder that prevents air contact with the groundwater as it is pumped into a sample container with a minimum of agitation and mixing. A check valve ensures that the water flows in only one direction.

Groundwater samples are cooled and preserved, with chemicals if required, to minimize chemical and/or biological changes after sample collection. A strict chain-of-custody protocol is followed for all samples collected by the WVDP.

Groundwater Screening Levels (GSLs) for Radiological Constituents: Background values for radiological constituents in groundwater were derived for the Corrective Measures Studies in 2009 using data from background wells 301, 401, 706, and 1302 in the sand and gravel unit on the north plateau for samples collected from 1991 through September 2009. The 95\% upper confidence limit (UCL) was applied in a similar statistical calculation for each radiological constituent. The site-specific GSLs for radiological constituents were set to the larger of the background levels or the NYSDEC Technical and Operational Guidance Series (TOGS) 1.1.1 Class GA groundwater quality standard for each radiological constituent. The NYSDEC TOGS standards are only established for gross alpha and gross beta concentrations, consequently most of the screening values for radiological constituents are set to equal the site background values. The GSLs for radiological constituents are listed in Table D-1A.

The site monitoring well radiological concentrations presented in the data tables in Appendix D-2 are compared with these GSLs. Bolding indicates that the measured concentration exceeded the GSL.

Groundwater Screening Levels for Metals: The calculated WVDP GSLs for metals were established in WVDP-494, North Plateau Plume Area Characterization Report. The GSLs for metals were selected as a greater of the NYSDEC TOGS 1.1.1 Class GA Groundwater Quality Standards or background concentrations in groundwater as documented in Appendix E of WVDP-494. The groundwater background concentrations were derived from a statistical calculation of the mean plus two standard deviations for metals data collected from four background wells (301, 401, 706, and well 1302). Elevated levels of chromium and nickel were identified in site wells constructed with stainless steel (which includes 301, 401, and 706), as presented to NYSDEC in a report entitled Final Report: Evaluation of the Pilot Program to Investigate Chromium \& Nickel Concentration in Groundwater in the Sand \& Gravel Unit (WVNSCO, 1998). The findings of this report were subsequently accepted by NYSDEC in their memorandum dated September 15, 1998. 
Consequently, the majority of the chromium and nickel results from these stainless-steel wells were omitted from the dataset used to establish background, relying primarily on the results from polyvinyl chloride (PVC) well 1302 for these two constituents. The groundwater screening values for metals are listed in Table D-1B.

The site monitoring well metals concentrations presented in the data tables in Appendix D-2 are compared with these GSLs. Bolding indicates that the measured concentration exceeded the GSL. 
TABLE D-1A

Groundwater Screening Levels (GSLs) for Radiological Constituents

\begin{tabular}{|c|c|c|c|c|}
\hline $\begin{array}{c}\text { Radiological } \\
\text { Constituent }\end{array}$ & $\begin{array}{c}\text { Range of Observed } \\
\text { Concentrations From } \\
\text { Background Monitoring } \\
\text { Wells } 301,401,706, \\
\text { and } 1302^{a} \\
(\mu \mathrm{Ci} / \mathrm{mL})\end{array}$ & 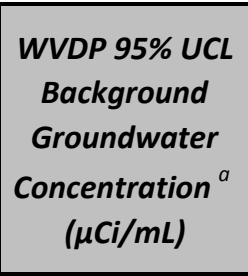 & $\begin{array}{c}\text { NYSDEC TOGS } 1.1 .1 \\
\text { Class GA } \\
\text { Groundwater } \\
\text { Quality Standards } \\
\left.\text { ( }{ }^{b} \text { Ci } / \mathrm{mL}\right)\end{array}$ & $\begin{array}{c}\text { WVDP GSLs }{ }^{c} \\
\quad(\mu C i / m L)\end{array}$ \\
\hline Gross alpha & $<7.78 \mathrm{E}-10-1.55 \mathrm{E}-08$ & $7.61 \mathrm{E}-09$ & $1.50 \mathrm{E}-08$ & $1.50 \mathrm{E}-08$ \\
\hline Gross beta & $<2.15 \mathrm{E}-09-2.35 \mathrm{E}-08$ & $1.56 \mathrm{E}-08$ & $1.00 \mathrm{E}-06$ & $1.00 \mathrm{E}-06$ \\
\hline Tritium & $<3.17 \mathrm{E}-08-2.63 \mathrm{E}-07$ & $1.78 \mathrm{E}-07$ & $\mathrm{NE}$ & $1.78 \mathrm{E}-07$ \\
\hline Carbon-14 & $<1.36 \mathrm{E}-11-5.02 \mathrm{E}-08$ & $2.82 \mathrm{E}-08$ & $\mathrm{NE}$ & $2.82 \mathrm{E}-08$ \\
\hline Cesium-137 & $5.79 \mathrm{E}-10-1.90 \mathrm{E}-08$ & $1.03 \mathrm{E}-08$ & $\mathrm{NE}$ & $1.03 \mathrm{E}-08$ \\
\hline lodine-129 & $<2.85 \mathrm{E}-10-1.58 \mathrm{E}-09$ & $9.61 \mathrm{E}-10$ & $\mathrm{NE}$ & $9.61 \mathrm{E}-10$ \\
\hline Potassium-40 & $<5.00 \mathrm{E}-08-3.56 \mathrm{E}-07$ & $1.99 \mathrm{E}-07$ & $\mathrm{NE}$ & $1.99 \mathrm{E}-07$ \\
\hline Radium-226 & $<1.10 \mathrm{E}-10-2.99 \mathrm{E}-09$ & $1.33 \mathrm{E}-09$ & $\mathrm{NE}$ & $1.33 \mathrm{E}-09$ \\
\hline Radium-228 & $<2.23 \mathrm{E}-10-3.20 \mathrm{E}-09$ & $2.16 \mathrm{E}-09$ & $\mathrm{NE}$ & $2.16 \mathrm{E}-09$ \\
\hline Strontium-90 & $<2.41 \mathrm{E}-10-6.40 \mathrm{E}-09$ & $5.90 \mathrm{E}-09$ & $\mathrm{NE}$ & $5.90 \mathrm{E}-09$ \\
\hline Technetium-99 & $<8.21 \mathrm{E}-10-8.61 \mathrm{E}-09$ & $5.02 \mathrm{E}-09$ & $\mathrm{NE}$ & $5.02 \mathrm{E}-09$ \\
\hline Total Uranium & $<1.27 \mathrm{E}-06-3.46 \mathrm{E}-03$ & $1.34 \mathrm{E}-03$ & $\mathrm{NE}$ & $1.34 \mathrm{E}-03$ \\
\hline Uranium-232 & $<1.71 \mathrm{E}-11-3.78 \mathrm{E}-10$ & $1.38 \mathrm{E}-10$ & $\mathrm{NE}$ & $1.38 \mathrm{E}-10$ \\
\hline Uranium-233/234 & $<3.85 \mathrm{E}-11-1.53 \mathrm{E}-09$ & $6.24 \mathrm{E}-10$ & $\mathrm{NE}$ & $6.24 \mathrm{E}-10$ \\
\hline Uranium-235/236 & $<1.80 \mathrm{E}-11-1.39 \mathrm{E}-10$ & $8.07 \mathrm{E}-11$ & $\mathrm{NE}$ & $8.07 \mathrm{E}-11$ \\
\hline Uranium-238 & $<1.32 \mathrm{E}-11-1.26 \mathrm{E}-09$ & $4.97 \mathrm{E}-10$ & $\mathrm{NE}$ & $4.97 \mathrm{E}-10$ \\
\hline
\end{tabular}

NE - No NYSDEC TOGS 1.1.1 groundwater quality standard has been established for this analyte.

${ }^{a}$ The data used for the calculation of background values was taken from background wells 301, 401, 706, and 1302 in the sand and gravel unit on the north plateau for samples collected from 1991 through September 2009. The background was set to the upper limit of the $95 \%$ confidence interval.

${ }^{\mathrm{b}}$ NYSDEC TOGS 1.1.1 (June 1998/2004 addendum) Class GA groundwater quality standards and guidance values.

${ }^{\mathrm{c}}$ The GSLs for radiological constituents were set equal to the larger of the background concentrations or the NYSDEC TOGS 1.1.1 Class GA Groundwater Quality Standards. 
TABLE D-1B

Groundwater Screening Levels for Metals

\begin{tabular}{|c|c|c|c|c|}
\hline Analyte $^{a}$ & $\begin{array}{c}\text { Range of Observed } \\
\text { Concentrations From } \\
\text { Background } \\
\text { Monitoring Wells } 301, \\
401,706, \text { and } 1302^{a} \\
(\mu \mathrm{g} / \mathrm{L})\end{array}$ & $\begin{array}{c}\text { Background } \\
\text { Groundwater } \\
\text { Concentration }^{b} \\
(\mu g / L)\end{array}$ & $\begin{array}{c}\text { NYSDEC TOGS } 1.1 .1 \\
\text { Class GA } \\
\text { Groundwater } \\
\text { Quality Standards } \\
(\mu g / L)\end{array}$ & $\begin{array}{c}\text { WVDP Groundwater } \\
\text { Screening Levels } \\
\text { (GSLs) }^{c} \\
(\mu g / L)\end{array}$ \\
\hline Antimony, total & $0.5-19.7$ & 15.1 & 3 & 15.1 \\
\hline Arsenic, total & $1.5-34.4$ & 20.9 & 25 & 25 \\
\hline Barium, total & $71.7-499$ & 441 & 1,000 & 1,000 \\
\hline Beryllium, total & $0.10-2.50$ & 1.85 & 3 & 3 \\
\hline Cadmium, total & $0.30-5.30$ & 7.27 & 5 & 7.27 \\
\hline Chromium, total $^{d}$ & $5-66$ & 52.3 & 50 & 52.3 \\
\hline Cobalt, total & $2.05-60.9$ & 67.8 & $\mathrm{NE}$ & 67.8 \\
\hline Copper, total & $1.4-90.5$ & 59.9 & 200 & 200 \\
\hline Lead, total & $0.5-120$ & 42.7 & 25 & 42.7 \\
\hline Mercury, total & $0.03-0.4$ & 0.263 & 0.7 & 0.7 \\
\hline Nickel, total $^{d}$ & $10-77.8$ & 59.5 & 100 & 100 \\
\hline Selenium, total & $1.0-25.0$ & 10.1 & 10 & 10.1 \\
\hline Silver, total & $0.1-10$ & 15.5 & 50 & 50 \\
\hline Thallium, total & $0.3-13.1$ & 13.9 & 0.5 & 13.9 \\
\hline Tin, total & $5.6-3,000$ & 4,083 & $\mathrm{NE}$ & 4,083 \\
\hline Vanadium, total & $0.6-73.1$ & 69.6 & $\mathrm{NE}$ & 69.6 \\
\hline Zinc, total & $5.71-256$ & 127 & 2,000 & 2,000 \\
\hline
\end{tabular}

NE - No TOGS 1.1.1 Class GA Groundwater quality standard has been established for this analyte.

${ }^{a}$ Analytes listed are those identified in the 6 NYCRR Part 373-2 Appendix 33 List.

${ }^{b}$ Data used for the calculation of background values was taken from wells 301, 401, 706, and 1302 in the S\&G unit on the north plateau for samples collected from 1991 to December 2008. The background concentration was set equal to the mean plus two standard deviations (as reported in WVDP-494). Ninety-five percent of measurements are expected to fall below this value. Data were rounded to three significant digits or the closest integer.

${ }^{c}$ Metals GSLs were set equal to the larger of the background concentration or the TOGS 1.1.1 Class GA Groundwater Quality Standards.

d Elevated chromium and nickel concentrations attributed to well corrosion were noted in wells 301, 401, and 706 over the monitoring period. All results suspected to be affected by corrosion (i.e., all chromium and nickel results for 301 and 401 , and all results after May 2004 from 706) were excluded from the background calculation. 
TABLE D-1C

Practical Quantitation Limits (PQLs)

\begin{tabular}{|c|c|c|c|}
\hline \multicolumn{4}{|c|}{6 NYCRR $^{a}$ Appendix 33 Volatile Organic Compounds } \\
\hline Compound & $\begin{array}{c}\text { PQL } \\
(\mu \mathrm{g} / \mathrm{L})\end{array}$ & Compound & $\begin{array}{c}\text { PQL } \\
(\mu \mathrm{g} / \mathrm{L})\end{array}$ \\
\hline Acetone & 10 & cis-1,3-Dichloropropene & 5 \\
\hline Acetonitrile & 100 & Ethyl Benzene & 5 \\
\hline Acrolein & 11 & Ethyl methacrylate & 5 \\
\hline Acrylonitrile & 5 & 2-Hexanone & 10 \\
\hline Allyl chloride & 5 & Isobutyl alcohol & 100 \\
\hline Benzene & 5 & Methacrylonitrile & 5 \\
\hline Bromodichloromethane & 5 & Methyl ethyl ketone & 10 \\
\hline Bromoform (methyl bromide) & 5 & Methyl iodide & 5 \\
\hline Bromomethane & 10 & Methyl methacrylate & 5 \\
\hline Carbon disulfide & 10 & 4-Methyl-2-pentanone (MIBK) & 10 \\
\hline Carbon tetrachloride & 5 & Methylene bromide & 10 \\
\hline Chlorobenzene & 5 & Methylene chloride & 5 \\
\hline Chloroethane & 10 & Pentachloroethane & 5 \\
\hline Chloroform & 5 & Propionitrile & 50 \\
\hline Chloromethane (methyl chloride) & 10 & Styrene & 5 \\
\hline Chloroprene & 5 & 1,1,1,2-Tetrachloroethane & 5 \\
\hline 1,2-Dibromo-3-chloropropane & 5 & 1,1,2,2-Tetrachloroethane & 5 \\
\hline Dibromochloromethane & 5 & Tetrachloroethylene & 5 \\
\hline 1,2-Dibromoethane & 5 & Toluene & 5 \\
\hline trans-1,4-Dichloro-2-butene & 5 & 1,1,1-Trichloroethane $(1,1,1-\mathrm{TCA})$ & 5 \\
\hline 1,1-Dichloroethane (1,1-DCA) & 5 & 1,1,2-Trichloroethane $(1,1,2-\mathrm{TCA})$ & 5 \\
\hline 1,2-Dichloroethane (1,2-DCA) & 5 & Trichloroethylene (TCE) & 5 \\
\hline 1,1-Dichloroethylene (1,1-DCE) & 5 & Trichlorofluoromethane & 5 \\
\hline trans-1,2-Dichloroethylene (1,2-DCE[trans]) & 5 & 1,2,3-Trichloropropane & 5 \\
\hline Dichlorodifluoromethane (DCDF Meth) & 5 & Vinyl acetate & 10 \\
\hline 1,2-Dichloropropane & 5 & Vinyl chloride & 10 \\
\hline trans-1,3-Dichloropropene & 5 & Xylene (total) & 5 \\
\hline 6 NYCRR $^{a}$ Appendix 33 Metals & $\begin{array}{c}\text { PQL } \\
(\mu \mathrm{g} / \mathrm{L})\end{array}$ & 6 NYCRR $^{a}$ Appendix 33 Metals & $\begin{array}{c}\text { PQL } \\
(\mu \mathrm{g} / \mathrm{L})\end{array}$ \\
\hline Aluminum $^{b}$ & 200 & Manganese ${ }^{b}$ & 15 \\
\hline Antimony & 10 & Mercury & 0.2 \\
\hline Arsenic & 10 & Nickel & 40 \\
\hline Barium & 200 & Selenium & 5 \\
\hline Beryllium & 1 & Silver & 10 \\
\hline Cadmium & 5 & Thallium & 2 \\
\hline Chromium & 10 & Tin & 3,000 \\
\hline Cobalt & 50 & Vanadium & 50 \\
\hline Copper & 25 & Zinc & 20 \\
\hline Lead & 3 & & \\
\hline
\end{tabular}

Note: Specific quantitation limits are highly matrix dependent and may not always be achievable.

${ }^{a}$ Title 6 of the Official Compilation of Codes, Rules, and Regulations of the State of New York.

${ }^{b}$ Not a 6 NYCRR Appendix 33 parameter; sampled for the north plateau early warning program. 
TABLE D-1C (continued)

Practical Quantitation Limits (PQLs)

\begin{tabular}{|c|c|c|c|}
\hline \multicolumn{4}{|c|}{6 NYCRR $^{a}$ Appendix 33 Semi-Volatile Organic Compounds } \\
\hline Compound & $\begin{array}{c}\text { PQL } \\
(\mu \mathrm{g} / \mathrm{L})\end{array}$ & Compound & $\begin{array}{c}\text { PQL } \\
(\mu \mathrm{g} / \mathrm{L})\end{array}$ \\
\hline Acenaphthene & 10 & 2,4-Dinitrotoluene & 10 \\
\hline Acenaphthylene & 10 & 2,6-Dinitrotoluene & 10 \\
\hline Acetophenone & 10 & Diphenylamine & 10 \\
\hline 2-Acetylaminofluorene & 10 & Ethyl methanesulfonate & 10 \\
\hline 4-Aminobiphenyl & 10 & Famphur & 10 \\
\hline Analine & 10 & Fluoranthene & 10 \\
\hline Anthracene & 10 & Fluorene & 10 \\
\hline Aramite & 10 & Hexachlorobenzene & 10 \\
\hline Benzo[a]anthracene & 10 & Hexachlorobutadiene & 10 \\
\hline Benzo[a]pyrene & 10 & Hexachlorocyclopentadiene & 10 \\
\hline Benzo[b]fluoranthene & 10 & Hexachloroethane & 10 \\
\hline Benzo[ghi]perylene & 10 & Hexachlorophene & 10 \\
\hline Benzo[k]fluoranthene & 10 & Hexachloropropene & 10 \\
\hline Benzyl alcohol & 10 & Indeno(1,2,3,-cd)pyrene & 10 \\
\hline Bis(2-chloroethyl)ether & 10 & Isodrin & 10 \\
\hline Bis(2-chloroethoxy)methane & 10 & Isophorone & 10 \\
\hline Bis(2-chloroisopropyl)ether & 10 & Isosafrole & 10 \\
\hline Bis(2-ethylhexyl)phthalate & 10 & Kepone & 10 \\
\hline 4-Bromophenyl phenyl ether & 10 & Methapyrilene & 10 \\
\hline Butyl benzyl phthalate & 10 & Methyl methanesulfonate & 10 \\
\hline Chlorobenzilate & 10 & 3-Methylcholanthrene & 10 \\
\hline 2-Chloronaphthalene & 10 & 2-Methylnapthalene & 10 \\
\hline 2-Chlorophenol & 10 & 1,4-Naphthoquinone & 10 \\
\hline 4-Chlorophenyl phenyl ether & 10 & 1-Naphthylamine & 10 \\
\hline Chrysene & 10 & 2-Naphthylamine & 10 \\
\hline Di-n-butyl phthalate & 10 & Nitrobenzene & 10 \\
\hline Di-n-octyl phthalate & 10 & 5-Nitro-o-toluidine & 10 \\
\hline Diallate & 10 & 4-Nitroquinoline 1-oxide & 40 \\
\hline Dibenz[a,h]anthracine & 10 & N-Nitrosodi-n-butylamine & 10 \\
\hline Dibenzofuran & 10 & N-Nitrosodiethylamine & 10 \\
\hline 3,3-Dichlorobenzidine & 10 & N-Nitrosodimethylamine & 10 \\
\hline 2,4-Dichlorophenol & 10 & N-Nitroso-di-n-propylamine & 10 \\
\hline 2,6-Dichlorophenol & 10 & N-Nitrosodiphenylamine & 10 \\
\hline Diethyl phthalate & 10 & N-Nitrosomethylethylamine & 10 \\
\hline Dimethoate & 10 & N-Nitrosomorpholine & 10 \\
\hline 7,12-Dimethylbenz[a]anthracene & 10 & N-Nitrosopiperidine & 10 \\
\hline 3,3-Dimethylbenzidine & 20 & N-Nitrosopyrrolidine & 10 \\
\hline 2,4-Dimethylphenol & 10 & Naphthalene & 10 \\
\hline Dimethyl phthalate & 10 & 0,0,0-Triethyl phosphorothioate & 10 \\
\hline 4,6-Dinitro-o-cresol & 25 & O,O-Diethyl O-2-pyrazinylphosphorothioate & 10 \\
\hline 2,4-Dinitrophenol & 25 & & \\
\hline
\end{tabular}

Note: Specific quantitation limits are highly matrix dependent and may not always be achievable.

${ }^{a}$ Title 6 of the Official Compilation of Codes, Rules, and Regulations of the State of New York. 
TABLE D-1C (concluded)

Practical Quantitation Limits (PQLS)

\begin{tabular}{|c|c|c|c|}
\hline \multicolumn{4}{|c|}{6 NYCRR $^{a}$ Appendix 33 Semi-Volatile Organic Compounds } \\
\hline Compound & $\begin{array}{c}\text { PQL } \\
(\mu \mathrm{g} / \mathrm{L})\end{array}$ & Compound & $\begin{array}{c}\text { PQL } \\
(\mu \mathrm{g} / \mathrm{L})\end{array}$ \\
\hline $\mathrm{p}$-(Dimethylamino)azobenzene & 10 & 2,3,4,6-Tetrachlorophenol & 10 \\
\hline p-Chloroaniline & 10 & Tetraethyl dithiopyrophosphate & 10 \\
\hline p-Chloro-m-cresol & 10 & 1,2,4-Trichlorobenzene & 10 \\
\hline p-Cresol & 10 & 2,4,5-Trichlorophenol & 25 \\
\hline p-Dichlorobenzene & 10 & 2,4,6-Trichlorophenol & 10 \\
\hline p-Nitroaniline & 25 & alpha,alpha-Dimethylphenethylamine & 50 \\
\hline p-Nitrophenol & 25 & m-Cresol & 10 \\
\hline p-Phenylenediamine & 10 & m-Dichlorobenzene & 10 \\
\hline Parathion & 10 & m-Dinitrobenzene & 10 \\
\hline Pentachlorobenzene & 10 & m-Nitroanaline & 25 \\
\hline Pentachloronitrobenzene & 10 & o-Cresol & 10 \\
\hline Pentachlorophenol & 25 & o-Dichlorobenzene & 10 \\
\hline Phenacetin & 10 & o-Nitroaniline & 25 \\
\hline Phenanthrene & 10 & o-Nitrophenol & 10 \\
\hline Phenol & 10 & o-Toluidine & 10 \\
\hline Pronamide & 10 & sym-Trinitrobenzene & 10 \\
\hline Pyrene & 10 & 2-Picoline & 10 \\
\hline Safrole & 10 & Pyridine & 10 \\
\hline 1,2,4,5-Tetrachlorobenzene & 10 & 1,4-Dioxane & 10 \\
\hline \multicolumn{4}{|l|}{ Other Organic Compounds } \\
\hline 1,2-Dichloroethylene (Total) & 5 & & \\
\hline N-Dodecane & 60 & & \\
\hline Tributyl phosphate & 10 & & \\
\hline
\end{tabular}

Note: Specific quantitation limits are highly matrix dependent and may not always be achievable.

${ }^{a}$ Title 6 of the Official Compilation of Codes, Rules, and Regulations of the State of New York. 
This page intentionally left blank 


\section{APPENDIX D-2 \\ Groundwater Monitoring Data}

TABLE D-2A

2012 Indicator Results From the Sand and Gravel Unit

\begin{tabular}{|c|c|c|c|c|c|c|c|}
\hline $\begin{array}{c}\text { Location } \\
\text { Code }\end{array}$ & $\begin{array}{l}\text { Hydraulic } \\
\text { Position }^{a}\end{array}$ & $\begin{array}{c}\text { Date } \\
\text { Collected }\end{array}$ & $\begin{array}{l}p H \\
s U\end{array}$ & $\begin{array}{c}\text { Conductivity } \\
\text { umhos/cm@ } \\
25^{\circ} \mathrm{C}\end{array}$ & $\begin{array}{c}\text { Gross Alpha } \\
\mu \mathrm{Ci} / \mathrm{mL}\end{array}$ & $\begin{array}{c}\text { Gross Beta } \\
\mu \mathrm{Ci} / \mathrm{mL}\end{array}$ & $\begin{array}{l}\text { Tritium } \\
\mu \mathrm{Ci} / \mathrm{mL}\end{array}$ \\
\hline \multicolumn{3}{|c|}{ Groundwater Screening Levels ${ }^{b}$} & $N A$ & $N A$ & $1.50 E-08$ & $1.00 E-06$ & $1.78 E-07$ \\
\hline 301 & UP & Mar-12 & 6.73 & 1180 & $-0.28 \pm 1.82 E-09$ & $6.20 \pm 2.14 \mathrm{E}-09$ & $3.99 \pm 4.76 E-08$ \\
\hline 301 & UP & Jun-12 & 6.60 & 1837 & $1.51 \pm 2.23 \mathrm{E}-09$ & $7.20 \pm 2.98 \mathrm{E}-09$ & $8.03 \pm 7.28 \mathrm{E}-08$ \\
\hline 301 & UP & Sep-12 & 6.39 & 2576 & $-0.67 \pm 3.30 \mathrm{E}-09$ & $6.96 \pm 4.95 \mathrm{E}-09$ & $-1.10 \pm 1.04 \mathrm{E}-07$ \\
\hline 301 & UP & Dec-12 & 6.83 & 2153 & $2.04 \pm 2.87 \mathrm{E}-09$ & $1.03 \pm 0.32 \mathrm{E}-08$ & $7.08 \pm 6.68 \mathrm{E}-08$ \\
\hline 302 & UP & Jun-12 & 6.71 & 4942 & $5.72 \pm 5.64 \mathrm{E}-09$ & $4.64 \pm 7.02 \mathrm{E}-09$ & $5.79 \pm 7.15 \mathrm{E}-08$ \\
\hline 302 & UP & Dec-12 & 7.00 & 4736 & $-4.23 \pm 6.64 \mathrm{E}-09$ & $2.33 \pm 0.92 \mathrm{E}-08$ & $3.69 \pm 6.44 \mathrm{E}-08$ \\
\hline 401 & UP & Mar-12 & 7.20 & 3790 & $0.00 \pm 5.98 \mathrm{E}-09$ & $1.19 \pm 0.57 \mathrm{E}-08$ & $3.52 \pm 4.77 \mathrm{E}-08$ \\
\hline 401 & UP & Jun-12 & 6.99 & 2822 & $0.86 \pm 3.16 \mathrm{E}-09$ & $6.37 \pm 4.03 E-09$ & $5.16 \pm 7.13 E-08$ \\
\hline 401 & UP & Sep-12 & 6.71 & 2841 & $6.01 \pm 4.65 E-09$ & $0.92 \pm 6.96 \mathrm{E}-09$ & $-0.52 \pm 1.04 E-07$ \\
\hline 401 & UP & Dec-12 & 7.06 & 2694 & $-0.62 \pm 7.24 \mathrm{E}-09$ & $1.59 \pm 0.49 \mathrm{E}-08$ & $4.23 \pm 6.27 \mathrm{E}-08$ \\
\hline 402 & UP & Jun-12 & 6.86 & 5382 & $1.91 \pm 4.40 \mathrm{E}-09$ & $2.96 \pm 6.07 \mathrm{E}-09$ & $2.69 \pm 6.98 \mathrm{E}-08$ \\
\hline 402 & UP & Dec-12 & 7.15 & 5476 & $1.25 \pm 0.92 \mathrm{E}-08$ & $1.24 \pm 0.67 \mathrm{E}-08$ & $8.80 \pm 6.84 \mathrm{E}-08$ \\
\hline 403 & UP & Jun-12 & 7.02 & 1697 & $2.96 \pm 2.42 \mathrm{E}-09$ & $1.10 \pm 0.30 \mathrm{E}-08$ & $3.13 \pm 8.13 \mathrm{E}-08$ \\
\hline 403 & UP & Dec-12 & 7.13 & 1820 & $-0.50 \pm 3.62 E-09$ & $1.34 \pm 0.37 \mathrm{E}-08$ & $5.23 \pm 8.89 \mathrm{E}-08$ \\
\hline 706 & UP & Mar-12 & 6.98 & 583 & $-4.43 \pm 8.68 \mathrm{E}-10$ & $5.88 \pm 2.29 \mathrm{E}-09$ & $2.80 \pm 4.77 \mathrm{E}-08$ \\
\hline 706 & UP & Jun-12 & 6.83 & 1016 & $0.18 \pm 1.39 \mathrm{E}-09$ & $1.28 \pm 0.21 \mathrm{E}-08$ & $4.56 \pm 6.81 \mathrm{E}-08$ \\
\hline 706 & UP & Sep-12 & 6.50 & 1075 & $0.45 \pm 1.04 \mathrm{E}-09$ & $8.25 \pm 1.38 \mathrm{E}-09$ & $8.25 \pm 8.78 \mathrm{E}-08$ \\
\hline 706 & UP & Dec-12 & 7.11 & 772 & $1.47 \pm 1.05 \mathrm{E}-09$ & $6.14 \pm 0.94 \mathrm{E}-09$ & $6.22 \pm 8.80 \mathrm{E}-08$ \\
\hline 1302 & UP & Dec-12 & 6.94 & 1036 & $-1.68 \pm 1.60 \mathrm{E}-09$ & $0.64 \pm 1.66 \mathrm{E}-09$ & $1.28 \pm 0.88 \mathrm{E}-07$ \\
\hline 1304 & DOWN & Mar-12 & 7.13 & 1876 & $-1.42 \pm 4.80 \mathrm{E}-09$ & $1.72 \pm 2.70 \mathrm{E}-09$ & $-0.61 \pm 4.72 E-08$ \\
\hline 1304 & DOWN & Jun-12 & 7.04 & 2408 & $1.60 \pm 2.18 \mathrm{E}-09$ & $4.08 \pm 2.67 \mathrm{E}-09$ & $3.48 \pm 8.96 \mathrm{E}-08$ \\
\hline 1304 & DOWN & Sep-12 & 7.00 & 1340 & $3.80 \pm 2.50 \mathrm{E}-09$ & $9.24 \pm 1.84 \mathrm{E}-09$ & $7.80 \pm 7.90 \mathrm{E}-08$ \\
\hline 1304 & DOWN & Dec-12 & 7.08 & 1277 & $0.74 \pm 3.91 \mathrm{E}-09$ & $6.94 \pm 1.90 \mathrm{E}-09$ & $9.33 \pm 8.55 \mathrm{E}-08$ \\
\hline
\end{tabular}

NA - Not applicable.

SU - Standard units.

${ }^{a}$ Hydraulic position is relative to other wells within the same hydrogeologic unit.

${ }^{b}$ The GSLS for radiological constituents are set equal to the larger of the background concentrations or the TOGS 1.1.1

Class GA Groundwater Quality Standards (see Table D-1A). 
TABLE D-2A (continued)

2012 Indicator Results From the Sand and Gravel Unit

\begin{tabular}{|c|c|c|c|c|c|c|c|}
\hline $\begin{array}{c}\text { Location } \\
\text { Code }\end{array}$ & $\begin{array}{l}\text { Hydraulic } \\
\text { Position }^{a}\end{array}$ & $\begin{array}{c}\text { Date } \\
\text { Collected }\end{array}$ & $\begin{array}{l}p H \\
S U\end{array}$ & $\begin{array}{c}\text { Conductivity } \\
\mu m h o s / c m @ \\
25^{\circ} \mathrm{C}\end{array}$ & $\begin{array}{c}\text { Gross Alpha } \\
\mu \mathrm{Ci} / \mathrm{mL}\end{array}$ & $\begin{array}{c}\text { Gross Beta } \\
\mu \mathrm{Ci} / \mathrm{mL}\end{array}$ & $\begin{array}{l}\text { Tritium } \\
\mu \mathrm{Ci} / \mathrm{mL}\end{array}$ \\
\hline \multicolumn{3}{|c|}{ Groundwater Screening Levels ${ }^{b}$} & NA & NA & $1.50 E-08$ & $1.00 E-06$ & $1.78 E-07$ \\
\hline 103 & DOWN & Mar-12 & 8.48 & 2570 & $2.43 \pm 4.76 \mathrm{E}-09$ & $3.78 \pm 0.59 \mathrm{E}-08$ & $0.78 \pm 4.72 \mathrm{E}-08$ \\
\hline 103 & DOWN & Jun-12 & 8.08 & 2388 & $5.40 \pm 2.66 \mathrm{E}-09$ & $3.35 \pm 0.37 \mathrm{E}-08$ & $4.72 \pm 8.99 \mathrm{E}-08$ \\
\hline 103 & DOWN & Sep-12 & 8.36 & 1916 & $3.05 \pm 1.64 \mathrm{E}-09$ & $1.82 \pm 0.22 \mathrm{E}-08$ & $5.83 \pm 7.15 \mathrm{E}-08$ \\
\hline 103 & DOWN & Dec-12 & 8.62 & 1388 & $2.50 \pm 1.63 \mathrm{E}-09$ & $1.21 \pm 0.22 \mathrm{E}-08$ & $6.23 \pm 8.95 \mathrm{E}-08$ \\
\hline 104 & DOWN & Mar-12 & 7.15 & 1698 & $4.51 \pm 6.37 \mathrm{E}-09$ & $4.90 \pm 0.22 E-05$ & $1.98 \pm 0.50 \mathrm{E}-07$ \\
\hline 104 & DOWN & Jun-12 & 7.13 & 1638 & $2.09 \pm 5.42 \mathrm{E}-09$ & $5.50 \pm 0.04 \mathrm{E}-05$ & $7.41 \pm 8.90 \mathrm{E}-08$ \\
\hline 104 & DOWN & Sep-12 & 6.92 & 1932 & $5.42 \pm 6.92 \mathrm{E}-09$ & $7.25 \pm 0.03 E-05$ & $1.49 \pm 0.99 \mathrm{E}-07$ \\
\hline 104 & DOWN & Dec-12 & 7.27 & 1832 & $-0.40 \pm 5.95 E-09$ & $6.57 \pm 0.03 E-05$ & $1.82 \pm 0.94 \mathrm{E}-07$ \\
\hline 111 & DOWN & Mar-12 & 6.67 & 544 & $1.00 \pm 2.49 \mathrm{E}-09$ & $2.34 \pm 0.11 \mathrm{E}-06$ & $2.45 \pm 4.75 \mathrm{E}-08$ \\
\hline 111 & DOWN & Jun-12 & 6.60 & 906 & $3.99 \pm 1.77 \mathrm{E}-09$ & $5.97 \pm 0.03 E-06$ & $5.75 \pm 9.13 \mathrm{E}-08$ \\
\hline 111 & DOWN & Sep-12 & 6.45 & 2042 & $1.57 \pm 1.28 \mathrm{E}-08$ & $7.96 \pm 0.12 \mathrm{E}-06$ & $1.46 \pm 0.98 \mathrm{E}-07$ \\
\hline 111 & DOWN & Dec-12 & 6.70 & 1102 & $8.32 \pm 6.53 \mathrm{E}-09$ & $6.05 \pm 0.08 \mathrm{E}-06$ & $1.10 \pm 0.84 \mathrm{E}-07$ \\
\hline 205 & DOWN & Jun-12 & 7.17 & 2485 & $3.23 \pm 2.46 \mathrm{E}-09$ & $7.75 \pm 2.62 \mathrm{E}-09$ & $3.86 \pm 6.12 \mathrm{E}-08$ \\
\hline 205 & DOWN & Dec-12 & 7.25 & 2678 & $-0.34 \pm 6.69 \mathrm{E}-09$ & $2.21 \pm 0.58 \mathrm{E}-08$ & $5.24 \pm 8.92 \mathrm{E}-08$ \\
\hline 406 & DOWN & Mar-12 & 6.98 & 1110 & $-0.48 \pm 1.50 \mathrm{E}-09$ & $6.50 \pm 1.92 \mathrm{E}-09$ & $1.57 \pm 4.75 \mathrm{E}-08$ \\
\hline 406 & DOWN & Jun-12 & 7.04 & 867 & $0.26 \pm 1.20 \mathrm{E}-09$ & $6.87 \pm 1.86 \mathrm{E}-09$ & $7.21 \pm 9.21 \mathrm{E}-08$ \\
\hline 406 & DOWN & Sep-12 & 7.17 & 712 & $2.18 \pm 8.32 \mathrm{E}-10$ & $3.83 \pm 0.67 \mathrm{E}-09$ & $8.69 \pm 7.36 \mathrm{E}-08$ \\
\hline 406 & DOWN & Dec-12 & 7.22 & 864 & $-0.46 \pm 1.76 \mathrm{E}-09$ & $6.50 \pm 2.11 \mathrm{E}-09$ & $5.89 \pm 8.87 \mathrm{E}-08$ \\
\hline 408 & DOWN & Mar-12 & 7.33 & 2982 & $0.31 \pm 1.15 \mathrm{E}-08$ & $1.92 \pm 0.10 \mathrm{E}-04$ & $5.13 \pm 4.81 \mathrm{E}-08$ \\
\hline 408 & DOWN & Jun-12 & 7.21 & 3622 & $3.51 \pm 8.59 \mathrm{E}-09$ & $1.98 \pm 0.01 \mathrm{E}-04$ & $0.21 \pm 1.16 \mathrm{E}-07$ \\
\hline 408 & DOWN & Sep-12 & 6.90 & 2499 & $0.10 \pm 1.30 \mathrm{E}-08$ & $2.14 \pm 0.01 E-04$ & $2.97 \pm 8.21 \mathrm{E}-08$ \\
\hline 408 & DOWN & Dec-12 & 7.21 & 3266 & $1.56 \pm 2.81 \mathrm{E}-09$ & $1.94 \pm 0.01 \mathrm{E}-04$ & $5.95 \pm 9.84 \mathrm{E}-08$ \\
\hline 501 & DOWN & Mar-12 & 7.40 & 2300 & $1.12 \pm 8.06 \mathrm{E}-09$ & $8.73 \pm 0.39 \mathrm{E}-05$ & $0.92 \pm 3.38 \mathrm{E}-08$ \\
\hline 501 & DOWN & Jun-12 & 7.40 & 2651 & $1.23 \pm 1.08 \mathrm{E}-08$ & $8.70 \pm 0.04 \mathrm{E}-05$ & $1.38 \pm 1.19 \mathrm{E}-07$ \\
\hline 501 & DOWN & Sep-12 & 6.45 & 2499 & $2.69 \pm 8.06 \mathrm{E}-09$ & $7.10 \pm 0.04 E-05$ & $2.42 \pm 8.05 \mathrm{E}-08$ \\
\hline 501 & DOWN & Dec-12 & 7.41 & 2498 & $1.16 \pm 2.27 \mathrm{E}-09$ & $7.87 \pm 0.07 E-05$ & $0.56 \pm 1.01 \mathrm{E}-07$ \\
\hline 502 & DOWN & Mar-12 & 7.39 & 2256 & $-2.28 \pm 7.74 \mathrm{E}-09$ & $8.45 \pm 0.38 E-05$ & $5.77 \pm 4.82 \mathrm{E}-08$ \\
\hline 502 & DOWN & Jun-12 & 7.36 & 2441 & $1.74 \pm 5.66 \mathrm{E}-09$ & $7.76 \pm 0.03 E-05$ & $1.38 \pm 1.19 \mathrm{E}-07$ \\
\hline 502 & DOWN & Sep-12 & 7.01 & 2392 & $0.50 \pm 1.23 \mathrm{E}-08$ & $7.91 \pm 0.04 \mathrm{E}-05$ & $4.13 \pm 8.25 \mathrm{E}-08$ \\
\hline 502 & DOWN & Dec-12 & 7.34 & 2295 & $0.55 \pm 2.52 \mathrm{E}-09$ & $8.13 \pm 0.07 E-05$ & $7.30 \pm 7.28 \mathrm{E}-08$ \\
\hline $602 \mathrm{~A}$ & DOWN & Jun-12 & 6.75 & 618 & $1.24 \pm 1.21 \mathrm{E}-09$ & $1.06 \pm 0.14 \mathrm{E}-08$ & $1.45 \pm 0.69 \mathrm{E}-07$ \\
\hline $602 \mathrm{~A}$ & DOWN & Dec-12 & 7.03 & 666 & $1.78 \pm 1.02 \mathrm{E}-09$ & $2.10 \pm 0.17 \mathrm{E}-08$ & $2.34 \pm 1.13 \mathrm{E}-07$ \\
\hline
\end{tabular}

Note: Bolding indicates radiological concentration that exceeds the GSL.

NA - Not applicable.

SU - Standard units.

${ }^{\text {a }}$ Hydraulic position is relative to other wells within the same hydrogeologic unit.

${ }^{b}$ The GSLs for radiological constituents are set equal to the larger of the background concentrations or the TOGS 1.1.1

Class GA Groundwater Quality Standards (See Table D-1A). 
TABLE D-2A (continued)

2012 Indicator Results From the Sand and Gravel Unit

\begin{tabular}{|c|c|c|c|c|c|c|c|}
\hline $\begin{array}{c}\text { Location } \\
\text { Code }\end{array}$ & $\begin{array}{l}\text { Hydraulic } \\
\text { Position }^{a}\end{array}$ & $\begin{array}{c}\text { Date } \\
\text { Collected }\end{array}$ & $\begin{array}{l}p H \\
S U\end{array}$ & $\begin{array}{c}\text { Conductivity } \\
\mu m h o s / c m @ \\
25^{\circ} \mathrm{C}\end{array}$ & $\begin{array}{c}\text { Gross Alpha } \\
\mu \mathrm{Ci} / \mathrm{mL}\end{array}$ & $\begin{array}{c}\text { Gross Beta } \\
\mu \mathrm{Ci} / \mathrm{mL}\end{array}$ & $\begin{array}{l}\text { Tritium } \\
\mu \mathrm{Ci} / \mathrm{mL}\end{array}$ \\
\hline \multicolumn{3}{|c|}{ Groundwater Screening Levels ${ }^{b}$} & NA & NA & $1.50 E-08$ & $1.00 E-06$ & $1.78 E-07$ \\
\hline 604 & DOWN & Jun-12 & 6.35 & 1474 & $1.24 \pm 1.60 \mathrm{E}-09$ & $8.44 \pm 3.09 E-09$ & $7.39 \pm 9.44 \mathrm{E}-08$ \\
\hline 604 & DOWN & Dec-12 & 6.86 & 1605 & $1.02 \pm 2.69 \mathrm{E}-09$ & $1.10 \pm 0.22 \mathrm{E}-08$ & $4.62 \pm 8.76 \mathrm{E}-08$ \\
\hline 8605 & DOWN & Mar-12 & 6.81 & 1030 & $1.03 \pm 0.54 \mathrm{E}-08$ & $5.59 \pm 0.25 E-06$ & $-0.81 \pm 4.72 E-08$ \\
\hline 8605 & DOWN & Jun-12 & 6.45 & 1376 & $9.61 \pm 8.15 E-09$ & $5.68 \pm 0.09 E-06$ & $2.52 \pm 9.23 \mathrm{E}-08$ \\
\hline 8605 & DOWN & Sep-12 & 6.64 & 1878 & $7.83 \pm 7.25 E-09$ & $4.75 \pm 0.08 \mathrm{E}-06$ & $5.16 \pm 8.63 E-08$ \\
\hline 8605 & DOWN & Dec-12 & 6.68 & 1308 & $1.47 \pm 0.31 \mathrm{E}-08$ & $7.60 \pm 0.24 \mathrm{E}-06$ & $1.02 \pm 0.81 \mathrm{E}-07$ \\
\hline 8607 & DOWN & Mar-12 & 6.66 & 1608 & $-1.95 \pm 5.34 \mathrm{E}-09$ & $2.78 \pm 0.44 \mathrm{E}-08$ & $-1.01 \pm 4.72 E-08$ \\
\hline 8607 & DOWN & Jun-12 & 6.23 & 1558 & $1.23 \pm 1.87 \mathrm{E}-09$ & $2.78 \pm 0.31 \mathrm{E}-08$ & $1.17 \pm 1.01 \mathrm{E}-07$ \\
\hline 8607 & DOWN & Sep-12 & 6.43 & 1376 & $-0.20 \pm 1.10 \mathrm{E}-09$ & $6.04 \pm 1.91 \mathrm{E}-09$ & $5.48 \pm 7.10 \mathrm{E}-08$ \\
\hline 8607 & DOWN & Dec-12 & 7.19 & 1222 & $0.53 \pm 2.82 \mathrm{E}-09$ & $2.74 \pm 0.21 \mathrm{E}-08$ & $1.27 \pm 0.91 \mathrm{E}-07$ \\
\hline 8609 & DOWN & Mar-12 & 7.09 & 2084 & $1.88 \pm 5.55 E-09$ & $8.95 \pm 0.41 \mathrm{E}-07$ & $1.10 \pm 0.49 E-07$ \\
\hline 8609 & DOWN & Jun-12 & 7.49 & 2008 & $0.19 \pm 3.40 \mathrm{E}-09$ & $1.23 \pm 0.06 \mathrm{E}-06$ & $1.92 \pm 8.43 \mathrm{E}-08$ \\
\hline 8609 & DOWN & Sep-12 & 6.74 & 2190 & $-1.44 \pm 5.67 \mathrm{E}-09$ & $1.32 \pm 0.05 E-06$ & $1.67 \pm 1.11 \mathrm{E}-07$ \\
\hline 8609 & DOWN & Dec-12 & 7.05 & 2250 & $0.86 \pm 1.06 \mathrm{E}-08$ & $1.58 \pm 0.06 E-06$ & $2.08 \pm 0.95 E-07$ \\
\hline 105 & DOWN & Mar-12 & 7.15 & 2198 & $-1.56 \pm 7.13 \mathrm{E}-09$ & $5.45 \pm 0.26 E-05$ & $2.25 \pm 0.50 \mathrm{E}-07$ \\
\hline 105 & DOWN & Jun-12 & 7.09 & 1951 & $-3.05 \pm 6.40 \mathrm{E}-09$ & $5.06 \pm 0.04 \mathrm{E}-05$ & $1.61 \pm 0.99 \mathrm{E}-07$ \\
\hline 105 & DOWN & Sep-12 & 6.91 & 2078 & $5.27 \pm 9.44 \mathrm{E}-09$ & $5.19 \pm 0.03 E-05$ & $3.15 \pm 1.27 E-07$ \\
\hline 105 & DOWN & Dec-12 & 7.29 & 2155 & $-1.39 \pm 5.48 \mathrm{E}-09$ & $6.05 \pm 0.03 E-05$ & $2.42 \pm 0.99 E-07$ \\
\hline 106 & DOWN & Mar-12 & 6.72 & 1221 & $1.10 \pm 3.25 \mathrm{E}-09$ & $9.85 \pm 0.44 \mathrm{E}-07$ & $3.17 \pm 0.52 E-07$ \\
\hline 106 & DOWN & Jun-12 & 6.90 & 1353 & $-1.05 \pm 2.61 \mathrm{E}-09$ & $9.89 \pm 0.52 \mathrm{E}-07$ & $5.54 \pm 1.22 \mathrm{E}-07$ \\
\hline 106 & DOWN & Sep-12 & 6.67 & 1534 & $2.36 \pm 4.90 \mathrm{E}-09$ & $1.15 \pm 0.04 \mathrm{E}-06$ & $7.38 \pm 1.59 E-07$ \\
\hline 106 & DOWN & Dec-12 & 6.90 & 1438 & $4.50 \pm 6.90 \mathrm{E}-09$ & $1.13 \pm 0.04 \mathrm{E}-06$ & 4.18 $\pm 1.14 E-07$ \\
\hline 116 & DOWN & Jun-12 & 7.02 & 1915 & $-4.92 \pm 3.62 E-09$ & $1.66 \pm 0.02 E-05$ & $-0.66 \pm 8.50 E-08$ \\
\hline 116 & DOWN & Dec-12 & 7.09 & 2030 & $-3.86 \pm 5.46 E-09$ & $2.04 \pm 0.02 E-05$ & $7.82 \pm 8.02 E-08$ \\
\hline 605 & DOWN & Jun-12 & 6.64 & 678 & $3.75 \pm 8.00 \mathrm{E}-10$ & $2.22 \pm 0.16 \mathrm{E}-08$ & $1.66 \pm 5.85 \mathrm{E}-08$ \\
\hline 605 & DOWN & Dec-12 & 6.98 & 826 & $-0.12 \pm 1.04 \mathrm{E}-09$ & $6.27 \pm 0.26 \mathrm{E}-08$ & $1.01 \pm 0.94 \mathrm{E}-07$ \\
\hline
\end{tabular}

Note: Bolding indicates radiological concentration that exceeds the GSL.

NA - Not applicable.

SU - Standard units.

${ }^{a}$ Hydraulic position is relative to other wells within the same hydrogeologic unit.

${ }^{\mathrm{b}}$ The GSLS for radiological constituents are set equal to the larger of the background concentrations or the TOGS 1.1.1

Class GA Groundwater Quality Standards (See Table D-1A). 
TABLE D-2A (continued)

2012 Indicator Results From the Sand and Gravel Unit

\begin{tabular}{|c|c|c|c|c|c|c|c|}
\hline $\begin{array}{c}\text { Location } \\
\text { Code }\end{array}$ & $\begin{array}{l}\text { Hydraulic } \\
\text { Position }^{a}\end{array}$ & $\begin{array}{c}\text { Date } \\
\text { Collected }\end{array}$ & $\begin{array}{l}p H \\
S U\end{array}$ & $\begin{array}{c}\text { Conductivity } \\
\mu m h o s / c m @ \\
25^{\circ} \mathrm{C}\end{array}$ & $\begin{array}{c}\text { Gross Alpha } \\
\mu \mathrm{Ci} / \mathrm{mL}\end{array}$ & $\begin{array}{c}\text { Gross Beta } \\
\mu \mathrm{Ci} / \mathrm{mL}\end{array}$ & $\begin{array}{l}\text { Tritium } \\
\mu C i / m L\end{array}$ \\
\hline \multicolumn{3}{|c|}{ Groundwater Screening Levels ${ }^{b}$} & NA & NA & $1.50 E-08$ & $1.00 E-06$ & $1.78 E-07$ \\
\hline 801 & DOWN & Mar-12 & 6.64 & 1342 & $0.69 \pm 4.95 \mathrm{E}-09$ & $1.45 \pm 0.06 \mathrm{E}-05$ & $2.29 \pm 0.51 E-07$ \\
\hline 801 & DOWN & Jun-12 & 6.60 & 1320 & $0.63 \pm 4.69 \mathrm{E}-09$ & $1.11 \pm 0.01 E-05$ & $1.25 \pm 1.18 \mathrm{E}-07$ \\
\hline 801 & DOWN & Sep-12 & 6.46 & 1180 & $0.90 \pm 3.76 E-09$ & 8.84 $\pm 0.09 E-06$ & $1.03 \pm 0.89 \mathrm{E}-07$ \\
\hline 801 & DOWN & Dec-12 & 6.73 & 1184 & $1.14 \pm 2.14 \mathrm{E}-08$ & $9.96 \pm 0.36 \mathrm{E}-06$ & $7.08 \pm 9.95 \mathrm{E}-08$ \\
\hline 802 & DOWN & Mar-12 & 6.33 & 155 & $0.60 \pm 1.20 \mathrm{E}-09$ & $2.26 \pm 0.32 \mathrm{E}-08$ & $-1.63 \pm 4.73 E-08$ \\
\hline 802 & DOWN & Jun-12 & 7.17 & 464 & $-0.28 \pm 8.10 \mathrm{E}-10$ & $2.12 \pm 0.04 \mathrm{E}-07$ & $5.54 \pm 6.09 E-08$ \\
\hline 802 & DOWN & Sep-12 & 6.91 & 909 & $4.83 \pm 7.33 \mathrm{E}-10$ & $5.81 \pm 0.07 \mathrm{E}-07$ & $-0.47 \pm 1.03 E-07$ \\
\hline 802 & DOWN & Dec-12 & 7.02 & 810 & $-1.16 \pm 8.97 \mathrm{E}-10$ & $5.70 \pm 0.07 \mathrm{E}-07$ & $4.22 \pm 7.03 E-08$ \\
\hline 803 & DOWN & Mar-12 & 7.25 & 2024 & $-2.15 \pm 7.29 E-09$ & $2.03 \pm 0.11 E-06$ & $5.69 \pm 4.84 \mathrm{E}-08$ \\
\hline 803 & DOWN & Jun-12 & 7.05 & 2252 & $0.81 \pm 4.19 E-09$ & $2.16 \pm 0.05 E-06$ & $1.46 \pm 0.69 \mathrm{E}-07$ \\
\hline 803 & DOWN & Sep-12 & 5.77 & 2316 & $0.65 \pm 1.48 \mathrm{E}-08$ & $2.04 \pm 0.06 E-06$ & $1.18 \pm 0.91 \mathrm{E}-07$ \\
\hline 803 & DOWN & Dec-12 & 7.20 & 2126 & $3.05 \pm 2.86 \mathrm{E}-09$ & $1.89 \pm 0.12 \mathrm{E}-06$ & $1.63 \pm 1.10 \mathrm{E}-07$ \\
\hline 804 & DOWN & Mar-12 & 6.76 & 1030 & $0.00 \pm 4.05 \mathrm{E}-09$ & $2.88 \pm 0.14 \mathrm{E}-07$ & $-3.24 \pm 4.68 \mathrm{E}-08$ \\
\hline 804 & DOWN & Jun-12 & 6.80 & 1164 & $5.72 \pm 2.55 \mathrm{E}-09$ & $3.34 \pm 0.07 E-07$ & $1.03 \pm 0.67 \mathrm{E}-07$ \\
\hline 804 & DOWN & Sep-12 & 6.46 & 1866 & $0.73 \pm 2.00 \mathrm{E}-09$ & $4.40 \pm 0.09 E-07$ & $-1.04 \pm 1.03 \mathrm{E}-07$ \\
\hline 804 & DOWN & Dec-12 & 6.65 & 1382 & $2.35 \pm 1.26 \mathrm{E}-09$ & $3.51 \pm 0.05 \mathrm{E}-07$ & $1.10 \pm 0.70 \mathrm{E}-07$ \\
\hline 8603 & DOWN & Jun-12 & 7.34 & 1964 & $0.78 \pm 4.05 \mathrm{E}-09$ & $5.11 \pm 0.04 \mathrm{E}-05$ & $4.86 \pm 8.76 \mathrm{E}-08$ \\
\hline 8603 & DOWN & Dec-12 & 7.43 & 2226 & $-0.78 \pm 5.74 \mathrm{E}-09$ & $6.31 \pm 0.04 \mathrm{E}-05$ & $2.60 \pm 0.98 \mathrm{E}-07$ \\
\hline 8604 & DOWN & Jun-12 & 7.17 & 1925 & $2.10 \pm 6.29 \mathrm{E}-09$ & $4.04 \pm 0.02 E-05$ & $2.14 \pm 1.23 E-07$ \\
\hline 8604 & DOWN & Dec-12 & 7.31 & 2106 & $-1.55 \pm 5.90 \mathrm{E}-09$ & $5.57 \pm 0.03 E-05$ & $1.50 \pm 0.90 \mathrm{E}-07$ \\
\hline 8612 & DOWN & Mar-12 & 7.01 & 2250 & $0.94 \pm 8.18 \mathrm{E}-09$ & $2.16 \pm 0.57 \mathrm{E}-08$ & $3.06 \pm 4.81 \mathrm{E}-08$ \\
\hline 8612 & DOWN & Jun-12 & 7.20 & 2186 & $3.82 \pm 3.55 E-09$ & $2.43 \pm 0.40 \mathrm{E}-08$ & $1.27 \pm 0.68 \mathrm{E}-07$ \\
\hline 8612 & DOWN & Sep-12 & 6.71 & 2174 & $-1.60 \pm 2.93 E-09$ & $1.27 \pm 0.35 \mathrm{E}-08$ & $0.17 \pm 1.05 E-07$ \\
\hline 8612 & DOWN & Dec-12 & 7.30 & 2122 & $-1.06 \pm 2.07 E-09$ & $2.00 \pm 0.31 \mathrm{E}-08$ & $1.38 \pm 0.77 \mathrm{E}-07$ \\
\hline GSEEP & DOWN & Mar-12 & 6.62 & 1296 & $-2.61 \pm 4.15 E-09$ & $8.26 \pm 0.64 \mathrm{E}-08$ & $2.08 \pm 0.51 E-07$ \\
\hline GSEEP & DOWN & Jun-12 & 6.83 & 1321 & $-0.57 \pm 1.80 \mathrm{E}-09$ & $1.46 \pm 0.06 \mathrm{E}-07$ & $2.29 \pm 1.11 E-07$ \\
\hline GSEEP & DOWN & Sep-12 & 6.72 & 1513 & $3.72 \pm 2.57 \mathrm{E}-09$ & $2.17 \pm 0.06 \mathrm{E}-07$ & $2.81 \pm 0.89 E-07$ \\
\hline GSEEP & DOWN & Dec-12 & 6.76 & 1343 & $0.46 \pm 1.27 E-09$ & $1.87 \pm 0.05 E-07$ & $3.93 \pm 1.25 E-07$ \\
\hline
\end{tabular}

Note: Bolding indicates radiological concentration that exceeds the GSL.

NA - Not applicable.

SU - Standard units.

${ }^{a}$ Hydraulic position is relative to other wells within the same hydrogeologic unit.

${ }^{b}$ The GSLs for radiological constituents are set equal to the larger of the background concentrations or the TOGS 1.1.1

Class GA Groundwater Quality Standards (See Table D-1A). 
TABLE D-2A (concluded)

2012 Indicator Results From the Sand and Gravel Unit

\begin{tabular}{|c|c|c|c|c|c|c|c|}
\hline $\begin{array}{c}\text { Location } \\
\text { Code }\end{array}$ & $\begin{array}{l}\text { Hydraulic } \\
\text { Position }^{a}\end{array}$ & $\begin{array}{c}\text { Date } \\
\text { Collected }\end{array}$ & $\begin{array}{l}p H \\
S U\end{array}$ & $\begin{array}{c}\text { Conductivity } \\
\text { umhos/cm@ } \\
25^{\circ} \mathrm{C}\end{array}$ & $\begin{array}{c}\text { Gross Alpha } \\
\mu \mathrm{Ci} / \mathrm{mL}\end{array}$ & $\begin{array}{c}\text { Gross Beta } \\
\mu \mathrm{Ci} / \mathrm{mL}\end{array}$ & $\begin{array}{l}\text { Tritium } \\
\mu \mathrm{Ci} / \mathrm{mL}\end{array}$ \\
\hline \multicolumn{3}{|c|}{${ }^{\text {Groundwater Screening Levels }^{b}}$} & NA & NA & $1.50 E-08$ & $1.00 E-06$ & $1.78 E-07$ \\
\hline SP04 & DOWN & Mar-12 & NS & NS & NS & $1.46 \pm 0.06 \mathrm{E}-06$ & NS \\
\hline SP04 & DOWN & Jun-12 & NS & NS & $1.82 \pm 2.55 \mathrm{E}-09$ & $1.40 \pm 0.02 E-06$ & $1.88 \pm 1.08 \mathrm{E}-07$ \\
\hline SP04 & DOWN & Dec-12 & NS & NS & $-6.07 \pm 2.07 E-09$ & $1.52 \pm 0.05 E-06$ & $2.35 \pm 0.97 E-07$ \\
\hline SP06 & DOWN & Mar-12 & NS & NS & NS & $1.01 \pm 0.07 \mathrm{E}-07$ & NS \\
\hline SP06 & DOWN & Jun-12 & NS & NS & $1.02 \pm 2.36 \mathrm{E}-09$ & $1.24 \pm 0.05 E-07$ & $4.63 \pm 8.82 \mathrm{E}-08$ \\
\hline SP06 & DOWN & Dec-12 & NS & NS & $-0.44 \pm 4.94 \mathrm{E}-09$ & $1.84 \pm 0.12 \mathrm{E}-07$ & $1.13 \pm 0.98 \mathrm{E}-07$ \\
\hline SP11 & DOWN & Mar-12 & NS & NS & NS & $5.17 \pm 0.28 \mathrm{E}-07$ & NS \\
\hline SP11 & DOWN & Jun-12 & NS & NS & $7.36 \pm 2.87 \mathrm{E}-09$ & $6.30 \pm 0.11 \mathrm{E}-07$ & $1.61 \pm 1.04 \mathrm{E}-07$ \\
\hline SP11 & DOWN & Dec-12 & NS & NS & $2.13 \pm 3.54 \mathrm{E}-09$ & $7.78 \pm 0.26 \mathrm{E}-07$ & $8.62 \pm 9.51 \mathrm{E}-08$ \\
\hline SP12 & DOWN & Mar-12 & NS & NS & NS & $2.00 \pm 0.10 \mathrm{E}-07$ & NS \\
\hline SP12 & DOWN & Jun-12 & 7.28 & 2126 & $-1.77 \pm 1.77 E-09$ & $2.04 \pm 0.06 \mathrm{E}-07$ & $1.09 \pm 0.99 \mathrm{E}-07$ \\
\hline SP12 & DOWN & Dec-12 & 6.73 & 2031 & $2.00 \pm 4.01 \mathrm{E}-09$ & $2.82 \pm 0.20 \mathrm{E}-07$ & $6.40 \pm 9.97 \mathrm{E}-08$ \\
\hline WP-A & DOWN & Sep-12 & 7.07 & 121 & $-0.81 \pm 2.56 \mathrm{E}-10$ & $1.91 \pm 0.11 \mathrm{E}-08$ & $8.75 \pm 0.45 E-06$ \\
\hline WP-C & DOWN & Sep-12 & 7.03 & 862 & $1.28 \pm 6.02 \mathrm{E}-10$ & $1.28 \pm 0.03 \mathrm{E}-07$ & $3.12 \pm 0.08 \mathrm{E}-05$ \\
\hline WP-H & DOWN & Sep-12 & 6.72 & 1240 & $1.76 \pm 0.76 \mathrm{E}-08$ & $3.37 \pm 0.05 E-06$ & $8.05 \pm 1.62 \mathrm{E}-07$ \\
\hline MP-01 & DOWN & Mar-12 & 7.18 & 3146 & $-0.08 \pm 1.10 \mathrm{E}-08$ & $2.88 \pm 0.14 \mathrm{E}-04$ & $0.61 \pm 4.80 \mathrm{E}-08$ \\
\hline MP-01 & DOWN & Jun-12 & 7.25 & 3752 & $2.90 \pm 3.96 \mathrm{E}-08$ & $2.89 \pm 0.01 E-04$ & $0.97 \pm 1.19 \mathrm{E}-07$ \\
\hline MP-01 & DOWN & Sep-12 & 7.16 & 3449 & $-1.39 \pm 1.07 E-08$ & $2.85 \pm 0.01 E-04$ & $1.20 \pm 0.91 \mathrm{E}-07$ \\
\hline MP-01 & DOWN & Dec-12 & 7.07 & 3182 & $3.66 \pm 4.80 \mathrm{E}-09$ & $2.34 \pm 0.01 \mathrm{E}-04$ & $0.94 \pm 1.02 \mathrm{E}-07$ \\
\hline $\mathrm{MP}-02$ & DOWN & Mar-12 & 7.18 & 2501 & $2.46 \pm 9.02 E-09$ & $3.14 \pm 0.14 \mathrm{E}-04$ & $1.63 \pm 4.80 \mathrm{E}-08$ \\
\hline MP-02 & DOWN & Jun-12 & 7.20 & 2309 & $-1.78 \pm 9.46 \mathrm{E}-09$ & $3.46 \pm 0.01 E-04$ & $0.77 \pm 1.17 \mathrm{E}-07$ \\
\hline MP-02 & DOWN & Sep-12 & 7.01 & 2734 & $4.72 \pm 9.79 \mathrm{E}-09$ & $3.34 \pm 0.01 E-04$ & $3.38 \pm 8.02 E-08$ \\
\hline MP-02 & DOWN & Dec-12 & 7.02 & 2588 & $2.92 \pm 3.26 \mathrm{E}-09$ & $2.89 \pm 0.01 E-04$ & $0.97 \pm 1.05 \mathrm{E}-07$ \\
\hline MP-03 & DOWN & Mar-12 & 7.41 & 1872 & $0.04 \pm 7.00 \mathrm{E}-09$ & $1.89 \pm 0.08 \mathrm{E}-04$ & $-0.31 \pm 4.11 \mathrm{E}-08$ \\
\hline MP-03 & DOWN & Jun-12 & 7.33 & 2471 & $-1.61 \pm 4.36 \mathrm{E}-09$ & $2.34 \pm 0.01 \mathrm{E}-04$ & $0.51 \pm 1.15 \mathrm{E}-07$ \\
\hline MP-03 & DOWN & Sep-12 & 7.18 & 2094 & $-1.01 \pm 1.00 \mathrm{E}-08$ & $2.23 \pm 0.01 E-04$ & $7.31 \pm 8.41 \mathrm{E}-08$ \\
\hline MP-03 & DOWN & Dec-12 & 7.39 & 1898 & $4.57 \pm 3.10 \mathrm{E}-09$ & $1.87 \pm 0.01 \mathrm{E}-04$ & $0.77 \pm 1.00 \mathrm{E}-07$ \\
\hline MP-04 & DOWN & Mar-12 & 7.33 & 2166 & $2.19 \pm 8.04 \mathrm{E}-09$ & $3.47 \pm 0.15 E-04$ & $0.00 \pm 4.78 \mathrm{E}-08$ \\
\hline MP-04 & DOWN & Jun-12 & 7.30 & 2662 & $-1.35 \pm 4.60 \mathrm{E}-09$ & $3.48 \pm 0.01 E-04$ & $1.81 \pm 1.21 \mathrm{E}-07$ \\
\hline MP-04 & DOWN & Sep-12 & 7.07 & 2232 & $4.84 \pm 7.73 \mathrm{E}-09$ & $3.04 \pm 0.01 E-04$ & $1.01 \pm 0.88 \mathrm{E}-07$ \\
\hline MP-04 & DOWN & Dec-12 & 7.31 & 2044 & $2.84 \pm 2.43 \mathrm{E}-09$ & $3.04 \pm 0.01 E-04$ & $1.35 \pm 1.07 \mathrm{E}-07$ \\
\hline
\end{tabular}

Note: Bolding indicates radiological concentration that exceeds the GSL.

NA - Not applicable.

NS - Not sampled.

SU - Standard units.

${ }^{a}$ Hydraulic position is relative to other wells within the same hydrogeologic unit.

${ }^{b}$ The GSLS or radiological constituents are set equal to the larger of the background concentrations or the TOGS 1.1.1 
TABLE D-2B

2012 Indicator Results From the Lavery Till-Sand Unit

\begin{tabular}{|c|c|c|c|c|c|c|c|}
\hline $\begin{array}{c}\text { Location } \\
\text { Code }\end{array}$ & $\begin{array}{l}\text { Hydraulic } \\
\text { Position }^{a}\end{array}$ & $\begin{array}{c}\text { Date } \\
\text { Collected }\end{array}$ & $\begin{array}{l}p H \\
S U\end{array}$ & $\begin{array}{c}\text { Conductivity } \\
\text { pmhos/cm@ } \\
25^{\circ} \mathrm{C}\end{array}$ & $\begin{array}{c}\text { Gross Alpha } \\
\mu \mathrm{Ci} / \mathrm{mL}\end{array}$ & $\begin{array}{c}\text { Gross Beta } \\
\mu \mathrm{Ci} / \mathrm{mL}\end{array}$ & $\begin{array}{l}\text { Tritium } \\
\mu \mathrm{Ci} / \mathrm{mL}\end{array}$ \\
\hline \multicolumn{3}{|c|}{ Groundwater Screening Levels $^{b}$} & $N A$ & $N A$ & $1.50 E-08$ & $1.00 E-06$ & $1.78 E-07$ \\
\hline 204 & DOWN & Mar-12 & 7.46 & 1728 & $-1.55 \pm 2.15 E-09$ & $2.87 \pm 2.53 \mathrm{E}-09$ & $0.59 \pm 4.71 E-08$ \\
\hline 204 & DOWN & Jun-12 & 7.50 & 1932 & $2.79 \pm 1.91 \mathrm{E}-09$ & $6.13 \pm 2.71 \mathrm{E}-09$ & $4.57 \pm 6.22 \mathrm{E}-08$ \\
\hline 204 & DOWN & Sep-12 & 7.04 & 1977 & $-0.74 \pm 1.54 \mathrm{E}-09$ & $2.00 \pm 3.03 E-09$ & $-1.29 \pm 1.02 \mathrm{E}-07$ \\
\hline 204 & DOWN & Dec-12 & 7.45 & 1957 & $1.45 \pm 2.34 \mathrm{E}-09$ & $5.72 \pm 2.42 \mathrm{E}-09$ & $5.83 \pm 9.00 \mathrm{E}-08$ \\
\hline 206 & DOWN & Jun-12 & 7.44 & 2066 & $6.87 \pm 2.80 \mathrm{E}-09$ & $5.32 \pm 2.81 \mathrm{E}-09$ & $5.30 \pm 6.16 \mathrm{E}-08$ \\
\hline 206 & DOWN & Dec-12 & 7.42 & 2042 & $-4.21 \pm 4.00 E-09$ & $3.20 \pm 3.02 E-09$ & $8.07 \pm 9.18 E-08$ \\
\hline
\end{tabular}

NA - Not applicable.

SU - Standard units.

${ }^{a}$ Hydraulic position is relative to other wells within the same hydrogeologic unit.

${ }^{b}$ The GSLs for radiological constituents are set equal to the larger of the background concentrations or the TOGS 1.1.1 Class GA Groundwater Quality Standards (See Table D-1A). 
TABLE D-2C

2012 indicator Results From the Weathered Lavery Till Unit

\begin{tabular}{|c|c|c|c|c|c|c|c|}
\hline $\begin{array}{c}\text { Location } \\
\text { Code }\end{array}$ & $\begin{array}{l}\text { Hydraulic } \\
\text { Position }^{a}\end{array}$ & $\begin{array}{c}\text { Date } \\
\text { Collected }\end{array}$ & $\begin{array}{l}p H \\
S U\end{array}$ & $\begin{array}{c}\text { Conductivity } \\
\text { umhos/cm@ } \\
25 \text { ㄷ }\end{array}$ & $\begin{array}{c}\text { Gross Alpha } \\
\mu \mathrm{Ci} / \mathrm{mL}\end{array}$ & $\begin{array}{c}\text { Gross Beta } \\
\mu \mathrm{Ci} / \mathrm{mL}\end{array}$ & $\begin{array}{l}\text { Tritium } \\
\mu \mathrm{Ci} / \mathrm{mL}\end{array}$ \\
\hline \multicolumn{3}{|c|}{ Groundwater Screening Levels ${ }^{b}$} & NA & NA & $1.50 E-08$ & $1.00 E-06$ & $1.78 E-07$ \\
\hline 908R & UP & Dec-12 & 7.11 & 1533 & $3.32 \pm 2.36 \mathrm{E}-09$ & 8.14士3.27E-09 & $-2.26 \pm 7.83 \mathrm{E}-08$ \\
\hline 1005 & UP & Jun-12 & 7.23 & 790 & $3.06 \pm 1.80 \mathrm{E}-09$ & $2.60 \pm 1.29 \mathrm{E}-09$ & $1.98 \pm 6.79 \mathrm{E}-08$ \\
\hline 1005 & UP & Dec-12 & 7.16 & 800 & $1.73 \pm 2.08 \mathrm{E}-09$ & $3.28 \pm 1.78 \mathrm{E}-09$ & $5.85 \pm 9.03 \mathrm{E}-08$ \\
\hline $1008 \mathrm{C}$ & UP & Jun-12 & 7.42 & 589 & $0.79 \pm 2.00 \mathrm{E}-09$ & $3.53 \pm 1.28 \mathrm{E}-09$ & $2.98 \pm 6.90 \mathrm{E}-08$ \\
\hline $1008 \mathrm{C}$ & UP & Dec-12 & 6.99 & 565 & $0.82 \pm 2.26 \mathrm{E}-09$ & $0.89 \pm 1.76 \mathrm{E}-09$ & $1.00 \pm 0.83 \mathrm{E}-07$ \\
\hline 906 & DOWN & Jun-12 & 7.28 & 577 & $1.28 \pm 0.70 \mathrm{E}-08$ & $5.65 \pm 3.57 \mathrm{E}-09$ & $2.65 \pm 6.87 \mathrm{E}-08$ \\
\hline 906 & DOWN & Dec-12 & 7.37 & 596 & $0.00 \pm 1.36 \mathrm{E}-09$ & $3.55 \pm 1.51 \mathrm{E}-09$ & $0.57 \pm 8.31 \mathrm{E}-08$ \\
\hline 1006 & DOWN & Jun-12 & 7.22 & 1600 & $6.49 \pm 5.03 E-09$ & $7.05 \pm 2.67 \mathrm{E}-09$ & $1.34 \pm 6.82 E-08$ \\
\hline 1006 & DOWN & Dec-12 & 6.99 & 1629 & $7.05 \pm 2.88 \mathrm{E}-09$ & $7.49 \pm 1.99 \mathrm{E}-09$ & $1.26 \pm 0.98 \mathrm{E}-07$ \\
\hline NDATR & DOWN & Mar-12 & 8.18 & 718 & $-0.47 \pm 2.60 \mathrm{E}-09$ & $5.45 \pm 0.20 \mathrm{E}-07$ & $3.30 \pm 0.37 E-07$ \\
\hline NDATR & DOWN & Jun-12 & 7.64 & 1013 & $3.14 \pm 1.62 \mathrm{E}-09$ & $8.70 \pm 0.09 E-07$ & $2.38 \pm 1.12 E-07$ \\
\hline NDATR & DOWN & Sep-12 & 6.91 & 1175 & $4.25 \pm 6.60 \mathrm{E}-09$ & $1.00 \pm 0.04 \mathrm{E}-06$ & $2.18 \pm 1.00 \mathrm{E}-07$ \\
\hline NDATR & DOWN & Dec-12 & 7.85 & 758 & $1.05 \pm 3.21 \mathrm{E}-09$ & $6.04 \pm 0.08 \mathrm{E}-07$ & $2.46 \pm 1.25 E-07$ \\
\hline 909 & DOWN & Jun-12 & 6.75 & 1372 & $3.52 \pm 3.31 \mathrm{E}-09$ & $2.13 \pm 0.07 E-07$ & $7.62 \pm 1.60 \mathrm{E}-07$ \\
\hline 909 & DOWN & Dec-12 & 6.63 & 1533 & $2.46 \pm 3.13 E-09$ & $4.01 \pm 0.10 \mathrm{E}-07$ & $8.89 \pm 1.71 E-07$ \\
\hline
\end{tabular}

Note: Bolding indicates radiological concentration that exceeds the GSL.

NA - Not applicable.

SU - Standard units.

${ }^{a}$ Hydraulic position is relative to other wells within the same hydrogeologic unit.

${ }^{b}$ The GSLs for radiological constituents are set equal to the larger of the background concentrations or the

TOGS 1.1.1 Class GA Groundwater Quality Standards (See Table D-1A). 
TABLE D-2D

2012 Indicator Results From the Unweathered Lavery Till

\begin{tabular}{|c|c|c|c|c|c|c|c|}
\hline $\begin{array}{c}\text { Location } \\
\text { Code }\end{array}$ & $\begin{array}{l}\text { Hydraulic } \\
\text { Position }^{a}\end{array}$ & $\begin{array}{c}\text { Date } \\
\text { Collected }\end{array}$ & $\begin{array}{l}p H \\
S U\end{array}$ & \begin{tabular}{|c|} 
Conductivity \\
umhos/cm@ \\
$25^{\circ} \mathrm{C}$
\end{tabular} & $\begin{array}{c}\text { Gross Alpha } \\
\mu \mathrm{Ci} / \mathrm{mL}\end{array}$ & $\begin{array}{c}\text { Gross Beta } \\
\mu \mathrm{Ci} / \mathrm{mL}\end{array}$ & $\begin{array}{l}\text { Tritium } \\
\mu \mathrm{Ci} / \mathrm{mL}\end{array}$ \\
\hline \multicolumn{3}{|c|}{ Groundwater Screening Levels ${ }^{b}$} & NA & NA & $1.50 E-08$ & $1.00 E-06$ & $1.78 E-07$ \\
\hline 405 & UP & Mar-12 & 7.23 & 1170 & $-0.26 \pm 1.72 E-09$ & $3.51 \pm 1.83 \mathrm{E}-09$ & $-0.70 \pm 4.70 E-08$ \\
\hline 405 & UP & Jun-12 & 7.36 & 1121 & $4.16 \pm 1.80 \mathrm{E}-09$ & $5.73 \pm 1.81 \mathrm{E}-09$ & $-3.65 \pm 8.02 E-08$ \\
\hline 405 & UP & Sep-12 & 6.93 & 1488 & $-2.30 \pm 2.29 E-09$ & $7.28 \pm 2.03 E-09$ & $6.36 \pm 7.71 \mathrm{E}-08$ \\
\hline 405 & UP & Dec-12 & 7.67 & 1341 & $6.69 \pm 5.33 \mathrm{E}-09$ & $1.19 \pm 0.33 \mathrm{E}-08$ & $5.95 \pm 9.18 \mathrm{E}-08$ \\
\hline 1303 & UP & Mar-12 & 8.03 & 272 & $1.07 \pm 1.52 \mathrm{E}-09$ & $0.04 \pm 2.01 \mathrm{E}-09$ & $-2.03 \pm 4.71 \mathrm{E}-08$ \\
\hline 1303 & UP & Jun-12 & 7.99 & 251 & $6.36 \pm 9.99 \mathrm{E}-10$ & $1.77 \pm 1.08 \mathrm{E}-09$ & $-2.66 \pm 8.07 E-08$ \\
\hline 1303 & UP & Sep-12 & 7.45 & 265 & $6.93 \pm 9.56 \mathrm{E}-10$ & $0.75 \pm 1.13 \mathrm{E}-09$ & $-1.52 \pm 6.33 E-08$ \\
\hline 1303 & UP & Dec-12 & 7.81 & 280 & $2.22 \pm 6.22 \mathrm{E}-10$ & $6.26 \pm 9.50 \mathrm{E}-10$ & $-0.59 \pm 8.36 \mathrm{E}-08$ \\
\hline 110 & DOWN & Mar-12 & 7.55 & 536 & $3.57 \pm 7.54 \mathrm{E}-10$ & $3.27 \pm 1.47 \mathrm{E}-09$ & $8.20 \pm 0.42 E-07$ \\
\hline 110 & DOWN & Jun-12 & 7.41 & 556 & $1.84 \pm 1.20 \mathrm{E}-09$ & $3.05 \pm 1.18 \mathrm{E}-09$ & $5.85 \pm 0.95 E-07$ \\
\hline 110 & DOWN & Sep-12 & 7.49 & 570 & $4.54 \pm 6.87 \mathrm{E}-10$ & $1.30 \pm 0.57 \mathrm{E}-09$ & $7.40 \pm 1.18 \mathrm{E}-07$ \\
\hline 110 & DOWN & Dec-12 & 7.50 & 562 & $2.25 \pm 1.64 \mathrm{E}-09$ & $2.91 \pm 1.54 \mathrm{E}-09$ & $7.16 \pm 1.50 \mathrm{E}-07$ \\
\hline 704 & DOWN & Mar-12 & 6.66 & 766 & $-9.27 \pm 9.62 E-10$ & $4.52 \pm 2.50 \mathrm{E}-09$ & $2.85 \pm 4.74 \mathrm{E}-08$ \\
\hline 704 & DOWN & Jun-12 & 6.41 & 1562 & $-0.54 \pm 2.48 E-09$ & $7.04 \pm 2.81 \mathrm{E}-09$ & $1.50 \pm 8.73 \mathrm{E}-08$ \\
\hline 704 & DOWN & Sep-12 & 6.43 & 1196 & $0.98 \pm 1.47 \mathrm{E}-09$ & $2.06 \pm 0.26 \mathrm{E}-08$ & $9.34 \pm 7.40 \mathrm{E}-08$ \\
\hline 704 & DOWN & Dec-12 & 6.90 & 980 & $1.15 \pm 2.05 \mathrm{E}-09$ & $5.16 \pm 1.73 \mathrm{E}-09$ & $5.85 \pm 9.03 E-08$ \\
\hline 707 & DOWN & Jun-12 & 6.56 & 399 & $3.64 \pm 9.35 \mathrm{E}-10$ & $3.95 \pm 1.53 \mathrm{E}-09$ & $2.89 \pm 9.11 \mathrm{E}-08$ \\
\hline 707 & DOWN & Dec-12 & 7.02 & 446 & $7.72 \pm 7.98 \mathrm{E}-10$ & $5.00 \pm 1.17 \mathrm{E}-09$ & $7.57 \pm 9.20 \mathrm{E}-08$ \\
\hline 107 & DOWN & Mar-12 & 7.75 & 697 & $-0.18 \pm 1.18 \mathrm{E}-09$ & $1.48 \pm 0.33 \mathrm{E}-08$ & $8.48 \pm 4.83 E-08$ \\
\hline 107 & DOWN & Jun-12 & 7.37 & 786 & $2.47 \pm 1.36 \mathrm{E}-09$ & $1.59 \pm 0.18 \mathrm{E}-08$ & $1.31 \pm 0.67 \mathrm{E}-07$ \\
\hline 107 & DOWN & Sep-12 & 7.45 & 799 & $1.73 \pm 1.23 \mathrm{E}-09$ & $1.49 \pm 0.14 \mathrm{E}-08$ & $1.28 \pm 0.76 \mathrm{E}-07$ \\
\hline 107 & DOWN & Dec-12 & 7.24 & 551 & $0.56 \pm 1.17 \mathrm{E}-09$ & $1.82 \pm 0.18 \mathrm{E}-08$ & $1.50 \pm 1.02 \mathrm{E}-07$ \\
\hline 108 & DOWN & Jun-12 & 7.72 & 572 & $1.91 \pm 1.07 \mathrm{E}-09$ & $1.69 \pm 1.06 \mathrm{E}-09$ & $2.52 \pm 0.80 \mathrm{E}-07$ \\
\hline 108 & DOWN & Dec-12 & 7.60 & 546 & $2.96 \pm 1.09 \mathrm{E}-09$ & $6.28 \pm 1.18 \mathrm{E}-09$ & $0.78 \pm 1.05 \mathrm{E}-07$ \\
\hline 409 & DOWN & Mar-12 & 8.06 & 344 & $0.75 \pm 1.13 \mathrm{E}-09$ & $1.70 \pm 1.51 \mathrm{E}-09$ & $-1.05 \pm 4.70 \mathrm{E}-08$ \\
\hline 409 & DOWN & Jun-12 & 7.75 & 343 & $1.42 \pm 1.16 \mathrm{E}-09$ & $1.94 \pm 1.11 \mathrm{E}-09$ & $-3.24 \pm 7.78 \mathrm{E}-08$ \\
\hline 409 & DOWN & Sep-12 & 7.56 & 330 & $1.79 \pm 0.96 \mathrm{E}-09$ & $1.24 \pm 0.60 \mathrm{E}-09$ & $0.68 \pm 6.63 \mathrm{E}-08$ \\
\hline 409 & DOWN & Dec-12 & 8.03 & 367 & $1.84 \pm 1.23 \mathrm{E}-09$ & $1.96 \pm 1.08 \mathrm{E}-09$ & $-0.58 \pm 8.19 E-08$ \\
\hline 910R & DOWN & Jun-12 & 7.09 & 1457 & $1.56 \pm 0.39 \mathrm{E}-08$ & $6.93 \pm 2.57 \mathrm{E}-09$ & $1.33 \pm 5.84 \mathrm{E}-08$ \\
\hline 910R & DOWN & Dec-12 & 7.15 & 1485 & $1.29 \pm 0.39 \mathrm{E}-08$ & $5.08 \pm 3.39 E-09$ & $1.77 \pm 8.70 \mathrm{E}-08$ \\
\hline
\end{tabular}

Note: Bolding indicates radiological concentration that exceeds the GSL.

NA - Not applicable.

SU - Standard units.

${ }^{a}$ Hydraulic position is relative to other wells within the same hydrogeologic unit.

${ }^{\mathrm{b}}$ The GSLs for radiological constituents are set equal to the larger of the background concentrations or the

TOGS 1.1.1 Class GA Groundwater Quality Standards (See Table D-1A). 
TABLE D-2E

2012 Indicator Results From the Kent Recessional Sequence

\begin{tabular}{|c|c|c|c|c|c|c|c|}
\hline $\begin{array}{l}\text { Location } \\
\text { Code }\end{array}$ & $\begin{array}{l}\text { Hydraulic } \\
\text { Position }^{a}\end{array}$ & $\begin{array}{c}\text { Date } \\
\text { Collected }\end{array}$ & $\begin{array}{l}p H \\
S U\end{array}$ & $\begin{array}{c}\text { Conductivity } \\
\text { pmhos/cm@ } \\
25^{\circ} \mathrm{C}\end{array}$ & $\begin{array}{c}\text { Gross Alpha } \\
\mu \mathrm{Ci} / \mathrm{mL}\end{array}$ & $\begin{array}{c}\text { Gross Beta } \\
\mu \mathrm{Ci} / \mathrm{mL}\end{array}$ & $\begin{array}{l}\text { Tritium } \\
\mu \mathrm{Ci} / \mathrm{mL}\end{array}$ \\
\hline \multicolumn{3}{|c|}{ Groundwater Screening Levels ${ }^{b}$} & NA & $N A$ & $1.50 E-08$ & $1.00 E-06$ & $1.78 E-07$ \\
\hline 901 & UP & Jun-12 & 7.27 & 424 & $8.22 \pm 7.96 \mathrm{E}-10$ & $2.35 \pm 0.81 E-09$ & $-0.65 \pm 8.24 E-08$ \\
\hline 901 & UP & Dec-12 & 6.93 & 418 & $9.14 \pm 9.58 \mathrm{E}-10$ & $2.36 \pm 1.23 \mathrm{E}-09$ & $1.76 \pm 8.67 \mathrm{E}-08$ \\
\hline 902 & UP & Jun-12 & 8.16 & 412 & $8.27 \pm 5.32 \mathrm{E}-10$ & $2.71 \pm 0.81 E-09$ & $2.83 \pm 6.55 \mathrm{E}-08$ \\
\hline 902 & UP & Dec-12 & 7.61 & 442 & $-1.15 \pm 7.46 \mathrm{E}-10$ & $2.07 \pm 1.23 \mathrm{E}-09$ & $2.34 \pm 8.73 \mathrm{E}-08$ \\
\hline $1008 \mathrm{~B}$ & UP & Dec-12 & 7.72 & 460 & $-3.91 \pm 6.78 \mathrm{E}-10$ & $4.28 \pm 0.76 E-09$ & $6.46 \pm 9.14 \mathrm{E}-08$ \\
\hline 903 & DOWN & Jun-12 & 7.46 & 984 & $-0.48 \pm 1.84 \mathrm{E}-09$ & 1.84士1.77E-09 & $0.00 \pm 6.64 \mathrm{E}-08$ \\
\hline 903 & DOWN & Dec-12 & 7.39 & 960 & $2.78 \pm 1.67 \mathrm{E}-09$ & $3.29 \pm 2.13 E-09$ & $7.00 \pm 8.24 \mathrm{E}-08$ \\
\hline 8610 & DOWN & Jun-12 & 7.41 & 1306 & $0.14 \pm 1.78 \mathrm{E}-09$ & $2.85 \pm 2.17 \mathrm{E}-09$ & $0.67 \pm 6.78 \mathrm{E}-08$ \\
\hline 8610 & DOWN & Dec-12 & 7.30 & 1382 & $1.33 \pm 3.38 \mathrm{E}-09$ & $8.37 \pm 4.36 \mathrm{E}-09$ & $0.57 \pm 8.28 \mathrm{E}-08$ \\
\hline 8611 & DOWN & Jun-12 & 7.34 & 1240 & $2.77 \pm 1.53 \mathrm{E}-09$ & $4.17 \pm 1.96 \mathrm{E}-09$ & $-1.98 \pm 6.40 \mathrm{E}-08$ \\
\hline 8611 & DOWN & Dec-12 & 7.35 & 1247 & $0.56 \pm 1.96 \mathrm{E}-09$ & $2.55 \pm 2.62 E-09$ & $7.50 \pm 9.25 \mathrm{E}-08$ \\
\hline
\end{tabular}

NA - Not applicable.

SU - Standard units.

${ }^{a}$ Hydraulic position is relative to other wells within the same hydrogeologic unit.

${ }^{\mathrm{b}}$ The GSLs for radiological constituents are set equal to the larger of the background concentrations or the TOGS 1.1.1

Class GA Groundwater Quality Standards (See Table D-1A).

TABLE D-2F

2012 Metals Results for Early Warning Monitoring Well 502

\begin{tabular}{|c|c|c|c|c|}
\hline \multirow{2}{*}{ Location } & $\begin{array}{c}\text { Date } \\
\text { Collected }\end{array}$ & $\begin{array}{c}\text { Aluminum } \\
\mu \mathrm{g} / \mathrm{L}\end{array}$ & $\begin{array}{c}\text { Iron } \\
\mu \mathrm{g} / \mathrm{L}\end{array}$ & $\begin{array}{c}\text { Manganese } \\
\boldsymbol{\mu g} / \mathrm{L}\end{array}$ \\
\hline \multirow{2}{*}{502} & Jun-12 & $<200$ & 12,700 & 47.8 \\
\cline { 2 - 5 } & Dec-12 & $<200$ & 18,700 & 49.5 \\
\hline
\end{tabular}


TABLE D-2G

2012 Results for Metals in Groundwater

Compared With WVDP Groundwater Screening Levels

\begin{tabular}{|c|c|c|c|c|c|c|c|c|c|c|}
\hline $\begin{array}{c}\text { Location } \\
\text { Code }\end{array}$ & $\begin{array}{c}\text { Hydraulic } \\
\text { Position }\end{array}$ & $\begin{array}{c}\text { Date } \\
\text { Collected }\end{array}$ & $\begin{array}{c}\text { Antimony } \\
\mu \mathrm{g} / \mathrm{L}\end{array}$ & $\begin{array}{c}\text { Arsenic } \\
\mu g / L\end{array}$ & $\begin{array}{c}\text { Barium } \\
\mu \mathrm{g} / \mathrm{L}\end{array}$ & $\begin{array}{c}\text { Beryllium } \\
\mu \mathrm{g} / \mathrm{L}\end{array}$ & $\begin{array}{c}\text { Cadmium } \\
\mu \mathrm{g} / \mathrm{L}\end{array}$ & $\begin{array}{c}\text { Chromium } \\
\mu \mathrm{g} / \mathrm{L}\end{array}$ & $\begin{array}{c}\text { Cobalt } \\
\mu g / L\end{array}$ & $\begin{array}{c}\text { Copper } \\
\mu g / L\end{array}$ \\
\hline Groundwc & ater Screeni & ng Levels ${ }^{a}$ & 15.1 & 25 & 1,000 & 3 & 7.27 & 52.3 & 67.8 & 200 \\
\hline \multicolumn{11}{|c|}{ Sand and Gravel Unit } \\
\hline 706 & UP & Mar-12 & $<3$ & $<10$ & $<200$ & $<1$ & $<5$ & 15 & $<50$ & $<25$ \\
\hline 706 & UP & Jun-12 & $<3$ & $<10$ & $<200$ & $<1$ & $<5$ & 29 & $<50$ & $<25$ \\
\hline 706 & UP & Sep-12 & $<3$ & $<10$ & $<200$ & $<1$ & $<5$ & 42 & $<50$ & $<25$ \\
\hline 706 & UP & Dec-12 & $<3$ & $<10$ & $<200$ & $<1$ & $<5$ & 96 & $<50$ & $<25$ \\
\hline 1302 & UP & Dec-12 & $<3$ & $<10$ & $<200$ & $<1$ & $<5$ & $<10$ & $<50$ & $<25$ \\
\hline 1304 & DOWN & Mar-12 & $<3$ & $<10$ & $<200$ & $<1$ & $<5$ & $<10$ & $<50$ & $<25$ \\
\hline 1304 & DOWN & Jun-12 & $<3$ & $<10$ & $<200$ & $<1$ & $<5$ & $<10$ & $<50$ & $<25$ \\
\hline 1304 & DOWN & Sep-12 & $<3$ & $<10$ & $<200$ & $<1$ & $<5$ & $<10$ & $<50$ & $<25$ \\
\hline 1304 & DOWN & Dec-12 & $<3$ & $<10$ & $<200$ & $<1$ & $<5$ & $<10$ & $<50$ & $<25$ \\
\hline 111 & DOWN & Dec-12 & $<3$ & $<10$ & $<200$ & $<1$ & $<5$ & 425 & $<50$ & $<25$ \\
\hline 502 & DOWN & Jun-12 & NS & $<10$ & 507 & NS & $<5$ & 1,070 & $<50$ & 43 \\
\hline 502 & DOWN & Dec-12 & NS & $<10$ & 509 & NS & $<5$ & 905 & $<50$ & 49 \\
\hline 8605 & DOWN & Dec-12 & $<3$ & $<10$ & $<200$ & $<1$ & $<5$ & $<10$ & $<50$ & $<25$ \\
\hline MP-01 & DOWN & Mar-12 & $<10$ & $<10$ & 410 & $<1$ & $<5$ & $<10$ & $<50$ & $<25$ \\
\hline MP-01 & DOWN & Jun-12 & $<10$ & $<10$ & 470 & $<1$ & $<5$ & 54 & $<50$ & $<25$ \\
\hline MP-01 & DOWN & Sep-12 & $<3$ & $<10$ & 402 & $<1$ & $<5$ & 68 & $<50$ & $<25$ \\
\hline MP-01 & DOWN & Dec-12 & $<3$ & $<10$ & 375 & $<1$ & $<5$ & $<10$ & $<50$ & $<25$ \\
\hline MP-02 & DOWN & Mar-12 & $<10$ & $<10$ & $<200$ & $<1$ & $<5$ & 17 & $<50$ & $<25$ \\
\hline MP-02 & DOWN & Jun-12 & $<10$ & $<10$ & $<200$ & $<1$ & $<5$ & $<10$ & $<50$ & $<25$ \\
\hline MP-02 & DOWN & Sep-12 & $<3$ & $<10$ & $<200$ & $<1$ & $<5$ & $<10$ & $<50$ & $<25$ \\
\hline MP-02 & DOWN & Dec-12 & $<3$ & $<10$ & $<200$ & $<1$ & $<5$ & $<10$ & $<50$ & $<25$ \\
\hline MP-03 & DOWN & Mar-12 & $<10$ & $<10$ & 236 & $<1$ & $<5$ & $<10$ & $<50$ & $<25$ \\
\hline MP-03 & DOWN & Jun-12 & $<10$ & $<10$ & 287 & $<1$ & $<5$ & $<10$ & $<50$ & $<25$ \\
\hline MP-03 & DOWN & Sep-12 & $<3$ & $<10$ & 264 & $<1$ & $<5$ & $<10$ & $<50$ & $<25$ \\
\hline MP-03 & DOWN & Dec-12 & $<3$ & $<10$ & 225 & $<1$ & $<5$ & $<10$ & $<50$ & $<25$ \\
\hline MP-04 & DOWN & Mar-12 & $<10$ & $<10$ & 268 & $<1$ & $<5$ & $<10$ & $<50$ & $<25$ \\
\hline MP-04 & DOWN & Jun-12 & $<10$ & $<10$ & 298 & $<1$ & $<5$ & $<10$ & $<50$ & $<25$ \\
\hline MP-04 & DOWN & Sep-12 & $<3$ & $<10$ & 239 & $<1$ & $<5$ & $<10$ & $<50$ & $<25$ \\
\hline MP-04 & DOWN & Dec-12 & $<3$ & $<10$ & 236 & $<1$ & $<5$ & $<10$ & $<50$ & $<25$ \\
\hline
\end{tabular}

Note: Bolding indicates a metal concentration that exceeds the GSL.

NS - Not sampled.

a GSLs have been established by selection of the larger of the WVDP background concentration or the 6 NYCRR TOGS 1.1.1

Class GA Groundwater Quality Standards. (See Table D-1B). 
TABLE D-2G (continued)

2012 Results for Metals in Groundwater

Compared with WVDP Groundwater Screening Levels

\begin{tabular}{|c|c|c|c|c|c|c|c|c|c|c|c|}
\hline \begin{tabular}{|c|} 
Location \\
Code
\end{tabular} & \begin{tabular}{|c|} 
Hydraulic \\
Position
\end{tabular} & $\begin{array}{c}\text { Date } \\
\text { Collected }\end{array}$ & \begin{tabular}{|l|} 
Lead \\
$\mu g / L$
\end{tabular} & \begin{tabular}{|c|} 
Mercury \\
$\mu g / L$
\end{tabular} & \begin{tabular}{|c|} 
Nickel \\
$\mu g / L$
\end{tabular} & \begin{tabular}{|c|} 
Selenium \\
$\mu \mathrm{g} / \mathrm{L}$
\end{tabular} & \begin{tabular}{|l|} 
Silver \\
$\mu g / L$
\end{tabular} & $\begin{array}{c}\begin{array}{c}\text { Thallium } \\
\mu \mathrm{g} / \mathrm{L}\end{array} \\
\end{array}$ & $\begin{array}{c}\text { Tin } \\
\mu g / L\end{array}$ & \begin{tabular}{|c|}
$\begin{array}{c}\text { Vanadium } \\
\mu \mathrm{g} / \mathrm{L}\end{array}$ \\
\end{tabular} & $\begin{array}{l}\text { Zinc } \\
\mu g / L \\
\end{array}$ \\
\hline Groundw & ater Screen & ng Levels ${ }^{a}$ & 42.7 & 0.7 & 100 & 10.1 & 50 & 13.9 & 4,083 & 69.6 & 2,000 \\
\hline \multicolumn{12}{|c|}{ Sand and Gravel Unit } \\
\hline 706 & UP & Mar-12 & $<3$ & $<0.2$ & 70 & $<5$ & $<10$ & $<0$ & $<3000$ & $<50$ & $<20$ \\
\hline 706 & UP & Jun-12 & $<3$ & $<0.2$ & 126 & $<5$ & $<10$ & $<0$ & $<3000$ & $<50$ & $<20$ \\
\hline 706 & UP & Sep-12 & $<3$ & $<0.2$ & 573 & $<5$ & $<10$ & $<0$ & $<3000$ & $<50$ & $<20$ \\
\hline 706 & UP & Dec-12 & $<3$ & $<0.2$ & 593 & $<5$ & $<10$ & $<0$ & $<3000$ & $<50$ & $<20$ \\
\hline 1302 & 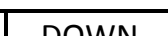 & Der 12 & $<3$ & $<0 ?$ & $<40$ & $<5$ & $<10$ & $<0$ & $<3000$ & $<50$ & $<30$ \\
\hline & & & & & & & & & & & \\
\hline 1304 & UP & Mar-12 & $<3$ & $<0.2$ & $<40$ & $<5$ & $<10$ & $<0$ & $<3000$ & $<50$ & $<20$ \\
\hline 1304 & UP & Jun-12 & $<3$ & $<0.2$ & $<40$ & $<5$ & $<10$ & NS & $<3000$ & $<50$ & $<20$ \\
\hline 1304 & UP & Sep-12 & $<3$ & $<0.2$ & $<40$ & $<5$ & $<10$ & $<0$ & $<3000$ & $<50$ & $<20$ \\
\hline 1304 & UP & Dec-12 & $<3$ & $<0.2$ & $<40$ & $<5$ & $<10$ & $<0$ & $<3000$ & $<50$ & $<20$ \\
\hline 111 & DOWN & Dec-12 & $<3$ & $<0.2$ & 41 & $<5$ & $<10$ & $<2$ & $<3000$ & $<50$ & $<20$ \\
\hline & & & & & & & & & & & \\
\hline 502 & DOWN & Jun-12 & $<3$ & $<0.2$ & 149 & $<5$ & $<10$ & NS & NS & $<50$ & $<20$ \\
\hline 502 & DOWN & Dec-12 & $<3$ & $<0.2$ & 163 & $<5$ & $<10$ & NS & NS & $<50$ & $<20$ \\
\hline \\
\hline 8605 & DOWN & Dec-12 & $<3$ & $<0.2$ & $<40$ & $<5$ & $<10$ & $<2$ & $<3000$ & $<50$ & $<20$ \\
\hline \\
\hline MP-01 & DOWN & Mar-12 & $<3$ & $<0.2$ & $<40$ & $<5$ & $<10$ & $<10$ & $<3000$ & $<50$ & $<20$ \\
\hline MP-01 & DOWN & Jun-12 & $<3$ & $<0.2$ & $<40$ & $<5$ & $<10$ & $<10$ & $<3000$ & $<50$ & $<20$ \\
\hline MP-01 & DOWN & Sep-12 & $<3$ & $<0.2$ & $<40$ & $<5$ & $<10$ & $<2$ & $<3000$ & $<50$ & $<20$ \\
\hline MP-01 & DOWN & Dec-12 & $<3$ & $<0.2$ & $<40$ & $<5$ & $<10$ & $<2$ & $<3000$ & $<50$ & $<20$ \\
\hline \\
\hline MP-02 & DOWN & Mar-12 & $<3$ & $<0.2$ & $<40$ & $<5$ & $<10$ & $<10$ & $<3000$ & $<50$ & $<20$ \\
\hline MP-02 & DOWN & Jun-12 & $<3$ & $<0.2$ & $<40$ & $<5$ & $<10$ & $<10$ & $<3000$ & $<50$ & $<20$ \\
\hline MP-02 & DOWN & Sep-12 & $<3$ & $<0.2$ & $<40$ & $<5$ & $<10$ & $<2$ & $<3000$ & $<50$ & $<20$ \\
\hline MP-02 & DOWN & Dec-12 & $<3$ & $<0.2$ & $<40$ & $<5$ & $<10$ & $<2$ & $<3000$ & $<50$ & $<20$ \\
\hline MP-03 & DOWN & Mar-12 & $<3$ & $<0.2$ & $<40$ & $<5$ & $<10$ & $<10$ & $<3000$ & $<50$ & $<20$ \\
\hline MP-03 & DOWN & Jun-12 & $<3$ & $<0.2$ & $<40$ & $<5$ & $<10$ & $<10$ & $<3000$ & $<50$ & $<20$ \\
\hline MP-03 & DOWN & Sep-12 & $<3$ & $<0.2$ & $<40$ & $<5$ & $<10$ & $<2$ & $<3000$ & $<50$ & $<20$ \\
\hline MP-03 & DOWN & Dec-12 & $<3$ & $<0.2$ & $<40$ & $<5$ & $<10$ & $<2$ & $<3000$ & $<50$ & $<20$ \\
\hline \\
\hline MP-04 & DOWN & Mar-12 & $<3$ & $<0.2$ & $<40$ & $<5$ & $<10$ & $<10$ & $<3000$ & $<50$ & $<20$ \\
\hline MP-04 & DOWN & Jun-12 & $<3$ & $<0.2$ & $<40$ & $<5$ & $<10$ & $<10$ & $<3000$ & $<50$ & $<20$ \\
\hline MP-04 & DOWN & Sep-12 & $<3$ & $<0.2$ & $<40$ & $<5$ & $<10$ & $<2$ & $<3000$ & $<50$ & $<20$ \\
\hline MP-04 & DOWN & Dec-12 & $<3$ & $<0.2$ & $<40$ & $<5$ & $<10$ & $<2$ & $<3000$ & $<50$ & $<20$ \\
\hline
\end{tabular}

Note: Bolding indicates a metal concentration that exceeds the GSL.

NS - Not sampled.

${ }^{a}$ GSLs have been established by selection of the larger of the WVDP background concentration or the 6 NYCRR TOGS 1.1.1

Class GA Groundwater Quality Standards (See Table D-1B). 
TABLE D-2G (continued)

2012 Results for Metals in Groundwater

Compared with WVDP Groundwater Screening Levels

\begin{tabular}{|c|c|c|c|c|c|c|c|c|c|c|}
\hline $\begin{array}{c}\text { Location } \\
\text { Code }\end{array}$ & \begin{tabular}{|l} 
Hydraulic \\
Position
\end{tabular} & $\begin{array}{c}\text { Date } \\
\text { Collected }\end{array}$ & $\begin{array}{c}\text { Antimony } \\
\mu g / L\end{array}$ & $\begin{array}{c}\text { Arsenic } \\
\mu g / L\end{array}$ & $\begin{array}{c}\text { Barium } \\
\mu g / L\end{array}$ & $\begin{array}{c}\text { Beryllium } \\
\mu \mathrm{g} / \mathrm{L}\end{array}$ & $\begin{array}{c}\text { Cadmium } \\
\mu \mathrm{g} / \mathrm{L}\end{array}$ & $\begin{array}{c}\text { Chromium } \\
\mu \mathrm{g} / \mathrm{L}\end{array}$ & $\begin{array}{c}\text { Cobalt } \\
\mu g / L\end{array}$ & $\begin{array}{c}\text { Copper } \\
\mu g / L\end{array}$ \\
\hline \multicolumn{3}{|c|}{ Groundwater Screening } & 15.1 & 25 & 1,000 & 3 & 7.27 & 52.3 & 67.8 & 200 \\
\hline \multicolumn{11}{|c|}{ Weathered Lavery Till Unit } \\
\hline NDATR & DOWN & Mar-12 & $<10$ & $<10$ & $<200$ & $<1$ & $<5$ & $<10$ & $<50$ & $<25$ \\
\hline NDATR & DOWN & Jun-12 & $<10$ & $<10$ & $<200$ & $<1$ & $<5$ & $<10$ & $<50$ & $<25$ \\
\hline NDATR & DOWN & Sep-12 & $<3$ & $<10$ & $<200$ & $<1$ & $<5$ & $<10$ & $<50$ & $<25$ \\
\hline NDATR & DOWN & Dec-12 & $<3$ & $<10$ & $<200$ & $<1$ & $<5$ & $<10$ & $<50$ & $<25$ \\
\hline 909 & DOWN & Dec-12 & $<3$ & 15 & 254 & $<1$ & $<5$ & $<10$ & $<50$ & $<25$ \\
\hline \multicolumn{11}{|c|}{ Unweathered Lavery Till Unit } \\
\hline 405 & UP & Mar-12 & $<3$ & $<10$ & $<200$ & $<1$ & $<5$ & 23 & $<50$ & $<25$ \\
\hline 405 & UP & Jun-12 & $<3$ & $<10$ & $<200$ & $<1$ & $<5$ & 30 & $<50$ & $<25$ \\
\hline 405 & UP & Sep-12 & $<3$ & $<10$ & $<200$ & $<1$ & $<5$ & 43 & $<50$ & $<25$ \\
\hline 405 & UP & Dec-12 & $<3$ & $<10$ & $<200$ & $<1$ & $<5$ & $<10$ & $<50$ & $<25$ \\
\hline 1303 & UP & Mar-12 & $<3$ & $<20$ & 266 & $<2$ & $<5$ & $<20$ & $<100$ & $<50$ \\
\hline 1303 & UP & Jun-12 & $<3$ & 13 & $<200$ & $<1$ & $<5$ & 10 & $<50$ & $<25$ \\
\hline 1303 & UP & Sep-12 & $<3$ & 14 & 201 & $<1$ & $<5$ & $<10$ & $<50$ & $<25$ \\
\hline 1303 & UP & Dec-12 & $<3$ & 14 & 200 & $<1$ & $<5$ & $<10$ & $<50$ & $<25$ \\
\hline
\end{tabular}

${ }^{a}$ GSLs have been established by selection of the larger of the WVDP background concentration or the 6 NYCRR TOGS 1.1.1 Class GA Groundwater Quality Standards (See Table D-1B). 
TABLE D-2G (concluded)

2012 Results for Metals in Groundwater

Compared with WVDP Groundwater Screening Levels

\begin{tabular}{|c|c|c|c|c|c|c|c|c|c|c|c|}
\hline $\begin{array}{c}\text { Location } \\
\text { Code }\end{array}$ & $\begin{array}{c}\text { Hydraulic } \\
\text { Position }\end{array}$ & \begin{tabular}{|c|} 
Date \\
Collected
\end{tabular} & $\begin{array}{l}\text { Lead } \\
\mu g / L\end{array}$ & $\begin{array}{c}\text { Mercury } \\
\mu g / L\end{array}$ & $\begin{array}{c}\text { Nickel } \\
\mu g / L\end{array}$ & $\begin{array}{c}\text { Selenium } \\
\mu g / L\end{array}$ & $\begin{array}{l}\text { Silver } \\
\mu g / L\end{array}$ & $\begin{array}{c}\text { Thallium } \\
\mu \mathrm{g} / \mathrm{L}\end{array}$ & $\begin{array}{c}\text { Tin } \\
\mu g / L\end{array}$ & $\begin{array}{c}\text { Vanadium } \\
\mu g / L\end{array}$ & $\begin{array}{l}\text { Zinc } \\
\mu g / L\end{array}$ \\
\hline \multicolumn{3}{|c|}{ Groundwater Screening } & 42.7 & 0.7 & 100 & 10.1 & 50 & 13.9 & 4,083 & 69.6 & 2,000 \\
\hline \multicolumn{12}{|c|}{ Weathered Lavery Till Unit } \\
\hline NDATR & DOWN & Mar-12 & $<3$ & $<0.2$ & $<40$ & $<5$ & $<10$ & $<10$ & $<3000$ & $<50$ & $<20$ \\
\hline NDATR & DOWN & Jun-12 & $<3$ & $<0.2$ & $<40$ & $<5$ & $<10$ & $<10$ & $<3000$ & $<50$ & $<20$ \\
\hline NDATR & DOWN & Sep-12 & $<3$ & $<0.2$ & $<40$ & $<5$ & $<10$ & $<2$ & $<3000$ & $<50$ & 61 \\
\hline NDATR & DOWN & Dec-12 & $<3$ & $<0.2$ & $<40$ & $<5$ & $<10$ & $<2$ & $<3000$ & $<50$ & $<20$ \\
\hline 909 & DOWN & Dec-12 & $<3$ & $<0.2$ & $<40$ & $<5$ & $<10$ & $<0$ & $<3000$ & $<50$ & $<20$ \\
\hline \multicolumn{12}{|c|}{ Unweathered Lavery Till Unit } \\
\hline 405 & UP & Mar-12 & $<3$ & $<0.2$ & 2,330 & $<5$ & $<10$ & $<0$ & $<3000$ & $<50$ & $<20$ \\
\hline 405 & UP & Jun-12 & $<3$ & $<0.2$ & 1,850 & $<5$ & $<10$ & $<0$ & $<3000$ & $<50$ & $<20$ \\
\hline 405 & UP & Sep-12 & $<3$ & $<0.2$ & 2,260 & $<5$ & $<10$ & $<0$ & $<3000$ & $<50$ & $<20$ \\
\hline 405 & UP & Dec-12 & $<3$ & $<0.2$ & 961 & $<5$ & $<10$ & $<0$ & $<3000$ & $<50$ & $<20$ \\
\hline 1303 & UP & Mar-12 & 12 & $<0.2$ & $<80$ & $<10$ & $<10$ & $<0$ & $<3000$ & $<100$ & $<40$ \\
\hline 1303 & UP & Jun-12 & 7 & $<0.2$ & $<40$ & $<5$ & $<10$ & NS & $<3000$ & $<50$ & 37 \\
\hline 1303 & UP & Sep-12 & 7 & $<0.2$ & $<40$ & $<5$ & $<10$ & $<0$ & $<3000$ & $<50$ & 38 \\
\hline 1303 & UP & Dec-12 & 7 & $<0.2$ & $<40$ & $<5$ & $<10$ & $<0$ & $<3000$ & $<50$ & 40 \\
\hline
\end{tabular}

Note: Bolding indicates a metal concentration that exceeds the GSL.

${ }^{a}$ GSLs have been established by selection of the larger of the WVDP background concentration or the 6 NYCRR TOGS 1.1.1

Class GA Groundwater Quality Standards (See Table D-1B). 
Table D-2H

2012 Radioactivity in Groundwater From Selected Monitoring Locations

\begin{tabular}{|c|c|c|c|c|c|c|c|c|}
\hline Location & $\begin{array}{l}\text { Hydraulic } \\
\text { Position }^{a}\end{array}$ & $\begin{array}{c}\text { Date } \\
\text { Collected }\end{array}$ & $\begin{array}{c}C-14 \\
\mu C i / m L\end{array}$ & $\begin{array}{c}S r-90 \\
\mu \mathrm{Ci} / \mathrm{mL}\end{array}$ & $\begin{array}{c}T c-99 \\
\mu \mathrm{Ci} / \mathrm{mL}\end{array}$ & $\begin{array}{c}\mathrm{I}-129 \\
\mu \mathrm{Ci} / \mathrm{mL}\end{array}$ & $\begin{array}{c}C s-137 \\
\mu C i / m L\end{array}$ & $\begin{array}{l}R a-226 \\
\mu C i / m L\end{array}$ \\
\hline Grour & \multicolumn{2}{|c|}{$\begin{array}{l}\text { dwater Screening } \\
\text { Levels }^{b}\end{array}$} & $2.82 E-08$ & 5.90E-09 & $5.02 E-09$ & $9.61 E-10$ & $1.03 E-08$ & $1.33 E-09$ \\
\hline \multicolumn{9}{|c|}{ Sand and Gravel Unit } \\
\hline 401 & UP & Dec-12 & $0.00 \pm 2.82 \mathrm{E}-08$ & $-6.12 \pm 9.47 \mathrm{E}-10$ & $-0.32 \pm 2.30 \mathrm{E}-09$ & $2.91 \pm 5.80 \mathrm{E}-10$ & $-2.69 \pm 2.76 \mathrm{E}-09$ & $3.03 \pm 1.53 \mathrm{E}-10$ \\
\hline 1304 & UP & Dec-12 & $-2.52 \pm 3.44 \mathrm{E}-08$ & $0.11 \pm 1.03 \mathrm{E}-09$ & $0.86 \pm 2.46 \mathrm{E}-09$ & $-2.41 \pm 8.27 \mathrm{E}-10$ & $0.34 \pm 2.46 \mathrm{E}-09$ & $3.38 \pm 1.65 \mathrm{E}-10$ \\
\hline 406 & DOWN & Dec-12 & $-1.46 \pm 3.40 \mathrm{E}-08$ & $0.52 \pm 1.04 \mathrm{E}-09$ & $3.40 \pm 2.56 \mathrm{E}-09$ & $2.60 \pm 7.57 \mathrm{E}-10$ & $0.20 \pm 2.83 \mathrm{E}-09$ & $4.70 \pm 1.93 \mathrm{E}-10$ \\
\hline 408 & DOWN & Dec-12 & $-0.41 \pm 2.64 \mathrm{E}-08$ & $8.79 \pm 0.01 \mathrm{E}-05$ & $1.35 \pm 0.27 \mathrm{E}-08$ & $3.08 \pm 5.27 \mathrm{E}-10$ & $-1.21 \pm 4.00 \mathrm{E}-09$ & $5.04 \pm 2.34 \mathrm{E}-10$ \\
\hline 501 & DOWN & Dec-12 & NS & $4.38 \pm 0.01 \mathrm{E}-05$ & NS & NS & NS & NS \\
\hline 502 & DOWN & Dec-12 & NS & $3.63 \pm 0.01 \mathrm{E}-05$ & NS & NS & NS & NS \\
\hline 8609 & DOWN & Dec-12 & NS & $7.54 \pm 0.16 \mathrm{E}-07$ & NS & NS & NS & NS \\
\hline 801 & DOWN & Dec-12 & NS & $4.86 \pm 0.04 \mathrm{E}-06$ & NS & NS & NS & NS \\
\hline MP-01 & DOWN & Dec-12 & $4.53 \pm 2.87 E-08$ & $1.20 \pm 0.01 \mathrm{E}-04$ & $2.94 \pm 0.30 \mathrm{E}-08$ & $3.05 \pm 5.27 \mathrm{E}-10$ & $0.83 \pm 3.97 \mathrm{E}-09$ & NS \\
\hline $\mathrm{MP}-02$ & DOWN & Dec-12 & $-1.10 \pm 2.60 \mathrm{E}-08$ & $1.45 \pm 0.01 \mathrm{E}-04$ & $4.50 \pm 0.35 \mathrm{E}-08$ & $0.77 \pm 1.00 \mathrm{E}-09$ & $1.08 \pm 4.73 \mathrm{E}-09$ & NS \\
\hline MP-03 & DOWN & Dec-12 & $0.89 \pm 2.70 \mathrm{E}-08$ & $8.76 \pm 0.02 \mathrm{E}-05$ & $2.35 \pm 0.29 \mathrm{E}-08$ & $6.14 \pm 6.84 \mathrm{E}-10$ & $1.31 \pm 3.89 \mathrm{E}-09$ & NS \\
\hline $\mathrm{MP}-04$ & DOWN & Dec-12 & $0.96 \pm 2.71 \mathrm{E}-08$ & $1.38 \pm 0.01 \mathrm{E}-04$ & $3.51 \pm 0.32 \mathrm{E}-08$ & $3.37 \pm 8.59 \mathrm{E}-10$ & $0.12 \pm 4.16 \mathrm{E}-09$ & NS \\
\hline & & & & Weathe & red Till Unit & & & \\
\hline NDATR & DOWN & Jun-12 & $-0.75 \pm 3.20 \mathrm{E}-08$ & $4.45 \pm 0.10 \mathrm{E}-07$ & $0.52 \pm 1.66 \mathrm{E}-09$ & $1.74 \pm 0.38 \mathrm{E}-08$ & $-0.11 \pm 2.96 \mathrm{E}-09$ & $3.25 \pm 2.52 \mathrm{E}-10$ \\
\hline NDATR & DOWN & Dec-12 & $-0.46 \pm 2.77 \mathrm{E}-08$ & $2.04 \pm 0.08 \mathrm{E}-07$ & $1.55 \pm 1.66 \mathrm{E}-09$ & $2.30 \pm 0.34 \mathrm{E}-08$ & $-0.59 \pm 2.49 E-09$ & $2.28 \pm 1.75 \mathrm{E}-10$ \\
\hline 909 & DOWN & Dec-12 & $-0.19 \pm 3.43 E-08$ & $1.40 \pm 0.05 E-07$ & $2.58 \pm 2.52 \mathrm{E}-09$ & $9.57 \pm 2.25 \mathrm{E}-09$ & $1.24 \pm 3.83 \mathrm{E}-09$ & $3.49 \pm 1.87 \mathrm{E}-10$ \\
\hline
\end{tabular}

Note: Bolding indicates radiological concentration that exceeds the GSL.

NS - Not sampled.

${ }^{a}$ Hydraulic position is relative to other wells within the same hydrologic unit.

${ }^{b}$ The GSLs for radiological constituents are set equal to the larger of the background concentrations or the TOGS 1.1.1 Class GA Groundwater Quality Standards (See Table D-1A). 
Table D-2H (continued)

2012 Radioactivity in Groundwater From Selected Monitoring Locations

\begin{tabular}{|c|c|c|c|c|c|c|c|c|}
\hline Location & $\begin{array}{l}\text { Hydraulic } \\
\text { Position }^{a}\end{array}$ & $\begin{array}{c}\text { Date } \\
\text { Collected }\end{array}$ & $\begin{array}{l}R a-228 \\
\mu C i / m L\end{array}$ & $\begin{array}{c}U-232 \\
\mu C i / m L\end{array}$ & $\begin{array}{c}U-233 / 234 \\
\mu \mathrm{Ci} / \mathrm{mL}\end{array}$ & $\begin{array}{c}U-235 / 236 \\
\mu \mathrm{Ci} / \mathrm{mL}\end{array}$ & $\begin{array}{c}U-238 \\
\mu C i / m L\end{array}$ & $\begin{array}{l}\text { Total U } \\
\mu g / m L\end{array}$ \\
\hline $\begin{array}{c}\text { Groundwater Screening } \\
\text { Levels }^{b}\end{array}$ & \multicolumn{2}{|c|}{$\begin{array}{l}\text { dwater Screening } \\
\text { Levels }^{b}\end{array}$} & $2.16 E-09$ & $1.38 E-10$ & $6.24 E-10$ & 8.07E-11 & 4.97E-10 & $1.34 E-03$ \\
\hline \multicolumn{9}{|c|}{ Sand and Gravel Unit } \\
\hline 401 & UP & Dec-12 & $4.47 \pm 3.22 \mathrm{E}-10$ & $2.48 \pm 4.08 \mathrm{E}-11$ & $2.87 \pm 1.07 \mathrm{E}-10$ & $3.28 \pm 4.19 \mathrm{E}-11$ & $6.96 \pm 5.21 \mathrm{E}-11$ & $3.33 \pm 0.22 \mathrm{E}-04$ \\
\hline 1304 & UP & Dec-12 & $3.85 \pm 3.41 \mathrm{E}-10$ & $0.23 \pm 1.13 \mathrm{E}-10$ & $1.36 \pm 1.49 \mathrm{E}-10$ & $2.67 \pm 9.13 \mathrm{E}-11$ & $0.58 \pm 1.03 \mathrm{E}-10$ & $4.38 \pm 0.29 E-04$ \\
\hline 406 & DOWN & Dec-12 & $1.31 \pm 3.14 \mathrm{E}-10$ & $0.52 \pm 8.30 \mathrm{E}-11$ & $2.10 \pm 9.48 \mathrm{E}-11$ & $1.24 \pm 6.87 \mathrm{E}-11$ & $1.19 \pm 1.20 \mathrm{E}-10$ & $2.91 \pm 0.18 \mathrm{E}-04$ \\
\hline 408 & DOWN & Dec-12 & $5.56 \pm 3.80 \mathrm{E}-10$ & $0.96 \pm 5.33 \mathrm{E}-11$ & $4.55 \pm 2.04 \mathrm{E}-10$ & $4.22 \pm 7.23 \mathrm{E}-11$ & $5.16 \pm 2.11 \mathrm{E}-10$ & $1.10 \pm 0.05 E-03$ \\
\hline MP-01 & DOWN & Dec-12 & NS & $5.21 \pm 9.23 \mathrm{E}-11$ & $4.96 \pm 2.17 \mathrm{E}-10$ & $3.43 \pm 9.04 \mathrm{E}-11$ & $2.97 \pm 1.74 \mathrm{E}-10$ & NS \\
\hline MP-02 & DOWN & Dec-12 & NS & $5.44 \pm 7.84 \mathrm{E}-11$ & $9.27 \pm 2.82 \mathrm{E}-10$ & $2.14 \pm 6.03 \mathrm{E}-11$ & $5.24 \pm 2.14 \mathrm{E}-10$ & NS \\
\hline MP-03 & DOWN & Dec-12 & NS & $1.46 \pm 6.56 \mathrm{E}-11$ & $6.42 \pm 2.28 \mathrm{E}-10$ & $0.88 \pm 1.03 E-10$ & $4.58 \pm 1.89 \mathrm{E}-10$ & NS \\
\hline MP-04 & DOWN & Dec-12 & NS & $1.90 \pm 6.49 \mathrm{E}-11$ & $1.11 \pm 0.29 \mathrm{E}-09$ & $1.40 \pm 1.11 \mathrm{E}-10$ & $1.00 \pm 0.27 \mathrm{E}-09$ & NS \\
\hline & & & & Weathe & ed Till Unit & & & \\
\hline NDATR & DOWN & Jun-12 & $9.07 \pm 4.19 \mathrm{E}-10$ & $3.82 \pm 6.40 \mathrm{E}-11$ & $1.48 \pm 0.29 \mathrm{E}-09$ & $4.52 \pm 5.62 \mathrm{E}-11$ & $9.54 \pm 2.32 \mathrm{E}-10$ & $3.40 \pm 0.27 \mathrm{E}-03$ \\
\hline NDATR & DOWN & Dec-12 & $3.85 \pm 4.44 \mathrm{E}-10$ & $1.37 \pm 4.66 \mathrm{E}-11$ & $1.13 \pm 0.20 \mathrm{E}-09$ & $1.80 \pm 3.19 \mathrm{E}-11$ & $9.07 \pm 1.78 \mathrm{E}-10$ & $2.85 \pm 0.16 E-03$ \\
\hline 909 & DOWN & Dec-12 & $9.29 \pm 4.06 \mathrm{E}-10$ & $1.59 \pm 9.36 \mathrm{E}-11$ & $7.91 \pm 2.03 E-10$ & $4.36 \pm 6.50 \mathrm{E}-11$ & $6.73 \pm 1.84 \mathrm{E}-10$ & $3.10 \pm 1.15 E-03$ \\
\hline
\end{tabular}

Note: Bolding indicates radiological concentration that exceeds the GSL.

NS - Not sampled.

${ }^{a}$ Hydraulic position is relative to other wells within the same hydrologic unit.

${ }^{\mathrm{b}}$ The GSLs for radiological constituents are set equal to the larger of the background concentrations or the TOGS 1.1.1 Class GA Groundwater Quality Standards (See Table D-1A). 
Table D-2H (concluded)

2012 Radioactivity in Groundwater From Selected Monitoring Locations

\begin{tabular}{|c|c|c|c|c|c|c|c|c|}
\hline Location & $\begin{array}{l}\text { Hydraulic } \\
\text { Position }^{a} \\
\end{array}$ & $\begin{array}{c}\text { Date } \\
\text { Collected }\end{array}$ & $\begin{array}{c}N p-237^{b} \\
\mu C i / m L\end{array}$ & $\begin{array}{c}P u-238^{b} \\
\mu C i / m L\end{array}$ & $\begin{array}{c}P u-239 / 240^{b} \\
\mu C i / m L\end{array}$ & $\begin{array}{c}P u-241^{b} \\
\mu C i / m L\end{array}$ & $\begin{array}{c}A m-241^{b} \\
\mu C i / m L\end{array}$ & $\begin{array}{c}C m-243 / 244^{b} \\
\mu C i / m L\end{array}$ \\
\hline \multicolumn{9}{|c|}{ Sand and Gravel Unit } \\
\hline MP-01 & DOWN & Dec-12 & $-0.92 \pm 8.68 \mathrm{E}-11$ & $0.47 \pm 4.08 \mathrm{E}-11$ & $0.55 \pm 5.76 \mathrm{E}-11$ & $-2.02 \pm 8.46 \mathrm{E}-09$ & $0.00 \pm 2.26 \mathrm{E}-11$ & $-2.79 \pm 2.58 \mathrm{E}-11$ \\
\hline $\mathrm{MP}-02$ & DOWN & Dec-12 & $0.76 \pm 1.01 \mathrm{E}-10$ & $0.00 \pm 4.74 \mathrm{E}-11$ & $1.22 \pm 6.80 \mathrm{E}-11$ & $-0.37 \pm 1.08 \mathrm{E}-08$ & $1.60 \pm 3.13 \mathrm{E}-11$ & $-0.53 \pm 2.73 \mathrm{E}-11$ \\
\hline MP-03 & DOWN & Dec-12 & $-4.48 \pm 7.66 \mathrm{E}-11$ & $-0.46 \pm 3.94 \mathrm{E}-11$ & $1.45 \pm 5.42 \mathrm{E}-11$ & $4.72 \pm 9.16 \mathrm{E}-09$ & $0.00 \pm 1.79 \mathrm{E}-11$ & $0.00 \pm 3.30 \mathrm{E}-11$ \\
\hline MP-04 & DOWN & Dec-12 & $4.24 \pm 7.66 \mathrm{E}-11$ & $0.49 \pm 4.22 \mathrm{E}-11$ & $1.06 \pm 5.89 \mathrm{E}-11$ & $-1.56 \pm 9.20 \mathrm{E}-09$ & $0.00 \pm 1.93 \mathrm{E}-11$ & $-0.49 \pm 2.86 \mathrm{E}-11$ \\
\hline
\end{tabular}

${ }^{a}$ Hydraulic position is relative to other wells within the same hydrologic unit.

${ }^{\mathrm{b}}$ Groundwater screening levels have not been established for Np-237, Pu-238, Pu-239/240, Pu-241, Am-241, or Cm-234/244. 


\section{APPENDIX E \\ Summary of Biological Data}

Table E-1

2012 Radioactivity Concentrations in Milk

\begin{tabular}{|l|c|c|c|c|}
\hline \multicolumn{1}{|c|}{ Location } & $\begin{array}{c}K-40 \\
(\mu \mathrm{Ci} / \mathrm{mL})\end{array}$ & $\begin{array}{c}\text { Sr-90 } \\
(\mu \mathrm{Ci} / \mathrm{mL})\end{array}$ & $\begin{array}{c}\text { I-129 } \\
(\mu \mathrm{Ci} / \mathrm{mL})\end{array}$ & $\begin{array}{c}\text { Cs-137 } \\
(\mu \mathrm{Ci} / \mathrm{mL})\end{array}$ \\
\hline $\begin{array}{l}\text { BFMBLSY } \\
\text { Once every five years }\end{array}$ & $1.32 \pm 0.16 \mathrm{E}-06$ & $6.76 \pm 6.06 \mathrm{E}-10$ & $1.00 \pm 2.40 \mathrm{E}-10$ & $-1.75 \pm 2.31 \mathrm{E}-09$ \\
\hline
\end{tabular}

Note: This milk sample (BFMBLSY) was collected from a dairy farm $5.5 \mathrm{~km}$ westnorthwest of the site. It was previously sampled in 2007.

\begin{tabular}{|l|c|c|c|c|}
\hline \multicolumn{1}{|c|}{ Location } & $\begin{array}{c}K-40 \\
(\mu \mathrm{Ci} / \mathrm{mL})\end{array}$ & $\begin{array}{c}\text { Sr-90 } \\
(\mu \mathrm{Ci} / \mathrm{mL})\end{array}$ & $\begin{array}{c}I-129 \\
(\mu \mathrm{Ci} / \mathrm{mL})\end{array}$ & $\begin{array}{c}\text { Cs-137 } \\
(\mu \mathrm{Ci} / \mathrm{mL})\end{array}$ \\
\hline $\begin{array}{l}\text { BFMSCHT } \\
\text { Once every five years }\end{array}$ & $1.26 \pm 0.16 \mathrm{E}-06$ & $1.26 \pm 0.86 \mathrm{E}-09$ & $1.05 \pm 2.29 \mathrm{E}-10$ & $-0.49 \pm 3.24 \mathrm{E}-09$ \\
\hline
\end{tabular}

Note: This milk sample (BFMSCHT) was collected from a dairy farm $4.9 \mathrm{~km}$ south of the site. It was previously sampled in 2007.

\begin{tabular}{|l|c|c|c|c|}
\hline \multicolumn{1}{|c|}{ Location } & $\begin{array}{c}K-40 \\
(\mu \mathrm{Ci} / \mathrm{mL})\end{array}$ & $\begin{array}{c}\text { Sr-90 } \\
(\mu \mathrm{Ci} / \mathrm{mL})\end{array}$ & $\begin{array}{c}I-129 \\
(\mu \mathrm{Ci} / \mathrm{mL})\end{array}$ & $\begin{array}{c}\text { Cs-137 } \\
(\mu \mathrm{Ci} / \mathrm{mL})\end{array}$ \\
\hline $\begin{array}{l}\text { BFMFLDMN } \\
\text { Annual }\end{array}$ & $1.31 \pm 0.17 \mathrm{E}-06$ & $1.19 \pm 0.85 \mathrm{E}-09$ & $2.02 \pm 1.82 \mathrm{E}-10$ & $4.87 \pm 4.25 \mathrm{E}-09$ \\
\hline
\end{tabular}

Note: The near-site milk sample (BFMFLDMN) is located $5.1 \mathrm{~km}$ southeast of the site. It was previously sampled in 2011.

\begin{tabular}{|l|c|c|c|c|}
\hline \multicolumn{1}{|c|}{ Location } & $\begin{array}{c}K-40 \\
(\mu \mathrm{Ci} / \mathrm{mL})\end{array}$ & $\begin{array}{c}\text { Sr-90 } \\
(\mu \mathrm{Ci} / \mathrm{mL})\end{array}$ & $\begin{array}{c}\text { I-129 } \\
(\mu \mathrm{Ci} / \mathrm{mL})\end{array}$ & $\begin{array}{c}\text { Cs-137 } \\
(\mu \mathrm{Ci} / \mathrm{mL})\end{array}$ \\
\hline $\begin{array}{l}\text { BFMCTLS } \\
\text { (Background) } \\
\text { Once every five years }\end{array}$ & $1.17 \pm 0.16 \mathrm{E}-06$ & $-5.06 \pm 5.98 \mathrm{E}-10$ & $0.44 \pm 1.80 \mathrm{E}-10$ & $-1.33 \pm 3.66 \mathrm{E}-09$ \\
\hline
\end{tabular}

Note: The control milk sample (BFMCTLS) is located $22 \mathrm{~km}$ south of the site. It was previously sampled in 2007. 
TABLE E-2

2012 Radioactivity Concentrations in Venison

\begin{tabular}{|l|c|c|c|c|c|}
\hline \multicolumn{1}{|c|}{ Location } & $\%$ Moisture & $\begin{array}{c}H-3 \\
(\mu \mathrm{Ci} / \mathrm{mL})\end{array}$ & $\begin{array}{c}\boldsymbol{K}-40 \\
(\mu \mathrm{Ci} / \mathrm{g}-d r y)\end{array}$ & $\begin{array}{c}\text { Sr-90 } \\
(\mu \mathrm{Ci} / g-d r y)\end{array}$ & $\begin{array}{c}\text { Cs-137 } \\
(\mu \mathrm{Ci} / g-d r y)\end{array}$ \\
\hline $\begin{array}{l}\text { BFDCTRL } \\
\text { (Background) }\end{array}$ & 73.8 & $0.44 \pm 1.07 \mathrm{E}-07$ & $1.20 \pm 0.07 \mathrm{E}-05$ & $-2.36 \pm 2.37 \mathrm{E}-09$ & $2.18 \pm 0.28 \mathrm{E}-07$ \\
\hline $\begin{array}{l}\text { BFDCTRL } \\
\text { (Background) }\end{array}$ & 73.6 & $1.12 \pm 0.94 \mathrm{E}-07$ & $9.97 \pm 0.74 \mathrm{E}-06$ & $0.66 \pm 2.72 \mathrm{E}-09$ & $2.09 \pm 2.71 \mathrm{E}-08$ \\
\hline $\begin{array}{l}\text { BFDCTRL } \\
\text { (Background) }\end{array}$ & 74.5 & $5.24 \pm 8.77 \mathrm{E}-08$ & $1.11 \pm 0.07 \mathrm{E}-05$ & $1.91 \pm 2.53 \mathrm{E}-09$ & $0.00 \pm 3.07 \mathrm{E}-08$ \\
\hline $\begin{array}{l}\text { BFDNEAR } \\
\text { (Near-Site) }\end{array}$ & 74.6 & $1.20 \pm 0.96 \mathrm{E}-07$ & $1.03 \pm 0.06 \mathrm{E}-05$ & $1.24 \pm 2.76 \mathrm{E}-09$ & $1.86 \pm 1.79 \mathrm{E}-08$ \\
\hline $\begin{array}{l}\text { BFDNEAR } \\
\text { (Near-Site) }\end{array}$ & 74.6 & $1.12 \pm 0.98 \mathrm{E}-07$ & $1.26 \pm 0.07 \mathrm{E}-05$ & $-1.80 \pm 2.60 \mathrm{E}-09$ & $0.00 \pm 2.94 \mathrm{E}-08$ \\
\hline $\begin{array}{l}\text { BFDNEAR } \\
\text { (Near-Site) }\end{array}$ & 73.1 & $1.04 \pm 0.96 \mathrm{E}-07$ & $1.06 \pm 0.07 \mathrm{E}-05$ & $-0.01 \pm 2.73 \mathrm{E}-09$ & $2.88 \pm 0.34 \mathrm{E}-07$ \\
\hline
\end{tabular}

Note: The venison samples are collected on an annual basis.

Table E-3

2012 Radioactivity Concentrations in Food Crops

\begin{tabular}{|l|c|c|c|c|c|c|}
\hline \multicolumn{1}{|c|}{ Location* } & $\%$ Moisture & $\begin{array}{c}H-3 \\
(\mu \mathrm{Ci} / \mathrm{mL}-\text { Dry })\end{array}$ & $\begin{array}{c}K-40 \\
(\mu \mathrm{Ci} / \mathrm{g}-\text { Dry })\end{array}$ & $\begin{array}{c}\text { Co-60 } \\
(\mu \mathrm{Ci} / \mathrm{g}-\text { Dry })\end{array}$ & $\begin{array}{c}\text { Sr-90 } \\
(\mu \mathrm{Ci} / \mathrm{g}-\text { Dry })\end{array}$ & $\begin{array}{c}\text { Cs-137 } \\
(\mu \mathrm{Ci} / \mathrm{g}-\text { Dry })\end{array}$ \\
\hline $\begin{array}{l}\text { BFVCTRC } \\
\text { (Background) }\end{array}$ & 78.1 & $-0.23 \pm 1.14 \mathrm{E}-07$ & $1.14 \pm 0.13 \mathrm{E}-05$ & $1.11 \pm 2.30 \mathrm{E}-08$ & $0.52 \pm 2.71 \mathrm{E}-09$ & $0.95 \pm 2.17 \mathrm{E}-08$ \\
\hline $\begin{array}{l}\text { BFVNEAC } \\
\text { (Near Site) }\end{array}$ & 79.4 & $-0.02 \pm 1.17 \mathrm{E}-07$ & $1.17 \pm 0.14 \mathrm{E}-05$ & $2.91 \pm 2.41 \mathrm{E}-08$ & $-0.43 \pm 2.68 \mathrm{E}-09$ & $0.32 \pm 2.10 \mathrm{E}-08$ \\
\hline
\end{tabular}

\begin{tabular}{|l|c|c|c|c|c|c|}
\hline \multicolumn{1}{|c|}{ Location* } & $\%$ Moisture & $\begin{array}{c}H-3 \\
(\mu \mathrm{Ci} / \mathrm{mL}-\text { Dry })\end{array}$ & $\begin{array}{c}K-40 \\
(\mu \mathrm{Ci} / \mathrm{g}-\text { Dry })\end{array}$ & $\begin{array}{c}\text { Co-60 } \\
(\mu \mathrm{Ci} / \mathrm{g}-\text { Dry })\end{array}$ & $\begin{array}{c}\text { Sr-90 } \\
(\mu \mathrm{Ci} / \mathrm{g}-\text { Dry })\end{array}$ & $\begin{array}{c}\text { Cs-137 } \\
(\mu \mathrm{Ci} / \mathrm{g}-\text { Dry })\end{array}$ \\
\hline $\begin{array}{l}\text { BFVCTRB } \\
\text { (Background) }\end{array}$ & 91.9 & $0.05 \pm 1.15 \mathrm{E}-07$ & $2.79 \pm 0.27 \mathrm{E}-05$ & $0.87 \pm 2.19 \mathrm{E}-08$ & $5.58 \pm 0.57 \mathrm{E}-08$ & $3.09 \pm 1.86 \mathrm{E}-08$ \\
\hline $\begin{array}{l}\text { BFVNEAB } \\
\text { (Near Site) }\end{array}$ & 84.2 & $0.24 \pm 1.17 \mathrm{E}-07$ & $2.65 \pm 0.25 \mathrm{E}-05$ & $0.22 \pm 2.58 \mathrm{E}-08$ & $4.15 \pm 2.97 \mathrm{E}-09$ & $-0.29 \pm 2.27 \mathrm{E}-08$ \\
\hline
\end{tabular}

\begin{tabular}{|c|c|c|c|c|c|c|}
\hline \multicolumn{7}{|c|}{ APPLES } \\
\hline Location* & $\%$ Moisture & $\begin{array}{c}H-3 \\
(\mu C i / m L-D r y)\end{array}$ & $\begin{array}{c}K-40 \\
(\mu \mathrm{Ci} / g-\text { Dry })\end{array}$ & $\begin{array}{c}\text { Co-60 } \\
(\mu \mathrm{Ci} / g-\text { Dry })\end{array}$ & $\begin{array}{c}S r-90 \\
(\mu \mathrm{Ci} / g-D r y)\end{array}$ & $\begin{array}{c}C s-137 \\
(\mu C i / g-D r y)\end{array}$ \\
\hline $\begin{array}{l}\text { BFVCTRA } \\
\text { (Background) }\end{array}$ & 83.6 & $0.79 \pm 1.20 \mathrm{E}-07$ & $5.89 \pm 0.72 \mathrm{E}-06$ & $0.54 \pm 1.78 \mathrm{E}-08$ & $0.80 \pm 2.62 \mathrm{E}-09$ & $0.76 \pm 1.58 \mathrm{E}-08$ \\
\hline $\begin{array}{l}\text { BFVNEAAF } \\
\text { (Near Site) }\end{array}$ & 82.6 & $-0.62 \pm 1.14 \mathrm{E}-07$ & $8.98 \pm 1.03 \mathrm{E}-06$ & $0.34 \pm 1.36 \mathrm{E}-08$ & $4.70 \pm 3.09 \mathrm{E}-09$ & $1.17 \pm 2.26 \mathrm{E}-08$ \\
\hline
\end{tabular}

*Food crops are sampled once every five years, consistent with guidance on periodic confirmatory sampling in DOE/EH-0173T. Food crop samples were previously collected in 2007. 
TABLE E-4

2012 Radioactivity Concentrations in Edible Portions of Fish From Cattaraugus Creek Cattaraugus Creek above the Springville Dam (BFFCATC)

\begin{tabular}{|c|c|c|c|}
\hline Species & \% Moisture & $\begin{array}{c}\text { Sr-90 } \\
\text { ( } \mu \mathrm{Ci} / \mathrm{g}-\mathrm{dry})\end{array}$ & $\begin{array}{c}\text { Cs-137 } \\
(\mu \mathrm{Ci} / \mathrm{g}-\mathrm{dry})\end{array}$ \\
\hline Hog-nosed Sucker- 9.5" & 79.1 & $3.78 \pm 0.31 \mathrm{E}-08$ & $5.13 \pm 6.06 \mathrm{E}-08$ \\
\hline Hog-nosed Sucker- 10" & 80.9 & $2.66 \pm 2.77 \mathrm{E}-09$ & $0.50 \pm 4.77 \mathrm{E}-08$ \\
\hline Hog-nosed Sucker-11" & 78.1 & $2.49 \pm 2.21 \mathrm{E}-09$ & $1.86 \pm 7.45 \mathrm{E}-08$ \\
\hline Hog-nosed Sucker- 12" & 77.5 & $1.52 \pm 2.52 \mathrm{E}-09$ & $1.21 \pm 3.11 \mathrm{E}-08$ \\
\hline Hog-nosed Sucker- 12" & 78.2 & $-0.68 \pm 2.35 \mathrm{E}-09$ & $3.64 \pm 3.32 E-08$ \\
\hline Hog-nosed Sucker- 12" & 79.3 & $-0.53 \pm 2.07 E-09$ & $-1.40 \pm 5.25 E-08$ \\
\hline White Sucker-10" & 79.4 & $2.83 \pm 0.28 \mathrm{E}-08$ & $-0.36 \pm 1.20 E-07$ \\
\hline White Sucker-11" & 80.1 & $2.60 \pm 0.27 \mathrm{E}-08$ & $0.49 \pm 1.19 \mathrm{E}-07$ \\
\hline White Sucker-11" & 80.0 & $7.10 \pm 3.85 \mathrm{E}-09$ & $3.23 \pm 5.22 \mathrm{E}-08$ \\
\hline White Sucker- 11.5" & 80.7 & $0.59 \pm 1.76 \mathrm{E}-09$ & $0.96 \pm 1.23 \mathrm{E}-07$ \\
\hline Average \% Moisture & 79.3 & & \\
\hline Median & & 2.64E-09 & $<5.66 \mathrm{E}-08$ \\
\hline Maximum & & $3.78 \mathrm{E}-08$ & $3.64 \mathrm{E}-08$ \\
\hline Minimum & & $<1.76 \mathrm{E}-09$ & $<3.11 \mathrm{E}-08$ \\
\hline
\end{tabular}

Note: Fish samples are collected once every five years, consistent with guidance on periodic confirmatory sampling in DOE/EH-0173T. Fish samples were previously collected in 2007.

TABLE E-4 (continued)

2012 Radioactivity Concentrations in Edible Portions of Fish From Cattaraugus Creek Cattaraugus Creek below the Springville Dam (BFFCATD)

\begin{tabular}{|c|c|c|c|}
\hline Species & \% Moisture & $\begin{array}{c}\text { Sr-90 } \\
(\mu \mathrm{Ci} / \mathrm{g}-\mathrm{dry})\end{array}$ & $\begin{array}{c}\text { Cs-137 } \\
\text { ( } \boldsymbol{\mu C i / g}-\text { dry })\end{array}$ \\
\hline Steelhead Trout-23" & 72.7 & $-1.56 \pm 2.60 \mathrm{E}-09$ & $2.85 \pm 2.55 \mathrm{E}-08$ \\
\hline Steelhead Trout-26.5" & 76.0 & $-2.26 \pm 2.19 \mathrm{E}-09$ & $0.00 \pm 3.91 \mathrm{E}-08$ \\
\hline Steelhead Trout-24" & 75.6 & $0.34 \pm 2.55 \mathrm{E}-09$ & $2.30 \pm 1.95 \mathrm{E}-08$ \\
\hline Steelhead Trout-22" & 75.8 & $0.78 \pm 2.67 \mathrm{E}-09$ & $1.28 \pm 1.88 \mathrm{E}-08$ \\
\hline Steelhead Trout-21" & 74.5 & $1.95 \pm 2.68 \mathrm{E}-09$ & $2.63 \pm 3.19 \mathrm{E}-08$ \\
\hline Steelhead Trout-25" & 73.0 & $1.88 \pm 3.04 \mathrm{E}-09$ & $0.05 \pm 1.47 \mathrm{E}-08$ \\
\hline Steelhead Trout-16" & 71.2 & $0.25 \pm 2.94 \mathrm{E}-09$ & $3.47 \pm 2.80 \mathrm{E}-08$ \\
\hline Steelhead Trout-17" & 72.2 & $-1.14 \pm 1.94 \mathrm{E}-09$ & $-0.64 \pm 2.41 \mathrm{E}-08$ \\
\hline Steelhead Trout-16" & 71.9 & $0.57 \pm 2.61 \mathrm{E}-09$ & $0.54 \pm 3.02 \mathrm{E}-08$ \\
\hline Steelhead Trout-15.5" & 73.9 & $1.10 \pm 2.14 \mathrm{E}-09$ & $2.73 \pm 2.89 \mathrm{E}-08$ \\
\hline Average \% Moisture & 73.7 & & $<2.87 \mathrm{E}-08$ \\
\hline Median & & $<2.60 \mathrm{E}-09$ & $<1.47 \mathrm{E}-08$ \\
\hline Maximum & & $<1.94 \mathrm{E}-09$ & \\
\hline Minimum & & & \\
\hline
\end{tabular}

Note: Fish samples are collected once every five years, consistent with guidance on periodic confirmatory sampling in DOE/EH-0173T. Fish samples were previously collected in 2007. 
TABLE E-4 (concluded)

2012 Radioactivity Concentrations in Edible Portions of Fish From Cattaraugus Creek Cattaraugus Creek Background (BFFCTRL)

\begin{tabular}{|c|c|c|c|}
\hline Species & \% Moisture & $\begin{array}{c}\text { Sr-90 } \\
(\mu \mathrm{Ci} / g-\text { dry })\end{array}$ & $\begin{array}{c}\text { Cs-137 } \\
(\mu \mathrm{C} / \mathrm{g}-\mathrm{dry})\end{array}$ \\
\hline Brown Trout-8.5" & 74.5 & $0.64 \pm 2.82 \mathrm{E}-09$ & $0.33 \pm 1.06 \mathrm{E}-07$ \\
\hline Brown Trout-9" & 71.4 & $-2.52 \pm 2.29 \mathrm{E}-09$ & $1.34 \pm 3.97 \mathrm{E}-08$ \\
\hline Brown Trout-9.5" & 77.7 & $0.76 \pm 2.81 \mathrm{E}-09$ & $-1.77 \pm 5.60 \mathrm{E}-08$ \\
\hline Brown Trout-11" & 74.7 & $0.61 \pm 2.64 \mathrm{E}-09$ & $1.68 \pm 4.21 \mathrm{E}-08$ \\
\hline Brown Trout-11.5" & 75.6 & $-0.10 \pm 2.39 \mathrm{E}-09$ & $-0.08 \pm 4.80 \mathrm{E}-08$ \\
\hline White Sucker-8" & 80.4 & $7.85 \pm 4.26 \mathrm{E}-09$ & $0.49 \pm 1.45 \mathrm{E}-07$ \\
\hline White Sucker-10" & 80.2 & $1.39 \pm 1.91 \mathrm{E}-09$ & $4.63 \pm 8.82 \mathrm{E}-08$ \\
\hline Bullhead-9" & 80.4 & $1.13 \pm 0.36 \mathrm{E}-08$ & $-0.04 \pm 9.72 \mathrm{E}-08$ \\
\hline Hog-nosed Sucker-8" & 79.6 & $1.60 \pm 0.37 \mathrm{E}-08$ & $8.24 \pm 9.85 \mathrm{E}-08$ \\
\hline Hog-nosed Sucker-11" & 77.6 & $6.39 \pm 2.10 \mathrm{E}-09$ & $-0.76 \pm 9.77 \mathrm{E}-08$ \\
\hline Average \% Moisture & 77.2 & & $<2.82 \mathrm{E}-09$ \\
\hline Median & & $1.60 \mathrm{E}-08$ & $<9.27 \mathrm{E}-08$ \\
\hline Maximum & & $<1.91 \mathrm{E}-09$ & $<3.97 \mathrm{E}-08$ \\
\hline Minimum & & & \\
\hline
\end{tabular}

Note: Fish samples are collected once every five years, consistent with guidance on periodic confirmatory sampling in DOE/EH-0173T. Fish samples were previously collected in 2007. 


\section{APPENDIX F \\ Summary of Soil and Sediment Monitoring Data}

TABLE F-1A

Radionuclide Comparison Values for Soils

\begin{tabular}{|c|c|c|c|c|c|}
\hline \multirow{2}{*}{ Radionuclide } & \multirow{2}{*}{ Units } & \multicolumn{2}{|c|}{$\begin{array}{c}\text { Consultation Triggers for Soil } \\
\text { Contamination }^{a}\end{array}$} & \multirow{2}{*}{$\begin{array}{c}\text { NUREG-1757 } \\
\text { Screening Values of } \\
\text { Common Radionuclides } \\
\text { for Soil Surface } \\
\text { Contamination Levels }^{b}\end{array}$} & \multirow{2}{*}{$\begin{array}{l}\text { Site-Specific Soil } \\
\text { Cleanup Goals }^{c}\end{array}$} \\
\hline & & $\begin{array}{c}\text { Residential } \\
\text { Soil } \\
\text { Concentration }\end{array}$ & $\begin{array}{c}\text { Industrial/ } \\
\text { Commercial } \\
\text { Concentration }\end{array}$ & & \\
\hline Co-60 & $\mu \mathrm{Ci} / \mathrm{g}$ & $4 \mathrm{E}-06$ & $6 \mathrm{E}-06$ & $3.8 \mathrm{E}-06$ & -- \\
\hline Sr-90 & $\mu \mathrm{Ci} / \mathrm{g}$ & -- & -- & $1.7 \mathrm{E}-06$ & $3.7 \mathrm{E}-06$ \\
\hline Sr-90+D ${ }^{d}$ & $\mu \mathrm{Ci} / \mathrm{g}$ & $2.3 \mathrm{E}-05$ & $1.07 \mathrm{E}-03$ & -- & -- \\
\hline Cs-137 & $\mu \mathrm{Ci} / \mathrm{g}$ & -- & -- & $1.1 \mathrm{E}-05$ & $1.4 \mathrm{E}-05$ \\
\hline Cs-137+D ${ }^{d}$ & $\mu \mathrm{Ci} / \mathrm{g}$ & $6 \mathrm{E}-06$ & $1.1 \mathrm{E}-05$ & -- & -- \\
\hline U-232 & $\mu \mathrm{Ci} / \mathrm{g}$ & -- & -- & -- & $1.4 \mathrm{E}-06$ \\
\hline U-233 & $\mu \mathrm{Ci} / \mathrm{g}$ & -- & -- & -- & $7.5 \mathrm{E}-06$ \\
\hline U-234 & $\mu \mathrm{Ci} / \mathrm{g}$ & $4.01 E-04$ & $3.31 E-03$ & $1.3 \mathrm{E}-05$ & $7.6 \mathrm{E}-06$ \\
\hline U-235 & $\mu \mathrm{Ci} / \mathrm{g}$ & -- & -- & $8 \mathrm{E}-06$ & $3.1 \mathrm{E}-06$ \\
\hline $\mathrm{U}-235+\mathbf{D}^{d}$ & $\mu \mathrm{Ci} / \mathrm{g}$ & $2.0 \mathrm{E}-05$ & $3.9 \mathrm{E}-05$ & $2.9 \mathrm{E}-07$ & -- \\
\hline U-238 & $\mu \mathrm{Ci} / \mathrm{g}$ & -- & -- & $1.4 \mathrm{E}-05$ & $8.9 \mathrm{E}-06$ \\
\hline $\mathrm{U}-238+\mathrm{D}^{d}$ & $\mu \mathrm{Ci} / \mathrm{g}$ & $7.4 \mathrm{E}-05$ & 1.79E-04 & $5 \mathrm{E}-07$ & -- \\
\hline Total U & $\mu \mathrm{g} / \mathrm{g}$ & $4.7 \mathrm{E}+01$ & $1.23 \mathrm{E}+03$ & -- & -- \\
\hline Pu-238 & $\mu \mathrm{Ci} / \mathrm{g}$ & $2.97 \mathrm{E}-04$ & $1.64 \mathrm{E}-03$ & $2.5 \mathrm{E}-06$ & $3.6 \mathrm{E}-05$ \\
\hline Pu-239 & $\mu \mathrm{Ci} / \mathrm{g}$ & $2.59 \mathrm{E}-04$ & $1.43 \mathrm{E}-03$ & $2.3 \mathrm{E}-06$ & $2.3 \mathrm{E}-05$ \\
\hline Pu-240 & $\mu \mathrm{Ci} / \mathrm{g}$ & -- & -- & -- & $2.4 \mathrm{E}-05$ \\
\hline Am-241 & $\mu \mathrm{Ci} / \mathrm{g}$ & $1.87 \mathrm{E}-04$ & $5.68 \mathrm{E}-04$ & $2.1 \mathrm{E}-06$ & $2.6 \mathrm{E}-05$ \\
\hline
\end{tabular}

a Memorandum of Understanding between the Environmental Protection Agency and the Nuclear Regulatory Commission

"Consultation and Finality on Decommissioning and Decontamination of Contaminated Sites",October 9, 2002.

${ }^{b}$ U.S. Nuclear Regulatory Commission. "Consolidated Decommissioning Guidance: Characterization, Survey and Determination of Radiological Criteria. NUREG-1757, Vol. 2, Rev. 1. September 2006.

${ }^{\mathrm{c}}$ Soil Cleanup goals developed from site-specific data for the WVDP Phase 1 Decommissioning Plan (DP), Rev. 2 , Table 5-14, December 2009 (most restrictive soil/sediment criteria).

${ }^{d}$ Concentrations apply to the parent radionuclide but assume that the daughter products are in equilibrium. 
TABLE F-2A

2012 Contaminants in On-Site Soils Downstream of the WVDP at Franks Creek (SNSP006)

RADIOACTIVE CONSTITUENTS

\begin{tabular}{|c|c|c|c|c|c|}
\hline Isotope & Units & $N$ & SNSP006 & $\begin{array}{c}\text { NUREG-1757 } \\
\text { Soil Screening } \\
\text { Contamination } \\
\text { Levels }^{a}\end{array}$ & $\begin{array}{c}\text { Site-Specific } \\
\text { Soil } \\
\text { Cleanup Goals }^{b}\end{array}$ \\
\hline Gross Alpha & $\mu \mathrm{Ci} / \mathrm{g}$ & 1 & $1.40 \pm 0.60 \mathrm{E}-05$ & -- & -- \\
\hline Gross Beta & $\mu \mathrm{Ci} / \mathrm{g}$ & 1 & $3.42 \pm 0.50 \mathrm{E}-05$ & -- & -- \\
\hline$K-40$ & $\mu \mathrm{Ci} / \mathrm{g}$ & 1 & $1.55 \pm 0.16 \mathrm{E}-05$ & -- & -- \\
\hline Co-60 & $\mu \mathrm{Ci} / \mathrm{g}$ & 1 & $-1.77 \pm 2.62 E-08$ & $3.8 \mathrm{E}-06$ & -- \\
\hline Sr-90 & $\mu \mathrm{Ci} / \mathrm{g}$ & 1 & $5.04 \pm 0.79 \mathrm{E}-07$ & 1.7E-06 & 3.7E-06 \\
\hline Cs-137 & $\mu \mathrm{Ci} / \mathrm{g}$ & 1 & $1.14 \pm 0.10 \mathrm{E}-05$ & $1.1 \mathrm{E}-05$ & $1.4 \mathrm{E}-05$ \\
\hline U-232 & $\mu \mathrm{Ci} / \mathrm{g}$ & 1 & $1.23 \pm 4.45 \mathrm{E}-08$ & -- & $1.4 \mathrm{E}-06$ \\
\hline \begin{tabular}{|l|}
$U-233 / 234$ \\
\end{tabular} & $\mu \mathrm{Ci} / \mathrm{g}$ & 1 & $5.99 \pm 1.35 \mathrm{E}-07$ & $1.3 \mathrm{E}-05$ & $7.6 \mathrm{E}-06^{d}$ \\
\hline U-235/236 & $\mu \mathrm{Ci} / \mathrm{g}$ & 1 & $2.62 \pm 3.34 \mathrm{E}-08$ & $8.0 \mathrm{E}-06^{c}$ & $3.1 \mathrm{E}-06^{d}$ \\
\hline $\mathrm{U}-238$ & $\mu \mathrm{Ci} / \mathrm{g}$ & 1 & $6.82 \pm 1.40 \mathrm{E}-07$ & $1.4 \mathrm{E}-05^{c}$ & $8.9 \mathrm{E}-06$ \\
\hline Total U & $\mu \mathrm{g} / \mathrm{g}$ & 1 & $1.79 \pm 0.09 E+00$ & -- & -- \\
\hline Pu-238 & $\mu \mathrm{Ci} / \mathrm{g}$ & 1 & $1.32 \pm 1.54 \mathrm{E}-08$ & $2.5 \mathrm{E}-06$ & $3.6 \mathrm{E}-05$ \\
\hline Pu-239/240 & $\mu \mathrm{Ci} / \mathrm{g}$ & 1 & $3.91 \pm 2.43 \mathrm{E}-08$ & $2.3 \mathrm{E}-06$ & $2.4 \mathrm{E}-05^{d}$ \\
\hline Am-241 & $\mu \mathrm{Ci} / \mathrm{g}$ & 1 & $4.06 \pm 2.14 \mathrm{E}-08$ & $2.1 \mathrm{E}-06$ & $2.6 \mathrm{E}-05$ \\
\hline
\end{tabular}

$\mathrm{N}$ - number of samples.

-- No reference standard available.

${ }^{a}$ U.S. Nuclear Regulatory Commission. "Consolidated Decommissioning Guidance:

Characterization, Survey and Determination of Radiological Criteria. NUREG-1757, Vol. 2, Rev. 1.

${ }^{b}$ Soil Cleanup goals developed from site-specific data for the WVDP Phase 1 Decommissioning Plan (DP), Rev. 2, Table 5-14, December 2009 (most restrictive soil/sediment criteria).

${ }^{c}$ WVDP-related uranium isotopes are not assumed to be in equilibrium with daughter products because of their relatively recent origin as processed nuclear materials. Therefore, the single-nuclide screening levels for U-235 and U-238 were selected for comparison with radionuclide concentrations.

${ }^{d}$ The site-specific cleanup goals selected for Pu-239/240 and U-233/U234 is the maxima of Pu-239 and Pu-240, and U-233 and U-234, respectively from Table 5-14 of the DP. Only criteria for U-235 (not U-236) are provided in DP Table 5-14. 
TABLE F-2B

2012 Contaminants in On-Site Soils From North Swamp (SNSW74A)

RADIOACTIVE CONSTITUENTS

\begin{tabular}{|c|c|c|c|c|c|}
\hline Isotope & Units & $N$ & SNSW74A & $\begin{array}{c}\text { NUREG-1757 Soil } \\
\text { Screeening } \\
\text { Contamination } \\
\text { Levels }^{b} \\
\end{array}$ & $\begin{array}{c}\text { Site-Specific } \\
\text { Soil } \\
\text { Cleanup Goals }^{b}\end{array}$ \\
\hline Gross Alpha & $\mu \mathrm{Ci} / \mathrm{g}$ & 1 & $1.57 \pm 0.61 \mathrm{E}-05$ & -- & -- \\
\hline Gross Beta & $\mu \mathrm{Ci} / \mathrm{g}$ & 1 & $2.50 \pm 0.46 \mathrm{E}-05$ & -- & -- \\
\hline$K-40$ & $\mu \mathrm{Ci} / \mathrm{g}$ & 1 & $1.63 \pm 0.16 \mathrm{E}-05$ & -- & -- \\
\hline Co-60 & $\mu \mathrm{Ci} / \mathrm{g}$ & 1 & $-2.08 \pm 2.67 \mathrm{E}-08$ & $3.8 \mathrm{E}-06$ & -- \\
\hline Sr-90 & $\mu \mathrm{Ci} / \mathrm{g}$ & 1 & $4.64 \pm 5.76 \mathrm{E}-08$ & $1.7 \mathrm{E}-06$ & $3.7 \mathrm{E}-06$ \\
\hline Cs-137 & $\mu \mathrm{Ci} / \mathrm{g}$ & 1 & $1.57 \pm 0.15 \mathrm{E}-06$ & $1.1 \mathrm{E}-05$ & $1.4 \mathrm{E}-05$ \\
\hline U-232 & $\mu \mathrm{Ci} / \mathrm{g}$ & 1 & $-1.04 \pm 3.04 \mathrm{E}-08$ & -- & $1.4 \mathrm{E}-06$ \\
\hline U-233/234 & $\mu \mathrm{Ci} / \mathrm{g}$ & 1 & $8.26 \pm 1.60 \mathrm{E}-07$ & $1.3 \mathrm{E}-05$ & $7.6 \mathrm{E}-06^{d}$ \\
\hline U-235/236 & $\mu \mathrm{Ci} / \mathrm{g}$ & 1 & $3.49 \pm 3.97 \mathrm{E}-08$ & $8.0 \mathrm{E}-06^{c}$ & $3.1 \mathrm{E}-06^{d}$ \\
\hline U-238 & $\mu \mathrm{Ci} / \mathrm{g}$ & 1 & $9.32 \pm 1.69 \mathrm{E}-07$ & $1.4 \mathrm{E}-05^{c}$ & $8.9 E-06$ \\
\hline Total U & $\mu \mathrm{g} / \mathrm{g}$ & 1 & $2.75 \pm 0.12 \mathrm{E}+00$ & -- & -- \\
\hline $\mathrm{Pu}-238$ & $\mu \mathrm{Ci} / \mathrm{g}$ & 1 & $0.62 \pm 1.92 \mathrm{E}-08$ & $2.5 \mathrm{E}-06$ & $3.6 \mathrm{E}-05$ \\
\hline Pu-239/240 & $\mu \mathrm{Ci} / \mathrm{g}$ & 1 & $2.48 \pm 1.92 \mathrm{E}-08$ & $2.3 \mathrm{E}-06$ & $2.4 \mathrm{E}-05^{d}$ \\
\hline Am-241 & $\mu \mathrm{Ci} / \mathrm{g}$ & 1 & $3.30 \pm 1.57 \mathrm{E}-08$ & $2.1 \mathrm{E}-06$ & $2.6 \mathrm{E}-05$ \\
\hline
\end{tabular}

$\mathrm{N}$ - number of samples.

-- No reference standard available.

${ }^{a}$ U.S. Nuclear Regulatory Commission. "Consolidated Decommissioning Guidance:

Characterization, Survey and Determination of Radiological Criteria. NUREG-1757, Vol. 2, Rev. 1.

${ }^{b}$ Soil Cleanup goals developed from site-specific data for the WVDP Phase 1 Decommissioning Plan (DP), Rev. 2, Table 5-14, December 2009 (most restrictive soil/sediment criteria).

${ }^{c}$ WVDP-related uranium isotopes are not assumed to be in equilibrium with daughter products because of their relatively recent origin as processed nuclear materials. Therefore, the single-nuclide screening levels for U-235 and U-238 were selected for comparison with radionuclide concentrations.

${ }^{d}$ The site-specific cleanup goals selected for Pu-239/240 and U-233/U234 is the maxima of Pu-239 and Pu-240, and U-233 and U-234, respectively from Table 5-14 of the DP. Only criteria for U-235 (not U-236) are provided in DP Table 5-14. 
TABLE F-2C

2012 Contaminants in On-Site Soils From Northeast Swamp (SNSWAMP)

RADIOACTIVE CONSTITUENTS

\begin{tabular}{|c|c|c|c|c|c|}
\hline Isotope & Units & $N$ & SNSWAMP & $\begin{array}{c}\text { NUREG-1757 Soil } \\
\text { Screening } \\
\text { Contamination } \\
\text { Levels }^{b}\end{array}$ & $\begin{array}{c}\text { Site-Specific } \\
\text { Soil } \\
\text { Cleanup Goals }\end{array}$ \\
\hline Gross Alpha & $\mu \mathrm{Ci} / \mathrm{g}$ & 1 & $2.16 \pm 0.68 \mathrm{E}-05$ & -- & -- \\
\hline Gross Beta & $\mu \mathrm{Ci} / \mathrm{g}$ & 1 & $5.32 \pm 0.19 \mathrm{E}-04$ & -- & -- \\
\hline$K-40$ & $\mu \mathrm{Ci} / \mathrm{g}$ & 1 & $1.29 \pm 0.15 \mathrm{E}-05$ & -- & -- \\
\hline Co-60 & $\mu \mathrm{Ci} / \mathrm{g}$ & 1 & $3.61 \pm 3.56 \mathrm{E}-08$ & $3.8 \mathrm{E}-06$ & -- \\
\hline Sr-90 & $\mu \mathrm{Ci} / \mathrm{g}$ & 1 & $2.65 \pm 0.02 E-04$ & $1.7 \mathrm{E}-06$ & 3.7E-06 \\
\hline Cs-137 & $\mu \mathrm{Ci} / \mathrm{g}$ & 1 & $4.21 \pm 0.36 \mathrm{E}-06$ & $1.1 \mathrm{E}-05$ & $1.4 \mathrm{E}-05$ \\
\hline U-232 & $\mu \mathrm{Ci} / \mathrm{g}$ & 1 & $-1.15 \pm 2.22 \mathrm{E}-08$ & -- & $1.4 \mathrm{E}-06$ \\
\hline U-233/234 & $\mu \mathrm{Ci} / \mathrm{g}$ & 1 & $6.60 \pm 1.33 \mathrm{E}-07$ & $1.3 \mathrm{E}-05$ & $7.6 \mathrm{E}-06^{d}$ \\
\hline U-235/236 & $\mu \mathrm{Ci} / \mathrm{g}$ & 1 & $4.59 \pm 4.38 \mathrm{E}-08$ & $8.0 \mathrm{E}-06^{c}$ & $3.1 \mathrm{E}-06^{d}$ \\
\hline U-238 & $\mu \mathrm{Ci} / \mathrm{g}$ & 1 & $7.02 \pm 1.35 \mathrm{E}-07$ & $1.4 \mathrm{E}-05^{c}$ & $8.9 \mathrm{E}-06$ \\
\hline Total U & $\mu \mathrm{g} / \mathrm{g}$ & 1 & $3.41 \pm 0.74 \mathrm{E}+00$ & -- & -- \\
\hline Pu-238 & $\mu \mathrm{Ci} / \mathrm{g}$ & 1 & $7.64 \pm 2.88 \mathrm{E}-08$ & $2.5 \mathrm{E}-06$ & $3.6 \mathrm{E}-05$ \\
\hline Pu-239/240 & $\mu \mathrm{Ci} / \mathrm{g}$ & 1 & $1.37 \pm 0.39 \mathrm{E}-07$ & $2.3 \mathrm{E}-06$ & $2.4 \mathrm{E}-05^{d}$ \\
\hline Am-241 & $\mu \mathrm{Ci} / \mathrm{g}$ & 1 & $2.34 \pm 0.35 \mathrm{E}-07$ & $2.1 \mathrm{E}-06$ & $2.6 \mathrm{E}-05$ \\
\hline
\end{tabular}

$\mathrm{N}$ - number of samples.

-- No reference standard available.

${ }^{a}$ U.S. Nuclear Regulatory Commission. "Consolidated Decommissioning Guidance: Characterization, Survey and Determination of Radiological Criteria. NUREG-1757, Vol. 2, Rev. 1.

${ }^{b}$ Soil Cleanup goals developed from site-specific data for the WVDP Phase 1 Decommissioning Plan (DP), Rev. 2, Table 5-14, December 2009 (most restrictive soil/sediment criteria).

${ }^{c}$ WVDP-related uranium isotopes are not assumed to be in equilibrium with daughter products because of their relatively recent origin as processed nuclear materials. Therefore, the single-nuclide screening levels for U-235 and U-238 were selected for comparison with radionuclide concentrations.

${ }^{d}$ The site-specific cleanup goals selected for Pu-239/240 and U-233/U234 is the maxima of Pu-239 and Pu-240, and U-233 and U-234, respectively from Table 5-14 of the DP. Only criteria for U-235 (not U-236) are provided in DP Table 5-14. 
TABLE F-2D

2012 Results in Surface Soils Collected at Air Stations Around the WVDP

\begin{tabular}{|c|c|c|c|c|c|}
\hline Analyte & Units & $N$ & \multicolumn{2}{|c|}{ SFRSPRD } & $\begin{array}{c}\text { Background Location } \\
\text { SFGRVAL }\end{array}$ \\
\hline Gross Alpha & $\mu \mathrm{Ci} / \mathrm{g}$ & 1 & \multicolumn{2}{|c|}{$1.93 \pm 0.53 \mathrm{E}-05$} & $2.51 \pm 0.70 \mathrm{E}-05$ \\
\hline Gross Beta & $\mu \mathrm{Ci} / \mathrm{g}$ & 1 & \multicolumn{2}{|c|}{$2.94 \pm 0.44 \mathrm{E}-05$} & $2.93 \pm 0.45 E-05$ \\
\hline K-40 & $\mu \mathrm{Ci} / \mathrm{g}$ & 1 & \multicolumn{2}{|c|}{$1.17 \pm 0.12 \mathrm{E}-05$} & $1.06 \pm 0.13 E-05$ \\
\hline Co-60 & $\mu \mathrm{Ci} / \mathrm{g}$ & 1 & \multicolumn{2}{|c|}{$1.21 \pm 2.54 \mathrm{E}-08$} & $0.05 \pm 2.61 \mathrm{E}-08$ \\
\hline Sr-90 & $\mu \mathrm{Ci} / \mathrm{g}$ & 1 & \multicolumn{2}{|c|}{$5.74 \pm 3.87 \mathrm{E}-08$} & $3.49 \pm 4.03 E-08$ \\
\hline Cs-137 & $\mu \mathrm{Ci} / \mathrm{g}$ & 1 & \multicolumn{2}{|c|}{$1.94 \pm 0.45 E-07$} & $3.50 \pm 0.58 \mathrm{E}-07$ \\
\hline U-232 & $\mu \mathrm{Ci} / \mathrm{g}$ & 1 & \multicolumn{2}{|c|}{$-0.84 \pm 2.86 \mathrm{E}-08$} & $-0.34 \pm 2.73 E-08$ \\
\hline U-233/234 & $\mu \mathrm{Ci} / \mathrm{g}$ & 1 & \multicolumn{2}{|c|}{$7.80 \pm 1.17 \mathrm{E}-07$} & $8.00 \pm 1.20 \mathrm{E}-07$ \\
\hline U-235/236 & $\mu \mathrm{Ci} / \mathrm{g}$ & 1 & \multicolumn{2}{|c|}{$5.56 \pm 3.67 \mathrm{E}-08$} & $3.71 \pm 3.70 \mathrm{E}-08$ \\
\hline U-238 & $\mu \mathrm{Ci} / \mathrm{g}$ & 1 & \multicolumn{2}{|c|}{$8.28 \pm 1.16 \mathrm{E}-07$} & $1.01 \pm 0.13 \mathrm{E}-06$ \\
\hline Total U & $\mu \mathrm{g} / \mathrm{g}$ & 1 & \multicolumn{2}{|c|}{$2.26 \pm 0.13 \mathrm{E}+00$} & $2.26 \pm 0.14 \mathrm{E}+00$ \\
\hline Pu-238 & $\mu \mathrm{Ci} / \mathrm{g}$ & 1 & \multicolumn{2}{|c|}{$0.60 \pm 1.19 \mathrm{E}-08$} & $2.75 \pm 9.34 \mathrm{E}-09$ \\
\hline $\mathrm{Pu}-239 / 240$ & $\mu \mathrm{Ci} / \mathrm{g}$ & 1 & \multicolumn{2}{|c|}{$0.46 \pm 1.11 \mathrm{E}-08$} & $1.65 \pm 1.70 \mathrm{E}-08$ \\
\hline Am-241 & $\mu \mathrm{Ci} / \mathrm{g}$ & 1 & \multicolumn{2}{|c|}{$0.93 \pm 1.46 \mathrm{E}-08$} & $0.61 \pm 1.06 \mathrm{E}-08$ \\
\hline Analyte & Units & $N$ & SFFXVRD & SFRT240 & $\begin{array}{c}\text { Background Location } \\
\text { SFGRVAL }\end{array}$ \\
\hline Gross Alpha & $\mu \mathrm{Ci} / \mathrm{g}$ & 1 & $1.84 \pm 0.59 \mathrm{E}-05$ & $1.61 \pm 0.57 \mathrm{E}-05$ & $2.51 \pm 0.70 \mathrm{E}-05$ \\
\hline Gross Beta & $\mu \mathrm{Ci} / \mathrm{g}$ & 1 & $2.45 \pm 0.44 \mathrm{E}-05$ & $1.83 \pm 0.38 \mathrm{E}-05$ & $2.93 \pm 0.45 \mathrm{E}-05$ \\
\hline $\mathrm{K}-40$ & $\mu \mathrm{Ci} / \mathrm{g}$ & 1 & $1.20 \pm 0.12 \mathrm{E}-05$ & $1.18 \pm 0.13 \mathrm{E}-05$ & $1.06 \pm 0.13 \mathrm{E}-05$ \\
\hline Co-60 & $\mu \mathrm{Ci} / \mathrm{g}$ & 1 & $-0.42 \pm 1.96 \mathrm{E}-08$ & $0.68 \pm 2.35 \mathrm{E}-08$ & $0.05 \pm 2.61 \mathrm{E}-08$ \\
\hline Sr-90 & $\mu \mathrm{Ci} / \mathrm{g}$ & 1 & $2.94 \pm 3.93 \mathrm{E}-08$ & $-1.72 \pm 3.60 \mathrm{E}-08$ & $3.49 \pm 4.03 \mathrm{E}-08$ \\
\hline \begin{tabular}{|l|} 
Cs-137 \\
\end{tabular} & $\mu \mathrm{Ci} / \mathrm{g}$ & 1 & $2.41 \pm 1.97 \mathrm{E}-08$ & $1.50 \pm 0.35 \mathrm{E}-07$ & $3.50 \pm 0.58 \mathrm{E}-07$ \\
\hline Pu-238 & $\mu \mathrm{Ci} / \mathrm{g}$ & 1 & $4.13 \pm 8.10 \mathrm{E}-09$ & $0.53 \pm 1.05 \mathrm{E}-08$ & $2.75 \pm 9.34 \mathrm{E}-09$ \\
\hline Pu-239/240 & $\mu \mathrm{Ci} / \mathrm{g}$ & 1 & $4.13 \pm 9.92 \mathrm{E}-09$ & $1.24 \pm 1.26 \mathrm{E}-08$ & $1.65 \pm 1.70 \mathrm{E}-08$ \\
\hline Am-241 & $\mu \mathrm{Ci} / \mathrm{g}$ & 1 & $-0.31 \pm 1.22 \mathrm{E}-08$ & $0.87 \pm 1.21 \mathrm{E}-08$ & $0.61 \pm 1.06 \mathrm{E}-08$ \\
\hline
\end{tabular}

$\mathrm{N}$ - number of samples. 
TABLE F-2E

2012 Radioactivity in Stream Sediments Around the WVDP

\begin{tabular}{|c|c|c|c|c|c|}
\hline Analyte & Units & $N$ & SFCCSED & SFSDSED & $\begin{array}{c}\text { Background Location } \\
\text { SFBISED }\end{array}$ \\
\hline Gross Alpha & $\mu \mathrm{Ci} / \mathrm{g}$ & 1 & $1.46 \pm 0.60 \mathrm{E}-05$ & $1.04 \pm 0.53 \mathrm{E}-05$ & $1.16 \pm 0.35 \mathrm{E}-05$ \\
\hline Gross Beta & $\mu \mathrm{Ci} / \mathrm{g}$ & 1 & $1.84 \pm 0.43 E-05$ & $1.89 \pm 0.46 \mathrm{E}-05$ & $1.69 \pm 0.29 E-05$ \\
\hline K-40 & $\mu \mathrm{Ci} / \mathrm{g}$ & 1 & $1.29 \pm 0.15 E-05$ & $1.32 \pm 0.14 \mathrm{E}-05$ & $1.37 \pm 0.15 \mathrm{E}-05$ \\
\hline Co-60 & $\mu \mathrm{Ci} / \mathrm{g}$ & 1 & $-0.97 \pm 2.77 E-08$ & $0.10 \pm 2.25 \mathrm{E}-08$ & $0.02 \pm 1.62 \mathrm{E}-08$ \\
\hline Sr-90 & $\mu \mathrm{Ci} / \mathrm{g}$ & 1 & $0.86 \pm 3.60 \mathrm{E}-08$ & $-0.38 \pm 2.90 \mathrm{E}-08$ & $0.04 \pm 4.97 E-08$ \\
\hline Cs-137 & $\mu \mathrm{Ci} / \mathrm{g}$ & 1 & $1.57 \pm 0.51 E-07$ & $1.58 \pm 0.45 E-07$ & $3.73 \pm 2.27 \mathrm{E}-08$ \\
\hline U-232 & $\mu \mathrm{Ci} / \mathrm{g}$ & 1 & $-0.61 \pm 2.13 \mathrm{E}-08$ & $1.10 \pm 2.85 \mathrm{E}-08$ & $0.00 \pm 5.52 \mathrm{E}-08$ \\
\hline U-233/234 & $\mu \mathrm{Ci} / \mathrm{g}$ & 1 & $6.17 \pm 1.11 \mathrm{E}-07$ & $4.73 \pm 0.93 E-07$ & $5.42 \pm 1.19 \mathrm{E}-07$ \\
\hline U-235/236 & $\mu \mathrm{Ci} / \mathrm{g}$ & 1 & $3.14 \pm 3.13 E-08$ & $2.24 \pm 2.94 \mathrm{E}-08$ & $5.73 \pm 3.88 \mathrm{E}-08$ \\
\hline U-238 & $\mu \mathrm{Ci} / \mathrm{g}$ & 1 & $5.84 \pm 1.09 E-07$ & $5.39 \pm 0.94 \mathrm{E}-07$ & $5.30 \pm 1.14 \mathrm{E}-07$ \\
\hline Total U & $\mu \mathrm{g} / \mathrm{g}$ & 1 & $1.95 \pm 0.11 E+00$ & $1.81 \pm 0.10 \mathrm{E}+00$ & $1.91 \pm 0.04 \mathrm{E}+00$ \\
\hline Pu-238 & $\mu \mathrm{Ci} / \mathrm{g}$ & 1 & $-3.30 \pm 9.69 E-09$ & $3.24 \pm 8.97 \mathrm{E}-09$ & $1.11 \pm 1.86 \mathrm{E}-08$ \\
\hline $\mathrm{Pu}-239 / 240$ & $\mu \mathrm{Ci} / \mathrm{g}$ & 1 & $5.34 \pm 9.60 \mathrm{E}-09$ & $8.09 \pm 9.51 \mathrm{E}-09$ & $1.44 \pm 1.44 \mathrm{E}-08$ \\
\hline Am-241 & $\mu \mathrm{Ci} / \mathrm{g}$ & 1 & $0.54 \pm 1.08 \mathrm{E}-08$ & $-1.49 \pm 9.67 \mathrm{E}-09$ & $1.70 \pm 2.24 \mathrm{E}-08$ \\
\hline Analyte & Units & $N$ & SFTCSED & -- & $\begin{array}{c}\text { Background Location } \\
\text { SFBCSED }\end{array}$ \\
\hline Gross Alpha & $\mu \mathrm{Ci} / \mathrm{g}$ & 1 & $1.07 \pm 0.55 \mathrm{E}-05$ & -- & $1.06 \pm 0.39 E-05$ \\
\hline Gross Beta & $\mu \mathrm{Ci} / \mathrm{g}$ & 1 & $1.72 \pm 0.42 \mathrm{E}-05$ & -- & $2.75 \pm 0.32 \mathrm{E}-05$ \\
\hline K-40 & $\mu \mathrm{Ci} / \mathrm{g}$ & 1 & $1.17 \pm 0.09 \mathrm{E}-05$ & -- & $1.30 \pm 0.14 \mathrm{E}-05$ \\
\hline Co-60 & $\mu \mathrm{Ci} / \mathrm{g}$ & 1 & $-0.12 \pm 2.26 \mathrm{E}-08$ & -- & $0.13 \pm 2.54 \mathrm{E}-08$ \\
\hline Sr-90 & $\mu \mathrm{Ci} / \mathrm{g}$ & 1 & $5.99 \pm 3.88 \mathrm{E}-08$ & -- & $-2.65 \pm 3.67 \mathrm{E}-08$ \\
\hline Cs-137 & $\mu \mathrm{Ci} / \mathrm{g}$ & 1 & $1.05 \pm 0.07 E-06$ & -- & $0.36 \pm 2.50 \mathrm{E}-08$ \\
\hline U-232 & $\mu \mathrm{Ci} / \mathrm{g}$ & 1 & $-0.02 \pm 3.06 \mathrm{E}-08$ & -- & $-0.91 \pm 2.50 \mathrm{E}-08$ \\
\hline U-233/234 & $\mu \mathrm{Ci} / \mathrm{g}$ & 1 & $5.10 \pm 1.00 \mathrm{E}-07$ & -- & $5.35 \pm 0.97 \mathrm{E}-07$ \\
\hline U-235/236 & $\mu \mathrm{Ci} / \mathrm{g}$ & 1 & $6.87 \pm 3.97 \mathrm{E}-08$ & -- & $4.23 \pm 3.77 \mathrm{E}-08$ \\
\hline U-238 & $\mu \mathrm{Ci} / \mathrm{g}$ & 1 & $5.77 \pm 0.99 \mathrm{E}-07$ & -- & $6.21 \pm 1.01 \mathrm{E}-07$ \\
\hline Total U & $\mu \mathrm{g} / \mathrm{g}$ & 1 & $1.59 \pm 0.10 E+00$ & -- & $2.28 \pm 0.14 \mathrm{E}+00$ \\
\hline Pu-238 & $\mu \mathrm{Ci} / \mathrm{g}$ & 1 & $-1.64 \pm 9.62 E-09$ & -- & $0.00 \pm 1.44 \mathrm{E}-08$ \\
\hline Pu-239/240 & $\mu \mathrm{Ci} / \mathrm{g}$ & 1 & $0.33 \pm 1.20 \mathrm{E}-08$ & -- & $0.98 \pm 1.39 \mathrm{E}-08$ \\
\hline Am-241 & $\mu \mathrm{Ci} / \mathrm{g}$ & 1 & $0.16 \pm 1.26 \mathrm{E}-08$ & -- & $-0.34 \pm 1.15 E-08$ \\
\hline
\end{tabular}

$\mathrm{N}$ - number of samples.

-- Not applicable; no additional sampling location.

${ }^{a}$ Sediment sampling at Bigelow Bridge (SFBISED), the upstream Cattaraugus Creek background, was discontinued in 2005. The ten-year historical average is used as the comparative reference for the Cattaraugus Creek locations.

${ }^{\mathrm{b}}$ Sampling data at the location upstream in Buttermilk Creek (SFBCSED) is presented as a ten-year rolling average as a comparative reference for Thomas Corners in Buttermilk Creek (SFTCSED) immediately downstream of facility effluents. 


\section{APPENDIX G \\ Summary of Direct Radiation Monitoring Data}

TABLE G-1

Summary of 2012 Semiannual Averages of Off-Site TLD Measurements ${ }^{\mathrm{a}}$

(mR \pm 2 SD/quarter)

\begin{tabular}{|c|c|c|c|}
\hline $\begin{array}{c}\text { Location } \\
\text { Number }\end{array}$ & 1st Half & 2nd Half & $\begin{array}{c}\text { Location } \\
\text { Average }\end{array}$ \\
\hline DFTLD01 & $16 \pm 2$ & $17 \pm 2$ & $17 \pm 2$ \\
\hline DFTLD02 & $17 \pm 2$ & $17 \pm 1$ & $17 \pm 1$ \\
\hline DFTLD03 & $14 \pm 1$ & $14 \pm 1$ & $16 \pm 2$ \\
\hline DFTLD04 & $16 \pm 2$ & $17 \pm 2$ & $16 \pm 2$ \\
\hline DFTLD05 & $15 \pm 2$ & $16 \pm 2$ & $16 \pm 1$ \\
\hline DFTLD06 & $15 \pm 1$ & $17 \pm 1$ & $16 \pm 1$ \\
\hline DFTLD07 & $14 \pm 1$ & $14 \pm 1$ & $16 \pm 2$ \\
\hline DFTLD08 & $16 \pm 2$ & $17 \pm 1$ & $15 \pm 1$ \\
\hline DFTLD09 & $16 \pm 2$ & $17 \pm 1$ & $15 \pm 2$ \\
\hline DFTLD10 & $14 \pm 2$ & $15 \pm 1$ & $16 \pm 1$ \\
\hline DFTLD11 & $15 \pm 2$ & $15 \pm 1$ & $17 \pm 1$ \\
\hline DFTLD12 & $15 \pm 1$ & $16 \pm 1$ & $16 \pm 2$ \\
\hline DFTLD13 & $17 \pm 1$ & $18 \pm 1$ & $16 \pm 1$ \\
\hline DFTLD14 & $15 \pm 2$ & $16 \pm 1$ & $16 \pm 1$ \\
\hline DFTLD15 & $15 \pm 1$ & $16 \pm 1$ & $14 \pm 1$ \\
\hline DFTLD16 & $15 \pm 1$ & $16 \pm 1$ & $17 \pm 1$ \\
\hline DFTLD20 & $14 \pm 1$ & $14 \pm 1$ & $17 \pm 1$ \\
\hline DFTLD23 (Background) & $16 \pm 1$ & & \\
\hline
\end{tabular}

${ }^{a}$ The frequency of collection at the TLD locations was reduced from quarterly to semiannual in 2008, however data are reported in units of $\mathrm{mR}$ per quarter for comparability with historical results.

${ }^{b}$ Off-site locations are shown on Figures A-12 and A-13.

Conversion factor: Milliroentgen $(\mathrm{mR})$ units are used to report exposure rates in air. To convert $\mathrm{mR}$ to $\mathrm{mrem}$ (dose to humans), a conversion factor of 1.03 must be applied. For example, a reported exposure rate of $18.1 \mathrm{mR} /$ quarter would be equivalent to $18.6 \mathrm{mrem} /$ quarter (based upon dose-equivalent phantom calibration using cesium-137). 
TABLE G-2

Summary of 2012 Semiannual Averages of On-Site TLD Measurements ${ }^{\text {a }}$ (mR土2SD/quarter)

\begin{tabular}{|c|c|c|c|}
\hline $\begin{array}{c}\text { Location } \\
\text { Number }^{b}\end{array}$ & 1st Half & 2nd Half & $\begin{array}{c}\text { Location } \\
\text { Average }\end{array}$ \\
\hline DNTLD24 & $547 \pm 66$ & $544 \pm 58$ & $545 \pm 62$ \\
\hline DNTLD28 & $17 \pm 2$ & $18 \pm 1$ & $18 \pm 2$ \\
\hline DNTLD32 & $15 \pm 1$ & $17 \pm 2$ & $16 \pm 2$ \\
\hline DNTLD33 & $18 \pm 2$ & $20 \pm 3$ & $18 \pm 2$ \\
\hline DNTLD34 & $18 \pm 2$ & $18 \pm 1$ & $18 \pm 1$ \\
\hline DNTLD35 & $19 \pm 2$ & $18 \pm 1$ & $50 \pm 8$ \\
\hline DNTLD36 & $18 \pm 2$ & $17 \pm 1$ & $127 \pm 17$ \\
\hline DNTLD38 & $50 \pm 7$ & $51 \pm 9$ & $14 \pm 1$ \\
\hline DNTLD40 & $123 \pm 17$ & $131 \pm 17$ & $17 \pm 1$ \\
\hline DNTLD43 & $14 \pm 1$ & 17 & \\
\hline
\end{tabular}

${ }^{a}$ The frequency of collection at the TLD locations was reduced from quarterly to semiannual in 2008, however data are reported in units of $\mathrm{mR}$ per quarter for comparability with historical results.

${ }^{b}$ On-site locations are shown on Figure A-11.

Conversion factor: Milliroentgen $(\mathrm{mR})$ units are used to report exposure rates in air. To convert $\mathrm{mR}$ to $\mathrm{mrem}$ (dose to humans), a conversion factor of 1.03 must be applied. For example, a reported exposure rate of $18.1 \mathrm{mR} /$ quarter would be equivalent to $18.6 \mathrm{mrem} /$ quarter (based upon dose-equivalent phantom calibration using cesium-137). 


\section{APPENDIX H \\ Summary of Quality Assurance Crosscheck Analyses}

TABLE H-1

Crosscheck Sample Comparisons From the DOE Mixed Analyte Performance

Evaluation Program (MAPEP) ${ }^{\text {; }}$; Study 26; February 2012

\begin{tabular}{|c|c|c|c|c|c|c|c|}
\hline Analyte & Matrix & Units & $\begin{array}{c}\text { Reported } \\
\text { Value }\end{array}$ & \begin{tabular}{|c}
$\begin{array}{c}\text { Reference } \\
\text { Value }\end{array}$ \\
\end{tabular} & Acceptance Range & Accept? ${ }^{b}$ & $\begin{array}{c}\text { Analyzed } \\
\text { by: }\end{array}$ \\
\hline \multicolumn{8}{|c|}{ MAPEP - 12 - GrF26, Air Filter - Gross Alpha/Beta } \\
\hline Gross alpha & Air Filter & $\mathrm{Bq} /$ sample & 0.499 & 1.2 & $0.4-2.0$ & Yes & ELAB \\
\hline Gross beta & Air Filter & Bq/sample & 2.50 & 2.4 & $1.2-3.6$ & Yes & ELAB \\
\hline \multicolumn{8}{|c|}{ MAPEP - 12-RdF26, Air Filter - Radiological } \\
\hline Am-241 & Air Filter & $\mathrm{Bq} /$ sample & 0.0660 & 0.073 & $0.051-0.095$ & Yes & GEL \\
\hline Cs-137 & Air Filter & Bq/sample & 1.910 & 1.79 & $1.25-2.33$ & Yes & GEL \\
\hline Co-60 & Air Filter & $\mathrm{Bq} /$ sample & 2.235 & 2.182 & $1.527-2.837$ & Yes & GEL \\
\hline Pu-238 & Air Filter & $\mathrm{Bq} /$ sample & 0.004 & 0.0015 & Sensitivity Evaluation & Yes & GEL \\
\hline Pu-239/240 & Air Filter & $\mathrm{Bq} /$ sample & 0.088 & 0.097 & $0.068-0.126$ & Yes & GEL \\
\hline Sr-90 & Air Filter & $\mathrm{Bq} /$ sample & 0.012 & $c^{c}$ & False Positive & Yes & GEL \\
\hline U-233/234 & Air Filter & $\mathrm{Bq} /$ sample & 0.010 & 0.0188 & $0.0132-0.0244$ & No & GEL \\
\hline $\mathrm{U}-238$ & Air Filter & $\mathrm{Bq} /$ sample & 0.111 & 0.124 & 0.087-0.161 & Yes & GEL \\
\hline \multicolumn{8}{|c|}{ MAPEP - 12 - GrW26, Water - Gross Alpha/Beta } \\
\hline Gross alpha & Water & $\mathrm{Bq} / \mathrm{L}$ & 2.02 & 2.14 & $0.64-3.64$ & Yes & ELAB \\
\hline Gross beta & Water & $\mathrm{Bq} / \mathrm{L}$ & 6.19 & 6.36 & $3.18-9.54$ & Yes & ELAB \\
\hline Gross alpha & Water & $\mathrm{Bq} / \mathrm{L}$ & 2.043 & 2.14 & $0.64-3.64$ & Yes & GEL \\
\hline Gross beta & Water & $\mathrm{Bq} / \mathrm{L}$ & 6.820 & 6.36 & $3.18-9.54$ & Yes & GEL \\
\hline \multicolumn{8}{|c|}{ MAPEP-12-XaW26, Water-Alkaline } \\
\hline lodine-129 & Water & $\mathrm{Bq} / \mathrm{L}$ & 12.2 & 12.29 & $8.60-15.98$ & Yes & GEL \\
\hline \multicolumn{8}{|c|}{ MAPEP - 12-MaW26, Water-Radiological } \\
\hline Cs-137 & Water & $\mathrm{Bq} / \mathrm{L}$ & 40.0 & 39.9 & $27.9-51.9$ & Yes & ELAB \\
\hline Co-60 & Water & $\mathrm{Bq} / \mathrm{L}$ & 23.5 & 23.72 & $16.60-30.84$ & Yes & ELAB \\
\hline $\mathrm{H}-3$ & Water & $\mathrm{Bq} / \mathrm{L}$ & 454 & 437 & $306-568$ & Yes & ELAB \\
\hline Sr-90 & Water & $\mathrm{Bq} / \mathrm{L}$ & 0.0930 & ${ }^{c}$ & False Positive & Yes & ELAB \\
\hline Am-241 & Water & $\mathrm{Bq} / \mathrm{L}$ & 1.5067 & 1.63 & $1.14-2.12$ & Yes & GEL \\
\hline Cs-137 & Water & $\mathrm{Bq} / \mathrm{L}$ & 41.15 & 39.9 & $27.9-51.9$ & Yes & GEL \\
\hline Co-60 & Water & $\mathrm{Bq} / \mathrm{L}$ & 23.9 & 23.72 & $16.60-30.84$ & Yes & GEL \\
\hline $\mathrm{H}-3$ & Water & $\mathrm{Bq} / \mathrm{L}$ & 481.7 & 437 & $306-568$ & Yes & GEL \\
\hline $\mathrm{Pu}-238$ & Water & $\mathrm{Bq} / \mathrm{L}$ & 0.5550 & 0.629 & $0.440-0.818$ & Yes & GEL \\
\hline $\mathrm{Pu}-239 / 240$ & Water & $\mathrm{Bq} / \mathrm{L}$ & 1.230 & 1.34 & $0.94-1.74$ & Yes & GEL \\
\hline Sr-90 & Water & $\mathrm{Bq} / \mathrm{L}$ & 0.01 & $c$ & False Positive & Yes & GEL \\
\hline \begin{tabular}{|l|} 
TC-99 \\
\end{tabular} & Water & $\mathrm{Bq} / \mathrm{L}$ & 26.3 & 27.9 & $19.5-36.3$ & Yes & GEL \\
\hline U-233/234 & Water & $\mathrm{Bq} / \mathrm{L}$ & 0.381 & 0.392 & $0.274-0.510$ & Yes & GEL \\
\hline U-238 & Water & $\mathrm{Bq} / \mathrm{L}$ & 2.537 & 2.76 & $1.93-3.59$ & Yes & GEL \\
\hline
\end{tabular}

ELAB - WVDP Environmental Laboratory.

GEL - General Engineering Laboratory.

Note: This report includes only those matrix/analyte combinations performed in support of the analysis of environmental samples collected as part of the WVDP monitoring program or special investigations.

${ }^{a}$ MAPEP monitors performance and requests corrective action as required.

b "Yes" - Result acceptable; "No" - Result not acceptable. Bias >+/- 50\% or the reported result is not statistically positive at two standard deviations.

${ }^{c}$ Although no actual reference value or acceptance range was provided, the results were assessed by MAPEP as acceptable. 
TABLE H-1 (continued)

Crosscheck Sample Comparisons From the DOE Mixed Analyte Performance

Evaluation Program (MAPEP) ${ }^{\text {a }}$; Study 26; February 2012

\begin{tabular}{|c|c|c|c|c|c|c|c|}
\hline Analyte & Matrix & Units & $\begin{array}{c}\text { Reported } \\
\text { Value }\end{array}$ & $\begin{array}{c}\begin{array}{c}\text { Reference } \\
\text { Value }\end{array} \\
\end{array}$ & $\begin{array}{c}\text { Acceptance } \\
\text { Range }\end{array}$ & Accept? ${ }^{b}$ & $\begin{array}{c}\text { Analyzed } \\
\text { by: }\end{array}$ \\
\hline \multicolumn{8}{|c|}{ MAPEP-12-MaW26, Water-Inorganic } \\
\hline Antimony & Water & $\mathrm{mg} / \mathrm{L}$ & 2.58 & 2.71 & $1.90-3.52$ & Yes & GEL \\
\hline Arsenic & Water & $\mathrm{mg} / \mathrm{L}$ & $<0.03$ & $<0.01$ & False Positive & Yes & GEL \\
\hline Barium & Water & $\mathrm{mg} / \mathrm{L}$ & 0.728 & 0.808 & $0.566-1.050$ & Yes & GEL \\
\hline Beryllium & Water & $\mathrm{mg} / \mathrm{L}$ & 0.733 & 0.808 & $0.566-1.050$ & Yes & GEL \\
\hline Cadmium & Water & $\mathrm{mg} / \mathrm{L}$ & 0.394 & 0.418 & $0.293-0.543$ & Yes & GEL \\
\hline Chromium & Water & $\mathrm{mg} / \mathrm{L}$ & 1.64 & 1.73 & $1.21-2.25$ & Yes & GEL \\
\hline Cobalt & Water & $\mathrm{mg} / \mathrm{L}$ & 1.29 & 1.45 & $1.02-1.89$ & Yes & GEL \\
\hline Copper & Water & $\mathrm{mg} / \mathrm{L}$ & 0.923 & 0.929 & $0.650-1.208$ & Yes & GEL \\
\hline Lead & Water & $\mathrm{mg} / \mathrm{L}$ & 0.693 & 0.779 & $0.545-1.013$ & Yes & GEL \\
\hline Mercury & Water & $\mathrm{mg} / \mathrm{L}$ & 0.00352 & 0.00375 & \begin{tabular}{|l|l|}
$0.00263-0.00488$ \\
\end{tabular} & Yes & GEL \\
\hline Nickel & Water & $\mathrm{mg} / \mathrm{L}$ & $<0.005$ & $<0.01$ & False Positive & Yes & GEL \\
\hline Selenium & Water & $\mathrm{mg} / \mathrm{L}$ & 0.203 & 0.223 & $0.156-0.290$ & Yes & GEL \\
\hline Thallium & Water & $\mathrm{mg} / \mathrm{L}$ & 0.730 & 0.846 & $0.592-1.100$ & Yes & GEL \\
\hline Uranium - total & Water & $\mathrm{mg} / \mathrm{L}$ & 0.197 & 0.222 & $0.155-0.289$ & Yes & GEL \\
\hline Vanadium & Water & $\mathrm{mg} / \mathrm{L}$ & 1.45 & 1.44 & $1.01-1.87$ & Yes & GEL \\
\hline Zinc & Water & $\mathrm{mg} / \mathrm{L}$ & 2.13 & 2.28 & $1.60-2.96$ & Yes & GEL \\
\hline \multicolumn{8}{|c|}{ MAPEP - 12 - MaS26, Soil - Inorganic } \\
\hline Antimony & Soil & $\mathrm{mg} / \mathrm{kg}$ & 50.1 & $\mathrm{NE}$ & $\mathrm{NE}$ & $\mathrm{NE}$ & GEL \\
\hline Arsenic & Soil & $\mathrm{mg} / \mathrm{kg}$ & 45.3 & 48.2 & $33.7-62.7$ & Yes & GEL \\
\hline Barium & Soil & $\mathrm{mg} / \mathrm{kg}$ & 645 & 655 & $459-852$ & Yes & GEL \\
\hline Beryllium & Soil & $\mathrm{mg} / \mathrm{kg}$ & 43.8 & 47.5 & 33.3-61.8 & Yes & GEL \\
\hline Cadmium & Soil & $\mathrm{mg} / \mathrm{kg}$ & 9.28 & 10.6 & $7.4-13.8$ & Yes & GEL \\
\hline Chromium & Soil & $\mathrm{mg} / \mathrm{kg}$ & 81.6 & 89.3 & $62.5-116.1$ & Yes & GEL \\
\hline Cobalt & Soil & $\mathrm{mg} / \mathrm{kg}$ & 99.8 & 113 & $79-147$ & Yes & GEL \\
\hline Copper & Soil & $\mathrm{mg} / \mathrm{kg}$ & 197 & 206 & $144-268$ & Yes & GEL \\
\hline Lead & Soil & $\mathrm{mg} / \mathrm{kg}$ & 69.5 & 74.4 & $52.1-96.7$ & Yes & GEL \\
\hline Mercury & Soil & $\mathrm{mg} / \mathrm{kg}$ & 0.0785 & 0.0733 & $00513-0.0953$ & Yes & GEL \\
\hline Nickel & Soil & $\mathrm{mg} / \mathrm{kg}$ & 163 & 186 & $130-242$ & Yes & GEL \\
\hline Selenium & Soil & $\mathrm{mg} / \mathrm{kg}$ & 12.5 & 14.2 & $9.9-18.5$ & Yes & GEL \\
\hline Silver & Soil & $\mathrm{mg} / \mathrm{kg}$ & 81.0 & 85.5 & 59.9-111.2 & Yes & GEL \\
\hline Thallium & Soil & $\mathrm{mg} / \mathrm{kg}$ & 13.1 & 14.4 & $10.1-18.7$ & Yes & GEL \\
\hline Uranium - total & Soil & $\mathrm{mg} / \mathrm{kg}$ & 24.6 & 26.5 & $18.6-34.5$ & Yes & GEL \\
\hline Vanadium & Soil & $\mathrm{mg} / \mathrm{kg}$ & 99.1 & 104 & $73-135$ & Yes & GEL \\
\hline Zinc & Soil & $\mathrm{mg} / \mathrm{kg}$ & 248 & 286 & $200-372$ & Yes & GEL \\
\hline
\end{tabular}

GEL - General Engineering Laboratory.

NE-Not Evaluated.

${ }^{a}$ MAPEP monitors performance and requests corrective action as required.

b "Yes" - Result acceptable. 
TABLE H-1 (continued)

Crosscheck Sample Comparisons From the DOE Mixed Analyte Performance

Evaluation Program (MAPEP) ${ }^{\text {; }}$; Study 26; February 2012

\begin{tabular}{|c|c|c|c|c|c|c|c|}
\hline Analyte & Matrix & Units & $\begin{array}{c}\text { Reported } \\
\text { Value }\end{array}$ & $\begin{array}{c}\text { Reference } \\
\text { Value }\end{array}$ & Acceptance Range & Accept? ${ }^{b}$ & $\begin{array}{c}\text { Analyzed } \\
\text { by: }\end{array}$ \\
\hline \multicolumn{8}{|c|}{ MAPEP - 12-MaS26, Soil - Radiological } \\
\hline Am-241 & Soil & $\mathrm{Bq} / \mathrm{kg}$ & 152 & 159 & 111-207 & Yes & GEL \\
\hline Cs-137 & Soil & $\mathrm{Bq} / \mathrm{kg}$ & -0.04 & c & False positive & Yes & GEL \\
\hline Co-60 & Soil & $\mathrm{Bq} / \mathrm{kg}$ & 0.97 & 1.56 & Sensitivity Evaluation & Yes & GEL \\
\hline $\mathrm{Pu}-238$ & Soil & $\mathrm{Bq} / \mathrm{kg}$ & 127.67 & 136 & $95-177$ & Yes & GEL \\
\hline $\mathrm{Pu}-239 / 240$ & Soil & $\mathrm{Bq} / \mathrm{kg}$ & 61.13 & 65.8 & $46.1-85.5$ & Yes & GEL \\
\hline $\mathrm{K}-40$ & Soil & $\mathrm{Bq} / \mathrm{kg}$ & 1495 & 1491 & $1044-1938$ & Yes & GEL \\
\hline Sr-90 & Soil & $\mathrm{Bq} / \mathrm{kg}$ & 391.7 & 392 & $274-510$ & Yes & GEL \\
\hline Tc-99 & Soil & $\mathrm{Bq} / \mathrm{kg}$ & 345.3 & 374 & $262-486$ & Yes & GEL \\
\hline U-233/234 & Soil & $\mathrm{Bq} / \mathrm{kg}$ & 62.90 & 68.1 & $47.7-88.5$ & Yes & GEL \\
\hline $\mathrm{U}-238$ & Soil & $\mathrm{Bq} / \mathrm{kg}$ & 309.33 & 329 & $230-428$ & Yes & GEL \\
\hline \multicolumn{8}{|c|}{ MAPEP - 12 - RdV26, Vegetation - Radiological } \\
\hline $\mathrm{Am}-241$ & Veg & Bq/sample & 0.005 & c & False positive & Yes & GEL \\
\hline Cs-137 & Veg & Bq/sample & -0.025 & c & False positive & Yes & GEL \\
\hline Co-60 & Veg & Bq/sample & 6.255 & 6.05 & 4.24-7.87 & Yes & GEL \\
\hline Pu-238 & Veg & Bq/sample & 0.194 & 0.219 & $0.153-0.285$ & Yes & GEL \\
\hline $\mathrm{Pu}-239 / 240$ & Veg & Bq/sample & 0.1226 & 0.152 & $0.106-0.198$ & Yes & GEL \\
\hline Sr-90 & Veg & Bq/sample & 1.613 & 2.11 & $1.48-2.74$ & Yes & GEL \\
\hline $\mathrm{U}-233 / 234$ & Veg & Bq/sample & 0.030 & 0.0411 & $0.0288-0.0534$ & Yes & GEL \\
\hline $\mathrm{U}-238$ & Veg & Bq/sample & 0.224 & 0.278 & $0.195-0.361$ & Yes & GEL \\
\hline \multicolumn{8}{|c|}{ MAPEP - 12-OrW26, Water-Organic Compounds } \\
\hline Heptachlor & Water & $\mu \mathrm{g} / \mathrm{L}$ & $<0.02$ & $<1.0$ & $\bar{c}$ & Yes & GEL \\
\hline 1,2,4-Trichlorobenzene & Water & $\mu \mathrm{g} / \mathrm{L}$ & $<10.0$ & $<10.0$ & $c^{c}$ & Yes & GEL \\
\hline 1,2-Dichlorobenzene & Water & $\mu \mathrm{g} / \mathrm{L}$ & $<10.0$ & $<10.0$ & $\bar{c}$ & Yes & GEL \\
\hline 1,3-Dichlorobenzene & Water & $\mu \mathrm{g} / \mathrm{L}$ & 50.2 & 53.76 & $10.39-97.14$ & Yes & GEL \\
\hline 1,4-Dichlorobenzene & Water & $\mu \mathrm{g} / \mathrm{L}$ & $<10.0$ & $<10.0$ & c & Yes & GEL \\
\hline 2,4,5-Trichlorophenol & Water & $\mu \mathrm{g} / \mathrm{L}$ & 61.8 & 57.19 & $25.35-89.02$ & Yes & GEL \\
\hline 2,4,6-Trichlorophenol & Water & $\mu \mathrm{g} / \mathrm{L}$ & 87.5 & 79.7 & $32.2-127.2$ & Yes & GEL \\
\hline 2,4-Dichlorophenol & Water & $\mu \mathrm{g} / \mathrm{L}$ & 169 & 138.6 & $59.3-218.0$ & Yes & GEL \\
\hline 2,4-Dimethylphenol & Water & $\mu g / L$ & 81.8 & 83.4 & $23.2-143.5$ & Yes & GEL \\
\hline 2,4-Dinitrophenol & Water & $\mu \mathrm{g} / \mathrm{L}$ & 98.5 & 81.4 & 11.9-167.7 & Yes & GEL \\
\hline 2,4-Dinitrotoluene & Water & $\mu \mathrm{g} / \mathrm{L}$ & 95.8 & 107.2 & 50.4-164.1 & Yes & GEL \\
\hline 2,6-Dichlorophenol & Water & $\mu g / L$ & $<10.0$ & $<10.0$ & $c$ & Yes & GEL \\
\hline 2,6-Dinitrotoluene & Water & $\mu \mathrm{g} / \mathrm{L}$ & 148 & 156.9 & 79.3-234.5 & Yes & GEL \\
\hline 2-Chloronaphthalene & Water & $\mu \mathrm{g} / \mathrm{L}$ & $<1.0$ & $<10.0$ & $c$ & Yes & GEL \\
\hline 2-Chlorophenol & Water & $\mu g / L$ & 104 & 113.3 & $41.8-184.7$ & Yes & GEL \\
\hline 2-Methylnaphthalene & Water & $\mu g / L$ & $<1.0$ & $<10.0$ & $c$ & Yes & GEL \\
\hline
\end{tabular}

GEL - General Engineering Laboratory.

${ }^{a}$ MAPEP monitors performance and requests corrective action as required.

$b$ "Yes" - Result acceptable; "W" - Result acceptable with warning 20\%<Bias<30\%; "No" - Result not acceptable.

${ }^{c}$ Although no actual reference value or acceptance range was provided, the results were assessed by MAPEP as acceptable. 
TABLE H-1 (concluded)

Crosscheck Sample Comparisons From the DOE Mixed Analyte Performance

Evaluation Program (MAPEP) ${ }^{\text {; }}$; Study 26; February 2012

\begin{tabular}{|c|c|c|c|c|c|c|c|}
\hline Analyte & Matrix & Units & $\begin{array}{c}\text { Reported } \\
\text { Value }\end{array}$ & $\begin{array}{c}\text { Reference } \\
\text { Value }\end{array}$ & $\begin{array}{c}\text { Acceptance } \\
\text { Range }\end{array}$ & Accept? ${ }^{b}$ & $\begin{array}{c}\text { Analyzed } \\
\text { by: }\end{array}$ \\
\hline \multicolumn{8}{|c|}{ MAPEP - 12 - OrW26, Water - Organic Compounds } \\
\hline 2-Methylphenol & Water & $\mu \mathrm{g} / \mathrm{L}$ & 73.2 & 81.5 & $21.6-141.4$ & Yes & GEL \\
\hline 2-Nitrophenol & Water & $\mu \mathrm{g} / \mathrm{L}$ & $<10.0$ & $<10.0$ & $c$ & Yes & GEL \\
\hline 4-Methylphenol & Water & $\mu \mathrm{g} / \mathrm{L}$ & 33.9 & 36.45 & $5.25-70.40$ & Yes & GEL \\
\hline 4,6-Dinitro-2-methylphenol & Water & $\mu \mathrm{g} / \mathrm{L}$ & $<10.0$ & $<10.0$ & $c^{c}$ & Yes & GEL \\
\hline 4-Bromophenyl-phenylether & Water & $\mu \mathrm{g} / \mathrm{L}$ & $<10.0$ & $<10.0$ & $\bar{c}$ & Yes & GEL \\
\hline 4-Chloro-3-methylphenol & Water & $\mu \mathrm{g} / \mathrm{L}$ & 69.7 & 64.43 & $29.42-99.43$ & Yes & GEL \\
\hline 4-Chlorophenyl-phenylether & Water & $\mu \mathrm{g} / \mathrm{L}$ & 156 & 156.7 & $72.6-240.7$ & Yes & GEL \\
\hline 4-Nitrophenol & Water & $\mu \mathrm{g} / \mathrm{L}$ & $<10.0$ & $<10.0$ & $c$ & Yes & GEL \\
\hline Acenaphthene & Water & $\mu \mathrm{g} / \mathrm{L}$ & 17.7 & 20.64 & $10.88-30.40$ & Yes & GEL \\
\hline Acenaphthylene & Water & $\mu \mathrm{g} / \mathrm{L}$ & $<1.0$ & $<10.0$ & ${ }^{c}$ & Yes & GEL \\
\hline Anthracene & Water & $\mu \mathrm{g} / \mathrm{L}$ & 44.4 & 70.65 & $35.69-105.61$ & Yes & GEL \\
\hline Benzo(a)anthracene & Water & $\mu \mathrm{g} / \mathrm{L}$ & 28.2 & 37.63 & $19.47-55.80$ & Yes & GEL \\
\hline Benzo(a)pyrene & Water & $\mu \mathrm{g} / \mathrm{L}$ & 24.8 & 31.47 & $11.86-51.09$ & Yes & GEL \\
\hline Benzo(b)fluoranthene & Water & $\mu \mathrm{g} / \mathrm{L}$ & 16.8 & 22.39 & $8.23-36.55$ & Yes & GEL \\
\hline Benzo(g,h,i)perylene & Water & $\mu \mathrm{g} / \mathrm{L}$ & 13.6 & 22.19 & $5.59-38.789$ & Yes & GEL \\
\hline Benzo(k)fluoranthene & Water & $\mu \mathrm{g} / \mathrm{L}$ & 19.8 & 24.82 & $5.94-43.71$ & Yes & GEL \\
\hline bis(2-chloroethoxy)methane & Water & $\mu \mathrm{g} / \mathrm{L}$ & $<10.0$ & $<10.0$ & S & Yes & GEL \\
\hline bis(2-chloroethyl)ether & Water & $\mu \mathrm{g} / \mathrm{L}$ & 45.5 & 51.94 & $19.21-84.68$ & Yes & GEL \\
\hline bis(2-chloroisopropyl)ether & Water & $\mu \mathrm{g} / \mathrm{L}$ & $<10.0$ & $<10.0$ & $c^{c}$ & Yes & GEL \\
\hline Bis(2-ethylhexyl)phthalate & Water & $\mu \mathrm{g} / \mathrm{L}$ & 17.8 & 27.75 & $9.50-46.00$ & Yes & GEL \\
\hline Butylbenzylphthalate & Water & $\mu \mathrm{g} / \mathrm{L}$ & 78.4 & 88.4 & $20.1-156.6$ & Yes & GEL \\
\hline Chrysene & Water & $\mu \mathrm{g} / \mathrm{L}$ & 15.0 & 22.01 & $10.35-33.68$ & Yes & GEL \\
\hline Di-n-butylphthalate & Water & $\mu \mathrm{g} / \mathrm{L}$ & $<10.0$ & $<10.0$ & ${ }^{c}$ & Yes & GEL \\
\hline Di-n-octylphthalate & Water & $\mu \mathrm{g} / \mathrm{L}$ & $<10.0$ & $<10.0$ & $c^{c}$ & Yes & GEL \\
\hline Dibenzo(a,h)anthracene & Water & $\mu \mathrm{g} / \mathrm{L}$ & 10.9 & 16.11 & $4.33-27.89$ & Yes & GEL \\
\hline Dibenzofuran & Water & $\mu \mathrm{g} / \mathrm{L}$ & $<10.0$ & $<10.0$ & $c^{c}$ & Yes & GEL \\
\hline Diethylphthalate & Water & $\mu \mathrm{g} / \mathrm{L}$ & $<10.0$ & $<10.0$ & $\bar{c}$ & Yes & GEL \\
\hline Dimethylphthalate & Water & $\mu \mathrm{g} / \mathrm{L}$ & 116 & 105.1 & $c$ & Yes & GEL \\
\hline Fluoranthene & Water & $\mu \mathrm{g} / \mathrm{L}$ & $<1.0$ & $<10.0$ & $c^{c}$ & Yes & GEL \\
\hline Fluorene & Water & $\mu \mathrm{g} / \mathrm{L}$ & 23.8 & 27.90 & $11.76-44.05$ & Yes & GEL \\
\hline Hexachlorobenzene & Water & $\mu \mathrm{g} / \mathrm{L}$ & 20.9 & 38.06 & $18.80-57.32$ & Yes & GEL \\
\hline Hexachlorobutadiene & Water & $\mu \mathrm{g} / \mathrm{L}$ & $<10.0$ & $<10.0$ & $c^{c}$ & Yes & GEL \\
\hline Hexachlorocyclopentadiene & Water & $\mu \mathrm{g} / \mathrm{L}$ & $<10.0$ & $<10.0$ & ${ }^{c}$ & Yes & GEL \\
\hline Hexachloroethane & Water & $\mu \mathrm{g} / \mathrm{L}$ & 86.5 & 91.2 & $15.2-167.1$ & Yes & GEL \\
\hline Indeno(1,2,3-c,d)pyrene & Water & $\mu \mathrm{g} / \mathrm{L}$ & 15.4 & 26.25 & $5.30-47.20$ & Yes & GEL \\
\hline Isophorone & Water & $\mu \mathrm{g} / \mathrm{L}$ & 39.9 & 50.56 & $23.82-77.30$ & Yes & GEL \\
\hline \begin{tabular}{|l|} 
Napthalene \\
\end{tabular} & Water & $\mu \mathrm{g} / \mathrm{L}$ & 143 & 124.5 & $44.3-204.6$ & Yes & GEL \\
\hline Nitrobenzene & Water & $\mu \mathrm{g} / \mathrm{L}$ & $<10.0$ & $<10.0$ & ${ }^{c}$ & Yes & GEL \\
\hline Pentachlorophenol & Water & $\mu \mathrm{g} / \mathrm{L}$ & 64.9 & 64.83 & $19.04-110.62$ & Yes & GEL \\
\hline Phenanthrene & Water & $\mu \mathrm{g} / \mathrm{L}$ & $<1.0$ & $<10.0$ & & Yes & GEL \\
\hline Phenol & Water & $\mu \mathrm{g} / \mathrm{L}$ & $<10.0$ & $<10.0$ & $14.86-199.28$ & Yes & GEL \\
\hline Pyrene & Water & $\mu \mathrm{g} / \mathrm{L}$ & 20.5 & 29.69 & $10.59-48.79$ & Yes & GEL \\
\hline
\end{tabular}

GEL - General Engineering Laboratory.

${ }^{a}$ MAPEP monitors performance and requests corrective action as required.

$b$ "Yes" - Result acceptable.

${ }^{c}$ Although no actual reference value or acceptance range was provided, the results were assessed by MAPEP as acceptable. 
TABLE H-2

Crosscheck Sample Comparisons From the DOE Mixed Analyte Performance Evaluation Program (MAPEP) ${ }^{\text {; }}$; Study 27; August 2012

\begin{tabular}{|c|c|c|c|c|c|c|c|}
\hline Analyte & Matrix & Units & $\begin{array}{c}\text { Reported } \\
\text { Value }\end{array}$ & $\begin{array}{c}\text { Reference } \\
\text { Value }\end{array}$ & Acceptance Range & Accept? ${ }^{b}$ & $\begin{array}{c}\text { Analyzed } \\
\text { by: }\end{array}$ \\
\hline \multicolumn{8}{|c|}{ MAPEP - 12 - GrF27, Air Filter - Gross Alpha/Beta } \\
\hline Gross Alpha & Air Filter & Bq/sample & 0.2253 & 0.97 & $0.29-1.65$ & No & GEL \\
\hline Gross Beta & Air Filter & Bq/sample & 1.930 & 1.92 & $0.96-2.88$ & Yes & GEL \\
\hline \multicolumn{8}{|c|}{ MAPEP - 12 - RdF27, Air Filter - Radiological } \\
\hline Am-241 & Air Filter & Bq/sample & 0.0716 & 0.0780 & $0.0546-0.1014$ & Yes & GEL \\
\hline Cs-137 & Air Filter & $\mathrm{Bq} /$ sample & -0.016 & c & False positive & Yes & $\overline{G E L}$ \\
\hline Co-60 & Air Filter & Bq/sample & 1.865 & 1.728 & $1.210-2.246$ & Yes & GEL \\
\hline Pu-238 & Air Filter & Bq/sample & 0.061 & 0.0625 & $0.0438-0.0813$ & Yes & GEL \\
\hline Pu-239/240 & Air Filter & $\mathrm{Bq} /$ sample & -0.002 & 0.00081 & $\bar{d}$ & Yes & GEL \\
\hline Sr-90 & Air Filter & Bq/sample & 0.914 & 1.03 & $0.72-1.34$ & Yes & $\overline{G E L}$ \\
\hline U-233/234 & Air Filter & Bq/sample & 0.009 & 0.0141 & $0.0099-0.0183$ & No & GEL \\
\hline$U-238$ & Air Filter & $\mathrm{Bq} /$ sample & 0.087 & 0.1 & $0.070-0.130$ & Yes & GEL \\
\hline \multicolumn{8}{|c|}{ MAPEP - 12 - GrW27, Water - Gross Alpha/Beta } \\
\hline Gross Alpha & Water & $\mathrm{Bq} / \mathrm{L}$ & 1.737 & 1.79 & $0.54-3.04$ & Yes & GEL \\
\hline Gross Beta & Water & $\mathrm{Bq} / \mathrm{L}$ & 8.893 & 9.1 & $4.6-13.7$ & Yes & GEL \\
\hline \multicolumn{8}{|c|}{ MAPEP - 12 - MaW27, Water - Radiological } \\
\hline Am-241 & Water & $\mathrm{Bq} / \mathrm{L}$ & 0.9407 & 1.06 & $0.74-1.38$ & Yes & GEL \\
\hline Cs-137 & Water & $\mathrm{Bq} / \mathrm{L}$ & 17.05 & 16.7 & $11.7-21.7$ & Yes & GEL \\
\hline Co-60 & Water & $\mathrm{Bq} / \mathrm{L}$ & 0.03 & $c$ & False positive & Yes & GEL \\
\hline $\mathrm{H}-3$ & Water & $\mathrm{Bq} / \mathrm{L}$ & 334.0 & 334 & $234-434$ & Yes & GEL \\
\hline Pu-238 & Water & $\mathrm{Bq} / \mathrm{L}$ & 0.0088 & 0.013 & $d$ & Yes & GEL \\
\hline $\mathrm{Pu}-239 / 240$ & Water & $\mathrm{Bq} / \mathrm{L}$ & 1.440 & 1.61 & $1.13-2.09$ & Yes & $\overline{G E L}$ \\
\hline Sr-90 & Water & $\mathrm{Bq} / \mathrm{L}$ & 11.13 & 12.2 & $8.5-15.9$ & Yes & GEL \\
\hline Tc-99 & Water & $\mathrm{Bq} / \mathrm{L}$ & 4.5 & 4.58 & $3.21-5.95$ & Yes & GEL \\
\hline U-233/234 & Water & $\mathrm{Bq} / \mathrm{L}$ & 0.414 & 0.451 & $0.316-0.586$ & Yes & GEL \\
\hline $\mathrm{U}-238$ & Water & $\mathrm{Bq} / \mathrm{L}$ & 2.960 & 3.33 & $2.33-4.33$ & Yes & GEL \\
\hline
\end{tabular}

GEL - General Engineering Laboratory.

Note: This report includes only those matrix/analyte combinations performed in support of the analysis of environmental samples collected as part of the WVDP monitoring program or special investigations.

${ }^{a}$ MAPEP monitors performance and requests corrective action as required.

b "Yes" -Result acceptable; "No" (Gross Alpha) = Result not acceptable, Bias $>+/-70 \%$ or the reported result is not statistically positive at two standard deviations (Result/Uncertainty); "No" (U-233/234) = Result not acceptable Bias > 30\%.

${ }^{c}$ Although no actual reference value or acceptance range was provided, the results were assessed by MAPEP as acceptable.

${ }^{\mathrm{d}}$ Sensitivity evaluation, reported a statistically zero result. 
TABLE H-2 (continued)

Crosscheck Sample Comparisons From the DOE Mixed Analyte Performance Evaluation

Program (MAPEP) ${ }^{\text {; }}$; Study 27; August 2012

\begin{tabular}{|c|c|c|c|c|c|c|c|}
\hline Analyte & Matrix & Units & $\begin{array}{c}\text { Reported } \\
\text { Value }\end{array}$ & $\begin{array}{c}\text { Reference } \\
\text { Value }\end{array}$ & $\begin{array}{c}\text { Acceptance } \\
\text { Range }\end{array}$ & Accept? ${ }^{b}$ & $\begin{array}{c}\text { Analyzed } \\
\text { by: }\end{array}$ \\
\hline \multicolumn{8}{|c|}{ MAPEP - 12 - MaW27, Water - Inorganic } \\
\hline Antimony & Water & $\mathrm{mg} / \mathrm{L}$ & 3.28 & 3.38 & 2.37-4.39 & Yes & GEL \\
\hline Arsenic & Water & $\mathrm{mg} / \mathrm{L}$ & 1.16 & 1.13 & $0.79-1.47$ & Yes & GEL \\
\hline Barium & Water & $\mathrm{mg} / \mathrm{L}$ & 3.72 & 4.00 & $2.80-5.20$ & Yes & GEL \\
\hline Beryllium & Water & $\mathrm{mg} / \mathrm{L}$ & $<0.005$ & $c$ & False Positive & Yes & GEL \\
\hline Cadmium & Water & $\mathrm{mg} / \mathrm{L}$ & 0.496 & 0.506 & $0.354-0.658$ & Yes & GEL \\
\hline Chromium & Water & $\mathrm{mg} / \mathrm{L}$ & 0.538 & 0.561 & $0.393-0.729$ & Yes & GEL \\
\hline Cobalt & Water & $\mathrm{mg} / \mathrm{L}$ & 2.91 & 3.11 & $2.18-4.04$ & Yes & GEL \\
\hline Copper & Water & $\mathrm{mg} / \mathrm{L}$ & $<0.01$ & $c^{c}$ & False Positive & Yes & GEL \\
\hline Lead & Water & $\mathrm{mg} / \mathrm{L}$ & 1.94 & 2.06 & $1.44-2.68$ & Yes & GEL \\
\hline Mercury & Water & $\mathrm{mg} / \mathrm{L}$ & 0.0032 & 0.00349 & $0.00244-0.00454$ & Yes & GEL \\
\hline Nickel & Water & $\mathrm{mg} / \mathrm{L}$ & 3.73 & 3.99 & $2.79-5.19$ & Yes & GEL \\
\hline Selenium & Water & $\mathrm{mg} / \mathrm{L}$ & $<0.005$ & ${ }^{c}$ & False Positive & Yes & GEL \\
\hline Thallium & Water & $\mathrm{mg} / \mathrm{L}$ & 2.17 & 2.47 & $1.73-3.21$ & Yes & GEL \\
\hline Uranium - total & Water & $\mathrm{mg} / \mathrm{L}$ & 0.244 & 0.268 & $0.188-0.348$ & Yes & GEL \\
\hline Vanadium & Water & $\mathrm{mg} / \mathrm{L}$ & 1.67 & 1.59 & $1.11-2.07$ & Yes & GEL \\
\hline Zinc & Water & $\mathrm{mg} / \mathrm{L}$ & 3.22 & 3.27 & $2.29-4.25$ & Yes & GEL \\
\hline \multicolumn{8}{|c|}{ MAPEP - 12 - MaS27, Soil - Inorganic } \\
\hline Antimony & Soil & $\mathrm{mg} / \mathrm{kg}$ & 106 & 111.5 & $78.1-145.0$ & Yes & GEL \\
\hline Arsenic & Soil & $\mathrm{mg} / \mathrm{kg}$ & 48.7 & 55.7 & $39.0-72.4$ & Yes & GEL \\
\hline Barium & Soil & $\mathrm{mg} / \mathrm{kg}$ & 785 & 896 & $627-1165$ & Yes & GEL \\
\hline Beryllium & Soil & $\mathrm{mg} / \mathrm{kg}$ & 43.5 & 47.0 & $32.9-61.1$ & Yes & GEL \\
\hline Cadmium & Soil & $\mathrm{mg} / \mathrm{kg}$ & 13.0 & 15.4 & $10.8-20.0$ & Yes & GEL \\
\hline Chromium & Soil & $\mathrm{mg} / \mathrm{kg}$ & 90.5 & 99.0 & 69.3-128.7 & Yes & GEL \\
\hline Cobalt & Soil & $\mathrm{mg} / \mathrm{kg}$ & 110 & 127 & $89-165$ & Yes & GEL \\
\hline Copper & Soil & $\mathrm{mg} / \mathrm{kg}$ & 202 & 204 & $143-265$ & Yes & GEL \\
\hline Lead & Soil & $\mathrm{mg} / \mathrm{kg}$ & 84.4 & 97.6 & 68.3-126.9 & Yes & GEL \\
\hline Mercury & Soil & $\mathrm{mg} / \mathrm{kg}$ & 0.172 & 0.172 & $0.120-0.224$ & Yes & GEL \\
\hline Nickel & Soil & $\mathrm{mg} / \mathrm{kg}$ & 260 & 300 & $210-390$ & Yes & GEL \\
\hline Selenium & Soil & $\mathrm{mg} / \mathrm{kg}$ & 14.0 & 17.7 & $12.4-23.0$ & W & GEL \\
\hline Silver & Soil & $\mathrm{mg} / \mathrm{kg}$ & 89.3 & 95.5 & 66.9-124.2 & Yes & GEL \\
\hline Thallium & Soil & $\mathrm{mg} / \mathrm{kg}$ & 77.4 & 91.0 & 63.7-118.3 & Yes & GEL \\
\hline Uranium - total & Soil & $\mathrm{mg} / \mathrm{kg}$ & 19.65 & 21.2 & $14.8-27.6$ & Yes & GEL \\
\hline Vanadium & Soil & $\mathrm{mg} / \mathrm{kg}$ & 248 & 271 & $190-352$ & Yes & GEL \\
\hline Zinc & Soil & $\mathrm{mg} / \mathrm{kg}$ & 462 & 549 & $384-714$ & Yes & GEL \\
\hline
\end{tabular}

GEL - General Engineering Laboratory.

${ }^{a}$ MAPEP monitors performance and requests corrective action as required.

b "Yes" - Result acceptable; "W" - Result acceptable with warning $20 \%<$ Bias $<30 \%$.

${ }^{\mathrm{C}}$ Although no actual value or acceptance range was provided, the results were assessed by MAPEP as acceptable. 
TABLE H-2 (continued)

Crosscheck Sample Comparisons From the DOE Mixed Analyte Performance Evaluation

Program (MAPEP) ${ }^{\text {; }}$; Study 27; August 2012

\begin{tabular}{|l|c|c|c|c|c|c|c|c|}
\hline \multicolumn{1}{|c|}{ Analyte } & Matrix & Units & $\begin{array}{c}\text { Reported } \\
\text { Value }\end{array}$ & $\begin{array}{c}\text { Reference } \\
\text { Value }\end{array}$ & $\begin{array}{c}\text { Acceptance } \\
\text { Range }\end{array}$ & ${\text { Accept? }{ }^{b}}^{\text {Analyzed }}$ \\
by:
\end{tabular}

GEL - General Engineering Laboratory.

${ }^{a}$ MAPEP monitors performance and requests corrective action as required.

b "Yes" - Result acceptable.

${ }^{c}$ Although no actual value or acceptance range was provided, the results were assessed by MAPEP as acceptable. 
TABLE H-2 (continued)

Crosscheck Sample Comparisons From the DOE Mixed Analyte Performance Evaluation

Program (MAPEP) ${ }^{\text {; }}$; Study 27; August 2012

\begin{tabular}{|c|c|c|c|c|c|c|c|}
\hline Analyte & Matrix & Units & $\begin{array}{c}\text { Reported } \\
\text { Value }\end{array}$ & $\begin{array}{c}\text { Reference } \\
\text { Value }\end{array}$ & $\begin{array}{c}\text { Acceptance } \\
\text { Range }\end{array}$ & Accept? ${ }^{b}$ & $\begin{array}{c}\text { Analyzed } \\
\text { by: }\end{array}$ \\
\hline \multicolumn{8}{|c|}{ MAPEP - 12-OrW27, Water - Organic Compounds } \\
\hline Heptachlor & Water & $\mu \mathrm{g} / \mathrm{L}$ & 5.16 & $c^{c}$ & c & $c^{c}$ & GEL \\
\hline 1,2,4-Trichlorobenzene & Water & $\mu \mathrm{g} / \mathrm{L}$ & 43.4 & 50.2 & $14.6-85.7$ & Yes & GEL \\
\hline 1,2-Dichlorobenzene & Water & $\mu \mathrm{g} / \mathrm{L}$ & 40.3 & 50.5 & $8.6-92.5$ & Yes & GEL \\
\hline 1,3-Dichlorobenzene & Water & $\mu \mathrm{g} / \mathrm{L}$ & 30.9 & 40.4 & 8.0-72.8 & Yes & GEL \\
\hline 1,4-Dichlorobenzene & Water & $\mu \mathrm{g} / \mathrm{L}$ & 44.3 & 56.3 & 8.7-104.8 & Yes & GEL \\
\hline 2,4,5-Trichlorophenol & Water & $\mu \mathrm{g} / \mathrm{L}$ & 110 & 116 & $50-183$ & Yes & GEL \\
\hline 2,4,6-Trichlorophenol & Water & $\mu \mathrm{g} / \mathrm{L}$ & $<10.0$ & $<10$ & $d$ & Yes & GEL \\
\hline 2,4-Dichlorophenol & Water & $\mu \mathrm{g} / \mathrm{L}$ & 63.4 & 63.0 & 25.1-100.8 & Yes & GEL \\
\hline 2,4-Dimethylphenol & Water & $\mu \mathrm{g} / \mathrm{L}$ & 107 & 109 & $31-186$ & Yes & GEL \\
\hline 2,4-Dinitrophenol & Water & $\mu \mathrm{g} / \mathrm{L}$ & 74.8 & 73 & $11-152$ & Yes & GEL \\
\hline 2,4-Dinitrotoluene & Water & $\mu \mathrm{g} / \mathrm{L}$ & 58.5 & 64.5 & $29.0-100.1$ & Yes & GEL \\
\hline 2,6-Dichlorophenol & Water & $\mu \mathrm{g} / \mathrm{L}$ & $<10.0$ & $<10$ & $d$ & Yes & GEL \\
\hline 2,6-Dinitrotoluene & Water & $\mu \mathrm{g} / \mathrm{L}$ & 16.8 & 18.6 & $8.0-29.2$ & Yes & GEL \\
\hline 2-Chloronaphthalene & Water & $\mu \mathrm{g} / \mathrm{L}$ & 87.1 & 107 & $43-170$ & Yes & GEL \\
\hline 2-Chlorophenol & Water & $\mu \mathrm{g} / \mathrm{L}$ & 61.2 & 75.5 & $28.5-122.5$ & Yes & GEL \\
\hline 2-Methylnaphthalene & Water & $\mu \mathrm{g} / \mathrm{L}$ & 49.0 & 46.6 & $11.9-81.4$ & Yes & GEL \\
\hline 2-Methylphenol & Water & $\mu \mathrm{g} / \mathrm{L}$ & 44.6 & 53.4 & $14.0-92.8$ & Yes & GEL \\
\hline 2-Nitrophenol & Water & $\mu \mathrm{g} / \mathrm{L}$ & 105 & 106 & $32-181$ & Yes & GEL \\
\hline 4-Methylphenol & Water & $\mu \mathrm{g} / \mathrm{L}$ & 55.0 & 59.0 & 8.7-113.8 & Yes & GEL \\
\hline 4,6-Dinitro-2-methylphenol & Water & $\mu \mathrm{g} / \mathrm{L}$ & $<10.0$ & $<10$ & $d$ & Yes & GEL \\
\hline 4-Bromophenyl-phenylether & Water & $\mu \mathrm{g} / \mathrm{L}$ & 102 & 115 & $45-185$ & Yes & GEL \\
\hline 4-Chloro-3-methylphenol & Water & $\mu \mathrm{g} / \mathrm{L}$ & 127 & 126 & $59-193$ & Yes & GEL \\
\hline 4-Chlorophenyl-phenylether & Water & $\mu \mathrm{g} / \mathrm{L}$ & 37.0 & 42.8 & $19.7-66.0$ & Yes & GEL \\
\hline 4-Nitrophenol & Water & $\mu \mathrm{g} / \mathrm{L}$ & 28.4 & 37.3 & $6.9-94.8$ & Yes & GEL \\
\hline Acenaphthene & Water & $\mu g / L$ & $<1.0$ & $<10$ & $d$ & Yes & GEL \\
\hline Acenaphthylene & Water & $\mu \mathrm{g} / \mathrm{L}$ & $<1.0$ & $<10$ & $d$ & Yes & GEL \\
\hline Anthracene & Water & $\mu \mathrm{g} / \mathrm{L}$ & $<1.0$ & $<10$ & $d$ & Yes & GEL \\
\hline Benzo(a)anthracene & Water & $\mu \mathrm{g} / \mathrm{L}$ & $<1.0$ & $<10$ & $d$ & Yes & GEL \\
\hline Benzo(a)pyrene & Water & $\mu \mathrm{g} / \mathrm{L}$ & $<1.0$ & $<10$ & $d$ & Yes & GEL \\
\hline Benzo(b)fluoranthene & Water & $\mu \mathrm{g} / \mathrm{L}$ & $<1.0$ & $<10$ & $d$ & Yes & GEL \\
\hline Benzo(g,h,i)perylene & Water & $\mu \mathrm{g} / \mathrm{L}$ & $<1.0$ & $<10$ & $d$ & Yes & GEL \\
\hline Benzo(k)fluoranthene & Water & $\mu \mathrm{g} / \mathrm{L}$ & $<1.0$ & $<10$ & $d$ & Yes & GEL \\
\hline bis(2-chloroethoxy)methane & Water & $\mu \mathrm{g} / \mathrm{L}$ & 67.8 & 71.5 & $35.6-107.5$ & Yes & GEL \\
\hline bis(2-chloroethyl)ether & Water & $\mu \mathrm{g} / \mathrm{L}$ & 10.9 & 15.5 & $6.4-24.6$ & Yes & GEL \\
\hline bis(2-chloroisopropyl)ether & Water & $\mu \mathrm{g} / \mathrm{L}$ & 42.3 & 55.9 & 19.4-92.4 & Yes & GEL \\
\hline Bis(2-ethylhexyl)phthalate & Water & $\mu \mathrm{g} / \mathrm{L}$ & $<10.0$ & $<10$ & $d$ & Yes & GEL \\
\hline Butylbenzylphthalate & Water & $\mu \mathrm{g} / \mathrm{L}$ & 50.0 & 62.5 & 11.7-113.3 & Yes & GEL \\
\hline
\end{tabular}

GEL - General Engineering Laboratory.

${ }^{a}$ MAPEP monitors performance and requests corrective action as required.

b "Yes" - Result acceptable.

${ }^{c}$ Analyte was not evaluated by MAPEP.

${ }^{d}$ Although no actual value or acceptance range was provided, the results were assessed by MAPEP as acceptable. 
TABLE H-2 (concluded)

Crosscheck Sample Comparisons From the DOE Mixed Analyte Performance Evaluation

Program (MAPEP) ${ }^{\text {a }}$; Study 27; August 2012

\begin{tabular}{|c|c|c|c|c|c|c|c|}
\hline Analyte & Matrix & Units & $\begin{array}{c}\text { Reported } \\
\text { Value }\end{array}$ & $\begin{array}{c}\text { Reference } \\
\text { Value }\end{array}$ & $\begin{array}{c}\text { Acceptance } \\
\text { Range }\end{array}$ & $\begin{array}{c}\text { Accept? } \\
b\end{array}$ & $\begin{array}{c}\text { Analyzed } \\
\text { by: }\end{array}$ \\
\hline \multicolumn{8}{|c|}{ MAPEP - 12 - OrW27, Water - Organic Compounds } \\
\hline Chrysene & Water & $\mu \mathrm{g} / \mathrm{L}$ & $<1.0$ & $<10$ & c & Yes & GEL \\
\hline Di-n-butylphthalate & Water & $\mu \mathrm{g} / \mathrm{L}$ & 62.7 & 64.9 & 25.9-103.9 & Yes & GEL \\
\hline Di-n-octylphthalate & Water & $\mu \mathrm{g} / \mathrm{L}$ & 73.4 & 81.1 & $21.4-140.8$ & Yes & GEL \\
\hline Dibenzo(a,h)anthracene & Water & $\mu \mathrm{g} / \mathrm{L}$ & $<1.0$ & $<10$ & $c$ & Yes & GEL \\
\hline Dibenzofuran & Water & $\mu \mathrm{g} / \mathrm{L}$ & 51.3 & 59.2 & $26.1-92.3$ & Yes & GEL \\
\hline Diethylphthalate & Water & $\mu \mathrm{g} / \mathrm{L}$ & 42.8 & 44.1 & $8.6-79.6$ & Yes & GEL \\
\hline Dimethylphthalate & Water & $\mu \mathrm{g} / \mathrm{L}$ & 66.5 & 59.8 & $8.8-128.6$ & Yes & GEL \\
\hline Fluoranthene & Water & $\mu \mathrm{g} / \mathrm{L}$ & $<1.0$ & $<10$ & $c$ & Yes & GEL \\
\hline Fluorene & Water & $\mu \mathrm{g} / \mathrm{L}$ & $<1.0$ & $<10$ & $\bar{c}$ & Yes & GEL \\
\hline Hexachlorobenzene & Water & $\mu \mathrm{g} / \mathrm{L}$ & 22.0 & 38.9 & $19.2-58.5$ & Yes & GEL \\
\hline Hexachlorobutadiene & Water & $\mu \mathrm{g} / \mathrm{L}$ & 25.5 & 35.8 & $5.3-67.2$ & Yes & GEL \\
\hline Hexachlorocyclopentadiene & Water & $\mu \mathrm{g} / \mathrm{L}$ & 55.1 & 65 & $11-146$ & Yes & GEL \\
\hline Hexachloroethane & Water & $\mu \mathrm{g} / \mathrm{L}$ & 24.1 & 32.3 & $4.9-59.7$ & Yes & GEL \\
\hline Indeno $(1,2,3-c, d)$ pyrene & Water & $\mu \mathrm{g} / \mathrm{L}$ & $<1.0$ & $<10$ & $c$ & Yes & GEL \\
\hline Isophorone & Water & $\mu \mathrm{g} / \mathrm{L}$ & 64.1 & 63.9 & $30.0-97.9$ & Yes & GEL \\
\hline Napthalene & Water & $\mu \mathrm{g} / \mathrm{L}$ & $<1.0$ & $<10$ & $c$ & Yes & GEL \\
\hline Nitrobenzene & Water & $\mu \mathrm{g} / \mathrm{L}$ & 45.8 & 48.9 & 20.1-77.7 & Yes & GEL \\
\hline Pentachlorophenol & Water & $\mu \mathrm{g} / \mathrm{L}$ & 115 & 124 & $41-207$ & Yes & GEL \\
\hline Phenanthrene & Water & $\mu \mathrm{g} / \mathrm{L}$ & $<1.0$ & $<10$ & $\bar{c}$ & Yes & GEL \\
\hline Phenol & Water & $\mu \mathrm{g} / \mathrm{L}$ & 23.4 & 44.7 & 7.9-107.8 & Yes & GEL \\
\hline Pyrene & Water & $\mu \mathrm{g} / \mathrm{L}$ & $<1.0$ & $<10$ & 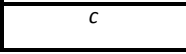 & Yes & GEL \\
\hline
\end{tabular}

GEL - General Engineering Laboratory.

${ }^{a}$ MAPEP monitors performance and requests corrective action as required.

b "Yes" - Result acceptable.

${ }^{c}$ Although no actual value or acceptance range was provided, the results were assessed by MAPEP as acceptable. 
TABLE H-3

Comparisons of Results From Crosscheck Samples Analyzed for Water Quality Parameters as Part of the EPA's 2012 Discharge Monitoring Report - Quality Assurance (DMR-QA) Study 32; (2012) for the National Pollutant Discharge Elimination System (NPDES)

\begin{tabular}{|c|c|c|c|c|c|c|}
\hline Analyte & Units & \begin{tabular}{|c|}
$\begin{array}{c}\text { Reported } \\
\text { Value }\end{array}$ \\
\end{tabular} & \begin{tabular}{|c}
$\begin{array}{c}\text { Reference } \\
\text { Value }\end{array}$ \\
\end{tabular} & $\begin{array}{c}\text { Acceptance } \\
\text { Range }^{a}\end{array}$ & Accept? ${ }^{b}$ & Analyzed by: \\
\hline Aluminum & $\mu \mathrm{g} / \mathrm{L}$ & 935 & 967 & $778-1,150$ & Yes & TestAmerica \\
\hline Aluminum & $\mu \mathrm{g} / \mathrm{L}$ & 2,770 & 2,520 & $2,080-2,930$ & Yes & GEL \\
\hline Ammonia (as N) & $\mathrm{mg} / \mathrm{L}$ & 6.1 & 6.77 & $4.97-8.56$ & Yes & TestAmerica \\
\hline Antimony & $\mu \mathrm{g} / \mathrm{L}$ & 509 & 532 & $372-640$ & Yes & TestAmerica \\
\hline Arsenic & $\mu \mathrm{g} / \mathrm{L}$ & 62.7 & 71.7 & $55.8-87.1$ & Yes & TestAmerica \\
\hline Barium & $\mu \mathrm{g} / \mathrm{L}$ & 439 & 434 & $376-489$ & Yes & TestAmerica \\
\hline Biochemical oxygen demand & $\mathrm{mg} / \mathrm{L}$ & 45.6 & 79.3 & $25.2-87.2$ & Yes & TestAmerica \\
\hline $\mathrm{BOD}$ & $\mathrm{mg} / \mathrm{L}$ & 97 & 90.4 & $45.7-135$ & Yes & GEL \\
\hline Cadmium & $\mu \mathrm{g} / \mathrm{L}$ & 310 & 315 & $268-358$ & Yes & TestAmerica \\
\hline Chlorine (total residual) & $\mu \mathrm{g} / \mathrm{L}$ & 110 & 154 & $94.0-214$ & Yes & WWTF \\
\hline Chromium (total) & $\mu \mathrm{g} / \mathrm{L}$ & 561 & 583 & $508-660$ & Yes & TestAmerica \\
\hline Chromium (hexavalent) & $\mu \mathrm{g} / \mathrm{L}$ & 82.8 & 71 & $52.7-86.7$ & Yes & TestAmerica \\
\hline Cobalt & $\mu \mathrm{g} / \mathrm{L}$ & 207 & 222 & $194-250$ & Yes & TestAmerica \\
\hline Copper & $\mu \mathrm{g} / \mathrm{L}$ & 310 & 303 & $273-335$ & Yes & TestAmerica \\
\hline Copper & $\mu \mathrm{g} / \mathrm{L}$ & 848 & 812 & 731-893 & Yes & GEL \\
\hline Cyanide, total & $\mathrm{mg} / \mathrm{L}$ & 0.305 & 0.293 & $0.145-0.447$ & Yes & TestAmerica \\
\hline Iron & $\mu \mathrm{g} / \mathrm{L}$ & 302 & 315 & $275-361$ & Yes & TestAmerica \\
\hline Iron & $\mu \mathrm{g} / \mathrm{L}$ & 433 & 406 & $356-463$ & Yes & GEL \\
\hline Lead & $\mu \mathrm{g} / \mathrm{L}$ & 1,410 & 1,470 & $1,290-1,640$ & Yes & TestAmerica \\
\hline Lead & $\mu \mathrm{g} / \mathrm{L}$ & 316 & 320 & $276-363$ & Yes & GEL \\
\hline Manganese & $\mu \mathrm{g} / \mathrm{L}$ & 2,520 & 2,480 & $2,230-2,750$ & Yes & TestAmerica \\
\hline Mercury, 1631E & $\mu \mathrm{g} / \mathrm{L}$ & 13.8 & 14.0 & $8.62-18.9$ & Yes & GEL \\
\hline Nickel & $\mu \mathrm{g} / \mathrm{L}$ & 2630 & 2690 & $2,420-3,000$ & Yes & TestAmerica \\
\hline Nitrate (as N) & $\mathrm{mg} / \mathrm{L}$ & 33.6 & 37.3 & 29.1-45.0 & Yes & TestAmerica \\
\hline Nitrite (as N) & $\mathrm{mg} / \mathrm{L}$ & 0.456 & 0.459 & $0.331-0.578$ & Yes & TestAmerica \\
\hline Oil \& Grease (Gravimetric) & $\mathrm{mg} / \mathrm{L}$ & 179 & 188 & $139-213$ & Yes & TestAmerica \\
\hline Oil \& Grease (Gravimetric) & $\mathrm{mg} / \mathrm{L}$ & 62.0 & 65.0 & $43.8-77.6$ & Yes & GEL \\
\hline $\mathrm{pH}$ & SU & 7.23 & 7.23 & $7.03-7.43$ & Yes & ELAB \\
\hline Phosphorus (total, as P) & $\mathrm{mg} / \mathrm{L}$ & 2.45 & 1.99 & $1.59-2.44$ & No & GEL \\
\hline Selenium & $\mu \mathrm{g} / \mathrm{L}$ & 1,210 & 1,230 & $981-1,430$ & Yes & TestAmerica \\
\hline Sulfate & $\mathrm{mg} / \mathrm{L}$ & 56.4 & 54.0 & $44.3-62.3$ & Yes & TestAmerica \\
\hline Settleable solids & $\mathrm{mg} / \mathrm{L}$ & 42 & 34.1 & $28.1-43.0$ & Yes & WWTF \\
\hline Settleable solids & $\mathrm{mL} / \mathrm{L}$ & 9.50 & 9.34 & $6.70-12.8$ & Yes & TestAmerica \\
\hline Suspended solids (total) & $\mathrm{mg} / \mathrm{L}$ & 18 & 25 & $16.7-30.7$ & Yes & TestAmerica \\
\hline Total dissolved solids & $\mathrm{mg} / \mathrm{L}$ & 334 & 358 & $271-445$ & Yes & GEL \\
\hline Total dissolved solids & $\mathrm{mg} / \mathrm{L}$ & 467 & 509 & $391-627$ & Yes & TestAmerica \\
\hline Total Kjeldahl nitrogen (as $\mathrm{N}$ ) & $\mathrm{mg} / \mathrm{L}$ & 26.4 & 25.7 & $16.9-33.0$ & Yes & TestAmerica \\
\hline Vanadium & $\mu \mathrm{g} / \mathrm{L}$ & 735 & 775 & $679-867$ & Yes & TestAmerica \\
\hline Zinc & $\mu \mathrm{g} / \mathrm{L}$ & 954 & 1,040 & $893-1,190$ & Yes & TestAmerica \\
\hline Zinc & $\mu \mathrm{g} / \mathrm{L}$ & 364 & 366 & $313-424$ & Yes & GEL \\
\hline
\end{tabular}

TestAmerica - TestAmerica Laboratories, Inc., Buffalo.

WWTF - WVDP Wastewater Treatment Facility Laboratory.

GEL - General Engineering Laboratory.

ELAB - WVDP Environmental Laboratory.

Samples provided by Environmental Research Associates (ERA).

${ }^{a}$ Acceptance limits are determined by ERA or the New York State Department of Health (NYSDOH), as applicable.

b "Yes" - Result acceptable; "No" - Result not acceptable. 
TABLE H-3 (concluded)

Comparisons of Results From Crosscheck Samples Analyzed for Water Quality Parameters as

Part of the EPA's 2012 Discharge Monitoring Report - Quality Assurance (DMR-QA) Study 32;

(2012) for the National Pollutant Discharge Elimination System (NPDES)

\begin{tabular}{|l|c|c|c|c|c|c|}
\hline \multicolumn{1}{|c|}{ Analyte } & Units & $\begin{array}{c}\text { Reported } \\
\text { Value }\end{array}$ & $\begin{array}{c}\text { Reference } \\
\text { Value }\end{array}$ & $\begin{array}{c}\text { Acceptance } \\
\text { Range }^{a}\end{array}$ & ${\text { Accept? }{ }^{b}}^{2}$ & Analyzed by: $^{c}$ \\
\hline \multicolumn{7}{|c|}{ Toxicity } \\
\hline $\begin{array}{l}\text { Fathead Minnow Acute MHSF } \\
25^{\circ}-\text { LC50 754 }\end{array}$ & $\%$ & 27.8 & 21.0 & $5.95-36.0$ & Yes & New England Bioassay \\
\hline $\begin{array}{l}\text { Fathead Minnow Chronic } \\
\text { MHSF - Survival NOEC 756 }\end{array}$ & $\%$ & 25.0 & 25.0 & $12.5-50.0$ & Yes & New England Bioassay \\
\hline $\begin{array}{l}\text { Ceriodaphnia Acute MHSF 250 - } \\
\text { LC50 764 }\end{array}$ & $\%$ & 100.0 & 46.1 & $7.23-85.1$ & No & New England Bioassay \\
\hline $\begin{array}{l}\text { Ceriodaphnia Chronic MHSF - } \\
\text { Survival NOEC 766 }\end{array}$ & $\%$ & 50.0 & 25.0 & $12.5-50.0$ & Yes & New England Bioassay \\
\hline $\begin{array}{l}\text { Ceriodaphnia Chronic MHSF - } \\
\text { Reproduction IC25 767 }\end{array}$ & $\%$ & 31.9 & 23.1 & $2.27-43.9$ & Yes & New England Bioassay \\
\hline $\begin{array}{l}\text { Ceriodaphnia Chronic MHSF - } \\
\text { Reproduction NOEC 768 }\end{array}$ & $\%$ & 25.0 & 12.5 & $6.25-25.0$ & Yes & New England Bioassay \\
\hline $\begin{array}{l}\text { Fathead Minnow Chronic } \\
\text { MHSF - Growth IC25 (ON) 808 }\end{array}$ & $\%$ & 24.3 & 29.4 & $9.33-49.4$ & Yes & New England Bioassay \\
\hline $\begin{array}{l}\text { Fathead Minnow Chronic } \\
\text { MHSF - Growth NOEC (ON) 810 }\end{array}$ & $\%$ & 25.0 & 25.0 & $12.5-50.0$ & Yes & New England Bioassay \\
\hline
\end{tabular}

Samples provided by Environmental Research Associates (ERA).

a Acceptance limits are determined by ERA or the New York State Department of Health (NYSDOH), as applicable.

b "Yes" - Result acceptable; "No" - Result not acceptable.

${ }^{c}$ Analyzing Laboratory- New England Bioassay A Division of GZA GeoEnvironmental, Inc. 
This page intentionally left blank 


\title{
APPENDIX I \\ West Valley Demonstration Project Act
}

\author{
West Valley Demonstration Project Act \\ (Public Law 96-368 [S.2443]; October 1, 1980)
}

(As presented in Exhibit $\mathrm{G}$ of the Cooperative Agreement between United States Department of Energy and New York State Energy Research and Development Authority on the Western New York Nuclear Service Center at West Valley, New York; Effective October 1, 1980 as amended September 18, 1981.)

\author{
EXHIBIT G \\ WEST VALLEY PROJECT DEMONSTRATION ACT
}

PUBLIC LAW 96-368 [S. 2443]; October 1, 1980

WEST VALLEY DEMONSTRATION PROJECT ACT

For Legislatize History of this and other Law'se Table 1, Public
Laz's and Legislative History, at end of final z'olume

An Act to authorize the Department of Energy to carry out a high.level liquid
nuclear waste management demonstratlon project at the Wegtern New
York Service Center in West Valley, New York.

Be it enacted by the Senate and House of Representatives of the United States of America in Congress assembled, SECTION 1. This Act may be cited as the "West Valley Demonstration Project Act".

SEC. 2. (a) The Secretary shall carry out, in accordance with this Act . project at the Western New York Service Center in West Valley, New note. York, for the purpose of demonstrating solidification techniques which can be used for preparing high level radioactive waste for disposal. Under the project the Secretary shall carry out the follow- Activities. ing activities:

(1) The Secretary shall solidify, in a form suitable for transportation and disposal, the high level radioactive waste at the Center by vitrification or by such other technology which the Secretary determines to be the most effective for solidification. (2) The Secretary shall develop containers suitable for the permanent disposal of the high level radioactive waste solidified permanent dispos

(3) The Secretary shall, as soon as feasible, transport, in accordance with applicable provisions of law, the waste solidified at the Center to an appropriate Federal repository for permanent disposal.

(4) The Secretary shall, in accordance with applicable licensing requirements, dispose of low level radioactive waste and transuranic waste produced by the solidification of the high level radioactive waste under the project.

(5) The Secretary shall decontaminate and decommission(A) the tanks and other facilities of the Center in which the high level radioactive waste solidified under the project was stored,

(B) the facilities used in the solidification of the waste, and (C) any material and hardware used in connection with the project,

in accordance with such requirements as the Commission may

(b) Before undertaking the project and during the fiscal year ending September 30,1981 , the Secretary shall carry out the following:
(1) The Secretary shall hold in the vicinity of the Center public Hearings.

(1) The Secretary shall hold in the vicinity of the Center public hearings to inform the residents of the area in which the Center
is located of the activities proposed to be undertaken under the is located of the activities proposed to be undertake

(2) The Secretary shall consider the various technologies available for the solidification and handling of high level radioactive waste taking into account the unique characteristic of such waste at the Center.

94 STAT. 1347

$\mathrm{G}-1$ 
P.L. 96-368

41 USC 501 note.

State costs, percentage.

Licensing amendment application.

42 USC 2011

42 USC 5801

note.

Publications in Federal Register.
LAWS OF 96th CONG.-2nd SESS. ' Oct. 1

(3) The Secretary shall-

(A) undertake detailed engineering and cost estimates for the project,

(B) prepare a plan for the safe removal of the high level radioactive waste at the Center for the purposes of solidification and include in the plan provisions respecting the safe breaching of the tanks in which the waste is stored, operating equipment to accomplish the removal, and sluicing techniques,

(C) conduct appropriate safety analyses of the project, and

(D) prepare required environmental impact analyses of the project.

(4) The Secretary shall enter into a cooperative agreement with the State in accordance with the Federal Grant and Cooperative Agreement Act of 1977 under which the State will carry out the following:

(A) The State will make available to the Secretary the facilities of the Center and the high level radioactive waste at the Center which are necessary for the completion of the project. The facilities and the waste shall be made available without the transfer of title and for such period as may be required for completion of the project.

(B) The Secretary shall provide technical assistance in securing required license amendments.

(C) The State shall pay 10 per centum of the costs of the project, as determined by the Secretary. In determining the costs of the project, the Secretary shall consider the value of the use of the Center for the project. The State may not use Federal funds to pay its share of the cost of the project, but may use the perpetual care fund to pay such share.

(D) Submiseion jointly by the Department of Energy and the State of New York of an application for a licensing amendment as soon as possible with the Nuclear Regulatory Commission providing for the demonstration.

(c) Within one year from the date of the enactment of this Act, the Secretary shall enter into an agreement with the Commission to establish arrangements for review and consultation by the Commission with respect to the project: Provided, That review and consultation by the Commission pursuant to this subsection shall be conducted informally by the Commission and shall not include nor require formal procedures or actions by the Commission pursuant to the Atomic Energy Act of 1954, as amended, the Energy Reorganization Act of 1974, as amended, or any other law. The agreement shall provide for the following:

(1) The Secretary shall submit to the Commission, for its review and comment, a plan for the solidification of the high level radioactive waste at the Center, the removal of the waste for purposes of its solidification, the preparation of the waste for disposal, and the decontamination of the facilities to be used in solidifying the waste. In preparing its comments on the plan, the Cominission shall specify with precision its objections to any provision of the plan. Upon submission of a plan to the Commission, the Secretary shall publish a notice in the Federal Register of the submission of the plan and of its availability for public inspection, and, upon receipt of the comments of the Commission respecting a plan, the Secretary shall publish notice in the Federal Register of the receipt of the comments and of the availability of the comments for public inspection. If the Secre-

94 STAT. 1348 
tary does not revise the plan to meet objections specified in the comments of the Commission, the Secretary shall publish in the Federal Register a detailed statement for not so revising the plan.

(2) The Secretary shall consult with the Commission with respect to the form in which the high level radioactive waste at the Center shall be solidified and the containers to ve used in the permanent disposal of such waste.

(3) The Secretary shall submit to the Commission safety Reports and analysis reports and such other information as the Commission may require to identify any danger to the public health and safety which may be presented by the project.

(4) The Secretary shall afford the Commission access to the Center to enable the Commission to monitor the activities under the project for the purpose of assuring the public health and safety.

(d) In carrying out the project, the Secretary shall consult with the Administrator of the Environmental Protection Agency, the Secrotary of Transportation, the Director of the Geological Survey, and the commercial operator of the Center.

SEc. 3. (a) There are authorized to be appropriated to the Secretary for the project not more than $\$ 5,000,000$ for the fiscal year ending September 30, 1981.

(b) The total amount obligated for the project by the Secretary shall be 90 per centum of the costs of the project.

(c) The authority of the Secretary to enter into contracts under this Act shall be effective for any fiscal year only to such extent or in such amounts as are provided in advance by appropriation Acts.

SEc. 4. Not later than February 1, 1981, and on February 1 of each calendar year thereafter during the term of the project, the Secretary shall transmit to the Speaker of the House of Representatives and the President pro tempore of the Senate an up-to-date report containing a detailed description of the activities of the Secretary in carrying out the project, including agreements entered into and the costs incurred during the period reported on and the activities to be undertaken in the next fiscal year and the estimated costs thereof.

SEC. 5. (a) Other than the costs and responsibilities established by this Act for the project, nothing in this Act shall be construed as affecting any rights, obligations, or liabilities of the commercial operator of the Center, the State, or any person, as is appropriate, arising under the Atomic Energy Act of 1954 or under any other law, contract, or agreement for the operation, maintenance, or decontamination of any facility or property at the Center or for any wastes at the Center. Nothing in this Act shall be construed as affecting any applicable licensing requirement of the Atomic Energy Act of 1954 or the Energy Reorganization Act of 1974. This Act shall not apply or be extended to any facility or property at the Center which is not used in conducting the project. This Act may not be construed to expand or diminish the rights of the Federal Government.

(b) This Act does not authorize the Federal Government to acquire title to any high level radioactive waste at the Center or to the Center or any portion thereof.

SBC. 6. For purposes of this Act:

(1) The term "Secretary" means the Secretary of Energy 12 USC 2021

(2) The term "Commission" means the Nuclear Regulatory Commission.

(3) The term "State" means the State of New York.

94 STAT. 1349 
P.L. 96-368

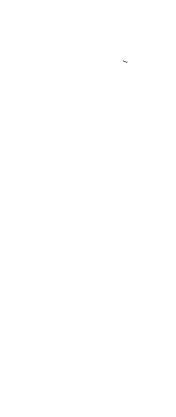

42 USC 2014.
LAWS OF 96th CONG.-2nd SESS.

Oct. 1

(4) The torm "high level radioactive waste" means the high level radiaactive waste which was produced by the reprocessing at the Center of spent nuclear fuel. Such torm includes both liquid wastes which are produced directly in reprocessing, dry solid material derived from such liquid wasto, and such other matorial as the Commission designates as high level radioactivo waste for purposes of protecting the public health and safety.

(5) The term "transuranic wasto" means material contaminated with elements which have an atomic number greater than 92, including nentunium, plutonium, americium, and curium, and which are in concentrations greater than 10 nanocuries per gram, or in such other concentrations as the Commission may prescribe to protect the public heal th and safety.

(6) The term "low level radicactive waste" means radioactive wasto not classified as high level radioactive waste, transuranic waste, or byproduct material as defined in section 11 . (2) of the Atomic Energy Act of 1954 .

(7) The torm "project" means the project prescribed by section 2(a)

(8) The term "Center" means the Weatern New York Service Contor in West Valley, Now York

Approved October 1, 1980. 